\title{
Citizenship and statelessness in Africa: the law and politics of belonging
}

Citation for published version (APA):

Manby, N. B. (2015). Citizenship and statelessness in Africa: the law and politics of belonging. [Doctoral Thesis, Maastricht University]. Wolf Legal Publishers (WLP). https://doi.org/10.26481/dis.20151020nm

Document status and date:

Published: 01/01/2015

DOI:

10.26481/dis.20151020nm

Document Version:

Publisher's PDF, also known as Version of record

\section{Please check the document version of this publication:}

- A submitted manuscript is the version of the article upon submission and before peer-review. There can be important differences between the submitted version and the official published version of record.

People interested in the research are advised to contact the author for the final version of the publication, or visit the DOI to the publisher's website.

- The final author version and the galley proof are versions of the publication after peer review.

- The final published version features the final layout of the paper including the volume, issue and page numbers.

Link to publication

\footnotetext{
General rights rights.

- You may freely distribute the URL identifying the publication in the public portal. please follow below link for the End User Agreement:

www.umlib.nl/taverne-license

Take down policy

If you believe that this document breaches copyright please contact us at:

repository@maastrichtuniversity.nl

providing details and we will investigate your claim.
}

Copyright and moral rights for the publications made accessible in the public portal are retained by the authors and/or other copyright owners and it is a condition of accessing publications that users recognise and abide by the legal requirements associated with these

- Users may download and print one copy of any publication from the public portal for the purpose of private study or research.

- You may not further distribute the material or use it for any profit-making activity or commercial gain

If the publication is distributed under the terms of Article $25 \mathrm{fa}$ of the Dutch Copyright Act, indicated by the "Taverne" license above, 


\title{
Citizenship and Statelessness in Africa: The law and politics of belonging
}

\author{
Bronwen Manby
}




\title{
Citizenship and Statelessness in Africa: The law and politics of belonging
}

\author{
Bronwen Manby
}

Coverphoto:

Côte d'Ivoire: OumarTraoré, 42, holds out his father's identity card from the time of the French colonial empire in West Africa. (C) UNHCR / H. Caux, October 2014

Published by:

ヤolf Legal Publishers (WLP)

PO Box 313

5060 AH Oisterwijk

The Netherlands

E-Mail:info@wolfpublishers.nl

www.wolfpublishers.com

All rights reserved. No part of this publication may be reproduced, stored in a retrieval system, or transmitted in any form or by any means, electronic, mechanical, photocopying, recording or otherwise, without prior written permission of the publisher. Whilst the authors, editors and publisher have tried to ensure the accuracy of this publication, the publisher, authors and editors cannot accept responsibility for any errors, omissions, misstatements, or mistakes and accept no responsibility for the use of the information presented in this work.

(C) Author / WLP 2015 


\title{
Citizenship and Statelessness in Africa: The law and politics of belonging
}

\author{
DISSERTATION \\ to obtain the degree of Doctor \\ at Maastricht University, \\ on the authority of the Rector Magnificus \\ Prof.dr. L.L.G. Soete \\ in accordance with the decision of the Board of Deans, \\ to be defended in public \\ on Tuesday 20th October 2015, at 16.00 hours
}

by

N. Bronwen Manby 



\section{Table of Contents}

Preface I

$\begin{array}{lll}\text { Abbreviations } & \text { III }\end{array}$

1. Introduction 1

$\begin{array}{lr}\text { PART I } & 7\end{array}$

$\begin{array}{lr}\text { 2. Citizenship, nationality and human rights } & 7\end{array}$

2.1 Citizenship or nationality? 10

2.2 Citizens' rights or human rights? $\quad 15$

$\begin{array}{ll}2.3 \text { A right to nationality? } & 18\end{array}$

3. International and African norms on citizenship 23

3.1 The recognition of the right to a nationality 23

$\begin{array}{lr}3.2 \text { Non-discrimination } & 26\end{array}$

$\begin{array}{ll}3.3 \text { Protection of stateless persons } & 30\end{array}$

3.4 Prevention and reduction of statelessness 31

3.5 Marriage $\quad 34$

3.6 Dual nationality $\quad 34$

$\begin{array}{ll}3.7 \text { State succession } & 36\end{array}$

3.8 Acquisition of nationality based on habitual residence 39

3.9 Loss and deprivation $\quad 42$

3.10 Due process in relation to expulsion $\quad 46$

$\begin{array}{ll}3.11 \text { Imposition of nationality } & 47\end{array}$

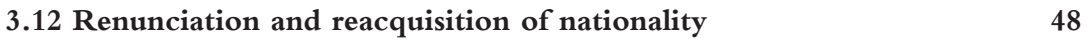

3.13 African human rights norms on nationality 49

3.12.1 The General Comment on Article 6 of the Children's Charter 52

3.12.2 The jurisprudence of the African human rights institutions 53

4. Empire to independence: the evolution of citizenship law in Africa 59

4.1 Citizenship and belonging before European colonisation 59

4.2 The European colonial period $\quad 63$

$\begin{array}{ll}4.3 \text { Transition to independence } & 81\end{array}$

5. Trends in African nationality law since independence 91

$\begin{array}{lr}5.1 \text { The balance of } j u s \text { soli and jus sanguinis } & 91\end{array}$

$\begin{array}{ll}5.2 \text { Gender equality } & 100\end{array}$

5.2.1 Nationality of children $\quad 104$

5.2.2 Nationality of spouses $\quad 105$

$\begin{array}{ll}5.3 \text { Dual nationality } & 111\end{array}$

$\begin{array}{ll}5.4 \text { Racial, ethnic and religious discrimination } & 114\end{array}$ 
$\begin{array}{lr}\text { 6. African nationality laws compared } & 119\end{array}$

$\begin{array}{ll}\text { 6.1 Children born in the country } & 121\end{array}$

6.1.1 Constitutional and legislative guarantees for the right to a nationality 121

6.1.2 Jus soli, double jus soli and birth + residence 124

6.1.3 Children of stateless parents or who would otherwise be stateless 126

6.1.4 Foundlings or children of unknown parents $\quad 127$

6.2 Children born outside the country 133

6.2.1 Adopted children 134

6.3 Citizenship by marriage $\quad 137$

$\begin{array}{lr}\mathbf{1 3} \text { Dual nationality } & \mathbf{1 4 0}\end{array}$

6.4.1 Dual nationality and public office 146

6.5 Rights for the African diaspora $\quad \mathbf{1 5 0}$

6.5.1 Ethiopia 151

6.5.2 Ghana 151

6.6 Citizenship by naturalisation 152

6.6.1 Restrictions on the political rights of naturalised persons $\quad 165$

6.6.2 Naturalisation for refugees and stateless persons $\quad 166$

6.7 Loss and deprivation of nationality 168

6.9 The right to challenge executive decisions on nationality 180

7. Nationality administration in practice 183

$\begin{array}{ll}7.1 \text { Birth registration } & 184\end{array}$

7.2 Inaccessible, discriminatory or absent systems for proof of nationality 191

$\begin{array}{ll}7.3 \text { Inaccessibility of naturalisation procedures } & 198\end{array}$

7.4 Conflict and loss of documents 203

$\begin{array}{ll}7.5 \text { Official and unofficial costs } & 204\end{array}$

7.6 The struggle to obtain a passport 206

$\begin{array}{lr}\text { PART II } & 209\end{array}$

$\begin{array}{ll}\text { 8. Who is a native? } & 209\end{array}$

8.1 Mass expulsions as "nation-building" 212

$\begin{array}{ll}\text { 8.2 Denationalisation as censorship } & 217\end{array}$

8.2.1 Zambia: Kenneth Kaunda and others become instant foreigners 219

8.2.2 Botswana: The case of John Modise 223

8.2.3 Swaziland: Critics are "un-Swazi" 224

8.3 Dual Citizenship, denationalisation and disenfranchisement in Zimbabwe 228

8.4 "Asians" and other "others" in Kenya and Uganda 245

8.5 The "Lebanese" of Sierra Leone 261

8.6 The Banyarwanda of Eastern Democratic Republic of Congo 274

8.7 Côte d'Ivoire's war of conjunctions: The "and" and the "or" 297

9. State succession since independence and its impact on nationality 323

9.1 Eritrea/Ethiopia: State succession and mass expulsion $\quad 324$

9.2 Sudan and South Sudan 332

9.3 The Bakassi Peninsula $\quad 345$ 
9.4 The Tebu and the "Aouzou strip" between Chad and Libya

10. Nomadic and "indigenous" populations 355

10.1 Nomadic pastoralism and nationality in Africa 355

10.1.1 The status of the Misseriya in Abyei 357

10.1.2 The Tuareg, Fulani and other West African pastoralists 360

10.2 Africa and the UN Declaration on the Rights of Indigenous Peoples 364

11. Between a rock and a hard place: Access to citizenship for refugees $\quad 369$

11.1 Former Liberian and Sierra Leonean refugees in Guinea 373

$\begin{array}{ll}\text { 11.2 Tanzania: Naturalisation stalled by regional politics } & 378\end{array}$

11.3 Palestinians in Egypt $\quad 382$

11.4 Western Sahara 385

11.5 Mauritanian refugees and returnees $\quad 390$

11.6 South Africa: the difficulties of bringing practice into line with the law 395

12. Orphans and vulnerable children $\quad 401$

12.1 Abandoned babies, orphaned children and children born out of wedlock 403

$\begin{array}{ll}12.2 \text { Child workers } & 406\end{array}$

$\begin{array}{ll}\text { 12.3 Enfants talibés } & 407\end{array}$

12.4 Child wives of "servile" origin and their children 407

13. Internal citizenship in a federal state 411

13.1 "Indigeneity" in Nigeria $\quad 412$

13.2 Nations, Nationalities and Peoples in Ethiopia 4422

13.3 The status of Zanzibari in Tanzania 426

$\begin{array}{ll}\text { PART III } & 431\end{array}$

14. Citizenship law as problem and solution 431

14.1 Citizenship law as an independent variable $\quad 433$

14.2 The political utility and disutility of manipulating citizenship law $\quad 437$

$\begin{array}{ll}14.3 \text { Not just an elite issue } & 441\end{array}$

$\begin{array}{ll}\text { 14.4 Marginal citizens } & 445\end{array}$

14.5 Africa is not unique; politicians can choose to change direction $\quad 446$

15. The Right to a Nationality 449

15.1 A balancing act between consent and attribution $\quad 449$

15.2
Law, policy and process

15.3 A focus on "statelessness" may not be the most useful approach 452

15.4 "Undetermined nationality" and "de facto statelessness" 454

15.5 The right to change nationality 456

15.6 The most inclusive citizenship law may be less stable than a median position 458

15.7 Towards the right to a nationality in Africa 459 
15.7.1 The implications of the drive to continental integration

15.7.2 General Comment of the Committee of Experts on the Rights and Welfare of the Child 462

15.7.3 A Protocol to the African Charter on Human and Peoples' Rights 462

15.8 Recommendations for law reform $\quad \mathbf{4 6 4}$

15.8.1 Removal of discrimination $\quad 464$

15.8.2 Rights based on birth in the country 464

15.8.3 Adaptation of rules for nomadic populations $\quad 465$

15.8.4 Access to naturalisation $\quad 465$

15.8.5 Dual nationality $\quad 465$

15.8.6 Civil registration, evidence and proof of nationality 465

15.8.7 Due process $\quad 466$

15.8.8 Protection and integration of stateless persons 466

15.8.9 Internal citizenship $\quad 466$

$\begin{array}{ll}\text { Valorisation Addendum } & 467\end{array}$

$\begin{array}{ll}\text { Citizenship Bibliography } & 471\end{array}$

$\begin{array}{ll}\text { List of African nationality laws and amendments since independence } & 507\end{array}$

\section{LIST OF TABLES}

Table 1: Commonwealth countries removing jus soli $\quad 94$

Table 2: The right to a nationality based on birth in the country 128

Table 3: Right to nationality by descent $\quad 131$

Table 4: Provisions on minor adopted children $\quad 136$

Table 5: Right to pass nationality to a spouse $\quad 138$

Table 6: Rules on dual nationality 144

Table 7: Right to acquire citizenship as an adult by naturalisation 156

$\begin{array}{lr}\text { Table 8: Criteria for loss or deprivation of citizenship } & 175\end{array}$

$\begin{array}{ll}\text { Table 9: Renunciation and reacquisition } & 178\end{array}$

Table 10: Birth registration rates (percentage of children under five) $\quad 188$

While every effort has been made to ensure that the tables and descriptions of the laws in African countries are accurate and up to date, very complex provisions have been simplified. Readers should not treat the tables as definitive nor accord them the status of legal advice: the provisions are varied, subject to interpretation, and difficult to represent in tabular form. The laws considered for the tables are national constitutions and nationality laws; but other laws are often relevant and may even be contradictory, including laws for the protection of children, on elections, on civil registration, on national identity systems and family codes. Information is up to date as of the end of 2014. 


\section{Preface}

This book is a upgraded, updated and expanded consolidation of a number of publications I have previously written on the right to a nationality in Africa, including: Struggles for Citizenship in Africa, Zed Books, London, 2009; Citizenship Law in Africa: A Comparative Study, Open Society Foundations, 2009; International Law and the Right to Nationality in Sudan, Open Society Foundations, 2011; Statelessness in Southern Africa, Briefing paper for UNHCR Regional Conference on Statelessness in Southern Africa Mbombela (Nelspruit), South Africa 1-3 November 2011; The Right to Nationality and the Secession of South Sudan: A Commentary on the Impact of the New Laws, Open Society Foundations, 2012; "The historical development of citizenship law in Africa", in Engin Isin and Peter Nyers (eds.) Handbook of Global Citizenship Studies, Routledge, 2014; and Nationality, Migration and Statelessness in West Africa, UNHCR and IOM, 2015; as well as various blog postings, submissions on constitutional and legislative reform, and other articles. While perhaps two-thirds of the material has been previously published in some form, there is scarcely a paragraph that has not been revised, in particular to provide greater detail and referencing, as well as to seek deeper analysis. The first two and last three chapters are wholly new.

In addition to those already thanked in previous acknowledgments, I should like to emphasise in particular my debts to Chidi Odinkalu and Ibrahima Kane, who have informed my thinking on these issues over many years and have been inspirational leaders and colleagues in advocacy efforts on the continent. I have benefited greatly from visiting fellowships at the Centre for the Study of Human Rights at the London School of Economics, as well as from ongoing discussions with the statelessness unit of UNHCR in Geneva, especially Mark Manly and his colleagues in the field.

Thanks are also due to Prof. René de Groot for suggesting this project and for the many opportunities I have had to learn from his inputs to various meetings. The text is submitted in satisfaction of the requirements for a doctorate awarded by the Maastricht University Faculty of Law. 



\section{Abbreviations}

ACHPR African Commission on Human and Peoples' Rights

ACERWC African Committee of Experts on the Rights and Welfare of the Child

ACRWC African Charter on the Rights and Welfare of the Child

AEF Afrique equatoriale française (French Equatorial Africa)

AOF Afrique occidentale française (French West Africa)

AU African Union

CAR Central African Republic

CEDAW Convention on the Elimination of All Forms of Discrimination Against Women

CERD Convention on the Elimination of All Forms of Racial Discrimination

CPA Comprehensive Peace Agreement (Sudan)

CRC Convention on the Rights of the Child

DRC Democratic Republic of Congo

EAC East African Community

ECOWAS Economic Community of West African States

ICCPR International Covenant on Civil and Political Rights

ICESCR International Covenant on Economic Social and Cultural Rights

IOM International Organisation for Migration

IRIN Integrated Regional Information Networks (formerly of the UN)

OAU Organisation of African Unity

PALOP Países Africanos de Lingua Oficial Portuguesa (African countries with Portuguese as the Official Language

PCA Permanent Court of Arbitration

PCIJ Permanent Court of International Justice

SADC Southern African Development Community

SADR Sahrawi Arab Democratic Republic

SPLA/M Sudan People's Liberation Army/Movement

STP São Tomé and Príncipe

UK United Kingdom (of Great Britain and Northern Ireland)

UN United Nations

UNDP UN Development Programme

UNHCHR UN High Commissioner for Human Rights

UNHCR UN High Commissioner for Refugees

UNICEF UN Children's Fund

UNOCHA UN Office for the Coordination of Humanitarian Affairs

UNODC UN Office for Drugs and Crime 



\section{Introduction}

This book takes a problem-solving attitude to questions of citizenship law on the African continent. The central question I seek to answer is the degree to which citizenship law as it has developed before and since independence has been a positive or negative force in the project of "nation-building" that has so preoccupied or bedevilled African states; the extent to which it has been a factor, and if so which particular provisions have been problematic - and which have been helpful. Based on this analysis, recommendations follow for amendments to citizenship laws that can help to solve some of the knotty questions of identity and belonging; not ideal-world amendments that could be applied if only things were different, but practical changes that have been shown to help reduce the tensions over who is counted as a member of the national community and thus benefits from resources.

I take as given the state system in Africa, within the borders largely established by the colonial powers and adopted by the newly formed Organisation of African Unity (OAU) in 1964. ${ }^{1}$ Though the arguments put forward — including by many armed irredentist groups on the continent - that these borders should be adapted to follow more "natural" lines of ethnicity, or pre-colonial political borders, are compelling at one level, it is a bloody business to change them, and may only have benefits in the very long term (see Eritrea or South Sudan). The fact is that the colonial boundaries now also have real meaning and have, in fact, created national communities, however fragile. In any event, there are large numbers of people who live as a matter of fact within the borders of the existing states and arguing about whether they belong or not is a futile task, likely to lead to further bloodshed. In Africa as at a global level, we have no way as an "international community" of addressing the challenges of migration and trans-border justice except through the framework of the existing state system. Wishing that history had been different is not a solution. This is not to argue that the borders should necessarily be immutable; but that wherever the borders are fixed there will be a need to devise provisions on legal citizenship that accommodate the realities of Africa's hyper-diverse states. For the sake of the rights of the individuals concerned, and for political stability, these rules should be non-discriminatory and allow for "strangers" to become "natives" in the course of time. Citizenship law should contribute to "nation-building" rather than undermining progress in that regard; and public discussion and campaigning for the content of legal citizenship is an under-used but potentially important tool in that task.

1 OAU Assembly, Res. 16 (II), Cairo Summit, $2^{\text {nd }}$ Ordinary Session, 1964. 
The approach I take is that of a lawyer, not a sociologist or political scientist, and my main focus is the role of law in exacerbating or helping to solve some of the identity-related problems of statehood and respect for human rights in Africa. What, first, are the aspects of nationality laws that are not in compliance with international norms and standards, or problematic for other reasons; and how have these contributed to political and security crises on the continent, or been manipulated for improper ends. Based on this analysis, secondly, what steps could therefore be taken in law to resolve some of these challenges. While starting from a legal standpoint, I try also to integrate at least some of the insights drawn from debates in other fields in order to make two additional overall points: firstly that research and debates around questions of autochthony and identity conflict in Africa should more often consider citizenship law as a point of entry; and secondly that international human rights law needs to take the right to belong more seriously — not just the avoidance of statelessness, but especially a person's right to the nationality of the place where he or she has the strongest links.

The book is split into three parts. Part I sets out the normative and legal framework, at international, African and national levels, and provides a comparison of the legal provisions across countries. Part II considers case studies of the application and misapplication of these laws in practice in particular countries. Part III consists of conclusions and recommendations based on the findings of the research, and outlines the efforts under way at African level to provide a new normative framework specifically for Africa.

After an introductory chapter setting the scene for this discussion within the different theoretical approaches to and definitions of citizenship and nationality from the perspective of sociologists, political scientists and lawyers, Part I establishes the international law around nationality and statelessness, with a specific focus on developments within the African Union human rights system.

The next two chapters outline the history of nationality law in Africa: the developments during the colonial period, and the trends since independence. Although concepts of nationality were established in Africa during the same period as they were developing in Europe and other regions, they were profoundly affected by the legal subordination of most Africans within the colonial regime. The colonial heritage still has pervasive effects today in Africa: not only in the framework of citizenship laws, which borrowed from European models; but also in the distinctions between different types of citizenship, founded on a distinction between "native" and "settler" that neatly reverses the situation during the colonial period. Since independence, African laws have also developed along their own trajectories, also influenced by international developments. The three strongest trends have been the removal of birthright citizenship in the Commonwealth states, the reduction and removal of gender discrimination across the continent, and the progressive introduction of amendments to allow dual nationality. Explicit legal racial and ethnic discrimination was introduced in several countries after independence, though later removed in some, and remains 
a strong reality in the administration of the law in many other countries.

Chapter six provides a detailed comparison of African nationality laws as they stand today, including tables listing provisions for all 54 countries (including the newest, South Sudan, as well as Morocco, which is not a member of the African Union; strenuous efforts were made to find laws applicable to the Sahrawi Arab Democratic Republic, without success). This is the legal heart of the book.

Very few African states have provisions in their law respecting the requirements of Article 6(4) of the African Charter on Human and Peoples' Rights that a child who would otherwise be stateless has the right to the nationality of the state where he or she is born. Nevertheless, around half do have provisions that ensure that second and third generation migrants will given the right to acquire the nationality of the country where they live. Some countries, however, guarantee by their restrictive legal provisions on access to citizenship that many thousands of people do not have the documentation that proves their right "to belong". The problems with the law include, above all, the very weak rights attached in many states to birth and residence in the country, even for children who cannot obtain the nationality of their parents; widespread (though diminishing) gender discrimination; and highly discretionary nature of naturalisation procedures. Existing laws and procedures fail to provide for those persons following a nomadic lifestyle, who number in the millions in Africa. In addition, the failure to acknowledge significant colonial-era population transfers and to grant nationality systematically to the populations resident in African countries at the time of transition to independence still has consequences today; while more recent transfers of territory following adjustments to borders have failed to take sufficient account of the people living in those zones.

The final chapter in Part I looks at nationality administration in practice. The practical impossibility of obtaining official documentation is a more common problem than an explicit legal denial of nationality. It is the low-level administrative decisions - to register a child's birth or enrol her in school, to issue an identity card or passport, to permit a house to be built or land to be cultivated - that determine whether someone has access to the rights that go with nationality, and thus for all practical purposes to nationality itself. Thus, the moment that most people find out that their nationality is contested is when they seek official documentation: a birth certificate, national identity card or passport. Especially in those many countries which provide that facts of location of birth or parentage can only be established if formally registered, the lack of effective civil registration systems becomes almost as important as content of the law itself. Yet birth registration across Africa is less than 50 percent: although some reach more than 90 percent, and rates have increased with a major push on civil registration at $\mathrm{AU}$ level, in some countries the rate remains below 10 percent, even in some unaffected by war and civil strife. Naturalisation procedures are also almost completely inaccessible, (ironically) especially to the nationals of other African countries, such that naturalised citizens can be numbered in handfuls, 
though the numbers of people who might wish to have access to citizenship through that route are in the tens of thousands.

After this examination of the international norms, history and contemporary framework of African citizenship laws and administration, Part II considers the impact of those laws in practice on the right to a nationality. Those most negatively affected are within three main groups: migrants - historical or contemporary — and their descendants, including refugees and former refugees, as well as those "returned" to a country of origin where they have few current links; border populations, including nomadic and pastoralist ethnic groups who regularly cross borders, as well as those affected by transfers of territory; and orphans and other vulnerable children, including those trafficked for various purposes.

Chapter eight takes case studies of individuals and groups who have been denationalised in Zambia, Botswana, Swaziland, Zimbabwe, Kenya and Uganda, Sierra Leone, the Democratic Republic of Congo, and finally Côte d'Ivoire, the best known (and most studied) example of all. In each case, nationality law has been abused by the government in power to secure its own future, through overly literal interpretations of the rules governing the nationality of individuals at the transition to independence, the manipulation of a prohibition on dual nationality, or the introduction of systems that directly or indirectly discriminate against particular ethnic groups. In the most extreme cases, the nationality question has led to war: notably in Côte d'Ivoire and Congo.

State successions since independence have had their own issues, considered in chapter nine, most dramatically the mass expulsions of alleged nationals of the other country that followed the secession of Eritrea from Ethiopia and the subsequent war between the two countries. The situation of people of South Sudanese descent in Sudan appears to be equally if not more precarious. The transfer of the Bakassi peninsula from Nigeria to Cameroon has left some hundred thousand inhabitants of the region vulnerable to lack of recognition of citizenship on either side of the new border; and other transfers of territory, or simply long-standing border disputes affect less well-known groups, such as the Tebu in Libya or Fulani along the borders of Niger.

Chapter ten then considers the situation of nomadic pastoralists and "indigenous peoples" in Africa. Although many millions of people in Africa follow a nomadic lifestyle, nationality laws remain based on the concept of a settled population. There are no norms at international level to take as inspiration, and initiatives to facilitate pastoralism as a lifestyle in marginal environments have been focused on the free movement of livestock across borders rather than the nationality of the people with them. In the absence of an international normative framework, pastoralist groups in Africa have made use of the international discussion around "indigenous peoples", although the conceptual framework is based on the situation of those peoples in the Americas, Australasia and elsewhere 
overwhelmed by settler populations from Europe, rather than the very different African context. African states have responded negatively to the "indigenous peoples" initiatives, and been criticised for it; but those groups making use of the label do so for the very good reason that it provides leverage and an audience in international circles that is not provided by other norms.

Another group of people with particular difficulties in accessing nationality rights are refugees: in particular, long-stay refugees and their children. Some states specifically restrict refugees from accessing their nationality, in others the discrimination is in practice rather than in law. Even a country such as Tanzania, with a jus soli law providing citizenship to those born on its territory that should allow the children of any migrant to integrate has not respected this provision in practice; and though Tanzania has historically had a generous attitude to refugees, most recently offering naturalisation to Burundians resident in the country since the 1970s, it has also abruptly changed its policies at several times, expelling large numbers of people who arguably are in fact Tanzanian nationals. Chapter 11 considers this case, as well as the situation of Palestinians and Sahrawis in North Africa, the situation of refugees from countries where the "cessation clauses" in the 1951 Convention have been invoked, and the difficulties of putting good laws into practice in South Africa.

Chapter 12 presents the particular situation of vulnerable children; unlike most of the other populations at risk of statelessness, this group - orphans, children born out of wedlock, children separated from their parents by conflict, as migrant workers or as victims of trafficking — is not in fact easily identifiable as a group. A child of any race, religion or ethnicity may find him or herself without any documentation of identity; and when that child becomes an adult one of the consequences may be statelessness.

The final set of country studies in chapter 13 considers "internal citizenship" in three African countries that have an explicitly federal system: Nigeria, Ethiopia and Tanzania. Exactly the same issues arise in relation to entitlements inside the country as those that apply between countries, notably in relation to political rights. Even those countries without a federal system established in law face similar issues.

Part III provides a concluding discussion of the impact of law on politics and politics on law, suggesting that, though law reform initiatives can be presented as being far from the concerns of people affected in remote provinces, they provide nonetheless the most promising way out of some of the morasses explored in previous chapters. A technical approach to legal provisions and administrative policies and their implementation in practice can draw out the political sting from some of these questions. Many officials in African countries are in fact eager to embrace such solutions, seeing clearly how their own laws create problems. Civil society initiatives with both the African Committee of Experts on the Rights and Welfare of the Child and the African Commission on Human and Peoples 
Rights have made real headway in getting the continental institutions to take on board the need for such reforms, in particular through a proposal for a protocol on the right to a nationality to the African Charter on Human and Peoples' Rights. The final pages of the book summarise the key recommendations for such standard-setting and for national law reform. 


\section{PART I}

\section{Citizenship, nationality and human rights}

Much of the contemporary academic and policy debate about citizenship from the sociological or political science perspective takes as its the key focus the integration of recent migrants into the national community: either into the "nation-states" of Europe, or the immigrant-founded states of the United States, Canada, Australia or others. There is a fundamental assumption that there is an existing national community of citizens, and the question is the status of newcomers. Moreover, the debate on the meaning of citizenship — whether as a normative or descriptive term - usually assumes that it is, as a matter of law and in practice, reasonably clear who is or is not a citizen, even if the political and legal content and rights of citizenship, and the status of aliens, is under debate. The only exception to this rule is the small group of legally anomalous "stateless persons" caught up in a conflict of laws between the states of their parents and place of birth. The debate is thus focused on the rights and duties citizens have or should have as existing members of the polity; or on immigration policy, and the rules for admitting and integrating new members; or on trends in relation to tolerance for dual nationality (also anomalous from the traditional point of view that a person can or should have loyalty to only one state). It does not take as its central focus the complex questions of defining the membership of the "nation" to start off with, having entered the story in Europe and elsewhere at a point where the existing limits of the nation and state are relatively well established (even if anomalies exist and newcomers have to find a place). ${ }^{1}$

From the international human rights law perspective, meanwhile, there is an active discussion around nationality, but mostly in the context of stateless persons: those who, as defined under the 1954 Convention Relating to the Status of Stateless Persons, are "not considered as a national by any State under the operation of its law" (Article 1(1)). There is a debate over the limits and meaning of statelessness, ${ }^{2}$ and on the amendments to national laws that may be necessary

1 See for example, the series of three books edited by Douglas B. Klusmeyer and Alexander Aleinikoff for the Carnegie Endowment for International Peace, culminating in Citizenship policies for an age of migration, Washington, D.C. 2002; Rainer Bauböck, Migration and citizenship : Legal status, rights and political participation, IMISCOE / Amsterdam University Press, 2006; Rainer Bauböck, and John F. Rundell, Blurred boundaries : Migration, ethnicity, citizenship European Centre for Social Welfare Policy and Research, Aldershot: Ashgate, 1998; Christian Joppke, Citizenship and Immigration, Cambridge : Polity Press, 2010.

2 See in particular, The Concept of Stateless Persons under International Law: The "Prato Conclusions", UNHCR, 2010, and the discussion below at chapter 15.3. 
to resolve the conflicts that mean that some children have the nationality neither of their parents nor of the country where they were born. However, thanks to the post-Second World War drafting environment, the sensitivities of states and the consequently limited mandate of the United Nations High Commission for Refugees (UNHCR), under whose purview the issue falls, the normative debate at international level has historically largely been concerned with the provision of protection for stateless people who (or children whose parents) are migrants within a "refugee-type" situation, and on the avoidance of conflicts of laws leading to statelessness - rather than on the right to a particular nationality, that of the state that is most relevant to the person concerned. On the ground, however, the problem faced by individuals is often the lack of clarity over whether a person is a national or not, and the difficulty of obtaining recognition of nationality, rather than the question of protection for recognition of "stateless persons" or the difficulties created by conflicts of law. Only quite recently has UNHCR begun to interpret its mandate to address this wider group. ${ }^{3}$

At the African level, there is a rich field of scholarship on questions of identity and belonging. ${ }^{4}$ However, the debates around the status of marginal groups are

3 This process was enabled by UN General Assembly Resolution A/RES/49/169 of 24 February 1995; followed by UNHCR Executive Committee Conclusion No. 78 (XLVI) on the Prevention and Reduction of Statelessness and the Protection of Stateless Persons, of 20 October 1995; and especially Conclusion No.106 (LVI) on Identification, Prevention and Reduction of Statelessness and Protection of Stateless Persons of 6 October 2006. See discussion in Mark Manly, "UNHCR's mandate and activities to address statelessness", in Alice Edwards and Laura van Waas (eds.) Nationality and Statelessness under International Law, Cambridge University Press, 2014, and the collection of documents maintained at the UNHCR REFWORLD webpage on statelessness at http://www.refworld.org/cgibin/texis/vtx/rwmain?page=statelessness, last accessed 22 December 2014.

4 See for example, Said Adejumobi, "Citizenship, Rights and the Problem of Conflicts and Civil Wars in Africa", Human Rights Quarterly, Vol.23, No.1, 2001, pp.148-170; Said Adejumobi, "Identity, Citizenship and Conflict: The African Experience", in W.Alade Fawole and Charles Ukeje, The Crisis of the State and Regionalism in West Africa: Identity, Citizenship and Conflict, CODESRIA, Dakar, 2005; Jean-François Bayart, Peter Geschiere and Francis Nyamnjoh, "Autochtonie, démocratie et citoyenneté en Afrique", Critique internationale (Special issue "J'étais là avant » : Problématiques politiques de l'autochtonie), Vol.10, 2001; Morten Bøås and Kevin Dunn (2013). Politics of Origin in Africa: Autochthony, Citizenship and Conflict, London, Zed Books, 2013; Bambi Ceuppens and Peter Geschiere, "Autochthony: Local or Global? New Modes in the Struggle over Citizenship and Belonging in Africa and Europe", Annual Review of Anthropology, Vol. 34, 2005, pp.385407; Patrick Chabal Power in Africa: An essay in political interpretation, London: Macmillan, 1992; Jean-Pierre Chauveau and Paul Richards, "West African Insurgencies in Agrarian Perspective: Côte d'Ivoire and Sierra Leone Compared", Journal of Agrarian Change,Vol.8, No.(4) 2008, pp. 515-552; Armando Cutolo and Peter Geschiere (eds.), "Dossier: Enjeux de l'autochtonie", Politique africaine, No.112, 2008 ; Peter Geschiere, The Perils of Belonging : Autochthony, Citizenship, and Exclusion in Africa and Europe. University of Chicago Press, 2009; Peter Geschiere, "Autochthony and Citizenship: New Modes in the Struggle over Belonging and Exclusion in Africa", Forum for Development Studies, Vol.32, No.2, 
not usually couched in the same terms as the literature on citizenship in Europe or North America, even though many of the same questions arise. Rather than examining questions of citizenship law and policy, the African literature deals with the conundrum of nation-building in post-independence Africa. It is concerned with the increased intensity of "autochtone-allochtone" or "indigenesettler" conflicts following the re-introduction of multi-party democracy during the 1990s, and with the relative contribution of ethnic diversity as a cause of conflict in relation to other factors such as regional underdevelopment, or the accessibility of rich and portable natural resources. Debates over the content of nationality law, the procedures for integration of immigrants and the meaning of citizenship have not been central to the analysis of conflict over access to land and natural resources, or the lack of access to such services as are provided by the state to its citizens. In a context where censuses are highly unreliable; where many, perhaps most, children are not registered at birth; where the economy is largely informal; and where a large percentage of adults get by with no formal documentation, the definition and content of the legal tie between a person and the state where he or she lives seems less urgent to determine. Law can be perceived to be essentially irrelevant in these contexts. ${ }^{5}$ The situation of those whose right to a nationality is under threat may not differ very much from their neighbours whose nationality is uncontested; while the same problems also arise in communities whose right to belong at the national level is uncontroversial and the issue at hand is the right to access resources in a particular local government area, not an international passport.

2005, pp.371-384; Peter Geschiere and Stephen Jackson, "Autochthony and the Crisis of Citizenship: Democratization, Decentralization, and the Politics of Belonging", African Studies Review (Introduction to Special Issue:Autochthony and the Crisis of Citizenship), Vol.49, No.2, 2006, pp.1-7; C. R. D. Halisi, Paul J. Kaiser and Stephen N. Ndegwa "Guest Editors' Introduction: The Multiple Meanings of Citizenship: Rights, Identity, and Social Justice in Africa", Africa Today (Special issue: Rethinking Citizenship in Africa), Vol. 45, No. 3/4, 1998, pp. 337-349; Mahmood Mamdani, Citizen and Subject: Contemporary Africa and the Legacy of Late Colonialism, Princeton University Press, 1996; Mahmood Mamdani, "Beyond Settler and Native as Political Identities: Overcoming the Political Legacy of Colonialism", Comparative Studies in Society and History, Vol.4, No.4, 2001, pp.651-664; Georges Nzongola-Ntalaja, "Citizenship, political violence, and democratization in Africa", Global Governance, Vol. 10 No.4, 2004, pp.403-407; Ukoha Ukiwo, "Ethnicity and citizenship in Africa: Some reflections" in Helen Lauer and Kofi Anyidoho (eds.) Reclaiming the human sciences and humanities through African perspectives Vol.2, Sub-Saharan Publishers, 2012, pp.1142-1153.

5 On the irrelevance of formal rules see, for example, Jean-Francois Bayart, Stephen Ellis and Beatrice Hibou, The Criminalization of the State in Africa, Oxford: James Currey, 1999; Patrick Chabal \& Jean-Pascal Daloz, Africa Works: Disorder as political instrument. Oxford: James Currey, 1999. Also the "greed or grievance" debates on civil wars, which do not address questions around legal identity, starting from this paper: Paul Collier and Anke Hoeffler, Greed and Grievance in Civil War, The World Bank Policy Research Working Paper 2355, May 2000. 
This book argues that it could be useful, nonetheless, for "the citizenship debates" to extend to Africa; and for the scholarship on "autochthony" and "indigeneity" in Africa to pay more attention to legal definitions of nationality and the processes by which it is acquired, as well as to more nebulous questions of how a sense of belonging and community is created. At the international law level, norm-setting needs to move to the concept that an individual has the right to the nationality of a particular state, the one where he or she has the closest connections, and to systems for sorting in cases of doubt; rather than a focus only on avoiding statelessness. This is not only because the lack of a recognised nationality in the state where you live is a real problem in itself; but also because the process of revising laws provides an access point to wider questions of nationbuilding. Citizenship laws and regulations are a tool to use in the building of an effective state that has been under-used (and under-studied) to date.

\subsection{Citizenship or nationality?}

Some discussion of terminology is a necessary preliminary before embarking on a debate over the role of law in identity, starting from the words "citizenship" and "nationality" themselves. They come from different historical and academic traditions, and in practice different authors use them to mean different things, even when discussing legal issues. It is not possible to give each a fixed and categorical definition, devoid of the context.

In international law, nationality and citizenship are now used as synonyms, to describe the legal relationship between the state and the individual; the terms can — and will in this text — be used interchangeably. ${ }^{7}$ However, different legal traditions have different usages at national level, especially if viewed in historical context; and other disciplines also have different ways of using the terms, whose meanings somehow seep into legal usage from time to time.

Nationality law developed during the $19^{\text {th }}$ century, as migration became much more common and individuals sought to change their allegiance from one state to another. The rules on nationality emerged from international litigation over the rights of states to intervene on behalf of their nationals when travelling abroad, or of companies registered in their territory in commercial disputes; that is, through the rules on diplomatic protection and on conflict of laws. This legal tradition led to the famous elaboration of the concept of nationality in the 1955 Nottebohm case before the International Court of Justice, as a legal bond between and individual state (that should be) based on "a genuine connection" and "durable link" between that individual and the state. The ICJ determined that the lack of a "genuine connection" between Nottebohm and Liechtenstein

6 Gershon Shafir, The Citizenship Debates: A Reader, University of Minnesota Press, 1998.

7 Paul Weis, Nationality and Statelessness in International Law (2nd Ed.), Kluwer, 1979, Chapter 1: "Nationality and its Synonyms"; Laurie Fransman, Fransman's British Nationality Law, Third Edition, Bloomsbury Professional, 2011, pp.3-7 
meant that, although Nottebohm was a naturalised citizen, Liechtenstein had no right to exercise diplomatic protection on his behalf in relation to Guatemala (a country where, as a matter of fact, he had much stronger links). In the muchquoted judgment, the court stated that:

According to the practice of States, to arbitral and judicial decisions and to the opinion of writers, nationality is a legal bond having as its basis a social fact of attachment, a genuine connection of existence, interest and sentiments, together with the existence of reciprocal rights and duties. It may be said to constitute the juridical expression of the fact that the individual upon whom it is conferred either directly by the law or as a result of an act of the authorities, is in fact more closely connected with the population of the State conferring nationality than with that of any other State. ${ }^{8}$

This terminology was widely applied, often in the formulation of "genuine link", and indeed incorporated into international treaties relevant to nationality. ${ }^{9}$

For lawyers in the Commonwealth tradition, however, "citizenship" is the term now used at domestic level in describing this legal bond, the rules adopted at country level by which it is decided whether a person does or does not have the right to legal membership of that state and the status of a person who is a member. Nationality can be used in the same sense, but tends to be more restricted to international law contexts. The complications of many-layered British nationality law mean that there is also a distinction between British nationality as a legal connection to the United Kingdom at international level, and the full rights of someone with the status of British citizen. ${ }^{10}$ In the French civil law tradition, meanwhile, nationalite is the term used at both international and national levels to describe the legal bond between a person and a political entity, and the rules for membership of the community. Where a Commonwealth state would have a

8 Nottebohm Case (Liechtenstein v. Guatemala) (second phase), Judgment of 6 April 1955, ICJ Reports 1955, p.23. Liechtenstein sought a ruling that Guatemala should recognize Friedrich Nottebohm as a Liechtenstein national.

9 For example, Article 5(1) of the Convention on the High Seas, 1958, on the nationality of ships, stating that "There must exist a genuine link between the State and the ship".

10 Most Commonwealth countries have a "citizenship act"; however, British legislation since 1914 has used the term "nationality" to cover a range of statuses governed in law, while the term "citizen" was first used in 1948, and the status of "British citizen" only introduced in 1981. British nationality law till today creates arcane distinctions between eight different grades of nationals (some of them almost obsolete), with only "British citizens" having full rights, including "right of abode" in the United Kingdom. As a result of these complications the UK has unilaterally made declarations in relation to the definition of its nationals for the purposes of the European Union, while the UK has not ratified the Protocol 4 to the European Convention on Human Rights (on the right of a person to enter the country of which he or she is a national) or the European Convention on Nationality 1997. See Fransman's British Nationality Law, p.65 and pp.87-89. 
national citizenship act, a member of the Francophonie has a code de la nationalité. Citoyenneté is not used in this context. ${ }^{11}$

This confusion of terms is reflected in international treaties, and usage is not consistent. "Nationality" and "national" are more commonly used in English language texts for the idea of legal membership of a country at international level: for example, the Universal Declaration of Human Rights states that "Everyone has the right to a nationality" (Article 15). Yet some treaties use "citizenship" and "citizen" in the same context: the International Convention on the Elimination of All Forms of Racial Discrimination refers to discrimination between citizens and non-citizens (Article 25), rather than nationals and non-nationals. French then contributes a third term, that of ressortissant, often used where "national" appears in the English version of a text. A ressortissant is a person falling under the jurisdiction of a state, but has a wider meaning than that of national, covering persons under the protection of a state; though the extent to which it covers non-nationals is not entirely clear. ${ }^{12}$

For sociologists and political scientists, by contrast, the scholarly debate over "citizenship" is mainly about the content of citizenship: what are (or should be) the rights of members of the national community. ${ }^{13}$ Discussions have centred on the different conceptions of citizenship, whether it is a legal status based on a notional contract between citizen and state and carrying with it rights and obligations; or whether citizenship is rather a "republican" (in the French sense) or "performative" idea, in which people become and are recognised as citizens through their participation in the political and public space. This is also the way in which citoyenneté is used in French, where the concept has been closely linked to political participation and the sovereignty of the "French People". ${ }^{14}$

"Nationality" also has its own traditions separate from international law. The proximity of "nationality" to the idea of "nation", means that in some contexts

11 For the wealth of possible confusions, see the discussion of the meanings of "citizenship" and "nationality" and their equivalents in many different European languages at the website of the EU Democracy Observatory on Citizenship, http://eudo-citizenship.eu/ databases/citizenship-glossary/terminology, last accessed 5 November 2014.

12 Weis, Nationality and Statelessness, pp.8-10. Compare the English law concept of allegiance, owed by more than nationals: see Colin R.G. Murray, "In the Shadow of Lord Haw Haw: Guantánamo Bay, Diplomatic Protection and Allegiance”, Public Law, 2011, No.1, pp.115138.

13 See for example T.H. Marshall "Citizenship and Social Class", and JGA Pocock "The Idea of Citizenship Since Classical Times", and other essays extracted in Gershon Shafir (ed.) The citizenship debates: A reader, University of Minnesota Press (1998).

14 Patrick Weil, Qu'est-ce qu'un Français: histoire de la nationalité française depuis la Révolution, Paris: Grasset, 2002 ; Gérard Noiriel, "Socio-histoire d'un concept. Les usages du mot "nationalité " au XIXe siècle", Genèses, Vol.20, 1995, pp. 4-23 ; Olivier Gohin, "La citoyenneté dans l'outre-mer français", Revue française d'administration publique, No.101, 2002, pp.69-82. 
the term nationality is used with the connotation that someone of a particular (legal) nationality should belong to the racial, religious or ethnic group believed to make that nation. In this sense, the difference between citizenship and nationality is seen not as the distinction between the rights of members of the polity and the rules that define who is a member, but between a definition based on active participation, and a status-based definition, in this case deriving from descent and identity.

Thus, some authors use "nationality" to mean a concept based on "nation" and identity, both among political theorists and in the context of legal discussions. Patrick Chabal, for example, uses "nationality" to mean "the cluster of historical and cultural characteristics which are (implicitly or explicitly) recognised by the national subjects as defining a particular country, if only in relation to other countries". ${ }^{15}$ Patricia Nanz, discussing the European Union citizenship regime, uses nationality to mean belonging, and citizenship to mean legal status. ${ }^{16}$ The frequent use of "nation-state" in both journalism and academic literature to mean, in different contexts, both a state based on a pre-existing culturally and ethnically unified nation, and a state that is in the process of building an idea of national identity, does not help with this confusion. ${ }^{17}$ The very name of the United Nations, a collective of states responsible for defining the rules on these issues at international level, reinforces the problem.

In law, however, neither "citizenship" nor "nationality" is used (in English or French) to indicate the ethnic origin of the individual concerned: the terms refer only to the legal bond between a person and a state, and the rights and obligations that accompany that bond. Yet even in legal usage, the terms to describe the main ways in which the legal status of national is acquired can lead to misunderstandings. In particular, the distinction between jus sanguinis and jus soli systems for acquiring nationality encourages the sense that jus sanguinis the law of blood, even if disguised in Latin - means membership of an ethnically

15 Chabal, Power in Africa, p.121.

16 Patricia Nanz, "Mobility, Migrants and Solidarity: Towards an Emerging European Citizenship" in Seyla Benhabib and Judith Resnik (eds.), Migrations and Mobilities: Citizenship, Borders and Gender NYU Press, 2009, p.44. See also Stephen Castles and Alastair Davidson, Citizenship and Migration: Globalization and the politics of belonging, Macmillan, 2000, p.12, on the "contradiction between citizenship and nationality, or between the nation of a citizen as an individual abstracted from cultural characteristics, and that of a national as a member of a community with common cultural values".

17 For example, see Richard Dowden, "The State of the State: The past, present and future of the nation state in Africa”, New Economy, Institute for Public Policy Research (London), Vol.11, No.3. September 2004. Jeffrey Herbst talks of finding "alternatives to the nationstate in Africa", States and Power in Africa: Comparative Lessons in Authority and Control, Princeton University Press, 2000, p.259. See also, Geschiere, The Perils of Belonging, on the idea of defining the nation in the "republican" way; Will Kymlicka, Multicultural Citizenship: A Liberal Theory of Minority Rights, OUP, 1995; Castles and Davidson, Citizenship and Migration, Chapter 1. 
defined nation; a meaning emphasised by the formerly almost universal rule that it was only a father that could pass nationality to his child, allegedly to avoid the possibility of dual nationality but in practice preserving male-line genealogies. Historically, indeed (and till today in some countries), this principle often had an ethnic or racial component, whereby citizenship was based on membership of the dominant ethnic, racial or religious group in a country. The fact that international lawyers will tell you that today the acquisition of citizenship by descent depends on no more than that you have a parent who has citizenship, however acquired (including by naturalisation, that is, on application as an adult), is easily ignored. ${ }^{18}$

Similar nuances exist in other languages. In a discussion of the management of nationality in the context of state succession in Sudan, Munzoul Assal argues that:

In Sudan... both law and common discourse focus on nationality (jinsiyya in Arabic) rather than on citizenship (muwatana in Arabic). [T] he concept of nationality valorises ethnicity... emphasising nationality instead of citizenship results in disenfranchising the less privileged segments of the population. There is a need to shift the emphasis from nationality to citizenship, which becomes particularly urgent as the constitutional foundation is being laid for two new states. ${ }^{19}$

Even in contexts divorced from ideas of ethnic affiliation, distinctions between nationality as the legal bond with a particular state applicable at the international level, and citizenship as the full right to participate in the public affairs of that state, are by no means irrelevant in the $21^{\text {st }}$ century. Most obviously, gender discrimination was the norm until very recently in most countries and, though diminishing, is still quite pervasive. In the realm of nationality law, some of the older international treaties in fact assumed that gender discrimination would be applied, while trying to minimise the statelessness that could result. ${ }^{20}$ In relation to citizenship as political participation, adult women were of course late to be given the universal right to vote (and still cannot in some countries), and often had or have lesser rights in relation to property, family decision-making and other matters.

18 And even in international treaties, the use of "national or social origin" in, for example, the list of prohibited grounds for discrimination contained in the International Covenant on Civil and Political Rights (Article 2), creates a sense of overlap between the idea of nationality and the idea of ethnic identity.

19 Munzoul A.M. Assal, Nationality and Citizenship Questions in Sudan after the Southern Sudan Referendum Vote, Christian Michelsen Institute, 2011. For more on the distinctions between jinsiyya and muwatana see Gianluca P. Parolin, Citizenship in the Arab world: Kin, Religion and Nation State, Amsterdam University Press, 2009.

20 For example, the 1957 Convention on the Nationality of Married Women. 
The distinction between the concept of citizenship as full membership and nationality as the basic legal link also allowed for - and was reinforced by - the systems of legalised racial, ethnic and religious discrimination that were implemented in the European colonial states, most of all in Africa; systems which of course also emphasised "primordial" membership rather than procedural systems of managing the right to belong. In African countries under colonial or white minority rule, only those of European descent had both nationality and full citizenship rights, and only a tiny minority of Africans were ever given the right to cross that line, whatever other criteria they might fulfil. Even once the 1946 constitution of the French $4^{\text {th }}$ Republic explicitly stated that there was a common citizenship across the Union française, the rules still allowed for different rights to political participation and civil liberties for those with French civil status and those indigènes or natives subject to local personal law. Britain retained similar distinctions to the date of independence. ${ }^{21}$ Only with the departure of the colonial empires was a unified citizenship status legislated in the newly independent African countries (see further, chapter 4).

\subsection{Citizens' rights or human rights?}

Today, the international framework of human rights law establishes what has come to be classified as a "peremptory norm" of non-discrimination. The norm, explicitly restated in most of the international human rights treaties, requires that all those who are nationals of a state enjoy the same rights, and that discrimination in access to nationality is not permitted on grounds of race, religion, ethnicity, gender or similar criteria. Even though this rule is of course often not respected in practice, it has effectively removed the permissibility of a distinction between citizenship (as participation) and nationality (as a legal bond not necessarily encompassing full civic rights) in international law: any person who has the nationality of the state must be an equal with all other nationals, and have the same rights to participate. That is, all nationals must also be full citizens; so nationality and citizenship have become international law synonyms, even if the subliminal messages buried in their etymologies and histories still influence the way that they are heard by different audiences - and even if the application of the law may bely this conclusion.

The only exceptions to non-discrimination permitted in relation to internationally recognised human rights are those between citizens and noncitizens related to entry and residence in the country and to political choice and

21 Even in Britain itself, those seeking assistance under the Poor Laws were disenfranchised until as late as 1918, when the link between economic substance and political rights was finally broken, and political rights became linked instead simply to personal status as citizen; plural voting for those graduated from university was only finally abolished by Representation of the People Act 1948 - the same year as the first major nationality law reform. 
participation. States are permitted to restrict to nationals the right to enter or to permanent residence within the state; the right to freedom of movement within the state; the right to vote, run for office, or hold a public position; and the right to diplomatic or consular protection.

Even these distinctions are becoming increasingly blurred. Perhaps most significantly for a discussion of nationality in international law, the rules on the right to diplomatic and consular protection when outside the country are becoming less stable. The contexts in which a state may exercise diplomatic protection have widened to include cases of dual nationality, stateless persons and refugees, and even for permanent residents who are not citizens. ${ }^{22}$ Meantime, citizenship rights are increasingly extended to non-citizen permanent residents, including the right to vote. ${ }^{23}$ These developments have led scholars such as Yasemin Soysal to argue that citizenship is an out-of-date concept. The source of legitimacy for a person's rights is no longer his or her citizenship of a state but international human rights law; the content of those rights is set at international and not state level: status and rights are now "post-national" rather than national. ${ }^{24}$ Above all, this analysis is rooted within the European Union, where supra-national rights protection has been most institutionalised.

Yet enforcement of human rights remains very much concentrated at the national level: although a weak international enforcement regime exists, it is

22 For example, the British government sought to exercise rights of diplomatic protection in the case of non-nationals ordinarily resident in the UK detained by the US government in Guantanamo Bay - even though this was less a product of legal pressure than of the desire to distance the United Kingdom from increasingly unpopular policies adopted by the United States. See, Murray, "In the Shadow of Lord Haw Haw". See also Olivier de Frouville "Affaire Ahmadou Sadio Diallo (République de Guinée c. République Démocratique du Congo). Exceptions préliminaires : Le roman inachevé de la protection diplomatique", Annuaire français de droit international Vol.53 (2007) pp.291-327 ; Annemarieke Vermeer-Kunzli, "Nationality and diplomatic protection", in Alessandra Annoni and Serena Forlatti (eds.) The Changing Role of Nationality in International Law, Routledge, London and New York, 2013.

23 Again in the case of Britain, citizens of Commonwealth countries who are resident in the UK are entitled to vote in national elections; while the European Union requires some reciprocal voting rights across its 27 states. See, for example, Bauböck, and Rundell Blurred boundaries; Benhabib and Resnik (eds.) Migration and Mobilities; Seyla Benhabib, The rights of others : aliens, residents, and citizens, Cambridge University Press, 2004; Riva Kastoryano, "Citizenship, Nationhood, and Non-Territoriality:Transnational Participation in Europe", PS: Political Science and Politics, Vol. 38, No. 4, 2005, pp. 693-696; Rainer Bauböck, "Expansive Citizenship:Voting beyond Territory and Membership, PS: Political Science and Politics, Vol. 38, No. 4 (Oct., 2005), pp. 683-687; David C. Earnest, Noncitizen Voting Rights: A Survey of an Emerging Democratic Norm, paper prepared for delivery at the 2003 annual convention of the American Political Science Association, Philadelphia, Pennsylvania, August 28-31, 2003.

24 See especially Yasemin Nuhoğlu Soysal, Limits of Citizenship: Migrants and Postnational Citizenship in Europe, University of Chicago Press, 1994. 
individual states that sign up for the treaties on which these rights are based, and individual states that are responsible to "respect, protect, and fulfil" the rights guaranteed to their citizens. ${ }^{25}$ States still retain their sovereignty in international law. Discrimination on the basis of citizenship is still permitted where other forms of discrimination are not. There are many rights and services available only to citizens (varying by country) that go beyond basic international law requirements and are in practice essential to existence for any person who wishes to interact with any public institution or formalised private body, and thus to play a full part in the political and economic life of the country: the right to hold a formal-sector job, to own land, to access scholarships for education, to have non-emergency healthcare at public expense, to claim welfare benefits, to move freely and reside anywhere within national borders. Those who hold no nationality at all are excluded from a much wider set of rights. ${ }^{26}$ Control on movement in particular is recognised as being within state discretion, and any state has the right to deny non-nationals the right to entry, effectively on any arbitrary ground. ${ }^{27}$ Much as human rights activists seek to import human rights principles into immigration jurisprudence at national level, only the most egregious abuses associated with detention and deportation - and not even all of those - are condemned by courts as human rights abuses. There are also strong arguments that protection of the full range of citizens' rights may in practice require limits on migration. ${ }^{28}$ States also still retain their discretion to

25 James A. Goldston, "Holes in the Rights Framework: Racial Discrimination, Citizenship, and the Rights of Noncitizens", Ethics and International Affairs,Vol.20, No.3, 2006, pp.321347; David Weissbrodt and Stephen Meili, "Human Rights and the Protection of NonCitizens: Whither Universality and Indivisibility of Rights?" Refugee Survey Quarterly Vol.28, No.4, 2010, pp.34-58.

26 Maureen Lynch, Lives on Hold: The Human Cost of Statelessness, Washington, Refugees International, 2005; Brad K. Blitz and Maureen Lynch, Statelessness and the Benefits of Citizenship: A Comparative Study, Geneva Academy of International Humanitarian Law and Human Rights, 2009; Katherine Southwick and Maureen Lynch, Nationality Rights for All: Global Survey on Statelessness, Refugees International, 2009; Brad K. Blitz, "Statelessness, protection and equality", Forced Migration Policy Briefing No.3, Refugee Studies Centre, University of Oxford, 2009; Brad K. Blitz, Maureen Lynch, Rajith Lakshman and Samantha Balaton Chrimes, The Cost of Statelessness: A Livelihoods Analysis, A project funded by the Bureau of Population, Refugees and Migration, United States Department of State, 2011.

27 For more on these issues see, Amal De Chickera, Unravelling Anomaly: Detention, Discrimination and the Protection Needs of Stateless Persons, London: Equal Rights Trust, 2010.

28 As Linda Bosniak has commented, the human rights community has felt it has to accept limits to human rights in overseeing immigration law; in part as a quid pro quo for the possibility of expanding or defending human rights and measures of economic redistribution and social justice for those who are in fact nationals, or whose right to nationality in due course is allowed (such as recognised refugees, spouses of nationals and long-term legal residents): In order to be "soft on the inside" a state may need to be "hard on the outside". Linda Bosniak, The Citizen and the Alien: Dilemmas of Contemporary Membership, Princeton University Press, 2006. 
decide who is a citizen, even if (as described in the next chapter) this discretion is now constrained by human rights law.

It thus remains the case, in Hannah Arendt's formulation, that in most contexts citizenship is the basis for "the right to have rights". ${ }^{29}$ The case studies in this book amply bear out the continuing meaning of statelessness for those whose citizenship is contested. Although human rights obligations set a minimum standard that is supposed to apply to all, citizenship is, after all, founded on the very idea that the state owes more to its own citizens than to other people in the world. Most humans are not altruistic enough to stretch their solidarity around the world at an even depth of feeling across geographies and cultures. If distinctions between citizens and aliens in state practice are therefore accepted as legitimate - or at least as inevitable - the key question becomes the existence of pathways to citizenship for those who, whether in compliance or defiance of immigration rules, are as a matter of fact settled within the state. Above all, the recognition of citizenship for those who have no viable connections to any other state. What are the rules and processes by which a resident, and especially his or her children, becomes a full member of the polity where their life is lived? How can we best integrate those people who are already resident in our states, to ensure that they have access to citizenship and to the rights of citizens? Michael Walzer notes that "the rule of citizens over non-citizens, of members over strangers, is probably the most common form of tyranny in human history"; thus, "the denial of membership is always the first in a long train of abuses". ${ }^{30}$ There is a delicate balancing act between the recognition of a national community in which greater levels of solidarity apply, and the idea of universal rights applying to all humans wherever they live.

\subsection{A right to nationality?}

The remainder of this text attempts to answer the question of what laws, in the particular context of Africa, create the best systems for national integration and social stability balanced with the respect for individual and universal human rights. That is, to tease out a theory and practice of a right to a nationality in an African setting. The African context is important: as it is a cliché to say, there are particular challenges related to the creation of a national identity and a sense of citizenship in states that were arbitrarily designed at the stroke of a pen in Berlin in 1885, whose designers treated the people they found in these territories as children while they were in charge. Among these challenges is the reality that African states are not easy to fit into either the idea of a "nation" as a group of

29 Hannah Arendt, The Origins of Totalitarianism, 1958.

30 Michael Walzer, Spheres of Justice: A Defense of Pluralism and Equality, New York: Basic Books, 1983, p.62. Walzer's discussion of membership of a political community is of particular interest to the status of "strangers" in African societies. See Chapter 2, especially pp.52-61 on alienage and naturalisation. 
people linked by a common cultural, ethnic, linguistic, religious or other identity, or the model of a "republic" made up of citizens voluntarily assenting to submit to and participate in the government of the state. African states are only too obviously neither unified cultural families nor voluntary comings-together.

As a corollary, the theorising of the means by which citizenship is acquired is also hard to fit to an African context: not the distinction between rights based on descent and on place of birth, which are universally understood, but the back-history of the way these concepts have been framed in a European history of feudal overlordship and allegiance (where citizenship was ascribed at birth), and enlightenment precepts starting with Locke and Rousseau around the social contract that binds citizens together (meaning that citizenship should be consented to, even notionally by choice of residence, as an adult man). ${ }^{31}$ Laws developed around monarchies and the divine right of kings assumed that allegiance was due to the sovereign from all in his territory, and that the other characteristics of a person were irrelevant, providing the person showed allegiance. By contrast, as the great dynastic monarchies began to decline, theorists favouring the city states of Switzerland or post-revolutionary France rather drew on descent as a proxy for consent (since a child could be assumed to wish to share his father's citizenship, with the option to reject it at majority), ${ }^{32}$ and thereby also created an assumption of shared identity rather than common political allegiance. ${ }^{33}$

In Africa, the European powers applied an extreme version of ascriptive membership, in two senses: both that the residents of annexed territories were ascribed the nationality of their annexing state; but also that "natives" in Africa were then subsequently ascribed the identity of particular "tribes", which further determined the legal rules to which they might be subject. In neither case was there any ability to expatriate themselves and choose another allegiance (and, notoriously, tribes were often invented as much as described). ${ }^{34}$ Ethnic identity had no relevance at all to the nationality of a "native" at the international level (that is, in relations between European states, whose jurisdictions crashed

31 For an exposition of the distinction between citizenship based on ascription or consent, with particular reference to the American context, see Rogers Smith and Peter Schuck, Citizenship without consent: Illegal aliens in the American polity, New Haven:Yale University Press, 1985.

32 The founding exponent of this view was the Swiss writer Emmerich deVattel, in his book The Law of Nations or the Principles of Natural Law, published in 1758, highly influential in the early history of citizenship in the United States of America. See Book I, Chapter 19, "Of Our Native Country, and Several Things That Relate to It", available at http:// lonang.com/library/reference/vattel-law-of-nations/, last accessed 24 December 2014.

33 See also Weil, Qu'est-ce qu'un français, chapter 1.

34 Among many other works, see Terence Ranger, "The Invention of Tradition in Colonial Africa", in Eric Hobsbawm and Terence Ranger (eds.), The Invention of Tradition, Cambridge University Press, 1983. For a plea for "dual nationality" and "naturalisation" to be permitted at a "tribal" level in contemporary Uganda, see Donald Rukare, "Should citizens be able to change their tribes?" The Monitor (Kampala), 23 January 2012. 
straight through existing ethno-political boundaries); but it had absolute and exclusive relevance for the person's rights and obligations within the territory of a particular European power. While a few black Africans and those of mixed-race crossed the barriers to acceptance as full citizens of their colonial states, most were permanently confined to a subordinate status within the framework of customary law assigned to govern their affairs as interpreted by European judges.

The different nationality laws inherited by African states along with their borders have been repeatedly amended, as the new governments have grappled — in good or bad faith - with the conundrum of the definition of citizenship in a legal universe that had to meld these parallel systems of colonial law and such national traditions as they could draw on. They have had to work with the multiplicity of popular understandings of belonging based on pre-colonial entities as impacted by the invented traditions of the colonial powers, and popular resentments of the economic disturbances brought by colonialism (above all, the expropriation of land). Part II of this book contains many illustrations of ways in which these efforts have turned out for the bad, when politicians have chosen to manipulate the lacunae in the law for their own short-term advantage rather than seeking to plug the gaps. The most prevalent way of doing so is an argument from "we were here first", an argument which has resonance across the world and especially in Africa, but is particularly hopeless as the basis for a stable polity (leaving aside the human rights implications) in an African context.

What, therefore, is a useful conceptualisation of the core content of nationality and its legal foundations if not the ascriptive one of the colonisers? History and experience is the only possible place to start: the legacy of colonisation, followed by the decision to respect colonial borders, creates a moral responsibility of solidarity to those who have shared that journey. At the African level, this idea already has a deep hold on popular consciousness: the heritage of the great panAfricanists is embedded in a shared sense of Africanness across the continent. ${ }^{35}$ The transformation of the OAU into the African Union, and the development of regional economic communities, brought further discussion of the promotion of freedom of movement, and even the recognition in principle of an African citizenship, but the most notable thinking has gone into the economics rather than politics of integration. Some individual thinkers and independence leaders, such as Julius Nyerere, also put serious thought into the creation of a national identity within the borders that had been inherited. ${ }^{36}$ But there has been much

35 Toyin Falola and Kwame Essien (eds.), Pan-Africanism and the politics of African citizenship and identity, New York: Routledge, 2014; Ian Duffield, "Pan-Africanism since 1940" in J. D. Fage, Michael Crowder, and Roland Oliver (eds.), The Cambridge History of Africa, 1984, Volume 8; Paul G. Adogamhe, "Pan-Africanism Revisited:Vision and Reality of African Unity and Development”, African Integration Review,Vol.2, No.2, 2008.

36 For a recent article considering his legacy, see Marie-Aude Fouéré, "Julius Nyerere, Ujamaa, and Political Morality in Contemporary Tanzania", African Studies Review, Vol.57, No.1, April 2014, pp. 1-24. 
less intellectual work around the adoption of practical rules for deciding who is a national and how to give recognition of that identity, within the context of the borders of today's states. The project of pan-Africanism (erratic as its progress has been) has not been matched by projects of imagination at the level of political units that actually exist.

Here we return to the fundamental idea of a "genuine link" to a state which grants its nationality, but applied in a positive rather than negative way: imposing a requirement on a state to recognise a person as a national, rather than in imposing a restriction on the state's rights to intervene on behalf of an individual outside its territorial jurisdiction. The Nottebohm judgment has been criticised for its conclusion that the lack of a "genuine connection" meant that the state had no right to exercise diplomatic protection on an individual's behalf. ${ }^{37}$ If applied more widely today, the "genuine link" requirement could leave many at risk of statelessness. ${ }^{38}$ However, considering the requirement the other way around, we come to the argument that, in certain circumstances a state should have to recognise an individual as one of its own and grant its nationality because there is a "genuine link" (rather than being prevented from doing so if there is not). ${ }^{39}$ The concept of mutual consent to the sovereignty of the state is transmuted into one of mutual acceptance of the ties created by a shared political history and lived experience. What is it that would give someone the right to call on a state for recognition of the person's part in that shared experience, in return for that person's allegiance to the state? The criteria are not hard to imagine, based as they are on rules that are already in currency: birth and residence of that person, and the birth and residence of his or her parents, grandparents, children or spouse; as well as similar connections to former political units that have been reconfigured to make up the state now in existence. In the words of the Nottebohm case: "the habitual residence of the individual concerned but also the centre of his interests, his family ties, his participation in public life, attachment shown by him for a given country and inculcated in his children, etc." ${ }^{40}$ Many African states already have rules that respect such ideas, and implement them in practice. Others do not; as this work sets out to show. In Part III, I return to the specifics of the rules that should be put in place.

37 The interpretation could be justified by the fact that he had blatantly sought to abuse the rules applying to nationality for his own benefit: Nottebohm had changed nationality from Germany to Liechtenstein purely to avoid being an "enemy alien" in Guatemala.

38 Robert D. Sloane, "Breaking the Genuine Link: The Contemporary International Legal Regulation of Nationality”, Harvard International Law Journal,Vol.50, No.1, 2009.

39 Most obviously argued in the context of diplomatic protection: Myres S. McDougal, Harold D. Lasswell and Lung-chu Chen, "Nationality and Human Rights:The Protection of the Individual in External Arenas", Yale Law Journal Vol.83 No.5, 1974, pp.900-998; Annemarieke Vermeer-Kunzli, "Nationality and diplomatic protection".

40 Nottebohm Case, p.22. 



\section{International and African norms on citizenship}

(1) Everyone has the right to a nationality.

(2) No one shall be arbitrarily deprived of his nationality nor denied the right to change his nationality.

— Article 15, Universal Declaration of Human Rights, 1948

The international regulation of nationality was historically organised for the benefit of states, rather than for people, with rules developed to prevent international friction rather than ensure individual rights. However, with the development of the international human rights system of treaties, constraints have been imposed on the discretion of states to determine for themselves who are their nationals. This chapter sets out the norms that have developed since the rules of nationality were first adopted. There is agreement that statelessness is to be avoided, that states may not discriminate in the grant or deprivation of nationality on any of the usual grounds, and that due process must be respected. Principles have also been elaborated to govern state succession, one of the primary generators of statelessness, though they are not formally endorsed by member states of the UN. At the African level, the African Commission on Human and Peoples' Rights has developed an extensive jurisprudence on matters related to nationality, even though the right to a nationality is not explicitly included in the African Charter on Human and Peoples' Rights. The very first case heard by the African Committee of Experts on the Rights and Welfare of the Child was on article 6 of the African Children's Charter, in which the treaty body gave a strong endorsement to the obligations of states to provide their nationality to children born on their territory who would otherwise be stateless.

\subsection{The recognition of the right to a nationality}

Historically, the rules developed to govern relations between sovereign states assumed that rights attached to individuals only through the protection of the sovereign state whose nationality they had. States had rights in the international arena, individuals did not; an individual person was not a proper subject of international law and must have a protector in the form of a state. The rules of diplomatic protection were likely to be more useful than human rights arguments (which indeed did not exist at the outset of these arguments) for any individual in trouble outside his or her state of nationality. At the same time, states had a very wide discretion to decide which individuals were its nationals, when to offer them diplomatic protection overseas, and what rights to grant to them at home. The grant of nationality was regarded as being within the "reserved 
domain" of states, a position affirmed by the Permanent Court of International Justice in $1923 .{ }^{1}$ The only limitations to this right related to the imposition of nationality on individuals which the state could not reasonably claim as its own, since that would infringe on the sovereignty of other states. ${ }^{2}$

Since that date, however, international human rights law has increasingly asserted limits to state discretion, in this as in other areas; both before but especially after the foundation of the United Nations hand the treaties of international human rights law. ${ }^{3}$

In 1930, the Hague Convention on Certain Questions Relating to the Conflict of Nationality Laws was the first recognition that state discretion was not absolute. It stated in its preamble that it is in the interest of the international community to ensure that all countries recognise that "every person should have a nationality". While affirming that each state may determine its own citizenship laws, Article 1 of the Convention notes that other states will recognize these laws only insofar as they are consistent with international conventions, custom, and "principles of law generally recognized with regard to nationality". ${ }^{4}$ The Hague Convention was an attempt to harmonise citizenship rules among states in order to guarantee citizenship to all while reducing the incidence of dual citizenship, seen as a problem both for individuals (who could, for example, be subject to military service obligations in two countries) as well as the national security of states (because of the divided loyalties of their citizens). ${ }^{5}$ Among the few ratifications of the treaty (which remains in force though largely superseded) were a number of African countries. ${ }^{6}$

1 Tunis and Morocco Nationality Decrees case, PCIJ Ser.B., No.4 (1923).

2 Weis, Nationality and Statelessness; Ruth Donner, The Regulation of Nationality in International Law, 2nd Ed, Transnational Publishers, 1994.

3 Johannes M.M. Chan, "The Right to a Nationality as a Human Right:The Current Trend Towards Recognition”, Human Rights Law Journal,Vol. 12, No.1-2, 1991, pp.1-14;

4 "It is for each State to determine under its own laws who are its nationals. This law shall be recognized by other States in so far as it is consistent with international conventions, international custom, and the principles of law generally recognized with regard to nationality." League of Nations, Convention on Certain Questions Relating to the Conflict of Nationality Law, 13 April 1930 (entered into force 1937), article 1.

5 Weis, Nationality and Statelessness; Alfred Michael Boll, Multiple nationality and international law, Martinus Nijhoff Publishers, 2007; Michel Verwilghen, "Conflits de nationalités, Plurinationalité et apatridie", Recueil des cours Vol.277, Hague Academy of International Law, 1999. A Special Protocol Concerning Statelessness adopted by the same Hague conference, which never entered into force, only dealt with readmission of nationals who had been deprived of their nationality after entering a foreign country.

6 Out of 23 states parties total (with a much larger number of signatories who did not ratify), five are African: Lesotho, Liberia, Mauritius, Swaziland and Zimbabwe; Egypt and South Africa signed but have not ratified. Britain ratified on behalf of itself "and all parts of the British Empire which are not separate members of the League of Nations", but only a handful of former British protectorates have formally notified their succession 
The adoption of the Universal Declaration of Human Rights in 1948 marked a significant step forward; in this as in other commitments shaped by the brutal history of the just-concluded war.Article 15 provides that "[e]veryone has a right to a nationality" and that " $[\mathrm{n}]$ o one shall be arbitrarily deprived of his nationality nor denied the right to change his nationality." Scholars are split on whether the Universal Declaration is itself international customary law or is simply a reflection of such law, ${ }^{7}$ but in either case the inclusion of nationality in the declaration implies that even states that have ratified none of the relevant treaties are bound to respect nationality as a human right. The critical omission from the declaration, however, was an indication as to which state had the obligation to fulfil the right. Although this lacuna remains, further restrictions on state discretion have been established, as this chapter sets out.

The Inter-American Convention on Human Rights, adopted in 1969 (entry into force 1978) was the first binding instrument to create a general right to a nationality, and also provides that a person has the right to the nationality of the state in whose territory he was born if he does not have the right to any other nationality. ${ }^{8}$ The European Convention on Nationality adopted by the Council of Europe in 1997 (entry into force 2000) also establishes as a basic principle that everyone has the right to a nationality and creates obligations in case of stateless children and adults. ${ }^{9}$

to these obligations. Belgium's ratification was "Subject to accession later for the Colony of the Congo". UN Treaty Collection Database, https://treaties.un.org/Pages/ LONViewDetails.aspx?src $=$ LON\&id $=512 \&$ chapter $=30 \&$ lang $=$ en, last accessed 15 January 2015.

7 See for example, Hurst Hannum, "The Status and Future of the Customary International Law of Human Rights: The Status of the Universal Declaration of Human Rights in National and International Law," Georgia Journal of International and Comparative Law, Vol.25, 1995, pp.287-397; Henry J. Steiner, Philip Alston, and Ryan Goodman, International Human Rights in Context: Law, Politics, Morals-Texts and Materials, Oxford: Oxford University Press ( $3^{\text {rd }}$ edition), 2007.

8 American Convention on Human Rights, Article 20-Right to Nationality. "(1) Every person has the right to a nationality. (2) Every person has the right to the nationality of the state in whose territory he was born if he does not have the right to any other nationality. (3) No one shall be arbitrarily deprived of his nationality or of the right to change it." An important advisory opinion affirmed the right to nationality as recognised in international law: Re Amendments to the Naturalisation Provisions of the Constitution of Costa Rica, InterAmerican Court of Human Rights, Advisory Opinion of 19 January 1984, OC-4/84.

9 European Convention on Nationality, Article 4-Principles. "The rules on nationality of each State Party shall be based on the following principles: (a) everyone has the right to a nationality; (b) statelessness shall be avoided; (c) no one shall be arbitrarily deprived of his or her nationality; (d) neither marriage nor the dissolution of a marriage between a national of a State Party and an alien, nor the change of nationality by one of the spouses during marriage, shall automatically affect the nationality of the other spouse." 


\subsection{Non-discrimination}

The most pervasive form of discrimination in the field of nationality is that based on sex, and it was presumed by the drafters of the Hague Convention of 1930 that the nationality of a woman and her children would follow that of her husband; a protocol adopted at the same time clarified that a mother should be able to confer nationality on her children at least where the father is unknown or stateless. ${ }^{10}$ The 1957 Convention on the Nationality of Married Women reinforced this understanding and focused on avoiding statelessness deriving from conflict of laws, while also attempting to give the woman more choice in the matter and withdrawing somewhat from the vision of the dependency of the whole family on the husband and father. ${ }^{11}$ Only with the 1979 adoption by the UN General Assembly of the Convention for the Elimination of All Forms of Discrimination Against Women (CEDAW) was nationality law brought within the remit of requirements for non-discrimination on the basis of sex. Article 9 requires that "Parties shall grant women equal rights with men to acquire, change or retain their nationality" and "with respect to the nationality of their children". Another widespread basis for discrimination in nationality laws linked to discrimination on the basis of the sex of the parent is the birth of a child in or out of wedlock; although this is not dealt with in Article 9 on nationality, Article 16(1)(d) of CEDAW specifies that men and women should have "[ $\mathrm{t}]$ he same rights and responsibilities as parents, irrespective of their marital status, in matters relating to their children".

In a general recommendation on equality in marriage and family relations adopted in 1994, the UN CEDAW committee elaborated that : "Without status as nationals or citizens, women are deprived of the right to vote or to stand for public office and may be denied access to public benefits and a choice of residence. Nationality should be capable of change by an adult woman and should not be arbitrarily removed because of marriage or dissolution of marriage or because her husband or father changes his nationality." In addition, "The shared rights and responsibilities enunciated in the Convention should be enforced at law and as appropriate through legal concepts of guardianship, wardship, trusteeship and adoption. States parties should ensure that by their laws both parents, regardless of their marital status and whether they live with their children or not, share equal rights and responsibilities for their children." 12

10 Protocol Relating to a Certain Case of Statelessness, 12 April 1930.

11 For a comprehensive discussion of the history of international law on gender discrimination and nationality, see Karen Knop and Christine Chinkin "Remembering Chrystal MacMillan: Women's Equality and Nationality in International Law", Michigan Journal of International Law, Vol.22, No.4, 2001, pp.523-586.

12 UN Committee on the Elimination of Discrimination Against Women (CEDAW), CEDAW General Recommendation No. 21: Equality in Marriage and Family Relations, para 6. This view was endorsed by the Human Rights Committee's General Comment No. 19: The family (Article 23), 1990, para 7, and General comment No. 28: Article 3 (The equality of 
Many other human rights treaties mention nationality in relation to their own subject matter. The Convention on the Elimination of All Forms of Racial Discrimination (Article 5), the Convention on the Rights of Persons with Disabilities (Article 18), and the Convention on the Protection of the Rights of All Migrant Workers and Members of Their Families (Article 29), all include provisions on nationality.

Although racial and ethnic discrimination remains present in a number of nationality laws globally - tied up as they often are with the idea of nation as family - there is increasing disquiet among human rights bodies at such provisions in nationality law, even where expressed as preferential access to naturalisation for some groups, rather than exclusions in relation to access to nationality from birth. The Committee on the Rights of the Child has commented unfavourably, for example, on discriminatory provisions in the Democratic Republic of Congo (DRC) and Liberia, as well as non-African countries. ${ }^{13}$ The 1961 Convention on the Reduction of Statelessness specifically prohibits denationalisation "on racial, ethnic, religious or political grounds", even if statelessness would not result. ${ }^{14}$ There is more ambivalence in the context of naturalisation, but the Committee on the Elimination of Racial Discrimination, the Human Rights Committee and the Committee on the Rights of the Child have all expressed disquiet about discrimination in naturalisation procedures (in Korea, Japan, Panama, Kuwait and other cases). Affinity-based naturalisation preferences, common in Hispanic countries, have been accepted by the Inter-American Court on Human Rights (with limits), but criticised by the UN bodies in the case of Israel's law of return or a Qatari provision favouring naturalisation of foreign nationals from Arab states. ${ }^{15}$ The Organisation for Security and Cooperation in Europe has accepted the idea of kin-based preferences in some circumstances, but placed restrictions on their use. ${ }^{16}$ While some language and cultural assimilation requirements are seen as reasonable in the case of naturalisation, discriminatory group preferences or exclusions are not.

rights between men and women), para 25 (2000); and by CERD in its General recommendation No. 21: Equality in marriage and family relations (1994). All available in Extracts of selected General Comments and Recommendations of the United Nations Human Rights Treaty Bodies relating to nationality and statelessness, November 2009, available at the UNHCR website http://www.refworld.org/statelessness.html, last accessed 26 January 2015. See also UNHCR, Revised Background Note on Gender Equality, Nationality Laws and Statelessness, 8 March 2013.

13 Committee on the Rights of the Child, Concluding Observations: Democratic Republic of the Congo, CRC/C/15/Add.153, 9 July 2001, para 28. Committee on the Rights of the Child, Concluding Observations: Liberia, CRC/C/LBR/CO/2-4, 13 December 2012, para 41.

14 Convention on the Reduction of Statelessness, Article 9.

15 For a survey, see Peter J. Spiro, "A new international law of citizenship”, American Journal of International Law, Vol.105, 2011, pp.694-746, at pp.727-730. The leading IACtHR case is Re Amendments to the Naturalisation Provisions of the Constitution of Costa Rica.

16 See chapter 3.11 on the Bolzano/Bozen Recommendations. 
The norm on non-discrimination does not extend to different treatment for citizens and aliens: while basic human rights are guaranteed to all in international law, a state may legitimately discriminate between its citizens and aliens on many other matters: the Convention on the Elimination of All Forms of Racial Discrimination (CERD), for example, states in its article 1(2) that "This Convention shall not apply to distinctions, exclusions, restrictions or preferences made by a State Party to this Convention between citizens and noncitizens". This permissible discrimination makes non-discrimination in access to citizenship itself the more important.

Access to nationality on an equal basis is thus foundational to the right to participate in public affairs, to vote and to hold public service positions, guaranteed by Article 25 of the International Covenant on Civil and Political Rights (ICCPR). Thus, in its General Comment on the impact of this article, the UN Human Rights Committee, responsible for oversight of the ICCPR, stated that:

No distinctions are permitted between citizens in the enjoyment of these rights on the grounds of race, colour, sex, language, religion, political or other opinion, national or social origin, property, birth or other status. Distinctions between those who are entitled to citizenship by birth and those who acquire it by naturalization may raise questions of compatibility with article 25 [to vote and participate in public affairs]. State reports should indicate whether any groups, such as permanent residents, enjoy these rights on a limited basis, for example, by having the right to vote in local elections or to hold particular public service positions. ${ }^{17}$

Given that freedom of movement within a state is guaranteed to all citizens (and, indeed, all those lawfully within a state) ${ }^{18}$, national migrants should not be discriminated against by local or regional governments compared to those born in the territory of that sub-national government. At the same time, affirmative action measures are permitted in international law to respond to historical injustice and contemporary disadvantage. ${ }^{19}$

In 2005, the UN Committee on the Elimination of Racial Discrimination adopted a General Recommendation on discrimination against non-citizens, which outlined states' obligations in relation to providing access to citizenship as follows. States should:

17 Human Rights Committee, General Comment No. 25: The right to participate in public affairs, voting rights and the right of equal access to public service, 1996.

18 ICCPR, Article 12(1): "Everyone lawfully within the territory of a State shall, within that territory, have the right to liberty of movement and freedom to choose his residence."

19 Human Rights Committee, General Comment No. 18: Non-discrimination, 1989. 
13. Ensure that particular groups of non-citizens are not discriminated against with regard to access to citizenship or naturalization, and to pay due attention to possible barriers to naturalization that may exist for long-term or permanent residents;

14. Recognize that deprivation of citizenship on the basis of race, colour, descent, or national or ethnic origin is a breach of States parties' obligations to ensure non-discriminatory enjoyment of the right to nationality;

15. Take into consideration that in some cases denial of citizenship for long-term or permanent residents could result in creating disadvantage for them in access to employment and social benefits, in violation of the Convention's anti-discrimination principles;

16. Reduce statelessness, in particular statelessness among children, by, for example, encouraging their parents to apply for citizenship on their behalf and allowing both parents to transmit their citizenship to their children; 17. Regularize the status of former citizens of predecessor States who now reside within the jurisdiction of the State party; $[\ldots . .]^{20}$

The European Convention on Nationality avoids any doubt on the universal application of these norms, and specifically bars discrimination in granting access to nationality: "The rules of a State Party on nationality shall not contain distinctions or include any practice which amount to discrimination on the grounds of sex, religion, race, colour, or national or ethnic origin". ${ }^{21}$

All African countries except Sudan, South Sudan, and Somalia are parties to the UN Convention on the Elimination of All Forms of Discrimination Against Women. Algeria, Egypt, Mauritania, Niger, and Tunisia ratified the convention with reservations relevant to their nationality laws, mainly referring to the provisions of shari'a law in relation to equality of men and women; in 2014, Tunisia withdrew its reservations. ${ }^{22}$ All African countries except Angola and South Sudan are parties to CERD; Angola signed in 2013. ${ }^{23}$

20 Committee on the Elimination of Racial Discrimination, General Recommendation No.30: Discrimination against Non-citizens, 2005.

21 European Convention on Nationality, Article 5(1).

22 List of participants to CEDAW at the UN treaties website, https://treaties.un.org/pages/ ViewDetails.aspx?src=TREATY\&mtdsg_no=IV-8\&chapter=4\&lang=en, last accessed 2 December 2014. See also "Tunisia : Withdrawal of the declaration with regard to Article 15(4) and of the reservations to Articles 9(2), 16 (c), (d), (f), (g), (h) and 29(1) made upon ratification”, UN Document C.N.220.2014.TREATIES-IV.8 (Depositary Notification). The decision to withdraw the reservations (Article 9(2) relates to the equal right to transmit nationality to children) was first announced in 2011.

23 List of participants to CERD at the UN treaties website, https://treaties.un.org/Pages/ ViewDetails.aspx?src $=$ TREATY\&mtdsg no $=I V-2 \&$ chapter $=4 \&$ lang $=$ en, last accessed 2 December 2014. 


\subsection{Protection of stateless persons}

The 1954 Convention relating to the Status of Stateless Persons was adopted in recognition that there were people who needed the same sort of protection as refugees, but who did not fall under the definition of refugee adopted in the 1951 Convention relating to the Status of Refugees. ${ }^{24}$ The objectives of the 1954 convention were to define a class of stateless persons, to regulate and improve their status and to assure to them the widest possible exercise of fundamental rights and freedoms. ${ }^{25}$ The convention provides the definition that:

'Stateless person' means a person who is not considered as a national by any State under the operation of its law. ${ }^{26}$

UNHCR Guidelines on this definition note that "establishing whether an individual is not considered as a national under the operation of its law ... is a mixed question of fact and law". Thus, "Where the competent authorities treat an individual as a non-national even though he or she would appear to meet the criteria for automatic acquisition of nationality under the operation of a country's laws, it is their position rather than the letter of the law that is determinative in concluding that a State does not consider such an individual as a national." 27

The 1954 Convention establishes a range of civil, economic, social and cultural rights for stateless people that must be respected by states who are party to the treaty. UNHCR has also issued guidelines on the procedures states parties to the treaty should adopt to identify stateless persons and on the measures to be provided for their protection at national level. ${ }^{28}$ (See

24 For a short summary of the drafting history of the convention, see Guy Goodwin-Gill, Convention Relating to the Status of Stateless Persons, UN Audiovisual Library of International Law, 2010, available at http://www.un.org/law/avl/, last accessed 12 September 2014.

25 See discussions by Carol A. Batchelor, in "Stateless Persons: Some Gaps in International Protection", International Journal of Refugee Law,Vol.7, No.2,1995, pp.232-259; "Statelessness and the Problem of Resolving Nationality Status," International Journal of Refugee Law, Vol.10, No. 1/2, 1998, pp.156-183, and “Transforming International Legal Principles into National Law: The Right to a Nationality and the Avoidance of Statelessness", Refugee Survey Quarterly, Vol. 25, No.3, 2006, pp.8-25.

26 Convention relating to the Status of Stateless Persons, 1954, article 1(1).

27 UNHCR, Guidelines on Statelessness No. 1: The definition of "Stateless Person" in Article 1(1) of the 1954 Convention relating to the Status of Stateless Persons, HCR/GS/12/01, 20 February 2012, paragraphs 16 \& 30. See also Ruma Mandal, The definition of "Stateless Person" in the 1954 Convention relating to the Status of Stateless Persons: Article 1(1) - The Inclusion Clause, UNHCR, 19 May 2010.

28 Guidelines on Statelessness No. 2: Procedures for Determining whether an Individual is a Stateless Person, HCR/GS/12/02; Guidelines on Statelessness No. 3: The Status of Stateless Persons at the National Level, HCR/GS/12/03, UNHCR 2012; all three Guidelines were compiled into a Handbook on Protection of Stateless Persons under the 1954 Convention Relating to the Status of Stateless Persons, UNHCR 2014. 
further chapter 15.4 for a discussion of the definition of stateless person and its usefulness in practice.)

\subsection{Prevention and reduction of statelessness}

The 1961 Convention on the Reduction of Statelessness, which entered into force in 1975, makes it a duty of states to prevent statelessness in nationality laws and practices. However, many of its articles are bound about with caveats reflecting "the unfortunate hallmarks of an international compromise". ${ }^{29}$ In relation to prevention at the outset of life, Article 1 mandates that "A Contracting State shall grant its nationality to a person born in its territory who would otherwise be stateless"; sub-articles give states a great deal of latitude in how they achieve this, allowing for application procedures rather than automatic attribution, though human rights principles increasingly restrict this discretion. ${ }^{30}$ In relation to withdrawal of nationality, Article 8(1) directs that "A Contracting State shall not deprive a person of his nationality if such deprivation would render him stateless." Although Article 8 does provide limited legitimate grounds (where, for example, citizenship has been gained by fraud or where a citizen swears allegiance to another state) for the deprivation of nationality even if the deprivation would result in statelessness, such deprivation can occur only through a procedure that respects due process, and new restrictions may not be added.

The International Covenant on Civil and Political Rights (ICCPR), adopted in 1966 (entry into force 1976), does not discuss the nationality of adults, but recognizes the right of "[e]very child ... to acquire a nationality". ${ }^{31}$ This provision is mirrored in the Convention on the Rights of the Child (CRC), which guarantees the right of every child to acquire a nationality, placing a duty on states parties to respect this right. ${ }^{32}$ The difference between the right to a nationality and the right to acquire a nationality is subtle, but the addition of "acquire" was apparently intended by some states to remove any implication that a state party accepted an unqualified obligation to accord its nationality to a child born on its territory. Whether it has this effect in fact is arguable. ${ }^{33}$

In its General Comment 17 on the rights of the child, the UN Human Rights Committee noted in relation to the right to acquire a nationality that:

29 Laura van Waas, "The UN Statelessness Conventions" in Edwards and van Waas (eds.) Nationality and Statelessness under International Law, p.75. A proposed Convention for the Elimination of Future Statelessness never went beyond the status of a draft.

30 See René de Groot, Preventing Statelessness among Children: Interpreting Articles 1-4 of the 1961 Convention on the Reduction of Statelessness and Relevant International Human Rights Norms, background paper for joint UNHCR / Open Society Justice Initiative Expert Meeting on Preventing Statelessness among Children, Dakar, Senegal 23-24 May 2011.

31 International Covenant on Civil and Political Rights, article 24(3).

32 Convention on the Rights of the Child, articles 7(1) and 8(1).

33 Jaap E. Doek, "The CRC and the right to acquire and to preserve a nationality," Refugee Survey Quarterly,Vol. 25,No.3, 2006. 
States are required to adopt every appropriate measure, both internally and in cooperation with other States, to ensure that every child has a nationality when he is born. In this connection, no discrimination with regard to the acquisition of nationality should be admissible under internal law as between legitimate children and children born out of wedlock or of stateless parents or based on the nationality status of one or both of the parents. ${ }^{34}$

The Human Rights Committee thus downplayed the distinction between the right to a nationality and the right to acquire a nationality, insisting on the obligation of states to ensure that a child has a nationality from the moment of birth, rather than following an application process.

In 2011, UNHCR convened an expert meeting on preventing statelessness among children, interpreting the 1961 Convention in light of other human rights obligations, especially the CRC. The conclusions of the meeting emphasised that "The concept 'otherwise stateless' requires evaluating the nationality of a child and not simply examining whether a child's parents are stateless" and that a state "cannot avoid its obligations to grant its nationality to an otherwise stateless person based on its interpretation of another State's nationality laws which conflicts with the interpretation applied by the State concerned." ${ }_{35}$ In the case of a child born outside the state of nationality of the parents, either or both their states of nationality must grant nationality if the child would otherwise be stateless. Young children (foundlings) found abandoned on the territory of a state must acquire the nationality of that state. The meeting recommended that provisions on foundlings "should apply to all young children who are not yet able to communicate accurately information pertaining to the identity of their parents or their place of birth."36

These treaties thus limit state discretion over citizenship, by requiring measures to reduce statelessness, including the grant of nationality to children who would otherwise be stateless, and by prohibiting both discrimination in granting citizenship and arbitrary deprivation of citizenship. These principles were confirmed in a 2005 judgment of the Inter-American Court of Human Rights:

Although the determination of who is a national of a particular state continues to fall within the ambit of state sovereignty, states' discretion must be limited by international human rights that exist to protect individuals against arbitrary state actions. States are particularly limited in their discretion ... by their obligations to guarantee equal protection before the law and to prevent, avoid, and reduce statelessness. ${ }^{37}$

34 Human Rights Committee, General Comment No. 17: Rights of the child (Article 24), para 8.

35 Interpreting the 1961 Statelessness Convention and Preventing Statelessness among Children (The “Dakar Conclusions”), UNHCR, 2011, paragraphs 12 and 13.

36 Ibid., para 44.

37 Dilcia Yean and Violeta Bosico v. Dominican Republic, Inter-American Court of Human Rights 
It remains the case that there is no jurisprudence similar to the Nottebohm case finding that a state is obliged to recognise the nationality of a person who has a genuine link, though there has been some recent debate in international legal fora on a wider obligation, it is still restricted to the situation of stateless people. ${ }^{38}$ In particular, it has been argued that the obligation to grant nationality to an otherwise stateless child born on a state's territory has now entered international customary law. ${ }^{39}$

All African countries with the exception only of South Sudan are parties to the ICCPR and to the Convention on the Rights of the Child. ${ }^{40}$ Djibouti and Mauritania entered comprehensive reservations to the CRC covering virtually all articles, stating that no provision of the convention would be implemented that is contrary to the beliefs of Islam; but only Tunisia made a reservation referring specifically to Article 7 (withdrawn in 2002). ${ }^{41}$

Accessions to the 1954 and 1961 conventions have greatly increased in recent years, and as of the end of 2014, there were 23 African state parties to the 1954 Convention relating to the Status of Stateless Persons; ${ }^{42}$ and 15 to the 1961 Convention on the Reduction of Statelessness. ${ }^{43}$

Case No. 12.189, 8 September 2005.

38 For example, the International Law Commission recommended that in the context of state succession persons with an "appropriate connection" to a successor state should have the right to opt for its nationality, but only if they would otherwise become stateless, leaving them to prove that negative. International Law Commission, Draft Articles on Nationality of Natural Persons in relation to the Succession of States, with commentaries, 1999 (Annex to UNGA Res. 55/153, 12 Dec. 2000), Article 11: Respect for the will of persons concerned. See further below chapter 3.7.

39 Chan, The Right to Nationality.

40 Somalia finally became the $195^{\text {th }}$ party to the CRC in early 2015 : "Government of Somalia ratifies UN Convention on the Rights of the Child", UNICEF, 20 January 2015.

41 "The Government of the Republic of Tunisia considers that article 7 of the Convention cannot be interpreted as prohibiting implementation of the provisions of national legislation relating to nationality and, in particular, to cases in which it is forfeited." See the reservations to the Convention on the Rights of the Child, available from the UN Treaty Collection website https://treaties.un.org/Pages/ViewDetails.aspx?src=TREATY\&mtdsg_no $=I V-$ 11\&chapter=4\&lang=en, last accssed 15 January 2015.

42 Algeria, Benin, Botswana, Burkina Faso, Chad, Côte d'Ivoire, Gambia, Guinea, Lesotho, Liberia, Libya, Madagascar, Malawi, Mozambique, Niger, Nigeria, Rwanda, Senegal, Swaziland, Tunisia, Uganda, Zambia, Zimbabwe.

43 Benin, Chad, Côte d'Ivoire, Gambia, Guinea, Lesotho, Liberia, Libya, Mozambique, Niger, Nigeria, Rwanda, Senegal, Swaziland, and Tunisia. Accessions to both treaties noted at the UN Treaty Collection website https://treaties.un.org/Pages/Treaties. aspx?id=5\&subid=A\&lang=en, last accessed 15 January 2015. 


\subsection{Marriage}

International law provides for no right for foreign spouses to acquire nationality, whether living in the country of the nationality desired or not.The rules included in the 1930 Hague Convention and the 1957 Convention on the Nationality of Married Women were framed in terms that left the rules on marriage up to the state except insofar as they risked creating statelessness and conflicts of law, while the 1957 Convention provided for a women to have a greater right to choose her nationality. CEDAW, adopted in 1979, provided for equality of rights of men and women in relation to nationality — but focused on the right of a woman to choose, rather than to confer her nationality on her husband, and not for any right to nationality in case of marriage. ${ }^{44}$ The 1961 Convention on the Reduction of Statelessness requires states to avoid statelessness in case of loss of nationality on marriage (Article 5); but not, for example, for a stateless person marrying a national to have the automatic right to nationality. The trend, as reflected in the 1997 European Convention on Nationality, is that marriage or dissolution of a marriage does not automatically affect the nationality of the other spouse (Article 4), for the acquisition of nationality by spouses of nationals to be "facilitated" (Article 6(4)), and for dual nationality to be permitted if automatically acquired by marriage (Article 14). In practice, the great majority of countries (in Africa, but also worldwide) do provide for some enhanced access to nationality for spouses.

\subsection{Dual nationality}

The historical principle established by international law was that dual or multiple nationality should be avoided: from the state's point of view it was seen as impossible to tolerate the idea that a person could have two sets of loyalties; while for the individual two nationalities implied two sets of obligations, especially the obligation of military service. ${ }^{45}$ The earliest international agreement on nationality law, the Hague Convention on Certain Questions Relating to the Conflict of Nationality Laws, was in fact aimed at reducing cases of dual nationality by providing agreed rules for which nationality should take priority, though its provisions did not achieve such a result and in any event it gained few ratifications. The Hague Convention also contained the rule that a state could not exercise diplomatic protection on behalf of its national against another

44 Convention on the Elimination of All Forms of Discrimination Against Women, Article 9(1): "States Parties shall grant women equal rights with men to acquire, change or retain their nationality. They shall ensure in particular that neither marriage to an alien nor change of nationality by the husband during marriage shall automatically change the nationality of the wife, render her stateless or force upon her the nationality of the husband."

45 Boll, Multiple nationality and international law; Verwilghen, "Conflits de nationalités, Plurinationalité et apatridie". 
state of which the person was also a national; ${ }^{46}$ an approach rejected by the United States in particular, which wished to retain the possibility of exercising diplomatic protection in favour of its citizens when visiting (but not resettling in) the countries of their birth nationality. The concept of dominant or effective nationality emerged to accommodate such cases. ${ }^{47}$

While it would be too soon to say that a legal norm to permit dual nationality has developed, the trend of practice among states has been increasingly to permit dual nationality, especially for children. ${ }^{48}$

Within the Council of Europe System, the Convention on the Reduction of Cases of Multiple Nationality and Military Obligations in Case of Multiple Nationality, adopted in 1963, established a mechanism seeking to ensure the loss of one nationality in case of acquisition of another, while also providing rules on where military service should be fulfilled, where multiple nationality nonetheless occurred. In 1993, however, the member states of the Council of Europe amended the Convention through a (second) protocol requiring states to allow multiple citizenship in some cases. ${ }^{49}$ The 1997 European Convention on Nationality "recognis[ed] that each State is free to decide which consequences it attaches in its internal law to the fact that a national acquires or possesses another nationality" but went on to require states to allow multiple nationality at least for children or in case of automatic acquisition through marriage, and to provide the same rights to persons with multiple nationality as to those with only their own. ${ }^{50}$

The rules of diplomatic protection have also developed to respond to this change in the view of multiple nationalities, including in the elaboration by the International Law Commission of Draft Articles on Diplomatic Protection adopted in 2006. In the context of dual nationality the ILC develops the idea

46 Article 4 "A State may not afford diplomatic protection to one of its nationals against as State whose nationality such person also possesses."

47 On dominant nationality in potential dual nationality cases, see Donner, Regulation of Nationality, Chapter II ("The principle of the "effective link" in nationality law"), section 4.

48 See generally, the essays in Thomas Faist and Peter Kivisto (eds.), Dual Citizenship in Global Perspective: From Unitary to Multiple Citizenship, Houndmills, UK: Palgrave Macmillan, 2007; Peter J. Spiro, "Dual Citizenship as Human Right", International Journal of Constitutional Law, Vol.8, No.1, 2010, pp.111-130; and see M.P.Vink, G.-R. de Groot and C. Luk (2013). MACIMIDE Global Dual Citizenship Database.Version 1.02. Maastricht: Maastricht University. Available at https://macimide.maastrichtuniversity.nl/ dual-citizenship-database, last accessed 15 January 2015; as well as the EUDO Global databases on acquisition and loss http://eudo-citizenship.eu/global-modes-of-acquisition and http://eudo-citizenship.eu/global-modes-of-loss, last accessed 15 January 2015.

49 Second Protocol amending the Convention on the Reduction of Cases of Multiple Nationality and Military Obligations in Cases of Multiple Nationality, Strasbourg, 2 February 1993.

50 European Convention on Nationality, 1997, Preamble and Articles 14-16. 
of a "predominant" nationality which will provide the state of that nationality the right to intervene, and suggests that in determining which nationality is predominant:

The authorities indicate that such factors include habitual residence, the amount of time spent in each country of nationality, date of naturalization (i.e., the length of the period spent as a national of the protecting State before the claim arose); place, curricula and language of education; employment and financial interests; place of family life; family ties in each country; participation in social and public life; use of language; taxation, bank account, social security insurance; visits to the other State of nationality; possession and use of passport of the other State; and military service. ${ }^{51}$

\subsection{State succession}

State succession, when sovereignty over a territory is transferred from one state to another, creates well-recognised challenges in relation to determination of the legal membership of the successor states. Whether in the context of decolonisation in Africa, the break-up of federal territories, or the secession of a part of a state to form its own new country, the transfer of legal authority creates multiple opportunities for people caught between different rules to find themselves stateless. ${ }^{52}$

The basic presumption in international law on nationality in the context of state succession is the following:

In the absence of agreement to the contrary, persons habitually resident in the territory of the new State automatically acquire the nationality of that State, for all international purposes, and lose their former nationality, but this is subject to a right in the new State to delimit more particularly who it will regard as its nationals. ${ }^{53}$

This customary law presumption is restated in the comprehensive "Draft Articles on Nationality of Natural Persons in Relation to the Succession of States" adopted in 1999 by the International Law Commission. ${ }^{54}$ The Draft Articles state that:

51 Commentary to Article 7:" A State of nationality may not exercise diplomatic protection in respect of a person against a State of which that person is also a national unless the nationality of the former State is predominant, both at the date of injury and at the date of the official presentation of the claim."

52 Donner, Regulation of Nationality, Chapter V ("Nationality and state succession"); Weis, Nationality and Statelessness, Chapter 11 ("Effect of territorial transfers on nationality"); Laura van Waas, Nationality Matters: Statelessness under International Law, School of Human Rights Research/Intersentia, 2009, Chapter VI (Addressing Statelessness in the Context of State Succession).

53 James R. Crawford, The Creation of States in International Law, 2nd Ed (2006), p.53.

54 International Law Commission, Draft Articles on Nationality of Natural Persons in relation to 
Every individual who, on the date of the succession of States, had the nationality of the predecessor State, irrespective of the mode of acquisition of that nationality, has the right to the nationality of at least one of the States concerned. (Article 1)

Subject to the provisions of the present draft articles, persons concerned having their habitual residence in the territory affected by the succession of States are presumed to acquire the nationality of the successor State on the date of such succession. (Article 5)

Further articles provide that states must take "all appropriate measures" to prevent statelessness arising from state succession (Article 4), and that persons shall not be denied the right to retain or acquire a nationality through discrimination "on any ground" (Article 15).

The assumption outlined by the ILC Draft Articles is that the nationality of a successor state will be attributed to persons on the basis of habitual residence in that state. But in addition, states "shall give consideration to the will of persons concerned whenever those persons are qualified to acquire the nationality of two or more States concerned." In particular, a state shall grant a right to opt for its nationality to persons who have an "appropriate connection" with that state - especially, but not only, if they would otherwise be stateless (Articles 23 \& 26). The commentary on the Draft Articles explains that a right to opt has been common practice in many cases of state succession, and that it can help to resolve problems of attribution of nationality where jurisdictions overlap. An "appropriate connection" can mean habitual residence, a legal connection with one of the constituent units of the predecessor state (this refers primarily to membership of one of the units of a former federal state that is being split up), or birth in the territory of a state concerned. But "in the absence of the abovementioned type of link between a person concerned and a State concerned further criteria, such as being a descendant of a person who is a national of a State concerned or having once resided in the territory which is a part of a State concerned, should be taken into consideration" (Article 11, commentary paragraph 10).

These provisions generally reflect the understanding of customary international law that when territory is transferred between different political authorities, those resident in that territory should not suddenly find themselves non-citizens within the new political arrangements. Nonetheless, it is contested whether the presumption based on habitual residence reflects existing customary law (since practice has not always followed this rule). ${ }^{55}$

the Succession of States, with commentaries, 1999. (Annex to UNGA Res. 55/153, 12 Dec. 2000).

55 Francesco Costamagna, "Statelessness in the context of state succession: an appraisal under international law", in Annoni and Forlatti (eds.) The Changing Role of Nationality in 
Until they are formally adopted by the UN General Assembly, the Draft Articles are not formally binding, but do provide the most authoritative guidance on the accepted norms of international law in this area. Although General Assembly's last resolution on the Draft Articles, adopted in 2011, "Emphasized the value of the articles in providing guidance to the States dealing with issues of nationality of natural persons in relation to the succession of States, in particular concerning the avoidance of statelessness", but kicked the question of further action into the indefinite future. ${ }^{56}$. Nonetheless, they remain the most powerful and detailed statement of the principles that should apply, and, in particular, are the strongest global level statement on the obligation of a state to grant its nationality to a person with the strongest links to that state or on the basis of option. ${ }^{57}$

State succession has been provided for with more binding force within the Council of Europe system. The 1997 European Convention on Nationality provides that

In deciding on the granting or the retention of nationality in cases of State succession, each State Party concerned shall take account in particular of:

a) the genuine and effective link of the person concerned with the State;

b) the habitual residence of the person concerned at the time of State succession;

c) the will of the person concerned;

d) the territorial origin of the person concerned. ${ }^{58}$

In 2006, the Council of Europe supplemented this provision with a specific Convention on the Avoidance of Statelessness in Relation to State Succession that elaborates on these rules, again based on the principle that everyone who had the nationality of the predecessor state should have the right to nationality of one or another of the successor states if he or she would otherwise become stateless. ${ }^{59}$ It creates specific obligations for predecessor and successor states,

International Law; Ineta Ziemele, "State succession and issues of nationality and statelessness" in Edwards and van Waas (eds.) Nationality and Statelessness under International Law.

56 UN General Assembly Resolution 66/92, "Nationality of natural persons in relation to the succession of States", of 9 December 2011, "Decided that, upon the request of any State, it will revert to the question of nationality of natural persons in relation to the succession of States at an appropriate time, in the light of the development of State practice in those matters".

57 Jeffrey L. Blackman, "State Successions and Statelessness: The Emerging Right to an Effective Nationality under International Law", Michigan Journal of International Law, Vol. 19, No. 3, 1997-1998, pp.1141-1194.

58 European Convention on Nationality, 1997, Article 18.

59 Council of Europe Convention on the Avoidance of Statelessness in relation to State Succession, Article 2-Right to a Nationality. "Everyone who, at the time of the State succession, had the nationality of the predecessor State and who has or would become stateless as a result of the State succession has the right to the nationality of a State 
prohibiting the predecessor state from withdrawing nationality if the person would become stateless, and requiring that:

A successor State shall grant its nationality to persons who, at the time of the State succession, had the nationality of the predecessor State, and who have or would become stateless as a result of the State succession if at that time:

a) they were habitually resident in the territory which has become territory of the successor State, or

b) they were not habitually resident in any State concerned but had an appropriate connection with the successor State.

"Appropriate connection" is then defined, broadly following the ILC Draft Articles, to include:

a) a legal bond to a territorial unit of a predecessor State which has become territory of the successor State;

b) birth on the territory which has become territory of the successor State;

c) last habitual residence on the territory of the predecessor State which has become territory of the successor State. ${ }^{60}$

\subsection{Acquisition of nationality based on habitual residence}

International law does not require any state to provide for a general system of naturalisation enabling persons not born on its territory to acquire nationality. This is an area where human rights law has yet to make any serious inroads on the discretion of states, which tend to guard closely the idea of naturalisation as a privilege not a right. Nevertheless, provisions relating to acquisition of nationality should not discriminate on the basis of gender, race, ethnic group etc (see above, chapter 3.2). At the regional level, the European Convention requires states parties to "provide in its internal law for the possibility of naturalisation of persons lawfully and habitually resident on its territory" (Article 6(3)), based on a maximum residence period of ten years, and for facilitated naturalisation for a range of categories of people, including spouses, children of people who have or acquire nationality, refugees and stateless persons. ${ }^{61}$

concerned in accordance with the [provisions of the treaty]." See also the Declaration on the Consequences of State Succession for the Nationality of Natural Persons (the Venice Declaration), adopted in 1980.

${ }^{60}$ Council of Europe Convention on the Avoidance of Statelessness in relation to State Succession, Article 18.

61 European Convention on Nationality Article 6(4): "Each State Party shall "facilitate in its internal law the acquisition of its nationality for the following persons: a. spouses of its nationals; b. children of one of its nationals [who do not otherwise acquire nationality]; $c$. children one of whose parents acquires or has acquired its nationality; d. children adopted by one of its nationals; e. persons who were born on its territory and reside there lawfully 
Some limited obligations are placed on states parties to the refugee conventions in relation to facilitating naturalisation of refugees and stateless persons. The 1951 UN Convention Relating to the Status of Refugees provides (Article 34) that states parties "shall as far as possible facilitate the assimilation and naturalisation of refugees," by such measures as expediting proceedings and reducing the costs of naturalisation. Similar provisions are included in the 1954 and 1961 statelessness conventions. ${ }^{62}$ The 1969 OAU Convention Governing the Specific Aspects of Refugee Problems in Africa does not include a similar provision on naturalisation, though its requirement (Article II.1) that countries of asylum should use their best endeavours to "secure the settlement" of refugees who are unable to return home could be interpreted in the same way. Both conventions require countries of asylum to issue travel documents to refugees. Almost all African countries are parties to the U.N. Refugee Convention, ${ }^{63}$ and the great majority to the African Refugee Convention. ${ }^{64}$

As a matter of fact, however, most states do provide for naturalisation in law, creating access to nationality for spouses of nationals and for habitual residents in the country. Acquisition is usually subject to the fulfilment of other conditions, including that residence be legal and marriage evidenced by official procedures (conditions are typically more stringent for habitual residents than spouses, and often include a clean criminal record, good health etc: for provisions in African laws see chapter 6.6).

There is no agreed definition of what is meant by the type of habitual residence that would qualify a person to apply for naturalisation, though the understanding is the term is based on an ordinary interpretation of the facts; nor is there definitive guidance on what length of residence is generally reasonable to apply in the context of naturalisation. Even the ILC Draft Articles provide no definition, though there have been some decisions within the UN system

and habitually; f. persons who are lawfully and habitually resident on its territory for a period of time beginning before the age of 18 , that period to be determined by the internal law of the State Party concerned; g. stateless persons and recognised refugees lawfully and habitually resident on its territory."

62 Convention relating to the Status of Stateless Persons, 1954, Article 32; Convention on the Reduction of Statelessness, 1961, Articles 1-4.

63 Excluding only Comoros, Eritrea, Libya, and Mauritius. Several countries have entered reservations to Article 34 of the UN Refugee Convention, including Botswana, Malawi, and Mozambique, indicating that they did not accept any obligation to grant more favourable naturalisation rights to refugees than to other foreigners. List of states parties available at the UN Treaty Collection website, together with reservations and declarations https://treaties.un.org/pages/Treaties.aspx?id=5\&subid=A\&lang=en last accessed 15 January 2015.

${ }^{64}$ Excluding Djibouti, Eritrea, Madagascar, Mauritius, Namibia, Somalia, and São Tomé \& Príncipe, as well as the SADR. All except for SADR had signed but not ratified by end 2014. Status of ratifications available on the African Union website http://www.au.int/ en/treaties, last accessed 15 January 2015. 
providing guidance in contexts relevant to nationality law: for example, the UN Human Rights Committee decided, in a case about the rights of recently arrived residents of New Caledonia to vote in a referendum on independence of the territory from France, that a ten year period of residence to qualify to vote was not unreasonable. ${ }^{65}$ In the case of stateless children, the 1961 Convention on the Reduction of Statelessness provides that a child who is otherwise stateless may be required to fulfil a period of habitual residence in the territory of the state of birth in order to acquire that State's nationality. The Convention provides that this period is not to exceed five years immediately preceding an application nor ten years in all; in its guidelines on preventing statelessness among children, UNHCR regards these as lengthy and encourages states to provide shorter periods. ${ }^{66}$

At the European level, the 2006 European Convention on the avoidance of statelessness in relation to State succession, defines "habitual residence" as "stable factual residence"; this interpretation is endorsed by UNHCR in its guidelines on avoiding statelessness among children, which notes that the term "does not imply a legal or formal residence requirement" in the case of stateless persons. ${ }^{67}$ Within the European Union system the European Court of Justice has established some jurisprudence on the length of time and other elements that might qualify a person to be treated as habitually resident. ${ }^{68}$ More generally, however, the country of "habitual residence" is considered (often in the context of taxation or eligibility for state benefits) to mean the state where the centre of a person's interests lie and where he or she has the strongest personal connections. Such connections need not be numerous but must have a degree of permanency greater than any connections with other states. ${ }^{69}$

What would count as habitual residence is particularly challenging in the context of nomadic populations, widespread across Africa. There is no treatylevel guidance, and the only state-endorsed document of normative value currently seems to be a rather general Recommendation adopted by the Council of Europe in 1983 that urged member states to facilitate the recognition of nationality for nomadic populations. The Recommendation suggested the following criteria for consideration in establishing a link on the basis of which

65 Gillot v. France, Human Rights Committee, U.N. Doc. A/57/40 (2002).

66 UNHCR, Guidelines on Statelessness No. 4: Ensuring Every Child's Right to Acquire a Nationality through Articles 1-4 of the 1961 Convention on the Reduction of Statelessness, HCR/GS/12/04, 21 December 2012, paragraph 40.

${ }_{67}$ UNHCR, Guidelines on Statelessness No. 4, paragraph 41. "The 1961 Convention does not permit Contracting States to make an application for the acquisition of nationality by individuals who would otherwise be stateless conditional upon lawful residence."

${ }_{68}$ "Habitual residence as connecting factor in EU civil justice measures", Library Briefing, Library of the European Parliament, 22 January 2013.

${ }^{69}$ See for example, statement by the UK Revenue and Customs agency at http://www. hmrc.gov.uk/cnr/article-14.2.htm, accessed 15 January 2015. 
nationality should be granted: whether the state is "the state of birth or origin" of the person concerned or the "state of origin" of his or her immediate family; whether it is the state of habitual residence or frequent periods of residence of the person (provided the residence is not unlawful); and the presence in the state of members of the person's immediate family. ${ }^{70}$ In its guidelines on avoiding statelessness among children, UNHCR notes that :

It follows from the factual character of "habitual residence" that in cases where it is difficult to determine whether an individual is habitually resident in one or another State, for example due to a nomadic way of life, such persons are to be considered as habitual residents in both States. ${ }^{71}$

\subsection{Loss and deprivation}

The view on the legality of denationalisation has changed greatly in recent decades as the emphasis has moved from the rights of states to the rights of individuals. Denationalisation was historically relatively permitted, and not only in the obvious cases still permitted today: even denationalisation on racial grounds was not regarded as being strictly illegal under international law, though it might be against public policy. On the other hand, denationalisation coupled with expulsion of a person would be to compel another state to accept the person concerned, which would be against international law. ${ }^{72}$ The denationalisations carried out by Germany during the second world war changed this view; as so much else in international human rights law. ${ }^{73}$

Article 15 of the Universal Declaration of Human Rights provides that "No one shall be arbitrarily deprived of his nationality". There is a distinction drawn in the UN Convention on the Reduction of Statelessness between "loss" of nationality, which happens automatically by operation of law; and "deprivation", which involves withdrawal initiated by the authorities of a state. However, as affirmed in resolutions of the UN Human Rights Council and UNHCR

70 Council of Europe Committee of Ministers Recommendation No. R. (83)1, 22 February 1983.

71 UNHCR, Guidelines on Statelessness No. 4, paragraph 42.

72 Weis, Nationality and Statelessness, Chapter 10 ("Limitations on Conferment and Withdrawal of Nationality"); Donner, Regulation of Nationality, chapter III ("The imposition and withdrawal of nationality").

73 In a case before the UK courts in which the major question at issue was recognition of German war-time denationalisation legislation it was held that: "Legislation enacted by a foreign State such as the 1941 decree, which takes away without compensation from a section of the citizen body singled out on racial grounds all their property on which the State can lay its hands and, in addition, deprives them of their citizenship, is contrary to international law and constitutes so grave an infringement of human rights that the English courts ought to refuse to recognize it as law at all". Oppenheimer v. Cattermole, Inspector of Taxes [1975] 1 All E.R. 538 at p.556 (cited in Weis, Nationality and Statelessness, p.122). 
guidance, a retrospective finding that a person was not a national and was issued nationality documents in error, or arbitrary application of rules relating to loss by operation of law, are equally subject to rules prohibiting arbitrary deprivation of nationality. ${ }^{74}$ The prohibition on arbitrary withdrawal applies whether or not a person would become stateless; though the prohibition is stronger if statelessness would be the result. Thus, any decision to revoke or cease recognition of citizenship must respect due process of law. In this text, "denationalisation" or "withdrawal" of nationality will be used to cover both circumstances.

The UN Human Rights Committee, considering the word arbitrary in other contexts, has said that "the notion of 'arbitrariness' must not be equated with 'against the law' but be interpreted more broadly to include such elements as inappropriateness and injustice," 75 and that "the concept of arbitrariness is intended to guarantee that even interference provided for by law should be in accordance with the provisions, aims and objectives of the [ICCPR] and should be, in any event, reasonable in the particular circumstances."76

The 1961 Convention on the Reduction of Statelessness provides in Article 9 that "A Contracting State may not deprive any person or group of persons of their nationality on racial, ethnic, religious or political grounds." This has been reinforced by the statements of the UN's human rights bodies. The Committee on the Elimination of Racial Discrimination's General Recommendation on discrimination against noncitizens included confirmation that "deprivation of citizenship on the basis of race, colour, descent, or national or ethnic origin is a breach of States parties' obligations" ${ }^{77}$ The UN Commission on Human Rights, guided by Articles 2 and 15(2) of the Universal Declaration, reaffirmed in 2005 that "arbitrary deprivation of nationality on racial, national, ethnic, religious, political, or gender grounds is a violation of human rights and fundamental freedoms." ${ }^{78}$ The Human Rights Council that replaced the Commission has repeatedly confirmed this statement, most recently in $2014 .{ }^{79}$ The definition of

74 Expert Meeting - Interpreting the 1961 Statelessness Convention and Avoiding Statelessness resulting from Loss and Deprivation of Nationality ("Tunis Conclusions"), UNHCR, March 2014, especially paragraph 9; see also footnote 79.

75 A.v. Australia, Communication No.560/1993, CCPR/C/59/D/560/1993, 30 April 1997, paragraph 9.2.

76 UN Human Rights Committee, General Comment No. 16, 1988 (on Article 17 of the ICCPR, Right to privacy), para 4.

77 General Recommendation No.30 of the Committee on the Elimination of Racial Discrimination on Discrimination against Non-citizens, HRI/GEN/1/Rev.7/Add.1, 4 May 2005.

78 Commission on Human Rights, Resolution 2005/45: Human Rights and Arbitrary Deprivation of Nationality, E/CN.4/RES/2005/45, 19 April 2005.

79 Human Rights Council, Resolution on Human rights and arbitrary deprivation of nationality, A/HRC/RES/26/14, 23 June 2014, which "Reiterates that arbitrary deprivation of nationality, especially on discriminatory grounds such as race, colour, sex, language, religion, political or other opinion, national or social origin, property, birth or other status is a violation of human rights and fundamental freedoms". See also periodic 
prohibited discrimination continues to develop and now may be said to include "indirect" discrimination, that is, discrimination based upon ostensibly raceneutral provisions that have a disproportionate effect on specific ethnic groups. ${ }^{80}$

The 1961 Convention provides a range of guarantees against statelessness in case of loss of nationality on acquiring another, and in case of marriage or end of marriage. ${ }^{81}$ In addition, it elaborates particular obligations on states to avoid statelessness when depriving a person of nationality. The 1961 Convention on the Reduction of Statelessness provides in Article 8(1) as its first principle that:

A Contracting State shall not deprive a person of its nationality if such deprivation would render him stateless.

Article 8(2) and (3) provide for exceptions to this general rule in limited circumstances, including if nationality was obtained by fraud; if a person born abroad does not return to the country or register the desire to retain nationality at majority; or if a naturalised person lives abroad at least seven years and does not declare an intention to retain nationality. ${ }^{82}$ In addition, various acts indicating disloyalty to the state may result in deprivation leading to statelessness, but these are only permitted if a state party to the treaty already had such provisions in its law at the time the treaty was ratified and made a declaration saying that it intended to keep them. ${ }^{83}$

Reports of the Secretary-General to the Human Rights Council on "Human rights and arbitrary deprivation of nationality".

80 See, for example, the European Court on Human Rights' landmark decision in the case D.H. and Others v. The Czech Republic, ECtHR Grand Chamber (application no. 57325/00), 13 November 2007, at paragraph 175, in which it reiterated that "a general policy or measure that has disproportionately prejudicial effects on a particular group may be considered discriminatory notwithstanding that it is not specifically aimed at that group."

81 Articles 5, 6 and 7.

82 Article 8(2) provides: "2. Notwithstanding the provisions of paragraph 1 of this article, a person may be deprived of the nationality of a Contracting State: (a) In the circumstances in which, under paragraphs 4 and 5 of article 7, it is permissible that a person should lose his nationality; (b) Where the nationality has been obtained by misrepresentation or fraud." Article 7, paragraphs 4 and 5, state: "4. A naturalized person may lose his nationality on account of residence abroad for a period, not less than seven consecutive years, specified by the law of the Contracting State concerned if he fails to declare to the appropriate authority his intention to retain his nationality. 5. In the case of a national of a Contracting State, born outside its territory, the law of that State may make the retention of its nationality after the expiry of one year from his attaining his majority conditional upon residence at that time in the territory of the State or registration with the appropriate authority."

83 Article 8(3) provides: "3. Notwithstanding the provisions of paragraph 1 of this article, a Contracting State may retain the right to deprive a person of his nationality, if at the time of signature, ratification or accession it specifies its retention of such right on one or more of the following grounds, being grounds existing in its national law at that time: (a) That, inconsistently with his duty of loyalty to the Contracting State, the person: (i) Has, in disregard 
Article 8(4) of the 1961 Convention provides that a "Contracting State shall not exercise a power of deprivation ... except in accordance with law, which shall provide for the person concerned the right to a fair hearing by a court or other independent body."

In 2014, UNHCR published comprehensive guidance based on expert conclusions on the obligations of states to avoid statelessness under the 1961 Convention. ${ }^{84}$ The meeting noted that the general object and purpose of the treaty is "to prevent and reduce statelessness, thereby ensuring every individual's right to a nationality", and highlighted the impact of other human rights norms, such as gender equality, on the provisions of the treaty. ${ }^{85}$

Thus under international law, citizenship cannot be revoked against the person's will except in restrictive circumstances, and in accordance with due process of law. Well-established principles forbid gender, racial, ethnic or other discrimination in the grant or withdrawal of citizenship, as well as restricting greatly any withdrawal of citizenship if a person would then be stateless; and in any event require that a system of challenge to such decisions should be available through the regular courts.

In the African context, the 2004 ruling of the independent Eritrea-Ethiopia Claims Commission stated that:

[I]nternational law limits States' power to deprive persons of their nationality. In this regard, the Commission attaches particular importance to the principle expressed in Article 15, paragraph 2, of the Universal Declaration of Human Rights, that "no one shall be arbitrarily deprived of his nationality." In assessing whether deprivation of nationality was arbitrary, the Commission considered several factors, including whether the action had a basis in law; whether it resulted in persons being rendered stateless; and whether there were legitimate reasons for it to be taken given the totality of the circumstances. ${ }^{86}$

of an express prohibition by the Contracting State rendered or continued to render services to, or received or continued to receive emoluments from, another State, or (ii) Has conducted himself in a manner seriously prejudicial to the vital interests of the State; (b) That the person has taken an oath, or made a formal declaration, of allegiance to another State, or given definite evidence of his determination to repudiate his allegiance to the Contracting State."

84 UNHCR, Tunis Conclusions.

85 See René de Groot, Avoiding Statelessness resulting from Loss and Deprivation of Nationality: Interpreting Articles 5-9 of the 1961 Convention on the Reduction of Statelessness and Relevant International Human Rights Norms, background paper prepared for UNHCR Expert Meeting, Tunis, 31 October - 1 November 2013; UNHCR, Tunis Conclusions.

86 Award of the Eritrea-Ethiopia Claims Commission in Partial Award (Civilian Claims), 44 ILM 601 (2005) at para 60. 


\subsection{Due process in relation to expulsion}

Under international law a person cannot be expelled from his or her country of citizenship, no matter what the destination. ${ }^{87} \mathrm{~A}$ state may expel individuals it claims are non-nationals from its territory or deport them to their alleged state of origin only if it respects minimum rules of due process, including the right to challenge on an individual basis both the reasons for expulsion and the allegation that a person is in fact a foreigner. Thus, the International Law Commission is developing Draft Articles on the expulsion of aliens, which provide that: "A State shall not make its national an alien, by deprivation of nationality, for the sole purpose of expelling him or her". ${ }^{88}$ As a related point, the UN Human Rights Committee has held that the right of a person to return to "his own country" includes "at the very least, an individual who, because of his or her special ties to or claims in relation to a given country, cannot be considered to be a mere alien." 89

In the African context, the right to due process in relation to expulsion has been repeatedly endorsed by the African Commission (see chapter 3.12.1), and by a May 2007 decision by the International Court of Justice in a case brought by Guinea that the government of what was then Zaire had not provided available and effective remedies enabling an individual to challenge an expulsion, because the decision (which was technically to "refuse entry") could not be appealed. ${ }^{90}$

87 This prohibition does not include extradition of a person (of whatever nationality) to stand trial in another country or for execution of a sentence imposed upon him or her, in accordance with due process of law and on the basis of legal agreements between states.

88 Expulsion of aliens: Texts and titles of the draft articles adopted by the Drafting Committee on second reading, International Law Commission Sixty-sixth session, UN General Assembly, A/CN.4/L.797, 24 May 2012.

89 Committee on Human Rights, General Comment No. 27: Freedom of movement (Article 12), 1999: "20. The wording of article 12, paragraph 4, does not distinguish between nationals and aliens ('no one').Thus, the persons entitled to exercise this right can be identified only by interpreting the meaning of the phrase 'his own country'.The scope of 'his own country' is broader than the concept 'country of his nationality'. It is not limited to nationality in a formal sense, that is, nationality acquired at birth or by conferral; it embraces, at the very least, an individual who, because of his or her special ties to or claims in relation to a given country, cannot be considered to be a mere alien. This would be the case, for example, of nationals of a country who have there been stripped of their nationality in violation of international law, and of individuals whose country of nationality has been incorporated in or transferred to another national entity, whose nationality is being denied them...." See also decisions of the Committee in Stewart vs. Canada (CCPR/C/58D/538/1993) and Nystrom vs. Australia (CCPR/C/102?D/1557/2007).

90 Legislative Order No. 83-033 of 12 September 1983, concerning immigration control, expressly ruled out a right of appeal in case of refusal of entry. Case concerning Ahmadou Sadio Diallo (Republic of Guinea v Democratic Republic of Congo), Preliminary Objections, International Court of Justice, 24 May 2007, paragraph 46. 
International law also prohibits the refoulement of refugees, that is, the forced removal of an individual to a place where he or she would be at risk of persecution under the definitions contained in the UN and African Refugee Conventions. Any person being expelled must have the individual right to challenge the removal on the basis that it would constitute a refoulement.

\subsection{Imposition of nationality}

Attribution of nationality on populations or individuals against their will was, historically, more frowned upon in international jurisprudence than denationalisation; usually on grounds that it violated the rights of the other potential state of nationality, rather than the individual him or herself. A state may not impose its nationality on a person who has no reasonable claim to it, or against the person's will; laws purporting to do so are not binding on other states. ${ }^{91}$ Consent to the imposition may be implied in some cases, for example in the context of state succession, by the existence of a strong factual link between the person and the state concerned, including that of habitual residence. ${ }^{92}$

The High Commissioner on National Minorities of the Organisation for Security and Cooperation in Europe has adopted a set of recommendations, the Bolzano/Bozen Recommendations on National Minorities in Inter-State Relations, which explain the conditions under which and the limitations within which states may support citizens of another country based on shared ethnic, cultural or historical ties. Though not formally part of international law, the Recommendations form a codification of good practice that is relevant to other regions as much as Europe. ${ }^{93}$ In relation to the grant or imposition of nationality on ethnic kin in neighbouring countries, the Recommendations state:

States may take preferred linguistic competencies and cultural, historical or familial ties into account in their decision to grant citizenship to individuals abroad. States should, however, ensure that such a conferral of citizenship respects the principles of friendly, including good neighbourly, relations and territorial sovereignty, and should refrain from conferring

91 See Serena Forlati, "Nationality as a human right" in Alessandra Annoni and Serena Forlati (eds.), The Changing Role of Nationality in International Law Routledge, London and New York, 2013.

92 Some authors have argued against the "imposition" of nationality on children, urging that they rather be required to choose a nationality at majority. Myres S. McDougal, Harold D. Lasswell, and Lung-chu Chen, "Nationality and Human Rights:The Protection of the Individual in External Arenas", Yale Law Journal,Vol. 83, No. 5 (Apr., 1974), pp. 900-998, at pp.918-922; this is a line of thinking dating back to the $18^{\text {th }}$ century Swiss theorist Emmerich de Vattel (see footnote 32).

93 Enrico Milano "The Conferral of Citizenship En Masse by Kin-States: Creeping Annexation or Responsibility to Protect?" in Francesco Palermo and Natalie Sabanadze (eds.), National Minorities in Inter-State Relations, Leiden: Nijhoff, 2011. 
citizenship en masse, even if dual citizenship is allowed by the State of residence. If a State does accept dual citizenship as part of its legal system, it should not discriminate against dual nationals. ${ }^{94}$

\subsection{Renunciation and reacquisition of nationality}

Renunciation of nationality is loss of nationality by specific act of the individual concerned. Two aspects of international law are relevant to the renunciation of a nationality: first, the right of every person to change nationality set out in the Universal Declaration of Human Rights; and secondly, the protections against statelessness provided by the 1961 Convention.

Where a state does not permit dual nationality, it will be necessary for a person to renounce their original nationality in order to acquire another. Article 15(2) of the Universal Declaration ("No one shall be arbitrarily deprived of his nationality nor denied the right to change his nationality") implies that this process shall not require the formal consent of the state concerned, but merely the completion of an administrative procedure. On the other hand, Article 7 of the 1961 Convention (which elaborates on provisions already included in Article 7 of the 1930 Hague Convention) requires states to ensure that the person would not become stateless in this process: for example, in the context where an application for naturalisation in another country requires proof of renunciation of the original nationality, but then the application is not in fact successful. Thus the state of existing nationality is required to put in place procedures to ensure that a person does in fact have another nationality before renunciation is accepted (or to provide that the renunciation shall lapse if the new nationality is not confirmed); while the state whose nationality is being acquired should only require proof of renunciation of the original nationality within a certain period after acquisition of its nationality is confirmed.

Equally, if a person has renounced nationality in one state and subsequently becomes stateless, the first state should provide for reacquisition of its nationality. ${ }^{95}$

94 The Bolzano/Bozen Recommendations on National Minorities in Inter-State Relations $\mathcal{E}$ Explanatory Note Organisation for Security and Cooperation in Europe, High Commissioner on National Minorities, June 2008, Recommendation 11. The High Commissioner was appointed in 1992 as a conflict-prevention organ in relation to tensions involving persons belonging to ethnic groups who constitute the numerical majority in one State but the numerical minority in another (usually neighbouring) State. The Recommendations build on the experience of Rolf Ekéus (High Commissioner on National Minorities 2001-2007), as set out in his 2001 statement on "Sovereignty, Responsibility and National Minorities", and on the "Report on the Preferential Treatment of National Minorities by their Kin-State", issued by the Council of Europe's Commission for Democracy through Law (Venice Commission) in the same year.

95 See, Interpreting the 1961 Statelessness Convention and Avoiding Statelessness resulting from Loss and Deprivation of Nationality (The "Tunis Conclusions"), UNHCR, 2013 


\subsection{African human rights norms on nationality}

The African Charter on Human and Peoples' Rights, adopted in 1981 (entry into force 1986), does not contain a provision on nationality. However, numerous articles of the African Charter on Human and Peoples' Rights are relevant to the right to nationality, including the rights to non-discrimination (Article 2); to equal treatment before the law (Article 3); and to a fair hearing and the right to appeal to competent national organs in respect of acts violating fundamental rights (Article 7). Perhaps most important is Article 5 which provides that:

Every individual shall have the right to the respect of the dignity inherent in a human being and to the recognition of his legal status.

The founding of this commitment to legal recognition in Africa's history is emphasised by the remainder of Article 5, which goes on to say that "All forms of exploitation and degradation of man, particularly slavery, slave trade, torture, cruel, inhuman or degrading punishment and treatment shall be prohibited."

Among the early post-independence trends in many African countries was the expulsion of foreigners, as part of the process of building a national identity. This applied not only to people of European and Asian descent, but also to other Africans. Even among those countries that did not forcibly expel "foreigners", measures for the "Africanisation" of the civil service and the economy were common. (See further below, chapter 8.1). With this history in mind, drafters of the African Charter on Human and Peoples' Rights included a specific prohibition on "mass expulsion of non-nationals".

Article 12 of the Charter also provides specific protections relevant to citizenship, immigration, and protection of refugees:

1. Every individual shall have the right to freedom of movement and residence within the borders of a State provided he abides by the law.

2. Every individual shall have the right to leave any country including his own, and to return to his country. This right may only be subject to restrictions, provided for by law for the protection of national security, law and order, public health or morality.

3. Every individual shall have the right, when persecuted, to seek and obtain asylum in other countries in accordance with laws of those countries and international conventions.

4. A non-national legally admitted in a territory of a State Party to the present Charter, may only be expelled from it by virtue of a decision taken in accordance with the law.

5. The mass expulsion of non-nationals shall be prohibited. Mass expulsion shall be that which is aimed at national, racial, ethnic or religious groups. 
All African countries except South Sudan (but including Morocco, which is not a member of the AU) are parties to the ACHPR; South Sudan signed in 2013. ${ }^{96}$

The African Commission on Human and Peoples' Rights has also considered issues touching on the right to a nationality in a large number of communications (see below). Highlighting its findings in these cases, the African Commission on Human and Peoples' Rights adopted a resolution on the right to a nationality in April 2013 stating that:

"[...] the right to nationality of every human person is a fundamental human right implied within the provisions of Article 5 of the African Charter on Human and Peoples' Rights and essential to the enjoyment of other fundamental rights and freedoms under the Charter." ${ }^{97}$

In May 2014, the Commission followed up this resolution with a commitment to move towards the drafting of a protocol to the African Charter on the right to a nationality. ${ }^{98}$ (This initiative is taken up further in chapter 15.7.3.)

The Protocol to the African Charter on Human and Peoples' Rights on the Rights of Women in Africa places strong non-discrimination requirements on states in general, but is weak on citizenship rights, thanks largely to the efforts of the North African states. ${ }^{99}$ It provides in Article 6 only that

g) a woman shall have the right to retain her nationality or to acquire the nationality of her husband;

h) a woman and a man shall have equal rights with respect to the nationality of their children except where this is contrary to a provision in national legislation or is contrary to national security interests.

Article 6(g) omits the reference in CEDAW to equal rights for men and women, focusing only on the right of a woman to choose her own nationality rather than to confer her nationality on her husband; while 6(h) is rendered empty by its subjection to national law. On the face of it, the provisions thus appear

96 List of countries which have signed, ratified/acceded to the African Charter on Human and Peoples' Rights, at the AU website, http://www.au.int/en/treaties, last accessed 27 November 2014.

97 African Commission on Human and Peoples' Rights, Resolution 234 on the Right to Nationality, 53rd Ordinary Session, 9- 23 April 2013, Banjul, The Gambia.

98 African Commission on Human and Peoples' Rights, Resolution 277 on the drafting of a Protocol to the African Charter on Human and Peoples' Rights on the Right to Nationality in Africa, 55th Ordinary Session, 28 April to 12 May 2014, Luanda, Angola.

99 See discussion of the drafting process in Fareda Banda, "Protocol to the African Charter on the Rights of Women in Africa," in Malcolm Evans and Rachel Murray (eds), The African Charter on Human and Peoples' Rights: The System in Practice 1986-2006, Cambridge University Press, 2008. 
to be in conflict with states' general obligations under the African Charter on Human and Peoples' Rights.

Thirty-six countries had ratified the Protocol to the African Charter on Human and Peoples' Rights on the Rights of Women in Africa as of 2014; another 15 had signed. Countries taking no action were Botswana, Egypt and Tunisia. ${ }^{100}$

The African Charter on the Rights and Welfare of the Child echoes in its Article 6 the words of the UN Convention on the Rights of the Child in providing for the right of a child to a name and to acquire a nationality. In addition, importantly, it integrates a requirement based on Article 1 of the Convention on the Reduction of Statelessness that the state where a child is born shall grant its nationality to that child if another is not acquired at birth.

1. Every child shall have the right from his birth to a name.

2. Every child shall be registered immediately after birth.

3. Every child has the right to acquire a nationality.

4. States Parties to the present Charter shall undertake to ensure that their Constitutional legislation recognize the principles according to which a child shall acquire the nationality of the State in the territory of which he has been born if, at the time of the child's birth, he is not granted nationality by any other State in accordance with its laws.

Forty-seven countries have ratified the ACRWC, and the remainder have all signed (those not yet parties are: Central African Republic, Democratic Republic of Congo, Sahrawi Arab Democratic Republic, Somalia, São Tomé and Príncipe, and Tunisia). ${ }^{101}$ Morocco is also not a party, since the treaty was adopted after it withdrew from the AU.

Other AU documents also support the avoidance of statelessness. For example, the Migration Policy Framework adopted in 2006 in parallel with the African Common Position on Migration and Development, included among many other recommendations that AU Member States should "incorporate key guidelines as recommended in the 1954 and 1961 Statelessness Conventions", and "develop national legislative and policy frameworks to counter statelessness, particularly in

100 The parties are Angola, Benin, Burkina Faso, Cameroon, Cape Verde, Comoros, Côte d'Ivoire, Djibouti, Congo, DRC, Equatorial Guinea, Gabon, Gambia, Ghana, Guinea, Guinea-Bissau, Kenya, Lesotho, Liberia, Libya, Mali, Malawi, Mozambique, Mauritania, Namibia, Nigeria, Rwanda, South Africa, Senegal, Seychelles, Swaziland, Tanzania, Togo, Uganda, Zambia, and Zimbabwe. Signature only from Algeria, Burundi, CAR, Chad, Eritrea, Ethiopia, Madagascar, Mauritius, Niger, SADR, STP, Sierra Leone, Somalia, South Sudan and Sudan. See status list available at http://www.au.int/en/treaties, last accessed 27 November 2014.

101 DRC and São Tomé and Príncipe, the last outstanding countries, signed in early 2010, while Swaziland was the most recent to ratify, in 2012. See list of countries that have signed, ratified or acceded to the Charter, available at http://www.au.int/en/treaties, last accessed 27 November 2014. 
cases of long-term residents, by reforming citizenship legislation and/or granting rights similar to those enjoyed by foreigners residing in the country." 102

\subsubsection{The General Comment on Article 6 of the Children's Charter}

In 2014, the African Committee of Experts on the Rights and Welfare of the Child, responsible for oversight of the Children's Charter, adopted a General Comment on Article 6. ${ }^{103}$ The General Comment recalled the Committee of Experts' decision in the Kenyan Nubian Children's Case (see next section) in which they recognised that "the lack of recognition as a full participant in the political and social life of the country where a person has been born and lived all his or her life, has been at the heart of many of Africa's most intractable political crises and civil conflicts."

The General Comment "reminds African States that States do not enjoy unfettered discretion in establishing rules for the conferral of their nationality, but must do so in a manner consistent with their international legal obligations." $\mathrm{T}$ he Committee therefore condemns discrimination in rules relating to nationality, both the still-to-common discrimination on the basis of sex, but also discrimination on the grounds of race and ethnic group, which still exists in the laws of several African countries. The Committee also makes various recommendations in line with these findings, including that States parties should adopt legal provisions that provide nationality to children born on their territory not only where the child is otherwise stateless, but also in other cases where the child has the strongest connection to that state.

On the general right of a child to acquire a nationality in Article 6(3):

[T] he Committee notes that it can be difficult to prove the risk of statelessness: that is, that a person does not have, or is not going to acquire, another nationality. In addition, it may be unreasonable to expect a child who may have a theoretical right to another nationality to take the steps needed to acquire that nationality. Thus, the Committee encourages States Parties to adopt legal provisions - already in place in many African States - that a child born in the State with one parent (either mother or father) also born in the State acquires the nationality of that State at birth.... [T]he Committee also believes that States should adopt provisions giving children born in their territory the right to acquire nationality after a period of residence that does not require the child to wait until majority before

102 Migration Policy Framework for Africa, EX.CL/276 (IX), AU Executive Council, Ninth Ordinary Session, 25 - 29 June 2006, Banjul, The Gambia, Paragraph 3.7.

103 African Committee of Experts on the Rights and Welfare of the Child, General Comment on Article 6 of the African Charter on the Rights and Welfare of the Child, ACERWC/GC/02 (2014), adopted by the Committee at its twenty-third Ordinary Session, 7 - 16 April, 2014. 
nationality can be confirmed. Additionally, a number of African States provide for a child born in the territory of parents who are lawfully and habitually resident there to acquire nationality at birth, and the Committee regards this as best practice. Further, the Committee encourages African States to facilitate the acquisition of nationality by children who were not born in their territory but who arrived there as children and have been resident there for a substantial portion of their childhood. ${ }^{104}$

In relation to Article 6(4), the Committee states:

A determination of whether a child has been granted nationality of another State at birth requires consideration of whether the child has acquired the nationality from either of his or her parents on the basis of descent. This determination must be made on the basis of an analysis of the nationality legislation and its implementation of the parents' State (or States) of nationality. States may also consult the authorities of the parents' country of nationality to establish whether the child is considered a national of that country or countries. States must accept that a child is not a national of another State if the authorities of that State indicate that he or she is not a national. A State can refuse to recognize a person as a national either by explicitly stating that he or she is not a national or by failing to respond to inquiries to confirm the child is a national. ${ }^{105}$

The General Comment considers a range of different circumstances which may place a child's right to nationality in jeopardy, and stands as the most comprehensive interpretation to date of a state's obligations under international law in relation to the grant of nationality to children born in that state.

\subsubsection{The jurisprudence of the African human rights institutions}

Several cases have been brought to the African Commission on Human and Peoples' Rights on behalf of politically active individuals whom governments have attempted (often successfully) to silence by denationalisation or deportation or by otherwise violating their rights on grounds of alleged nationality or immigration status.

Perhaps most importantly the African Commission has found that the provision of Article 5 that states "Every individual shall have the right to the respect of the dignity inherent in a human being and to the recognition of his legal status" applies specifically to attempts to denationalize individuals and render them stateless. Thus, in the long-running case of John Modise, who spent years confined either to the South African "homeland" of Bophuthatswana or the no-man's land between South Africa and Botswana because of the Botswanan government's refusal to recognise his nationality, the Commission found against 
the Botswanan government and ruled, among other conclusions, that Modise's "personal suffering and indignity" violated Article 5. ${ }^{106}$ Similarly, in Amnesty International v. Zambia, the Commission considered the deportations of William Banda and John Chinula from Zambia to Malawi and found that "[b]y forcing [the complainants] to live as stateless persons under degrading conditions, the [Zambian] government ... [had] deprived them of their family and [was] depriving their families of the men's support, and this constitutes a violation of the dignity of a human being, thereby violating Article 5." ${ }^{107}$

In addition, the Commission has held that Article 7(1)(a), with its reference to "the right to an appeal to competent national organs," includes both the initial right to take a matter to court, as well as the right to appeal from a first instance decision to higher tribunals. In several cases relating to deportations or denial of citizenship, the Commission has held that the fact that someone is not a citizen "by itself does not justify his deportation"; there must be a right to challenge expulsion on an individual basis. ${ }^{108}$ In the case of Banda and Chinula, Zambia had also denied their rights to freedom of expression. ${ }^{109}$

The Commission found against the Zambian government's notorious constitutional amendment that required anyone who wanted to compete for the presidency to prove that both parents were Zambians from birth (an amendment patently aimed at preventing former president Kenneth Kaunda from running for president again), and ruled that the provision violated Articles 2, 3, and 13. ${ }^{110}$ The Commission noted that freedom of movement among the components of what had been the Central African Federation (now the states of Malawi, Zambia, and Zimbabwe) meant that to suggest that an indigenous Zambian could only be a person who himself was born in and whose parents were born in what came (later) to be known as the sovereign territory of the state of Zambia would be arbitrary. The retroactive application of such a law thus could not be justified according to the Charter.

Founding its decisions on Articles 2 and 7 as well as Article 12, the Commission has ruled against both Angola and Zambia in cases relating to individual deportations or mass expulsions on the basis of ethnicity, commenting that mass expulsions "constitute a special violation of human rights." ${ }^{111}$ Zambia had

106 Communication 97/93, Modise v. Botswana (2000), paragraph 91.

107 Communication No. 212/98, Amnesty International v. Zambia (1999), paragraph 50.

108 Communication No. 212/98, Amnesty International v. Zambia, paragraph 33. See also Communication No.159/96, Union Interafricaine des Droits de l'Homme and Others $v$. Angola (2000); Communication 97/93, Modise v. Botswana; Communications Nos. 27/89, 49/91 and 99/93, Organisation Mondiale Contre la Torture and Others v. Rwanda (2000); Communication No.71/92, Rencontre Africain pour la Défense des Droits de l'Homme v. Zambia (2000).

109 Communication No. 212/98, Amnesty International v. Zambia.

110 Communication 211/98, Legal Resources Foundation v. Zambia (2001).

111 Communication No.159/96, Union Interafricaine des Droits de l'Homme and Others $v$. 
expelled West Africans indiscriminately, without giving them the opportunity to appeal against their deportation, and had kept them in a special camp for up to two months. ${ }^{112}$ Similarly, the Commission adopted a decision finding the Guinean government in violation of Article 2 and Article 12 (among others), for "massive violations of the rights of refugees" following a speech by Guinea's president, Lansana Conte, in which he incited soldiers and civilians to attack Sierra Leonean refugees. ${ }^{113}$ Again, the Commission has ruled that the exception in Article 12(2) of the Charter relating to "the protection of national security, law and order, public health or morality" does not pre-empt the right to have a case heard, and that it is for the state to prove the threat to national security, law and order, public health or morality. ${ }^{114}$

The Commission has ruled that States have obligations to respect their rights to family life and other rights under the Charter, even when expelling non-nationals. In the case of Kenneth Good, an Australian academic and long-term resident of Botswana who was deported after he wrote an article criticising the president, the Commission found that Botswana had violated Articles 1, 2, 7(1)(a), 9, 12(4) and 18(1) and 18(2) of the Charter. In particular, the Commission confirmed that non-nationals are entitled to the right to due process just as nationals, and that the "ouster clause" in the Botswana Immigration Act preventing the courts from reviewing his case was in violation of the Charter's general provisions on due process under Article 7, as well as the specific provision of Article 12.4. The hasty nature of the deportation order also violated the complainant's right to family life, given that he was separated from his minor daughter who lived with him. $^{115}$

In two important cases from Côte d'Ivoire, the African Commission considered the restrictive provisions on standing for election as president and the provisions of a 1998 land law providing that land could only be owned by Ivorian citizens. In the case of the nationality of the president, who was required under the 2000 constitution both to be Ivorian by birth him or herself and to have both parents Ivorian by birth, the Commission stated:

$[\mathrm{T}]$ he right to vote and to stand for elections is an individual right and conditions must be made to ensure that the individual exercises these rights without reference to his/her attachment to other individuals. The Commission thus finds the requirement that an individual can only exercise the right to stand for the post of a President not only if he/

\footnotetext{
Angola, paragraph 16. See also Communication No.292/2004, Institute for Human Rights and Development in Africa v. Angola (2008).

112 Rencontre Africain pour la Défense des Droits de l'Homme v. Zambia.

113 Communication No.249/02, Institute for Human Rights and Development in Africa (on behalf of Sierra Leonean refugees in Guinea) v. Republic of Guinea (2004).

114 Communication No.212/98, Amnesty International v. Zambia, paragraph 42.

115 Communication No.313/05, Kenneth Good v. Republic of Botswana (2009).
} 
she is born in Côte d'Ivoire, but also that his parents must be born in Côte d'Ivoire unreasonable and unjustifiable, and find this an unnecessary restriction on the right to participate in government guaranteed under Article 13 of the African Charter. [The Article] is also discriminatory because it applies different standards to the same categories of persons, that is persons born in Cote d'Ivoire are now treated based on the places of origin of their parents, a phenomenon which is contrary to the spirit of Article 2 of the African Charter. ${ }^{116}$

In its ruling on the 1998 land law, whose Article 26 restricted ownership of property to Ivorian citizens, the Commission found Côte d'Ivoire in violation of Articles 2 and 14 of the African Charter (equality before the law and right to property), since the application of the law "would give rise to the expropriation of their land from a category of the population, on the sole basis of their origin" and recommended restoration of their land to those deprived, as well as full implementation of 2004 amendments that reduced the impact of Article $26 .{ }^{117}$

The very first decision on the merits of a communication to the African Committee of Experts on the Rights and Welfare of the Child, issued in 2011, concerned the nationality of children of Nubian descent born in Kenya. The Committee of Experts found the Kenyan state in violation of its obligations under Article 6 of the African Charter on the Rights and Welfare of the Child, despite the reforms of the new 2010 constitution, which still fails to provide sufficient guarantees against statelessness since it does not provide that children born in Kenya of stateless parents or who would otherwise be stateless acquire Kenyan nationality at birth. ${ }^{118}$ The Committee noted the "strong and direct link between birth registration and nationality" 119 and stated that :

[T]he African Committee cannot overemphasise the overall negative impact of statelessness on children. While it is always no fault of their own, stateless children often inherit an uncertain future. For instance, they might fail to benefit from protections and constitutional rights granted by the State. These include difficulty to travel freely, difficulty in accessing justice procedures when necessary, as well as the challenge of finding oneself in a legal limbo vulnerable to expulsion from their home country. Statelessness is particularly devastating to children in the realisation of

116 Communication No.246/02, Mouvement ivoirien des droits humains (MIDH) v. Côte d'Ivoire (2008).

117 Communication No.262/02, Mouvement ivoirien des droits humains (MIDH) v. Côte d'Ivoire (2008).

118 Communication 002/2009, Institute for Human Rights and Development in Africa and Open Society Justice Initiative on behalf of Children of Nubian Descent in Kenya, African Committee of Experts on the Rights and Welfare of the Child, 22 March 2011 (the "Kenyan Nubian Children's case"), paragraph 53.

119 Kenyan Nubian Children's case, paragraph 42. 
their socio-economic rights such as access to health care, and access to education. In sum, being stateless as a child is generally antithesis to the best interests of children. ${ }^{120}$

In considering the significance of the wording of Article 6(3), on the right to acquire a nationality, the Committee of Experts held that:

The African Committee notes that Article 6(3) does not explicitly read, unlike the right to a name in Article 6(1), that "every child has the right from his birth to acquire a nationality". It only says that "every child has the right to acquire a nationality". Nonetheless, a purposive reading and interpretation of the relevant provision [Article 6(3)] strongly suggests that, as much as possible, children should have a nationality beginning from birth. This interpretation is also in tandem with Article 4 of the African Children's Charter that requires that "in all actions concerning the child undertaken by any person or authority the best interests of the child shall be the primary consideration". Moreover, this interpretation is further supported by the UN Human Rights Committee that indicated: "states are required to adopt every appropriate measure, both internally and in cooperation with other States, to ensure that every child has a nationality when he is born". ${ }^{121}$ Moreover, by definition, a child is a person below the age of 18 (Article 2 of the African Children's Charter), and the practice of making children wait until they turn 18 years of age to apply to acquire a nationality cannot be seen as an effort on the part of the State Party to comply with its children's rights obligations. ${ }^{122}$

\footnotetext{
120 Kenyan Nubian Children's case, paragraph 46.

121 Human Rights Committee, General Comment No. 17 : Rights of the Child (Article 24), 1989, paragraph 8. (African Committee's emphasis.)

122 Kenyan Nubian Children's Case, paragraph 42.
} 



\section{Empire to independence: the evolution of citizenship law in Africa}

The past is never dead. It's not even past. - William Faulkner

Many of the problems related to citizenship law and its application today can be traced back to the history of nationality in Africa, and in particular the ways in which the current states were created and their membership defined by the European colonial powers. Though pre-colonial traditions of belonging continue to be highly influential at sub-state level, they have had little impact on the rules for accessing nationality expressed in statute law.

Belonging and citizenship at the level of the colonial state were determined by the European power with control of the territory. However, it was a two-(or more) level citizenship that was created, in which most Africans did not have full civil and political rights. Though differentiated citizenships began to break down as independence approached, it was only in 1994, with the final liberation of South Africa, that the concept of the equality of all citizens was in principle accepted by all states in Africa.

At the same time, the practical effect of colonisation was to create new territorial units that were mostly not rooted in any pre-existing state structures, and indeed often cut through territorial boundaries, splitting populations speaking the same language and sharing the same political institutions. The colonisers also brought vastly increased migration, either through forced recruitment or as a side effect of the pattern of economic development produced by membership of an empire, both within Africa (as of mineworkers to South Africa) and from other continents to Africa (including not only white Europeans but for example, also the south Asians brought to eastern and southern regions of Africa by the British). These population movements have been the basis of many of the populations at risk of statelessness today.

\subsection{Citizenship and belonging before European colonisation}

Africa's pre-colonial political and territorial entities had of course highly variable systems for determining who was or was not a member of each polity. As in other parts of the world, these questions were less urgent in an era of lower population densities and lower levels of migration; but, again as in other parts of the world, there were systems for welcoming and managing travellers passing through a territory, or for integrating those who wished to stay. In the densely forested areas of central or west Africa, communities tended to be small 
enough that membership was effectively determined by family linkages rather than political or religious rules. In larger communities, even in quite similar geographical zones, political structures could vary widely: as for example in the case of the Yoruba kingdoms, compared to the "acephalous" decentralised system in the Igbo territories, both in the southern part of today's Nigeria; or in the empires - Ghana, Mali, Songhai, Kanem-Burnu - that succeeded each other across the Sahel. Membership of a political unit might be decided on the basis of male or (less commonly) female-line descent, with entry-points for strangers through initiation into membership of secret societies or age-grade structures, as well as payment of tribute as an indication of allegiance to a particular monarch, admission by a chief, or approval by an assembly of existing members. As in other continents, different levels of citizenship status were common, with distinctions by noble status or caste, between slave or free, and of course between men and women. ${ }^{1}$ Very often, belonging and membership was related to the grant of usage rights over land for farming or grazing: so, for example, in eastern Congo, agreements for "strangers" to use land facilitated their integration into the community. Similar procedures existed in West Africa, in the system known as the tutorat in Côte d'Ivoire, or through chefs de terre or "earth priests" in Burkina Faso or elsewhere. In time, and depending on political circumstances, late-comers would be integrated into the community and themselves become "autochthonous" or "indigenous"; though an autonomous status could also be maintained indefinitely. ${ }^{2}$

In North Africa, the concepts of nationality and citizenship as they developed in Islam and under the Ottoman empire remain relevant today. The notion of the Muslim community, or umma, developed over centuries and provided a sense of common identity across political boundaries, so that borders of even the most formalised states were blurred. The idea of a "nation-state" and nationality started to emerge in the Arab world in the $19^{\text {th }}$ century, and the word jinsiyya (ultimately derived from Greek genos: nation, kin-group) was used for the concept of nationality, with the same connotations of ethnic or descent-

1 See, for example, George B.N. Ayittey, Indigenous African institutions, Ardsley-on-Hudson, NY: Transnational Publishers, 1991; Said Adejumobi, "Identity, Citizenship and Conflict: The African Experience", in W. Alade Fawole and Charles Ukeje, The Crisis of the State and Regionalism in West Africa: Identity, Citizenship and Conflict, Dakar: CODESRIA, 2005; Martin Uzochukwu Gasiokwu, ECOWAS : Problems of citizenship and free movement, Jos, Nigeria: Mono Expressions, 1998, pp.47-54; Ralph Austen, Trans-Saharan Africa in World History, OUP, 2011, pp.49-77.

2 Jean-Claude Willame, Banyarwanda et Banyamulenge: Violences ethniques et gestion de l'identitaire au Kivu, Bruxelles : Institut africain (Cahiers africains No.25, March 1997) / Paris : L'Harmattan ; Jean-Pierre Chauveau, "Question foncière et construction nationale en Côte d'Ivoire", Politique africaine, No.78, 2000, pp.94-126, and other works by the same author, including the chapter (and contributions by other authors) in Richard Kuba and Carola Lentz (eds.), Land and the Politics of Belonging in West Africa, Leiden/Boston: Brill, 2006. 
based membership of a community that exist in other languages. From the early $20^{\text {th }}$ century the new term muwatana (derived from the word watan for place of residence or homeland), was used for citizenship: the status of a person who is not a foreigner, who is a native of the place, though without the connotations of rights and political participation as exist in English or (especially) French. ${ }^{3}$ The idea of the united umma was undermined by increasing resistance to the control of the Ottoman empire over Arab territories, and by Ottoman sultans themselves as they sought a secular alternative to the religious sovereignty conferred by the Muslim caliphate in their relations with non-Muslims.

The obvious dysfunctions and abuse of the millet system, by which non-Muslim communities within Ottoman territories had jurisdiction over their own affairs on matters of personal status, led to the adoption in 1869 of the first Ottoman Nationality Law, intended - in the face of European states' insistence on the complete extraterritoriality of their merchants' communities in Ottoman territory - to determine the reach of the sultan's authority over non-Muslims. The nationality law conferred nationality through paternal descent, as well as to a child of an alien father if both were born on the territory (following the double jus soli principle introduced in France in 1851, though at that time with the option to repudiate the attribution on majority), and an individual born on Ottoman soil could apply for nationality within three years of majority; in addition, naturalisation was possible on the basis of five years' residence; and a final provision stated that all those resident in Ottoman territories would be considered Ottoman nationals until their foreign nationality was established. Conversion to Islam was not listed as a means for acquisition of nationality, breaking with the Muslim tradition, though naturalisation continued to be granted to converts as a matter of practice. The distinction between Ottoman Muslims and Ottoman non-Muslims was theoretically done away with for political purposes. ${ }^{4}$

In Ethiopia, the one country in Africa not to be colonised, the first nationality law was adopted in 1930. Prior to that date, the power to admit foreigners as subjects was the prerogative of the emperor, sparingly used. ${ }^{5}$ The 1930 law (1922, in the Ethiopian calendar), was one of the oldest to be adopted in the Ethiopian legal system; even before the first modern constitution of $1931 .^{6}$

3 Parolin, Citizenship in the Arab world, pp.24-25; Jacqueline Bendeddouche, Notion de nationalité et nationalité algérienne, $2^{\text {nd }}$ Ed., Algiers: Société Nationale d'Édition et de Diffusion, 1982.

4 Parolin, Citizenship in the Arab World, chapter 3, pp.71-79 and p.100.

5 Fasil Nahum, "Ethiopian nationality law and practice" Journal of Ethiopian Law, Vol.8, No.1,1972, pp.168-183; Robert Allen Sedler, "Nationality, domicile and the personal law in Ethiopia", Journal of Ethiopian Law, Vol.2, No.1, 1965, pp.161-179.

6 Proclamation Promulgating the Ethiopian Nationality Law, 15 Hamle 1922 (Ethiopian calendar). See also Aberra Jembere, An introduction to the legal history of Ethiopia, 1434-1974, Münster; London: Lit Verlag, 2000. 
Looking to European models, it adopted a descent-based system through the male line only, unless the child was born out of wedlock (though the concept of illegitimacy was mostly foreign to Ethiopia). Women married to Ethiopian men automatically acquired Ethiopian nationality; naturalisation for others was permitted on the basis of quite stringent conditions, including fluent knowledge of written and spoken Amharic; though in 1933 the law was amended to allow the emperor to waive the conditions at his discretion. ${ }^{7}$ The law did not permit loss of Ethiopian nationality in any other circumstances than acquisition of another nationality; and reacquisition of Ethiopian nationality required only a return to Ethiopia, renunciation of the other nationality, and application for readmission, with no discretion. The 1931 constitution itself stated only that "All the natives of Ethiopia, subjects of the empire, form together the Ethiopian Empire"; the details were left to the law. ${ }^{8}$ The revised constitution of 1955, which replaced its 1931 predecessor and strengthened the powers of parliament, left the citizenship provisions in the law unchanged; however, it restricted the right to vote and stand for office to nationals from birth only; while ministers were required not only be subjects from birth themselves, but their parents too. ${ }^{9}$

The nature of membership of pre-colonial political entities was thus in some ways similar to, but in others very different from, the nationality laws attached to the state system brought to Africa by colonisation. But even in the European territories, the concept of nationality in international law was only developed during the later $19^{\text {th }}$ century, in parallel to the age of European empires in Africa and in part as a response to this early form of globalisation. The major treaties and jurisprudence came in the $20^{\text {th }}$ century, in the context of the two world wars and attempts to manage their aftermath and avoid their recurrence. Many of the rules of international law concerning state recognition and state rights and responsibilities, including rights to determine who are their nationals and the rights they have over them, were thus only elaborated during the period when Africa was already colonised, and indeed, were influenced by the expansion of European empires and the dispersal of European nationals around the globe. In the litigation before nascent international bodies that developed these rules, the nationality of a person (physical or legal) was important because it related to the rights of a state to demand the loyalty of that person and protect them against the demands of another state; not as a matter of individual rights. The European conceptualisation of the state and of nationality came to Africa as part of the same package.

7 Proclamation amending the Nationality Law of 15 Hamle 1922, 25 Meskerem 1926 (Ethiopian calendar).

8 Constitution of Ethiopia, 1931, Articles 1 and 18.

9 Nahum, "Ethiopian nationality law and practice"; Constitution of Ethiopia, 1955, Articles 1,67 and 95 . 


\subsection{The European colonial period}

As the European empires in Africa expanded, residents of territory annexed by a European power were considered to become nationals of that state, unless treaties provided otherwise. The rules on the duties of states in this regard developed relatively early, since, by contrast with the attribution of nationality for a person within one state, transfers of territory involved at least two states, and ceased to be a matter of only domestic concern. Nevertheless, the first rules were established in domestic legislation and courts. Thus, in the case of the British annexation of territories in Africa, the rule was that all persons who were nationals of the annexed territory become British nationals unless another provision was made in the instrument of annexation; and residents of British territory annexed by another state become aliens. It was also established by English court decisions that this rule did not apply to those who left the territory prior to the transfer of sovereignty, unless they subsequently returned or voluntarily claimed the status of British subjects: this was rule applied in the case of the annexation of the Boer Republics in South Africa, for example. ${ }^{10}$ In France, the 1945 nationality code provided that all those who remained domiciled in French-annexed territories acquired French nationality, and, conversely, that those resident in ceded territories lost French nationality. ${ }^{11}$ Ethiopia also followed this rule in its 1952 incorporation of Eritrea as an autonomous territory under imperial jurisdiction: a proclamation stated that "all inhabitants of the territory of Eritrea except persons possessing other nationality are hereby declared to be subjects of Our Empire and Ethiopian nationals"; as well as "all inhabitants born in the territory of Eritrea and having at least one indigenous parent or grandparent". If they had another nationality they were permitted to renounce Ethiopian nationality within six months and retain the foreign nationality. ${ }^{12}$ Nonetheless, there were cases of annexation or incorporation in which nationality was not conferred on all inhabitants of the transferred territory. Change of sovereignty did not affect third-country nationals; that is, nationals of other states recognised by the international state system. ${ }^{13}$

There was, however, at that time a clear distinction between the claim of an individual to the protection of his or her country of nationality against other

10 Weis, Nationality and Statelessness, chapter 11; discussed in the context of the colony of Lagos by Arthur V.J. Nylander, The Nationality and Citizenship Laws of Nigeria, Lagos: University of Lagos, 1973, pp.7-8.

11 Ordonnance $n^{\circ} 45 / 2447$ du 19 octobre 1945 portant code de la nationalité française. «Article 12 :Dans le cas où le traité ne contient pas de telles dispositions les personnes qui demeurent domiciliées dans les territoires rattachés à la France acquièrent la nationalité française. Article 13 : Dans la même hypothèse, les personnes domiciliées dans les territoires cédés perdent la nationalité française, à moins qu'elles n'établissent effectivement leur domicile hors de ces territoires.»

12 Imperial Order No.C of 1952, cited in Nahum, "Ethiopian nationality law and practice."

13 Weis, Nationality and Statelessness, pp.140-149. 
states, and the rights of that individual within the territory of which he or she had nationality. The context of empire only strengthened this rule. Not only were the conditions for grant of nationality within the sovereign discretion of the state concerned; but a nationality recognised at the international level in itself did not necessarily give the individual concerned full rights within the state of nationality, since it was accepted that only a limited few could participate fully in government and claim the role of a "citizen". Women were in most countries of the world excluded from full citizenship rights until at least the early twentieth century. In the colonial states of Africa and elsewhere all those not of European descent were similarly disadvantaged. Citizenship law and practice ensured that all but a tiny number of Africans were subordinate in status to the white-skinned citizens of the colonial states. To be a "native" (indigène) was to be an inferior being whose culture was denigrated, who had no right to influence the decisionmaking processes that governed daily life, whose property was regularly forfeited, who could be forced to work or move home, and who had only limited civil liberties protections. Only a tiny minority of Africans ever achieved the right to be treated on the same legal basis as whites, even where there was an ideology of assimilation as in the French and Portuguese colonies; while those of mixed race created legal and intellectual confusions that the colonial powers struggled to resolve within their worldview. ${ }^{14}$

Thus, colonial rule transformed existing relations between first-comers and latecomers within African polities, first by the imposition of an additional level of political authority that radically altered previous power relationships and also affected the interpretation of the rules of membership of any community; and, secondly, by a vastly increased volume of migration (forced and voluntary).

The territories of the British empire in Africa belonged to one of three categories. First established were the "colonies": initially the coastal trading enclaves, including Gambia, Lagos, the Gold Coast and Freetown as well as the Cape Colony and Natal in South Africa; later joined by Southern Rhodesia, and most of Kenya excluding the coastal strip. The defeated Boer republics of Transvaal and Orange Free State became colonies also, and in 1910 joined with the Cape Colony and Natal to form the Union of South Africa, also as a colony, but with a substantial measure of self-government. In 1931, South Africa became a "dominion", the only African territory to obtain this semi-independent status, created by the Statute of Westminster 1931 and granted to the more significant colonies, including Canada, Australia and New Zealand, as well as

14 Alexander Keese, Living with ambiguity: Integrating an African elite in French and Portuguese Africa, 1930-61, Stuttgart : Steiner, 2007; Martin Deming Lewis, "One Hundred Million Frenchmen: The "Assimilation" Theory in French Colonial Policy", Comparative Studies in Society and History, Vol. 4, No. 2, 1962, pp. 129-153; Kristin Mann and Richard Roberts (eds.), Law in Colonial Africa, Portsmouth NH and London: Heinemann and James Currey, 1991. On those of mixed race, see Emmanuelle Saada, Les enfants de la colonie: Les métis de l'Empire français entre sujétion et citoyenneté, Paris : La Découverte, 2007. 
India, Pakistan and Ceylon (Sri Lanka). The remaining territories, including all those added in the late 19th century "Scramble for Africa", were designated "protectorates". Colonies and dominions were "within the crown's dominion"; while "protectorates", including most other British-controlled territories in Africa, were nominally foreign territory managed by local government structures established under British protection. ${ }^{15}$ Finally, there were formerly German territories mandated to British administration by the League of Nations (later trust territories, under UN mandate), including part of Togo (which was administered as part of the Gold Coast), part of Cameroon (administered from Nigeria), and Tanganyika.

Until 1948, the single status of "British subject" was applied to all those born within the crown's dominions (including the United Kingdom); during the $19^{\text {th }}$ century, the term "British protected person" emerged to cover the people indigenous to a protectorate. The British Nationality and Status of Aliens Act 1914 was the first statute intended to apply throughout the empire, and retained the principal nationality category of "British subject" previously developed through common law and a patchwork of other statutes. ${ }^{16}$ A person born in Lagos or any other colony had the same status as one born in Britain. However, "the simple nomenclature 'British subject' affords, within the Empire, no clue as to his rights". ${ }^{17}$ The 1914 Act expressly allowed the self-governing territories to treat "different classes of British subjects" differently. ${ }^{18}$ Although a British subject had the same rights of British protection in relation to foreign countries, the status was differentiated throughout the empire, with each colony deciding its own laws, including laws that discriminated on racial grounds; a matter fiercely disputed between representatives of India, South Africa, and others at imperial conferences. ${ }^{19}$ Separate legislation was adopted to provide for naturalisation in

15 Another category of territory within the empire included protected states (where Britain only controlled defence and external relations): there were no protected states in Africa, though Zanzibar was treated as a protected state for some nationality purposes, since it had its own internal nationality law from 1911. Fransman's British Nationality Law catalogue entry on Tanzania; see also chapter 13.3, The status of Zanzibari in Tanzania.

16 Rieko Karatani, Defining British citizenship : Empire, Commonwealth and Modern Britain London: Frank Cass, 2002; Laurie Fransman, Fransman's British Nationality Law, Third Edition, Bloomsbury Professional, 2011, Chapter 3.

17 E.F.W. Gey van Pittius, Nationality within the British Commonwealth of Nations, London: PS King \& Son, 1930, p.163.

18 British Nationality and Status of Aliens Act 1914, section 26: "Nothing in this Act shall take away or abridge any power vested in, or exercisable by, the Legislature or Government of any British Possession, or affect the operation of any law at present in force which has been passed in exercise of such a power, or prevent any such Legislature or Government from treating differently different classes of British subjects."

19 Daniel Gorman, "Wider and Wider Still?: Racial Politics, Intra-Imperial Immigration and the Absence of an Imperial Citizenship in the British Empire", Journal of Colonialism and Colonial History, Vol.3, No.3, 2002. See also Daniel Gorman, Imperial Citizenship: Empire and the Question of Belonging, Manchester: Manchester University Press, 2007; Clive Parry, 
each colony as a distinct process from naturalisation in the UK, which did not give rights in the UK nor in other colonies; the colonies adopted their own laws to provide local rules. ${ }^{20}$ Of particular significance for the later development of nationality law and the rights of nationals and non-nationals were the very different rights applied to the "different classes of British subjects" in the colonial territories in relation to land ownership. Africans in the British colonies deemed suitable for European settlement — South Africa, Southern Rhodesia and Kenya in particular - were confined to "native reserves" where they could hold land under customary law; whereas only Europeans could have freehold title in the fertile lands expropriated for their settlement. Africans were brought in as labourers or sometimes sharecroppers in those zones, but denied the right to own land themselves.

Birth in a protectorate did not confer British subject status, unless the father was a British subject; and British protected persons were treated on the same footing as aliens for the purpose of naturalisation as a British subject. The fiction was maintained, through the concept of "indirect rule", that the protectorates were really semi-autonomous, internally governed by indigenous "tribal authorities", with control over their own "tribal" subjects. ${ }^{21}$ In practice, the British colonial administrators interfered quite freely in matters supposedly within the purview of those authorities. Whereas many pre-colonial political entities had been multiethnic, the colonisers had an anthropological desire to sort their subjects into different ethnic groups, and to define some as "native" to a particular area and others as "strangers". The "natives" were allocated the right to be represented by a chief, the "strangers" were subordinate; but the boundary between native and stranger could be very difficult to define. The allocation of a person to a tribe was entirely based on primordial identity: in Nigeria, for example, a "native of Nigeria" was "any person whose parents were members of any tribe or tribes indigenous to Nigeria and the descendants of such persons, and includes persons one of whose parents was a member of such tribe"; there was no provision for "naturalisation" as the member of one tribe or another. ${ }^{22}$ The distinction between

Nationality and citizenship laws of the Commonwealth and of the Republic of Ireland, London: Stevens, 1957.

20 Act for the Naturalisation of Aliens, 10 \& 11 Vict, cap 83, 1847; replaced by the Naturalisation Act, 1870, which preserved the separate processes for the colonies; replaced in turn by the British Nationality and Status of Aliens Act 1914, which gave colonies the power to grant certificates of imperial naturalisation valid across the empire, with the same effect as those granted by the Secretary of State, while still providing powers to grant only local naturalisation as a separate status. This was endorsed, after ongoing argument, by the imperial conference of 1930. Karatani, Defining British citizenship, Chapters 2 and 3.

21 The policy of "indirect rule" was most famously articulated by Lord Lugard in his book, The Dual Mandate in British Tropical Africa, published in 1922, which stated that Britain should allow Africans to "develop along their own lines", rather than attempt to govern Africa according to European standards.

22 Interpretation Ordinance 27 of 1939. 
first-comers or late-comers in a particular location for the purposes of access to land and other rights was flattened by this focus on ethnicity. ${ }^{23}$ British protected persons, as well as "natives" within the colonies, were in general governed by the customary law of the "tribe" concerned, as modified by statute and British interpretation; "Native Courts" were established to adjudicate disputes between natives and sanction minor offences, applying "native law and custom, so far as it is not repugnant to natural justice, equity and good conscience", ${ }^{24}$

The British Nationality Act of 1948, the first attempt to create a single comprehensive system of nationality law by statute, established the new status of "citizen of the United Kingdom and colonies" (a status abolished in 1981). British subject became an umbrella status (with limited rights in itself) derived from newly created citizenships of the Commonwealth, including both the new status of "citizen of the UK and colonies" as well as the citizenships of those territories now recognised as "independent Commonwealth countries" under the act (mainly the former "dominions", including South Africa, but also Southern Rhodesia). ${ }^{25}$ Citizenship of the UK and colonies continued to be granted on a jus soli basis to all those born in the UK or in one of the colonies, and an alien could naturalise as a citizen of the UK and colonies in any colony as well as in the UK. A citizen of the UK and colonies had the right to free movement throughout the empire; however, Africans, Europeans and others retained their separate legal systems in the remaining colonies in Africa (including Kenya), meaning that freedom of movement for those of Asian or African descent was in practice restricted a great deal more than that of those of British or other European descent. "Pass laws" were applied across the British territories to "non-Europeans", whether in a colony or protectorate.

This regime of linked citizenships did not extend to the protectorates, which retained their subordinate status. The status of "British protected person" was codified by the new law, and continued to apply to persons born in a protectorate who were not citizens of the UK and colonies (that is, whose parents were not citizens of the UK and colonies, previously British subjects; though after 1948

23 For a discussion, see Carola Lentz, "Introduction" in Kuba and Lentz, Land and the Politics of Belonging in West Africa.

24 The standard language, taken here from the Sierra Leone Native Courts Ordinance, 1933. On the definition of "native" see Christopher Joon-Hai Lee, "The "Native" Undefined: Colonial Categories, Anglo-African Status and the Politics of Kinship in British Central Africa, 1929-38", Journal of African History, Vol.46, No.3, 2005, pp. 455-478.

25 The dominions that became "indepedent Commonwealth countries" were Canada, Australia, New Zealand, South Africa, Newfoundland, India, Pakistan and Ceylon. Southern Rhodesia was never a dominion but was treated as such in some respects and also became an "independent Commonwealth country". Robert R. Wilson and Robert E. Clute, "Commonwealth Citizenship and Common Status", American Journal of International Law, Vol. 57, No. 3, 1963, pp. 566-587; Randall Hansen, "The Politics of Citizenship in 1940s Britain:The British Nationality Act", Twentieth Century British History,Vol.10, No.1, 1999, pp.67-95. 
it was possible in some circumstances to be both a British protected person and a citizen of the UK and colonies or a foreign national). British protected person status provided some rights both in the protectorate concerned and in the UK, including treatment as a British national for the purposes of protection when outside his or her own protectorate; but a British protected person remained an alien in many contexts, and was a lesser status than citizenship of the United Kingdom and colonies, including being barred from seeking redress against state acts in the courts. The term British protected person was also used to refer to persons in the mandated territories (which became Trust Territories under the new United Nations regime), but this was as a matter of "crown prerogative" rather than statute. ${ }^{26}$

This legal structure remained essentially unchanged until the former protectorates achieved independence in the 1960s. In southern Africa, however, the structure of nationality law in British territories took a different route, due in particular to the much larger settler populations of British and other European descent. As demands grew from Africans for self-government, so also did resistance to this process from the white population.

Efforts to shore up defences against growing African demands for political power saw the British territories of Northern and Southern Rhodesia and Nyasaland (today's Zambia, Zimbabwe and Malawi) linked together for ten years as the Central African Federation from 1953 to 1963. The creation of the federation was supported by the white minority government of Southern Rhodesia, which had for many years sought greater access to the mineral riches of Northern Rhodesia in particular; but strongly opposed by the African leadership in the protectorates of Northern Rhodesia and Nyasaland. Promised protections for African interests in the new federal political arrangements were very weak, and the vast majority of Africans were excluded from voting in federal elections on the basis of educational and property qualifications.

At the time the Federation was established, Northern Rhodesia and Nyasaland were separate protectorates. Southern Rhodesia was an "independent Commonweath country”, which had had its own citizenship law since 1949, following the general scheme envisaged by the 1948 British Nationality Act (see chapter 8.3). On federation, each of the three territories retained its separate status for nationality purposes, until the Federation enacted a new law in 1957, the Citizenship of Rhodesia and Nyasaland and British Nationality Act. The act provided for jus soli citizenship of the federation for those born before or after

26 The usage of "British protected person" is very complicated, and varied over time and in different contexts, according to definitions established by the British Protected Persons Order No.499 of 1934 and subsequent Orders in Council. See Fransman's British Nationality Law, chapter 3.3.3 et seq; Weis, Nationality and Statelessness, pp.20-22; also Nylander Nationality and Citizenship Laws of Nigeria, pp.18-19. The term still exists, and confers some limited rights in relation to the United Kingdom. 
the date of creation of the Federation, and for other transitional provisions. ${ }^{27}$ However, many British protected persons from Northern Rhodesia and Nyasaland failed to acquire the merged citizenship automatically (though they remained British protected persons under British nationality law), creating room for later confusion. ${ }^{28}$

At the tip of the continent, South Africa had its own particular history, as the creation of different classes of citizenship reached its apogee with the elaboration of extraordinarily complex race- and ethnicity-based citizenship distinctions. Like Southern Rhodesia, South Africa had its own citizenship law from 1949, providing for a right to citizenship premised on birth in the territory. ${ }^{29}$ The victory of the National Party in elections in the same year of 1948, however, meant that the distinctions between natives and Europeans became even more exaggerated. Ultimately, a majority of black South Africans had their nominal nationality taken away, told that instead they belonged to one of ten supposedly independent and ethnically designated "homelands". ${ }^{30}$ These same distinctions were applied in Namibia, administered by South Africa under an initial League of Nations mandate granted in 1920, an administration which continued illegally in the face of United Nations resolutions adopted after South Africa left the British Commonwealth in 1962.

French territories in sub-Saharan Africa were from the early 20th century divided between French West Africa (Afrique occidentale française, AOF), French Central Africa (Afrique équatoriale française, AEF), and Madagascar. Algeria, in North Africa, had a special status, forming part of metropolitan France; Morocco and Tunisia were protectorates, with nominally autonomous governments under French protection. As in the British colonies, there was a clear division between categories of national: between French nationality - the legal link between the individual and the state, and French citizenship - the status of a person with

27 Citizenship of Rhodesia and Nyasaland and British Nationality Act, 1957 (No. 12 of 1957). Excluded from jus soli were children born out of wedlock in Northern Rhodesia or Nyasaland whose fathers were not British subjects. Those who were British subjects, Southern Rhodesian citizens or registered in one of the territories as a citizen of the UK and colonies acquired Federation citizenship automatically under the transitional provisions.

28 Fransman's British Nationality Law, catalogue entry on Malawi.

29 South African Citizenship Act No.44 of 1949, section 3; the jus soli right was subject to the usual exceptions relating to father's status as a diplomat or enemy alien, as well as if he was prohibited immigrant.

30 In fact, only four of the ten "homelands" (Transkei, Bophuthatswana, Venda and Ciskei) were ever recognised as independent by the South African government; the remaining six (Gazankulu, KaNgane, KwaNdebele, KwaZulu, Lebowa and QwaQwa) were only selfgoverning. See Bently J. Anderson, "The Restoration of The South African Citizenship Act: An Exercise in Statutory Obfuscation", Connecticut Journal of International Law, Vol. 9 (1993-1994), for an outline of the undoing of this process. Also Fransman's British Nationality Law, catalogue entries on Namibia and South Africa. 
full civil and political rights. But the legal regime to achieve this distinction was quite different.

Rules on the acquisition of French citizenship were first codified in the constitutions adopted in the wake of the French revolution, which were based on the same jus soli principles that had been understood as in operation under the ancien régime, attributing French nationality to those born in France and domiciled there, and, for the first years after the revolution, even automatically to those resident in the country for a period of time. In 1804, however, the Code Napoléon separated French citizenship as a constitutional matter from the exercise of civil rights; within this new civil code, jus sanguinis applied, so that a person was French if born to a French father.After successive debates on the issue, in 1851 a general reform reinstated a variant on jus soli principles, introducing for the first time the double jus soli rule for those born in France of foreign parents themselves born in France; such children could also repudiate French nationality at majority (which many did, to avoid military conscription). ${ }^{31}$

France's first colony in Africa, Algeria, had a unique legal status throughout its occupation. From 1834, just four years after Algiers was captured by French troops, the territory was annexed to France, and in theory simply formed a continuation of French territory across the Mediterranean Sea. However, native Muslims and Jews did not obtain full rights as French citizens. Two legal systems were established, with separate laws, magistrates and tribunals for those with personal status (statut personnel) established by the French civil code, and those with local (religious) law personal status. Even though, in 1865, it was declared that "tout individu musulman est français" and that natives (indigènes) could acquire full rights to French citizenship, this was only if they renounced their status as Muslim (or Jewish) and showed assimilation to French culture in other ways. ${ }^{32}$ This was the foundation of the distinction based on personal status between French citizens (citoyens français), who were of European stock; and French subjects (sujets français), including black Africans, Muslim Algerians, and other indigènes of Madagascar, the Antilles, Melanesia, and other non-European territories (although the term indigène was freely used, including in law, it was never defined, and the legally meaningful term was that of sujet). In 1870, the (much smaller) Jewish population of Algeria was collectively awarded French civil status, but the same did not happen for Muslim Algerians. ${ }^{33}$

31 Weil, Qu'est-ce qu'un Français.

32 Senatus-consulte sur l'état des personnes et la naturalisation en Algérie, 1865. On the development of Algerian nationality law, see generally: Patrick Weil, Le statut des musulmans en Algérie coloniale: Une nationalité française dénaturée, EUI Working Paper, HEC No. 2003/3, European University Institute, 2003 ; Bendeddouche, Notion de nationalité et nationalité algérienne. French legislation applicable to Algeria is available with commentary in the "Digithèque de matériaux juridiques et politiques » of the University of Perpignan, http://mjp.univperp.fr/mjp.htm, last accessed 27 February 2014.

33 "Les israelites indigènes des départements de l'Algérie sont déclarés citoyens français ; en 
In 1881, France adopted a law that further formalised the division of the residents of its overseas territories into two categories. ${ }^{34}$ It extended the application of the Code de l'indigénat, a collection of legal provisions added to the Penal Code that had been developed in Algeria, across the French empire. The Code provided for a range of offences specific to indigènes, applied and interpreted by colonial administrators or executive-dominated colonial tribunals; French citizens in the overseas territories were governed by the French civil code in the civil courts. These provisions remained legally in force until 1946 (though the practical effect lasted longer). Although the French imperial system did not employ the British concept of indirect rule under customary law, and the indigénat regime did not rely on the fiction of custom, there was a very similar distinction between French subjects governed by local personal law and the indigénat, and French citizens of French civil status, the vast majority of European descent. ${ }^{35}$

A major new nationality law was adopted in France in 1889, which confirmed a return to jus soli citizenship, integrating the provisions into the civil code. The law provided for a child born in France to acquire French nationality automatically if still domiciled there at majority or if born of a parent also born on French territory. These rules also applied in Algeria, and thus allowed people of European origin born in Algeria to become French. There was never any doubt that indigenous inhabitants of the French territories in Africa had acquired French nationality on annexation of the territory. However, the decrees applying metropolitan laws did not apply to them. The decree implementing the 1889 law, not adopted till 1897, in fact excluded from its application the status both of the indigènes in the French colonies and of foreigners considered

conséquence, leur statut réel et leur statut personnel seront, à compter de la promulgation du présent décret, réglés par la loi française. Toutes dispositions législatives, décret, règlement ou ordonnance contraires sont abolis. » Décret du 24 octobre 1870, relatif à la naturalisation des israélites de l'Algérie, known as the Décret Crémieux, after its author, the minister of justice in the French Government of National Defence formed during the Franco-German war of 1870-71. The confusion between the questions of French civil status, French citizenship and French nationality were such that the process of renouncing another personal status to acquire French civil status was often termed naturalisation (as in the case of the Décret Crémieux and Sénatus consulte of 1865), even though in principle those doing so were in fact already French nationals. The rights granted by the Décret Crémieux were revoked by the anti-semitic laws of the second world war Vichy regime in France, applied to Algeria in 1940, and reinstated by the Comité français de la Liberation nationale in 1943.

34 Loi No.10.680 du 28 Juin 1881, confere aux Administrateurs des communes mixtes en territoire civil la répression, par voie disciplinaire, des infractions spéciales à l'Indigénat.

35 Christian Bruschi, "La nationalité dans le droit colonial," Procès: Cahiers d'analyse politique et juridique, 1987-1988, special issue on "Le droit colonial", pp. 29-83 ; Gregory Mann, "What Was the Indigénat? The 'Empire of Law' in French West Africa", Journal of African History, Vol. 50, No. 3, 2009, pp. 331-353; Pierre Lampué «L'étendue d'application du statut personnel des autochtones dans les territoires français d'outre-mer " Civilisations, Vol.7, No.1, 1957, pp.1-15. 
indigènes born on colonial soil. ${ }^{36}$ Even the new nationality code adopted in 1945 initially did not extend to the natives of French overseas territories. ${ }^{37}$ Moreover, it remained the case that Muslim Algerians and other sujets français could not become French citizens (rather than subjects) unless they took steps to acquire French civil status as well as French nationality. A body of texts describing the criteria to show sufficient assimilation to French civilisation to be accorded this status was steadily elaborated. ${ }^{38}$

Following the First World War, in which Algerians were conscripted to fight for the French army, the law of 4 February 1919 theoretically made it easier for Muslim Algerians to acquire French citizenship, in particular by making the decision on whether the criteria were fulfilled a judicial rather than administrative one. The reality was different, since the conditions applied were so strict as to make it difficult for Muslims to fulfil them. By 1936, only 7,817 people had been "naturalised" under this law, with a rejection rate of more than 50 percent. The same year, the Front populaire government proposed a new law ${ }^{39}$ that would grant French citizenship and the right to vote to around 20,000 to 25,000 Algerian Muslims, even if they kept their Muslim personal status. Opposition from French colons afraid of becoming an electoral minority ensured that the law was never passed. Algeria was included in the general relaxation of access to French citizenship following the Second World War (see below), but by independence in 1962, only around 10,000 Algerian Muslims had renounced their Muslim personal status to become full French citizens. ${ }^{40}$

Tunisia and Morocco were both French protectorates, established in 1881 and 1912 respectively, as France was awarded control of the territories when the decaying Ottoman empire began to be divided up by the European powers. Although from a strictly legal point of view the respective treaties did not deprive the countries of their status as sovereign states, leaving the Bey and the Sultan in nominal office, France effectively took over control of the two territories, whose residents became French protected persons (protégés français). Following World War I, part of Togo and most of Cameroon were similarly placed under French control by League of Nations mandate, and their populations became French administered persons (administrés français); after 1945, this was converted to United Nations trusteeship. French regulation of Tunisian and Moroccan nationality gave rise to the first issue of substance submitted to the Permanent

36 Roger Decottignies and Marc de Biéville, Les nationalités africaines, Paris : Collection du Centre de Recherches, d'Etudes et de Documentation sur les Institutions et la Législation Africaines, No.4, 1963, pp.15-16.

37 Ordonnance n 45/2447 du 19 octobre 1945 portant Code de la nationalité française.

38 Saada, Les enfants de la colonie, pp. 116-121 and pp.126-131.

39 Known as the Blum-Viollette draft, after Léon Blum, at that time president of the Council of Ministers, and Maurice Viollette, former governor-general of Algeria (1925-1927), and at that time minister of state for north Africa.

40 Weil, Le statut des musulmans en Algérie colonial, p.14; Saada, Les enfants de la colonie, p.128. 
Court of International Justice (PCIJ) established by the League of Nations after the first world war. ${ }^{41}$ Decrees adopted in 1921 by France and by the French administrations in Tunis and Morocco gave French nationality to persons born in Tunis and Morocco of at least one parent also born in the same territory (with exceptions). The United Kingdom protested against the decrees, which would impose French nationality on some British subjects, and the Council of the League of Nations referred the case to the PCIJ for an advisory opinion on whether the application of the decrees was by international law solely a matter of domestic jurisdiction. The court found that, though in principle questions of nationality were within the "reserved domain" of states, the dispute was not solely a matter of domestic jurisdiction because of the obligations undertaken by France towards other states in the treaties establishing the protectorates. Following the court's ruling, the question was settled by direct negotiation, and the French government undertook to ensure that a child born in Tunis of a British subject who was himself also born in Tunis should have the right to decline French nationality (though this right would not extend to the next generation): the parties thus agreed on a right of option rather than the unilateral imposition of nationality. ${ }^{42}$

In $\mathrm{AOF}$ and $\mathrm{AEF}$, almost all persons of African origin were sujets français. Though French subjects had the theoretical right to become full citizens with French civil status, no more than 16 West Africans were granted this status each year between 1935 and 1949: the famed French commitment to assimilation applied only in the cultural domain until the very last years before independence. ${ }^{43}$ The exception to this rule was the French citizenship recognised in 1916 for the inhabitants (black African as well as white) of four communes in Senegal - Dakar, Saint Louis, Gorée and Rufisque — who had enjoyed special privileges since the 1830s, including the option to access the courts under the civil code and, from 1848, the right to elect a deputy to the French parliament. ${ }^{44}$ The law was, however, primarily directed at the possibility of military conscription in those territories; it was not envisaged that the citizens of the four communes would be able to move to France and live there as Muslims. ${ }^{45}$

During the last years of colonial rule, the legal status of the French colonies went through major changes that had no parallel in the British African territories and had important impacts on the development of nationality law — and on the "idea" of francophone Africa, especially West Africa - that still have

${ }^{41}$ Advisory Opinion No. 4, Nationality Decrees Issued in Tunis and Morocco, Permanent Court of International Justice, (1923) PCIJ, Ser. B, No. 4

42 Weis, Nationality and Statelessness, pp.71-76.

43 Catherine Coquery-Vidrovitch, "Nationalité et citoyenneté en Afrique occidentale français: Originaires et citoyens dans le Sénégal colonial," Journal of African History, Vol.42 (2001), pp.285-305.

44 Bruschi, "La nationalité dans le droit colonial".

45 Saada, Les enfants de la colonie pp.120-121. 
resonance today. ${ }^{46}$ For a decade after the Second World War the ambition of French colonial policy became the creation of a system - either federal or more assimilationist — of fully or semi-autonomous states within an overall French polity, under the continuing leadership of the French metropolitan territory. The ambitions of African leaders were shaped by this framework, leading them to organise collectively and aim in the first instance at full participation in French institutions, rather than seeking independent control of each individual territory (as in the British protectorates); at least until it became apparent that true equality within the French system would not be possible.

The first steps of this policy were laid during the 1944 "Brazzaville conference" between General de Gaulle and the "Free French" and indigenous leaders from the French African territories, at which promises of greater African autonomy were made, in recognition of the support of the colonial territories in the struggle against the Vichy regime and German forces. A 1944 ordinance adopted by the Comite français de la Liberation nationale, representing the united forces fighting with the Allies during the Second World War also repealed the separate criminal laws applied to Muslims in Algeria under the code de l'indigenat, and relaxed the rules by which they could become citoyens français, removing the requirement to renounce Muslim personal status for those with a higher status or educational level (known as évolués), and benefiting about 60,000 Muslims. ${ }^{47}$

Following the end of the Second World War and the liberation of France, these promises led to a rapid evolution in the legal arrangements for the empire. ${ }^{48}$ In 1946, the new constitution of the $4^{\text {th }}$ Republic, drafted by a constituent assembly in which the African colonies were represented for the first time in such a discussion, created the Union française, which granted a degree of autonomy to the sub-Saharan territories. ${ }^{49}$ The colonies became overseas territories with decentralised local government status, and were also represented in the Assembly of the Union. In 1956 a loi cadre (framework law) further increased the autonomy of the individual French colonies in west and central Africa, and greatly broadened the electorate, while at the same time repatriating to France

46 For a comprehensive discussion, see Frederick Cooper, Citizenship between Empire and Nation: Remaking France and French Africa, 1945-1960, Princeton University Press, 2014; also Frederick Cooper, "The politics of citizenship in colonial and postcolonial Africa", Studia Africana,Vol.16, October 2005, pp.14-23.

47 Ordonnance du 7 mars 1944 relative au statut des Français musulmans d'Algérie. See Weil Le statut des musulmans en Algérie coloniale; Charles André Julien, L'Afrique du Nord en Marche : Nationalismes musulmans et souveraineté française, R. Julliard, 1952, pp.257-9.

48 Cooper, Citizenship between Empire and Nation; François Borella, L'évolution politique et juridique de l'Union française depuis 1946, Paris: Librairie générale de droit et de jurisprudence, 1958; K. E. Robinson, “The Public Law of Overseas France since the War", Journal of Comparative Legislation and International Law, Vol. 32, No. 3/4, 1950, pp. 37-57.

49 See Cooper, Citizenship between Empire and Nation, chapter 2, for a detailed discussion of the two constituent assemblies (the first proposed constitution being defeated, and the second approved, in a referendum in which most Africans did not have a vote); 
some of the powers previously wielded by the AOF and AEF administrations. The Senegalese politician Léopold Sédar Senghor and others accused the French state of the "balkanisation" of AOF by this process. ${ }^{50}$ The French protectorates of Morocco and Tunisia gained independence the same year.

In 1958, the increasingly violent resistance to continued French rule in Algeria led to the collapse of the $4^{\text {th }}$ Republic and the renegotiation of the structure of the French Union. The new constitution for the $5^{\text {th }}$ Republic provided for the free association of autonomous republics within a Communauté française, in which France was the senior partner. The French Community was a less assimilationist and more federal system, and individual French colonies were given the right to approve their membership by referendum. The Community's jurisdiction as a whole was limited to foreign policy, defence, the currency, a common economic and financial policy and policy on strategic matters and, except for special agreements, justice, higher education, external and public transport and telecommunications. Although all France's sub-Saharan African colonies - except for Sekou Tourés Guinea, which rejected the constitution and thus opted for independence ${ }^{51}$ — joined the Community as federated states sharing a common nationality, the momentum towards full independence as individual territories was irresistible. The Community as originally envisaged functioned only during 1959, and in 1960, the constitution was amended to allow members of the Community to claim independence more easily - and, led by Mali (initially in a union with Senegal), the territories of AOF and AEF almost all did so. Even those that formally remained members of the Community in effect became fully independent. ${ }^{52}$ In 1962 Algeria also gained independence, ending its bloody civil war.

During this evolution of the legal framework for the relationship between France and its colonies, the nationality regime also went through important changes; which seemed dramatic from the point of view of metropolitan France, though always inadequate to respond to the aspirations of French nationals in Algeria and overseas.

The first step in this process was the adoption in 1946 of the Loi Lamine Guèye, by the constituent assembly that drafted the new constitution. Named after a Senegalese delegate to the assembly, its single article provided that:

50 Joseph-Roger de Benoist, La balkanisation de l'Afrique occidentale française, Dakar : Nouvelles éditions africaines, 1979 ; Benyamin Neuberger, "The African Concept of Balkanisation", Journal of Modern African Studies, Vol. 14, No. 3 (1976), pp. 523-529.

51 Georges Fischer, "L'indépendance de la Guinée et les accords franco-guinéens", Annuaire français de droit international,Vol.4, 1958.

52 Cooper, Citizenship between Empire and Nation, chapters 6 and 7.The Community formally remained in existence until the relevant articles of the Constitution were repealed in 1995. Some few (non-African) colonies chose instead to remain part of France, under the status of overseas départements (equivalent to the départements making up the French metropolitan territory itself). 
A partir du 1er juin 1946, tous les ressortissants des territoires d'OutreMer ont la qualité de citoyen, au même titre que les nationaux français de la métropole et des territoires d'Outre-Mer. Des lois particulières établiront les conditions dans lesquelles ils exerceront leurs droits de citoyens. ${ }^{53}$

The political significance of this change was enormous, even though the meaning remained ambiguous in practice, especially the second sentence, and the degree to which individual laws in each territory could in fact detract from the concept of a common citizenship. ${ }^{54}$ In parallel, the colonial ministry adopted decrees dismantling the code de l'indigénat (though the lack of judicial officers to staff ordinary civil courts meant that administrative tribunals continued in practice to judge lesser crimes) and another law abolished forced labour. ${ }^{55}$ The 1946 constitution repeated the language of the Lamine Gueye Law in its Article 80 (giving the "quality of citizen" to inhabitants of the overseas territories), created a new umbrella status of citoyen de l'Union française in Article 81, ${ }^{56}$ and provided in Article 82 that those citizens who had not acquired French civil status would retain their existing personal status unless they renounced it, elevating the concept of "personal status" to a constitutional principle. ${ }^{57}$ No text was ever adopted specifying how the renunciation described in Article 82 of the constitution might be effected; although the earlier decrees on procedures to

53 Loi 46-940 du 7 mai 1946 tendant à proclamer citoyens tous les ressortissants des territoires d'outre-mer. "From 1 June 1946 all nationals of the Overseas territorites have the status of citizen, on the same basis as French nationals in the metropolitican territory or in the Overseas territories. Individual laws will establish the conditions under which they will exercise their rights as citizens". The law was adopted by the first constituent assembly, its adoption being a tactical manoeuvre by Lamine Guèye to ensure that the principle would be endorsed by the final constitution. See Cooper, Citizenship between Empire and Nation, pp.88-91.

54 Borella, L'Evolution politique et juridique de l'Union française (Chapter VI : La situation de l'individu); James E. Genova, "Constructing Identity in Post-War France: Citizenship, Nationality, and the Lamine Guèye Law, 1946-1953", International History Review, Vol.26, No.1, 2004, pp.56-79.

55 Cooper, Citizenship between Empire and Nation, pp.67-68.

56 Article 81 provided for those who were not within the overseas territories but rather inhabitants of protectorates (Tunisia and Morocco) and trust territories (Togo and Cameroon), who did not have French nationality, to have citizenship of the Union and (at least) some of the rights guaranteed in the constitution (though not to be French citizens): "Tous les nationaux français et les ressortissants de l'Union française ont la qualité de citoyen de l'Union française qui leur assure la jouissance des droits et libertés garantis par le préambule de la présente Constitution.» Constitution of the 4th Republic, 27 October 1946.

57 «Les citoyens qui n'ont pas le statut civil français conservent leur statut personnel tant qu'ils n'y ont pas renoncé. Ce statut ne peut en aucun cas constituer un motif pour refuser ou limiter les droits et libertés attachés à la qualité de citoyen français. " Article 82, 1946 Constitution. 
be admitted to the status of French citizen theoretically remained in effect. ${ }^{58}$ In 1953, the application of the 1945 nationality code was extended to indigenous inhabitants of France's overseas territories, with some first attempts to adapt rules on establishing descent and other matters to the terms of customary law. ${ }^{59}$

In electoral law, however, the subordination of the French colonies remained, and thus the subordinate citizenship of French nationals "native" to the colonies. In this distinction, the issue of statut personnel, regulating which rules applied to a person's relations with other individuals and the disposition of his or her property, remained critical. A person whose statut personnel was governed by the French civil code was a full French citizen in political rights; whereas those governed by customary or Muslim law did not have full rights, despite the statement of a single common citizenship. The laws governing eligibility to vote were gradually made more expansive, but separate electoral colleges were retained for persons with French civil status and others until 1956 (and in Algeria even after that date). ${ }^{60}$ Moreover, the colonies were granted only a limited number of seats in the legislature: by 1955 the overseas departments and territories had 83 deputies in the Assembly (of which 30 were Algerian), to metropolitan France's 544, though the comparative populations were roughly equal. Similar inequalities were apparent in the lower-ranking assemblies established in each overseas territory. ${ }^{61}$

The new constitution of 1958 and the establishment of the Communauté française gave the member states of the Community a large degree of autonomy; but, since international relations were left to France, the inhabitants of those states retained their French nationality and a French common citizenship until bilateral accords superseded the effort to maintain the Community. ${ }^{62}$ The exception was Guinea

58 Lampué, «L'étendue d'application du statut personnel »; and Cooper, Citizenship between Empire and Nation, pp.152-163 on the importance of civil registration and the mechanics of changing status.

59 Décret n53-161 du 24 février 1953 déterminant les modalités d'application du Code de la nationalité française aux territoires d'outre-mer. See also Decottignies and de Biéville, Les nationalités africaines, pp.16-17 ; Stanislas Melone, "La nationalité des personnes physiques ", Encyclopédie juridique de l'Afrique : Vol VI, Droits des personnes et de la famille, Dakar : Nouvelles éditions africaines, 1982, p.84.

${ }_{60}$ In November 1946 under 800,000 people in French West Africa were voters ; rising to one million by June 1951, 6 million in January 1956 and ten million by March 1957, the first election under universal suffrage. Cooper, Citizenship between Empire and Nation, p.139.

61 Borella, L'évolution politique et juridique de l'Union française.

62 Décision présidentielle du 9 février 1959: “Au sein de la Communauté, il n'existe qu'une nationalité qui est la nationalité de la République française et de la Communauté”. Cited in Decottignies and de Biéville, Les nationalités africaines, p.17. On diagreements on this point see Cooper, Citizenship between Empire and Nation, pp.349-365; also P.F. Gonidec, "Note sur la nationalité et citoyennetés dans la Communauté", Annuaire française de droit international, Vol.5, 1959, pp.748-761 ; P.F. Gonidec, " La nationalité dans les Etats de la 
while the Community was still in place, which rejected membership of the Community and thus was recognised as according its own nationality, though it did not in fact adopt a nationality law until 1960. ${ }^{63}$ In French (formerly German) Togo and Cameroon, the League of Nations mandate had prohibited the grant of French nationality, and various decrees adopted during the 1930s, 40 s and 50 s had respected this distinction by creating a particular status for the inhabitants of these territories that entitled them to French protection at the international level (a conundrum avoided for the British by the ambiguous status of "British protected person"); their individual nationalities were finally conclusively recognised by 1958 ordinances giving the two territories a status in the Communauté française. ${ }^{64}$

Portugal drew similar distinctions between "European" and "native" in its five colonies in Africa. Although Angola, Cape Verde, Guinea Bissau, Mozambique, and São Tomé and Príncipe were subject to repeated changes in political status, the basic policies on the ground remained more or less stable. ${ }^{65}$ During the eighteenth century, Portuguese overseas territories were named colonias (colonies); they were rebranded as provincias (overseas provinces) in the 1820 Portuguese constitution. They were once again renamed colonias in the 1911 constitution, a status they kept until 1951, when they were again called provincias. Two categories of citizenship were introduced in 1899, for the purposes of labour regulations: the indigena (native) and the não-indigena (non-native). The não-indígenas, European-born Portuguese and white-skinned foreigners, as well as those of mixed-race, were full Portuguese citizens subject to metropolitan laws, whereas the indigenas were administered by the customary laws of each territory, as modified by Portuguese legislation and interpretation. The indigenato code, applied in all Portuguese colonies except Cape Verde and São Tomé and Príncipe, was applied administratively, without possible appeal to any court of law. ${ }^{66}$ Gradually, a third category emerged, that of assimilado, that is, a person (initially usually Asian or Afro-Portuguese but including some Africans) who claimed the status of não-indigena on the basis of his or her education, knowledge

Communauté et dans les Etats 'marginaux' " Annuaire français de droit international, Vol.7, 1961, pp.814-835.

63 Ordonnance No.011 du 1er mars 1960 portant Code de la nationalité guinéenne. The law nonetheless followed the French model closely. See Decottignies and de Biéville, Les nationalités africaines, pp.145-147.

64 Decottignies and de Biéville Les nationalités africaines, pp.19-20 ; Melone, « La nationalité des personnes physiques " pp.84-85.

65 See Malyn Newitt, A History of Mozambique, Hurst \& Company, London, 1995, pp. 378577. In practice, Cape Verde and São Tomé and Príncipe were subjected, at least formally, to slightly different policies from Portuguese Guinea (today's Guinea-Bissau), Angola and Mozambique. See also, Paul Nugent, Africa Since Independence: A Comparative History, 2004, Palgrave Macmillan, pp. 17-19 and pp. 261-271.

66 Peter Karibe Mendy, "Portugal's Civilizing Mission in Colonial Guinea-Bissau: Rhetoric and Reality," The International Journal of African Historical Studies, 2003, vol. 36, no. 1, p. 44. 
of Portuguese language and culture, profession, and income. From 1917 clear procedures were adopted to establish status, ${ }^{67}$ and a 1954 decree-law established a more complete and less arbitrary framework on the status of indigena in the mainland territories, as well as the rules and procedures by which an indigena could become a ciudadano. ${ }^{68}$ Formal legal equality in the colonies was established by the Portuguese only in 1961, in the midst of liberation wars in Africa, when any African could formally choose to become a Portuguese citizen and the worst kinds of forced labour were abolished. ${ }^{69}$

Similar rules applied in the Belgian, Spanish, German, and Italian colonies while they were operational, though with less elaborated ideologies and legal structures of empire. ${ }^{70}$ Though the systems differed, in all colonial territories those with subject status (natives, indigènes, indígenas) were not only subject to different legal regimes but were also usually obliged to work, to pay specific taxes (in kind, but also in labour), and to obtain a pass to travel within or to leave the country; while European citizens could leave the country freely, were exempt from labour legislation, and paid taxes at different rates.

Liberia had its own very particular history with regard to citizenship, starting from its foundation in 1822 by the American Colonization Society as "an asylum from the most grinding oppression" for former American slaves. ${ }^{71}$ The fundamental assumption of the new state was that the body of citizens was made up of the emigrants from America and their descendants. The "Constitution of the Commonwealth of Liberia" adopted by the board of directors of the

67 Newitt, A History of Mozambique, pp.382-385 and 441-444. These formal prerequisites could be waived and the assimilado status granted "to any African who had proved he had exercised a public charge, that he was employed in the colonial administration corps, that he had a secondary school education, that he was a licensed merchant, a partner in a business firm, or the proprietor of an industrial establishment." Bruno da Ponte, The Last to Leave, Portuguese Colonialism in Africa, International Defence and Aid Fund, 1974, p. 40.

68 Decreto-lei No.39666 of 26 May 1954 ; see André Durieux, Essai sur le statut des indigènes portugais de la Guinée, de l'Angola et du Mozambique, Bruxelles: Académie Royale des Sciences Coloniales, 1955.

${ }^{69}$ Bridget O'Laughlin, "Class and the customary: the ambiguous legacy of the Indigenato in Mozambique", African Affairs, Vol.99, No.394, 2000, pp. 5-42; Mahmood Mamdani, "Indirect Rule and the Struggle for Democracy: A Response to Bridget O'Laughlin", African Affairs,Vol. 99, No.394, 2000, pp. 43-46. See also Shubi Ishemo, "Forced labour and migration in Portugal's African colonies", in Robin Cohen (ed.), The Cambridge Survey of World Migration, 1995, pp.162-165.

70 Nugent, Africa Since Independence. On Italy, see Fabrizio de Donno, "La Razza ArioMediterranea : Ideas of Race and Citizenship in Colonial and Fascist Italy, 1885-1941", Interventions : International Journal of Postcolonial Studies, Vol. 8, No. 3, 2006, pp.394-412; laws for the Italian colonies are extracted in Felice de Dominicis, Commento alla legge sulla Cittadinza Italiana del 13 giugno 1912, Torino: Unione Tipografico-Editrice Torinese, 1916, appendix II.4 "Norme riguardanti la sudditanza colonial". On Belgium, see chapter 8.6 on DR Congo.

71 Constitution of Liberia 1847, preamble. 
American Colonization Society in 1839 gave the governor and council powers "To prescribe uniform rules of naturalization for all persons of color, and all persons now citizens of any part of the Commonwealth of Liberia shall continue to be so, and all colored persons emigrating from the United States of America or any district or territory thereof, with the approbation, or under the sanction of the American Colonization Society [...]". ${ }^{72}$ The constitution clearly established the colonists as legally separate from the "several African tribes", from whom the purchase of land had been arranged. The first constitution of an independent Liberia, freed from the control of the American Colonization Society in 1847, described "the people of the Republic of Liberia" as "originally the inhabitants of the United States of North America", distinguishing themselves from "the natives of the country". ${ }^{73}$ With a view to that history, it was also provided that: "The great object of forming these Colonies, being to provide a home for the dispersed and oppressed children of Africa, and to regenerate and enlighten this benighted continent, none but persons of color shall be eligible to citizenship in this Republic"; and only citizens could own property. ${ }^{74}$ These principles remained in place in the 1956 and 1973 nationality laws and the 1984 constitution.

Gradually authority was extended over the "native tribes", and in 1869 the Interior Department was established to govern all aspects of the hinterland, "with due regard to native customary law and native institutions". Thus, in a similar way to that of the European colonies, "natives" were subject to executive power and ruled by customary law and Americo-Liberians to statutory law and the civil courts, with different forms of government in the hinternland and coastal provinces. Those natives who assimilated to Americo-Liberian culture, especially by converting to Christianity and achieving literacy, could, however, come to be recognised as citizens. Only in 1904 did President Barclay declare that all the residents of the interior were citizens (largely to establish the claims of the Liberian state to the territory against encroachment by France and Britain); and only in 1944 did the newly elected Tubman administration extend greater rights to political representation to members of indigenous ethnic groups as part of his "unification" drive. Yet the "Hinterland Regulations" adopted in 1948 effectively continued to exclude the indigenous population from meaningful participation in political power — until 1964 when four new interior counties were created with full representation in the House of Representatives. ${ }^{75}$ The

72 Constitution of the Commonwealth of Liberia, 1838, Article 9.

73 Constitution of Liberia 1847, preamble.

74 Constitution of Liberia 1847, Article V(15). In a 1955 revision to the constitution the phrase "persons of color" was replaced by "Negroes or persons of Negro descent". A similar provision exists in Haiti, for similar reasons: see Olivier Vonk, Nationality Law in the Western Hemisphere: A Study on Grounds for Acquisition and Loss of Citizenship in the Americas and the Caribbean, Leiden/Boston: Brill Nijhoff, 2015, pp.247-249.

75 Amos Sawyer, The Emergence of Autocracy in Liberia: Tragedy and Challenge, ICS Press, 1992; Thomas P. Wrubel, "Liberia: The Dynamics of Continuity", Journal of Modern African Studies,Vol. 9, No. 2, 1971, pp.189-204; Stephen Lubkemann, Deborah H. Isser and Philip 
first comprehensive nationality law was only adopted in 1955, the previous announcements operating more at the political than legal level. ${ }^{76}$

\subsection{Transition to independence}

As in other areas of law, differences in the legal systems of the colonisers have strongly influenced the principles that have been applied since independence, though both African and European states have since amended and modified the principles on which their nationality law was originally based.

The circumstances of state creation through colonisation, followed by state recognition following decolonisation, also meant that it was difficult for indigenous African traditions of determining membership to influence the ways in which the new national laws were drafted. Though these systems survived and continued to have immense influence on peoples' daily lives, for the colonisers their legal effect was for the most part at sub-national scale only. The colonial powers might pay attention to an interpretation of "customary" rules when their courts came to be used to settle disputes among their African subjects, but they had little relevance to the determination of an individual's membership of the colonial state. Thus, even though it is likely that any codified indigenous system would have adopted provisions with many similarities to those that were developed in Europe if Africa had become integrated into the international state system in a different way, indigenous traditions of belonging had little if any influence on the ways in which nationality laws came to be drafted at independence.

The external power with African territories to be broken up into independent states was the Ottoman empire, whose reach had extended across North Africa as far as Algeria (though not Morocco, which remained independent until protectorates were established over different parts of its territory by France and Spain). In 1918, the Armistice of Moudros ended both hostilities between the Ottoman empire and the Allies of World War I, and Islamic political unity under Ottoman rule; the treaties of Sèvres and Lausanne completed the process and included transitional provisions relating to the nationality of former Ottoman subjects. The 1920 Treaty of Sèvres provided for Ottoman nationality to be transferred to the new states for individuals who were "habitually resident" in their territory (the language used in the English text; the French has établis, a

\footnotetext{
A.Z. Banks III, "Constraint of Customary Justice in Post-Conflict Liberia", in Deborah Isser (ed.) Customary Justice and the Rule of Law in War-torn Societies, Washington DC: US Institute of Peace, 2011;Augustine Konneh,"Citizenship at the Margins: Status, Ambiguity, and the Mandingo of Liberia", African Studies Review,Vol. 39, No. 2, 1996, pp. 141-154.

76 Aliens and Nationality Law, Title 3 of the Liberian Code of Laws of 1956; codifying and updating a patchwork of various laws on immigration and naturalisation and on nationality first adopted over previous decades, including a 1938 naturalisation law and 1945-46 consular service regulations.
} 
somewhat more demanding requirement). Former Ottoman subjects resident in a territory detached from Turkey and who differed in "race" from the majority population of that territory, also had the right, to be exercised within one year, to opt for Turkish nationality or the nationality of the state where the majority of the population was of the same race as the person concerned. Special provisions were established for Egypt and Sudan (and Cyprus). These provisions were largely incorporated into the 1923 Treaty of Lausanne, with the exception of the provisions on Egypt, which had become independent in 1922. The period for the right of option was extended to two years, but subjected to the consent of the state whose nationality was chosen.

Egypt had a particular status within the Ottoman empire, with a set of rules on "indigenous nationality" applying only to Egypt that helped to foster a strong national identity from the late $19^{\text {th }}$ century; though for international purposes Egyptians were treated as Ottoman nationals. Independent Egypt's nationality was first regulated in 1926, by a law aimed at sorting out the status of former Ottoman subjects in the country. The law established 5 November 1914 as the starting point for Egyptian nationality, the date the Allies entered into war with the Ottoman empire, decided to be the day that Ottoman rule over Egypt had ended. Ottoman subjects habitually resident in Egypt on that date and up to the date of entry into force of the law became Egyptian; however, the legislation greatly restricted the right to opt for Egyptian nationality generally provided in the Sèvres and Lausanne treaties, by requiring birth in the territory as well as membership of the same "race", and reducing the period for option to six months. In 1929, a new law removed some of the restrictions on option; in relation to those born after the entry into force of the law, it maintained a paternal jus sanguinis basis for nationality established by the 1926 law, and also created rights based on Arab and Muslim identity that are still present in Egyptian nationality law. A child born in Egypt of a father also born there would have Egyptian nationality if the father ethnically belonged to a country where the majority of the population spoke Arabic or practised Islam. Naturalisation was also restricted to those of a common cultural, linguistic and religious background. ${ }^{77}$

In the countries colonised by European powers, the citizenship laws adopted by the new states at independence were to a large extent based on models from the power that had colonised them; these were mostly included in the independence constitutions in the Commonwealth countries, whereas they were usually left to legislation in the civil law countries. Citizenship of most of the new states was in principle usually granted on an equal footing to individuals of different racial and ethnic groups, using the versions of nationality laws that had applied to the colonisers' own full citizens rather than to the "natives" in their colonies.

77 Decree-Law of 26 May 1926 and Decree-Law of 27 February 1929. See Parolin, Citizenship in the Arab World, pp.79-82. 
Most Commonwealth countries had constitutions drafted according to the standard "Lancaster House" 78 template that structured the negotiations with the independence leaders of each African state. This template established more or less uniform rules that created three ways of becoming a citizen of the new state: some became citizens automatically; some became entitled to citizenship and could register as of right; while others who were potential citizens could apply to naturalise through a discretionary process. Those who became citizens automatically were: firstly, persons born in the country before independence who were citizens of the United Kingdom and colonies or British protected persons at the date of independence, with a parent (or sometimes grandparent) also born there; and secondly, persons born outside the country whose fathers became citizens in accordance with the other provisions.

In West Africa (Ghana, Gambia, Nigeria, and Sierra Leone) the transitional provisions included in the independence constitutions stated that a citizen of the UK and colonies or British protected person born and resident in the country became a citizen by birth at independence if at least one parent or grandparent was also born in the country. In East Africa (Kenya, Tanzania and Uganda) the conditions were more restrictive and at least one parent had to be also born in the country.

Those persons born in the country whose parents were both (or whose grandparents were all) born outside the country were entitled to citizenship by way of registration, as were other citizens of the UK and colonies or British protected persons who were ordinarily resident in the country. Others could naturalise if they fulfilled the normal conditions set; provision was sometimes also made for easier access to citizenship for nationals of other Commonwealth countries, both in the transitional measures and on an ongoing basis; citizens of other Commonwealth countries were also not "aliens" for the purposes of domestic law, but occupied an intermediate status. The laws were not gender neutral, and special provisions relating to married women were included, usually making them dependent on their husband's status. ${ }^{79}$

Mirroring terms were adopted in British law, providing for the classes of persons who would lose citizenship of the UK and colonies or British protected person

78 Lancaster House was the building in London where many of the constitutions were negotiated and finalised.

79 Fransman's British Nationality Law, Chapter 3 and catalogue entries on Commonwealth countries; see also "Second Report on State Succession and its impact on the nationality of natural and legal persons, by Mr.Vaclav Mikulka, Special Rapporteur", A/CN.4/474 and Corr.1 and 2. Extract from the Yearbook of the International Law Commission, 1996 Vol.II(1). Some people with a residual connection with the UK (through birth, descent or marriage - if a woman) retained their previous status. So too did people who, though closely connected with the new state, failed after independence to qualify for citizenship of the newly independent country. They too remained citizens of the UK and Colonies or British Protected Persons. 
status when they acquired the citizenship of the new state; and for those who would retain their British connection. These provisions were drafted with a view to retaining the citizenship of those of British descent, but initially also provided equal rights to those of Asian or African origin. This situation soon changed. In Kenya in particular, where most of the territory had been a British colony, "within the crown's dominions" but not self-governing, the status of Kenyan Asians who were citizens of the UK and colonies at the date of independence created alarm at the prospect of immigration into Britain; especially as it became clear that the new Kenyan government would not be sympathetic to the Asian population. The Commonwealth Immigration Acts of 1962 and 1968 were designed to restrict and then remove the right of abode in the UK from the Kenyan Asians, exempting from immigration control only those citizens of the UK and colonies who had one parent or grandparent born, adopted, registered or naturalised in the UK. ${ }^{80}$

In southern Africa, the creation of the Central African Federation could not halt the move to independence. Elaborate schemes to provide Africans with some greater but limited political power did not hold back public protest in the two protectorates at the prospect of domination by while Southern Rhodesians, and frantic negotiations did not prevent the ultimate agreement for Nyasaland and Northern Rhodesia to secede and become independent on their own terms. ${ }^{81}$ The Federation was dissolved on 1 January 1964; in November 1965 Southern Rhodesia declared it was leaving the Commonwealth and becoming independent, enabling it to preserve white minority rule (see chapter 8.3)

On the independence of Zambia and Malawi, the standard terms applicable to other British protectorates applied: those born in the territory of one parent also born there became citizens automatically; provisions which excluded many of those of Asian or European descent, though habitual residents born in the country could register as citizens during a transitional period. ${ }^{82}$ However, the independence constitutions and subsequent laws of Zambia and Malawi did not make any special provision for persons with a connection to the other territories of the former Central African Federation, an omission which later resulted in several cases brought to the African Commission on Human and Peoples' Rights (see chapter 8.2.1).

Zimbabwe, Namibia and South Africa had rather different trajectories, both legally and politically, resulting from their self-governing legal status and whiteminority governments. Since its earlier unilateral declaration of independence

80 Karatani, Defining British citizenship, pp.156-163.

81 Colin Leys and Cranford Pratt, A New Deal in Central Africa, Praeger, 1960; JJB Somerville, “The Central African Federation”, International Affairs, Vol.39, No.3, 1963, pp.386-402.

82 The status of those of Asian descent in British nationality law who were citizens of the $\mathrm{UK}$ and colonies prior to independence is complex, and has been subject to litigation in the UK. See Fransman's British Nationality Law, catalogue entry on Zambia. 
had never been recognised by Britain, Zimbabwe was the only country of these three that had the same legal pattern as other former British territories, with an independence constitution and matching Zimbabwe Act adopted in the UK in 1979, when it made the transition from Rhodesia to Zimbabwe. However, there was already a thirty-year history in relation to independent regulation of nationality, and the 1979 constitution provided for continuity of citizenship; for those born after the act came into force it re-enacted the citizenship provisions already in existence without major revision (see further below, chapter 8.3). ${ }^{83}$

In Namibia and South Africa, however, there was no succession of states as such on the attainment of majority rule, since there was merely a change in government in an existing state with existing nationality laws. Nonetheless, the transitions of the 1990s in South Africa and Namibia also brought some changes to nationality law aimed at integration of previously established populations. The new government that took power in South Africa in 1994 took immediate steps to facilitate the grant of citizenship to several categories of migrants and refugees, as a transitional measure, offering a series of amnesties to particular groups of foreigners from the region, including migrant workers and refugees from the Mozambican civil war (see further, chapter 11.6). Namibia adopted a specific piece of legislation offering Namibian citizenship to those who would have been Namibian citizens if they or their ancestors had not fled persecution before 1915, reintegrating those who had fled the German genocide of the Herero from 1904 to $1907 .{ }^{84}$

The practice in the French colonies was different. After the collapse of the shortlived 1958 constitution of the French Community, the regulation of nationality became the responsibility of the new fully independent states. ${ }^{85}$ According to French law, nationality in the context of the state successions was based on the criterion of domicile, a requirement based on residence (though with more particular definition in French law). Thus, French nationals domiciled in the newly independent states lost French nationality on the date of transfer of sovereignty. However, in order to avoid the loss of French nationality by those of metropolitan origin, a law of 28 July 1960 modified the 1945 nationality code to permit French nationals born in metropolitan France and their descendants to keep their French nationality even if they were domiciled in the new state (including those of African origin, but mainly providing for the métis) ${ }^{86}$; persons born and domiciled in the

83 Fransman's British Nationality Law, Zimbabwe catalogue entry.

84 Namibian Citizenship (Special Conferment) Act No.14 of 1991.

85 Cooper, Citizenship between Empire and Nation, pp.414-428.

86 Loi No.60-752 du 28 juillet 1960 portant modifications de certaines dispositions du Code de la nationalité, Art 1, «Les dispositions de l'aliéna précédent [article 13 : «Les personnes domiciliées dans les territoires cédés perdent la nationalité française, à moins qu'elles n'établissent effectivement leur domicile hors de ces territoires »] ne s'appliquent pas aux personnes qui sont ou étaient domiciliés, à la date d'entrée en vigueur d'un traité portant cession de territoire ou de l'accession à l'indépendance, dans un territoire qui avait le 
new states were also allowed to retain their French nationality under certain conditions (for example, based on service in the French army). ${ }^{87}$

In Algeria, the question of nationality in the context of state succession was of particular sensitivity. Algeria had a unique status among all the European colonies in Africa, given the size of the population of European origin (more than a million people) and the legal status of the territory as an integral part of France. The process of defining who would be entitled to be an Algerian national after independence was the very process of deciding what the Algerian "nation" would be. Would the new state be race-religion-and-colour-blind, or would it differentiate between different categories of citizen, just as the French had differentiated on the grounds of personal religious status? The texts adopted by the Front de liberation nationale (FLN) had appealed to those of European descent to integrate into the post-colonial state and promised a non-discriminatory future legal regime. In the March 1962 Evian Accords that ended the civil war it was agreed that the Algerian-born colons would have the right to opt for Algerian nationality or to remain in Algeria as foreigners, with a three-year period of permitted dual nationality.

It had initially been proposed that French-born persons resident in Algeria would also become nationals of origin at independence; however, this proved unacceptable to the leaders of the liberation struggle, and in the final settlement they were given the right to naturalise, providing they renounced their French nationality, but not the status of nationals of origin. Those Algerians who had renounced Muslim personal status to become full French citizens were also Algerians of origin as of right, though they could renounce Algerian nationality and remain French if they so wished. The code also stated that those convicted of "crimes against the nation" after the date of the Evian Accords would not have a right to nationality; while those participating in the liberation struggle were given a right to opt for Algerian nationality. ${ }^{88}$ The great majority of Algerians, of "statut civil du droit local originaires d'Algérie" lost their French nationality; although

statut de territoire d'outre-mer de la République française à la date du 31 décembre 1946. Ces personnes sont réglés par les dispositions du titre VII du présent Code, à moins qu'elles ne soient originaires, conjoints, veufs ou veuves d'originaires du territoire de la république française, tel qu'il est constitué à la date de promulgation de la loi no 60.752 du 28 juillet 1960, ainsi que leurs descendants, auquel cas elles sont dispensées de toute formalité ».

Article 5 then added a new Title VII on «La reconnaissance de la nationalité française »: «Les personnes ... auxquelles une autre nationalité est conférée par disposition générale, alors qu'elles possèdent la nationalité française, peuvent se faire reconnaitre cette dernière nationalité par une déclaration reçue par le juge compétent du lieu où elles établissent leur domicile sur le territoire de la République française ".

87 Melone, «La nationalité des personnes physiques ", pp.88-89 ; Bruschi, « La nationalité dans le droit colonial ", text with note 213 ; Donner, Regulation of Nationality, ChapterV, "Nationality and State Succession", section 3.2.2.

88 Loi, No.63-92 du 27 mars 1983 portant Code de la nationalité algérienne, arts 8-10 and 43. Bendeddouche, Notion de nationalité et nationalité algérienne. 
those who wished to were permitted by a French ordinance of 21 July 1962 to retain French nationality if they transferred their domicile to France and made a signed declaration during a transitional period of five years. ${ }^{89}$

In relation to those born after independence, the law included a limited double jus soli provision ${ }^{90}$, and was on the face of it non-discriminatory in relation to the role of religion (though it discriminated on the basis of gender). However, the massive departure of those of French civil status in the period between the Evian accords and the referendum of July 1962 left the new government feeling threatened by the concept of three years of dual nationality for people whose loyalty was so suspect. Article 34 of the 1963 Code de la nationalité, in the section of the law dealing with evidence and dispute resolution, introduced a critical element of religious identity to the concept of nationality. The article defined "Algerian" as a person of Muslim religion whose father and father's father was born in Algeria. This definition made clear that neither Christian nor Jewish Algerians would be fully regarded as part of the national community. ${ }^{91}$ Even though the situation was less contested, some of the other north African states also adopted nationality provisions inspired by more general post-independence efforts to consolidate an Arab nationality and Muslim identity. ${ }^{92}$

There were important variations among the sub-Saharan francophone countries; and in some cases there was a long gap between the end of colonial rule and the adoption of a new nationality law - five years in the case of Dahomey (future Benin) - with a consequent lack of clarity on the status of those born or resident during this period and on the possible conflict of laws with the French nationality code. Explicit transitional provisions were usually limited to giving the formal right to opt for nationality of the host country to those who had come to the newly independent state from elsewhere in the French African territories, an option that had to be exercised within a limited time and was directed primarily at the educated elite who had served in the civil service across the French territories. ${ }^{93}$

89 Ordonnance $\mathrm{n}^{\circ}$ 62-825 du 21 juillet 1962 relative à certaines dispositions concernant la nationalité française, arts 1-4.The main group targetted with this provision were the harkis, those who had fought for the French army during the civil war.

90 Loi no.63-96 du 27 mars 1963 portant Code de la nationalité algérienne, article 11 provided for nationality to be given to a child born in Algeria of two parents also born in Algeria after the date of independence (that is, unlike the similar provision in most other nationality codes, it would not apply to anyone already alive at the date of independence, and it required for a positive option for nationality rather than a default attribution).

91 See also circulaire du 9 mai 1963 relative à l'application de la loi No.63-96 du 27 mars 1963 portant Code de la nationalité algérienne. A French court decision of 1965 in the tribunal de grande instance, ruled that because the Algerian nationality code gave nationality of origin only to Muslims, the person concerned - a Jewish Algerian - kept French nationality even though his parents had not obtained full French citizenship before independence. Bendeddouche, Notion de nationalité et nationalité algérienne, p.146.

92 Parolin, Citizenship in the Arab World.

93 Melone, "La nationalité des personnes physiques " pp.86-90 ; Alexandre Zatzepine, Le 
For those born after independence, the new nationality codes mostly followed the general outline and adopted variants of the substantive and procedural provisions of French law applicable at the time, the 1945 nationality code. All countries provided for nationality by descent from a father who was a national, with most (though not all) distinguishing between children born in and out of wedlock, with rights for the child of a national mother and foreign father only if born out of wedlock and not recognised by the father, or only if the father was unknown or stateless. A majority also adopted variants on double jus soli, applying equally to those born before or after independence, while some also provided for the automatic attribution of nationality to those born in the country and still resident there at majority and others only the right to opt for nationality at that time. In Niger, which also had a provision on double jus soli, the law created a presumption that this was fulfilled based simply on habitual residence in the country at independence. ${ }^{94}$ Mali's double jus soli rule, however, restricted rights based on birth in the territory to those "of African origin", without providing a definition of what that meant. ${ }^{95}$

In some countries there were no explicit transitional rules for the attribution of nationality on the date of independence, with the definition of the citizen body in effect being left to the cumulative application of the general rules; though, led by Senegal, the first to adopt a nationality code, many called on the idea of possession d'état, allowing a person who had always been treated as a national to claim formal recognition of that nationality (a concept originally taken from the French Code Napoléon of 1804, where it was applied in the context of family law, and progressively to other spheres). All the francophone countries included provisions in their laws on the means of obtaining proof of or contesting the nationality of a person, conferring this role on the lower level courts. ${ }^{96}$

Côte d'Ivoire, the most highly developed economy of AOF and the recipient of the greatest number of migrant workers to the new cocoa and coffee plantations, adopted somewhat different rules. Unusually, the new nationality code provided for equal rights for men and women in relation to citizenship by descent. It also did not attribute nationality on the basis of double jus soli, but rather, in a provision that was believed at the time to be more liberal, to every person born in Côte d'Ivoire unless both of his or her parents were "foreigners" (étrangers). In a fateful omission, the law did not define what "foreigner" meant. In addition, those born in the country could acquire nationality "by declaration" at majority, and those resident in the country at independence could naturalise without further conditions within a limited period. A very large number of people never

droit de la nationalité des républiques francophones d'Afrique et de Madagascar, Paris : Pichon et Durand-Auzias, 1963, pp.10-31.

94 Loi No.61-26 déterminant la nationalité nigérienne, Article 7.

95 Code de la nationalité malienne, Loi n 62-18 AN-RM du 3 février 1962.

96 Zatzepine, Le droit de la nationalité, pp.32-75 and pp.94-109. 
in fact took the steps needed to obtain recognition of nationality (see further below, chapter 8.7).

Guinea simply copied over the French law virtually verbatim despite its revolutionary rhetoric and despite (or because of) its earlier exit from French nationality. The transitional provisions did not establish rules relating to the attribution of nationality to those who became Guinean at independence; and even the date of entry into force of the new nationality code was not clear. ${ }^{97}$ Thanks to its status as a trust territory, Cameroon adopted a nationality code even before it was formally independent; the first French-administered territory to do so. ${ }^{98}$ Togo, however, only adopted a law regulating nationality more than a year after the dissolution of the French community. ${ }^{99}$ Both followed more or less closely the French model, while emphasising a jus soli attribution of nationality. ${ }^{100}$

In the five former Portuguese colonies (known collectively as the Países Africanos de Lingua Oficial Portuguesa, PALOP), most of the new national constitutions and political regimes were given a socialist content when independence was attained following the 1974 collapse of the Estado Novo in Portugal. Some countries also voted for rules favouring the grant of nationality to those who had fought against the Portuguese and penalising those who had collaborated with the colonial regime. For example, in Mozambique individuals who had participated in the liberation struggle within the structures of FRELIMO (the Frente de Libertação de Moçambique) were given the right to opt for Mozambican nationality, and nationality was excluded for people who had been members of "colonial-fascist political organisations". ${ }^{101}$ CapeVerde and Guinea Bissau had matching provisions mutually facilitating access to the other's nationality, based on the relationship created by the single party that brought both to independence, the Partido africano de independência da Guiné e Cabo Verde (PAIGC), founded by Amilcar Cabral. Generally, transitional measures favoured the automatic attribution of the nationality of the new state: for example Angola's first nationality law provided that those born in Angola who did not want to maintain Angolan nationality had to declare their renunciation within one year of independence; the other four lusophone countries attributed nationality to a range of categories of person, including based on double jus soli and to those domiciled in the country at independence, and also provided for renunciation within one year. ${ }^{102}$

97 Decottignies and de Biéville Les nationalités africaines, p.153.

98 Ordonnance No.59-66 du 26 novembre 1959.

99 Loi No.61-18 du 25 juillet 1961.

100 Decottignies and de Biéville Les nationalités africaines, entries on Cameroon and Togo.

101 Lei da nacionalidade de 20 de Junho de 1975, Articles 3 and 7.

102 Angola Lei de 10 de novembro de 1975, Article 1 ; Cabo Verde Decreto-Lei No.71/76 de 24 de julho, Article 1 ; Guiné Bissau Lei da nacionalidade No.1/76 de 4 de maio, Article 1 ; Mozambique Sao Tomé \& Príncipe, Lei da nacionalidade de 1 de decembro 1975, Article 1. 
Prospectively, the PALOP countries kept Portugal's basic civil law system, maintaining much of Portuguese colonial legislation, including the framework of the provisions on nationality that had been applied in the metropolitan territories. These rules, relatively constant since the $19^{\text {th }}$ century, favoured double jus soli and the automatic attribution or right to opt for Portuguese nationality for children of foreigners still resident in the territory at majority; on the other hand, the matching new Portuguese law adopted at the same time did not avoid statelessness for some of those who previously had full Portuguese citizenship. ${ }^{103}$ By contrast with the other former colonies, the lusophone states adopted gender equality right from the date of independence in respect of transmission of nationality to children and (except Mozambique and São Tomé) to spouses.

Belgium's hasty abandonment of its central African colony in Congo without putting in place a comprehensive framework to cater for those resident on the territory created problems that still resonate today. Right up to the last minute before independence, Belgian scholars were debating the possibility of creating a "Congolese nationality" as a sub-category of Belgian nationality, in order to provide clarity on the status of autochthonous Congolese both in Congo and in Belgium, as well as of other "foreign nationals", including the Rwandanspeaking populations of the east. Independent Congo did not adopt provisions on nationality until 1964, four years after independence (see chapter 8.6). Rwanda adopted a nationality law in 1963, but Burundi not until 1971, nine years after independence. Italy's colonies of Somaliland and Eritrea were conferred to Britain as United Nations trust territories following the second world war, and eventually joined to British Somalia and reunited to Ethiopia (see chapter 9.1) by referendum at independence. The legacy of their existence as separate colonial territories was to give both a sense of separate identity that eventually led to their secession from the states to which they had been (re)joined.

103 Rui Manuel Moura Ramos, Estudos de Direito Português da Nacionalidade, Lisbon: Coimbra Editora, 2013. 


\section{Trends in African nationality law since independence}

The three most striking trends in nationality law in African countries since the 1960s have been, firstly, the abandonment in the Commonwealth countries of jus soli citizenship based on birth in the territory, in favour of a descentbased jus sanguinis system (and a similar limitation of jus soli rights in a few of the former French colonies); secondly, the adoption of greater equality between men and women in relation to the ability to pass nationality to their children, which is now the norm, and to a lesser extent to their husbands; and finally a major shift towards tolerance of dual nationality, which was a minority position at independence, but is now permitted in the clear majority of African countries.

There are weaker trends in relation to racial, ethnic and religious distinctions, where explicitly discriminatory provisions exist in a small minority of countries, have been removed or reduced in some, but introduced in others or left untouched since independence - and discrimination in the application of the law is widely prevalent. The nationality status of those who migrated to the country before independence, and their descendants, remains contested in very many countries. ${ }^{1}$

\subsection{The balance of jus soli and jus sanguinis}

Nationality laws globally, whether in the common law or civil law tradition, combine in different strengths the two basic concepts of jus soli, where an individual obtains citizenship simply because he or she was born in a particular country; and jus sanguinis, where citizenship is based on descent from parents who themselves are citizens. In its historical origins, jus soli citizenship was based on concepts of feudal loyalty: a person born in a particular territory owed allegiance to the sovereign of that territory. This concept of citizenship was dominant in Britain throughout its history, including during the colonial period, until it was diluted in 1981. More limited forms of jus soli may apply to children born on the territory of a person also born on the territory (double jus soli); to children born on the territory who are still resident there at majority; or to children born on the territory of unknown or stateless parents, or who cannot claim the citizenship of their parents. Jus sanguinis rules, criticised today for their tendency to exclude from citizenship those who are descended from individuals who have migrated from one place to another, were originally

1 The information in this chapter is an expanded version of an article first published as Bronwen Manby, "The historical development of citizenship law in Africa", in Engin Isin and Peter Nyers (eds.), Handbook of Global Citizenship Studies, Routledge, 2014. 
introduced in France in the early $19^{\text {th }}$ century as an initiative of the postrevolutionary government aimed at creating independent citizens who were no longer the permanent subjects of a single sovereign. ${ }^{2}$ At the same time, these new rules exacerbated gender discrimination, since the citizenship of children born in wedlock was presumed to be exclusively passed through the male line. A jus sanguinis principle need not have any ethnic or racial basis - the requirement is only that the parent be a citizen (including by naturalisation) - but is often interpreted otherwise.

There is also a common distinction in law between citizenship from birth (termed "of origin" in the civil law countries) and citizenship by acquisition. Citizenship from birth/of origin may be based either on descent (jus sanguinis) or on birth in the country (jus soli), but implies that a child is automatically attributed a citizenship from the moment of birth without any further procedures required for recognition by the state. ${ }^{3}$ Citizenship by acquisition relates to those who have become citizens at a later date, usually as adults, by various processes including declaration (the lodging of a form is sufficient), registration (nondiscretionary but the authorities must note the acquisition), and naturalisation (discretionary grant, usually on the basis of long-term residence). ${ }^{4}$ In many countries, the rights of those who are citizens from birth or by acquisition are the same; but others apply distinctions, especially in relation to the holding of public office. In addition, citizenship by acquisition may in most cases be more easily withdrawn. Gender discrimination in relation to the attribution of citizenship from birth may thus be highly significant to the exercise of other rights: for example, in some countries the children born in wedlock of citizen fathers are citizens from birth, and the children of citizen mothers born in wedlock of foreign fathers only have the right to acquire citizenship on application shortly before or after majority. Although this procedure is usually theoretically non-discretionary (declaration or registration), those concerned may be excluded from the rights of birth citizens.

2 See Weil, Qu'est-ce qu'un français; and Patrick Weil, "From conditional to secured and sovereign :The new strategic link between the citizen and the nation-state in a globalised world", International Journal of Constitutional Law Vol.9, Nos.3-4, 2011, pp.615-635. Weil's work is in part a critique of Rogers Brubaker, Citizenship and Nationhood in France and Germany, Cambridge, MA: Harvard University Press, 1992.

3 In some circumstances in some countries, the law provides that an individual can obtain retroactive recognition of citizenship from birth / of origin after birth. There is also a confusion caused by the fact that in many Commonwealth countries, the term used in law for citizenship from birth is often citizenship "by birth", based on the laws drafted at independence which borrowed the term used in British for citizenship granted at birth on the basis of birth in a territory (by jus soli). This usage has continued even where jus soli citizenship no longer exists.

4 See glossary developed by the EUDO Citizenship Observatory at http://eudo-citizenship. eu/databases/citizenship-glossary/glossary, last accessed 15 January 2014. 
At independence, the Commonwealth countries adopted a jus soli rule, usually enshrined in their independence constitutions, which reflected the longstanding system in the UK that had been formalised in the 1948 Nationality Act as it applied both in the United Kingdom and in its colonies. Under these constitutions, a child born on the territory after independence was a citizen from birth as of right, subject only to the exception that this did not apply if the father was entitled to diplomatic immunity or was an enemy alien and the mother was not a citizen. Provision was made for citizenship by descent for those not born in the country, but only for children whose fathers were citizens at the time of the birth.

Most of the Commonwealth countries took steps quite rapidly to amend the jus soli provisions included in their independence constitutions in order to restrict the right to nationality of children born in the country. The trend to remove jus soli has continued throughout the period since the 1960s (see Table 1), and in the case of Kenya's 1985 constitutional amendment, the abandonment of jus soli was made retroactive to independence, meaning that persons who had been citizens by birth at independence but whose parents were not citizens then lost their citizenship. Today only Lesotho and Tanzania among the Commonwealth countries have retained an absolute jus soli law for children born on their territory; and a draft new constitution for Tanzania due to be adopted in 2015 would amend its law. ${ }^{5}$

5 In the case of Tanzania, the jus soli provision has not in practice been applied, in particular to children of refugees born in Tanzania, though the state has taken other measures to extend nationality rights to refugee populations. See chapter 11.2. 
Table 1: Commonwealth countries removing jus soli

\begin{tabular}{|c|c|c|}
\hline Country & Jus soli provision & $\begin{array}{l}\text { Amendment removing jus soli } \\
\text { (in chronological order) }\end{array}$ \\
\hline Sierra Leone & 1961 Constitution Article 4 & 1962 Sierra Leone Constitution (Amendment) (No.2) Act ${ }^{6}$ \\
\hline Malawi & 1964 Constitution Article 4 & 1966 Constitution and Citizenship Act ${ }^{7}$ \\
\hline Uganda & 1962 Constitution Article 9 & 1967 Constitution Article $4^{8}$ \\
\hline Swaziland & 1967 Constitution Article 127 & 1968 Constitution Article 21 \\
\hline Ghana & $\begin{array}{l}1957 \text { Ghana Nationality and } \\
\text { Citizenship Act }\end{array}$ & $\begin{array}{l}1969 \text { Ghana Nationality (Amendment) Decree (retroactive } \\
\text { to } 1957 \text { ) }\end{array}$ \\
\hline Nigeria & 1960 Constitution Article 10 & 1979 Constitution Article $23^{9}$ \\
\hline Botswana & 1966 Constitution Article 21 & 1982 Constitution Amendment Act \\
\hline Kenya & 1963 Constitution Article $3^{10}$ & $\begin{array}{l}1985 \text { Constitution of Kenya (Amendment) Act (retroactive } \\
\text { to } 1963 \text { ) }\end{array}$ \\
\hline Zambia & 1964 Constitution Article 5 & 1991 Constitution Article $5^{11}$ \\
\hline Seychelles & 1976 Constitution Article 6 & 1993 Constitution Article 9 \\
\hline Mauritius & 1968 Constitution Article 22 & 1995 Constitution Amendment Act \\
\hline Gambia & 1965 Constitution Article 3 & 1996 Constitution Article 10 \\
\hline Zimbabwe & 1979 Constitution Article $5^{12}$ & 1996 Constitution of Zimbabwe Amendment Act \\
\hline Tanzania & 1961 Constitution Article 3 & [Proposed draft Constitution would remove] \\
\hline Lesotho & 1966 Constitution Article $25^{13}$ & - \\
\hline
\end{tabular}

${ }^{6}$ The amendment both removed jus soli to provide only for citizenship on a jus sanguinis basis through the father, and also introduced the requirement that the father be of "negro African descent". In 1973, a double jus soli provision was introduced, so that a child born in Sierra Leone of a father also born there would acquire nationality, but still with the requirement that the father be of "negro African descent". In 2006 the gender discrimination was removed, but racial discrimination remained

7 The constitution repealed previous constitutional provisions, leaving citizenship to the law. In addition to providing that a child born in Malawi must have a parent who was a citizen, the law also required that the parent be "a person of African race".

8 The 1995 Constitution Art.10 restored a jus soli right, but only for a child born in Uganda with a parent or grandparent who was a member of one of the indigenous communities of Uganda listed in a schedule.

9 The 1974 Constitution (Amendment) Decree restricted the initial jus soli provisions but retained a right to citizenship based on birth in the country if one parent or grandparent was also born there (subject to some further restrictions); the 1979 Constitution then removed all rights based only on birth in the territory after independence, requiring a parent or grandparent to have been a citizen for a child born in the country to have citizenship.

10 Unchanged but renumbered as Article 89 of the 1969 Constitution.

11 The 1973 Constitution created a half-way house, requiring that one of the child's parents be a citizen or the father be an "established resident" (ordinarily resident at least four years preceding the birth) - this is a similar provision to that in force in the UK since 1983.

12 Zimbabwe's post-transition law carried forward restrictions on jus soli introduced after Southern Rhodesia declared UDI in 1963. Those born in Zimbabwe obtained citizenship on a jus soli basis, but with an unusually large set of exceptions, including if the relevant parent (father if in wedlock, mother if not) was not legally present in Zimbabwe, or, if not a citizen, was not ordinarily resident in Zimbabwe.

13 The 1966 independence constitution in fact restricted the jus soli right in that Article 25 required the father to be a "Commonwealth citizen" (a status created by the 1948 British 
The majority of these revisions removed jus soli completely, including for children who do not have the right to any other nationality (except, usually, for foundlings), without providing any more dilute rights based on birth such as those common in the civil law countries (see box below, where the case of Ghana illustrates the struggles in the Commonwealth countries over the weight placed on birth in the territory against descent from those who had migrated to the country). ${ }^{14}$

The new citizenship laws in the former French colonies were for the most part based on the French Civil Code, as it had evolved since the Revolution and was applied in France. Since 1889, the civil code had automatically attributed nationality not only to the child of a citizen born in France, but also to a child born in France of one parent born in France, and to a child born in France of foreign parents, if he or she remained there until majority (though in that case with the option to reject it). ${ }^{15}$ The code also allowed for naturalisation after a residence period (reduced from 10 years to three years in 1927, and increased again to five years in 1945). These terms were included in most of the new nationality codes of the AOF and AEF territories. Also common was the concept of possession d'état de national: the recognition (on application to court) of the nationality of those who have always behaved and been accepted as if they were nationals. In addition to provisions relating directly to citizenship, the laws relating to the family and to civil registration are important in nationality matters in the civil law countries especially in relation to proof of descent.

By comparison to the Commonwealth countries, the basic framework of the civil law countries has remained quite stable, and in particular those countries that adopted the double jus soli provisions have retained this rule to date. Nonetheless, the restriction of rights based on birth in the country was also reflected in some of the civil law countries, including Côte d'Ivoire and Niger, which (in 1972 and 1973 respectively) both removed the right to opt for nationality at majority for those born in the country of foreign parents, though Niger retained its double jus soli rule. ${ }^{16}$ In Côte d'Ivoire, the same amending act even removed the right to nationality for an abandoned infant found in Côte d'Ivoire. Since the original

Nationality Act but no longer meaningful), unless the child would otherwise be stateless. These terms were preserved in the 1971 Citizenship Order (section 5), still in force. However, the 1993 Constitution provided for jus soli citizenship for all, with only the usual exceptions if the father was entitled to diplomatic immunity or an enemy alien.

14 Also, Ousman Kobo, “We are citizens too': The politics of citizenship in independent Ghana", Journal of Modern African Studies,Vol.48, 2010, pp 67-94.

15 From 1851, when double jus soli was first introduced, until 1889, a child born in France of a father also born there, had the option to reject the attribution of nationality on attaining majority, while acquisition on the basis of birth on the territory was not automatic but on the basis of declaration. These rules were changed largely to prevent men born in France from avoiding military service. See Weil, Qu'est-ce qu'un français, chapter 2.

16 Cote d'Ivoire Loi no. 72-852 du 21 décembre 1972; Niger Loi no. 73-10 du 27 Février 1973. 
law had not provided for double jus soli, birth in the country now provided no rights to nationality in any circumstances.

Another exception among the former French colonies was Algeria, influenced by the Ottoman and Muslim traditions of descent-based nationality; and by the politics of France's ongoing relationship with the country (see also discussion on Algeria in chapter 4.2 and 4.3). A 1970 ordonnance increased the primacy of descent over birth in the territory, removing the limited double jus soli provision in the 1963 nationality code. ${ }^{17}$ The 1970 ordonnance also kept, in only slightly amended form, the provision under a section headed "evidence" (preuve), stating that nationality of origin can be shown by establishing that the person is of Muslim religion, whose father and grandfather were also born in Algeria; thus, a "triple jus soli" element was introduced, but on the basis of religious discrimination. The law also made naturalisation more difficult, including for women married to Algerian men. In 2005, the provision was again amended, this time to reduce gender discrimination by providing that the two generations of people born in the country could be either the male or female line - but they must still be of Muslim personal status. ${ }^{18}$

The other north African countries also drew on Arab and Muslim traditions to emphasise jus sanguinis principles, initially through the father's line, as well as privileging other Arabs or Muslims. ${ }^{19}$ In Egypt, a 1950 nationality law had removed a limited double jus soli provision included in the 1929 decree-law (providing for a child born in Egypt whose father was also born in Egypt to be Egyptian if the father ethnically belonged to a country whose language was Arabic or religion Muslim). However, the 1956 nationality law (adopted after the 1952 revolution, the independence of Sudan and the nationalisation of the Suez Canal) strengthened the requirements for attachment to Egypt, reduced access to citizenship for the children of stateless fathers, and the ability of the government

17 Loi no.63-96 du 27 mars 1963 portant Code de la nationalité algérienne, article 11 provided for nationality to be given to a child born in Algeria of two parents also born in Algeria after the date of independence (that is, unlike the similar provision in most other nationality codes in former French territories, it would not apply to anyone already alive at the date of independence). This provision was excluded from Ordonnance No.70-86 du 15 décembre 1970 which replaced the nationality code.

18 Ordonnance No.70-86 du 15 décembre 1970, article 32 ; as amended by Ordonnance No.05-01 du 27 février 2005.

19 Parolin, Citizenship in the Arab World, pp.95-100; also works by Delphine Perrin: "Identite et transmission du lien national au Maghreb :Etude comparée des codes de la nationalité", L'Année du Maghreb 2007, pp.479-497 ; "Beyond the borders: Dual nationality in Western Mediterranean Countries”, in I. Schäfer and J. R. Henry (eds.), Mediterranean policies from above and from below, Baden-Baden: Nomos, 2009, pp.537-561; "Immigration and Citizenship Law in the Maghreb: Turning Aliens into Citizens", EUI Working Papers, RSCAS 2011/40 Robert Schuman Centre For Advanced Studies and EUDO Citizenship Observatory, 2011; "Citizenship struggles in the Maghreb", in Isin and Nyers, Routledge Handbook of Global Citizenship Studies, 2014. 
to deprive those suspected of disloyalty (notably to Israel) of their nationality. The 1958 nationality law of the short-lived United Arab Republic between Egypt and Syria again reinforced ideas of membership in an Arab community; the 1975 nationality law which replaced it in Egypt (the 1958 law had remained in effect until then, just for Egyptians) once again narrowed access to nationality for the children of foreign men as well as extending the residence requirements for naturalisation. ${ }^{20}$ Libya's 1980 law on Arab citizenship purported (it is not clear how far it was ever applied) to create access on demand to Libyan citizenship for those of Arab ethnicity or Muslim religion, and made apostasy from Islam a grounds for deprivation of nationality. ${ }^{21}$ Tunisia and Morocco also privileged a descent-based citizenship regime, historically only through the father (or mother if born out of wedlock) with very limited rights based on birth in the territory. Mauritania, which had provisions at independence more common to the other countries of AOF, removed all jus soli rights in 2010 to create a pure jus sanguinis regime, with protection only for foundlings. ${ }^{22}$

For details on different forms of jus soli in force today, see chapter 6.1 and Table 2.

\section{Ghana's debates over jus soli}

Although in most Commonwealth countries the original citizenship provisions were included in the independence constitution, Ghana the first to gain independence - was an exception, and the Ghana Independence Act 1957 and Ghana (Constitution) Order in Council 1957/277 simply referred the question to national legislation.

The Ghana Nationality and Citizenship Act 1 of 1957 included in its transitional provisions the usual terms contained in later Commonwealth independence constitutions: any citizen of the UK and colonies or British protected person born and resident in Ghana became a citizen of Ghana provided that at least one parent or grandparent was also born in Ghana. Thus some British protected persons born in Ghana did not become Ghanaian citizens (and so remained British protected persons), notably the community of Lebanese descent, but also those from neighbouring African territories. For those born in the territory after independence, jus soli applied (subject only to the usual exceptions relating to the child's father being entitled to diplomatic immunity or an enemy alien). Those

20 Law 160 of 1950, Law 391 of 1956, Law No 82 of 1958 and Law No 26 of 1975. Parolin, Citizenship in the Arab World, pp.81-82; Centre for Migration and Refugee Studies (CMRS), American University in Cairo, Africa Citizenship and Discrimination Audit: The Case Study of Egypt, prepared for the Open Society Justice Initiative, 2005.

21 Arab Citizenship Law, No.18 of 1980.

22 Loi. No. 2010-023 du 11 février 2010 abrogeant et remplaçant certaines dispositions de la loi 61-112 du 12 juin 1961 portant Code de la nationalité mauritanienne. 
born outside the country before independence became citizens if at least one parent was born in Ghana; those born outside the country after independence became citizens if the father was a citizen born in the country or a citizen by registration or naturalisation, or if the mother was a citizen by birth. British protected persons ordinarily resident in Ghana for at least five years and who renounced any other nationality could register as citizens, as could women married to a citizen of Ghana. In 1960, the act was amended by the Constitution (Consequential Provisions) Act (CA8) to take account of the adoption of a new republican constitution, adjusting the relationships with other Commonwealth states.

The law ran into political difficulties immediately after the Convention People's Party (CPP) government of Kwame Nkrumah took power in 1957, and was challenged by politicians of immigrant descent. The Immigration Act 15 of 1957 and the Deportation Act 19 of 1957 were enacted to "legalise" the deportations of two prominent leaders of Hausa origin. ${ }^{23}$ The acts provided for controls over foreigners, and amendments to the Deportation Act in 1958 and 1959 facilitated the deportations of people involved in opposition politics who were not eligible for automatic citizenship under the transitional provisions. The Aliens Act 160 of 1963 required all foreigners to obtain residence permits, regulating their employment and making them subject to deportation if they did not have the correct papers, and the government also promoted economic advancement of "indigenous" populations. The position of migrant populations became increasingly precarious.

The Ghana Nationality Act 62 of 1961 repealed the 1957 Act, but in relation to citizenship by birth provided in similar terms that a person born in Ghana after the commencement of the Act was a citizen by birth. Those who were already citizens remained so. The grounds for deprivation of citizenship were widened.

The Ghana Nationality Decree, NLCD 191 of 1967, adopted by the National Liberation Council that had taken power the year before, made the terms relating to the transition to independence significantly more generous: a person born in Ghana who was a citizen of the UK and colonies or British protected person before the date of independence was given citizenship by birth with no requirement that a parent or grandparent also be born in the country. Jus soli was continued for those born after independence. ${ }^{24}$

23 Amadu Baba and Othman Lalemie; however, it was claimed that both they and their parents had born in Ghana. See Akin L. Mabogunje, Regional Mobility and Resource Development in West Africa, Centre for Developing-Area Studies, McGill University, Montreal, Canada, 1972, pp.123-124.

24 Ghana Nationality Decree, NLCD 191 of 1967, Article 1. 
The Ghana Nationality (Amendment) Decree NLCD 333 of 1969 restored the restrictions of the 1957 Act in relation to those born before independence, requiring a person born in Ghana also to have a parent or grandparent born in Ghana; but removed the jus soli rule for those born since independence by adding the requirement that one parent be a citizen wherever the child was born. These changes had retroactive effect and thus took away nationality from many who had acquired citizenship on the basis of the 1967 decree. ${ }^{25}$

The 1969 Constitution of the Republic of Ghana, which reinstated a civilian government, simplified the law under the uniform requirement that a person born in or outside Ghana became a citizen of Ghana if at least one parent was a citizen of Ghana at the time of the birth, thus removing jus soli acquisition definitively.

Citizenship politics reached its nadir at this date: following the adoption of the Aliens Compliance Order 1969 and other measures, more than 200,000 people were expelled from the country in 1969-1970, most of them migrants from other West African countries.

The Nationality Act 361 of 1971 introduced confusingly different rules for those born before independence, between independence and the entry into force of the 1969 constitution, and after the entry into force of the constitution. A person born in Ghana before independence was a citizen if at least one parent or grandparent was born in Ghana; a person born outside was a citizen if at least one parent was born in Ghana. Those born in or outside of the country since independence and before the entry into force of the constitution were citizens if at least one parent and also at least one grandparent or great-grandparent were also born in Ghana; except that if the relevant parent or grandparent had "by any means lost his citizenship of Ghana". A person born in Ghana was also a citizen by birth if either parent was a citizen by registration or naturalisation; and if born outside Ghana if both parents were citizens by registration or naturalisation. Those born in or outside the country after the entry into the force of the constitution were citizens if either parent was a citizen, restated the provisions of the 1969 constitution.

25 A court ruling in 1972 on a case brought by two people of Lebanese descent born in Ghana of parents born elsewhere found that the deprivation of their naturalised citizenship granted under the 1967 decree through the 1969 amendment was unlawful, on the grounds that the amendment had not specifically divested those who had acquired citizenship under the decree of their rights. Shalabi and Another v. The Attorney-General [1972] 1 GLR 259-270, cited in Mohammed Mustafa Husseini "The citizenship question in Sub-Saharan Africa - With Ghana as a case study: Part III", Zongolink, http://www. zongolink.com/index.php/opinion/97-the-citizenship-question-in-sub-saharan-africawith-ghana-as-a-case-study, last accessed 27 February 2014. 
The Ghana Nationality (Amendment) Decree 1972 NRCD 134, adopted by a new military government, the National Redemption Council, was brought in to overrule the court decision and declare that only those qualified as citizens under the 1971 Nationality Act were citizens, and that those who had previously had rights to citizenship no longer did so, except that those particular people who had been awarded citizenship by a court were able to keep it. Those deprived of their citizenship by the 1969 amendment decree were given the right to apply for naturalisation only, on the basis of ten years' residence. Further amendment decrees in 1978 and 1979 deprived named persons of their nationality on the basis of naturalisation (many of them Lebanese). ${ }^{26}$

The 1979 Constitution of the Republic of Ghana restored more generous provisions. A person born in Ghana after the entry into force of the Constitution was a citizen if at the date of his birth either parent or any grandparent was a citizen of Ghana. Those born outside the country were citizens if either parent was a citizen of Ghana.

The 1992 Constitution of the Republic of Ghana extended the grandparent connection to those born outside the country: those born in or outside Ghana since the entry into force of the 1992 constitution (on 7 January 1993) are citizens by birth if either parent or one grandparent was or is a citizen of Ghana at the time of the birth. There are no rights to citizenship based only on birth in the territory, even for children who would otherwise be stateless, though children of unknown parents are presumed to be Ghanaian.

The convoluted history of these provisions is summarised in the Citizenship Act 591 of 2000, the current legislation regulating nationality (which preserves the distinctions among people born on different dates), as amended by the Dual Citizenship Regulation Act 91 of 2002, permitting dual nationality for the first time and thus potentially permitting recognition of nationality for many who had been previously refused on the basis of mixed parentage.

\subsection{Gender equality}

At independence and until recently, most citizenship laws in Africa discriminated on the basis of gender. Female citizens were not able to pass on their citizenship to their foreign spouses or to their children, if the father was not also a citizen.

26 Emmanuel K. Akyeampong, "Race, Identity and Citizenship in Black Africa: The case of the Lebanese in Ghana”, Africa,Vol.76., No.3, 2006, pp.297-323. 
From the early 1990s, however, this situation began to change, as women's rights organisations fought for reforms based on the international human rights consensus on the equal status of men and women. A key moment was the 1992 Unity Dow case in Botswana, where the Court of Appeal upheld a woman's right to pass Botswana citizenship to her children (see box).

Since the 1990s, Algeria, Botswana, Burkina Faso, Burundi, Côte d'Ivoire, Djibouti, Egypt, Ethiopia, Gambia, Guinea, Kenya, Lesotho, Libya, Mali, Mauritius, Morocco, Niger, Rwanda, Senegal, Sierra Leone, Sudan, Tunisia, Uganda, and Zimbabwe have enacted reforms providing for greater, though not in all cases total, gender equality. The most recent reforms were in Senegal, which removed all gender discrimination in the transmission of nationality to children and spouses in 2013, ${ }^{27}$ and in Niger, which removed discrimination in transmission of nationality by marriage in 2014 (equality in relation to children was introduced in 1999). ${ }^{28}$ Other challenges in national courts have also succeeded; in September 2014, the Benin Constitutional Court declared four articles of the nationality code to be unconstitutional on the grounds of gender discrimination in relation to a woman's right to transmit nationality to her children and spouse. ${ }^{29}$

Nonetheless, gender equality remains controversial in relation to questions of nationality..$^{30}$ The Protocol to the African Charter on Human and Peoples' Rights on the Rights of Women in Africa, adopted as late as 2003, effectively creates exceptions allowing discrimination in the right of a man to acquire the nationality of his wife, and a child to acquire the nationality of its mother (see chapter 3.12). In other cases, such as Mali, gains in nationality law reforms have been lost in other legal battles. ${ }^{31}$ No case on gender equality in citizenship laws

27 Loi No.2013-05 du 29 juillet 2013.

28 Loi No.2014-60 du 5 novembre 2014.

29 Décision DCC 14-172, Benin: Cour Constitutionnelle, 16 September 2014, available at: http://www.refworld.org/docid/547729054.html, last accessed 28 November 2014.

30 On gender and citizenship in Africa, see generally: Jennifer C. Seely, Emma Diambogne Diouf, Charlotte-Anne Malischewski, Maria Vaikath and Kiah Young-Burns "Secondclass citizens? Gender in African citizenship law", Citizenship Studies, Vol. 17, Nos.3-4, 2013, pp.429-446; Ayesha Imam and Evelien Kamminga Women in search of citizenship: Experiences from West Africa, Royal Tropical Institute (KIT), Netherlands, 2012; Charmaine Pereira, "Understanding Women's Experiences of Citizenship in Nigeria: From Advocacy to Research", in Elizabeth Annan-Yao et al, Gender, Economies and Entitlements in Africa, CODESRIA, Dakar, 2004; Sara C. Mvududu and Patricia McFadden, Reconceptualizing the Family in a Changing Southern African Environment, Women \& Law in Southern Africa, 2001; Mounira Charrad, "Unequal Citizenship: Issues of Gender Justice in the Middle East and North Africa", in Maitrayee Mukhopadhyay and Navsharan Singh, (eds.), Gender Justice, Citizenship and Development, Zubaan, New Delhi/ International Development Research Centre, Ottawa, 2007; Suad Joseph (ed.), Gender and Citizenship in the Middle East, Syracuse University Press, 2000.

31 In Mali nationality law was successfully (if partially) reformed in 1995 to create rights for 
has yet been brought to the African Commission on Human and Peoples' Rights to test such provisions against the African Charter itself.

\section{Botswana: The Unity Dow Citizenship Case}

In 1992, a court case brought by Unity Dow, a lawyer, ${ }^{32}$ challenged the constitutionality of Botswana's Citizenship Act on the grounds that it discriminated on the basis of gender. Botswana's independence constitution, like those of other Commonwealth countries, had provided for citizenship to be recognised on a jus soli basis. However, the citizenship provisions of the 1966 constitution were repealed in 1982, and the rules on citizenship delegated to a new law, the 1982 Citizenship Act. This new act now provided that a child became a citizen based on birth in Botswana only if not attributed the citizenship of another country through the father. In 1984, this provision was amended again, to attribute citizenship to a child born in Botswana only if his or her father was a citizen of Botswana (or his or her mother if he or she was born out of wedlock). The 1982 Act stated that a woman married to a citizen of Botswana could apply for naturalisation on preferential terms, but not a man in the same situation; the 1984 amendments then applied the same conditions to women naturalising on the basis of marriage as to any other foreigner. ${ }^{33}$ Thus Unity Dow, a citizen of Botswana married to an American, was prevented from passing on her Botswana nationality to her children or husband.

Dow contested the discriminatory sections of the Citizenship Act on the grounds that they violated the constitutional bill of rights.

women in relation to transmission of nationality to their children and spouses. Subsequently, a long campaign for a new family law that would entrench these and other reforms led to the initial adoption of a progressive draft new Code des personnes et de la famille by the National Assembly; but this proposal was finally defeated in December 2011, with the signing into law of a version that perpetuated rather than removed gender discrimination. The title of the law dealing with nationality (which replaced the 1962 nationality code) in both versions removed the remaining gender discrimination in transmission of nationality, but retained discrimination on the basis of birth in or out of wedlock. However, the version that became law also enshrined provisions on male marital power that could imply continued discrimination in transmission of nationality. See press releases related to the Code de la famille on the website of the Féderation Internationale des Droits de l'Homme, http:// www.fidh.org/fr/afrique/mali/ last accessed 25 March 2014.

32 In 1998, after the case was decided, the president appointed Unity Dow as the first woman to sit as a judge on the High Court.

33 Citizenship Act No.25 of 1982, sections 4, 5 and 13 (as amended by the Citizenship (Amendment) Act No. 17 of 1984). 
In 1991 and 1992, first the High Court and then the Court of Appeal found in favour of Dow. ${ }^{34}$

The High Court judgment commented as follows:

[T] he time that women were treated as chattels or were there to obey the whims and wishes of males is long past and it would be offensive to modern thinking and the spirit of the Constitution to find that the Constitution was deliberately framed to permit discrimination on the ground of sex. ${ }^{35}$

The Court of Appeal found that, although Article 15 of the Constitution, which provides that "no law shall make any provision that is discriminatory either of itself or in its effect" does not include sex in its list of prohibited grounds of discrimination, it should be read with Article 3 of the Constitution, which provides that every person in Botswana is entitled to "all the fundamental rights and freedoms of the individual ... whatever his race, place of origin, political opinions, colour, creed or sex." The provisions of the Citizenship Act preventing women from passing Botswana citizenship to their children were thus unconstitutional. It thus agreed that the High Court "was right in holding that section 4 of the Citizenship Act infringes the fundamental rights and freedoms of the respondent conferred by sections 3 (on fundamental rights and freedoms of the individual), 14 (on freedom of movement) and 15 (on protection from discrimination) of the Constitution." 36

The Citizenship Act was amended to conform with the judgment in Dow in 1995, and now allows for children to acquire citizenship by descent if either the father or the mother was a citizen of Botswana at the time of birth, as well as for naturalisation of foreign spouses for both men and women - though only on the same terms as for any other person applying for naturalisation. ${ }^{37}$

34 See Metlhaetsile Women's Information Centre, The Citizenship Case: The Attorney General of the Republic of Botswana vs. Unity Dow, Court Documents, Judgements, Cases and Materials, 1995, available at http://www.law-lib.utoronto.ca/Diana/fulltext/dow1.

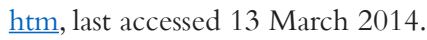

35 Unity Dow v. Attorney-General, High Court of Botswana, Misca. 124/1990, 11 June 1991, reported in 1991 BLR 233 (HC).

36 Attorney-General v. Unity Dow, Court of Appeal, Lobatse, 3 July 1992 (no 4/91).

37 Botswana Citizenship (Amendment) Act, 1995. See also Committee on the Rights of the Child, Consideration of Reports Submitted by States Parties Under Article 44 of the Convention: Initial reports of States parties due in 1997: Botswana, CRC/C/51/Add.9, 27 February 2004. 


\subsubsection{Nationality of children}

With respect to the right of a woman married to a foreigner to pass her nationality to her children, discrimination was almost universal at independence and further elaborated in many countries by discrimination based on the birth of the child in or out of wedlock. In this, the laws reflected the situation in the law of the colonial powers at that time, and indeed globally. ${ }^{38}$

Nonetheless, some early laws did not discriminate in relation to the right of parents to transmit nationality: for example, Chad, which obtained independence in 1960, changed its rules between 1961 and 1962 to remove gender discrimination $^{39}$; Côte d'Ivoire did not discriminate in 1961, but introduced discrimination on the basis of birth in or out of wedlock (though not gender) in $1972 .{ }^{40}$ Some of the more recent reforms increasing gender equality provided only for greater access to nationality for the children of national mothers, rather than total equality: for example in Sudan, where a child of a national mother was given the right to claim nationality rather than automatic attribution; or in Sierra Leone where 2006 reforms still retained gender discrimination in relation to children born outside the country.

Even some relatively recent nationality laws still discriminate. In Burundi, for example, the 2005 constitution provides that children of Burundian men or women have the same right to a nationality; but the nationality code of 2000 still provides that the status of children born of a citizen mother is technically the right to acquire citizenship "by declaration" and automatic attribution of nationality of origin is restricted to those born of a citizen father. ${ }^{41}$ Swaziland's 2005 constitution explicitly provides that a child born after the constitution came into force is a citizen only if his or her father is a citizen. ${ }^{42}$ The unrecognised state of Somaliland has also adopted a citizenship law that explicitly discriminates on the basis of gender, providing that citizenship from birth is granted to "anyone whose father is a descendant of persons who resided in the territory of Somaliland on 26 June 1960 and before.” 43

38 Bernard Dutoit, Daniel Dumuse, Yves Gonset and Hélène Marie de Riedmatten, La nationalité de la femme mariée, Volumes I (Europe), II (Africa) and III (Americas, Asia and Oceania), and supplements. Geneva, Librairie Droz, various dates.

39 Loi No.31-60 du 27 février 1961 ; Ordonnance No.33 du 14 août 1962.

40 Loi No.61-415 du 14 décembre 1961, amended by Loi No.72-852 du 21 Décembre 1972.

41 Constitution of Burundi, 2005, Article 12, Loi n 1-013 du 18 juillet 2000 portant réforme du code de la nationalité burundaise, articles 2, 4 and 5 .

42 Constitution of the Kingdom of Swaziland, 2005, article 43.

43 Republic of Somaliland, Citizenship Law, No.22/2002 (unofficial translation). 


\subsubsection{Nationality of spouses}

Gender discrimination in relation to the transmission of nationality by marriage has been more difficult to change. However, by 2014, discrimination in the grant of nationality to a spouse had been removed in just under a half of African countries; even though in some countries the decision was rather to remove the privileged access to nationality for a foreign wife, than to extend the easier terms to a husband.

At independence, the anglophone countries adopted the English modified dualist system, by which marriage in itself had no effect on a person's nationality, but a woman marrying a citizen could obtain nationality by registration (an easier and less discretionary system than naturalisation), usually on condition that she renounced her former nationality. Some francophone countries also followed a similar system where the woman could obtain the nationality of her husband by option, upon application submitted within a certain time after marriage. Algeria, significantly given its history, adopted a completely dualist system, by which marriage gave no additional rights, and a foreign wife or husband must naturalise in the same way as any other alien. Most francophone countries, however, followed the combined unitary and dualist system of the French nationality code of 1945 , by which a woman marrying a national automatically acquired the nationality of her husband, but with the ability to refuse this within a certain period of the marriage. Ethiopia's 1930 nationality law (since superseded) and Somalia had a completely unitary system, by which an alien woman marrying a national automatically acquired her husband's nationality. In the case of a woman marrying a foreigner, similar variations applied in relation to her ability to retain her nationality of origin, though there was often more tolerance if she acquired the nationality of her husband automatically. ${ }^{44}$

By 1990, the absolute dualist system, in which marriage had no effect at all on nationality, was only in place in Algeria and Liberia (where the 1956 law had attributed Liberian - or foreign - nationality to a woman on marriage, but the 1973 law removed all effect of marriage on nationality). However, a system of facilitated naturalisation for spouses had become more common than the system of nationality by registration or declaration (that is, it made acquisition more difficult). Facilitated naturalisation, previously in place only for Sudan and South Africa, had been adopted in Angola, Botswana, Djibouti, Mozambique and Seychelles. At the same time, demands for gender equality had already brought equal rights for spouses in transmission of nationality in Angola, Cape Verde, Djibouti, Ghana, Guinea-Bissau, Namibia and Seychelles; in Burkina Faso, unusually, the reform was to provide that a foreign husband also acquired his wife's nationality automatically. ${ }^{45}$

44 See generally Bernard Dutoit, Daniel Dumuse, Yves Gonset and Hélène Marie de Riedmatten, La nationalité de la femme mariée : Vol. 2 Afrique Librairie Droz, Geneva, 1976.

45 Bernard Dutoit and Denis Masmejan, La nationalité de la femme mariée : Vol. 2 Afrique : Supplément 1976-1990, Librairie Droz, Geneva, 1991. 
Since then, often explicitly in response to increasing demands for gender equality in marriage rights - and hence the possibility that foreign men and not just foreign women will obtain nationality on easy terms - the dualist system has made a come-back on the African continent, either in modified form, so that nationality is acquired on marriage by a non-discretionary process of declaration or registration, or only on the basis of discretionary naturalisation as for any other foreigner. In Botswana, reforms enacted in response to the Unity Dow case (see box) removed gender discrimination, but also removed any rights in case of marriage: spouses must henceforward naturalise on the same terms as any other foreigner. Similarly, marriage in itself now provides no rights in Djibouti, DRC, Liberia and Zambia. Algeria, however, restored the right to nationality through marriage in 2005 (for either spouse), but only by a process of facilitated naturalisation. ${ }^{46}$ Niger's 1984 nationality code provided for the right of a woman married to a Nigerien man to opt for nationality (replacing automatic attribution in the post-independence code), but 2014 reforms bringing gender equality created conditions similar to those for naturalisation. ${ }^{47}$ Similar sorts of disquiet have in other cases just lengthened the period a spouse must wait: in 2010, Namibia amended its constitution to change the period for acquisition of citizenship by marriage from two to 10 years. ${ }^{48}$

In the case of Zambia, where there have been no rights based on marriage since 1996, this revision was on the basis of a Constitution Review Commission that considered the subject of citizenship in detail, and received many submissions suggesting that citizenship was too easy to obtain for people who were not members of the "indigenous" Zambian population. ${ }^{49}$ The Commission recommended restricting citizenship to birth, descent, and registration (i.e. naturalisation); and the amendments to the constitution adopted on its recommendation included deleting altogether the clause providing for marriage to be the grounds for citizenship by registration. ${ }^{50} \mathrm{~A}$ revived constitutional process almost twenty years later proposed that a person married to a citizen for five years would be entitled to apply to be registered as a citizen "as prescribed". ${ }^{1}$

In Zimbabwe, the groundbreaking Rattigan case heard in the Supreme Court in 1995 ruled that a foreign husband should have the same rights of residence in Zimbabwe as a foreign wife. In direct response to the case the government adopted the $14^{\text {th }}$ amendment to the constitution, which removed, prospectively, all rights to citizenship based on marriage; the amendment also removed gender discrimination

46 Ordonnance $n^{\circ} 70-86$ du 15 décembre 1970 portant Code de la nationalité algérienne as modified by Ordonnance No. 05-01 du 27 février 2005.

$47 \quad$ Niger Loi No.2014-60 du 5 novembre 2014.

48 Namibian Constitution Second Amendment Act, 2010 (Act No. 7 of 2010), section 1.

49 Zambia Constitution Review Commission report, 16 June 1995, p.40.

50 Deletion of article 6(1)(c) from the Constitution of the Republic of Zambia of 1991 by Act No. 18 of 1996, article 6.

51 Zambia draft constitution, 2014. 
in relation to transmission of citizenship to children, but at the same time created greater restrictions on acquisition of nationality based on birth in the territory (see further chapter 8.3).$^{52}$ In 2009, as part of a constitutional amendment allowing for the installation of a government of national unity, gender discrimination was completely removed from the constitution in relation to citizenship by birth and marriage. ${ }^{53}$ The 2009 amendments also increased the general period for naturalisation to 10 years, but provided that those married to a citizen could naturalise in five (albeit subject to all the other usual conditions). These changes were confirmed in the 2013 constitution, reducing the period of residence in case of marriage but making acquisition of citizenship still subject to satisfication of conditions to be established in law (yet to be adopted by end 2014). ${ }^{54}$

In Côte d'Ivoire and the DRC also, anxiety has been expressed in constitution- or law-drafting processes about the ease with which foreign men marrying female citizens may acquire nationality. In the DRC, the law provides that an application for citizenship by marriage must be approved by decree of the Council of Ministers and considered by the National Assembly. ${ }^{55}$ In Côte d'Ivoire, however, where rules on marriage have changed several times, the latest version returns to a more open attitude. The 1961 nationality code started from the position of automatic acquisition by a foreign woman of her husband's Ivorian nationality. From 2004, a man could acquire Ivorian citizenship from his wife, but only after a delay of 2 years; a woman could acquire citizenship from an Ivorian man immediately, by declaration. The current provisions, adopted in 2013, return to the unitary system, but with gender neutrality (as in the case of Burkina Faso), so that either a woman or a man of foreign nationality marrying an Ivorian acquires Ivorian nationality automatically at the time of celebration of the marriage. ${ }^{56}$

52 Constitution of Zimbabwe Amendment (No. 14) Act, 1996; see also Tandeka C. Nkiwane, "Gender, Citizenship, and Constitutionalism in Zimbabwe:The Fight Against Amendment 14", Citizenship Studies,Vol. 4, No. 3, 2000.

53 Constitution of Zimbabwe Amendment (No.19) Act, 2009. The Citizenship Act (last amended in 2003) continued to quote the pre-1996 version of the constitution, leading to significant confusion.

54 Zimbabwe Constitution 2013, article 38.

55 In DRC, gender discrimination was ultimately removed, though the conditions under which citizenship may be required by marriage are extremely restrictive; Loi No.04/024 du 12 novembre 2004 rélative a la nationalité congolaise, article 19.

56 Loi n 61-415 du 14 Décembre 1961 portant Code de la nationalité ivoirienne, Article 12, as amended by Loi No.2004-662 du 17 décembre 2004 and Loi No.2013-654 du 13 septembre 2013. 


\section{Partial reforms on gender equality in North Africa}

All of the countries of north Africa have since the 1990s adopted reforms increasing gender equality; a notable development by comparison with the Arab countries of the middle east; reforms granting the right to women to transmit nationality to their children have, however, been easier to achieve than the right to transmit nationality to a husband. ${ }^{57}$

As a protectorate, Tunisia had laws regulating its nationality from $1914^{58}$, but adopted its own nationality code in 1956, which provided for the standard forms of gender discrimination at that time: nationality was transmitted to a child only through the father, unless he was unknown or stateless, or the child born out of wedlock; and only a wife acquired nationality through marriage. ${ }^{59}$ From 1963 , the nationality code provided for a child of a Tunisian mother or father born in Tunisia to be Tunisian; those born abroad were automatically Tunisian only through the father, but could claim nationality by declaration if born outside the country of a Tunisian mother and foreign father. Reforms in 1993 and 2002 changed the procedures slightly for those born abroad, but the code remained discriminatory on its face: Tunisian women could not pass nationality to their husbands, while children born abroad could only acquire by declaration, not automatically. ${ }^{60}$ In 2010 , the law was reformed to remove discrimination in the transmission of nationality by descent for those born after it came into effect. ${ }^{61}$ In 2014, the new government in Tunisia withdrew its reservations to CEDAW in relation to the transmission of nationality to children; however, gender discrimination in marriage remained in the law. ${ }^{62}$

57 For a comparison of North African with Middle Eastern trends, see Laura van Waas and Zahra Albarazi "Transformations of nationality legislation in North Africa", in Isin and Nyers, Routledge Handbook of Global Citizenship Studies, 2014; also Perrin, "Citizenship struggles in the Maghreb" in the same volume.

58 Decrees of 19 June 1914 and 8 Novembrer 1921, discussed in the 1923 Advisory Opinion of the Permanent Court of International Justice on the Nationality decrees issued in Tunis and Morocco, and documents submitted by the French government: see publications of the PCIJ, Series B and C, available at the ICJ website http://www.icj-cij.org/pcij/index. php?p1=9, last accessed 26 November 2014.

59 Décret No.34 du 26 janvier 1956 portant promulgation du Code de la nationalité tunisienne.

${ }^{60}$ Loi nº3-7 du 22 avril 1963 ratifiant le décret loi No.63-6 du 28 février 1963 portant refonte du Code de la nationalité tunisienne, sections 12 and 13 ; See Souhayma Ben Achour, "L'étranger et la nationalité tunisienne : Le droit tunisien de la nationalité, est-il discriminatoire?", paper presented at International Colloquium on "L'étranger", Faculté de droit et des sciences politiques de Tunis, 2005.

61 Loi No.2010-55 du 1 décembre 2010.

62 List of participants to CEDAW at the UN treaties website, https://treaties.un.org/pages/ 
The other north African countries have all adopted reforms in the new millennium. In Egypt, an important 2004 reform to the 1975 Nationality Law amended the law to provide that children born to Egyptian mothers were Egyptian citizens regardless of their father's status or their place of birth. Previously, the child of an Egyptian woman born outside the country could not be an Egyptian citizen from birth unless born out of wedlock or to a stateless or unknown father. ${ }^{63}$ Children of Egyptian women married to Palestinian men born before the reform were excluded, though a number successfully challenged the discrimination in court. In May 2011, following the Egyptian revolution of earlier that year and responding to protests by women, the Ministries of Interior and Foreign Affairs issued a decree allowing Egyptian women married to Palestinian men to transmit their nationality to their children. ${ }^{64}$ However, gender discrimination in marriage persists. The 1975 law provided for foreign wives of Egyptian men to be eligible for citizenship by naturalisation, provided the relevant minister does not object (Article 7); however, this right is not granted to non-Egyptian spouses of Egyptian women, who must follow the criteria stipulated for naturalisation, as for any other foreigner living in the country (Article 4). (See also chapter 11.3.)

In 2005, Algeria went beyond the example of Tunisia and Egypt, amending the nationality law to allow an Algerian woman married to a foreigner to transmit Algerian nationality to her children and also to her spouse on equal terms. ${ }^{65}$

ViewDetails.aspx?src $=$ TREATY\&mtdsg no=IV-8\&chapter=4\&lang=en, last accessed 2 May 2014. See also "Tunisia : Withdrawal of the declaration with regard to Article 15(4) and of the reservations to Articles 9(2), 16 (c), (d), (f), (g), (h) and 29(1) made upon ratification", UN Document C.N.220.2014.TREATIES-IV.8 (Depositary Notification), 23 April 2014. The decision to withdraw the reservations (Article 9(2) relates to the equal right to transmit nationality to children) was first announced in 2011.

63 Law No. 154 of 2004 amending some provisions of Law No.26 of 1975 concerning Egyptian nationality, Official Gazette, Vol.28, 14 July 2004. The Ministry of Interior also issued Decree No. 12025 of 2004, explaining the process of application for citizenship for those born to Egyptian mothers and non-Egyptian fathers. Al-Waqa'e'Al-Masreya / Government Bulletin, issue 166, 24 July 2004. See also http://www.learningpartnership. org/egypt, last accessed 13 March 2014.

64 "Egypt to grant citizenship to kids of Palestinian dads", Jerusalem Post, 8 May 2011; "Post-Revolution, Egypt Establishes the Right of Women Married to Palestinians to Pass Nationality to Children", the Arab Women's Right to Nationality Campaign in Lebanon, 13 May 2011, available in English at http://www.learningpartnership.org/lib/ post-revolution-egypt-establishes-right-women-married-palestinians-pass-nationalitychildren-1, last accessed 27 November 2014.

65 Ordonnance No. 05-01 du 27 février 2005 revising Ordonnance No.70-86 du 15 décembre 1970 portant code de la nationalité algérienne. See also Convention on the Rights of the Child, Consideration of Reports Submitted by States Parties under Article 44 of the Convention: Concluding Observations: Algeria, CRC/C/15/Add.269, 12 October 2005. 
In April 2007, after a long campaign by women's rights organisations, amendments to the Nationality Code came into force in Morocco. The reform finally gave Moroccan women married to foreign men the right to pass Moroccan citizenship to their children (with retroactive effect), and benefited many children who had previously been effectively stateless, notably the children of Palestinian men and Moroccan women. However, in the case of marriage, the law only provides for a foreign woman married to a Moroccan man for five years to acquire marriage by declaration (opposable by the government), and not a foreign man married to a Moroccan woman. In addition, despite other recent reforms that also brought a greater level of gender equality in marriage, Morocco's family code (known as the Moudawana) states that a Moroccan Muslim woman cannot marry a nonMuslim man, and the two codes read together indicate that the family code should take preference, with implications also in relation to whether the children are born out of wedlock. ${ }^{66}$

The Association Démocratique des Femmes du Maroc welcomed the reforms to the law, but called for further reform, including the extension of gender neutrality to the passing of citizenship to a spouse, noting that "over 300 foreign men married to Moroccan women have been waiting for years to obtain Moroccan nationality although their request files fulfill all needed conditions". ${ }^{67}$ Gender discrimination also still affects the provision of the nationality code providing for Moroccan nationality to be given to children born in Morocco of foreign parents who were themselves also born in Morocco. This provision applies in a gender-neutral way only if the parents were born after the law came into force; all other children born in Morocco (thus including all those being born today) can claim nationality only if their father was born in Morocco, is an Arabic-speaking Muslim, and comes from a country where Arabic-speaking Muslims are in the majority. ${ }^{68}$

Unexpectedly, Libya adopted a new nationality law in 2010, before the fall of Ghaddafi, which also included changes that somewhat reduce

66 See Dahir No 1-04-22 du 12 Hija 1424 (3 Fevrier 2004) portant promulgation de la Loi No 70-03 portant Code de la famille, articles 2 and 39 ; Code de la nationalité marocaine, Loi ${ }^{\circ}$ 62-06 promulguée par le dahir n 1-07-80 du 23 mars 2007 - 3 rabii I 1428, Article 3. The Code de la famille also forbids a Moroccan man from marrying a woman who is not Muslim, unless she is Christian or Jewish ("sauf si elle appartient aux gens de la Livre"): Ibid., Article 39.

67 Association Démocratique des Femmes du Maroc, "We've Won a Battle but not the War", press release posted 26 January 2007, available at http://www.learningpartnership.org/lib/wevewon-battle-not-war, last, accessed 27 November 2014. Other information provided by Khadija Elmadmad. See also Khadija Elmadmad, "Maroc: La dimension juridique des migrations", in Mediterranean Migration Report 2007-2008, Euro-Mediterranean Consortium for Applied Research on International Migration, European University Institute, 2008.

68 Code de la nationalité marocaine, article 9. 
gender inequality. In 1998, the Committee on the Rights of the Child considered a report from Libya and expressed the concern that "decisions related to the acquisition of nationality are only based on the status of the father." ${ }^{69}$ In 2003, the committee noted with approval that Libya was considering adopting a rule that would permit a Libyan mother to transfer her nationality to her children, irrespective of her husband's nationality. ${ }^{70}$ But the 2010 law only implements this promise in the most limited way possible, and leaves gender discrimination entrenched, so that Libya still gives the automatic right to nationality only to the child of a Libyan father, whether born in country or abroad. Although the law allows for the grant of nationality to the child of a Libyan mother and foreign father, this is at the discretion of the state, and regulations are required to implement it. $^{71}$ Despite the 2010 reforms, virtually every article thus still enshrines lesser rights for women: given the breakdown of central authority in the country, no further reform was likely.

\subsection{Dual nationality}

Dual nationality, long regarded as anomalous and regrettable in international law, is increasingly permitted around the world, and Africa is no exception. Although it is still too early to talk of a norm allowing dual nationality - some countries remain strongly against - the trend is clear (see chapter 3.6).

At independence, many African countries took the decision that dual citizenship should not be allowed: they wished to ensure that those who might have a claim to another citizenship - especially those of European, Asian, or Middle Eastern descent-had to choose between the two possible loyalties. Those who did not take the citizenship of the newly independent country were then regarded with suspicion, as a possible "fifth column" for the former colonial powers and other interests. A person acquiring another nationality automatically lost his or her birth nationality; and renunciation of another nationality was required for naturalisation. In almost all the Commonwealth countries a child with dual nationality from birth had to renounce one or the other at majority; civil law countries, however, often permitted dual nationality of origin, even where they prohibited it in case of voluntary act.

Dual nationality in case of marriage was equally frowned upon. Commonwealth countries required renunciation of foreign nationality before a woman marrying a

69 Committee on the Rights of the Child, Consideration of Reports Submitted by States Parties under Article 44 of the Convention: Concluding Observations: Libyan Arab Jamahiriya, CRC/C/15/Add.84, 23 January 1998.

70 Committee on the Rights of the Child, Consideration of Reports Submitted by States Parties under Article 44 of the Convention: Concluding Observations: Libyan Arab Jamahiriya, CRC/C/15/Add.209, 4 July 2003.

71 Libya Nationality Law No.24 of 2010, Article 3. 
national could obtain his nationality by registration. Practice in the civil law countries was more varied, but for the most part did not allow dual nationality in the case of marriage. ${ }^{72}$ As an exception, however, dual nationality was sometimes allowed in the case of a foreign woman married to a male citizen, or a female citizen married to a foreign man, even where dual nationality was generally not allowed.

Increasingly, however, an African diaspora with roots in individual African countries, in addition to the earlier involuntary diaspora of slavery, has grown to match migrations from Europe and Asia. ${ }^{73}$ These "hyphenated" Africans, with roots both in an African country and a European or American one, have brought political pressure to bear on their "home" governments to change the rules on dual citizenship and to concede that people with connections to two different countries need not necessarily be disloyal to either state. In addition, there are increasing numbers of Africans with connections to two African countries - and not only persons whose roots lie in ethnic groups found on the borders between two states. A Nigerian-Ghanaian is as likely a combination as a Nigerian-American or Ghanaian-British. Though a less organised lobby group, these people too seek acknowledgment of their multiple identities.

In recent years, many African states have either changed their rules to allow dual nationality in more circumstances or are considering such changes. A few countries allowed dual nationality in all circumstances right from the start (including Chad and Gabon). However, those countries that have changed the rules since independence in the 1960s or 70s to allow dual nationality for nationals from birth (although not always those by naturalisation) are: Burundi, CapeVerde, Comoros, Congo Republic, Djibouti, Gambia, Ghana, Guinea Bissau, Kenya, Mali, Mauritania, Mauritius, Mozambique, Niger, Nigeria, Rwanda, Sierra Leone, Somalia, Sudan and Tunisia (see Table 6: Rules on dual nationality).

Kenya, Tanzania, and Uganda have historically been among those countries most opposed to dual nationality because of suspicions about their large populations of Asian descent. The growing diaspora of people of African origin and the economic significance of their remittances to and investments in their countries of origin, however, have produced political pressure to change the law. However,

72 As of 1975, Cameroon, Chad, Egypt, Ghana, Kenya, Lesotho, Madagascar, Malawi, Mauritius, Morocco, Nigeria, Sierra Leone, Sudan, Tanzania, Uganda, and Zambia required renunciation of previous nationality in case of acquisition of a new nationality following marriage; but not in the case of Burundi, Gambia, Libya, Mauritania, Rhodesia, Swaziland. Tunisia. By 1990, Gabon, Namibia, \& Niger allowed dual nationality for married women; Cape Verde, GuineaBissau and Zaire had joined those forbidding dual nationality. Dutroit et al 1976 \& 1990.

73 Beth Elise Whitaker, "The Politics of Home: Dual Citizenship and the African Diaspora”, International Migration Review, Vol.45, No.4, 2011, pp.755-783; Okechukwu C. Iheduru, "African states, global migration, and transformations in citizenship politics", Citizenship Studies, Vol.15, No.2, 2011, pp181-203; George Bob-Milliar and Gloria Bob-Milliar, "Mobilizing the African Diaspora for development: The politics of dual citizenship in Ghana”, in Falola and Essien (eds.), Pan-Africanism, pp.137-151. 
although Kenya and Uganda changed their laws, similar changes proposed for Tanzania's new constitution were rejected by a constituent assembly in $2014 .^{74}$

Amendment of the law is also under active discussion in other countries. In Zambia, dual nationality has been proposed in various forms in constitutional debates over several years, and the draft constitution put forward in 2014 provided for dual citizenship for citizens from birth and by naturalisation. ${ }^{75}$ Cameroon's main opposition party proposed a draft law to permit dual nationality in $2014 .{ }^{76}$ In Liberia, a Citizenship Retention Act was introduced to the House of Representatives in 2007, proposing that Liberians who had left during the civil war and naturalised as citizens in other countries should be allowed to retain (or reclaim) their Liberian nationality. ${ }^{77}$ Several countries have ambiguities in the law: for example, the 2004 Somali Transitional Federal Charter permitted dual nationality for the first time (in a context where those involved in the debate were themselves mostly holders of other passports), and this permission was repeated in the 2012 Provisional Constitution; but the 1962 nationality law has yet to be revised to reflect this change ${ }^{78}$; while the Congolese national assembly adopted a resolution that the prohibition on dual nationality was suspended in its application to its own members (see chapter 8.6).

Some governments, however, have moved in the opposite direction, using a prohibition on dual citizenship for political purposes. This is most evident in Zimbabwe, where, in recent years, those persons who have a potential claim on another citizenship have been required to renounce it, even if they have never had any legal relationship with the second state. The new rules were clearly aimed at excluding possible opposition supporters from voting in general elections. Despite constitutional amendments adopted in 2009 that opened up the possibility of law reform to allow dual citizenship, confirmed by the new 2013 constitution which provided for dual nationality to be permitted for those who held Zimbabwean citizenship from birth, the Citizenship Act had yet to be reformed by the end of 2014 (see chapter 8.3). The Republic of Sudan (North Sudan) introduced a ban on dual nationality specifically for people who became nationals of the new Republic

74 Uganda Uganda Citizenship and Immigration Control Act 1999 (amended 2009), sections 15-19, Constitution 1995 (Amended 2005), article 15; Constitution of Kenya, 2010, Articles 15(4) and 16. Erick Kabbendera, "Tanzanian Assembly rejects dual citizenship in draft law”, East African, 27 September 2014.

75 Constitution of Zambia Bill 2007; debates on the Zambian Economist blog for June 2008, available at http://zambian-economist.blogspot.com, last accessed 14 December 2014; Zambia draft constitution 2014, articles 16 and 18.

76 «Proposition de loi modifiant et completant la loi n 1968-lf-3 du 11juin 1968 portant code de nationalite camerounaise presentée par le SDF ", AfricaPresse.com, 14 April 2014.

77 See Letter on behalf of Non-Resident Liberians to President Ellen Johnon Sirleaf, 14 December 2007, available at http://szinnah.blogspot.com/2008/01/alvin-teage-jallohattorney-counselor.html, last accessed 24 April 2014.

78 Transitional Federal Charter, 2004, Art 10; Provisional Constitution 2012, Article 8. 
of South Sudan in 2011, even though dual nationality has been generally allowed since 1993. The new state of South Sudan followed continental trends by adopting a nationality law that permits dual nationality (see chapter 9.2). ${ }^{79}$

\subsection{Racial, ethnic and religious discrimination}

In a number of countries in Africa, citizenship by descent is explicitly limited to individuals whose ancestral origins are believed to lie within the particular state or within the African continent. Several countries in Africa - including Liberia, Sierra Leone, the Democratic Republic of the Congo and Uganda - have an explicitly racial or ethnic basis for citizenship, and others - including Algeria, Egypt, Libya and the other north African countries - include an element of religious discrimination also. While some of these provisions have been present since independence, others have been introduced more recently.

Liberia, founded by freed slaves, takes the most extreme position in relation to race: since its first constitution was adopted in 1847, those not "of Negro descent" have not only been excluded from citizenship from birth, but - "in order to preserve, foster, and maintain the positive Liberian culture, values, and character"- are prohibited from becoming citizens even by naturalisation. Moreover, only citizens may hold property in Liberia. ${ }^{80}$ Sierra Leone, which at independence had the usual Commonwealth jus soli rule, introduced racial discrimination in 1962, providing that only people of "negro-African descent" may be citizens from birth, and introducing more restrictive rules for the naturalisation of those who are not of "negro-African descent". Though gender discrimination in these provisions, defining "negro-African descent" only through the male line, has been removed, the racial discrimination remains (see chapter 8.5).

Nigeria, Swaziland and Uganda introduced ethnic rather than racially discriminatory terms into their laws, many years after independence. In Nigeria, the 1979 Constitution introduced the concept of "indigeneity" in relation to citizenship and public appointments that has dominated identification procedures in the country since then (see chapter 13.1). In Swaziland, an ethnic element was introduced in 1974 and remains in place today. Although the law does not specifically refer to ethnicity, the attitudes reflected in the provision of the 1992 Citizenship Act providing for citizenship "by KuKhonta", that is, by customary law, have in practice ensured that those who are not ethnic Swazis find it very difficult to

79 Before the secession of states, the government of the "New Sudan" as South Sudan, was then known, adopted a Nationality Act that, in addition to discriminating on the basis of gender, also required anyone acquiring "New Sudanese" nationality by naturalisation to renounce any other nationality. Sudan Nationality Act, 2003, Laws of the New Sudan, section 9. The actual law adopted in 2011 following secession reversed this provision.

80 Constitution of the Republic of Liberia, 1986, articles 22 and 27. 
obtain recognition of citizenship ${ }^{81}$ (see chapter 8.2.3). In Uganda, ethnic discrimination was introduced by the 1995 constitution, which provides for a right to citizenship from birth for every person born in Uganda "one of whose parents or grandparents is or was a member of any of the indigenous communities existing and residing within the borders of Uganda as at the first day of February, 1926". When the 1995 constitution was being negotiated, representatives of Uganda's Asian population argued that they should be recognised as indigenous by this definition. Although several other ethnic groups whose status was also controversial were successful-including the Banyarwanda, as well as the Batwa, Lendu and Karamojong - the Asians were not, and remain second-class citizens in that regard (see chapter 8.4).

In a few cases, such as in Malawi, discriminatory provisions were first introduced and then reduced or removed. Malawi introduced a racial element to its law in 1966, when the jus soli rule was amended to restrict citizenship not only to persons who have at least one parent who is a citizen but also requiring that parent to be "a person of African race" (unless the child would otherwise be stateless); there is also preferential treatment to allow registration as a citizen for those "of African race," or with Commonwealth or Malawian ties. Persons not "of African race" could not obtain Malawian nationality from birth, and could only naturalise as citizens. ${ }^{82}$ References to "African race" were deleted in 1992. ${ }^{83}$ Elsewhere, there have been efforts to address past injustices dating from the succession of states at the time of independence: new citizenship legislation in Kenya adopted in light of the 2010 constitution made some important (if flawed) efforts to integrate historical migrant populations that had previously had difficulty in accessing Kenyan nationality (see chapter 8.4). ${ }^{84}$

Somalia and DRC both retain ethnically discriminatory provisions established in the 1960s. In Somalia's case an unchanged article of the 1962 citizenship law provides for any person "who by origin, language or tradition belongs to the Somali Nation", is living in Somalia (though not necessarily born there), and

81 "A person who has Khontaed, that is to say, has been accepted as a Swazi in accordance with customary law and in respect of whom certificate of Khonta granted by or at the direction of the King is in force, shall be a citizen of Swaziland." Swaziland Citizenship Act No.14 of 1992, section 5. See also Constitution of Swaziland, Article 42, which appears to provide that persons born before the constitution came into effect are citizens "by operation of law" if either parent is a citizen and also if the person is "generally regarded as Swazi by descent." Article 43 of the constitution removes this (not entirely clear) ethnic basis for children born after the constitution came into effect, but entrenches gender discrimination, providing that citizenship is only passed by a father who is a Swazi citizen.

82 Malawi Citizenship Act, No.28 of 1966, sections 4, 5 and 12-15 (provisions left in place by amendments in Acts No. 37 of 1967 and 5 of 1971).

83 Malawi Citizenship (Amendment) Act, 1992 (No. 22 of 1992).

84 Kenya Citizenship and Immigration Act, No. 12 of 2011, articles 15 and 16, adopted by requirement of the 2010 Constitution. 
renounces any other nationality to obtain citizenship by operation of law. ${ }^{85}$ In DRC, the terms agreed in the 2004 peace deal that ended the civil war in most of the DRC form the basis of the new constitution and citizenship law, which today recognise as a Congolese citizen from birth "every person belonging to the ethnic groups and nationalities of which the individuals and territory formed what became Congo at independence" in 1960. Although the law, significantly, moved this date closer to the present day — it had been 1885 — the basis of Congolese nationality is still founded, as it was from the date of the first postindependence constitution in 1964, on ethnicity rather than on birth, residence, or other objective criteria (see chapter 8.6). ${ }^{86}$

In north Africa, religious discrimination was the rule in nationality law, but has been reduced somewhat in recent years. Nonetheless, Algeria, Egypt, Libya and Morocco still provide to different degrees for privileged access to citizenship for those of Muslim religion and/or Arab origin.

In Algeria, the law relating to those born after independence was on the face of it non-discriminatory in relation to the role of religion (though it discriminated on the basis of gender). However, in a chapter of the 1963 Code de la nationalité dealing with evidence and dispute resolution, "Algerian" was defined as a person of Muslim religion whose father and father's father was born in Algeria. This definition was retained in slightly amended form in the 1970 ordonnance that replaced the original nationality code. ${ }^{87}$ Egypt - and Libya until 2010, when reforms were enacted - both allowed for deprivation of citizenship, however acquired, if the person was "described as Zionist"; from 1980 until 2010, Libya's law also endorsed the concept of an "Arab nationality" creating a specific preference for naturalisation of any person of Arab descent (with the exception of Palestinians)..$^{88}$

In the some countries, discriminatory provisions do not affect basic access to citizenship, but create preferential terms for ethnic or racial categories. In Mali, though the law does not generally discriminate in the rules it applies for children with citizen parents, the provision on double jus soli restricts access to nationality to children born in Mali of a mother or father who was also born in the country and also has nationality of origin of another African country. ${ }^{89}$ In Chad, the provision

85 Law No.28 of 22 December 1962 on Somali Citizenship, articles 2 and 3. See also N.A. Noor Mohammed The Legal System of the Somali Democratic Republic, Charlottesville, VA: Michie, 1972, Chapter 2, "Citizenship".

86 Loi No 04-024 du 12 novembre 2004 relative à la nationalité congolaise.

87 Code de la nationalité algérienne, article 32.

88 Law No. 26 of 1975 (as amended 2004); Libya Law No. 17 of 1954 on Nationality and Law No.18 of 1980 on "Arab nationality" (though the status of this second law was never clear); Law No.24 of 2010, which replaced the nationality code, did not provide differential treatment for Arabs or Muslims.

89 Code des personnes et de la famille, 2011, Article 227. The original term was "of African origin": there was argument over whether this phrasing implied a racial content or was merely geographical. See Cooper, Citizenship between Empire and Nation, p.419, note 142. 
on possession d'état de Tchadien is similarly restricted to those of "African ancestry" (de souche africain). ${ }^{90} \mathrm{R}$ wanda introduced a provision in its 2003 constitution that "All persons originating from Rwanda and their descendants shall, upon their request, be entitled to Rwandan nationality". ${ }^{91}$

Of course racial or ethnic discrimination may well be applied even if it is not written into the law. This has been most evident in the application of transitional provisions relating to succession of states at independence, which rarely explictly discriminated on the basis of race or ethnicity, ${ }^{92}$ but often were applied with discriminatory effect. These situations make up the case studies discussed in chapter 8: in Côte d'Ivoire, most obviously, the lack of definition of "foreigner" in relation to those born in the country of two parents who were "foreign", while the absence of double jus soli provision allowed the law later to be given an ethnic meaning (see chapter 8.7). Another case (not treated at length in this book) are members of the Karana community of Indo-Pakistani origin in Madagascar, who were already prior to independence subject to French decrees aimed at protecting French nationality from dilution through Asian immigration, and who still struggle to obtain recognition of Malagasy nationality. The application of double jus soli and the attribution of nationality based on birth and residence till majority in the 1945 French nationality code never applied in Madagascar, and the restriction of jus soli to children of unknown parents was continued after independence. ${ }^{93}$

90 Ordonnance no.33/PG-INT du 14 août 1962 portant Code de la nationalité tchadienne, article 14.

91 Constitution of the Republic of Rwanda, 2003, Article 7.

92 An exception is the 1968 independence constitution of Equatorial Guinea, which provided as one of its transitional provisions that those of African descent born in the country would obtain nationality:"Con independencia de lo que en su día disponga la Ley de Nacionalidad, se considerarán nacionales guineanos las personas de ascendencia africana que hayan nacido en Guinea Ecuatorial y sus hijos, aunque hayan nacido fuera de ella, siempre que en uno y otro caso vengan poseyendo como tales la nacionalidad guineana."

93 Decottignies and de Biéville, Les nationalités africaines, pp.14-15 and 201-210 ; Caroline McInerney, "Accessing Malagasy Citizenship:The Nationality Code and its impact on the Karana", Tilburg Law Review, Vol.19, 2014, pp.182-193; also Bureau of Democracy, Human Rights, and Labor, Country Reports on Human Rights Practices: Madagascar, U.S. Department of State, sucessive years. 



\section{African nationality laws compared}

This chapter provides a detailed comparative overview of the provisions currently in force in African nationality laws, starting from the provisions related to the right to a nationality for children born in or outside the country, and the basis on which nationality is granted, and the protections against statelessness that result. It then considers citizenship by marriage and citizenship by naturalisation, dual nationality and preferential rights applied to members of some non-citizen groups. Finally, it looks at loss and deprivation of citizenship and the general requirements for due process in decisions relating to nationality, as well as renunciation and reacqusition. Through this comparison the chapter both sets out the current state of African nationality laws, and also aims to provide an indication of the extent to which they comply with international norms. ${ }^{1}$

In summary, just over half of Africa's countries have nationality laws that are reasonably satisfactory on paper in terms of protections against statelessness for children born on their territory, providing either for some version of jus soli for all children, whether or not one of their parents is a citizen. However, only a minority provide specific protection for children who would otherwise be stateless, and sixteen have no provision for children of unknown parents. There are seven countries that have no rights based on birth in the territory in general and also fail to include a default provision under their citizenship law for children born in the territory with no other option to have a right to a nationality from birth, even in the case of foundlings: Botswana, Côte d'Ivoire, Gambia, Mauritius, Nigeria, Seychelles and Zambia.

Another dozen countries provide the fallback right to their nationality only for foundlings or children whose parents are unknown: Burundi, Djibouti, Eritrea, Ethiopia, Ghana, Kenya, Libya, Madagascar, Mauritania, Sudan, Swaziland and Zimbabwe. Though protection for foundlings in the law is very important for orphans, especially in a post-conflict situation, it is a significantly less generous provision than protection for children who cannot obtain the nationality of one of their parents. Egypt, for example, in addition to including requirements that discriminate on the basis of religion and language for children born on its territory, also provides only for the child of unknown-but not statelessparents to be a citizen. There are believed to be from 400,000 to over one million persons at risk of statelessness in the country. ${ }^{2}$

1 The information in this chapter is an updated, corrected, expanded and rearranged version of material first published in Bronwen Manby, Citizenship Law in Africa: A Comparative Study, New York: Open Society Foundations, 2009 ( $3^{\text {rd }}$ edition forthcoming, 2015).

2 Maureen Lynch, Lives on Hold: The Human Cost of Statelessness, Washington, Refugees 
Thus, almost half of African countries have citizenship laws that mean that at least some children born on their territory will be stateless. This lack of rights based on place of birth is of particular concern where citizenship by descent is allowed only or primarily through the father, leaving the children of noncitizen fathers especially vulnerable. This situation exists in Madagascar, Sudan (though the 2005 constitution and citizenship act do allow children of Sudanese mothers to apply for nationality), Swaziland, and, despite 2007 reforms that introduced greater gender equality, for some children of non-Muslim fathers in Morocco.

For those born outside the country, all countries provide for transmission of nationality for at least one generation through the father; most to the child of either a father or mother. A handful restrict transmission of nationality on the basis of descent only to one generation outside the country.

Gender discrimination in the transmission of nationality from parent to child now applies in only around a dozen countries, though in relation to transmission of nationality between spouses discrimination still applies in just under half of all countries. Acceptance of dual nationality is now the norm, with the substantial majority countries now permitting two nationalities to be held, at least in some circumstances. Provisions on loss of nationality are extremely complex, and very broad in some countries; however, more than twenty countries provide that birth nationality cannot be lost; and for another half dozen only in case of acquisition of another nationality.

The complexities obvious in the tables below, and the many exceptions to each supposed rule, in fact understate the challenges of interpreting Africa's citizenship laws. In many countries - especially those where the issue of nationality has been most controversial - it takes advanced legal skills to make any sense of the question of who has a right to citizenship, which represents only the first of many hurdles that someone seeking to claim that right will have to clear. Some states are still using laws that were adopted at or soon after independence and have been little changed since, while others have undertaken comprehensive reforms, often in the context of a general constitutional review. Many have adopted a series of amendments to their existing laws — such as to introduce partial or total gender equalitysometimes leading to complex provisions that seem to contradict themselves and create corresponding difficulties in determining an individual's position. In some cases, the constitution and the nationality law in fact provide for different rules (noted with a double exclamation mark in the tables below), or the constitution establishes general principles which are not reflected in the law, or not applied in practice. Even where these tables indicate that the situation is the same under different conditions or in different countries, such an indication may rest on an interpretation of the law that itself could be subject to challenge.

International, 2005, p.28. The numbers registered with UNHCR as formally stateless are much lower, in the tens rather than hundreds: Eirwen-Jane Pierrot, $A$ responsibility to protect: UNHCR and statelessness in Egypt, UNHCR, 2013. 
Moreover, other laws may provide additional complications. In the civil law countries, including those that do not have comprehensive legislation on child rights such as Benin and Senegal, the family codes contain many important provisions relating to the status of children that are important for nationality (such as rules on the establishment of descent, the procedures for adoption etc); though not all contain specific provisions on the right to a nationality. ${ }^{3}$ In the case of Burkina Faso the nationality law is in fact included within the family code; while for Guinea it is within the general civil code. Togo's children's code contains provisions on nationality that are significantly different from those in the (pre-existing but unrepealed) nationality code. Equally, the laws relating to civil registration and national identity documentation can in some countries be almost as significant as the nationality law in providing a person with practical access to proof of a theoretical right to nationality; it is not possible to provide a comprehensive comparison of these provisions here.

\subsection{Children born in the country}

\subsubsection{Constitutional and legislative guarantees for the right to a nationality}

Despite the provisions of the Article 6(4) of the African Charter on the Rights and Welfare of the Child and Article 1 of the Convention on the Reduction of Statelessness, most African countries fail to provide in their constitutions or in legislation for an explicit right to their nationality for children born on their territory who would otherwise be stateless.

The constitutions of Angola, Ethiopia, Guinea-Bissau, Kenya, Malawi, Rwanda and South Africa stand out, in that they all provide in general terms for the right to a nationality for all, or that every child has the right to a name and nationality. ${ }^{4}$ However, the implementing laws do not necessarily ensure that this promise is fulfilled.

Most of the former French and Portuguese colonies provide, in line with the civil law monist tradition, that the terms of treaties on nationality to which the State is a party apply even if they are contradicted by national law. ${ }^{5}$ Other

3 For example, Benin Loi $N^{\circ} 2002$ - 07 portant Code des personnes et de la famille; Senegal Loi n72-61 du 12 juin 1972 portant code de la famille modifiée par les lois no.74-37 du 18 juillet 1974 et 89-01 du 17 janvier 1989.

4 Constitution of the Federal Democratic Republic of Ethiopia, 1994, article 36; Guiné Bissau Constitution 1984, as amended to 1996, article 44; Constitution of Kenya, 2010, article 53(1) (a); Constitution of Malawi,1966, Article 23(2); Constitution of the Republic of Rwanda, 2003, Article 7; Constitution of the Republic of South Africa, 1996, article 28(1)(a).

5 Angola Nationality Law 2005, Art 6 ; Benin Code de la nationalité, Art 2 ; Burkina Faso Code des personnes et de la famille 1989, art 135; Cameroon Code de la nationalité, Art 3 ; CAR Code de la nationalité Art 3 ; Chad Code de la nationalité Art 3 ; Comoros Code de la nationalité Art 2 ; Congo Code de la nationalité Art 5 ; Cote d'Ivoire Code de la nationalité Art 3 ; Djibouti Code de la nationalité Art 1 ; Gabon Code de la nationalité Art 4 ; Madagascar Code de la nationalité Art 7 ; Mali Code de la nationalité 1962 Art 2 ; 
countries have established the right to a nationality in other laws, notably specific legislation relating to children's rights, rather than the constitution. For example:

- Botswana's Children's Act states that every child has "a right to a nationality from birth". 6

- Gambia's Children's Act states that every child has a right to acquire a nationality. ${ }^{7}$

- Ghana's Children's Act and Sierra Leone's Child Rights Act both provide, rather ambiguously, that "No person shall deprive a child of the right from birth to a name, the right to acquire a nationality or the right as far as possible to know his natural parents and extended family."

- Guinea's Code de l'enfant provides for every child to have the right to a nationality. ${ }^{9}$

- Kenya's 2001 Children Act provides for every child to have a right to a name and nationality. ${ }^{10}$

- Mali's Code de protection de l'enfant provides that every child has the right to an identity, which includes the right to a nationality. ${ }^{11}$

- Tanzania's 2009 Law of the Child Act provides for a child to have the right to a name and nationality, and that "a person shall not deprive a child of the right to a name, nationality...."12

- Togo's Code de l'enfant includes a number of provisions on nationality, including that a child has the right to the nationality of either parent, in line with the country's constitution (though these provisions are not reflected in the (older) nationality code).$^{13}$

- Tunisia's Child Protection Code provides, in Article 5, that "every child shall have the right to an identity from birth. The identity shall comprise name, surname, date of birth and nationality." ${ }^{14}$

Mauritania Code de la nationalité Art 6 ; Morocco Code de la nationalité Art 1 ; Niger Code de la nationalité 1984, Art 3.

6 Botswana Children's Act No.8 of 2009, section 12.

7 Gambia Children's Act No.5 of 2005, section 8.

8 Sierra Leone Child Rights Act (No.7 of 2007), section 24. Ghana Children's Act 1998 (no.560), section 4 . The obligations placed on the state by this section are not very clear, and appear not to include granting nationality to stateless children.

9 Guinea Loi L/2008/011/AN du 19 aout 2008 portant Code de l'enfant Guinéen, article 1.

10 "Every child shall have a right to a name and nationality and where a child is deprived of his identity the Government shall provide appropriate assistance and protection, with a view to establishing his identity." Kenya Children Act (No. 8 of 2001), section 11.

11 Mali Ordonnance $\mathrm{N}^{\circ} 02-062 / \mathrm{P}-\mathrm{RM}$ du 5 juin 2002 portant code de protection de l'enfant, art 4.

12 Law of the Child Act No.21 of 2009, section 6.

13 Togo Loi no.2007-017 du 6 juillet 2007 portant code de l'enfant, arts.17-24

14 Loi No.95-92 du 9 novembre 1995 rélative a la publication du Code de la protection de l'enfant, article 5 . 
The Liberian Children's Law adopted in 2011, however, does not contain specific guarantees on the right to a nationality, though other provisions are relevant; similarly the Nigerian Child Rights Act 2003 provides only for the right to a name, and not a nationality. ${ }^{15}$

It is not sufficient, however, to provide for a right to a nationality in the abstract in the constitution or children's law: the nationality law must fulfil this promise. It can do this in two ways: either by providing for a child who would otherwise be stateless to have the nationality of the state where he or she is born, or for children to acquire nationality automatically on the basis of some version of jus soli. In general, the latter provides stronger protection against statelessness, since proving the negative (that another nationality is not acquired at birth) can be very difficult to do.

Among the five African countries that have provided a constitutional right to a nationality, Guinea- Bissau, Rwanda and South Africa go the furthest in implementing this right in their citizenship laws. In Rwanda, the nationality law provides that a child born in the territory of non-citizen parents can apply for nationality at majority, and also that a child born in Rwanda who cannot acquire the nationality of one of his or her parents shall be Rwandan. ${ }^{16}$ The South African Citizenship Act provides for citizenship on a jus soli basis for any child who does not have the citizenship of any other country or the right to any other citizenship, as well as a the general right for a child born in the country of non-citizen parents to be able to apply for citizenship at majority; however, these rights are dependent on the child's birth being registered. ${ }^{17}$ Guinea Bissau provides for a child of stateless parents or parents of unknown nationality or who would otherwise be stateless to acquire nationality at birth, as well as for a newborn foundling. ${ }^{18}$

In Ethiopia, however, despite reforms adopted in 2003, the law does not explicitly provide a right to Ethiopian nationality for a child born in the country who would otherwise be stateless, while in practice problems continue in relation to gender discrimination in the implementation of its citizenship law as well as the fallout from the war with Eritrea that has left many Ethiopians of Eritrean origin stateless (see chapter 9.1). In Malawi, the constitutional a right to a nationality for children is not ensured by the provisions of the citizenship legislation. However, the 1966 Citizenship Act is unusual in specifically providing for the registration of stateless persons as citizens, if they can show that they are stateless and were born in Malawi or have a parent who is Malawian; the applicant must also satisfy

15 Liberia Children's Act 2011, section 4(2) ; Nigeria Child Rights Act 2003, section 5.

16 Loi organique No. 30/2008 du 25/07/2008 portant code de la nationalité rwandaise, sections 8 and 9 .

17 South Africa Citizenship Act (No. 88 of 1995, as amended to 2010), sections 2(2)(a) and 4(3).

18 Lei No.2/1992 de 6 de abril, as amended 2010, article 5. 
the authorities that he or she has been ordinarily resident in Malawi for three years, intends to remain there, and has no serious criminal convictions. If the person is under 21, an application can be made on his or her behalf. ${ }^{19}$

\subsubsection{Jus soli, double jus soli and birth + residence}

The countries with the strongest protections against statelessness for children born on their territory are those that follow a jus soli rule, granting citizenship automatically to any child born on their soil Few countries in Africa (today only Chad, Lesotho, and Tanzania ${ }^{20}$ ) base their law on jus soli in the first instance (with the standard exception for the children of diplomats or other state representatives and, in some cases, also for the children of enemy aliens). Liberia provides for a jus soli rule in its law, but on a racial basis only for "Negroes", and does not repeat this in the more recent constitution; and so does Uganda, but only to those who are members of one of the ethnic groups listed in the constitution (see chapter $5.4)$.

Cape Verde, Namibia, South Africa, and São Tomé and Príncipe grant citizenship to children born of parents who are resident in the country on a long-term basis. In Namibia and South Africa, it is explicitly stated that this residence must be legal, though not in São Tomé and Príncipe. ${ }^{21}$ Cape Verde is the most generous, providing simply that children of parents resident in the country for more than five years are citizens, and otherwise that, absent any evidence to the contrary in their birth documentation, children born in the country are citizens; CapeVerde also permits dual citizenship. ${ }^{22}$

More than 25 countries, mostly in the civil law tradition, have adopted measures that provide some general rights based on birth in the territory while stopping short of a jus soli rule, by providing either that children born in their territory of noncitizen parents can claim or are attributed nationality if they are still resident there at majority, or that children born in the territory of at least one parent also

19 Malawi Citizenship Act, 1966, section 18.

20 A draft constitution due for adoption in 2015 would remove this provision to replace it with a pure descent-based system. The jus soli right has not been applied in any event: see chapter 11.2.

21 In South Africa, both parents must be permanent residents and, since reforms adopted in 2010, the child only qualifies for citizenship by birth if still resident in the country at majority. South Africa Citizenship Act (No. 88 of 1995, as amended to 2010), section 2(3). In the case of Namibia, the child of parents who are "ordinarily resident" (excluding those who are illegal immigrants or diplomats etc) in the country are Namibian citizens from birth by operation of law (Constitution, 1990, Article 4(1)(b)). See also Committee on the Rights of the Child, Consideration of reports submitted by States parties under Article 44 of the Convention, Initial reports of States parties due in 1993: São Tomé and Príncipe, CRC/C/8/ Add.49, 1 December 2003, paragraph 153.

22 Cape Verde Decreto-Lei No.53/93 de 30 de agosto de 1993, articles 1 and 6. What the evidence to the contrary would be, therefore, is not clear. 
born there are automatically citizens from birth, a provision known as double jus soli. Those providing for double jus soli are: Benin, Burkina Faso, Cameroon, Congo Republic, Gabon, Guinea, Mozambique, Niger and Senegal. Variants of double jus soli are provided in Algeria (under the heading on evidence, it is provided that nationality of origin can be claimed if both father and grandfather must were born in the territory and of Muslim religion ${ }^{23}$ ); Mali (the parent born in the country must must have the nationality of another African state ${ }^{24}$ ); Morocco (nationality is not attributed automatically but can be claimed, and with preferential rights for a child of a father born in Morocco who is "attached to" a country of Muslim religion and Arabic language ${ }^{25}$ ); Sierra Leone (either a parent or grandparent may be born in the country, but must be of "negro African descent"26); South Sudan (the person concerned may be born in or outside of South Sudan, but is South Sudanese if a parent, grandparent or great-grandparent was born in South Sudan and a member of one of the indigenous ethnic groups of South Sudan ${ }^{27}$ ); Togo (both parents must also have been born in the country and the child must be habitually resident and in possession d'état de togolais ${ }^{28}$ ); and Tunisia (both father

23 Code de la nationalité 1970, as amended 2005, Article 32. "Lorsque la nationalité algérienne est revendiquée à titre de nationalité d'origine, elle peut être prouvée par la filiation découlant de deux ascendants en ligne paternelle ou maternelle, nés en Algérie et y ayant joui du statut musulman."

24 Code des personnes et de la famille, 2011, article 227.

25 Code de la nationalite marocaine, 1958, as amended to 2007, Article 9(1) Acquisition de la nationalité marocaine par la naissance et la résidence au Maroc: "Sauf opposition du ministre de la justice conformément aux articles 26 et 27 du présent dahir, acquiert la nationalité marocaine si, dans les deux ans précédant sa majorité, il déclare vouloir acquérir cette nationalité, tout enfant né au Maroc de parents étrangers qui y sont eux-mêmes nés postérieurement à la mise en vigueur du présent dahir, à condition d'avoir une résidence habituelle et régulière au Maroc. Sauf opposition du ministre de la justice conformément aux articles 26 et 27, acquiert la nationalité marocaine, si elle déclare opter pour celle-ci, toute personne née au Maroc de parents étrangers et ayant une résidence habituelle et régulière au Maroc, dont le père lui-même est né au Maroc, lorsque ce dernier se rattache à un pays dont la fraction majoritaire de la population est constituée par une communauté ayant pour langue l'arabe ou pour religion l'islam et appartenant à cette communauté. Dispositions transitoires : Toutefois, les personnes, nées au Maroc de parents étrangers, qui y sont eux-même nés, visées au $\ 1$ du présent article âgées de 18 à 20 ans à la date d'entrée en vigueur de la présente loi, disposent d'un délai d'un an à compter de cette date pour demander l'acquisition de la nationalité marocaine.»

26 Citizenship Act 1973, as amended 2005, Article 2.

27 Citizenship Act 2011, Article 8.

28 Code de la nationalite 1978, Article 1 : «Est Togolais l'enfant né au Togo d'un père et d'un mère nés au Togo, qui a sa résidence habituelle sur le territoire de la République Togolaise et jouit de la possession d'état de Togolais. La possession d'état au sens de l'alinéa qui précède, consiste notamment dans le fait pour l'intéressé: a) de s'être constamment et publiquement comporté comme un Togolais;

b) d'avoir été constamment et publiquement traité comme tel par la population et les 
and grandfather must have been born in Tunisia ${ }^{29}$ ).

A small number of countries automatically attribute nationality to a child born on the territory who is still resident there at majority, again, based on the French legal tradition: Benin, Burkina Faso, Congo Republic and Guinea.Those giving a person born on the territory and resident there for a period the right to acquire their nationality by registration or declaration (requiring a positive action, at the latest at majority, but without discretion for the state) are: Benin, Cameroon, Central African Republic (CAR), Comoros, DRC, Equatorial Guinea, Gabon, Guinea, Mali, Mozambique, ${ }^{30}$ Rwanda, South Africa and Togo. Gabon's 1998 nationality code contains interesting and perhaps unique provisions relating to children born in the border zones of countries neighbouring Gabon or raised by Gabonese citizens: if such children make a declaration during the 12 months preceding their majority that they have lived in Gabon for the preceding 10 years, or if they were from before the age of 15 brought up by a Gabonese citizen or on state assistance, they can claim Gabonese nationality of origin. ${ }^{31}$

The right to opt for nationality is often not effective in practice, however. In the Central African Republic, for example, which gives all children born in its territory the right to acquire nationality by declaration from the age of 12 , the Committee on the Rights of the Child expressed concern at violations of the right to a nationality for children whose birth had not been registered or for children whose parents were not nationals of the CAR. ${ }^{32}$

\subsubsection{Children of stateless parents or who would otherwise be stateless}

Only 13 African countries specifically provide in their nationality laws (in accordance with Article 1 of the 1961 Convention on the Reduction of Statelessness and Article 6(4) of the African Charter on the Rights and Welfare of the Child) that children born on their territory who would otherwise be stateless have the right to nationality: Angola, Burkina Faso, Cameroon, Cape Verde, Chad, Guinea Bissau,

autorités togolaises.

Le ministre de la justice peut, par décision motivée, s'opposer à l'attribution de la nationalité togolaise s'il est établi que cet enfant n'a pas la possession d'état de Togolais. "

29 Code de la nationalité 1963, as amended to 2010, Article 7 : « Est Tunisien, l'enfant né en Tunisie et dont le père et le grand-père paternel y sont eux-mêmes nés. »

30 In the case of Mozambique, the parents of a child born in the country may declare that they wish the child to be Mozambican, within one year of the child's birth, or the child may claim nationality within one year of majority (Constitution, 2004, Article 24).

31 Gabon code de la nationalité, Loi n 37-1998, art 14. This provision is similar to those of several Latin American countries, which have specific provisions in their constitutions aiming to assist in resolving the citizenship status of indigenous communities in border areas (see section $\mathrm{xx}$ ).

32 Code de la nationalite, arts 18-21; Committee on the Rights of the Child, Concluding Observations of the Committee on the Rights of the Child: Central African Republic, CRC/C/15/ Add.138, 16 October 2000, paragraph 38. 
Lesotho, Malawi, Namibia, ${ }^{33}$ São Tomé and Príncipe, South Africa and Togo. In the case of Angola and Malawi this is on application, rather than automatically (and in Malawi as an adult and discretionary, not a child).

In addition, Angola, Benin, Cape Verde, DRC, Gabon, Guinea Bissau, Mozambique, Rwanda, São Tomé and Príncipe and Tunisia have provisions granting nationality to the children of stateless parents; however, by itself this is not sufficient protection for those whose parents themselves have a nationality but cannot transmit it to their children.

\subsubsection{Foundlings or children of unknown parents}

Protection for children of unknown parents dates back to the Hague Convention of 1930, which provides in Article 14 that:

A child whose parents are both unknown shall have the nationality of the country of birth. If the child's parentage is established, its nationality shall be determined by the rules applicable in cases where the parentage is known. A foundling is, until the contrary is proved, presumed to have been born on the territory of the State in which it was found.

Article 2 of the 1961 UN Convention on the Reduction of Statelessness also requires that "A foundling found in the territory of a Contracting State shall, in the absence of proof to the contrary, be considered to have been born within that territory of parents possessing the nationality of that State". This provision is respected by a much larger number of countries than the requirement to grant nationality to children who would otherwise be stateless.

In many countries, the provisions on unknown parents relate to foundlings only, that is infants. A provision on unknown parents may be assumed to cover a child that is older at the date he or she was found, and some specifically set an age. Kenya, Swaziland, Uganda and Zimbabwe specifically state that the child found may be significantly older than a new born child to have the right to citizenship: up to the age of eight in the case of Kenya, seven for Swaziland, five for Uganda and fifteen in Zimbabwe's 2013 constitution. ${ }^{34}$ A proposed new Tanzanian constitution would adopt the same wording as Kenya. ${ }^{35}$

33 Namibia provides that the exceptions to the right to citizenship from birth of a child born in the country of parents who are ordinarily resident - most importantly the exclusion if the parents are illegal immigrants, but also if they have diplomatic or similar status — do not apply if the child would be stateless. Constitution of Namibia, 1990, Article 4(1)(b). This may not, however, be a complete protection, since it requires the parents to be ordinarily resident.

34 Kenya Constitution 2010, article 14(4), Citizenship and Immigration Act 2011, section 9 ; Swaziland Constitution 2005, Article 47, Citizenship Act 1992 section 17 ; Uganda Constitution 1995, Article 11; Constitution of Zimbabwe 2013, Chapter 3 (sections 35 to 43).

35 See resources at the International IDEA ConstitutionNet website: http://www. constitutionnet.org/country/tanzania-country-constitutional-profile, last accessed 27 January 2015. 
Some sixteen countries do not have a provision relating to foundlings or children of unknown parents, an omission of particular importance in countries currently or previously affected by conflict: Botswana, Côte d'Ivoire, Equatorial Guinea, Gambia, Lesotho, Liberia, Malawi, Mauritius, Namibia, Nigeria, Seychelles, Sierra Leone, Somalia ${ }^{36}$, South Africa, Tanzania, Togo, and Zambia.

Table 2: The right to a nationality based on birth in the country

\begin{tabular}{|c|c|c|c|c|c|c|c|}
\hline Country & $\begin{array}{c}\text { Birth } \\
\text { in } \\
\text { country }\end{array}$ & $\begin{array}{l}\text { Birth and } \\
\text { one } \\
\text { parent } \\
\text { also born }\end{array}$ & $\begin{array}{l}\text { Birth and } \\
\text { resident } \\
\text { at } \\
\text { majority }\end{array}$ & $\begin{array}{c}\text { Child } \\
\text { other- } \\
\text { wise } \\
\text { stateless }\end{array}$ & $\begin{array}{c}\text { Parents } \\
\text { stateless (s) } \\
\text { or } \\
\text { unknown (u) }\end{array}$ & $\begin{array}{c}\text { Found- } \\
\text { lings }\end{array}$ & $\begin{array}{c}\text { Relevant legal provision } \\
\text { (most recent amendment in } \\
\text { brackets) }\end{array}$ \\
\hline Algeria & & $\mathrm{JS} / 2^{\wedge} \sim$ & & & $\mathrm{u}$ & $\mathrm{x}$ & L1970(2005)Art7 \& Art32 \\
\hline Angola & & & & os & $\mathrm{s}+\mathrm{u}$ & $\mathrm{x}$ & $\begin{array}{c}\text { C2010Art9 } \\
\text { L2005Arts9\&14 }\end{array}$ \\
\hline Benin a & & $\mathrm{JS} / 2$ & $(\mathrm{JS}+)(\mathrm{JS})$ & & $\mathrm{s}+\mathrm{u}$ & $\mathrm{x}$ & L1965Arts7-11,24-32 \\
\hline Botswana & & & & & & & L1998(2004)Art4 \\
\hline Burkina Faso & & $\mathrm{JS} / 2$ & $(\mathrm{JS}+)$ & os & $\mathrm{u}$ & $\mathrm{x}$ & L1989Arts141-144 \& 155-161 \\
\hline Burundi & & & & & $\mathrm{u}$ & $\mathrm{x}$ & L2000Art3 \\
\hline Cameroon & & $\mathrm{JS} / 2$ & (JS) & os & $\mathrm{u}$ & $\mathrm{x}$ & L1968Arts9-12\&20 \\
\hline Cape Verde & $\mathrm{JS}^{\star}$ & & & os & $\mathrm{s}+\mathrm{u}$ & & L1993Arts1,3,4,6 \\
\hline CAR & & & (JS) & & $\mathrm{u}$ & & L1961Arts6-7,10, 18-20 \\
\hline Chad & JS & & & os & $\mathrm{u}$ & & L1962Arts11-13 \\
\hline Comoros & & & (JS) & & & $\mathrm{x}$ & L1979Arts10,13,20-26 \\
\hline Congo Rep. & & $\mathrm{JS} / 2$ & $(\mathrm{JS}+)$ & & $\mathrm{u}$ & $\mathrm{x}$ & L1961(1993)Arts8-10\&20 \\
\hline Côte d'Ivoire & & & & & & & L1961(2013)Art6 \\
\hline DRC & & & (JS) & & $s+u$ & $\mathrm{x}$ & $\begin{array}{c}\text { C2005Art10 } \\
\text { L2004Arts6,8,9,21 }\end{array}$ \\
\hline Djibouti & & & & & $\mathrm{u}$ & & L2004Art6 \\
\hline Egypt & & & & & $\mathrm{u}$ & $\mathrm{x}$ & L1975(2004)Art2 \\
\hline Eq. Guinea & & & (JS) & & & & L1990Arts2-3 \\
\hline Eritrea & & & & & $\mathrm{u}$ & & L1992Art2 \\
\hline Ethiopia & & & & & & $\mathrm{x}$ & L2003Art3 \\
\hline Gabon & & $\mathrm{JS} / 2$ & $(\mathrm{JS})$ & & $\mathrm{s}+\mathrm{u}$ & $\mathrm{x}$ & L1998Arts11-12\&14 \\
\hline Gambia & & & & & & & C1996(2001) \\
\hline Ghana & & & & & $\mathrm{u}$ & $\mathrm{x}$ & $\begin{array}{l}\text { C1992(2001)Art6 } \\
\text { L2000Art8 }\end{array}$ \\
\hline Guinea & & $\mathrm{JS} / 2$ & $(\mathrm{JS}+)(\mathrm{JS})$ & & $\mathrm{u}$ & $\mathrm{x}$ & L1983Arts34-37,56, 62 \\
\hline G. Bissau & & & & os & $\mathrm{s}+\mathrm{u}$ & $\mathrm{x}$ & L1992(2010)Art5 \\
\hline Kenya & & & & & $\mathrm{u}$ & $\mathrm{x}$ & $\begin{array}{l}\text { C2010Art14(4) } \\
\text { L2011Art9 }\end{array}$ \\
\hline Lesotho & JS & & & os & & & C1993Art38 \\
\hline Liberia !! b & $\mathrm{JS} \sim$ & & & & & & $\begin{array}{l}\text { C1986Art27 } \\
\text { L1973Art20.1 }\end{array}$ \\
\hline Libya & & & & & $\mathrm{u}$ & & L2010Art3 \\
\hline
\end{tabular}

36 The version of the Somali Citizenship Law No.28 of 22 December 1962 available on the REFWORLD website is missing articles 14-16. I believe Article 15 may contain a foundling provision, but have not been able to trace a copy of the full text. 


\begin{tabular}{|c|c|c|c|c|c|c|c|}
\hline Country & $\begin{array}{c}\text { Birth } \\
\text { in } \\
\text { country }\end{array}$ & $\begin{array}{l}\text { Birth and } \\
\text { one } \\
\text { parent } \\
\text { also born }\end{array}$ & $\begin{array}{c}\text { Birth and } \\
\text { resident } \\
\text { at } \\
\text { majority }\end{array}$ & $\begin{array}{c}\text { Child } \\
\text { other- } \\
\text { wise } \\
\text { stateless }\end{array}$ & $\begin{array}{c}\text { Parents } \\
\text { stateless (s) } \\
\text { or } \\
\text { unknown (u) }\end{array}$ & $\begin{array}{c}\text { Found- } \\
\text { lings }\end{array}$ & $\begin{array}{c}\text { Relevant legal provision } \\
\text { (most recent amendment in } \\
\text { brackets) }\end{array}$ \\
\hline Madagascar & & & & & $\mathrm{u}$ & $\mathrm{x}$ & L1960Art11 \\
\hline Malawi & & & & (os) & & & L1966(1992)Art18 \\
\hline Mali & & $\mathrm{JS} / 2 \sim$ & (JS) & & $\mathrm{u}$ & $\mathrm{x}$ & L2011Arts225-227\&237 \\
\hline Mauritania & & & & & & $\mathrm{x}$ & L1961(2010)Art10 \\
\hline Mauritius & & & & & & & C1968(1995)Art22 \\
\hline Morocco $\mathrm{c}$ & & $(\mathrm{JS} / 2 \times 2 \sim)$ & & & $\mathrm{u}$ & $\mathrm{x}$ & L1958(2007)Arts7\&9 \\
\hline Mozambique & JS & $\mathrm{JS} / 2$ & (JS) & & $s+u$ & & $\begin{array}{l}\text { C2004Art23-25 } \\
\text { L1975(1987)Art2 }\end{array}$ \\
\hline Namibia & JS* & & & os & & & C1990(2010)Art4(1)(d) \\
\hline Niger & & $\mathrm{JS} / 2$ & & & $\mathrm{u}$ & $\mathrm{x}$ & L1984(2014)Arts8-10 \\
\hline Nigeria & & & & & & & - \\
\hline Rwanda & & & (JS) & & $\mathrm{s}+\mathrm{u}$ & $\mathrm{x}$ & L2008Arts8-9 \\
\hline SADR & $\mathrm{n} / \mathrm{a}$ & & & & & & $\mathrm{n} / \mathrm{a}$ \\
\hline STP & $\mathrm{JS}^{\star}$ & & & os & $\mathrm{s}$ & $\mathrm{x}$ & L1990Art5 \\
\hline Senegal & & $\mathrm{JS} / 2$ & & & & $\mathrm{x}$ & L1961(2013)Arts1\&3 \\
\hline Seychelles & & & & & & & C1993(2011)Arts8\&9 \\
\hline S. Leone & & $\mathrm{JS} / 2^{\wedge} \sim$ & & & & & L1973(2006)Arts2-3 \\
\hline Somalia & JS & & & & & & L1962Art3 \\
\hline South Africa & & & (JS) & os & & & $\begin{array}{c}\text { C1996Art28(1)(a) L1995(2010) } \\
\text { ts2(2), 2(3)\&4(3) }\end{array}$ \\
\hline South Sudan & & $\mathrm{JS} / 2^{\wedge} \sim$ & & & & $\mathrm{x}$ & L2011Art8 \\
\hline Sudan & & & & & & $\mathrm{x}$ & L1994(2011)Arts4\&5 \\
\hline Swaziland & & & & & & $\mathrm{x}$ & C2005Art47 / L1992Art17 \\
\hline Tanzania & JS & & & & & & L1995Art5 \\
\hline Togo !! & & $\mathrm{JS} / 2 \mathrm{x} 2$ & (JS) & os & & & L1978Arts1,2\&8 \\
\hline Tunisia & & $\mathrm{JS} / 2^{\wedge}$ & & & $s+u$ & $\mathrm{x}$ & L1963(2010)Arts7-10 \\
\hline Uganda & JS & & & & & $\mathrm{x}$ & $\begin{array}{l}\text { C1995(2005)Arts10-11 } \\
\text { L1999(2009)Art12-14 }\end{array}$ \\
\hline Zambia & & & & & & & C1991(2009)Art5 \\
\hline Zimbabwe & & & & & & $\mathrm{x}$ & C2013Art36(3) \\
\hline
\end{tabular}

\section{n/a: not available}

!! legislation conflicts with the constitution (or, in Togo, with other legislation)

JS: jus soli attribution: a child born in the country is a citizen (with exclusions for children of diplomats \& some other categories)

JS ${ }^{\star}$ : child born in country of parents who are legal residents is a citizen

(JS): child born in country of non-citizens is eligible to apply for citizenship at majority and/or after residence period

(JS+): child born in country of non-citizens is automatically attributed citizenship at majority and/or after residence period

JS/2: double jus soli attribution: child born in country of one parent also born in the country is a citizen

$\mathrm{JS} / 2 \times 2$ : child born in country of both parents also born there is a citizen

(JS/2): child born in the country of a parent also born there has the right to opt for nationality

$\sim$ racial, ethnic or religious discrimination in law impacts on jus soli rights (in Algeria, ascendants must be of Muslim religion; in Egypt only applies to father, who must be of Egyptian origin or from a Muslim or Arab country ; in Liberia jus soli applies only to "negroes'; in Mali, the parent born in the country must be "of African origin"; in Morocco there is preferential treatment if the father is a Muslim or Arab; in Somalia, the jus soli right only applies to those of "Somali origin"; in Liberia and Sierra Leone parent or grandparent must be "negro" or of "negro-African descent"; in Uganda, the jus soli provision applies only to those who are members of one of "indigenous communities".

$\wedge$ Rights to citizenship from grandparents: in Algeria a parent and grandparent must both be born in Algeria; in Tunisia it applies only if both father and grandfather born in Tunisia ; in South Sudan a person born in or outside of South Sudan is South Sudanese if any parent, grandparent or great-grandparent was born in South Sudan or is or was a member of one of the indigenous ethnic groups of South Sudan; in Sierra Leone either a parent or a grandparent should be born in the country.

(os): grant to otherwise stateless child is discretionary

a : in Benin - child of mother born in country has right to renounce at majority; otherwise stateless mentioned - but then specified to be in case of unknown or stateless parents

b: Liberia's jus soli provision is contained in the law and not repeated in (but not repealed by) the constitution

c: Morocco's double jus soli rules are complex and do not result in automatic attribution of nationality: a person born in the country may acquire nationality by declaration at majority (unless the minister of justice opposes) if both parents were also born there after the 2007 amendment to the law came into effect, or if the father was also born there and is a Muslim or Arab and comes from a country where Muslims / Arabs are the majority.

Countries indicated in bold have particularly weak legal protections against statelessness 


\subsubsection{Children of citizens}

A substantial majority of African countries provide for a child born in the country of one parent who is a national, whether that parent is the father or mother, and whether or not the child is born in or out of wedlock; and most of these extend this right to those born outside the country too. (See Table 3: Right to citizenship by descent). Some countries, including Cape Verde, Ghana, Nigeria, Uganda and Zimbabwe, provide citizenship if one grandparent is a citizen, with variants depending on whether the person was born in or outside the country.

A significant number of countries, however, still discriminate by giving only a citizen father the unequivocal right to pass citizenship to his child; and some of those countries that do not discriminate between the parents if a child is born in the country still allow only a father to pass on citizenship to a child born outside of the country. In total, at least a dozen countries still discriminate on the grounds of gender in granting citizenship rights to children who are either born in their country or born overseas (including Benin, Burundi, Guinea, Liberia, Libya, Madagascar, Mauritania, Sierra Leone, Somalia, Sudan, Swaziland and Togo. See chapter 5.2.1 and Table 3-which, however, does not reflect absolutely all provisions that discriminate by gender). In several of these countries, the child of a citizen mother and noncitizen father born in the country can claim citizenship, but does not have citizenship automatically as of right; thus, the law is discriminatory in individual provisions relating to citizenship from birth, but the total effect of all the provisions is to allow both sexes to pass citizenship to their children. Sometimes, for example in Benin, the discrimination appears only in provisions allowing for the child of a citizen mother to repudiate nationality at majority, but if no action is taken he or she will have citizenship. ${ }^{37}$ In the case of the Congo Republic, provisions permitting repudiation apply to any child with one parent who is a foreigner not born in Congo. ${ }^{38}$ In Mali, 2011 reforms created the same situation for a child of one Malian parent (previously only for the mother) if the other is a foreigner: only if both parents are nationals or the other parent is unknown or stateless does this not apply. ${ }^{39}$

Only a few countries still discriminate on the basis of whether a child is born in or out of wedlock, requiring additional procedures to establish descent: Benin, Burundi, Cameroon, Côte d'Ivoire, Gabon, Guinea, Libya, Madagascar, Mali, Niger, Somalia, Sudan, Swaziland, and Togo. For example, in provisions that are typical, in Madagascar transmission of citizenship to a child born in wedlock is

37 See Loi No.95-70 du 25 aout 1995 portant modification du code de la nationalité malienne, Art 8-5 (Nouveau) ; Loi N 65-17 du 23 juin 1965 portant code de la nationalité béninoise, Arts. 8, 12, 13 and 18. In September 2014, the Benin Constitutional Court ruled these discriminatory articles in the nationality code to be unconstitutional: Décision DCC 14-172, Benin: Cour Constitutionnelle, 16 September 2014.

38 Code de la nationalité congolaise, 1961, Arts 7-9. (Some details are not captured in the tables).

39 Code des personnes et de la famille, article 224. 
restricted to the father, however, a child born in wedlock of a Malagasy mother may claim Malagasy nationality up to the age of majority (21 years), and a child born out of wedlock takes the nationality of the mother, or may claim nationality of the father if descent is established. ${ }^{40}$ In the case of Swaziland, the child of a Swazi father born in the country is a Swazi national, whether born in or out of wedlock. The child of a Swazi mother and a non-national father has no right to Swazi nationality if the parents were married; if born out of wedlock and not recognised by the father, the child is a national by birth. ${ }^{41}$

Racial or ethnic discrimination in relation to citizenship by descent is present in the laws of half a dozen countries (see above, chapter 5.4).

Table 3: Right to nationality by descent

\begin{tabular}{|c|c|c|c|c|c|c|c|c|c|c|}
\hline \multirow[t]{3}{*}{ Country } & \multicolumn{4}{|c|}{ Born in country } & \multicolumn{4}{|c|}{ Born abroad } & \multirow{3}{*}{ Legal Provision } & \multirow{3}{*}{$\begin{array}{c}\text { Date } \\
\text { Gender } \\
\text { equality } \\
\text { achieved }\end{array}$} \\
\hline & \multicolumn{2}{|c|}{\begin{tabular}{|l|} 
In wedlock \\
\\
+ Father (F) \\
\&/or \\
Mother (M) \\
is a national \\
\end{tabular}} & \multicolumn{2}{|c|}{$\begin{array}{l}\begin{array}{l}\text { Out of } \\
\text { wedlock }\end{array} \\
\text { + Father (F) } \\
\text { \&/or } \\
\text { Mother (M) } \\
\text { is a national } \\
\end{array}$} & \multicolumn{2}{|c|}{$\begin{array}{l}\text { In wedlock } \\
+ \text { Father (F) } \\
\text { \&/or } \\
\text { Mother (M) } \\
\text { is a national }\end{array}$} & \multicolumn{2}{|c|}{$\begin{array}{l}\text { Out of } \\
\text { wedlock } \\
+ \text { Father (F) } \\
\text { \&/or } \\
\text { Mother (M) } \\
\text { is a national }\end{array}$} & & \\
\hline & F & $\mathbf{M}$ & $\mathbf{F}$ & $\mathbf{M}$ & F & $\mathbf{M}$ & $\mathbf{F}$ & $\mathbf{M}$ & & \\
\hline Algeria & $\mathrm{R}$ & $\mathrm{R}$ & $\mathrm{R}$ & $\mathrm{R}$ & $\mathrm{R}$ & $\mathrm{R}$ & $\mathrm{R}$ & $\mathrm{R}$ & L1970(2005)Art6 & 2005 \\
\hline Angola & $\mathrm{R}$ & $\mathrm{R}$ & $\mathrm{R}$ & $\mathrm{R}$ & $\mathrm{R}$ & $\mathrm{R}$ & $\mathrm{R}$ & $\mathrm{R}$ & $\begin{array}{l}\text { C2010Art9 } \\
\text { L2005Art9 }\end{array}$ & 1975 \\
\hline Benin & $\mathrm{R}$ & $\mathrm{R}$ & $\mathrm{R}$ & $\mathrm{R}$ & $\mathrm{R}$ & $\mathrm{R} \dagger$ & $\mathrm{R}$ & $\mathrm{R} \dagger$ & L1965Arts12\&13 & - \\
\hline Botswana & $\mathrm{R}$ & $\mathrm{R}$ & $\mathrm{R}$ & $\mathrm{R}$ & $\mathrm{R}$ & $\mathrm{R}$ & $\mathrm{R}$ & $\mathrm{R}$ & L1998(2002\&04)Arts4\&5 & 1995 \\
\hline Burkina Faso & $\mathrm{R}$ & $\mathrm{R}$ & $\mathrm{R}$ & $\mathrm{R}$ & $\mathrm{R} \dagger$ & $\mathrm{R} \dagger$ & $\mathrm{R} \dagger$ & $\mathrm{R} \dagger$ & L1989Art140 & $1989 ?$ \\
\hline Burundi !! & $\mathrm{R}$ & $C^{\star}$ & $\mathrm{C}$ & $C^{\star}$ & $\mathrm{R}$ & $C^{\star} \star$ & $\mathrm{C}$ & $\mathrm{C}^{\star}$ & $\begin{array}{l}\text { C2005Art12 } \\
\text { L2000Art2 }\end{array}$ & - \\
\hline Cameroon & $\mathrm{R}$ & $\mathrm{R}$ & $\mathrm{C}$ & $\mathrm{C}$ & $\mathrm{R}$ & $\mathrm{R}$ & $\mathrm{C} \dagger$ & $(\mathrm{C} \dagger$ & L1968Arts6-8 & - \\
\hline Cape Verde & $\mathrm{R}$ & $\mathrm{R}$ & $\mathrm{R}$ & $\mathrm{R}$ & $\mathrm{C}^{\wedge}$ & $\mathrm{C}^{\wedge}$ & $\mathrm{C}^{\wedge}$ & $\mathrm{C}^{\wedge}$ & L1993Arts1,5 & 1976 \\
\hline CAR & $\mathrm{R}$ & $\mathrm{R}$ & $\mathrm{R}$ & $\mathrm{R}$ & $\mathrm{R}$ & $\mathrm{R}$ & $\mathrm{R}$ & $\mathrm{R}$ & L1961Arts6-8 & 1961 \\
\hline Chad & $\mathrm{R}$ & $\mathrm{R}$ & $\mathrm{R}$ & $\mathrm{R}$ & $\mathrm{R} \dagger$ & $\mathrm{R} \dagger$ & $\mathrm{R} \dagger$ & $\mathrm{R} \dagger$ & L1962Arts9-10 & 1962 \\
\hline Comoros & $\mathrm{R}$ & $\mathrm{R}$ & $\mathrm{R}$ & $\mathrm{R}$ & $\mathrm{R}$ & $\mathrm{R}$ & $\mathrm{R}$ & $\mathrm{R}$ & L1979Arts10-13 & $1979 ?$ \\
\hline Congo Rep. & $\mathrm{R}$ & $\mathrm{R}$ & $\mathrm{R}$ & $\mathrm{R}$ & $\mathrm{R}$ & $\mathrm{R}$ & $\mathrm{R}$ & $\mathrm{R}$ & L1961(1993)Arts7-9 & 1961 \\
\hline Côte d'Ivoire & $\mathrm{R}$ & $\mathrm{R}$ & $\mathrm{R}$ & $\mathrm{R}$ & $\mathrm{R}$ & $\mathrm{R}$ & $\mathrm{C}$ & $\mathrm{C}$ & L1961(2013)Art7 & - \\
\hline DRCongo & $\mathrm{R}$ & $\mathrm{R}$ & $\mathrm{R}$ & $\mathrm{R}$ & $\mathrm{R}$ & $\mathrm{R}$ & $\mathrm{R}$ & $\mathrm{R}$ & $\begin{array}{c}\text { C2005Art10 } \\
\text { L2004Art4,6,7 }\end{array}$ & $2004 ?$ \\
\hline
\end{tabular}

40 Ordonnance no. 1960-064 portant Code de la nationalité malgache (amended by loi no. 1961-052 ; loi no.1962-005 ; ordonnance no.1973-049 ; and loi no.1995-021), section 16. Committee on the Rights of the Child, Consideration of reports submitted by States parties pursuant to article 44 of the convention, Initial reports of States parties due in 1993, Madagascar, CRC/C/8/Add.5, 13 September 1993, p. 92.

41 Constitution of the Kingdom of Swaziland, 2005, article 43; Citizenship and Immigration Act No.14 of 1992 sections 6 and 7 (prior to 1992 either parent could pass nationality). Other countries in Africa that discriminate in this way include Benin, Burundi, Guinea, Liberia, Libya, Madagascar, Mali, Mauritania, Senegal, Sierra Leone, Somalia, Sudan, Togo, and Tunisia. 


\begin{tabular}{|c|c|c|c|c|c|c|c|c|c|c|}
\hline \multirow[t]{3}{*}{ L2004Art4,6,7 } & \multicolumn{4}{|c|}{$2004 ?$} & \multicolumn{4}{|c|}{ Born abroad } & \multirow{3}{*}{ Legal Provision } & \multirow{3}{*}{$\begin{array}{c}\text { Date } \\
\text { Gender } \\
\text { equality } \\
\text { achieved }\end{array}$} \\
\hline & \multicolumn{2}{|c|}{$\begin{array}{l}\text { In wedlock } \\
\text { + Father (F) } \\
\text { \&/or } \\
\text { Mother }(\mathrm{M}) \\
\text { is a national }\end{array}$} & \multicolumn{2}{|c|}{$\begin{array}{l}\begin{array}{l}\text { Out of } \\
\text { wedlock }\end{array} \\
+ \text { Father (F) } \\
\text { \&/or } \\
\text { Mother (M) } \\
\text { is a national }\end{array}$} & \multicolumn{2}{|c|}{$\begin{array}{l}\text { In wedlock } \\
\text { + Father (F) } \\
\text { \&/or } \\
\text { Mother (M) } \\
\text { is a national }\end{array}$} & \multicolumn{2}{|c|}{$\begin{array}{l}\text { Out of } \\
\text { wedlock } \\
+ \text { Father (F) } \\
\text { \&/or } \\
\text { Mother (M) } \\
\text { is a national }\end{array}$} & & \\
\hline & $F$ & $\mathbf{M}$ & $F$ & $\mathbf{M}$ & $\mathbf{F}$ & $\mathbf{M}$ & F & $\mathbf{M}$ & & \\
\hline Djibouti & $\mathrm{R}$ & $\mathrm{R}$ & $\mathrm{R}$ & $\mathrm{R}$ & $\mathrm{R}$ & $\mathrm{R}$ & $\mathrm{R}$ & $\mathrm{R}$ & L2004Art4,5 & 1981? \\
\hline Egypt & $\mathrm{R}$ & $\mathrm{R}$ & $\mathrm{R}$ & $\mathrm{R}$ & $\mathrm{R}$ & $\mathrm{R}$ & $\mathrm{R}$ & $\mathrm{R}$ & $\begin{array}{c}\text { C2014 Art6 } \\
\text { L1975(2004)Art2 }\end{array}$ & 2004 \\
\hline Eq. Guinea & $\mathrm{R}$ & $\mathrm{R}$ & $R$ & $\mathrm{R}$ & $\mathrm{R}$ & $\mathrm{R}$ & $\mathrm{R}$ & $\mathrm{R}$ & L1990Art2 & $1990 ?$ \\
\hline Eritrea & $\mathrm{R}$ & $\mathrm{R}$ & $\mathrm{R}$ & $\mathrm{R}$ & $\mathrm{R}$ & $\mathrm{R}$ & $\mathrm{R}$ & $\mathrm{R}$ & $\begin{array}{l}\text { C1997Art3 } \\
\text { L1992Art2 }\end{array}$ & 1992 \\
\hline Ethiopia & $\mathrm{R}$ & $\mathrm{R}$ & $\mathrm{R}$ & $\mathrm{R}$ & $\mathrm{R}$ & $\mathrm{R}$ & $\mathrm{R}$ & $\mathrm{R}$ & $\begin{array}{l}\text { C1994 Art6 } \\
\text { L2003Art3 }\end{array}$ & 2003 \\
\hline Gabon & $\mathrm{R}$ & $\mathrm{R}$ & $\mathrm{R}$ & $\mathrm{R}$ & $\mathrm{R}$ & $\mathrm{R}$ & $\mathrm{C}$ & $\mathrm{C}$ & L1998Arts11\&13 & - \\
\hline Gambia & $\mathrm{R}$ & $\mathrm{R}$ & $\mathrm{R}$ & $\mathrm{R}$ & $\mathrm{Rx} 1$ & $\mathrm{Rx} 1$ & $\mathrm{R} \times 1$ & $\mathrm{Rx} 1$ & C1996(2001)Arts9-10 & 1996 \\
\hline Ghana & $\mathrm{R}^{\wedge}$ & $\mathrm{R}^{\wedge}$ & $\mathrm{R}^{\wedge}$ & $\mathrm{R}^{\wedge}$ & $\mathrm{R}^{\wedge}$ & $\mathrm{R}^{\wedge}$ & $\mathrm{R}^{\wedge}$ & $\mathrm{R}^{\wedge}$ & $\begin{array}{l}\text { C1992Art6(2) } \\
\text { L2000Art7 }\end{array}$ & 1969 \\
\hline Guinea & $\mathrm{R}$ & $\mathrm{R}$ & $\mathrm{C}$ & $\mathrm{C}$ & $\mathrm{R}$ & $\mathrm{R} \dagger$ & $\mathrm{C} \dagger$ & $\mathrm{C} \dagger$ & L1983Art30-32 & - \\
\hline G, Bissau & $\mathrm{R}$ & $\mathrm{R}$ & $\mathrm{R}$ & $\mathrm{R}$ & $\mathrm{C}$ & $\mathrm{C}$ & $\mathrm{C}$ & $\mathrm{C}$ & L1992(2010)Art5 & $1975 ?$ \\
\hline Kenya & $\mathrm{R}$ & $\mathrm{R}$ & $\mathrm{R}$ & $\mathrm{R}$ & $\mathrm{R}$ & $\mathrm{R}$ & $\mathrm{R}$ & $\mathrm{R}$ & $\begin{array}{l}\text { C2010Art14 } \\
\text { L2011Arts6-7 } \\
\end{array}$ & 2010 \\
\hline Lesotho & $\mathrm{R}$ & $\mathrm{R}$ & $\mathrm{R}$ & $\mathrm{R}$ & $\mathrm{Rx} 1$ & $\mathrm{Rx} 1$ & $\mathrm{Rx} 1$ & $\mathrm{Rx} 1$ & C1993Arts38\&39 & 1993 \\
\hline Liberia !! & $\mathrm{R}$ & $\mathrm{R}$ & $\mathrm{R}$ & $\mathrm{R}$ & $\mathrm{C}$ & - & $\mathrm{C}$ & - & $\begin{array}{c}\text { C1984 Arts27-28 } \\
\text { L1973Arts20.1 \& } 21.31 \\
\end{array}$ & - \\
\hline Libya & $\mathrm{R}$ & $C^{\star}$ & $\mathrm{R}$ & $\mathrm{C}^{\star}$ & $\mathrm{C}$ & - & $\mathrm{C}$ & - & L2010Arts3\&11 & - \\
\hline Madagascar & $\mathrm{R}$ & $\mathrm{C}^{\star}$ & $\mathrm{C}^{\star}$ & $\mathrm{R}$ & $\mathrm{R}$ & $\mathrm{C}^{\star}$ & $C^{\star}$ & $\mathrm{R}$ & L1960Arts9\&16 & - \\
\hline Malawi & $\mathrm{R}$ & $\mathrm{R}$ & $\mathrm{R}$ & $\mathrm{R}$ & $\mathrm{Rx} 1$ & $\mathrm{Rx} 1$ & $\mathrm{Rx} 1$ & $\mathrm{Rx} 1$ & L1966(1992)Arts4\&5 & $1966 ?$ \\
\hline Mali & $\mathrm{R} \dagger$ & $\mathrm{R} \dagger$ & $\mathrm{C} \dagger$ & $\mathrm{C} \dagger$ & $\mathrm{R} \dagger$ & $\mathrm{R} \dagger$ & $\mathrm{C} \dagger$ & $\mathrm{C} \dagger$ & L2011Art224 & 2011 \\
\hline Mauritania & $\mathrm{R}$ & $\mathrm{R} \dagger$ & $\mathrm{R}$ & $\mathrm{R} \dagger$ & $\mathrm{R}$ & $C^{\star} \star$ & $\mathrm{R}$ & $\mathrm{C}^{\star}$ & L1961(2010)Arts8\&13 & - \\
\hline Mauritius & $\mathrm{R}$ & $\mathrm{R}$ & $\mathrm{R}$ & $\mathrm{R}$ & $\mathrm{Rx} 1$ & $\mathrm{Rx} 1$ & $\mathrm{R} \times 1$ & $\mathrm{Rx} 1$ & C1968(1995)Art22\&23 & 1995 \\
\hline Morocco & $\mathrm{R}$ & $\mathrm{R}$ & $\mathrm{R}$ & $\mathrm{R}$ & $\mathrm{R}$ & $\mathrm{R}$ & $\mathrm{R}$ & $\mathrm{R}$ & L1958(2007)Art6 & 2007 \\
\hline Mozambique !! & $\mathrm{R}$ & $\mathrm{R}$ & $\mathrm{R}$ & $\mathrm{R}$ & $\mathrm{C}$ & $\mathrm{C}$ & $\mathrm{C}$ & $\mathrm{C}$ & $\begin{array}{l}\text { C2004Art23\&24 } \\
\text { L1975(1987)Art1 }\end{array}$ & 1975 \\
\hline Namibia & $\mathrm{R}$ & $\mathrm{R}$ & $\mathrm{R}$ & $\mathrm{R}$ & $\mathrm{C}$ & $\mathrm{C}$ & $\mathrm{C}$ & $\mathrm{C}$ & $\begin{array}{c}\text { C1990(2010)Art4(1)(c)\&(2) } \\
\text { L1990Art2 } \\
\end{array}$ & 1990 \\
\hline Niger & $\mathrm{R}$ & $\mathrm{R}$ & $\mathrm{C}$ & $\mathrm{C}$ & $\mathrm{R}$ & $\mathrm{R}$ & $\mathrm{C}$ & $\mathrm{C}$ & L1984(2014)Art11 & 1999 \\
\hline Nigeria & $\mathrm{R}^{\wedge}$ & $\mathrm{R}^{\wedge}$ & $\mathrm{R}^{\wedge}$ & $\mathrm{R}^{\wedge}$ & $\mathrm{R}$ & $\mathrm{R}$ & $\mathrm{R}$ & $\mathrm{R}$ & C1999Art25 & 1999 \\
\hline Rwanda & $\mathrm{R}$ & $\mathrm{R}$ & $\mathrm{R}$ & $\mathrm{R}$ & $\mathrm{R}$ & $\mathrm{R}$ & $\mathrm{R}$ & $\mathrm{R}$ & L2008Art6 & 2004 \\
\hline SADR & $\mathrm{n} / \mathrm{a}$ & & & & & & & & & - \\
\hline STP & $\mathrm{R}$ & $\mathrm{R}$ & $\mathrm{R}$ & $\mathrm{R}$ & $\mathrm{C}$ & $\mathrm{C}$ & $\mathrm{C}$ & $\mathrm{C}$ & $\begin{array}{l}\text { C2003Art3 } \\
\text { L1990Art5 }\end{array}$ & 1975 \\
\hline Senegal & $\mathrm{R}$ & $\mathrm{R}$ & $\mathrm{R}$ & $\mathrm{R}$ & $\mathrm{R}$ & $\mathrm{R}$ & $\mathrm{R}$ & $\mathrm{R}$ & L1961(2013)Art5 & 2013 \\
\hline Seychelles & $\mathrm{R}$ & $\mathrm{R}$ & $\mathrm{R}$ & $\mathrm{R}$ & $\mathrm{R}$ & $\mathrm{R}$ & $\mathrm{R}$ & $\mathrm{R}$ & C1993(2011)Art11 & $1979 ?$ \\
\hline Sierra Leone $\sim \mathrm{a}$ & - & - & - & - & $\mathrm{R}$ & - & $\mathrm{R}$ & - & L1973(2006)Art5 & 2006 \\
\hline Somalia !! & $\mathrm{R}$ & - & $\mathrm{R}$ & - & $\mathrm{R}$ & - & $\mathrm{R}$ & - & L1962Art2 & - \\
\hline South Africa & $\mathrm{R}$ & $\mathrm{R}$ & $\mathrm{R}$ & $\mathrm{R}$ & $\mathrm{R}$ & $\mathrm{R}$ & $\mathrm{R}$ & $\mathrm{R}$ & L1995(2010)Art2(1) & 1995 \\
\hline South Sudan & $\mathrm{R}$ & $\mathrm{R}$ & $\mathrm{R}$ & $\mathrm{R}$ & $\mathrm{R}$ & $\mathrm{R}$ & $\mathrm{R}$ & $\mathrm{R}$ & $\begin{array}{l}\text { C2011Art45(1) } \\
\text { L2011Art8(3) }\end{array}$ & 2011 \\
\hline Sudan !! & $\mathrm{R}$ & $\mathrm{C}$ & $\mathrm{R}$ & $\mathrm{C}$ & $\mathrm{R}$ & $\mathrm{C}$ & $\mathrm{R}$ & $\mathrm{C}$ & $\begin{array}{c}\text { C2005Art7 } \\
\text { L1994(2011)Art4 }\end{array}$ & - \\
\hline Swaziland !! & $\mathrm{R}$ & - & $\mathrm{R}$ & $\mathrm{C}^{\star}$ & $\mathrm{Rx} 1$ & - & $\mathrm{Rx} 1$ & $C^{\star}$ & $\begin{array}{l}\text { C2005Art42-43 } \\
\text { L1992Art7 }\end{array}$ & - \\
\hline
\end{tabular}




\begin{tabular}{|c|c|c|c|c|c|c|c|c|c|c|}
\hline \multirow[t]{3}{*}{ L1992Art7 } & \multicolumn{4}{|l|}{-} & \multicolumn{4}{|c|}{ Born abroad } & \multirow{3}{*}{ Legal Provision } & \multirow{3}{*}{$\begin{array}{c}\text { Date } \\
\text { Gender } \\
\text { equality } \\
\text { achieved }\end{array}$} \\
\hline & \multicolumn{2}{|c|}{\begin{tabular}{|l} 
In wedlock \\
\\
+ Father $(\mathrm{F})$ \\
\&/or \\
Mother $(\mathrm{M})$ \\
is a national
\end{tabular}} & \multicolumn{2}{|c|}{$\begin{array}{l}\begin{array}{l}\text { Out of } \\
\text { wedlock }\end{array} \\
\text { + Father (F) } \\
\text { \&/or } \\
\text { Mother (M) } \\
\text { is a national }\end{array}$} & \multicolumn{2}{|c|}{$\begin{array}{l}\text { In wedlock } \\
\text { + Father }(\mathrm{F}) \\
\text { \&/or } \\
\text { Mother }(\mathrm{M}) \\
\text { is a national }\end{array}$} & \multicolumn{2}{|c|}{$\begin{array}{l}\begin{array}{l}\text { Out of } \\
\text { wedlock }\end{array} \\
+ \text { Father (F) } \\
\text { \&/or } \\
\text { Mother (M) } \\
\text { is a national }\end{array}$} & & \\
\hline & $F$ & $\mathbf{M}$ & $F$ & $\mathbf{M}$ & $F$ & M & $F$ & $\mathbf{M}$ & & \\
\hline Tanzania & $\mathrm{R}$ & $\mathrm{R}$ & $\mathrm{R}$ & $\mathrm{R}$ & $\mathrm{Rx} 1$ & $\mathrm{Rx} 1$ & $\mathrm{Rx} 1$ & $\mathrm{Rx} 1$ & L1995Arts5\&6 & $1995 ?$ \\
\hline Togo !! & $\mathrm{R}$ & $C^{\star}$ & $\mathrm{R}$ & $C^{\star} \star$ & $\mathrm{R}$ & $C^{\star}$ & $\mathrm{R}$ & $C^{\star}$ & $\begin{array}{l}\text { C1992Art32 } \\
\text { L1978Art3 }\end{array}$ & - \\
\hline Tunisia & $\mathrm{R}$ & $\mathrm{R}$ & $\mathrm{R}$ & $\mathrm{R}$ & $\mathrm{R}$ & $\mathrm{R}$ & $\mathrm{R}$ & $\mathrm{R}$ & L1963(2010)Art6 & 2010 \\
\hline Uganda & $\mathrm{R}^{\wedge}$ & $\mathrm{R}^{\wedge}$ & $\mathrm{R}^{\wedge}$ & $\mathrm{R}^{\wedge}$ & $\mathrm{R}^{\wedge}$ & $\mathrm{R}^{\wedge}$ & $\mathrm{R}^{\wedge}$ & $\mathrm{R}^{\wedge}$ & $\begin{array}{l}\text { C1995(2005)Art10 } \\
\text { L1999(2009)Art12 }\end{array}$ & 1967 \\
\hline Zambia & $\mathrm{R}$ & $\mathrm{R}$ & $\mathrm{R}$ & $\mathrm{R}$ & $\mathrm{R}$ & $\mathrm{R}$ & $\mathrm{R}$ & $\mathrm{R}$ & C1991(1996)Art5 & 1973 \\
\hline Zimbabwe !! & $\mathrm{R}^{\wedge}$ & $\mathrm{R}^{\wedge}$ & $\mathrm{R}^{\wedge}$ & $\mathrm{R}^{\wedge}$ & $\mathrm{C}^{\wedge}$ & $\mathrm{C}^{\wedge}$ & $\mathrm{C}^{\wedge}$ & $\mathrm{C}^{\wedge}$ & $\begin{array}{l}\text { C2013Arts36\&37 } \\
\text { L1984(2003)Art5 }\end{array}$ & 1996 \\
\hline
\end{tabular}

n/a: not available

!! legislation conflicts with the constitution and/or other legislation - the constitutional provisions are noted here unless they provide only general principles and the detailed rules are established by legislation

- no rights

$\mathrm{R}$ : child is citizen from birth as of right

$t:$ child has right to repudiate on majority

$\mathrm{C}$ : can claim citizenship following an administrative process (including compulsory birth registration, establishing parentage, or registration with consular authorities)

* mother passes citizenship automatically only if father of unknown nationality or stateless or if father does not claim

Rx1: child born outside country is citizen as of right only if one parent both a citizen and born in country

$\mathrm{Rx} 1(\mathrm{C})$ : child born outside country must register a claim to be a citizen if citizen parent not born in country

Cx1: child born outside country is citizen only if one parent both a citizen and born in country, and admin. process completed

$\wedge$ Rights to citizenship from grandparents: if born in the country \& one grandparent is a citizen (Ghana \& Nigeria); if born in or outside the country $\&$ one grandparent is a citizen (Cape Verde, Uganda and Zimbabwe if birth registered in Zimbabwe)

$\sim$ racial, religious or ethnic discrimination in citizenship law: specified groups listed for preferential treatment (in Liberia only "negroes" can be citizens; in Somalia, must be of "Somali origin" to be citizen from birth; in Sierra Leone, a citizen parent does not transmit nationality to a child born in the country unless the parent or grandparent was also born in Sierra Leone and of negro-African descent; in Uganda, a child is not a citizen if born in the country unless the parent is citizen by birth - requiring membership of one of the indigenous communities listed in the 3rd schedule to the constitution.)

a: in Sierra Leone, the law makes no provision for those born in the country of a parent who is a citizen, but without a parent or grandparent also born in the country.

NB. There is simplification of complex provision

\subsection{Children born outside the country}

In most African countries, a child born to a citizen acquires citizenship, wherever that child is born (see Table 3: Right to citizenship by descent). However, a handful of African countries allow for citizenship to be passed for only one generation outside the country: a citizen from birth born in the country can pass his or her citizenship to a foreign-born child but that child cannot pass his or her citizenship on in turn. Provisions to this effect, which derive from a British rule, are in force in Gambia, Lesotho, Malawi, Mauritius, Swaziland, and Tanzania, and permitted to be established by legislation according to the Kenyan 2010 constitution (but not implemented in practice). ${ }^{42}$

42 The Kenya Constitution 2010 provided in Article 14(3) that: "Parliament may enact legislation limiting the effect of clauses (1) and (2) on the descendants of Kenyan citizens who are born outside Kenya."The Kenya Citizenship and Immigration Act 2011 provides in section 7, headed 
In some cases, though nationality may be transmitted, there are additional requirements either to take positive steps to claim the right to nationality or to notify the authorities of the birth. These provisions, while in principle acceptable, may leave some children stateless, since they are often little known and if nationality is not claimed within the relevant time limits the right may be lost. It may also be very difficult to fulfil the requirements in practice, especially where the country of the parents' nationality has no diplomatic representation in their country of residence.

For example, Mozambique requires all children born outside the country to declare their intention of remaining Mozambican within one year of majority (unless their parents were abroad in service of the state). The nationality law but not the constitution also requires that they renounce any other nationality to which they are entitled. ${ }^{43}$ For Swaziland, a child born abroad of a father also born abroad must notify the authorities of his or her desire to retain Swazi citizenship within one year of majority; if this is not done, the person ceases to be a citizen. ${ }^{44}$ Namibian and South African children born abroad must only be registered with the authorities. ${ }^{45}$ Under the 2013 constitution, Zimbabwe requires birth registration in Zimbabwe of children born abroad (unless the parents were ordinarily resident in Zimbabwe or posted abroad on state duties). ${ }^{46}$

Other countries, such as Chad, reflect concerns about conflicts of laws and explicitly state that a child born abroad of one non-Chadian parent may opt for the other nationality. ${ }^{47}$

\subsubsection{Adopted children}

Most African countries provide for children adopted from abroad to become nationals, either automatically or upon a non-discretionary registration procedure (see Table 4: Provisions on adopted children). Some provide only for a discretionary naturalisation process, and other countries have no provisions

"Limitation as to descent" that "A person born outside Kenya shall be a citizen by birth if on the date of birth that person's mother or father was or is a citizen by birth". This provision is clearly based on similar provisions in other Commonwealth countries distinguishing citizens by descent born outside the country; but since it provides only for citizens by birth, it does not, in fact, limit citizenship by descent for those born outside the country. The ambiguity was removed by the Security Laws (Amendment) Act, 2014. In Lesotho, the 1971 citizenship order discriminates on the basis of gender in relation to children born abroad, providing that only the father may pass nationality to children if they are not born in Lesotho; but the 1993 constitution provides for equal rights.

43 Constitution 2004, Article 23(3); Lei da nacionalidade, 1975, Article 8(1).

44 Constitution, 2005, Article 43(3).

45 Constitution 1990, Article 4; Citizenship Act No.14 of 1990, Article 2.

46 Constitution 2013, Article 37.

47 Code de la nationalité, 1962, Article 9. 
at all on adopted children. A few, including Sierra Leone and Sudan, have specifically amended their laws to exclude adopted children or adoptive parents from the definition of "child" or "parent". In some countries, such as the Central African Republic, a child that is the subject of a legitimative adoption by the father becomes a national as of right, but an adoption by a non-biological parent does not have the same effect.

- Automatic acquisition (subject to completion of legal adoption process) in: Angola, Benin, Botswana (if child under three years old), Chad, Côte d'Ivoire, Gabon, Ghana, Guinea Bissau, Mali, Mauritius, Mozambique, Namibia, Rwanda, São Tomé \& Príncipe, Senegal, Seychelles, Swaziland, Tunisia and Zambia.

- Option: Burundi, Cameroon, Cape Verde, CAR, DRC, Eritrea, Ethiopia, Kenya, Madagascar, South Africa, Uganda and Zimbabwe.

- Discretionary naturalisation: Botswana (if child more than three years old), Lesotho, Mauritania.

- No mention: Algeria, Burkina Faso, Comoros, Congo Republic, Egypt, Gambia, Liberia, Libya, Malawi, Morocco, Niger, Nigeria, Somalia, South Sudan, and Togo.

In those countries strongly influenced by Islamic law, the principled objection to full legal adoption means that transmission of the nationality of the adoptive parent is usually not provided for. Sudan, for example, specifically amended its nationality law in 1994 to remove the right to nationality based on adoption. ${ }^{48}$ However, Morocco's nationality code provides for a Moroccan national caring for a child of unknown parents in the system known as kafala to be able to present a request for acquisition of Moroccan nationality by the child; or for the child itself to do so during the two years preceding his or her majority. ${ }^{49}$

\footnotetext{
48 Nasredeen Abdulbari, "Citizenship Rules in Sudan and Post-Secession Problems”, Journal of African Law Vol.55, No.2, 2011, pp.157-180.

49 Code de la nationalité marocaine 1958, amended 2007, Article 9(2).
} 
Table 4: Provisions on minor adopted children

\begin{tabular}{|c|c|c|c|c|c|c|c|}
\hline Country & Auto. & Opt. & Disc. & Nat. only & $\begin{array}{c}\text { No } \\
\text { provision }\end{array}$ & Comments & Legal provision \\
\hline Algeria & & & & & $\mathrm{x}$ & & - \\
\hline Angola & $\mathrm{x}$ & & & & & $\begin{array}{l}\text { if ties with family } \\
\text { extinguished }\end{array}$ & L2005Art11 \\
\hline Benin & $\mathrm{x}$ & & & & & & L1965Art17 \\
\hline Botswana & $\mathrm{x}$ & & $\mathrm{x}$ & & & $\begin{array}{l}\text { automatic only if under } 3 \\
\text { yrs old; if more than } 3 \text { yrs } \\
\text { old discretionary based on } \\
\text { "good character" }\end{array}$ & L1998(2004)Art7-8 \\
\hline Burkina Faso & & & & & $\mathrm{x}$ & & - \\
\hline Burundi & & $\mathrm{x}$ & & & & & L2000Art5 \\
\hline Cameroon & & $\mathrm{x}$ & & & & & L1968Art21 \\
\hline Cape Verde & & $\mathrm{x}$ & & & & automatic if stateless & L1993Art10-11 \\
\hline CAR & & $\mathrm{x}$ & & & & automatic if legitimisation & L1961Art22 \\
\hline Chad & $\mathrm{x}$ & & & & & & L1962Art24 \\
\hline Comoros & & & & & $\mathrm{x}$ & & - \\
\hline Congo Rep. & & & & & $\mathrm{x}$ & & - \\
\hline Côte d'Ivoire & $\mathrm{x}$ & & & & & & L1961(2013)Art11 \\
\hline DRC & & $\mathrm{x}$ & & & & & L2004Arts13(2)\&17 \\
\hline Djibouti & & & & $\mathrm{x}$ & & & L2004Art13 \\
\hline Egypt & & & & & $\mathrm{x}$ & & - \\
\hline Eq. Guinea & & & & $\mathrm{x}$ & & & L1990Art4(b) \\
\hline Eritrea & & $\mathrm{x}$ & & & & & L1992Art5 \\
\hline Ethiopia & & $\mathrm{x}$ & & & & $\begin{array}{l}\text { if resident in Ethiopia with } \\
\text { adoptive parents }\end{array}$ & L2003Art7 \\
\hline Gabon & $\mathrm{x}$ & & & & & & L1998Art25 \\
\hline Gambia & & & & & $\mathrm{x}$ & & - \\
\hline Ghana & $\mathrm{x}$ & & & & & & $\begin{array}{l}\text { C1992(2001)Art6 } \\
\text { L2000Art9 }\end{array}$ \\
\hline Guinea & & & & $\mathrm{x}$ & & automatic if legitimisation & L1983Art48 \\
\hline G. Bissau & $\mathrm{x}$ & & & & & & L1992(2010)Art7 \\
\hline Kenya & & $\mathrm{x}$ & & & & & L2011Art14 \\
\hline Lesotho & & & $\mathrm{x}$ & & & & C1993Art11 \\
\hline Liberia & & & & & $\mathrm{x}$ & & - \\
\hline Libya & & & & & $\mathrm{x}$ & & - \\
\hline Madagascar & & $\mathrm{x}$ & & & & & L1960Art17 \\
\hline Malawi & & & & & $\mathrm{x}$ & & - \\
\hline Mali & $\mathrm{x}$ & & & & & & L2011Art230 \\
\hline Mauritania & & & $\mathrm{x}$ & & & Govt can oppose & L1961(2010)Art13 \\
\hline Mauritius & $\mathrm{x}$ & & & & & & C1968(1995)Art3 \\
\hline Morocco & & & & & $\mathrm{x}$ & $\begin{array}{l}\text { Provisions based on kafala } \\
\text { guardianship }\end{array}$ & L1958(2007)Art9(2) \\
\hline Mozambique & $\mathrm{x}$ & & & & & & C2004Art29 \\
\hline Namibia & $\mathrm{x}$ & & & & & becomes citizen by descent & C1990(2010)Art2(2)(b) \\
\hline Niger & & & & & $\mathrm{x}$ & automatic if legitimisation & L1984(2014)Arts \\
\hline Nigeria & & & & & $\mathrm{x}$ & & - \\
\hline Rwanda & $\mathrm{x}$ & & & & & & L2008Art12 \\
\hline SADR & & & & & & & - \\
\hline
\end{tabular}




\begin{tabular}{|c|c|c|c|c|c|c|c|}
\hline Country & Auto. & Opt. & Disc. & Nat. only & $\begin{array}{c}\text { No } \\
\text { provision }\end{array}$ & Comments & Legal provision \\
\hline STP & $\mathrm{x}$ & & & & & & L1990Art9 \\
\hline Senegal & $\mathrm{x}$ & & & & & & L1961(2013)Art9 \\
\hline Seychelles & $\mathrm{x}$ & & & & & & L1994(2013)Art 3 \\
\hline S. Leone & & & & $\mathrm{x}$ & & $\begin{array}{c}\text { "parent" excludes adoptive } \\
\text { parent }\end{array}$ & L1973(2006)Art1(1) \\
\hline Somalia & & & & & $\mathrm{x}$ & & - \\
\hline South Africa & & $\mathrm{x}$ & & & & $\begin{array}{c}\text { birth must be registered } \\
\text { under B\&DRA }\end{array}$ & L1995(2010)Art3 \\
\hline South Sudan & & & & & $\mathrm{x}$ & & - \\
\hline Sudan & & & & $\mathrm{x}$ & & $\begin{array}{l}1993 \text { Act removed adopted } \\
\text { child from the definition of } \\
\text { "child" }\end{array}$ & - \\
\hline Swaziland & $\mathrm{x}$ & & & & & & C2005Art43(5) \\
\hline Tanzania & & & & $\mathrm{x}$ & & & L1995Art10 \\
\hline Togo & & & & & $\mathrm{x}$ & & - \\
\hline Tunisia & $\mathrm{x}$ & & & & & & L1963(2010)Art18 \\
\hline Uganda & & $\mathrm{x}$ & & & & & $\begin{array}{l}\text { C1995(2005)Art11 } \\
\text { L1999(2009)Art13(2) }\end{array}$ \\
\hline Zambia & $\mathrm{x}$ & & & & & & L1975Art11 \\
\hline Zimbabwe & & $\mathrm{x}$ & & & & & $\begin{array}{c}\text { C2013Art38(3) } \\
\text { L1984(2003)Art7(5) }\end{array}$ \\
\hline
\end{tabular}

Auto:: Acquisition of nationalti automatic on completion of adoption formalities

Opt.: Child has the right to opt for nationality

Disc: Child can apply for nationality, award is discretionary

Nat.: Naturalisation

\subsection{Citizenship by marriage}

The most common ground for acquiring citizenship as an adult is on the basis of marriage. In most countries, marriage to a citizen allows the spouse — or only the wife - to acquire nationality either automatically or on the more favourable terms of registration (in common law countries) or option/declaration (in civil law countries). Automatic acquisition of nationality on marriage, previously the norm when women were assumed to follow the nationality of their father or husband, is now much less common, only in place in nine African countries (Benin, Central African Republic, Comoros, Congo Republic, Equatorial Guinea, Guinea, Somalia, and Togo; Burkina Faso retains automatic acquisition, but for a spouse of either sex, Mali introduced the same system in 2011 and Côte d'Ivoire in 2013).

Two dozen countries today still do not allow women to pass their citizenship to their noncitizen spouses, or apply discriminatory residence qualifications to foreign men married to citizen women who wish to obtain citizenship (Benin, Burundi, Cameroon, Central African Republic, Comoros, Republic of Congo, Egypt, Equatorial Guinea, Guinea, Lesotho, Libya, Madagascar, Malawi, 
Mauritania, Morocco, Nigeria ${ }^{50}$, Sierra Leone, Somalia, Sudan, Swaziland, Tanzania, Togo, and Tunisia). In some cases, marriage only shortens the period within which naturalisation can be applied for, and all other conditions for naturalisation must still be fulfilled.

In some countries, especially those that follow the French model, the state may object to the acquisition of nationality by the spouse for up to a year after the application is made. In others, the grant of nationality on marriage is discretionary to a greater or lesser degree. These rules can render the interpretation of rights on marriage quite difficult, with Egypt's provisions relating to the situation of a woman who marries an Egyptian or a foreigner, or whose husband changes nationality being particularly complex.

Most civil law countries specify that all facts related to civil status must be established in accordance with the civil registration law, which thus excludes customary marriage; only a few, including Namibia or Togo, state that customary marriages are recognised for the purposes of acquisition of nationality, provided they are recorded in some way.

Table 5: Right to pass nationality to a spouse

\begin{tabular}{|c|c|c|c|c|c|c|}
\hline Country & $\begin{array}{c}\text { Nationality } \\
\text { by } \\
\text { marriage }\end{array}$ & $\begin{array}{c}\text { Res. } \\
\text { period } \\
\text { (if any) }\end{array}$ & $\begin{array}{l}\text { Marriage } \\
\text { period } \\
\text { (if any) }\end{array}$ & Level of discretion & $\begin{array}{l}\text { Relevant legal } \\
\text { provision(s) }\end{array}$ & $\begin{array}{c}\text { Year } \\
\text { of } \\
\text { equality }\end{array}$ \\
\hline Algeria & $=$ & 2 yrs & $3 \mathrm{yrs}$ & By decree & L1970(2005)Art9bis & 2005 \\
\hline Angola & $=$ & & $5 \mathrm{yrs}$ & $\begin{array}{l}\text { On application; marriage period } \\
\text { waived if loses other nationality }\end{array}$ & L2005Art12 & 1975 \\
\hline Benin & $\mathrm{w}$ & & & $\begin{array}{l}\text { Automatic unless declines; govt } \\
\text { can oppose }\end{array}$ & L1965Arts18-23 & - \\
\hline Botswana & $=$ & 5 yrs & & $\begin{array}{l}\text { Same conditions as naturalisation } \\
\text { except shorter residence period }\end{array}$ & L1998(2002\&04)Art14 & 1995 \\
\hline Burkina Faso & $=$ & & & $\begin{array}{l}\text { Automatic unless declines; govt } \\
\text { can oppose }\end{array}$ & L1989Art151-154 & $1989 ?$ \\
\hline Burundi & $\mathrm{w}$ & & & By declaration & L2000Arts $4,10-12$ & - \\
\hline Cameroon & $\mathrm{w}$ & & & On request; govt can oppose & L1968Art17-19 & - \\
\hline CapeVerde & $=$ & & & By declaration & L1993Art7 & 1976 \\
\hline CAR & $\mathrm{w}$ & & & $\begin{array}{l}\text { Automatic unless declines; govt } \\
\text { can oppose }\end{array}$ & L1961Art13-17 & - \\
\hline Chad & $=$ & & & $\begin{array}{l}\text { On request if marriage celebrated } \\
\text { in Chad; govt can oppose }\end{array}$ & L1962Arts17-18 & 1962 \\
\hline Comoros & $\mathrm{w}$ & & & $\begin{array}{l}\text { Automatic unless declines; govt } \\
\text { can oppose }\end{array}$ & L1979Arts15-19 & - \\
\hline Congo Rep. & $\mathrm{w}$ & 5 yrs & & Automatic unless declines & L1961(1993)Art18-19 & - \\
\hline
\end{tabular}

50 Constitution of the Republic of Nigeria, 1999, article 26. For the most part, immigration authorities have accepted applications for registration by foreign husbands, but there have been some cases brought to court where this has been denied. Comment by Ayo Obe on the Claiming Equal Citizenship section of the Learning Partnership website (no longer available; accessed 12 December 2007). 


\begin{tabular}{|c|c|c|c|c|c|c|}
\hline Country & $\begin{array}{c}\text { Nationality } \\
\text { by } \\
\text { marriage }\end{array}$ & $\begin{array}{c}\text { Res. } \\
\text { period } \\
(\text { if any })^{\star}\end{array}$ & $\begin{array}{l}\text { Marriage } \\
\text { period } \\
\text { (if any) }\end{array}$ & Level of discretion & $\begin{array}{l}\text { Relevant legal } \\
\text { provision(s) }\end{array}$ & $\begin{array}{c}\text { Year } \\
\text { of } \\
\text { equality }\end{array}$ \\
\hline Côte d'Ivoire & $=$ & & & $\begin{array}{l}\text { Automatic unless declines; govt } \\
\text { can oppose }\end{array}$ & L1961(2013)Arts12-16 & 2013 \\
\hline DR Congo & $=$ & & $7 \mathrm{yrs}$ & $\begin{array}{l}\text { Marriage has no effect as of right, } \\
\text { acquisition authorised by decree } \\
\text { approved by National Assembly }\end{array}$ & L2004Art18-20 & 2004 \\
\hline Djibouti & $=$ & & $10 \mathrm{yrs}$ & $\begin{array}{l}\text { Marriage has no effect as of right; } \\
\text { period of marriage reduced to } 5 \\
\text { yrs if there is a child }\end{array}$ & L2004Arts10-12 & 2004 \\
\hline Egypt & $\mathrm{w}$ & & $2 \mathrm{yrs}$ & On application; govt can oppose & $\begin{array}{l}\text { L1975(2004)Art6-8, } \\
\text { 11-13, } 25\end{array}$ & - \\
\hline Eq. Guinea & $\mathrm{w}$ & & & $\begin{array}{l}\text { Automatic (and loses nationality } \\
\text { of origin) }\end{array}$ & L1990Art5 & - \\
\hline Eritrea & $=$ & 3 yrs & & On application shall be granted & L1992Art6 & 1992 \\
\hline Ethiopia & $=$ & $1 \mathrm{yr}$ & $2 \mathrm{yrs}$ & On application may be granted & L2003Art6 & 2003 \\
\hline Gabon & $=$ & & $3 \mathrm{yrs}$ & $\begin{array}{l}\text { On application, but marriage has } \\
\text { no effect as of right \& govt may } \\
\text { oppose }\end{array}$ & L1998Arts20-24 & 1998 \\
\hline Gambia !! & $=$ & $7 \mathrm{yrs}$ & & On application shall be entitled & C1996(2001)Art11 & 1996 \\
\hline Ghana & $=$ & & & On application may be registered & $\begin{array}{l}\text { C1992Art7(1) } \\
\text { L2000Art10 }\end{array}$ & 1992 \\
\hline Guinea & $\mathrm{w}$ & & & $\begin{array}{l}\text { Automatic unless declines; govt } \\
\text { may oppose }\end{array}$ & L1983Arts49-55 & - \\
\hline G. Bissau & $=$ & $1 \mathrm{yr}$ & 3 yrs & By declaration & L1992(2010)Art8 & 1976 \\
\hline Kenya & $=$ & & 7 yrs & $\begin{array}{l}\text { On application, subject to } \\
\text { conditions including clean } \\
\text { criminal record }\end{array}$ & $\begin{array}{l}\text { C2010Art15(1) } \\
\text { L2011Art11-12 }\end{array}$ & 2010 \\
\hline Lesotho & $\mathrm{w}$ & & & On application shall be entitled & C1993Art40 & - \\
\hline Liberia & & & & No additional rights on marriage & L1973Art21.30 & \\
\hline Libya & $\mathrm{w}$ & & $2 \mathrm{yrs}$ & $\begin{array}{l}\text { On proposal of the secretary of } \\
\text { the General People's Committee } \\
\text { for Public Security }\end{array}$ & L2010Art10 & - \\
\hline Madagascar & $\mathrm{w}$ & & & $\begin{array}{l}\text { On request, automatic if stateless; } \\
\text { govt can oppose }\end{array}$ & L1960Art22-26 & - \\
\hline Malawi !! & $\mathrm{w}$ & $5 \mathrm{yrs}$ & & $\begin{array}{l}\text { Must satisfy most conditions } \\
\text { relating to regular naturalisation, } \\
\text { including good character }\end{array}$ & $\begin{array}{l}\text { C1994(1998)Art24(1)(iv) } \\
\text { L1966(1992)Art16 }\end{array}$ & - \\
\hline Mali & $=$ & & & Govt can oppose & L2011Arts233-236 & 2011 \\
\hline Mauritania & $\mathrm{w}$ & $5 \mathrm{yrs}$ & & On request & L1961(2010)Art16 & - \\
\hline Mauritius & $=$ & 4 yrs & & $\begin{array}{c}\text { On application, though } \\
\text { exceptions may be prescribed }\end{array}$ & $\begin{array}{l}\text { C1968(1995)Art24 } \\
\text { L1968(1995)Art7(2) }\end{array}$ & 1995 \\
\hline Morocco & $\mathrm{w}$ & $5 \mathrm{yrs}$ & & By declaration; govt may oppose & L1958(2007)Art10 & - \\
\hline $\begin{array}{l}\text { Mozam- } \\
\text { bique !! }\end{array}$ & $=$ & & 5 yrs & $\begin{array}{c}\text { By declaration, must fulfil } \\
\text { conditions set by law; marriage } \\
\text { period waived if stateless. Law } \\
\text { provides only for a woman marry- } \\
\text { ing a Mozambican, who must fulfil } \\
\text { conditions for naturalisation }\end{array}$ & $\begin{array}{c}\text { C2004Art26 } \\
\text { L1975(1987)Art10 }\end{array}$ & 2004 \\
\hline Namibia & $=$ & $10 \mathrm{yrs}$ & & $\begin{array}{l}\text { On application shall be granted, } \\
\text { marriage under customary law } \\
\text { specified as included }\end{array}$ & $\begin{array}{l}\text { C1990(2010)Art4(3) } \\
\text { L1990Art3 }\end{array}$ & 1990 \\
\hline Niger & $=$ & 3 yrs & & $\begin{array}{l}\text { By decree, provided satisfies } \\
\text { conditions similar to those for } \\
\text { naturalisation }\end{array}$ & L1984(2014)Arts13-19 & 2014 \\
\hline
\end{tabular}




\begin{tabular}{|c|c|c|c|c|c|c|}
\hline Country & $\begin{array}{c}\text { Nationality } \\
\text { by } \\
\text { marriage }\end{array}$ & $\begin{array}{c}\text { Res. } \\
\text { period } \\
\left(\text { if } \text { any) }{ }^{\star}\right.\end{array}$ & $\begin{array}{l}\text { Marriage } \\
\text { period } \\
\text { (if any) }\end{array}$ & Level of discretion & $\begin{array}{l}\text { Relevant legal } \\
\text { provision(s) }\end{array}$ & $\begin{array}{c}\text { Year } \\
\text { of } \\
\text { equality }\end{array}$ \\
\hline Nigeria & $\mathrm{w}$ & & & $\begin{array}{l}\text { On application, provided } \\
\text { satisfies conditions including } \\
\text { good character }\end{array}$ & C1999Art26 & - \\
\hline Rwanda & $=$ & & $3 \mathrm{yrs}$ & On application may acquire & L2008Art11 & 2004 \\
\hline SADR & & & & & $\mathrm{n} / \mathrm{a}$ & \\
\hline STP & $=$ & & & $\begin{array}{l}\text { By declaration if domiciled in } \\
\text { STP }\end{array}$ & L1990Art6 & 1990 \\
\hline Senegal & $=$ & & $5 \mathrm{yrs}$ & On request; govt can oppose & L1961(2013)Art7 & 2013 \\
\hline Seychelles & $(=)$ & 5 yrs & $10 \mathrm{yrs}$ & $\begin{array}{c}\text { On application, provided satisfies } \\
\text { conditions including no criminal } \\
\text { record }\end{array}$ & $\begin{array}{c}\text { C1993(2011)Art12 } \\
\text { L1994(2013)Art6 }\end{array}$ & 1979 \\
\hline Sierra Leone & $\mathrm{w}$ & & & On application may be granted & L1973(2006)Art7 & - \\
\hline Somalia & $\mathrm{w}$ & & & Automatic & L1962Art13 & - \\
\hline South Africa & $=$ & $\begin{array}{l}\text { "pre- } \\
\text { scribed } \\
\text { period" }\end{array}$ & $\begin{array}{l}\text { "pre- } \\
\text { scribed } \\
\text { period" }\end{array}$ & $\begin{array}{c}\text { On application, provided } \\
\text { admitted as a permanent resident }\end{array}$ & L1995(2010)Art5(5) & $1994 ?$ \\
\hline South Sudan & $=$ & 5 yrs & & On application may acquire & L2011Art13 & 2011 \\
\hline Sudan & $\mathrm{w}$ & 2 yrs & & On application may be granted & L1994(2011)Art8 & - \\
\hline Swaziland & $\mathrm{w}$ & & & By declaration & $\begin{array}{l}\text { C2005Art44 } \\
\text { L1992Art8 }\end{array}$ & - \\
\hline Tanzania & $\mathrm{w}$ & & & On application shall be entitled & L1995Art11 & - \\
\hline Togo & $\mathrm{w}$ & & & $\begin{array}{c}\text { Automatic unless declines; } \\
\text { customary marriages recognised if } \\
\text { recorded in writing }\end{array}$ & L1978Art5-7 & - \\
\hline Tunisia & $\mathrm{w}$ & $2 \mathrm{yrs}$ & & $\begin{array}{l}\text { By declaration, automatic if loses } \\
\text { other nationality; govt can oppose }\end{array}$ & L1963(2010)Arts13-17 & - \\
\hline Uganda & $=$ & & 5 yrs & On application shall be registered & $\begin{array}{l}\text { C1995(2005)Art12(2)(a) } \\
\text { L1999(2009)Art14(2)(a) }\end{array}$ & 1995 \\
\hline Zambia !! & & & & $\begin{array}{l}\text { No provision in constitution; law } \\
\text { refers to previous constitution } \\
\text { and woman's right to apply after } \\
3 \text { yrs of marriage, provided of } \\
\text { "sound mind" }\end{array}$ & $\begin{array}{l}\text { C1991(1996)Art6 } \\
\text { L1975(1994)Art15 }\end{array}$ & - \\
\hline Zimbabwe !! & $=$ & $5 \mathrm{yrs}$ & & On application shall be entitled & $\begin{array}{c}\text { C2013Art38 } \\
\text { L1984(2003)Art4(3) }\end{array}$ & 2009 \\
\hline
\end{tabular}

\footnotetext{
!! legislation conflicts with the constitution - the constitutional provisions are noted here (in Zambia the Citizenship Act refers to a provision in the abrogated 1973 constitution which is not included in the 1991 constitution)

* If residence period noted then residence is after marriage

$=$ Equal rights for men and women to pass citizenship

w Only a foreign woman acquire nationality on basis of marriage to a national man

(w) while some of the conditions for naturalisation are waived, grant is discretionary

- No additional rights in case of marriage (though residence period may be reduced: see table on naturalisation)

$\mathrm{m}+\mathrm{w}$ men and women can both pass citizenship, but not on equal terms

aut. Spouse acquires citizenship automatically, without further procedures (unless chooses to refuse)
}

\subsection{Dual nationality}

Even though relatively few countries have a positive statement in their law that dual nationality is generally permitted, it is now the case that substantially more African countries permit than prohibit dual nationality. Even in those countries where dual nationality is prohibited, the rules are often not enforced in practice. In other cases, the law is ambiguous or silent but effectively allows dual nationality. 
In order to understand the extent to which a law permits dual nationality it is necessary to consider not only any specific statement about multiple nationality, but also the provisions on loss or deprivation of nationality, and whether renunciation of another nationality is one of the conditions to acquire nationality. Hence, it may be the case that a state prohibits dual nationality in all circumstances, or only for adults but not for children who have two nationalities from birth, or only for those who voluntarily acquire another nationality as an adult, or only for those who naturalise but not for women who have acquire nationality (of another state or the state concerned) on marriage.

The states where dual nationality is allowed in most circumstances are :Algeria,Angola, Benin, Burkina Faso ${ }^{51}$, Burundi, Cape Verde, Chad, Comoros, Congo Republic, Djibouti, Gabon, Ghana, Guinea-Bissau, Kenya, Mali, Morocco, Mozambique, Nigeria $^{52}$, Rwanda, São Tomé \& Príncipe, Senegal, Seychelles, Sierra Leone, Somalia, South Sudan, Sudan, and Tunisia (see Table 6: Rules on dual nationality).

Some countries allow dual nationality only with the explicit permission of the authorities, including Egypt, Eritrea (in some circumstances ${ }^{53}$ ), Libya, Mauritania, South Africa and Uganda. South Africa's law has been through a few iterations since 1994, and a citizen by birth acquiring another nationality must have permission to continue to hold South African nationality; while a person applying for naturalisation must satisfy the minister that they are either a citizen of a country that allows dual nationality, or that, if their presumed other nationality is with a country that does not allow dual nationality, they have renounced that nationality. ${ }^{54}$ Uganda has an elaborate range of additional conditions that apply to people seeking to naturalise who wish to retain their other nationality, that are not applied to those who renounce. ${ }^{55}$

Thirteen countries prohibit dual nationality only in some circumstances - either only for a person naturalising as a citizen (Gambia, Mauritius, Namibia, Swaziland, Togo, and Zimbabwe), or only for citizens from birth who voluntarily acquire

51 In Burkina Faso, the law is silent on the issue, neither providing for loss of nationality on acquisition of another nor for a person applying for naturalisation to have to renounce their previous nationality, so the presumption is that dual nationality is allowed. However, interpretation in practice may vary, in light of this silence.

52 Nigeria does not permit a person to naturalise as Nigerian while also holding another nationality by naturalisation - however, a Nigerian may acquire another nationality without losing it, and a person with another nationality of origin may acquire Nigerian nationality without renouncing their other nationality.

53 In Eritrea the 1992 nationality law provided that those who already had another nationality were allowed to keep their other nationality, but only with permission; dual nationality is not prohibited for those born since 1992 with dual nationality of origin, but those acquiring Eritrean nationality must renounce any other nationality, and nationality will be lost on voluntary acquisition of another nationality. Eritrea Nationality Proclamation No.12 of 1992, articles 2(5), 4(2)(e) and 8(1)(a).

54 South African Citizenship Act, 1995, as amended 2010, sections (5)(1)(h) and 6.

55 Citizenship \& Immigration Control Act 1999, amended 2009, section 19 A-G. 
another nationality (Benin, CAR, Côte d'Ivoire, Guinea, and Madagascar). Togo appears to forbid dual nationality both for naturalised citizens and for citizens from birth; but the interpretation is that a national of origin has to request permission to renounce nationality, so dual nationality is only truly forbidden for those who naturalise and have to renounce their other nationality. ${ }^{56}$ In a provision with no parallel elsewhere, Sudan generally permits dual nationality - but not for those who acquired Southern Sudanese nationality on the secession of South Sudan. ${ }^{57}$

Liberia has one of the strictest bans on dual nationality anywhere in Africa, establishing a range of behaviours that result in automatic revocation of Liberian nationality (see chapter 6.7). But a number of other countries also provide for automatic loss of nationality in case both of acquisition and of retention of another as an adult (mainly the southern African Commonwealth countries). Some laws that generally provide for loss of nationality on acqusition of another permit a woman who automatically acquires her husband's nationality upon marriage to retain her nationality of birth.

Several countries have rules that have been changed to allow dual nationality in the constitution but the legislation has yet to be updated, including Comoros, Congo Republic, Gambia, Mozambique, São Tomé \& Príncipe, Somalia, and Zimbabwe.

The most confusion surrounds the common wording in the francophone countries that a person who voluntarily acquires another nationality loses his or her nationality of origin, but that this loss is subject to permission of the relevant ministry. These provisions were drafted during a time when it was presumed that most countries would not allow dual nationality; thus, in order to acquire another nationality a person would necessarily have to renounce the nationality of origin; but at the same time, states wished to ensure that a person could not change nationality simply to avoid obligations such as military service. However, the wording only applies to those who "voluntarily acquire" another nationality; and therefore does not affect those who are born with two nationalities. Additional confusion is added by the fact that national military service has never been implemented in these countries, so that the military recruitment registers referred to in the legislation (copying from French law), establishing the period during which nationality could not be lost, were never implemented. ${ }^{58}$

In practice, interpretation and application of these laws varies widely. For example, in West Africa, Senegal interprets language which is very similar to that in Benin, Côte d'Ivoire, Guinea and (until 2014) Niger to mean that dual nationality is permitted

56 Rapport de la Commission ad hoc chargée de réviser les textes relatifs à la nationalité et de définir les modalités pratiques des audiences foraines d'établissement de certificats d'origine et de nationalité, Lomé, 12-16 septembre 2011.

57 Sudan Constitution 2005 Article 7(4); Sudanese Nationality Act 1994 (as amended 2011), Article 10(2).

58 Many of the Commonwealth countries dealt with this situation through standard provisions allowing dual nationality among children, who then had to opt between the age of 18 and 21 . 
in all circumstances. ${ }^{59}$ In Benin, Guinea and Niger, it is well known that many have acquired another nationality, including senior officials and government ministers, but no action is taken to deprive the person formally of their nationality of origin. Only in Côte d'Ivoire is there a real effort to enforce the rules on loss of nationality in case of acquisition of another - and the process there is highly politicised, rather than a matter of neutral administrative or judicial action; even the right of a person to two nationalities of origin has been contested. ${ }^{60}$ In 2014, Niger became the latest country to adopt a law explicitly making dual nationality permissible in all circumstances. ${ }^{61}$

In some countries, the courts have attempted to re-interpret the law. In Lesotho, the constitution provides that an adult citizen cannot be a citizen of another country (unless he or she acquires this dual citizenship by marriage). However, in a 2005 case the High Court found that the provision on loss of citizenship under the Lesotho Citizenship Order of 1971 "does not deal with a Lesotho citizen who is domiciled in Lesotho but acquires a citizenship of the Republic of South Africa while he is working there. If the intention was that such a person should lose his residence and domicile, then Parliament should have specified this. It would be wrong to read into

59 Senegal has two provisions that appear to forbid dual nationality : Article 16 bis provides that : "La nationalité sénégalaise acquise par décision de l'autorité publique est incompatible avec le maintien d'une autre allégeance " Article 18 provides : "Perd la nationalité sénégalaise, le sénégalais majeur qui acquiert volontairement une nationalité étrangère. Toutefois, jusqu'à l'expiration d'un délai de quinze ans à partir, soit de l'incorporation dans l'armée active, soit de l'inscription sur les tableaux de recensement en cas de dispense du service actif, la perte de la nationalité sénégalaise est subordonnée à l'autorisation du Gouvernement. Cette autorisation est accordée par décret. Ne sont pas astreints à solliciter cette autorisation: $1^{\circ}$ ) les exemptés du service militaire; $2^{\circ}$ ) les titulaires d'une réforme définitive; $3^{\circ}$ ) tous les hommes, même insoumis, après l'âge où ils sont totalement dégagés des obligations du service militaire, conformément à la loi sur le recrutement de l'année. " However, the sub-articles providing modalities for implementation of Article 16bis were repealed, and there is no requirement to renounce another nationality as a qualification for naturalisation. Article 20, before it was reformed in 2013, allowed Senegalese women who had married foreigners to retain their nationality unless they expressly state they wish to give it up. The notes to the nationality code in the version published by Editions Juridiques Afriaines, 1993, also cite jurisprudence that, in case of double nationality, the provisions of the Family Code relating to the jurisdiction of the Senegalese courts should be applied. ("En cas de double nationalité, application des articles 849 et 853 du Code de la Famille pour appliquer la compétence des tribunaux sénégalais au défendeur dont il est établi qu'il possède aussi la nationalité sénégalaise. CA Dakar no.234 du 8.12.1972.”). The official interpretation of the Ministry of Justice is that dual nationality is permitted, despite what appears to be the clear surface meaning of the law. Interview with Bienvenu Moussa Habib Dione, Senegalese Ministry of Justice, May 2014; and document provided by the ministry for the then Minister of Justice at the time of Senegalese nationality law reform of 2013.

60 A memo on this point, noting that dual nationality of origin is permitted under Ivorian law, and that a person does not lose nationality unless he or she requests to do so and is authorised by decree, was published by Me. François Guei, a member of the Conseil Constitutionnel of Côte d'Ivoire, in May 2010 (copy on file with author).

61 Loi No.2014-60 du 5 novembre 2014. 
such a person's act an intention to terminate rights of domicile and residence into the Order." Thus, citizenship by birth could not be lost by acquisition "of another citizenship to get a job while his domicile remains in Lesotho." ${ }^{\circ 2}$ A case decided by the Lesotho Court of Appeal in 2008, however, ruled that citizenship by birth could be lost if the person involved acquired another citizenship; though the court also urged the Lesotho Parliament to enact legislation permitting Lesotho citizens to hold dual nationality with at least South Africa (a destination for tens of thousands of men and women from Lesotho seeking work to alleviate dire poverty), given what the court characterized as "the economic interdependence of the two countries." 3

The reality of economic migration was explicitly recognised in the Guinea Bissau law of 1992, which provides that dual citizenship is allowed if a person acquires another citizenship because he or she has emigrated "essentially for economic reasons"; 2010 amendments removed any restrictions. ${ }^{64}$ Several High Court rulings in Namibia have affirmed that under the constitution a citizen from birth can only lose his or her nationality by voluntary renunciation and that dual nationality is permitted for citizens from birth, despite section 26 of the Citizenship Act which states that no Namibian citizen may also be a citizen of a foreign country. ${ }^{65}$

Table 6: Rules on dual nationality

\begin{tabular}{|c|c|c|c|c|c|}
\hline \multirow[t]{2}{*}{ Country } & \multicolumn{3}{|c|}{ Dual nationality permitted? } & \multirow{2}{*}{$\begin{array}{c}\text { Restrictions on public } \\
\text { office }\end{array}$} & \multirow[t]{2}{*}{ Relevant legal provisions } \\
\hline & Yes & $\begin{array}{c}\text { Some- } \\
\text { times }\end{array}$ & No & & \\
\hline Algeria & $\mathrm{x}$ & & & $\begin{array}{c}\text { President cannot be dual } \\
\text { national }\end{array}$ & $\begin{array}{l}\text { C1989(1996)Art73 } \\
\text { L1970(2005)Art18 }\end{array}$ \\
\hline Angola & $\mathrm{x}$ & & & & L2005Art15(1)(a)\&30-31 \\
\hline Benin & $\mathrm{x}$ & & & & L1965Art46\&49 \\
\hline Botswana & & $x \dagger^{\star}$ & & & L1998(2002\&04)Art15 \\
\hline Burkina Faso & $\mathrm{x}$ & & & & [no provision] \\
\hline Burundi & $\mathrm{x}(2000)$ & & & & L2000Art21 \\
\hline Cameroon & & & $\mathrm{x}$ * & & L1968Art31 \\
\hline CapeVerde & $\mathrm{x}(1992)$ & & & $\begin{array}{l}\text { President cannot be dual } \\
\text { national }\end{array}$ & $\begin{array}{c}\text { C1992(2010)Arts5\&110 } \\
\text { DL1993Art18 }\end{array}$ \\
\hline
\end{tabular}

${ }^{62}$ Mokoena vs. Mokoena and Others CIV/APN/216/2005 (unreported); see also Mokoena vs. Mokoena and Others C of A (CIV), No.2 of 2007.

63 Director of Immigration and others vs. Pholoana Adam Lekhoaba and Anor. C of A (CIV) No.22/07 (unreported), available on the website of the Southern African Legal Information Institute (SAFLII) at http://www.saflii.org/ls/cases/LSCA/2008/4.html.

${ }^{64}$ Lei No. 2/92 de 6 de abril, artigo 10 amended by Lei da nacionalidade No.6/2010 de 21 de junho. São Tomé \& Príncipe has a similar provision allowing dual nationality "because of emigration." Lei da nacionalidade No.6/90, artigo 12.

65 Tlhoro v Minister of Home Affairs (Case No. (P) A159/2000) [2008] NaHC 65 (2 July 2008), reaffirmed by Le Roux $v$ Chief of Immigration and Others (A322/2010, High Court of Namibia). See also Werner Menges, "Court confirms legality of dual citizenship for some Namibians", The Namibian, 9 July 2008; Werner Menges, "Dual citizenship legal for born Namibians", The Namibian, 7 June 2011. 


\begin{tabular}{|c|c|c|c|c|c|}
\hline \multirow[t]{2}{*}{ Country } & \multicolumn{3}{|c|}{ Dual nationality permitted? } & \multirow{2}{*}{$\begin{array}{c}\text { Restrictions on public } \\
\text { office }\end{array}$} & \multirow[t]{2}{*}{ Relevant legal provisions } \\
\hline & Yes & $\begin{array}{c}\text { Some- } \\
\text { times }\end{array}$ & No & & \\
\hline Central African Rep & & $x \dagger^{\star}$ & & & L1961Arts46-49 \\
\hline Chad & $x(1962)$ & & & $\begin{array}{c}\text { President cannot be dual } \\
\text { national }\end{array}$ & $\begin{array}{l}\text { C1996Art62 } \\
\text { L1962Art6-7 }\end{array}$ \\
\hline Comoros!! & $\mathrm{x}(2001)$ & & & & $\begin{array}{l}\text { C2001Art5 } \\
\text { L1979Art51 }\end{array}$ \\
\hline Congo Rep.!! & $\mathrm{x}(2002)$ & & & & $\begin{array}{c}\text { C2002Art13 } \\
\text { L1961(1993)Art47 }\end{array}$ \\
\hline Côte d'Ivoire & & $x \dagger^{\star}$ & & & L1961(2013)Arts48-52 \\
\hline Dem. Rep. Congo & & & $\mathrm{x}$ & & $\begin{array}{c}\text { C2005Art10 } \\
\text { L2004Art1, 22, 26, } 51 \\
\end{array}$ \\
\hline Djibouti & $\mathrm{x}(2004)$ & & & $\begin{array}{c}\text { President cannot be dual } \\
\text { national }\end{array}$ & $\begin{array}{l}\text { C1992Art24 } \\
\text { L2004Art11 }\end{array}$ \\
\hline Egypt & & $(\mathrm{x})^{*}$ & & $\begin{array}{c}\text { President \& prime minister, } \\
\text { and their spouses and parents, } \\
\text { cannot be dual nationals }\end{array}$ & $\begin{array}{c}\text { C2014Arts141\&164 } \\
\text { L1975(2004)Arts10-12 }\end{array}$ \\
\hline Equatorial Guinea & & & $\mathrm{x}$ & $\begin{array}{c}\text { President cannot be dual } \\
\text { national }\end{array}$ & $\begin{array}{c}\text { C2012Art35 } \\
\text { L1990Arts4(a),12\&19 }\end{array}$ \\
\hline Eritrea a & & & $\mathrm{x}$ & & L1992Arts2,4\&8 \\
\hline Ethiopia & & & $\mathrm{x}$ & & L2003Arts5,6\&20 \\
\hline Gabon & $\mathrm{x}(1962)$ & & & & L1998Art7 \\
\hline Gambia !! b & & $x \neq(2001)$ & & $\begin{array}{c}\text { President cannot be dual } \\
\text { national }\end{array}$ & C1996(2001)Art12,12A,13 \& 62 \\
\hline Ghana & x (1996) & & & $\begin{array}{c}\text { President and members of } \\
\text { parliament cannot be dual } \\
\text { nationals }\end{array}$ & $\begin{array}{l}\text { C1992(1996)Arts8,62\&94 } \\
\text { L2000Art14\&16 }\end{array}$ \\
\hline Guinea & & $\mathrm{x} \dagger$ & & & L1983Art95 \\
\hline Guinea Bissau & $\mathrm{x}(2010)$ & & & & L1992(2010)Art10 \\
\hline Kenya & $\mathrm{x}(2010)$ & & & $\begin{array}{c}\text { President and deputy presi- } \\
\text { dent cannot be dual nationals }\end{array}$ & $\begin{array}{c}\text { C2010Arts15(4),16,99\&137 } \\
\text { L2011Art8 }\end{array}$ \\
\hline Lesotho & & & $\mathrm{x}$ * & & C1993Art41 \\
\hline Liberia & & & $\mathrm{x}$ & & $\begin{array}{c}\text { C1984Art28 } \\
\text { L1973Art21.2\&22.1 } \\
\end{array}$ \\
\hline Libya & & (x) & & & L2010Arts5\&9 \\
\hline Madagascar & & $x \dagger^{\star}$ & & & L1960Arts27,42\&47 \\
\hline Malawi & & & $\mathrm{x}$ & & L1966(1992)Arts6-11\&20-22 \\
\hline Mali & $\mathrm{x}(1995)$ & & & & L2011Art249 \\
\hline Mauritania & & (x) (2010) & & & L1961(2010)Arts30-31 \\
\hline Mauritius & & $x \neq(1995)$ & & & L1968(1995)Arts9(4)\&14 \\
\hline Morocco & $\mathrm{x}$ & & & & L1958(2007)Art11,19\&20 \\
\hline Mozambique !! & $\mathrm{x}(2004)$ & & & $\begin{array}{l}\text { President cannot be dual } \\
\text { national }\end{array}$ & $\begin{array}{c}\text { C2004Arts27,31,33\&147 } \\
\text { L1975(1987)Arts10\&14 }\end{array}$ \\
\hline Namibia b & & $x \neq(1990)$ & & & $\begin{array}{l}\text { C1990(2010)Art4(8)(a) } \\
\text { L1990Art7(1)\&26 }\end{array}$ \\
\hline Niger & $\mathrm{x}(2014)$ & & & & L1984(2014)Arts19\&34 \\
\hline Nigeria $b$ & $\mathrm{x}(1999)$ & & & $\begin{array}{c}\text { President, state governors } \\
\text { and members of national and } \\
\text { state assemblies cannot be } \\
\text { dual nationals }\end{array}$ & $\begin{array}{c}\text { C1999Arts27\&28(1), } \\
66,107,137 \& 182\end{array}$ \\
\hline Rwanda & $\mathrm{x}(2003)$ & & & & $\begin{array}{l}\text { C2003Art7 } \\
\text { L2008Art3 }\end{array}$ \\
\hline $\begin{array}{l}\text { Sahrawi Arab Dem. } \\
\text { Rep. }\end{array}$ & & & & & $\mathrm{n} / \mathrm{a}$ \\
\hline $\begin{array}{l}\text { São Tomé and } \\
\text { Príncipe!! }\end{array}$ & $\mathrm{x}$ & & & $\begin{array}{c}\text { President and prime minister } \\
\text { cannot be dual nationals }\end{array}$ & $\begin{array}{l}\text { C2003Arts3,78\&100 } \\
\text { L1990Arts10\&12 }\end{array}$ \\
\hline
\end{tabular}




\begin{tabular}{|c|c|c|c|c|c|}
\hline \multirow[t]{2}{*}{ Country } & \multicolumn{3}{|c|}{ Dual nationality permitted? } & \multirow{2}{*}{$\begin{array}{c}\text { Restrictions on public } \\
\text { office }\end{array}$} & \multirow[t]{2}{*}{ Relevant legal provisions } \\
\hline & Yes & $\begin{array}{l}\text { Some- } \\
\text { times }\end{array}$ & No & & \\
\hline Senegal c & & $\mathrm{x}$ & & $\begin{array}{l}\text { President cannot be dual } \\
\text { national }\end{array}$ & $\begin{array}{c}\text { C2001(2008)Art28 } \\
\text { L1961(2013)Arts1,16bis,18,20 }\end{array}$ \\
\hline Seychelles & $\mathrm{x}$ & & & & $\begin{array}{l}\text { C1993(2011)Art13(2) } \\
\text { L1994(2013)Art12 }\end{array}$ \\
\hline Sierra Leone & $\mathrm{x}(2006)$ & & & & L1973(2006)Arts10,16 \\
\hline Somalia !! & $\mathrm{x}(2004)$ & & & & $\begin{array}{c}\text { C2012Art8 } \\
\text { L1962Arts2,4,6,10 }\end{array}$ \\
\hline South Africa d & & $(\mathrm{x})$ & & & L1995(2010)Art5(1)(h)\&6 \\
\hline South Sudan & $\mathrm{x}$ & & & & $\begin{array}{l}\text { C2011Art45(5)\&(6) } \\
\text { L2011Arts10\&15 }\end{array}$ \\
\hline Sudan !! & $\mathrm{x}$ & & & & $\begin{array}{c}\text { C2005Art7(4) } \\
\text { L1994(2011)Art10(2) }\end{array}$ \\
\hline Swaziland & & $x \ddagger^{\star}$ & & & $\begin{array}{l}\text { C2005Arts42(3)\&49(1)(c) } \\
\text { L1992Art10(1)(c) }\end{array}$ \\
\hline Tanzania & & & $\mathrm{x}$ & & L1995Art7 \\
\hline Togo & & $x \ddagger^{\star}$ & & $\begin{array}{l}\text { President cannot be dual } \\
\text { national }\end{array}$ & $\begin{array}{l}\text { C1992(2002)Art62 } \\
\text { L1978Art23 }\end{array}$ \\
\hline Tunisia & $\mathrm{x}(1975)$ & & & & L1963(2010)Arts21\&30 \\
\hline Uganda d & & (x) (2005) & & $\begin{array}{l}\text { List of posts for which } \\
\text { cannot be dual national, } \\
\text { including president, } \\
\text { vice-president, prime } \\
\text { minister, cabinet ministers, } \\
\text { heads of security services }\end{array}$ & $\begin{array}{l}\text { C1995(2005)Art15 } \\
\text { L1999(2009)Arts15-19,19A-G } \\
\text { and schedule } 5\end{array}$ \\
\hline Zambia & & & $x$ * & & $\begin{array}{l}\text { C1991(2009)Arts7(b)\&9 } \\
\text { L1975(1994)Arts16\&19 }\end{array}$ \\
\hline Zimbabwe !! & & $x \neq$ & & & $\begin{array}{c}\text { C2013Art42 } \\
\text { L1984(2003)Art4(1)(iv)\&9 }\end{array}$ \\
\hline
\end{tabular}

n/a not available

!! constitution conflicts with legislation: constitutional provisions noted here (in case of Sudan, dual nationality is permitted with any country other than South Sudan)

(x) permission of government required ; and in S Africa not permitted if the other country does not allow

$\star$ allowed for married woman (in some circumstances)

$\ddagger$ dual nationality allowed for nationals from birth / prohibited for those who naturalise

t dual nationality allowed for naturalized citizens / prohibited for those who voluntarily acquire another nationality

a Eritrea allows those who already had another nationality before 1992 to keep it, with permission

b Gambia, Namibia \& Nigeria state that a naturalized citizen who then acquires another nationality loses first naturalized nationality

c Senegal's legal provisions are almost the same as those in Benin, Guinea, Niger and Cote d'Ivoire, and in addition, it is stated that a person who acquires Senegalese nationality cannot hold another nationality - however, these laws are not applied and are interpreted to mean that dual nationality is permitted in all circumstances (except if the other country prohibits it).

d South Africa requires proof that the other country permits dual nationality.

e Uganda's dual nationality provisions, as amended in 2009, are very complex and create significant conditions to be able to hold dual nationality (especially by acquisition). It is not permitted to hold three nationalities, and the other country must permit dual nationality.

\subsubsection{Dual nationality and public office}

A number of African countries have rules prohibiting people with dual citizenship or those who are naturalised citizens rather than citizens from birth from holding senior public office, on the grounds that such office holders should not have divided loyalties.

The constitutions or nationality laws of several countries prohibit the president (and vice president and/or prime minister) from holding dual nationality, including Algeria, CapeVerde, Chad, Djibouti, Egypt, Equatorial Guinea, Gambia, Ghana, Kenya, Mozambique, São Tomé and Príncipe, Senegal,Togo and Uganda. (In other cases, such exclusions are provided in the electoral code: these have not been surveyed for this overview.) 
Ghana has an absolute prohibition on dual citizens holding a set of listed positions ${ }^{66}$, and several Ghanaian politicians have been barred from taking up ministerial positions until they have renounced a foreign nationality. ${ }^{67}$ In Côte d'Ivoire, the constitution prohibits those who have ever held another citizenship from becoming the president of the republic or the president or vice president of parliament. ${ }^{68}$ Uganda has a whole list of public offices that cannot be held by dual nationals, introduced at the time general rules on dual nationality were relaxed. Kenya's 2010 constitution similarly introduced, at the same time as the general prohibition on dual citizenship was lifted, a ban on dual nationals holding any state office (except for judges and members of commissions). ${ }^{69}$ Similar rules have recently been the subject of challenge in Egypt (see box).

In Nigeria, the 1999 Consitution appears to ban holders of elected public office from holding another nationality "subject to" the provisions of the article that permits dual nationality in most cases $^{70}$; however, the Court of Appeal has held that dual nationality is in fact no disqualification for public office for a Nigerian national from birth, given that the constitution allows a national from birth to hold another nationality. ${ }^{71}$ Nonetheless, cases of alleged dual nationality continue to be litigated: for example, the Peoples Democratic Party challenged the 2011 victory of the Oyo State governor-elect, Senator Abiola Ajimobi, of the Action Congress of Nigeria, on the grounds that the governor-elect held dual nationality with the United States. The Election Petitions Tribunal dismissed the petitions on grounds of lack of evidence presented to prove the case, and the Court of Appeal dismissed the appeal. ${ }^{72}$

66 Ghana Citizenship Act of 2000, section 16(2) lists the following posts to which a dual citizen may not be appointed: "(a) Chief Justice and Justices of the Supreme Court; (b) Ambassador or High Commissioner; (c) Secretary to the Cabinet; (d) Chief of Defence Staff or any Service Chief; (e) Inspector-General of Police; (f) Commissioner, Custom, Excise and Preventive Service; (g) Director of Immigration Service; (h) Commissioner, Value Added Tax Service; (i) Director-General, Prisons Service; (j) Chief Fire Officer; (k) Chief Director of a Ministry; (l) The rank of a Colonel in the Army or its equivalent in the other security services; and (m) Any other public office that the Minister may by legislative instrument prescribe." See also, Constitution of the Republic of Ghana, 1992, article 94(2).

${ }^{67}$ For example, in the cases of Ekow Spio-Garbrah,Akwasi Agyemang Prempeh, and Stephen Dee Larbi. The rules were litigated in the case of Professor Stephen Kwaku Asare vs. Attorney-General [2012] SCGLR 460, decision delivered on 22 May 2012; discussed in Daniel Korang, "Limited rights of dual citizens: a resurgence of caste system?” 10 August 2013, at http:/ /www.ghanaweb. com/GhanaHomePage/features/artikel.php?ID=281797, last accessed 28 February 2014.

68 Constitution of Côte d'Ivoire, articles 35 and 65.

69 Constitution of Kenya, 2010, Article 78.

70 For example, Article 182 (1)(a) of the 1999 constitution provides that: "No person shall be qualified for election to the office of governor of a state if; subject to the provision of 28 of this constitution, he has voluntarily acquired the citizenship of a country other than Nigeria or except in such cases as may be prescribed by the National Assembly, he has made a declaration of allegiance to such other country." Similar provisions apply to members of the Federal House of Representatives and Senate, to State Houses of Assembly, and to the President (articles 66, 107, and 137).

71 Ogbeide v. Osula [2004] 12 NWLR, Part 886, page 86.

72 Yemi Banjo, "Oyo gov election: PDP heads for tribunal, Accuses Ajimobi of having dual 


\section{Egypt: dual nationality and political rights}

The Egyptian constitution provides that "Egyptian Nationality is defined by law." ${ }^{73}$ The law in force is Law No. 26 of 1975 Concerning Egyptian Nationality (as amended in 2004), which forbids an Egyptian nationals from obtaining nationality of another country without the permission of the minister of the interior. ${ }^{74}$ However, in practice a person is considered to retain Egyptian nationality together with the new nationality unless a notice is published in the Official Gazette that Egyptian nationality is lost. $^{75}$

Between 1998 and 2003, 26 individuals lost their nationality because they obtained foreign nationalities without the consent of the Egyptian government. In addition, between 1986 and 2004, 7,196 individuals lost their Egyptian nationality after being allowed to obtain foreign nationalities and abandon their Egyptian one. It is possible for a person to appeal the minister's decision to revoke nationality with the Council of State. ${ }^{76}$

citizenship", Tribune, 19 May 2011; Yemi Banjo and Saliu Gbadamosi, "Ajimobi is Oyo gov -Tribunal Dismisses PDP's, AA's petitions; Bauchi tribunal upholds Yuguda's election”, Tribune, 11 November 2011; “Appeal court affirms Ajimobi’s election”, Tribune, 6 January 2012.

73 Constitution of the Arab Republic of Egypt, 1971, article 6; the 2014 Constitution, article 6, repeats this provision but also adds that nationality is the right of any child of an Eyptian father or mother.

74 "It is not permitted for an Egyptian to obtain a foreign nationality without the Minister of Interior's permission; otherwise he will be considered an Egyptian citizen in all forms and situations provided the Council of Ministers does not decide to revoke his citizenship in accordance with Article 16 of this Law. The Egyptian citizen will lose his nationality if he obtains a foreign citizenship after receiving permission from the authorities. However, it is permitted that the applicant's request to obtain a foreign nationality contain a request to keep the Egyptian citizenship for himself, his wife, and his children. If he expresses his wish to keep his Egyptian citizenship during a period that does not exceed one year following his naturalization, he and his family will keep their Egyptian citizenship despite their naturalization." Egypt Nationality Act (No. 26 of 1975), section 10 (unofficial translation by UNHCR). See also instructions on dual citizenship approval, available from Egyptian embassies, for example in Washington DC at http://www.egyptembassy. net/consular-services/immigration-citizenship/dual-citizenship-approval/, last accessed 28 February 2014. In addition, Law 45 of 1982 prohibits Egyptians who work for the diplomatic corps from marrying foreigners, and Law 232 of 1959 also prohibits military officers from marrying foreigners.

75 According to expert evidence given to the UK Special Immigration Appeals Commission in the case of Abu Hamza vs. Secretary of State for the Home Department, Appeal No: SC/23/2003, preliminary issue open judgment, dated 5 November 2010.

76 A. Khalil, Halat Isqat wa Zawal Al-Genseya Al-Misriya. (Cases of Revocation and Loss of Egyptian Citizenship), cited in CMRS, Africa Citizenship and Discrimination Audit: The Case Study of Egypt, 2005. On the other hand, between 1986 and 2005, 819 persons had their 
The issue of dual nationality in Egypt has proved contentious in recent years, particularly as it relates to politicians and other prominent public figures; even though no restrictions were placed on dual nationality for elected representatives in the 1971 constitution or in the 1975 nationality law. The controversy came to the fore on the eve of the parliamentary elections in October 2000, when a candidate contested the credentials of his opponent and asked for his exclusion on the grounds that he had both Dutch and Egyptian nationalities. In January 2001, three court decisions barred Egyptians who held dual nationality from being members of parliament. In the first case, the Administrative Court ruled that a business magnate, Rami Lakah, who held a French passport in addition to his Egyptian nationality, could not be a parliamentarian. Basing its decision on Article 90 of the 1971 constitution, which required an oath to preserve the safety of the nation, the court held that, since Egyptians who carry other nationalities are exempt from military service and prohibited from enrolling in military and police academies, "it cannot be imagined that the person who is required to look after the country's interest may share his loyalty to Egypt with another country." The second and third decisions, by the Supreme Administrative Court, went against Mohamed Ahmed Mohamed Saleh, who was said to have forfeited Egyptian nationality after gaining German nationality, and Talaat Mutawi, who held American and Egyptian passports. The decisions were final and could not be appealed. In September 2001, the Supreme Administrative Court confirmed that the parliamentary membership of Lakah was null and void because he had dual nationality. ${ }^{77}$

These decisions encouraged other persons to file similar appeals against prominent ruling National Democratic Party candidates believed to hold dual nationality, including Economy Minister Youssef Boutros Ghali, Minister of Housing Mohamed Ibrahim Suleiman, and a businessman, Mohamed Abul-Enein. Ghali and Suleiman presented the court with documents attesting that they did not hold a second nationality. ${ }^{78}$

Mohamed Moussa, chairman of the Constitutional and Legislative Affairs Committee in the Peoples' Assembly (the Egyptian parliament), said that the 26-member committee would convene, prepare a report on the ruling, and present it to the plenary assembly. This would take place at the start of the new parliamentary session in November 2001. The assembly would then put the matter to a vote. A two-thirds majority was required for the annulment of Lakah's membership. Although Zakariya Shalash, head of the

citizenship restored following a decision/decree issued by the Minister of Interior in accordance with section 18 of the Nationality Law (Ibid.).

77 Amira Howeidy, "Egyptian to the core", Al-Ahram Weekly On-line, 11 - 17 January 2001, Issue 516.

78 Ibid. 
Court of Cassation, argued that the court rulings should be implemented immediately in accordance with the constitution, the assembly argued that it had sole jurisdiction over its own affairs, ${ }^{79}$ and confirmed the cancellation of the membership of both Lakah and Mutawi. ${ }^{80}$

In 2004, the Constitutional and Legislative Affairs Committee stated its opinion that appointing dual nationality persons to the cabinet did not violate the law or the constitution, on the grounds that the court ruling banning dual nationality persons from standing for election did not apply to appointed ministers and executive officials. The chair of the committee, Mohamed Moussa, added that he saw no need to amend the nationality law, noting that dual nationals should enjoy all constitutional and legal rights granted to citizens except nomination for parliament. ${ }^{81}$

Nationality and public office in Egypt came back to prominence following the upheavals set off by the 2011 Arab awakening and the fall of President Hosni Mubarak. New strict nationality requirements were introduced for those wishing to be run for president in 2012, requiring that candidates be born in Egypt to Egyptian parents, not be dual nationals, and not be married to a foreigner. ${ }^{82}$ At least one Islamist candidate, Hazim Abu Isma' il, was removed from the ballot because of his mother's acquisition of US citizenship. ${ }^{83}$ In 2014, the new constitution confirmed these new conditions. Article 141 stated that "A presidential candidate must be an Egyptian born to Egyptian parents, and neither he or his parents or his spouse may have held any other nationality." Article 164 provided the same criteria for the Prime Minister.

\subsection{Rights for the African diaspora}

Some African countries - among them Ethiopia and Ghana-have created an intermediate status for members of their diaspora, in addition to or instead of creating a right to dual nationality.

79 Omayma Abdel-Latif, “On the edge”, Al-Ahram Weekly Online, 30 August - 5 September 2001, Issue 549.

80 Akher Sa'a (Cairo), 2 November 2001. Assistance in research in Arabic was kindly given by Abdel Salam Hassan, formerly of the Sudan Human Rights Organisation and Justice Africa.

81 Asharq Al-awsat (London), 18 July 2004.

82 "Egypt sets presidential election rules”, BBC News, 30 January 2012.

83 Gianluca Parolin, "Egypt: Citizenship Requirements at the Test of Presidential Elections", http://eudo-citizenship.eu/news/citizenship-news/655-egypt-citizenship-requirements, 4 June 2012, last accessed 28 February 2014. 


\subsubsection{Ethiopia}

Ethiopia has never recognized dual nationality. The 1930 Nationality Law, the 1995 Constitution and the 2003 Proclamation on Ethiopian Nationality all provide that when an Ethiopian acquires another nationality, he or she automatically loses his or her Ethiopian nationality, and that an applicant for naturalisation must renounce another nationality.

Hundreds of thousands of people of Ethiopian descent live in foreign countries. While most left for economic reasons, political turbulence during military rule from 1974 to 1991 forced many others to seek refuge abroad, mainly in the United States and Europe. Many of these people have for practical reasons accepted the citizenship of their host countries; and although advocacy for dual nationality was not successful, since 2002, "foreign nationals of Ethiopian origin" may be issued special identity cards that entitle the holder to various benefits. A foreign national of Ethiopian origin is defined as follows:

A foreign national, other than a person who forfeited Ethiopian nationality and acquired Eritrean nationality, who had been an Ethiopian national before acquiring a foreign nationality; or at least one of his parents, grand parents or great grand parents was an Ethiopian national. ${ }^{84}$

Holders of such cards enjoy rights and privileges that other foreigners do not, including visa-free entry, residence, and employment, the right to own immovable property in Ethiopia, and the right to access public services.

\subsubsection{Ghana}

Ghana's substantial overseas diaspora has resulted in a change to the previous prohibition on holding two passports. ${ }^{85}$ Since 2002, Ghana has accepted dual citizenship, although the Citizenship Act prohibits Ghanaians who have acquired citizenship of another country from being elected to the presidency or to parliament, and from appointment to certain public offices. ${ }^{86}$

Ghana is also the first African state to provide the right of return and indefinite stay for members of the broader African diaspora. Under Section 17(1)(b) of the Immigration Act 573 of 2000 , the minister of the interior may, with the approval of the president, grant the "right of abode" to a person of African descent. This provision was a response to lobbying from the many African Americans who have

84 "Proclamation No. 270/2002: Providing Ethiopians resident abroad with certain rights to be exercised in their country of origin," 5 February 2002.

85 Doreen Lwanga, "Ghana upholds the spirit of pan-African citizenship", Pambazuka News, 7 March 2007; Constitution of the Republic of Ghana, articles 10 and 13; GhanaDemocracy and Political Participation, Dakar: Open Society Initiative for West Africa and AfriMAP, 2007, pp. 27-28.

86 Dual Citizenship Regulation Act (No. 91 of 2002), 1 December 2002, amending the Citizenship Act, 2000 (Act 591). 
moved to Ghana since its independence and taken up residence in the country. The government has also indicated that it intends to adopt provisions facilitating travel and investment by members of the Ghanaian diaspora. ${ }^{87}$ A Non-Resident Ghanaians Secretariat (NRGS) was set up in May 2003 to promote further links with Ghanaians abroad and to encourage return. ${ }^{88}$

\subsection{Citizenship by naturalisation}

All African countries permit, in principle, the acquisition of citizenship by naturalisation on the basis of long term residence and other conditions. ${ }^{89}$ In some countries, acquiring citizenship by naturalisation is relatively straightforward, at least in theory. In practice, however, obtaining citizenship by naturalisation can be very difficult.

More than 20 countries provide for a right to naturalise based on legal residence of five years; but in Chad, Nigeria, Sierra Leone, and Uganda, the period required is up to 15 or 20 years, while in the Central African Republic, it is 35 years. South Africa provides a two-step process. A person must first become a permanent resident, a process which usually takes five years (except when married to a citizen); a further five years' residence is required to become a citizen..$^{90}$

Other countries apply much stricter rules, often designed specifically to make it more difficult for those persons who are not "natives" of the country to obtain citizenship. In many countries investigations are required, including interviews and police inquiries. Under the 2004 nationality law adopted by the Democratic Republic of Congo, applications for naturalisation must be considered by the

87 Lois Beckett, "Ghana: Echoes From Panafest-Diasporans Demand Full Ghanaian Citizenship" Ghana Mail, 4 August 2007.

88 John Anarfi and Stephen Kwankye, "Migration from and to Ghana:A Background Paper," Working Paper C4, Development Research Centre on Migration, Globalisation and Poverty, University of Sussex, December 2003.

89 The suggested definition for naturalisation in the EUDO citizenship glossary is: "Any mode of acquisition after birth of a nationality not previously held by the target person that requires an application by this person or his or her legal agent as well as an act of granting nationality by a public authority." See http://eudo-citizenship.eu/databases/ citizenship-glossary/glossary\#Nation, last accessed 15 January 2015. In many African countries there is also the possibility of acquiring citizenship by an easier process known in the Commonwealth countries (though not consistently), as "registration" and in civil law countries as "declaration" or "option". These non- or less-discretionary processes are usually open to spouses of citizens or to persons born in the country and still resident there at majority (and are covered above in relation to the rules applied to children born in the country or in case of marriage). Confusingly, in some Commonwealth countries, such as Kenya and Zambia, law reforms adopted since independence mean that there is only one process, known as registration, and this is discretionary rather than being a purely administrative process (the original meaning of registration in the independence constitutions and laws).

90 South African Citizenship Act (No. 88 of 1995), section 5. 
Council of Ministers and submitted to the National Assembly before being awarded by presidential decree; in this it follows the Belgian example, where naturalisation is by act of parliament. ${ }^{11}$ In addition, the individual must have rendered "distinguished service" (d'éminents services) or his or her naturalisation must represent a real benefit with an observable impact for the country (un intérêt réel à impact visible) to the country, while conviction for a whole series of crimes related to the civil war excludes naturalisation. ${ }^{92}$

In North Africa, Muslims and Arabs often have easier access to nationality by naturalisation. In Egypt, naturalisation is rarely granted, and categories of people who in many other countries have the right to recognition of citizenship from birth can only be naturalised, including those born in the country of parents also born there or who are born there and are still resident in the country at majority. There are preferential terms for those who are of Egyptian or Arab origin or who are Muslims. ${ }^{93}$ Libya, seeking to buttress the concept of a pan-Arab identity, renamed its nationality "Arabic nationality" in 1980, and provided for any person of Arab descent (with the exception of Palestinians) to have the right to claim citizenship on entering Libya if he or she intended to live there (and renounced any other nationality). The only non-Arabs who could naturalise were women. The 2010 nationality law, however, removed this ethno-linguistic bias. ${ }^{94} \mathrm{~A}$ similar sort of preference is shown in the Rwanda, where the constitution provides that "All persons originating from Rwanda and their descendants shall, upon their request, be entitled to Rwandan nationality" (though no modalities are provided in the 2008 nationality law, other than application for a nationality certificate). ${ }^{95}$

Liberia and Sierra Leone, in line with their other provisions based on race, take the position that only those persons "of Negro descent" may be citizens from birth. Sierra Leone also has more restrictive rules for naturalisation of "nonNegroes" than "Negroes," while Liberia forbids "non-Negroes" from becoming citizens at all. Ghana does not discriminate on racial grounds in general, but as noted in chapter 5.4, provides for preferential treatment for naturalisation for those of African descent. ${ }^{96}$

In addition to requirements of legal residence, some countries apply criteria to naturalisation based on cultural assimilation, in particular knowledge of the national language(s). At the most demanding, Ethiopia used to require an applicant to "Know Amharic language perfectly, speaking and writing it fluently"; in 2003, the law was reformed to require only that the applicant be "able to

\footnotetext{
91 As of 2014, Code de la nationalité belge, 28 June 1984, Article 12.

92 Loi nº 04-024 du 12 novembre 2004 relative à la nationalité congolaise, articles 11-12.

93 Law No.26 of 1975 concerning Egyptian nationality, article 4.

94 Nationality Law No.17 of 1954, articles 5 and 7; Libya Law No.18 of 1980 pertaining to the resolutions of the Nationality Act; Libya Nationality Law No.24 of 2010.

95 Rwandan Constitution 2003, Article 7.

96 Ghana Citizenship Act (No.591 of 2000), section 14.
} 
communicate in any one of the languages spoken by the nations/nationalities of the Country." ${ }^{97}$ In 2008, Rwanda similarly deleted a requirement that a candidate for naturalisation be able to speak Kinyarwanda, in favour of a provision that he or she should "respect Rwandan culture and be patriotic." " Botswana requires a knowledge of Setswana or another language spoken by a "tribal community" in Botswana; ${ }^{99}$ Ghana requires knowledge of an indigenous Ghanaian language; ${ }^{100}$ and other countries have similar requirements. Egypt, in line with its generally preferential treatment for Arab foreigners, requires an applicant for naturalisation to "be knowledgeable in Arabic." 101 Sudan's 1993 Nationality Act, however, removed a requirement to know Arabic that had been included in the 1957 legislation (apparently to allow non-Arab Muslims easier access to Sudanese nationality). ${ }^{102}$ Mauritania redefined the languages required for naturalisation in 2010, removing French and Bambara (mainly spoken in Mali) from the list. ${ }^{103}$ Even where there are no such rules on paper, cultural criteria may be applied. In Swaziland and Madagascar, persons who are not of Swazi or Malagasy ethnic origin often find it impossible to obtain citizenship. ${ }^{104}$

Naturalisation procedures are often left almost entirely to the discretion of the executive in both the civil and common law systems. A large number of countries provide that no reasons need be given for the refusal to approve a naturalisation and the decision cannot be challenged. ${ }^{105}$ In some cases, as in Niger, a failure to provide a decision on an application within a defined period is treated as a rejection, and the person must start again from scratch, while "the formal or implicit rejection of a request for naturalisation is not subject to any challenge". ${ }^{106}$ In Liberia, however, uniquely in Africa, the Aliens and Nationality Law gives "exclusive jurisdiction" to naturalise persons as citizens of Liberia to the circuit courts in each county, which are to hear the application in open court.

97 Proclamation 378/2003 on Ethiopian Nationality, section 5(3).

98 Organic law n ${ }^{\circ}$ 29/2004 of 3 December 2004 on Rwandan nationality, section 15; Organic law no.30/2008 of 25 July 2008 on Rwandan nationality.

99 Citizenship (Amendment) Act, 1995, section 5, amending section 12 of the Citizenship Act, 1982.

100 Constitution of the Republic of Ghana, 1992, article 9(2); Ghana Citizenship Act, 2000, section 14(e).

101 Egypt Nationality Act (No. 26 of 1975).

102 Section 8, Sudanese Nationality Law 1957; Section 7, Sudanese Nationality Law 1993.

103 Loi No.2010-023 du 11 février 2010, replacing Article 19 of the nationality code to provide a new list of national languages: Arabic, Pular, Soninké and Wolof (previously Toucouleur, Saracollé, Wolof, Bambara, Hassaniya, Arabic and French. Toucouleur and Pular are effectively the same, and so are Saracollé and Soninké).

104 Bureau of Democracy, Human Rights, and Labor, "Swaziland" and "Madagascar", in the annual Country Reports on Human Rights Practices, U.S. Department of State.

105 Among them, Central African Republic, Comoros, Congo Republic, Côte d'Ivoire, Djibouti, Equatorial Guinea, Guinea, Lesotho, Madagascar, Mali, Mauritania, Niger, Seychelles, Swaziland, Togo, Zambia and Zimbabwe.

106 Niger, Code de la nationalité 1984, article 24. 
The attorney-general may also "designate an immigration officer to conduct a personal investigation of the person", on the basis of which the attorney-general may petition the court in support or opposition to the application; the court must give reasons in case of denial of the application. ${ }^{107}$

Discretion in naturalisation is exemplified in the fact that almost all countries have provisions on the books allowing for the grant of nationality by naturalisation in case of "exceptional services" rendered to the country or other similar criteria. Such provisions are often controversial: proposed amendments to the law to give the president more discretion to award naturalisation led to protests in Angola during 2014. ${ }^{108}$ Comoros takes this to a higher level with its 2008 law on "economic citizenship", providing for the naturaliation of "economic partners" intending to invest a minimum sum in the country. ${ }^{109}$ Controversially, the law has been invoked mainly for the grant of Comoros nationality documents to stateless persons, known as bidoon, from the United Arab Emirates (UAE) and more recently Kuwait, who have been pressed to take up this option. Human Rights Watch noted reports from Le Monde and Al Jazeera in 2009 that the UAE government paid US $\$ 200$ million to the government of the Comoros, at that time equal to 40 percent of the islands' GDP, to offer citizenship to stateless UAE residents. The Comoros ambassador to the UAE was quoted in the Financial Times in 2012 saying that more than one thousand stateless persons had obtained Comoros citizenship in this way. The hope held out was that on the basis of the Comoros documents, the bidoon could then regularise their status in UAE; but in at least one case the new nationality merely facilitated the deportation of the activist - to Thailand. ${ }^{110}$

107 Aliens and Nationality Law, 1973, arts 21.1 to 21.5. Among the requirements to naturalise are that a person must "state that he does not believe in anarchy".

108 António Rocha, "Angolanos indignados com proposta de mudanças na Lei da Nacionalidade ", Deutsche Welle, 7 October 2014.

109 Loi relative à la citoyenneté économique en Union des Comores, 2008, full text published in Al Watwan newspaper, 3 December 2008. The law was passed by 18 to 15 votes in the national assembly.

110 See, for example, "Stateless Arabs lose bid to call Comoros home" AFP, 27 July 2008 ; "UAE: Free Blogger Activist — Advocate for Stateless 'Bidun' Says Authorities Threaten to Deport Him" Human Rights Watch, 28 May 2012; "UAE: Stop Expulsion of Bidun Activist", Human Rights Watch, 15 July 2012; Camilla Hall and Michael Peel, "UAE's stateless acquire foreign passports", Financial Times, 4 June 2012; "Kuwait's stateless Bidun 'offered Comoros citizenship"” BBC News, 10 November 2014; "Kuwait 'playing games' with lives of more than 100,000 Bidun residents", Amnesty International, 10 November 2014. 
Table 7: Right to acquire citizenship as an adult by naturalisation

\begin{tabular}{|c|c|c|c|c|}
\hline Country & Res. period & $\begin{array}{c}\text { Language / cultural require- } \\
\text { ments }\end{array}$ & Character & Ren. Other \\
\hline Algeria & $7 \mathrm{yrs}$ & $\begin{array}{l}\text { Assimilation into Algerian } \\
\text { community }\end{array}$ & $\begin{array}{l}\text { Good morality; no conviction involving loss } \\
\text { of civil rights (condemnation infamante) }\end{array}$ & No \\
\hline Angola & $10 \mathrm{yrs}$ & $\begin{array}{l}\text { Civic and moral guarantees of } \\
\text { integration into Angolan society }\end{array}$ & $\begin{array}{l}\text { Can be opposed before Supreme Court if } \\
\text { no effective connection, sentenced to prison } \\
\text { more than } 8 \text { years, crime against security } \\
\text { of state, worked for foreign state without } \\
\text { authorisation, military service for another } \\
\text { state }\end{array}$ & No \\
\hline Benin & $\begin{array}{l}3 \text { yrs } \\
\text { none for } \\
\text { husband }\end{array}$ & $\begin{array}{l}\text { assimilation into Beninois c } \\
\text { ommunity, in particular " } \\
\text { sufficient knowledge" of } \\
\text { Beninois language or French }\end{array}$ & $\begin{array}{l}\text { Good conduct and morals; no convictions of } \\
\text { more than a year of imprisonment. }\end{array}$ & No \\
\hline Botswana & 11 yrs $(10+1)$ & $\begin{array}{l}\text { Sufficient knowledge of Setswana } \\
\text { or any language spoken by any } \\
\text { "tribal community" in Botswana }\end{array}$ & Good character & No \\
\hline Burkina Faso & $\begin{array}{l}10 \text { yrs } \\
2 \text { yrs if born } \\
\text { in BF }\end{array}$ & - & $\begin{array}{l}\text { Good conduct and morals; no convictions for } \\
\text { more than one year of imprisonment }\end{array}$ & No \\
\hline Burundi & $\begin{array}{l}10 \text { yrs / } \\
5 y r s \text { for hus- } \\
\text { band }\end{array}$ & $\begin{array}{l}\text { Attachment to Burundi and } \\
\text { "assimilation with Burundian } \\
\text { citizens" }\end{array}$ & $\begin{array}{l}\text { Good conduct and morals; no convictions for } \\
\text { any "crime" or "délit" }\end{array}$ & No \\
\hline Cameroon & $\begin{array}{l}5 \text { yrs / none } \\
\text { for husband }\end{array}$ & $\begin{array}{c}\text { Cameroon the "centre of his/her } \\
\text { principal interests" }\end{array}$ & $\begin{array}{l}\text { Good conduct, life and morals; no convictions } \\
\text { for any "crime" or "délit" }\end{array}$ & Yes \\
\hline Cape Verde & $5 \mathrm{yrs}$ & - & Produce police report & No \\
\hline CAR & $35 \mathrm{yrs}$ & - & - & No \\
\hline Chad & $15 \mathrm{yrs}$ & - & $\begin{array}{l}\text { Good conduct and morals; no convictions to } \\
\text { prison sentence }\end{array}$ & No \\
\hline Comoros & $\begin{array}{l}10 \text { yrs / } \\
5 \text { yrs for } \\
\text { husband }\end{array}$ & $\begin{array}{l}\text { Assimilation with the Comorian } \\
\text { community }\end{array}$ & Good conduct and morals & No \\
\hline Congo Republic & $10 \mathrm{yrs}$ & $\begin{array}{l}\text { Assimilation with Congolese } \\
\text { community }\end{array}$ & $\begin{array}{l}\text { Good conduct and morals; no convictions to } \\
\text { more than } 1 \mathrm{yr} \text { of prison }\end{array}$ & Yes \\
\hline Côte d'Ivoire a & $5 \mathrm{yrs}$ & - & Good conduct and morals. & No \\
\hline
\end{tabular}




\begin{tabular}{|c|c|c|c|c|}
\hline Health / income & Other1 & $\begin{array}{l}\text { Minor children } \\
\text { included? }\end{array}$ & $\begin{array}{l}\text { Limits on rights for } \\
\text { naturalised } 2\end{array}$ & Legal provision \\
\hline $\begin{array}{l}\text { Good mental and } \\
\text { physical health; means } \\
\text { of subsistence. }\end{array}$ & $\begin{array}{c}\text { No conditions if exceptional services or } \\
\text { special interest to Algeria }\end{array}$ & Yes, automatically & $\begin{array}{l}\text { President must have } \\
\text { nationality of origin }\end{array}$ & $\begin{array}{l}\text { C1989(1996)Art73 } \\
\text { L1970(2005)Arts10-17 }\end{array}$ \\
\hline $\begin{array}{l}\text { Capacity to make } \\
\text { decisions (reger a sua } \\
\text { pessoa); means of } \\
\text { subsistence }\end{array}$ & $\begin{array}{c}\text { Nat Ass can authorise naturalisation } \\
\text { if relevant services or exceptional } \\
\text { qualifications. }\end{array}$ & Yes, on application & $\begin{array}{l}\text { President must have } \\
\text { nationality of origin, } \\
\text { naturalised person can only } \\
\text { be member of national } \\
\text { assembly after } 7 \text { yrs }\end{array}$ & $\begin{array}{l}\text { C2010Arts110,129, } 145 \\
\text { L2005Arts10,13,17-18 }\end{array}$ \\
\hline $\begin{array}{l}\text { Good physical and } \\
\text { mental health }\end{array}$ & $\begin{array}{l}\text { no residence period if born in Benin or } \\
\text { important services or interest for Benin }\end{array}$ & Yes, automatically & $\begin{array}{l}\text { President must be national } \\
\text { of origin or naturalised } 10 \\
\text { yrs; generally } 5 \text { yrs before } \\
\text { public functions; } 3 \text { yrs } \\
\text { before can vote }\end{array}$ & $\begin{array}{c}\text { C1990Art44 } \\
\text { L1965Arts34-36, 41-43 }\end{array}$ \\
\hline- & $\begin{array}{l}\text { Any person may be registered if signal } \\
\text { honour or distinguished service, } \\
\text { or special circumstances; language } \\
\text { requirement may be waived }\end{array}$ & $\begin{array}{l}\text { Yes, at discretion of } \\
\text { minister }\end{array}$ & $\begin{array}{l}\text { President \& vice president } \\
\text { must be citizen by birth or } \\
\text { descent }\end{array}$ & $\begin{array}{c}\text { C1966(2002)Arts33\&39 } \\
\text { L1998(2002\&04) } \\
\text { Arts9-14 }\end{array}$ \\
\hline Good mental health; & $\begin{array}{l}\text { period reduced to } 2 \text { years if born in } \mathrm{BF} \\
\text { or important services etc; important } \\
\text { investments if a business person }\end{array}$ & Yes, automatically & $\begin{array}{l}3 \text { yrs before public functions } \\
\text { or vote }\end{array}$ & $\begin{array}{c}\text { L1989Arts162-170, } \\
180-184\end{array}$ \\
\hline- & $\begin{array}{l}\text { Exception to res period can be made in } \\
\text { cases of "exceptional service" to Burundi }\end{array}$ & Yes, automatically & $\begin{array}{c}\text { President must be national } \\
\text { from birth; otherwise } 10 \mathrm{yrs} \\
\text { before can be elected }\end{array}$ & $\begin{array}{c}\text { C2005Art97 } \\
\text { L2000Arts3 \& 7-9 }\end{array}$ \\
\hline $\begin{array}{l}\text { Good physical and } \\
\text { mental health }\end{array}$ & $\begin{array}{l}\text { no residence period if born in Cameroon } \\
\text { or "exceptional services" }\end{array}$ & No & $\begin{array}{l}5 \text { yrs before eligible to be } \\
\text { elected }\end{array}$ & $\begin{array}{l}\text { L1968Arts25-27, } 30 \\
\& 31\end{array}$ \\
\hline $\begin{array}{l}\text { Capacity to make } \\
\text { decisions; means of } \\
\text { subsistence }\end{array}$ & $\begin{array}{l}\text { Period can be waived if of } \mathrm{CV} \text { descent, } \\
\text { or if sizable investment promised }\end{array}$ & Yes, on application & $\begin{array}{l}\text { President must have } \\
\text { nationality of origin }\end{array}$ & $\begin{array}{l}\text { C1992(2010)Art110 } \\
\text { L1993Arts8,12,13 (cross } \\
\text { refer to L1992Art12) }\end{array}$ \\
\hline- & $\begin{array}{l}\text { In addition to } 35 \mathrm{yr} \text { res, must also have } \\
\text { sufficient investments in permanent } \\
\text { agriculture or property and have received } \\
\text { a national honour; no conditions if } \\
\text { "exceptional services"; no residence } \\
\text { period some cases for children or spouse }\end{array}$ & $\begin{array}{c}\text { Yes, automatically } \\
\text { if father acquires } \\
\text { (or mother if father } \\
\text { dead), though can be } \\
\text { opposed }\end{array}$ & $\begin{array}{l}3 \text { yrs before can vote or be } \\
\text { appointed to office; } 5 \text { yrs } \\
\text { before can be elected }\end{array}$ & L1961Art26-31, 41-45 \\
\hline $\begin{array}{l}\text { no physical or mental } \\
\text { incapacity that could } \\
\text { be a charge on the } \\
\text { collectivity }\end{array}$ & $\begin{array}{c}\text { Period can be waived if "exceptional } \\
\text { services" and the person was born in } \\
\text { Chad }\end{array}$ & Yes, automatically & $\begin{array}{l}\text { President must be national } \\
\text { from birth, of two parents } \\
\text { also nationals of origin; } \\
\text { otherwise, decrees may } \\
\text { establish restrictions }\end{array}$ & $\begin{array}{l}\text { C1996Art62 } \\
\text { L1962Arts21-24 }\end{array}$ \\
\hline $\begin{array}{l}\text { Sound mind; physical } \\
\text { health means will not } \\
\text { become a charge on } \\
\text { the public }\end{array}$ & $\begin{array}{l}\text { Period reduced to } 5 \text { yrs if born in } \\
\text { Comoros or in case of "important } \\
\text { services"; no residence period in some } \\
\text { cases for children or spouse. Fee set in } \\
\text { law at } 20,000 \mathrm{~F}(1979)\end{array}$ & $\begin{array}{c}\text { Yes, automatically } \\
\text { if father acquires } \\
\text { (or mother if father } \\
\text { dead), though can be } \\
\text { opposed }\end{array}$ & $\begin{array}{c}10 \text { yrs before can be elected, } \\
5 \text { yrs before can vote or be } \\
\text { appointed to office }\end{array}$ & L1979Arts28-35, 48-50 \\
\hline $\begin{array}{l}\text { Sound mind; physical } \\
\text { health means will not } \\
\text { become a charge on } \\
\text { the public }\end{array}$ & $\begin{array}{c}\text { no residence period in some cases for } \\
\text { children or spouse, or if exceptional } \\
\text { services }\end{array}$ & $\begin{array}{c}\text { Yes, automatically } \\
\text { if father acquires } \\
\text { (or mother if father } \\
\text { dead), though can be } \\
\text { opposed }\end{array}$ & $\begin{array}{l}\text { President must be national } \\
\text { of origin; otherwise } 10 \mathrm{yrs} \\
\text { before can be elected, } 5 \\
\text { yrs before can vote or be } \\
\text { appointed to office }\end{array}$ & $\begin{array}{c}\text { C2002Art57 } \\
\text { L1961(1993)Arts27-34; } \\
\text { 44-46 }\end{array}$ \\
\hline $\begin{array}{l}\text { Sound mind; physical } \\
\text { health means will not } \\
\text { become a charge on } \\
\text { the public }\end{array}$ & $\begin{array}{l}\text { period reduced to } 2 \text { yrs if born in CI } \\
\text { or if "important services"; no residence } \\
\text { period in some cases for children or } \\
\text { spouse, or if "exceptional services" }\end{array}$ & Yes, automatically & $\begin{array}{l}\text { President must be national } \\
\text { of origin, of both parents } \\
\text { also nationals of origin; } 10 \\
\text { yrs before can be elected, } \\
5 \text { yrs before can vote or be } \\
\text { appointed to office }\end{array}$ & $\begin{array}{c}\text { C2000Art35 } \\
\text { L1961(2013)Arts 25-32, } \\
\text { 42-47 }\end{array}$ \\
\hline
\end{tabular}




\begin{tabular}{|c|c|c|c|c|}
\hline Country & Res. period & $\begin{array}{l}\text { Language / cultural require- } \\
\text { ments }\end{array}$ & Character & Ren. Other \\
\hline $\begin{array}{l}\text { Dem. Rep. } \\
\text { Congo }\end{array}$ & $7 \mathrm{yrs}$ & $\begin{array}{l}\text { Speak one of the Congolese } \\
\text { languages; must then maintain } \\
\text { clear cultural, professional, } \\
\text { economic, emotional or familial } \\
\text { links with the DRC }\end{array}$ & $\begin{array}{l}\text { Good conduct and morals; never convicted } \\
\text { for treason, war crimes, genocide, terrorism, } \\
\text { corruption or various other crimes. }\end{array}$ & Yes \\
\hline Djibouti & $\begin{array}{l}10 \text { yrs } / 5 \text { yrs } \\
\text { for spouse } \\
\text { if there are } \\
\text { children } \\
\end{array}$ & $\begin{array}{l}\text { Assimilation, in particular suffi- } \\
\text { cient knowledge of one of the } \\
\text { languages used }\end{array}$ & $\begin{array}{l}\text { Good conduct and morals; no convictions } \\
\text { for "crime" or "délit" against state security, } 6 \\
\text { mths in prison for crime of dishonesty. }\end{array}$ & No \\
\hline Egypt b & $10 \mathrm{yrs}$ & Knowledge of Arabic & $\begin{array}{l}\text { Good conduct and reputation, no convictions } \\
\text { for crime against honour }\end{array}$ & No \\
\hline Equatorial Guinea & $10 \mathrm{yrs}$ & - & - & Yes \\
\hline Eritrea $c$ & $20 \mathrm{yrs}$ & $\begin{array}{l}\text { Understands and speaks one of } \\
\text { the languages of Eritrea }\end{array}$ & $\begin{array}{l}\text { High integrity and not convicted of any } \\
\text { crime }\end{array}$ & Yes \\
\hline Ethiopia & $4 \mathrm{yrs}$ & $\begin{array}{l}\text { Able to communicate in any } \\
\text { one of the languages spoken by } \\
\text { the nations/nationalities of the } \\
\text { Country }\end{array}$ & $\begin{array}{c}\text { Good character, no record of criminal con- } \\
\text { viction }\end{array}$ & Yes \\
\hline Gabon & $5 \mathrm{yrs}$ & - & $\begin{array}{l}\text { Good conduct and morals; no convictions for } \\
\text { "crime" or "délit" }\end{array}$ & No \\
\hline Gambia !! & $15 \mathrm{yrs}$ & & Good character & Yes \\
\hline Ghana & 6 yrs & $\begin{array}{l}\text { Speak and understand an indig- } \\
\text { enous language; assimilated into } \\
\text { Ghanaian way of life }\end{array}$ & $\begin{array}{l}\text { Good character attested by two Ghanaian } \\
\text { lawyers, senior office holders or notaries } \\
\text { public; no conviction to prison sentence }\end{array}$ & No \\
\hline Guinea & $\begin{array}{l}5 \text { yrs / } \\
2 \text { yrs for } \\
\text { husband }\end{array}$ & - & $\begin{array}{l}\text { Good conduct and morals; no conviction to } \\
\text { more than } 1 \mathrm{yr} \text { in prison }\end{array}$ & No \\
\hline Guinea Bissau & $6 \mathrm{yrs}$ & $\begin{array}{l}\text { Basic knowledge of and iden- } \\
\text { tification with Guinea-Bissau's } \\
\text { culture }\end{array}$ & $\begin{array}{l}\text { Govt can oppose in case of conviction to } 6 \\
\text { yrs prison or crime vs state \& other cases }\end{array}$ & No \\
\hline
\end{tabular}




\begin{tabular}{|c|c|c|c|c|}
\hline Health / income & Other1 & $\begin{array}{l}\text { Minor children } \\
\text { included? }\end{array}$ & $\begin{array}{l}\text { Limits on rights for } \\
\text { naturalised } 2\end{array}$ & Legal provision \\
\hline- & $\begin{array}{l}\text { Must have rendered distinguished service } \\
\text { or naturalisation must be of real benefit } \\
\text { to the country. Other conditions also } \\
\text { apply in case of marriage. }\end{array}$ & Yes, automatically & $\begin{array}{l}\text { President must be national } \\
\text { of origin; laws may place } \\
\text { restrictions. }\end{array}$ & $\begin{array}{c}\text { C2006Art72 } \\
\text { L2004Art11,18-25, } 49\end{array}$ \\
\hline Good health & $\begin{array}{c}\text { Period reduced to } 5 \text { years if important } \\
\text { services }\end{array}$ & Yes, automatically & & L2004Arts12-22 \\
\hline \multirow[t]{2}{*}{$\begin{array}{l}\text { Mentally sane and no } \\
\text { disability; "legal means } \\
\text { to earn a living" }\end{array}$} & $\begin{array}{l}\text { No residence period for foreigner born } \\
\text { in Egypt if applies within one year of } \\
\text { majority, but other conditions apply. No } \\
\text { other conditions (except remains dis- } \\
\text { cretionary) for: (i) person born in Egypt } \\
\text { with father of "Egyptian origin"; (ii) } \\
\text { person of "Egyptian origin" after } 5 \text { years } \\
\text { residence; (iii) person born in Egypt } \\
\text { of foreign father also born in Egypt if } \\
\text { father from Arab or Muslim country - if } \\
\text { application within one year of majority. } \\
\text { No conditions if "honourable services to } \\
\text { Egypt and to the heads of the Egyptian } \\
\text { religious sects". }\end{array}$ & Yes, automatically & $\begin{array}{l}\text { President \& Prime minister } \\
\text { must be an Egyptian born } \\
\text { to Egyptian parents; oth- } \\
\text { erwise } \\
10 \text { yrs before can be elected } \\
\text { or be appointed to office; } 5 \\
\text { yrs before can vote }\end{array}$ & $\begin{array}{c}\text { C2014 Arts141\&164 } \\
\text { L1975(2004)Arts4-6, } 9\end{array}$ \\
\hline & $\begin{array}{l}\text { Residence requirement can be reduced } \\
\text { to } 5 \text { yrs if important services or invest- } \\
\text { ments; or to } 2 \text { yrs in case of person born } \\
\text { in EG who failed to opt under Art2, } \\
\text { adopted children or husbands. }\end{array}$ & No & $\begin{array}{l}\text { President must be national } \\
\text { of origin }\end{array}$ & $\begin{array}{c}\text { C2012Art35 } \\
\text { L1990Arts4,6-17 }\end{array}$ \\
\hline $\begin{array}{c}\text { Free of mental and } \\
\text { physical disabilities, not } \\
\text { a burden on society, } \\
\text { ability to provide for } \\
\text { one \& family's own } \\
\text { needs, } \\
\end{array}$ & $\begin{array}{l}\text { Residence period } 10 \text { yrs if before 1974). } \\
\text { Must not have committed "anti-people } \\
\text { act during the liberation struggle of the } \\
\text { Eritrean people" }\end{array}$ & Yes, on application & $\begin{array}{l}\text { President must be national } \\
\text { by birth }\end{array}$ & $\begin{array}{c}\text { C1997Art40 } \\
\text { L1992Art4,6,\&7 }\end{array}$ \\
\hline $\begin{array}{l}\text { Sufficient and lawful } \\
\text { source of income to } \\
\text { maintain himself and } \\
\text { his family }\end{array}$ & $\begin{array}{l}\text { Foreigner making "outstanding contribu- } \\
\text { tion" may be exempted from conditions. }\end{array}$ & Yes, on application & No & $\begin{array}{c}\text { C1994Art33 } \\
\text { L2003Art4-12, } 18\end{array}$ \\
\hline $\begin{array}{l}\text { No grave physical or } \\
\text { mental incapacity }\end{array}$ & $\begin{array}{l}\text { Should have "invested" in the country; } \\
\text { period can be reduced if the person has } \\
\text { provided "exceptional services" }\end{array}$ & Yes, automatically & $\begin{array}{l}\text { President must be national } \\
\text { of origin (and only 4th } \\
\text { generation descendant of } \\
\text { naturalised can be can- } \\
\text { didate); otherwise } 10 \mathrm{yrs} \\
\text { before can be elected }\end{array}$ & $\begin{array}{l}\text { C1991(2003)art10 } \\
\text { L1998Arts9,26,30-32 }\end{array}$ \\
\hline $\begin{array}{c}\text { Capable of supporting } \\
\text { self and dependents }\end{array}$ & & Yes, on application & $\begin{array}{l}\text { President must be national } \\
\text { by birth or descent }\end{array}$ & $\begin{array}{c}\text { C1996(2001)Arts12\&62 } \\
\text { L1965Art3-6 \& } \\
\text { Schedule 2 } \\
\end{array}$ \\
\hline- & $\begin{array}{l}\text { "Capable of making a substantial contri- } \\
\text { bution to progress or advancement in any } \\
\text { area of national activity"; conditions can } \\
\text { be waived in "special circumstances" }\end{array}$ & Yes, on application & $\begin{array}{l}\text { President must be citizen } \\
\text { from birth }\end{array}$ & $\begin{array}{l}\text { C1992Arts9,62,94 } \\
\text { L2000Art11-14 }\end{array}$ \\
\hline $\begin{array}{c}\text { Sound mind, physical } \\
\text { health means will not } \\
\text { become a charge on } \\
\text { the public. }\end{array}$ & $\begin{array}{l}\text { period reduced to } 2 \text { years if born in } \\
\text { Guinea or "important services"; no resi- } \\
\text { dence period in some cases for children } \\
\text { or spouse, or if "exceptional services" }\end{array}$ & $\begin{array}{c}\text { Yes, automatically } \\
\text { if father acquires } \\
\text { (or mother if father } \\
\text { dead) }\end{array}$ & $\begin{array}{l}10 \text { yrs before can elected; } \\
5 \text { yrs before can vote or be } \\
\text { appointed to public office }\end{array}$ & $\begin{array}{c}\text { L1983Arts62,72-80, } \\
88-94\end{array}$ \\
\hline- & $\begin{array}{c}\text { no residence period if services rendered } \\
\text { to the Guinean people before or after } \\
\text { the liberation struggle or for Guinea's } \\
\text { development }\end{array}$ & Yes, on application & No & L1992(2010)Arts6,9, 12 \\
\hline
\end{tabular}




\begin{tabular}{|c|c|c|c|c|}
\hline Country & Res. period & $\begin{array}{c}\text { Language / cultural require- } \\
\text { ments }\end{array}$ & Character & Ren. Other \\
\hline Kenya & 7 yrs & $\begin{array}{l}\text { "Adequate knowledge of Kenya } \\
\text { and of the } \\
\text { duties and rights of citizens"; able } \\
\text { to understand and speak Kiswa- } \\
\text { hili or a local dialect }\end{array}$ & No convictions more than 3 yrs prison & No \\
\hline Lesotho & 5 yrs & $\begin{array}{c}\text { Adequate knowledge of Sesotho } \\
\text { or English }\end{array}$ & Good character & Yes \\
\hline Liberia $\sim$ & 2 yrs & $\begin{array}{c}\text { "No person shall be naturalised } \\
\text { unless he is a Negro or of Negro } \\
\text { descent" }\end{array}$ & $\begin{array}{c}\text { Good moral character and attached to princi- } \\
\text { ples of Liberian constitution; must "state that } \\
\text { he does not believe in anarchy" }\end{array}$ & Yes \\
\hline Libya $\sim$ & $10 \mathrm{yrs}$ & & $\begin{array}{l}\text { Sound conduct and behaviour, no convictions } \\
\text { for crime breaching honour or security }\end{array}$ & No \\
\hline Madagascar & 5 yrs & $\begin{array}{l}\text { Assimilation into the Malagasy } \\
\text { community, including sufficient } \\
\text { knowledge of Malagasy language }\end{array}$ & $\begin{array}{l}\text { Good conduct and morals; no conviction } \\
\text { more than } 1 \mathrm{yr} \text { in prison or various other } \\
\text { offences }\end{array}$ & No \\
\hline Malawi & 7 yrs & $\begin{array}{l}\text { Knowledge of prescribed vernac- } \\
\text { ular language or English }\end{array}$ & Good character \& suitable citizen & Yes \\
\hline Mali & $10 \mathrm{yrs}$ & $\begin{array}{l}\text { Integration into the Malian } \\
\text { community }\end{array}$ & $\begin{array}{c}\text { Good conduct and morals; no convictions } \\
\text { more than } 1 \mathrm{yr} \text { in prison or various other } \\
\text { offices }\end{array}$ & No \\
\hline Mauritania & $10 \mathrm{yrs}$ & $\begin{array}{l}\text { Must speak fluently one of: Arab, } \\
\text { Pulaar, Soninké or Wolof }\end{array}$ & $\begin{array}{l}\text { Good conduct and morals; no convictions } \\
\text { with prison sentence }\end{array}$ & No \\
\hline Mauritius & 6 yrs $(1+5)$ & $\begin{array}{l}\text { Knowledge of English or any } \\
\text { other language spoken in Mauri- } \\
\text { tius, and of the responsibilities of } \\
\text { a citizen of Mauritius }\end{array}$ & Good character & Yes \\
\hline Morocco & $5 y r s$ & Sufficient knowledge of Arabic & $\begin{array}{l}\text { Good conduct and morals; no convictions for } \\
\text { various crimes }\end{array}$ & No \\
\hline Mozambique !! & $10 \mathrm{yrs}$ & $\begin{array}{l}\text { Knowledge of Portuguese or a } \\
\text { Mozambican language }\end{array}$ & Good reputation (idoneidade civica) & No \\
\hline Namibia & 10 yrs & $\begin{array}{l}\text { Adequate knowledge of the } \\
\text { responsibilities and privileges of } \\
\text { Namibian citizenship }\end{array}$ & $\begin{array}{l}\text { Good character; no convictions in Namibia } \\
\text { for listed offences }\end{array}$ & Yes \\
\hline Niger & $10 \mathrm{yrs}$ & - & $\begin{array}{l}\text { Good conduct and morals; no convictions } \\
\text { to prison }\end{array}$ & No \\
\hline
\end{tabular}




\begin{tabular}{|c|c|c|c|c|}
\hline Health / income & Other1 & $\begin{array}{l}\text { Minor children } \\
\text { included? }\end{array}$ & $\begin{array}{l}\text { Limits on rights for } \\
\text { naturalised } 2\end{array}$ & Legal provision \\
\hline $\begin{array}{l}\text { "Understands the na- } \\
\text { ture of the application" } \\
\text {; not judged bankrupt }\end{array}$ & $\begin{array}{l}\text { Has been determined to be "capable of } \\
\text { making a substantive contribution to the } \\
\text { progress or advancement in any area of } \\
\text { national development within Kenya", } \\
\text { Special provisions for stateless persons. }\end{array}$ & Yes, on application & $\begin{array}{l}\text { President \& deputy pres- } \\
\text { ident must be citizen by } \\
\text { birth; otherwise } \\
10 \text { yrs before can be elected } \\
\text { as MP }\end{array}$ & $\begin{array}{l}\text { C2010Arts99\&137 } \\
\text { L2011Arts13\&22 }\end{array}$ \\
\hline $\begin{array}{l}\text { No mental incapacity; } \\
\text { financially solvent }\end{array}$ & $\begin{array}{l}\text { Preferential treatment for persons from } \\
\text { Commonwealth countries and stateless } \\
\text { persons (some conditions waived).. }\end{array}$ & $\begin{array}{l}\text { Yes, on application, if } \\
\text { of "good character" }\end{array}$ & No & L1971Arts9-12 \\
\hline- & $\begin{array}{l}\text { Residence period may be waived by } \\
\text { president. } \\
\text { Exclusive jurisdiction to naturalise is } \\
\text { conferred on the circuit courts. }\end{array}$ & $\begin{array}{l}\text { Yes, if born outside } \\
\text { (so jus soli does not } \\
\text { apply) and father } \\
\text { naturalises, providing } \\
\text { resident in Liberia } \\
\end{array}$ & $\begin{array}{l}\text { President and vice presi- } \\
\text { dent must be "natural born } \\
\text { Liberian citizen" }\end{array}$ & $\begin{array}{l}\text { C1984Arts27\&52 } \\
\text { L1973Art21.1 to } 21.10 \\
\text { \& } 21.31\end{array}$ \\
\hline $\begin{array}{l}\text { Lawful entry; legiti- } \\
\text { mate, steady source of } \\
\text { income; free of infec- } \\
\text { tious diseases; not older } \\
\text { than } 50 \text { yrs. }\end{array}$ & $\begin{array}{l}\text { On proposal of the secretary of the } \\
\text { General People's Committee for Public } \\
\text { Security; conditions do not apply to } \\
\text { various cases, including those offering } \\
\text { significant or exceptional services. } \\
\text { Palestinians may not be granted national- } \\
\text { ity, except Palestinian women married to } \\
\text { Libyan men. }\end{array}$ & No & $\begin{array}{l}10 \text { yrs before can be ap- } \\
\text { pointed to high positions. }\end{array}$ & L2010Arts9-11\&18 \\
\hline $\begin{array}{l}\text { Sound mind; physical } \\
\text { health means will not } \\
\text { become a charge on } \\
\text { the public }\end{array}$ & $\begin{array}{c}\text { No residence period if important services } \\
\text { to the state or wife of foreigner who } \\
\text { naturalises }\end{array}$ & Yes, automatically & $\begin{array}{l}10 \text { yrs before can be elected; } \\
5 \text { ys before can vote or be } \\
\text { appointed }\end{array}$ & L1960Arts27-29, 35-41 \\
\hline Financially solvent & $\begin{array}{l}\text { Preferential treatment for Common- } \\
\text { wealth citizens, citizens of other African } \\
\text { states, and persons with a close connec- } \\
\text { tion to Malawi, women married to Ma- } \\
\text { lawian citizens, and for stateless persons } \\
\text { born in Malawi; and all conditions may } \\
\text { be waived in "special circumstances" }\end{array}$ & No & $\begin{array}{l}\text { President and vice President } \\
\text { must be citizens by birth or } \\
\text { descent }\end{array}$ & $\begin{array}{c}\text { C1994(1998)Art80 } \\
\text { L1966(1992)Arts12-21 }\end{array}$ \\
\hline Sound mind & $\begin{array}{l}\text { Period reduced to } 5 \text { years for a person } \\
\text { who has provided "exceptional services" } \\
\text { to the state or for child of foreign parents }\end{array}$ & $\begin{array}{c}\text { Yes, automatically } \\
\text { if father or mother } \\
\text { acquires }\end{array}$ & $\begin{array}{l}\text { President must have nation- } \\
\text { ality of origin; } 5 \text { yrs before } \\
\text { can be elected, } 2 \text { yrs before } \\
\text { can vote or be appointed }\end{array}$ & $\begin{array}{l}\text { C1992Art31 } \\
\text { L2011Arts231, 238- } \\
\text { 244\&247-8 }\end{array}$ \\
\hline Sound mind and body & $\begin{array}{l}\text { Residence period can be reduced to } 5 \\
\text { yrs if born in Mauritania, or married } \\
\text { under sharia law to a Mauritanian, or if } \\
\text { "exceptional services." }\end{array}$ & Yes, automatically & $\begin{array}{c}\text { President must be born } \\
\text { Mauritanian; } 5 \text { yrs before } \\
\text { can be elected or appointed } \\
\text { to public office }\end{array}$ & $\begin{array}{c}\text { C1991Art26 } \\
\text { 1961(2010)Arts15, } \\
18-19\end{array}$ \\
\hline- & $\begin{array}{l}\text { Preferential terms for Commonwealth } \\
\text { citizens; residence period can be reduced } \\
\text { if, for instance, the person has made } \\
\text { investments in Mauritius }\end{array}$ & $\begin{array}{l}\text { Yes, on application } \\
\text { (discretionary) }\end{array}$ & No & L1968(1995)Arts5-10 \\
\hline $\begin{array}{c}\text { Sound body and mind; } \\
\text { sufficient means of } \\
\text { existence }\end{array}$ & $\begin{array}{l}\text { Conditions may be waived if "exception- } \\
\text { al services" or an "exceptional interest" } \\
\text { for Morocco. }\end{array}$ & Yes, automatically & $\begin{array}{l}5 \text { yrs before can be elected } \\
\text { or appointed to public office }\end{array}$ & $\begin{array}{l}\text { L1958(2007)Art11-13 } \\
\text { \& 16-18 }\end{array}$ \\
\hline $\begin{array}{l}\text { Capacity to make deci- } \\
\text { sions (reger a sua pessoa) } \\
\text { means of subsistence }\end{array}$ & $\begin{array}{l}\text { Residence period and language can be } \\
\text { waived if the person has provided "rele- } \\
\text { vant services" to the state }\end{array}$ & Yes, on application & $\begin{array}{c}\text { President must be national } \\
\text { of origin; naturalised cit- } \\
\text { izens cannot be deputies, } \\
\text { members of government or } \\
\text { in diplomatic or military } \\
\text { service } \\
\end{array}$ & $\begin{array}{l}\text { C2004Arts27,30, } 147 \\
\text { L1975(1987)Arts11-13 }\end{array}$ \\
\hline- & $\begin{array}{l}\text { Honorary citizenship may be granted if } \\
\text { "distinguished service" }\end{array}$ & $\begin{array}{l}\text { Yes, on application } \\
\text { (discretionary) }\end{array}$ & $\begin{array}{l}\text { President must be citizen by } \\
\text { birth or descent }\end{array}$ & $\begin{array}{c}\text { C1990(2010) } \\
\text { Art4(5)\&28 } \\
\text { L1990Art5,6 \& } 14\end{array}$ \\
\hline- & $\begin{array}{l}\text { Residence period can be waived if } \\
\text { exceptional services }\end{array}$ & Yes, automatically & $\begin{array}{c}\text { President must be national } \\
\text { of origin; } \\
10 \text { yrs before can elected } \\
\text { or appointed to public } \\
\text { functions for which must } \\
\text { be Nigerien; } 5 \text { yrs for other } \\
\text { positions }\end{array}$ & $\begin{array}{c}\text { C2010Art47 } \\
\text { L1984(2014)Arts21-29 }\end{array}$ \\
\hline
\end{tabular}




\begin{tabular}{|c|c|c|c|c|}
\hline Country & Res. period & $\begin{array}{c}\text { Language / cultural require- } \\
\text { ments }\end{array}$ & Character & Ren. Other \\
\hline Nigeria & $15 \mathrm{yrs}$ & $\begin{array}{l}\text { Acceptable to and assimilated } \\
\text { into the way of life of the local } \\
\text { community in which he is to live } \\
\text { permanently }\end{array}$ & Good character & $\begin{array}{l}\text { Only of oth- } \\
\text { er non-birth } \\
\text { nationalities }\end{array}$ \\
\hline Rwanda & 5 yrs & $\begin{array}{l}\text { Respect Rwandan culture and } \\
\text { be patriotic }\end{array}$ & $\begin{array}{l}\text { Good behaviour and morals; no convictions } \\
\text { for } 6 \mathrm{mths} \text { prison }\end{array}$ & No \\
\hline \multicolumn{5}{|l|}{ Sahrawi ADR } \\
\hline $\begin{array}{l}\text { São Tomé and } \\
\text { Príncipe }\end{array}$ & 5 yrs & $\begin{array}{l}\text { Knowledge of Portuguese or an- } \\
\text { other national language; civic and } \\
\text { moral guarantees of Integration } \\
\text { into STP society }\end{array}$ & - & Yes \\
\hline Senegal & $10 \mathrm{yrs}$ & - & $\begin{array}{l}\text { Good morality; no convictions to prison } \\
\text { sentence }\end{array}$ & $\begin{array}{l}\text { No, but stated to } \\
\text { be incompatible } \\
\text { with another } \\
\text { nationality }\end{array}$ \\
\hline Seychelles & $15 \mathrm{yrs}$ & $\begin{array}{c}\text { Obtains at least } 80 \text { per cent of } \\
\text { marks in } 1 \text { of the } 3 \text { national lan- } \\
\text { guages in a citizenship qualifying } \\
\text { examination }\end{array}$ & $\begin{array}{l}\text { Not been sentenced to prison sentence } 1 \mathrm{yr} \\
\text { or more }\end{array}$ & No \\
\hline Sierra Leone & $15 \mathrm{yrs}$ & $\begin{array}{c}\text { Adequate knowledge of indige- } \\
\text { nous language }\end{array}$ & Good character & No \\
\hline Somalia & 7 yrs & - & Good civil and moral conduct & Yes \\
\hline South Africa & $5 \mathrm{yrs}$ & $\begin{array}{l}\text { Communicate in one of } 11 \\
\text { official languages }\end{array}$ & $\begin{array}{l}\text { Good character, adequate knowledge of the } \\
\text { privileges and responsibilities of citizenship }\end{array}$ & $\begin{array}{l}\text { Yes if other } \\
\text { country does } \\
\text { not allow dual } \\
\text { citizenship }\end{array}$ \\
\hline South Sudan & $10 \mathrm{yrs}$ & - & $\begin{array}{l}\text { Not convicted offence related to honesty and } \\
\text { moral turpitude }\end{array}$ & - \\
\hline Sudan & $10 \mathrm{yrs}$ & - & $\begin{array}{l}\text { Good morals; not convicted of a crime } \\
\text { against honour or honesty. }\end{array}$ & - \\
\hline Swaziland & $5 \mathrm{yrs}$ & $\begin{array}{l}\text { Adequate knowledge siSwati or } \\
\text { English }\end{array}$ & Good character & $\begin{array}{l}\text { Not always, but } \\
\text { can be required } \\
\text { to do so }\end{array}$ \\
\hline
\end{tabular}




\begin{tabular}{|c|c|c|c|c|}
\hline Health / income & Other1 & $\begin{array}{l}\text { Minor children } \\
\text { included? }\end{array}$ & $\begin{array}{l}\text { Limits on rights for } \\
\text { naturalised } 2\end{array}$ & Legal provision \\
\hline- & $\begin{array}{c}\text { Capable of making a contribution to the } \\
\text { advancement, progress and well-being } \\
\text { of Nigeria }\end{array}$ & No & $\begin{array}{l}\text { President and state gover- } \\
\text { nors must be citizens by } \\
\text { birth }\end{array}$ & $\begin{array}{l}\text { C1999Arts27-28, } \\
131 \& 177\end{array}$ \\
\hline \multirow[t]{2}{*}{$\begin{array}{l}\text { Not a burden on the } \\
\text { state }\end{array}$} & $\begin{array}{l}\text { The owner of "sustainable activities in } \\
\text { Rwanda"; not implicated in the ideology } \\
\text { of genocide; conditions can be waived } \\
\text { for a person "of interest" to Rwanda }\end{array}$ & Yes, automatically & $\begin{array}{l}\text { President must be national } \\
\text { of origin \& at least one par- } \\
\text { ent also national of origin }\end{array}$ & $\begin{array}{c}\text { C2003Art99 } \\
\text { L2008Arts5\&13-17 }\end{array}$ \\
\hline & & & & $\mathrm{n} / \mathrm{a}$ \\
\hline $\begin{array}{c}\text { Capacity to make deci- } \\
\text { sions (reger a sua pessoa); } \\
\text { means of subsistence }\end{array}$ & $\begin{array}{c}\text { Conditions can be waived in case of } \\
\text { relevant services or higher state interests/ } \\
\text { reasons. } \\
\text { Govt can oppose in court within } 1 \mathrm{yr} \text { on } \\
\text { national security grounds or that com- } \\
\text { mitted major crime. }\end{array}$ & Yes, on application & $\begin{array}{l}\text { President and Prime Min- } \\
\text { ister must be nationals of } \\
\text { origin }\end{array}$ & $\begin{array}{l}\text { C2003Art78\&100 } \\
\text { L1990Arts7\&10 }\end{array}$ \\
\hline $\begin{array}{l}\text { Sound mind; physical } \\
\text { health means will not } \\
\text { become a charge on } \\
\text { the public. }\end{array}$ & $\begin{array}{l}\text { Residence period may be reduced if the } \\
\text { person has provided important services } \\
\text { to Senegal or if naturalisation is an } \\
\text { exceptional interest for Senegal. }\end{array}$ & Yes, automatically & $\begin{array}{l}10 \text { yrs before can be elected } \\
\text { or appointed to posts for } \\
\text { which need to be Sene- } \\
\text { galese, or be minister or } \\
\text { member of civil service; } 5 \\
\text { yrs before can practice in } \\
\text { profession for which need } \\
\text { to be Senegalese. }\end{array}$ & $\begin{array}{l}\text { L1961(2013)Arts10, } \\
\text { 12, 16bis }\end{array}$ \\
\hline- & $\begin{array}{c}\text { "Special circumstances" must justify the } \\
\text { naturalisation: (a) extraordinary ability } \\
\text { in science, arts, education, economics, } \\
\text { business, law or sports; (b) degree in an } \\
\text { area which is likely to contribute signifi- } \\
\text { cantly to the development of Seychelles; } \\
\text { (c) significant contribution to the devel- } \\
\text { opment of Seychelles; or } \\
\text { (d) marriage to a Seychellois \& there are } \\
\text { children. } \\
\begin{array}{c}\text { Special terms for spouses, investors, those } \\
\text { who have studied in Seychelles \& those } \\
\text { with Seychellois ancestry. } \\
\text { Conditions may be waived if distin- } \\
\text { guished service rendered. }\end{array} \\
\end{array}$ & $\begin{array}{l}\text { Yes, on application } \\
\text { (discretionary) }\end{array}$ & No & $\begin{array}{l}\text { C1993(2011)Arts10-13 } \\
\text { L1994(2013)Art4-6 }\end{array}$ \\
\hline- & $\begin{array}{c}\text { Capable of making useful and substantial } \\
\text { contribution to advancement, progress } \\
\text { and wellbeing of SL. } \\
\text { Residence period } 8 \text { yrs for a person "of } \\
\text { Negro African descent." }\end{array}$ & Yes, on application & $\begin{array}{l}\text { Naturalised citizen cannot } \\
\text { be president, member of } \\
\text { any commission, diplomat } \\
\text { or member of armed forces, } \\
\text { senior civil servant, or MP }\end{array}$ & $\begin{array}{c}\text { L1973(2006)Arts7- } \\
9 \& 22, \text { Schedules 2\&3 }\end{array}$ \\
\hline- & $\begin{array}{c}\text { Period can be reduced to } 2 \text { yrs for "child } \\
\text { of a Somali mother". Honorary citi- } \\
\text { zenship possible in case of "exceptional } \\
\text { circumstances" }\end{array}$ & No & No & L1962Arts4-9 \\
\hline- & $\begin{array}{c}\text { Must first acquire permanent residence, } \\
\text { which usually takes } 5 \text { years. } \\
\text { Conditions may be waived in "excep- } \\
\text { tional circumstances". }\end{array}$ & Yes, on application & No & $\begin{array}{c}\text { C1996Art3 } \\
\text { L1995(2010)Art5 }\end{array}$ \\
\hline $\begin{array}{l}\text { Sound mind (if of un- } \\
\text { sound mind, parent or } \\
\text { guardian may apply) }\end{array}$ & $\begin{array}{l}\text { Conditions may be waived if individual } \\
\text { has served in the national interest }\end{array}$ & Yes, on application & $\begin{array}{l}\text { President must be citizen } \\
\text { by birth }\end{array}$ & $\begin{array}{l}\text { C2011Art98 } \\
\text { L2011Arts10-11 }\end{array}$ \\
\hline $\begin{array}{c}\text { Sound mind; lawful } \\
\text { way of earning a living }\end{array}$ & $\begin{array}{l}\text { Notwithstanding any provision to the } \\
\text { contrary, President can grant nationality } \\
\text { to any alien }\end{array}$ & Yes, on application & $\begin{array}{l}\text { President must be citizen } \\
\text { by birth }\end{array}$ & $\begin{array}{c}\text { C2005Art53 } \\
\text { L1994(2011)Arts7,9 }\end{array}$ \\
\hline $\begin{array}{c}\text { Adequate means of } \\
\text { support }\end{array}$ & $\begin{array}{l}\text { Must fcontribute to the development of } \\
\text { the country". } \\
\text { Special procedure for those supported by } \\
\text { chief's council. }\end{array}$ & No & No & $\begin{array}{l}\text { C2005Arts } 45 \& 49 \\
\text { L1992Art9 }\end{array}$ \\
\hline
\end{tabular}




\begin{tabular}{|c|c|c|c|c|}
\hline Country & Res. period & $\begin{array}{c}\text { Language / cultural require- } \\
\text { ments }\end{array}$ & Character & Ren. Other \\
\hline Tanzania & 8 yrs & $\begin{array}{l}\text { Adequate knowledge of Kiswahi- } \\
\text { li or English }\end{array}$ & Good character & Yes \\
\hline Togo & $\begin{array}{l}5 \text { yrs/ } \\
\text { imm. for } \\
\text { husband }\end{array}$ & $\begin{array}{l}\text { Assimilation to the Togolese } \\
\text { community, including sufficient } \\
\text { knowledge of a Togolese lan- } \\
\text { guage }\end{array}$ & $\begin{array}{l}\text { Good conduct and morals; no convictions } \\
\text { more than } 2 \text { yrs in prison }\end{array}$ & Yes \\
\hline Tunisia & $\begin{array}{l}5 \text { yrs / } \\
\text { imm. for } \\
\text { husband }\end{array}$ & Sufficient knowledge of Arabic & $\begin{array}{l}\text { Good conduct and morals; no convictions for } \\
\text { more than } 1 \mathrm{yr} \text { in prison }\end{array}$ & No \\
\hline \multirow[t]{2}{*}{ Uganda d } & $\begin{array}{l}10 \text { yrs (if "legal } \\
\text { and voluntary" }\end{array}$ & - & - & $\begin{array}{l}\text { In some circum- } \\
\text { stances }\end{array}$ \\
\hline & $\begin{array}{c}20 \text { yrs } \\
\text { (if not "legal } \\
\text { and voluntary") }\end{array}$ & $\begin{array}{l}\text { Adequate knowledge of "a } \\
\text { prescribed vernacular language" } \\
\text { or English }\end{array}$ & Good character & $\begin{array}{l}\text { In some circum- } \\
\text { stances }\end{array}$ \\
\hline Zambia !! & 10 yrs & $\begin{array}{c}\text { Adequate knowledge of English } \\
\text { or any other language commonly } \\
\text { used by indigenous inhabitants } \\
\text { in Zambia }\end{array}$ & Good character & Yes \\
\hline Zimbabwe !! & 10 yrs & - & Good character;"fit and proper person" & Yes \\
\hline
\end{tabular}

1. Most countries require the person to be adult, currently and legally resident and to intend to remain so if they wish to naturalise; these provisions are not included here.

2. Provisions in the nationality law and constitution (not including electoral code)

n/a not available

imm. Immediate

$\sim$ racial, ethnic or religious discrimination applies

!! the position is ambiguous in that legislation conflicts with the constitution; constitutional provisions noted here (in Zambia the Citizenship Act refers

to a provision in the abrogated 1973 constitution, which is repeated in a different article of the 1991 constitution, so it is presumed the law remains valid)

\subsubsection{Restrictions on the political rights of naturalised persons}

There are often distinctions between the rights enjoyed by naturalised citizens as against citizens from birth. Only a few, including Ethiopia, provide that all citizens have equal rights, regardless of how nationality was obtained. In particular, the state may usually deprive a naturalised citizen of his or her nationality much more easily; in the Commonwealth countries it is common for deprivation only to be possible at all in the case of naturalised citizens.

Some countries also place restrictions on the role of naturalised citizens in public life (see the second to last column in Table 7). Citizenship laws in Benin, 


\begin{tabular}{|c|c|c|c|c|}
\hline Health / income & Other1 & $\begin{array}{l}\text { Minor children } \\
\text { included? }\end{array}$ & $\begin{array}{l}\text { Limits on rights for } \\
\text { naturalised } 2\end{array}$ & Legal provision \\
\hline- & $\begin{array}{c}\text { In terms of potential contribution, would } \\
\text { be a suitable citizen. } \\
\text { Child born outside country of father } \\
\text { who was citizen by descent may natu- } \\
\text { ralise without other conditions }\end{array}$ & Yes, on application & $\begin{array}{l}\text { President must be citizen } \\
\text { by birth }\end{array}$ & $\begin{array}{l}\text { C1977(1995)Art39 } \\
\text { L1995Arts8-10, \& 2nd } \\
\text { schedule }\end{array}$ \\
\hline Sound body and mind & $\begin{array}{l}\text { Togo centre of principal interests. } \\
\text { No residence period if born in Togo or } \\
\text { "exceptional services" }\end{array}$ & $\begin{array}{l}\text { Yes, automatically if } \\
\text { father acquires }\end{array}$ & $\begin{array}{l}\text { President must be citizen } \\
\text { from birth; } \\
5 \text { yrs before can be elected } \\
\text { or appointed to post where } \\
\text { must be Togolese national }\end{array}$ & $\begin{array}{c}\text { C1992(2002)Art62 } \\
\text { L1978Arts10-14,19, } 38\end{array}$ \\
\hline $\begin{array}{l}\text { State of health means } \\
\text { would not be a charge } \\
\text { on the public. }\end{array}$ & $\begin{array}{c}\text { No residence period required if person } \\
\text { was Tunisian by origin, or if "exceptional } \\
\text { services". }\end{array}$ & $\begin{array}{l}\text { Yes, automatically, if } \\
\text { father acquires (or } \\
\text { mother if widow) }\end{array}$ & $\begin{array}{l}\text { President must be national } \\
\text { by birth; otherwise } 5 \text { yrs } \\
\text { before can be elected or } \\
\text { appointed to public office } \\
\text { if reserved for Tunisians, } \\
\text { or vote }\end{array}$ & $\begin{array}{c}\text { C2014Art74 } \\
\text { L1963(2010)Arts19-27 }\end{array}$ \\
\hline- & $\begin{array}{l}\text { Significant additional conditions apply if } \\
\text { wishes to hold dual nationality. }\end{array}$ & No & $\begin{array}{l}\text { President must be citizen } \\
\text { by birth }\end{array}$ & $\begin{array}{l}\text { C1995(2005)Art12(2) } \\
\text { (b) \&102 } \\
\text { L1999(2009)Art14(2) } \\
\text { (b),15,19,19B \&19C }\end{array}$ \\
\hline- & $\begin{array}{l}\text { May be refused if "immigration file con- } \\
\text { tains substantial inconsistencies as to put } \\
\text { his or her demeanour in issue". } \\
\text { Significant additional conditions apply if } \\
\text { wishes to hold dual nationality. }\end{array}$ & & & $\begin{array}{l}\text { C1995(2005)Art13 } \\
\text { L1999(2009) } \\
\text { Art16\&19,19A,19C }\end{array}$ \\
\hline Sound mind & $\begin{array}{l}\text { Conditions may be waived if "distin- } \\
\text { guished service" to Zambia or other } \\
\text { "special circumstances" exist }\end{array}$ & Yes, on application & $\begin{array}{l}\text { Both parents of president } \\
\text { must be citizens by birth or } \\
\text { descent }\end{array}$ & $\begin{array}{l}\text { C1991(1996)Art6-7\&34 } \\
\text { L1975(1994)Arts12-18 }\end{array}$ \\
\hline Sound mind & $\begin{array}{l}\text { Residence period can be reduced by the } \\
\text { president under "special circumstances" }\end{array}$ & $\begin{array}{l}\text { Yes, on application } \\
\text { (discretionary) }\end{array}$ & $\begin{array}{c}\text { President } \& \text { vice president } \\
\text { must be citizen by birth or } \\
\text { descent } \\
\text { Equal rights }\end{array}$ & $\begin{array}{l}\text { C2013Arts35,38(2)\&91 } \\
\text { L1984(2003)Arts4\&5 }\end{array}$ \\
\hline
\end{tabular}

a Côte d'Ivoire instituted a temporary special naturalisation procedure in 2013. The provisions here are the normal procedures

b Egypt has five separate grounds for naturalisation, based on racial and religious origin

c Eritrea provides additional criteria for the attribution of nationality to persons resident in Eritrea between 1934 and 1952 ; these are described as naturalisation but are non-discretionary, and more in the nature of transitional provisions

d Uganda has particularly complex distinctions between registration and naturalisation which are hard to represent in table form; significant additional conditions apply if the person wishes to have dual citizenship.

Burkina Faso, Burundi, Cameroon, Central African Republic, Comoros, Congo Republic, Côte d'Ivoire, Egypt, Gabon, Guinea, Kenya, Libya, Madagascar, Mali, Mauritania, Morocco, Niger, Senegal, Togo and Tunisia impose a waiting period of two to 10 years before naturalised citizens can hold a range of offices. Mozambique has a wide prohibition on naturalised citizens being deputies of the parliament, members of the government, and members of the diplomatic service and military. Constitutional prohibitions on naturalised citizens holding the presidency exist in at least 23 countries: Botswana, Burundi, Côte d'Ivoire, Equatorial Guinea, Gabon, Ghana, Kenya, Liberia, Malawi, Mali, Mauritania, Mozambique, Niger, Nigeria, Rwanda, São Tomé and Príncipe, Sierra Leone, 
South Sudan, Sudan, Tanzania, Togo, Uganda, and Zambia. (Other countries may have provided the same ban in the electoral code; these have not been surveyed as part of this research.) In Gabon, the President must be fourth generation Gabonese; in Côte d'Ivoire and Zambia, both parents must also be citizens of origin; in Rwanda, at least one parent of the president must be a national of origin; Mozambique and Sierra Leone permanently bar naturalised citizens from a wide range of offices. In Algeria, the Constitutional Council has at least twice criticized (in 1989 and 1995) a clause introduced into the electoral law forbidding candidates to stand for election as president if they or their spouses do not hold Algerian nationality of origin. ${ }^{111}$

The African Commission considered restrictions on political rights based on the nationality of the parents of a candidate (but not the type of nationality of the candidate him or herself) in its decision on the provisions of Article 35 of the constitution of Côte d'Ivoire as applied to Alassane Ouattara, and found them to be in violation of the African Charter (see above, chapter 3.12.2).

\subsubsection{Naturalisation for refugees and stateless persons}

Very few if any African states provide for easier terms of access to citizenship for stateless persons or refugees, despite their obligations under the African and international refugee conventions, and a move, prompted by lobbying from UNHCR, towards greater ratification of the 1961 UN Convention on the Reduction of Statelessness. Some countries specifically provide that refugees may not naturalise, even if there is no practical possibility of their returning home (see further, chapter 7.3 and chapter 11).

Even where the law appears to provide for naturalisation, it is not always interpreted as doing so: for example, Uganda's 2006 Refugee Act provides that "The Constitution and any other law in force in Uganda regulating naturalisation shall apply to the naturalisation of a recognized refugee", but officials do not apply this rule. ${ }^{112}$

In 2007, Sierra Leone adopted a new Refugees Protection Act, which provides explicitly for the "facilitation of lasting solutions" and local integration of refugees; though it stopped short of providing for naturalisation of long-term refugees and speaks, rather, of promoting voluntary repatriation or resettlement in third countries. ${ }^{113}$ Ghana allows for refugees to naturalise according to the

111 Committee on the Elimination of Racial Discrimination, Consideration of Reports Submitted by States Parties under Article 9 of the Convention: Twelfth Periodic Reports due in 1995: Algeria, CERD/C/280/Add.3, 5 June 1996. Samia Bourouba, Jurisprudence and Human Rights Standards in Arab Courts: Algeria - Iraq - Jordan - Morocco - Palestine, Raoul Wallenberg Institute, 2013.

112 Refugee Act, 2006 Article 45. See also chapter 7.3.

113 Sierra Leone Refugees Protection Act, No. 6 of 2007, Part V, Article 23. However, the act also annexes (among others) article 34 of the UN Refugee Convention relating to 
usual provisions of the law, ${ }^{114}$ though studies of long-term Liberian refugees in Ghana showed many difficulties in practice. ${ }^{115}$ Guinea Bissau's 2008 law provides for naturalisation of refugees to be facilitated. ${ }^{116}$ Other longer-standing laws that provide for naturalisation include Lesotho's 1983 Refugees Act, which allows a refugee to apply for naturalisation after six years (the 12 months prior to the application and another five years). In Mozambique, the 1991 Refugee Act explicitly provides for naturalisation of refugees on the same terms as other foreigners. ${ }^{117}$ In many other countries, the normal rules of naturalisation apply either explicitly or implicitly. ${ }^{118}$ A few countries provide in general terms that refugees who qualify under the normal rules may be assisted to obtain naturalisation. ${ }^{119}$

Few countries globally have adopted legislation to facilitate naturalisation specifically for stateless persons. ${ }^{120}$ In Africa, only Malawi and Lesotho have explicit measures in their nationality law, both providing for registration of stateless persons in some circumstances. ${ }^{121}$

naturalisation, which requires states parties to "facilitate the assimilation and naturalisation of refugees" and "expedite naturalisation proceedings."

114 "Subject to the relevant laws and regulations relating to naturalization, the Board may assist a refugee who has satisfied the conditions applicable to the acquisition of Ghanaian nationality to acquire Ghanaian nationality." Ghana Refugee Law (No. 305D of 1992), section 34(2).

115 Shelly Dick, Responding to protracted refugee situations: A case study of Liberian refugees in Ghana, UNHCR Evaluation \& Policy Analysis Unit, EPAU/2002/06, July 2002. U.S. Committee for Refugees and Immigrants, World Refugee Survey 2008.

116 The law reduces the period of residence required for naturalisation in Guinea Bissau from 10 years to 7 years. Lei No.6/2008, Estatudo do Refugiado, Article 34.

117 Jonathan Klaaren and Bonaventure Rutinwa, "Towards the Harmonisation of Immigration and Refugee Law in SADC" Migration Dialogue for Southern Africa (MIDSA), Report No.1, 2004, pp.90-91.

118 For the north African countries and Djibouti, see Khadija Elmadmad, Asile et Réfugiés dans les pays afro-arabes, Editions EDDIF, Casablanca, 2002.

119 For example, Nigeria's National Commission For Refugees, etc. Act, 1989, Article 17 states that: "Subject to the provisions of relevant laws and regulations relating to naturalisation, the Federal Commissioner shall use his best endeavours to assist a refugee, who has satisfied the criteria relating to the acquisition of Nigerian nationality, to acquire the status of naturalisation under such relevant laws and regulations." Ghana has a provision that "Subject to the relevant laws and regulations relating to naturalisation, the Board may assist a refugee who has satisfied the conditions applicable to the acquisition of Ghanaian nationality to acquire Ghanaian nationality." Ghana Refugee Law, 1992 (PNDCL 305D), section 14.

120 See the EUDO global statelessness database at http://eudo-citizenship.eu/34uncategorised/1111-global-database-on-protection-against-statelessness, last accessed 15 January 2015.

121 Lesotho Citizenship Order 1971, Article 10; Malawi Citizenship Act 1966 (as amended to 1992), Section 18. 
Ultimately, the countries that deal most effectively and humanely with long-term refugees are those with the most liberal naturalisation regimes for foreigners in general, in which special measures for naturalisation of refugees are not required because the existing system works. At the same time, especially for refugees who have been held in camps or settled in particular areas, there may be need for specific measures to provide access to naturalisation procedures. UNHCR has facilitated such processes on several occasions, usually combined with assistance for those who wish to return to their country of origin, as in the case of the Mauritanian refugees in Senegal (see chapter 11.5).

\subsection{Loss and deprivation of nationality}

The prohibition in Article 15 of the Universal Declaration of "arbitrary deprivation" of nationality applies equally to automatic withdrawal of nationality by operation of law (known as "loss" of nationality in the 1961 Convention), as it does to situations where the withdrawal is initiated by the authorities of the State (deprivation). Additional prohibitions apply if withdrawal would result in the person becoming stateless. ${ }^{122}$

The constitutions of only two countries in Africa, South Africa and Ethiopia, prohibit the state from withdrawing citizenship, however acquired, against a person's will; and even in those two cases the protection is not as far-reaching as it appears on first sight.

Article 33 of the constitution of Ethiopia provides that "No Ethiopian national shall be deprived of his or her Ethiopian nationality against his or her will"; however, acquisition of another citizenship results in the automatic loss of Ethiopian nationality. ${ }^{123}$ In practice, Ethiopians of Eritrean descent found this provision to be easily violated (see chapter 9.1).

In the case of South Africa, the citizenship legislation is in conflict with the constitution. Article 20 of the South African constitution states simply that "No citizen may be deprived of citizenship". ${ }^{124}$ However, the Citizenship Act does in fact provide for automatic loss or discretionary deprivation of citizenship, including citizenship from birth. The South African Citizenship Act No. 88 of 1995 was adopted before the constitution came into effect, and initially provided for loss of citizenship of a citizen from birth or by acquisition both in case of acquisition of another nationality (without permission) and if he or she is also a citizen of another country and served in the armed forces of that country in a war against South Africa. ${ }^{125}$ The act also provided for deprivation from

122 UNHCR, Tunis Conclusions. See also chapter 3.9.

123 Constitution of the Federal Democratic Republic of Ethiopia, 1994, Article 33; Proclamation No.378/2003 on Ethiopian Nationality, Article 17.

124 Constitution of the Republic of South Africa, 1996, article 20.

125 South African Citizenship Act, No. 88 of 1995, section 6 (in 2004 an amendment act, No.17 of 2004, removed a provision in the 1995 Act that had provided for deprivation of 
a naturalised citizen in cases of fraud, conviction of a crime, or if it was in the "public interest"; in case of deprivation for fraud, there was no protection against statelessness (as permitted by the 1961 Convention). ${ }^{126}$ These provisions on loss and deprivation remain in effect; and, in 2010, the act was amended to introduce a hard-to-interpret further ground for automatic loss of nationality of a naturalised citizen (not a citizen from birth), if he or she "engages, under the flag of another country, in a war that the Republic does not support." 127

More than half of Africa's 54 states forbid deprivation of nationality against the person's will from a national from birth, whether or not the person would become stateless: Botswana, Burkina Faso, Burundi, Cape Verde, Chad, Comoros, DRC, Ethiopia, Gabon, Gambia, Ghana, Kenya, Lesotho, Libya, Malawi, Mauritania, Mauritius, Namibia, Nigeria, Rwanda, Seychelles, Somalia, South Africa, Swaziland, Tanzania, Uganda, Zambia and Zimbabwe. But the situation is not always clear: in the case of Comoros, the 2001 constitution states that a citizen by birth cannot be deprived of his or her nationality, but, as in South Africa, the 1979 nationality code is not in compliance with this provision. ${ }^{128}$

The most common provision for automatic loss of birth nationality is in case of acquisition of another, in countries where dual nationality is not allowed. Countries appearing to provide for loss of nationality in case of acquisition of another as an adult are Botswana, Cameroon, Central African Republic, Côte d'Ivoire, DRC, Egypt, Equatorial Guinea, Eritrea, Ethiopia, Guinea, Lesotho, Liberia, Malawi, Tanzania, Togo and Zambia. However, these provisions can be hard to interpret, as noted in chapter 6.4; and there is particular confusion in cases where the language of the legislation states both that a person who voluntarily acquires another nationality automatically loses his or her nationality of origin, and also that this loss is subject to permission, sometimes only for men during a period in which they could be called up for military service. In practice, official interpretation and application of these laws varies widely, or small differences in wording result in different outcomes. South Africa's law, for example, is clear that loss is automatic, but a person may apply for permission to retain South African nationality (rather than making loss subject to permission). There is a campaign for repeal of this rule among the South African diaspora who have lost South

citizenship on use of another passport).

126 South African Citizenship Act, No. 88 of 1995, section 8

127 South Africa Citizenship Amendment Act, No.17 of 2010, adding subsection 6(3) to the principal act. This amendment came into force on 1 January 2013. See Submission on the South African Citizenship Amendment Bill, B 17 - 2010 (Citizenship Rights in Africa Initiative, 6 August 2010), arguing that the new provision was unconstitutional.

128 Constitution de l'Union des Comores, 23 December 2001, article 5; Loi No.79-12 du 12 décembre 1979 portant code de la nationalité comoorienne, articles 51-56. The 1979 law disallows dual nationality, and also allows for nationality to be taken away if a citizen works for a foreign state and does not give up his or her position on request (a common provision in civil law countries). 


\section{African citizenship. ${ }^{129}$}

There is an apparent anomaly in many laws in relation to fraud: the nationality legislation of almost all African countries provides for deprivation of citizenship acquired by naturalisation in case of fraud, but rarely is fraud mentioned in regard to the recognition of nationality from birth. The assumption would be that recognition of nationality when the conditions providing a right to nationality were not in fact fulfilled (whether or not there was active fraud) would be void ab initio, requiring no formal deprivation procedure; this is clearly the interpretation applied in some of the controversial cases of retroactive loss of recognition described in chapter 8.2. At a larger scale, the case of Zimbabwe show how such laws relating to loss of nationality in case of acquisition or retention of another, although apparently in conformity with international law (which is neutral on dual citieznzhip), can in certain political circumstances be bent to withdraw nationality from a very large number of people on the grounds that they were awarded it in error. The 2013 constitution now permits dual nationality except for those who naturalise as Zimbabwean (see chapter 8.3).

Liberia has one of the strictest bans on dual nationality anywhere in the continent, and also extends the ban to a range of actions by the person concerned which could imply dual nationality, even if the person does not in fact have another nationality: citizenship of any kind is automatically lost if the person acquires another nationality or serves in the armed forces or votes in an election in another state, without any further government action to cancel the citizenship. ${ }^{130}$ These rules have been applied to deny passports to former Liberian refugees in possession of voter cards in their country of refuge, for example (see chapter 11.1).

Gender discrimination can also be problematic for loss of citizenship: in Togo, for example, a foreign woman both automatically becomes Togolese on marriage to a Togolese man (a relatively common provision) and also automatically loses Togolese nationality if she is then divorced (much more unusual). ${ }^{131} \mathrm{~A}$ Burkinabè who acquires another nationality on marriage (almost certainly a woman), automatically loses her Burkinabè nationality. ${ }^{132}$ The law of Equatorial Guinea states that a foreign woman who marries an Equatoguinean citizen automatically acquires Equatoguinean nationality and loses her nationality of origin -

129 See Dual SA Citizenship community on Facebook, https://www.facebook.com/ DualSACitizenship, last accessed20 November 2014.

130 Aliens and Nationality Law, 1973, sections 21.2;21.50-59 and 22.1-22.4. See also George K. Fahnbulleh, "Constitution and Laws of Liberia are clear with regards to the citizenship issue" The Perspective (Atlanta, Georgia), 4 August 2005.

131 Ordonnance No.78-34 du 7 septembre 1978 portant Code le la nationalité togolaise, article 23 .

132 Zatu no AnVII 0013/FP/PRES du 16 novembre 1989, portant institution et application du Code des personnes et de la famille, article 188. 
extraordinarily purporting to dictate to another country the rules for loss of its nationality. ${ }^{133}$

A fairly substantial number of countries have a provision framed along the lines provided in Article 8(3) the 1961 Convention on the Reduction of Statelessness for deprivation if person works for a foreign state in defiance of an express prohibition to do so: Angola, Benin, Cameroon, CAR, Comoros ${ }^{134}$, Congo Republic, Côte d'Ivoire, Djibouti, Egypt, Equatorial Guinea, Eritrea, Guinea, Guinea Bissau, Liberia, Madagascar, Morocco, Mozambique, Niger, São Tomé \& Príncipe, South Sudan, Sudan, Togo and Tunisia. ${ }^{135}$

Only a small handful of countries provide for deprivation of birthright citizenship in case of a crime against the state - as of 2014, they were Egypt, Eritrea and Mali. ${ }^{136}$

Until 2010, the Libyan Nationality Law was perhaps the most extreme, allowing for deprivation of citizenship, however acquired, if the person was "described as Zionist" or visited Israel, converts from Islam to another religion, left the country immediately following the "Great El Fateh September Revolution," obtained refugee status elsewhere, was convicted of smuggling assets out of Libya, or a range of other conditions. In 2010 the law was significantly amended to allow revocation of birth nationality only if based on fraud or false information, and of naturalised citizenship only within ten years of obtaining it and on the basis of fraud or "actions affecting Libya's security or interests", or residence outside the country for more than two years without permission. Unusually and problematically, the law provides for children to be deprived of nationality if the father's is revoked. ${ }^{137}$

The Egyptian Nationality Law still gives very similarly extensive powers to the government to revoke citizenship, whether by naturalisation or from birth, including on grounds that an individual has enrolled in the military of another country or worked against the interests of the Egyptian state in various ways. The same law also allows for revocation of citizenship if a person "was described as being a Zionist at any time" and provides additional grounds for the revocation of

133 Ley num.8/1990 de fecha 24 de octubre, Reguladora de la Nationalidad Ecuatoguineana, articulo 5 .

134 Again, this provision in the Comoros legislation is not in compliance with the constitution.

135 In some cases, this would count as loss rather than deprivation - in that the final loss is automatic; however, given that the government action is required to demand that the person give up the employment, even if there is no final ruling, it is counted here as deprivation.

136 Egypt Law No. 26 of 1975 Concerning Egyptian Nationality, Article 16(7); Eritrea Nationality Proclamation 1992 Article 8; Mali Code des personnes et de la famille, 2011, Article 251.

137 Libya Nationality Law No.17 of 1954, article 10(2); Libya Nationality Law No.18 of 1980, article 10; Libya Nationality Law No.24 of 2010, Articles 12 and 13. 
citizenship from those who obtained it by naturalisation. ${ }^{138}$ Although in practice most cases in which Egyptian citizenship has been lost arise because a person has obtained dual citizenship without permission (see above, chapter 6.4.1), the provisions relating to national security are troubling: between 1986 and 2004 the minister of interior reportedly refused to grant Egyptian citizenship to seven women married to Egyptians, all for reasons related to national security; yet no explanation was given. ${ }^{139}$ The potential for loss of citizenship on the mere allegation of being a "Zionist" both infringes rights to freedom of expression and allows the deprivation of citizenship rights without any evidence that the person concerned is indeed a "Zionist" or that being a "Zionist" is a threat to the Egyptian state.

Deprivation of naturalised citizenship is far easier under the law. Almost all African countries provide for deprivation of citizenship by naturalisation under some circumstances, such as a conviction on charges of treason or a similar crime against the state, conviction on charges of less serious crimes, or a finding that citizenship was acquired by fraud.

Often, there is a "catch all" provision allowing for deprivation for a very wide range of causes. The Commonwealth countries borrow language from the British precedents and provide for deprivation on the grounds of "disloyalty" or the "public good"; while the francophone countries talk about behaviour "incompatible with the status of a national" or "prejudicial to the interests of the country". ${ }^{140}$ Countries including such provisions in relation to naturalised citizens include: Algeria, Benin, Botswana, Burkina Faso, Cameroon, CAR, Chad, Comoros, Congo, Côte d'Ivoire, Djibouti, Egypt, Equatorial Guinea, Eritrea, Gambia, Ghana, Guinea, Lesotho, Liberia, Libya, Madagascar, Malawi, Mali, Mauritania, Mauritius, Morocco, Namibia, Niger, Nigeria, São Tomé and Príncipe, Senegal, Seychelles, Sierra Leone, Sudan, Tanzania, Togo, Tunisia and Uganda. A naturalised citizen may be deprived of nationality if he refuses to do military service in Benin, Congo Republic, Djibouti, Guinea, Madagascar, Mali, Morocco, and Tunisia. ${ }^{141}$ Equatorial Guinea allows naturalised citizenship to be

138 Egyptian Nationality Law, (No. 26 of 1975), Official Gazette No. 22, 29 May 1975, sections 15 and 16.

139 Khalil, Cases of Revocation and Loss of Egyptian Citizenship, cited in CMRS, Africa Citizenship and Discrimination Audit: The Case Study of Egypt, 2005, p.5. No statistics available for Libya.

140 For example: "qui s'est livré à des actes ou qui a un comportement incompatibles avec la qualité de Sénégalais ou préjudiciables aux intérêts du Sénégal.” Loi No.61-70 du 7 mars 1961 déterminant la nationalité sénégalaise, article 21.

141 Benin Code de la nationalité, article 51 ; Congo Republic Code de la nationlité article 55; Djibouti Code de la nationalité 1981 (still in effect for provisions not contrary to law of 2004), article 34; Guinea Code Civil article 106 ; Madagascar Code de la nationalité, article 50; Mali Code de la nationalité, article 43 ; Morocco Code de la nationalité, article 22; Tunisia Code de la nationalité, article 33. 
taken away "in the interests of public order." ${ }^{142}$ A few other countries, including Gambia, Lesotho, and Mauritius, allow deprivation of naturalised citizenship if a person exercises in another country "rights accorded exclusively to that country's citizens", which usually include voting in an election. ${ }^{143}$

A number of countries have a provision based on Article 7 of the Convention on the Reduction of Statelessness (and British law at the time of independence in the 1960s) allowing for deprivation of nationality from an individual with naturalised citizenship if he or she stays outside the country for an extended period (the Convention provides seven years) without notifying the authorities of an intention to retain citizenship. These include Botswana, Egypt, Guinea, Lesotho, Liberia, Libya, Malawi, Mauritius, Namibia, Sierra Leone, Swaziland and Tanzania.

In Malawi, for example, which has provisions that were typical for many Commonwealth countries, someone who has been granted citizenship through registration or naturalisation (only) can be deprived of his or her citizenship on very broad grounds and on the decision only of the designated minister. Citizenship can be revoked where the minister "is satisfied" that the person "has shown himself by act or speech to be disloyal or disaffected towards the Government of Malawi"; when he has traded or associated with or assisted an enemy during war; when within five years of receiving citizenship he is sentenced to a prison term exceeding 12 months; when he resides outside Malawi for a continuous period of seven years without being in the service of Malawi or an international organization or without registering annually at a Malawian consulate his intention to retain his citizenship; or when Malawian citizenship was obtained through fraud, misrepresentation, or concealment of any material fact. ${ }^{144}$ These provisions in the (1966) Citizenship Act appear to violate a (1994) constitutional prohibition on arbitrary deprivation or denial of citizenship. ${ }^{145}$

Kenya's 1963 constitution had near-identical provisions; ${ }^{146}$ however, the 2010 constitution improved this situation, in particular by removing the broadest grounds and providing for a person to have been convicted rather than only suspected of various crimes. Yet it still provides fails to forbid deprivation of nationality if the person would thereby become stateless. ${ }^{147}$ In 2013, the

142 Ley num.8/1990 de fecha 24 de octubre, Reguladora de la Nationalidad Ecuatoguineana, artículo 18.

143 Constitution of the Second Republic of The Gambia, 1996, article 13(1)(c); Lesotho Citizenship Order 1971, section 23(3)(d); Mauritius Citizenship Act 1968, article 15(1)(a) (ii).

144 Malawi Citizenship Act, section 25.

145 Constitution 1994, section 47.

146 Constitution of the Republic of Kenya, 1963, article 94.

147 Constitution of Kenya, 2010, article 17. The Citizenship and Immigration Act 2011, section21, provides for procedures in relation to revocation, referring to the conditions established by the constitution. 
Seychelles inserted a new article to its citizenship law expanding the grounds for deprivation of citizenship by naturalisation if the minister "is satisfied" that the person has been involved in terrorism, piracy, drugs offences, treason, and other offences, or has acted with disloyalty. ${ }^{148}$

Quite a large number of countries allow nationality by naturalisation to be revoked only during a fixed period after it has been acquired, and not indefinitely: Algeria, Benin, Burkina Faso, CAR, Comoros, Congo Republic, Gabon, Libya, Madagascar, Mauritania, Morocco, Niger, Senegal and Tunisia

Few countries provide for protection against statelessness in deprivation cases: just Lesotho, Mauritius, and Zimbabwe (since $2013^{149}$ ) provide in principle for protection from statelessness in all cases where nationality is revoked by act of the government; and Namibia, Rwanda, Senegal, South Africa and Swaziland provide partial protection, allowing statelessness to result in some circumstances or providing a rather vague guarantee. ${ }^{150}$ Namibia allows deprivation of nationality on the grounds that a person was already deprived in another country, increasing the likelihood of rendering them stateless. ${ }^{151}$ Tunisia made a declaration on ratifying the 1961 Convention stating that it did not consider itself bound by the provisions in article 8 prohibiting the deprivation of an individual's nationality if it would render them stateless ${ }^{152}$

148 Section 11A of the Citizenship Act, No. 18 of 1994, inserted by Act 11 of 2013.

149 Zimbabwe's law is in conflict with its new constitution, stating that the minister should seek to avoid statelessness but can still revoke naturalised citizenship if "he is satisfied that it is not conducive to the public good that the person should continue to be a citizen of Zimbabwe." Zimbabwe Constitution 2013, Article 39(3); Citizenship of Zimbabwe Act, Chapter 4:01 Laws of Zimbabwe, section 11(3).

150 Lesotho Constitution 1993, as amended to 2001, Article 42 (however, this provision is not respected in the Citizenship Order 1971 Article 23); Mauritius Citizenship Act 1968, as amended to 1995, Article 11(3)(b); Namibia Constitution 1990, as amended to 2010, Article 9(4); Rwanda Nationality Law 2003, Article 19; Senegal Nationality Code 1961 as amended 2013, Article 21; South African Citizenship Act 1996, as amended 2013, Article 8; Swaziland Constiuttion 2005, section 49(5).

151 Namibia Citizenship Act 1990, Article 9(3)(e)(ii).

152 Submission by the United Nations High Commissioner for Refugees for the Office of the High Commissioner for Human Rights, Compilation Report - Universal Periodic Review: Tunisia, November 2011. 
Table 8: Criteria for loss or deprivation of citizenship

\begin{tabular}{|c|c|c|c|c|c|c|c|c|c|c|c|c|}
\hline \multirow[t]{2}{*}{ Country } & \multirow{2}{*}{ 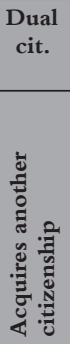 } & \multicolumn{2}{|c|}{$\begin{array}{l}\text { Citizen- } \\
\text { ship from } \\
\text { birth }\end{array}$} & \multicolumn{8}{|c|}{ Citizenship by naturalisation } & \multirow[t]{2}{*}{ Relevant legal provisions } \\
\hline & & 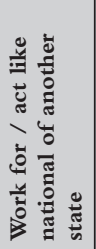 & 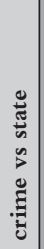 & 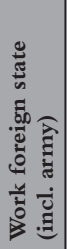 & 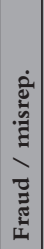 & 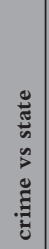 & 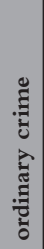 & 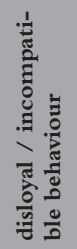 & 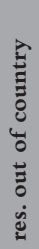 & 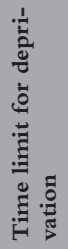 & 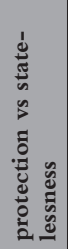 & \\
\hline Algeria & & & & & $\mathrm{x}$ & $\mathrm{x}$ & $\mathrm{x}$ & $\mathrm{x}$ & & $\begin{array}{l}10 \\
\text { yrs }\end{array}$ & & L1970(2005)Arts13, 18-24 \\
\hline Angola & & $\mathrm{x}$ & & $\mathrm{x}$ & $\mathrm{x}$ & $\mathrm{x}$ & & & & & & L2005Art15 \\
\hline Benin & & $\mathrm{x}$ & & & $\mathrm{x}$ & $\mathrm{x}$ & $\mathrm{x}$ & $\mathrm{x}$ & & $\begin{array}{l}10 \\
\text { yrs }\end{array}$ & & L1965Arts15, 46-53, 62-63 \\
\hline Botswana & $\mathrm{x}$ & & & & $\mathrm{x}$ & $\mathrm{x}$ & & $\mathrm{x}$ & $\mathrm{x}$ & & & L1998(2002\&04) Arts15-18 \\
\hline Burkina Faso & & & & & $\mathrm{x}$ & $\mathrm{x}$ & $\mathrm{x}$ & $\mathrm{x}$ & & $\begin{array}{c}10 \\
\text { yrs }\end{array}$ & & L1989Arts149, 187-191, 199 \\
\hline Burundi & & & & $\mathrm{x}$ & $\mathrm{x}$ & & & & & & & L2000Art30-34 \\
\hline Cameroon & $\mathrm{x}$ & $\mathrm{x}$ & & $\mathrm{x}$ & & $\mathrm{x}$ & & $\mathrm{x}$ & & & & L1968Arts31,34,39 \\
\hline Cape Verde & & & & & & & & & & & & $\begin{array}{l}\text { C1992(2010)Art40 } \\
\text { DL1993Art17 }\end{array}$ \\
\hline CAR & $\mathrm{x}$ & $\mathrm{x}$ & & $\mathrm{x}$ & $\mathrm{x}$ & $\mathrm{x}$ & $\mathrm{x}$ & $\mathrm{x}$ & & $\begin{array}{l}10 \\
\text { yrs }\end{array}$ & & L1961Arts46-54 \& 63, 69 \\
\hline Chad & & & & $\mathrm{x}$ & $\mathrm{x}$ & $\mathrm{x}$ & & $\mathrm{x}$ & & & & L1962Art26-28 \& 40 \\
\hline Comoros !! & $\mathrm{x}$ & $\mathrm{x}$ & & $\mathrm{x}$ & $\mathrm{x}$ & $\mathrm{x}$ & $\mathrm{x}$ & $\mathrm{x}$ & & $\begin{array}{l}10 \\
\text { yrs }\end{array}$ & & $\begin{array}{c}\text { C2001Art5 } \\
\text { L1979Arts51-59, } 68\end{array}$ \\
\hline Congo Republic !! & $\mathrm{x}$ & $\mathrm{x}$ & & & $\mathrm{x}$ & $\mathrm{x}$ & $\mathrm{x}$ & $\mathrm{x}$ & & $\begin{array}{l}10 \\
\text { yrs }\end{array}$ & & $\begin{array}{c}\text { C2002Art13 } \\
\text { L1961(1993)Arts47-56 \& 65-66 }\end{array}$ \\
\hline Côte d'Ivoire & $\mathrm{x}$ & $\mathrm{x}$ & & & $\mathrm{x}$ & $\mathrm{x}$ & $\mathrm{x}$ & $\mathrm{x}$ & & & & L1961(2013)Arts48-56, 65-66 \\
\hline DR Congo & $\mathrm{x}$ & & & & $\mathrm{x}$ & & & & & & & L2004Art1,27-29, \\
\hline Djibouti & & $\mathrm{x}$ & & & $\mathrm{x}$ & $\mathrm{x}$ & $\mathrm{x}$ & $\mathrm{x}$ & & & & $\begin{array}{c}\text { L2004 Art } 11 \\
\text { L1981Arts34-35 }\end{array}$ \\
\hline Egypt & $\mathrm{x}$ & $\mathrm{x}$ & $\mathrm{x}$ & $\mathrm{x}$ & $\mathrm{x}$ & $\mathrm{x}$ & $\mathrm{x}$ & $\mathrm{x}$ & $\mathrm{x}$ & & & L1975(2004)Arts10,12,15-19 \\
\hline Equatorial Guinea & $\mathrm{x}$ & $\mathrm{x}$ & & $\mathrm{x}$ & & $\mathrm{x}$ & $\mathrm{x}$ & $\mathrm{x}$ & & & & L1990Art19 \\
\hline Eritrea & $\mathrm{x}$ & $\mathrm{x}$ & $\mathrm{x}$ & $\mathrm{x}$ & $\mathrm{x}$ & $\mathrm{x}$ & $\mathrm{x}$ & $\mathrm{x}$ & & & & L1992Art3,6,8 \\
\hline Ethiopia & $\mathrm{x}$ & & & & & & & & & & yes & $\begin{array}{c}\text { C1994Art33 } \\
\text { L2003Arts19\&20 }\end{array}$ \\
\hline Gabon & & & & & $\mathrm{x}$ & $\mathrm{x}$ & $\mathrm{x}$ & & & $7 \mathrm{yrs}$ & & L1998Art34-36 \\
\hline Gambia !! & & & & & $\mathrm{x}$ & & $\mathrm{x}$ & $\mathrm{x}$ & & & & $\begin{array}{l}\text { C1996(2001)Art13 } \\
\text { L1965Art7-10 }\end{array}$ \\
\hline Ghana & & & & & $\mathrm{x}$ & $\mathrm{x}$ & & $\mathrm{x}$ & & & & $\begin{array}{l}\text { C1992 Art } 9 \\
\text { L2000Art18 }\end{array}$ \\
\hline Guinea & $\mathrm{x}$ & $\mathrm{x}$ & & & $\mathrm{x}$ & $\mathrm{x}$ & $\mathrm{x}$ & $\mathrm{x}$ & $\mathrm{x}$ & & & L1983Art95-108, 130-131, 135 \\
\hline Guinea Bissau & & & & & $\mathrm{x}$ & $\mathrm{x}$ & & & & & & L1992(2010)Art10 \\
\hline Kenya & & & & & $\mathrm{x}$ & $\mathrm{x}$ & $\mathrm{x}$ & & & & & $\begin{array}{c}\text { C2010Art17 } \\
\text { L2011Arts19(4)\&21 }\end{array}$ \\
\hline Lesotho & $\mathrm{x}$ & & & & $\mathrm{x}$ & & $\mathrm{x}$ & $\mathrm{x}$ & $\mathrm{x}$ & & yes & $\begin{array}{c}\text { C1993Art42(2) } \\
\text { L1971Arts22-23 } \\
\end{array}$ \\
\hline Liberia & $\mathrm{x}$ & $\mathrm{x}$ & & & $\mathrm{x}$ & & & $\mathrm{x}$ & $\mathrm{x}$ & & & $\begin{array}{c}\text { C1984Art28 } \\
\text { L1973Art21.50-54\& Art22.1-4 }\end{array}$ \\
\hline Libya & $\mathrm{x}$ & & & & $\mathrm{x}$ & $\mathrm{x}$ & & $\mathrm{x}$ & $\mathrm{x}$ & $\begin{array}{l}10 \\
\text { yrs }\end{array}$ & & L2010Arts5,12,13 \\
\hline Madagascar & $\mathrm{x}$ & $\mathrm{x}$ & & & $\mathrm{x}$ & $\mathrm{x}$ & $\mathrm{x}$ & $\mathrm{x}$ & & $\begin{array}{l}10 \\
\text { yrs }\end{array}$ & & L1960Art42-54\&63 \\
\hline Malawi & $\mathrm{x}$ & & & & $\mathrm{x}$ & $\mathrm{x}$ & $\mathrm{x}$ & $\mathrm{x}$ & $\mathrm{x}$ & & & L1966(1992)Arts23-27 \\
\hline
\end{tabular}




\begin{tabular}{|c|c|c|c|c|c|c|c|c|c|c|c|c|}
\hline \multirow[t]{2}{*}{ Country } & \multirow{2}{*}{$\begin{array}{c}\begin{array}{c}\text { Dual } \\
\text { cit. }\end{array} \\
\\
\end{array}$} & \multicolumn{2}{|c|}{$\begin{array}{l}\text { Citizen- } \\
\text { ship from } \\
\text { birth }\end{array}$} & \multicolumn{8}{|c|}{ Citizenship by naturalisation } & \multirow[t]{2}{*}{ Relevant legal provisions } \\
\hline & & 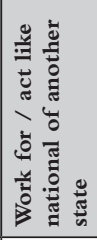 & 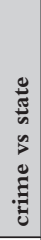 & 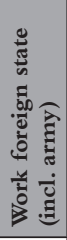 & 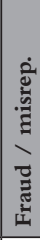 & 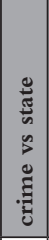 & 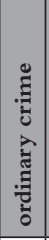 & 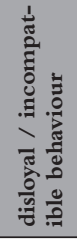 & 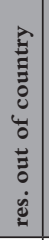 & 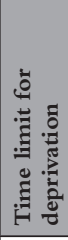 & 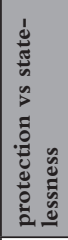 & \\
\hline Mali & & & $\mathrm{x}$ & & $\mathrm{x}$ & $\mathrm{x}$ & $\mathrm{x}$ & $\mathrm{x}$ & & & & L2011Arts249-254 \\
\hline Mauritania & $(\mathrm{x})$ & & & & $\mathrm{x}$ & $\mathrm{x}$ & $\mathrm{x}$ & $\mathrm{x}$ & & $\begin{array}{l}20 \\
\mathrm{yrs}\end{array}$ & & L1961(2010)Arts22, 30-31,33 \\
\hline Mauritius & & & & & $\mathrm{x}$ & $\mathrm{x}$ & $\mathrm{x}$ & $\mathrm{x}$ & $\mathrm{x}$ & & yes & L1968(1995)Arts11\&14 \\
\hline Morocco & & $\mathrm{x}$ & & & $\mathrm{x}$ & $\mathrm{x}$ & $\mathrm{x}$ & $\mathrm{x}$ & & $\begin{array}{l}10 \\
\text { yrs }\end{array}$ & & L1958(2007)Arts14,19-24 \\
\hline Mozambique !! & & $\mathrm{x}$ & & & & $\mathrm{x}$ & & & & & & $\begin{array}{c}\text { C2004Art31 } \\
\text { L1975Arts14-15 }\end{array}$ \\
\hline Namibia & & & & & $\mathrm{x}$ & $\mathrm{x}$ & $\mathrm{x}$ & $\mathrm{x}$ & $\mathrm{x}$ & & yes & $\begin{array}{l}\text { C1990(2010)Art4(7)\&(8) } \\
\text { L1990Arts7-9 }\end{array}$ \\
\hline Niger & & $\mathrm{x}$ & & & & $\mathrm{x}$ & $\mathrm{x}$ & $\mathrm{x}$ & & $\begin{array}{c}10 \\
\text { yrs }\end{array}$ & & L1984(2014)Art34-36 \\
\hline Nigeria & & & & $\mathrm{x}$ & & $\mathrm{x}$ & $\mathrm{x}$ & $\mathrm{x}$ & & & & C1999Arts28-30 \\
\hline Rwanda & & & & & $\mathrm{x}$ & $\mathrm{x}$ & & & & & & $\begin{array}{c}\text { C2003Art7 } \\
\text { L2008Arts18-21 }\end{array}$ \\
\hline Sahrawi ADR & $\mathrm{n} / \mathrm{a}$ & & & & & & & & & & & \\
\hline STP & & $\mathrm{x}$ & & $\mathrm{x}$ & & $\mathrm{x}$ & & $\mathrm{x}$ & & & & L1990Art12 \\
\hline Senegal & & & & & & $\mathrm{x}$ & $\mathrm{x}$ & $\mathrm{x}$ & & $\begin{array}{l}15 \\
\mathrm{yrs}\end{array}$ & \begin{tabular}{|c|} 
par- \\
tial \\
\end{tabular} & L1961(2013)Arts18\&20 \\
\hline Seychelles & & & & & $\mathrm{x}$ & $\mathrm{x}$ & $\mathrm{x}$ & $\mathrm{x}$ & & & & L1994Arts10-11\&11A \\
\hline Sierra Leone & & & & & & $\mathrm{x}$ & $\mathrm{x}$ & $\mathrm{x}$ & $\mathrm{x}$ & & & L1973(2006)Arts15-18 \\
\hline Somalia !! & & & & & $\mathrm{x}$ & $\mathrm{x}$ & & & & & & $\begin{array}{c}\text { C2012Art8 } \\
\text { L1962Arts10-11 } \\
\end{array}$ \\
\hline South Africa !! & (x) & & & $\mathrm{x}$ & $\mathrm{x}$ & $\mathrm{x}$ & $\mathrm{x}$ & & & & $\begin{array}{c}\text { par- } \\
\text { tial } \\
\end{array}$ & $\begin{array}{c}\text { C1996(2009)Art20 } \\
\text { L1995(2010)Arts6-8 }\end{array}$ \\
\hline South Sudan !! & & $\mathrm{x}$ & & $\mathrm{x}$ & $\mathrm{x}$ & $\mathrm{x}$ & & & & & & $\begin{array}{l}\text { C2011Art45 } \\
\text { L2011Art15 }\end{array}$ \\
\hline Sudan & & $\mathrm{x}$ & & & $\mathrm{x}$ & $\mathrm{x}$ & $\mathrm{x}$ & $\mathrm{x}$ & & & & L1994(2011)Arts10\&11 \\
\hline Swaziland & & & & & $\mathrm{x}$ & & & & $\mathrm{x}$ & & \begin{tabular}{|c|} 
par- \\
tial \\
\end{tabular} & $\begin{array}{l}\text { C2005Art49-50 } \\
\text { L1992Art10\&11 } \\
\end{array}$ \\
\hline Tanzania & $\mathrm{x}$ & & & & $\mathrm{x}$ & $\mathrm{x}$ & $\mathrm{x}$ & $\mathrm{x}$ & $\mathrm{x}$ & & & L1995Arts7,13-17 \\
\hline Togo & $\mathrm{x}$ & $\mathrm{x}$ & & $\mathrm{x}$ & $\mathrm{x}$ & $\mathrm{x}$ & $\mathrm{x}$ & $\mathrm{x}$ & & & & L1978Arts23-29,41 \\
\hline Tunisia & & $\mathrm{x}$ & & & $\mathrm{x}$ & $\mathrm{x}$ & $\mathrm{x}$ & $\mathrm{x}$ & & $\begin{array}{c}10 \\
\text { yrs }\end{array}$ & & L1963(2010)Arts30-38 \\
\hline Uganda & $(\mathrm{x})$ & & & $\mathrm{x}$ & $\mathrm{x}$ & $\mathrm{x}$ & $\mathrm{x}$ & $\mathrm{x}$ & & & & $\begin{array}{l}\text { C1995(2005)Arts14-15 } \\
\text { L1999(2009)Arts17-20 }\end{array}$ \\
\hline Zambia!! & $\mathrm{x}$ & & & & $\mathrm{x}$ & & & & & & & $\begin{array}{l}\text { C1991(1996)Art7\&9 } \\
\text { L1975(1994)Art19-23 }\end{array}$ \\
\hline Zimbabwe !! & $(\mathrm{x})$ & & & & $\mathrm{x}$ & $\mathrm{x}$ & & & & & yes & $\begin{array}{c}\text { C2013Art39 } \\
\text { L1984(2003)Art10(4),10-13 }\end{array}$ \\
\hline
\end{tabular}

\section{n/a not available}

(x) permission of government required for dual citizenship

!! Constitution conflicts with legislation, constitutional provisions noted here

$\mathrm{x}^{\mathrm{MS}}$ permission required during period in which military service obligations apply or if person concerned is a national of an enemy country ren. Protection against statelessness only for person voluntarily renouncing nationality 


\subsection{Renunciation and reacquisition}

While the nationality laws of most African countries include provisions allowing a person to renounce his or her nationality, not all do so. There are no provisions in DRC, Cameroon, Chad, Djibouti, Equatorial Guinea, Eritrea, Liberia, Libya, Mauritania, Niger, South Sudan or Tunisia. In addition, a large proportion of the remainder require the person to obtain permission to release himself or herself from obligations to the state, at least in some circumstances: Algeria, Benin, Botswana, Burkina Faso, Central African Republic, Comoros, Republic of Congo, Cote d'Ivoire, Egypt, Ethiopia, Gambia, Guinea, Kenya, Lesotho, Madagascar, Malawi, Mauritius, Morocco, Namibia, Nigeria, Senegal, Seychelles, Sierra Leone, Somalia, Sudan, Tanzania, Togo, Uganda, Zambia and Zimbabwe (see Table 9). This requirement to be released from nationality is derived from the feudal concept of perpetual allegiance previously prevalent in Europe, but largely relinquished by European states during the $20^{\text {th }}$ century (under pressure from the United States, wishing the possibility of gaining naturalised citizens in the context where dual nationality was not considered a possibility); and also linked to Islamic law. ${ }^{153}$

These provisions are sometimes merely routine, providing a protection against statelessness, but can be problematic, in some contexts effectively depriving citizens of a right to free movement and expression. ${ }^{154}$ For example, an individual who has obtained refugee status and then nationality in another country because of persecution suffered in his or her country of birth may wish no longer to be a national of this first country. Yet the government of the latter country, responsible for this persecution, may be unwilling to release the individual from the alleged obligations of citizenship. ${ }^{155}$ Even where a person wishes to acquire the nationality of a new country of residence in other cirucmstances, but dual nationality is not permitted, restrictions on renunciation may prevent change of nationality (one of the elements guaranteed by Article 15 of the Universal Declaration).

Another way in which provisions on renunciation may be problematic is if there is no protection against statelessness, requiring an assurance that the person has

153 Spiro, "A new international law of citizenship", pp.707-709; Parolin, Citizenship in the Arab World, p.108.

154 In the case of Morocco, this rule led to official protests from Morocco at the proposal by the Netherlands to end recognition of dual citizenship, since more than 200,000 people hold Dutch and Moroccan citizenship; ultimately, the new law provided exceptions where the other country required permission to renounce nationality. Sarah Touahri, "Morocco decries move by Netherlands to eradicate dual nationality," Magharebia, 9 July 2008.

155 For example, the Sudanese government has for political reasons harassed and detained former citizens who have obtained refugee status and then nationality in other countries when they have returned to Sudan. See Amnesty International, "UA 325/08 Incommunicado detention/risk of torture: SUDAN", AI Index: AFR 54/044/2008, 26 November 2008. 
already or will definitely acquire another nationality; or be able to reacquire the nationality of origin in case this does not happen. While such provisions are present in most countries permitting renunciation, they do not exist or are not watertight in: Cameroon, Chad, DRC, Equatorial Guinea, Eritrea, Gabon, Liberia, Libya, Niger, Nigeria, Rwanda, South Africa, Sudan, Tanzania or Zimbabwe.

Table 9: Renunciation and reacquisition

\begin{tabular}{|c|c|c|c|c|}
\hline \multirow[t]{2}{*}{ Country } & \multicolumn{2}{|c|}{ Renunciation } & \multirow[t]{2}{*}{ Reacquisition } & \multirow{2}{*}{$\begin{array}{l}\text { Relevant legal } \\
\text { provisions }\end{array}$} \\
\hline & Conditions applied & $\begin{array}{c}\text { Protection } \\
\text { vs } \\
\text { statelessness }\end{array}$ & & \\
\hline Algeria & If auth by decree & Yes & After 18 months residence & L1970(2005)Arts14,18 \\
\hline Angola & $\begin{array}{c}\text { By declaration } \\
\text { (manifestarem a pretensão) }\end{array}$ & Yes & $\begin{array}{l}\text { After } 5 \text { yrs residence, if renounced } \\
\text { If deprived, Nat.Ass. must authorise; } \\
\text { reacquisition may be opposed } \\
\text { on grounds similar to those for } \\
\text { deprivation }\end{array}$ & L2005Arts15-17 \\
\hline Benin & If auth by decree & Yes & $\begin{array}{l}\text { By decree after inquiry, if resident in } \\
\text { Benin, not if deprived or expelled }\end{array}$ & L1965Art37-39\&42 \\
\hline Botswana & $\begin{array}{l}\text { By registration, minister } \\
\text { may withhold if resident } \\
\text { in Botswana }\end{array}$ & Yes & $\begin{array}{l}\text { Only if lost for dual nationality \& is } \\
\text { resident in Botswana }\end{array}$ & L1998(2004)Arts16,17 \\
\hline Burkina Faso & If auth by kiti (decree) & Yes & Must be resident & L1989Arts171-175,186 \\
\hline Burundi & By declaration & Yes & If lost because of dual nationality & L2000Arts30-32\&38-41 \\
\hline Cameroon & By decree; no conditions & No & $\begin{array}{l}\text { If resident in Cameroon, not if } \\
\text { deprived }\end{array}$ & L1968Arts28-31\&36-39 \\
\hline Cape Verde & By declaration & Yes & $\begin{array}{l}\text { By declaration if lost because of dual } \\
\text { nationality }\end{array}$ & DL1993Arts17-19 \\
\hline CAR & If auth by decree & Yes & $\begin{array}{l}\text { By decree after inquiry, must be } \\
\text { resident in CAR, not if deprived }\end{array}$ & L1961Arts32-36\&47 \\
\hline Chad & If auth by decree & Yes & $\begin{array}{l}\text { By decree after inquiry, not if } \\
\text { deprived }\end{array}$ & L1962Arts19-20,26,30\&40 \\
\hline Comoros & If auth by decree & Yes & $\begin{array}{c}\text { By decree after inquiry, must be } \\
\text { resident }\end{array}$ & L1979Arts37-41\&51-52 \\
\hline Congo Rep. & If auth by decree & Yes & $\begin{array}{c}\text { Must be resident, not if expelled or } \\
\text { under house arrest }\end{array}$ & L1961(1993)Arts36-40\&51 \\
\hline Côte d'Ivoire & If auth by decree & Yes & $\begin{array}{l}\text { By decree after inquiry, must be } \\
\text { resident, not if deprived }\end{array}$ & $\begin{array}{c}\text { L1961(2013)Arts34- } \\
\text { 38,48-49 }\end{array}$ \\
\hline DRC & No provision & - & $\begin{array}{l}\text { By decree if naturalised \& must fulfil } \\
\text { same conditions as for naturalisation; } \\
\text { by declaration if of origin \& must } \\
\text { have maintained links to DRC }\end{array}$ & L2004Arts30-33 \\
\hline Djibouti & No provision & - & No provision & - \\
\hline Egypt & No provision & - & $\begin{array}{c}\text { By decree, after delay of } 5 \text { yrs since } \\
\text { withdrawn or forfeited }\end{array}$ & L1975(2004)Arts10\&18 \\
\hline Eq. Guinea & No provision & & Only by a law & L1990Art20 \\
\hline Eritrea & $\begin{array}{l}\text { May be deprived if } \\
\text { renounces }\end{array}$ & No & No provision & L1992Art8 \\
\hline Ethiopia & $\begin{array}{c}\text { Shall not be released } \\
\text { unless fulfils military } \\
\text { obligations and serves any } \\
\text { criminal penalty }\end{array}$ & Yes & $\begin{array}{l}\text { If domiciled in Ethiopia and } \\
\text { renounces other nationality }\end{array}$ & L2003Arts19\&22 \\
\hline Gabon & By decree, no conditions & No & $\begin{array}{l}\text { By decree after inquiry, must be } \\
\text { resident in Gabon, not if deprived }\end{array}$ & L1998Arts27-29\&34 \\
\hline
\end{tabular}




\begin{tabular}{|c|c|c|c|c|}
\hline \multirow[t]{2}{*}{ Country } & \multicolumn{2}{|c|}{ Renunciation } & \multirow[t]{2}{*}{ Reacquisition } & \multirow{2}{*}{$\begin{array}{c}\text { Relevant legal } \\
\text { provisions }\end{array}$} \\
\hline & Conditions applied & \begin{tabular}{|c|}
$\begin{array}{c}\text { Protection } \\
\text { vs } \\
\text { statelessness }\end{array}$ \\
\end{tabular} & & \\
\hline Gambia & $\begin{array}{l}\text { By registration, minister } \\
\text { may withhold if resident } \\
\text { in Gambia and would be } \\
\text { contrary to public policy }\end{array}$ & Yes & If lost because of dual nationality & $\begin{array}{l}\text { C1996(2001)Art14 } \\
\text { L1965Art7 }\end{array}$ \\
\hline Ghana & $\begin{array}{c}\text { By registration, no } \\
\text { conditions }\end{array}$ & Yes & If lost because of dual nationality & L2000Arts16\&17 \\
\hline Guinea & If auth by decree & Yes & $\begin{array}{l}\text { By decree after inquiry, must be } \\
\text { resident, not if deprived }\end{array}$ & L1983Arts81-84\&99 \\
\hline G. Bissau & By declaration & Yes & $\begin{array}{c}\text { By declaration, if established domicile } \\
\text { in country }\end{array}$ & L1992(2010)Arts10-11 \\
\hline Kenya & $\begin{array}{l}\text { By registration, no } \\
\text { conditions }\end{array}$ & Yes & $\begin{array}{l}\text { If lost because of dual nationality, on } \\
\text { application }\end{array}$ & L2011Arts10\&19 \\
\hline Lesotho & $\begin{array}{c}\text { By registration, minister } \\
\text { may withhold if not } \\
\text { conducive to public good } \\
\text { or during a war } \\
\end{array}$ & Yes & $\begin{array}{l}\text { If renounced or because of dual } \\
\text { nationality, and renounces other } \\
\text { nationality }\end{array}$ & L1971Arts22\&25 \\
\hline Liberia & No provision & - & No provision & - \\
\hline Libya & No provision & - & No provision & - \\
\hline Madagascar & If auth by decree & Yes & $\begin{array}{l}\text { By decree after inquiry, must be } \\
\text { resident, not if deprived }\end{array}$ & L1960Arts30-34\&45 \\
\hline Malawi & $\begin{array}{l}\text { By registration, may be } \\
\text { withheld if during a war } \\
\text { or if contrary to public } \\
\text { policy }\end{array}$ & Yes & If has renounced other nationality & L1966(1992)Arts23\&27 \\
\hline Mali & By declaration & Yes & By decree after inquiry & L2011Arts243-244\&249-250 \\
\hline Mauritania & No provision & - & $\begin{array}{c}\text { By decree after inquiry, not if } \\
\text { deprived }\end{array}$ & L1961(2010)Arts25-29\&31 \\
\hline Mauritius & $\begin{array}{l}\text { By registration, minister } \\
\text { may withhold }\end{array}$ & Yes & In case of marriage, if marriage ends & L1968(1995)Art14 \\
\hline Morocco & If auth by decree & Yes & On application & L1958(2007)Arts15\&19 \\
\hline Mozambique & By declaration & Yes & $\begin{array}{l}\text { Must be domiciled in Mozambique } \\
\text { and satisfy conditions relating to } \\
\text { integration }\end{array}$ & $\begin{array}{c}\text { C2004Arts31-32 } \\
\text { L1975(1987)Arts14\&16 }\end{array}$ \\
\hline Namibia & $\begin{array}{l}\text { By registration, may be } \\
\text { withheld if during a war }\end{array}$ & Yes & $\begin{array}{c}\text { If lost because of dual nationality or } \\
\text { some forms of deprivation, not if is a } \\
\text { national of another country }\end{array}$ & L1990Arts8\&13 \\
\hline Niger & No provision & - & $\begin{array}{l}\text { By decree after inquiry, must be } \\
\text { resident, not if deprived }\end{array}$ & L1984(2014)Arts38-42 \\
\hline Nigeria & $\begin{array}{c}\text { By registration, may be } \\
\text { withheld if during a war } \\
\text { or contrary to public } \\
\text { policy }\end{array}$ & No & No provision & C1999Art29 \\
\hline Rwanda & $\begin{array}{l}\text { Shall inform director- } \\
\text { general, shall not } \\
\text { compromise laws of } \\
\text { Rwanda or for purpose } \\
\text { of seeking refugee status }\end{array}$ & Yes & $\begin{array}{c}\text { If deprived because of dual } \\
\text { nationality, not if deprived as } \\
\text { naturalised citizen or if expelled as } \\
\text { security threat }\end{array}$ & L2008Arts18,22-24 \\
\hline SADR & & & & $\mathrm{n} / \mathrm{a}$ \\
\hline STP & By declaration & Yes & $\begin{array}{c}\text { By declaration after } 2 \text { yrs residence } \\
\text { in STP }\end{array}$ & L1990Arts12\&13 \\
\hline Senegal & If auth by decree & Yes & No provision & L1961(2013)Art18-19 \\
\hline Seychelles & $\begin{array}{l}\text { By registration, may } \\
\text { be withheld if gains } \\
\text { nationality of country } \\
\text { with which at war }\end{array}$ & Yes & No provision & L1994(2013)Art10 \\
\hline
\end{tabular}




\begin{tabular}{|c|c|c|c|c|}
\hline \multirow[t]{2}{*}{ Country } & \multicolumn{2}{|c|}{ Renunciation } & \multirow[t]{2}{*}{ Reacquisition } & \multirow{2}{*}{$\begin{array}{l}\text { Relevant legal } \\
\text { provisions }\end{array}$} \\
\hline & Conditions applied & $\begin{array}{c}\begin{array}{c}\text { Protection } \\
\text { vs } \\
\text { statelessness }\end{array} \\
\end{array}$ & & \\
\hline S. Leone & $\begin{array}{l}\text { By registration, may be } \\
\text { withheld if resident in SL, } \\
\text { if has rights inconsistent } \\
\text { with an alien nationality, or } \\
\text { if contrary to public good }\end{array}$ & Yes & If lost because of dual nationality & L1973(2006)Arts15\&19A \\
\hline Somalia & $\begin{array}{l}\text { By declaration, must be } \\
\text { resident abroad }\end{array}$ & Yes & $\begin{array}{l}\text { If resident in Somalia for } 3 \mathrm{yrs} \text { and } \\
\text { fulfils conditions for naturalisation }\end{array}$ & L1962Arts10\&12 \\
\hline South Africa & $\begin{array}{l}\text { By registration, no } \\
\text { conditions }\end{array}$ & No & $\begin{array}{l}\text { If reasons for loss or deprivation no } \\
\text { longer exist or are of no consequence }\end{array}$ & L1995(2010)Arts7\&13 \\
\hline South Sudan & By presidential order & No & No provision & L2011Art15 \\
\hline Sudan & $\begin{array}{l}\text { By presidential order, may } \\
\text { refuse if Sudan at war }\end{array}$ & No & $\begin{array}{l}\text { May reinstate for person from whom } \\
\text { withdrawn, without prejudice to } \\
\text { automatic withdrawal from person of } \\
\text { S.Sudan nationality }\end{array}$ & L1994(2011)Arts10\&16 \\
\hline Swaziland & By declaration & Yes & No provision & $\begin{array}{l}\text { C2005Art50 } \\
\text { L1992Art11 }\end{array}$ \\
\hline Tanzania & $\begin{array}{c}\text { By registration, minister } \\
\text { may withhold if during } \\
\text { war or contrary to public } \\
\text { policy } \\
\end{array}$ & No & No provision & L1995Art13 \\
\hline Togo & If auth by decree & Yes & $\begin{array}{c}\text { By decree after inquiry if resident in } \\
\text { Togo, not if deprived }\end{array}$ & L1978Arts15-18\&23-24 \\
\hline Tunisia & No provision & - & No provision & - \\
\hline Uganda & $\begin{array}{l}\text { By registration, may } \\
\text { be withheld if acquires } \\
\text { nationality of country } \\
\text { with which at war or } \\
\text { contrary to public policy }\end{array}$ & Yes & $\begin{array}{l}\text { If lost because of dual nationality and } \\
\text { no adverse effect to public order \& } \\
\text { security }\end{array}$ & L1999(2009)Arts19G\&20 \\
\hline Zambia & $\begin{array}{l}\text { By registration, may be } \\
\text { withheld if during war }\end{array}$ & Yes & $\begin{array}{l}\text { If lost because of dual nationality and } \\
\text { board satisfied that not aware of loss }\end{array}$ & L1975(1994)Arts21\&23 \\
\hline Zimbabwe & $\begin{array}{l}\text { By registration, may be } \\
\text { withheld if is a national } \\
\text { of a country with which } \\
\text { at war }\end{array}$ & No & Not if a national of another country & L1984(2003)Arts10\&14 \\
\hline
\end{tabular}

$\star$ Only in case of repudiation of nationality attributed at birth

Most rules on reacquisition have exemptions for "exceptional circumstances", which are not noted here.

\subsection{The right to challenge executive decisions on nationality}

Decisions in nationality matters, including the issue of identity documents (that are not formally proof of nationality, but are accepted as such for normal purposes), tend to the discretionary; most obviously in the case of naturalisation, but this is so even where formally an official has no discretion. Among the most important protections against statelessness is therefore the right of an individual to challenge decisions relating to the right to a nationality through both administrative and judicial channels.

Many civil law countries' nationality laws contain provisions relating to adjudication of nationality decisions by the courts, either directly, in case of confirmation of nationality of origin; or by review of decisions relating to deprivation of citizenship and, in some cases, also of naturalisation. Constitutional 
due process protections would also apply, and Burundi's 2005 constitution, for example, specifically provides that no one can be arbitrarily deprived of his or her nationality. ${ }^{156}$

Legal challenge to nationality decisions tends to be more difficult in the common law system. The civil law tradition of administrative courts does not exist, and judicial review is a more cumbersome procedure. The nationality law in Botswana, Lesotho, Malawi, Mauritius, Seychelles, Tanzania, and Zambia - all with a British legal inheritance - explicitly state in their legislation that a decision on any matter under the nationality law cannot be reviewed in court. ${ }^{157}$ In Zimbabwe, the law provides that minister need give no reasons for any decision under the act, rendering any challenge more difficult. ${ }^{158}$ These are all countries which do not allow for deprivation of birthright citizenship (though some provide for loss in case of acquisition of another nationality); but it is questionable what the protection against statelessness in deprivation cases provided by Mauritius means, if the decision of the minister cannot be challenged. In Swaziland, where a certificate of nationality "shall" be issued by the minister to a person who is qualified to be a citizen, it is also provided that the minister "may revoke" a certificate and no grounds are specified. ${ }^{159}$

A few countries, including Botswana, Seychelles, Swaziland, and Zambia establish an administrative body appointed by the minister or the president to advise on decisions to grant or (less often) deprive citizenship; ${ }^{160}$ but such mechanisms cannot justify the exclusion of review by the normal courts. Lesotho and Malawi do not even establish a citizenship board for these decisions, though they provide for review of a decision to deprive nationality by an "enquiry" conducted by persons appointed by the minister. In Namibia, the Namibian Citizenship Act also provides for an administrative review of deprivation of nationality; though it does not explicitly provide for judicial review as well, this is permitted under the constitution. However, in relation to denial of naturalisation, no challenge is permitted. ${ }^{161}$ In South Africa, however, section 25 of the Citizenship Act specifically provides that any decision of the minister may be reviewed by the High Court. ${ }^{162}$

156 Burundi Constitution 2005, article 34.

157 Botswana Citizenship Act 1998, amended 2004, section 22; Lesotho Citizenship Order 1971, Article 26; Malawi Citizenship Act 1966, Article 29; Mauritius Citizenship Act 1968 Article 17; Seychelles Citizenship Act 1994, Article 14; Tanzania Citizenship Act 1995 23; Zambia Citizenship Act 1975, amended 1994, Article 9.

158 Zimbabwe Citizenship Act 1984, amended 2003, section 16.

159 Swaziland Citizenship and Immigration Act 1992, Article 20.

160 Botswana Citizenship Act 1998, amended 2004, section 22; Seychelles Citizenship Act 1994, amended to 2013, section 9A; Swaziland Constitution 2005, article 53.

161 Namibian Citizenship Act, sections 5(8), 9(5) and 17; Constitution, Article 12 (right to a fair trial).

162 South Africa Citizenship Act, 1995 (as amended), section 25 
Due process is especially important in deprivation cases, and several constitutions and laws create credible due process hurdles for governments seeking to revoke citizenship. In Kenya for example, the 2010 constitution requires a naturalised citizen (citizenship by birth cannot be revoked) to have been actually convicted of a serious crime, including treason, before deprivation can take place. ${ }^{163}$ Less specifically, Burundi, Malawi, and Rwanda have constitutional provisions forbidding arbitrary deprivation of nationality. ${ }^{164}$ Meanwhile, Gambia, Ghana, Liberia and Rwanda all provide that deprivation (of naturalised citizenship) can only be done by a court, on the government's application; ${ }^{165}$ and a majority, though not all, others provide for judicial review of administrative decisions to deprive.

163 Kenya Constitution, 2010, Section 17.

164 Burundi Constitution 2005, Article 34; Malawi Constitution 1994 (as amended to 1998), Article 47 ; Rwanda Constitution 2003, Article 7.

165 Gambia Constitution 1996, article 13; Ghana Constitution 1992 Article 9, Citizenship Act 2000, Article 18; Liberia Aliens and Nationality Law 1973, Articles 21.53; Rwanda Nationality Law No.30 of 2008, Article 20. 


\section{Nationality administration in practice}

In practice, individual Africans far more often face the practical impossibility of obtaining official documentation than an explicit legal denial of nationality. Yet something as simple as an inability to access birth registration or an indefinite delay in obtaining a national identification card upon reaching adulthood - processes regarded as purely administrative - can have consequences just as damaging and permanent as if denationalisation had been enacted in the law or by executive decree. It is the low-level administrative decisions - to register a child's birth or enrol her in school, to issue an identity card or passport, to permit a house to be built or land to be cultivated, and of course to vote - that determine whether someone has access to the rights that go with nationality, and thus for all practical purposes to nationality itself.Thus, the regulations and décrets that provide detailed rules for application of the laws, as well as the internal directives of government departments and the level of training of the officials who implement them, may in practice be at least as important as the law itself in shaping the understanding of the government officials responsible for issue of identity and other documentation, and thus access to proof of nationality in practice. ${ }^{1}$

In some cases, problems in these systems are deliberate. But in others, they may simply be due to the weakness of state administration in general. Indeed, some authors have used the concept of statelessness in Africa simply to mean the lack of effective states, rather than anything to do with the right to a nationality in national or international law. ${ }^{2}$

The recognition of a right to a nationality starts with registration of birth. The African Charter on the Rights and Welfare of the Child, like the UN Convention on the Rights of the Child, combines the right to birth registration and the right to acquire a nationality within one single article, making this explicit link. Birth registration establishes the place of birth and parental affiliation, which in legal terms serve as proof of acquisition of the parents' nationality, or the nationality of the State where the child is born. While birth registration in and of itself does not normally confer nationality upon children, it is a key form of proof of the link between the child and a State. Yet birth registration is below 50 percent across Africa.Access to documentation that can prove place of birth and parentage (critical steps in proving a right to citizenship) is thus already difficult in many countries, without the additional complications of ethnic and political discrimination. Refusal

1 Much of the information in this chapter was first published in Manby, Nationality, Migration and Statelessness in West Africa.

2 Jennifer A. Widner "States and Statelessness in Late Twentieth-Century Africa", Daedalus, Vol. 124, No. 3, 1995, pp. 129-153. Somalis by this argument are perhaps automatically "stateless". 
to register births or accept applications for documentation is often perpetrated by low-level local officials or bureaucrats, who have little knowledge of the law, receive next to no supervision from the central government and whose actions are completely non-transparent and very difficult to appeal.

Many African countries, especially but not only those of civil law tradition, require that all their citizens acquire identity documents at majority. Without a national ID card, an individual will not be able to access any state benefit, or many in the private sector. The processes for administering national identity documentation are thus even more critical than those for birth registration (though birth registration may also be the first requirement for a national ID) - yet international law has virtually no standards to provide a normative framework for such systems. When it comes to international travel, those countries in the Commonwealth tradition inherited a legal regime in which a passport is a privilege not a right; although this is gradually being undermined. With the strengthening of regional freedom of movement regimes, national identity documents are also being accepted for international travel - making them yet more important.

\section{An Egyptian-Sudanese-Ethiopian-Eritrean stateless woman in Egypt ${ }^{3}$}

Mary was born and raised in Sudan. Her father, who was a Sudanese Christian of Egyptian heritage, abandoned the family when she was eleven. Mary's mother was of mixed Ethiopian-Eritrean origin and had never formally elected a nationality after Eritrea's secession. Mary never possessed a birth certificate or any formal identity documents. When she tried to acquire documents by formally applying for Sudanese nationality her request was denied as she was unable to produce any evidence of her father's nationality. She was denied Ethiopian nationality after the Ethiopian Embassy determined her mother to be Eritrean, and denied Eritrean nationality as she was unable to fulfil the evidence requirements. Mary is therefore stateless. She has no legal right to reside in any country and is thus at risk of immigration-related detention. She is unable to enrol in public education facilities or take up legal employment, and is therefore forced to risk taking up potentially exploitative, informal work. Mary's application for refugee status in Egypt was denied by UNHCR Cairo as she had no well-founded fear of persecution.

\subsection{Birth registration}

Both the UN and the African child rights conventions recognise the close connection between birth registration, identity and nationality by including

\footnotetext{
3 "Case study 3" from Pierrot, UNHCR and statelessness in Egypt.
} 
these rights within the same article of the treaty. ${ }^{4}$ The African Committee of Experts on the Rights and Welfare of the Child affirmed this link, noting in the Kenyan Nubian Children's Case that "there is a strong and direct link between birth registration and nationality". ${ }^{5}$ Birth registration is critical to establishing in legal terms the place of birth and parental affiliation, which in turn serves as documentary proof underpinning acquisition of the parents' nationality (jus sanguinis), or the nationality of the state based on where the child is born (jus soli). In many of the civil law countries the nationality law requires any facts related to birth, marriage and descent to be established according to the laws on civil registration; this is not stated to be the case in most of the Commonwealth countries, but in South Africa, for example, recognition of the nationality of a stateless child (but not the child of a citizen) is conditional on the child's birth being registered in accordance with the Births and Deaths Registration Act. ${ }^{6}$ In a few cases, birth registration is itself proof of nationality: in Angola, Botswana and Rwanda, for example, the law provides that nationality is proved by a birth certificate. ${ }^{7}$

However, according to UNICEF, 56 percent of African children under five years old had not been registered as of 2013 (85 million children), with the situation much worse in rural areas; in some countries more than 90 percent of children are not registered. Even where higher rates are reported, individual children may not actually have a birth certificate, due to high fees or a lack of legal entitlement to proof of registration: for instance, in Eastern and Southern Africa, only about half of the registered children have a birth certificate, compared to 88 per cent of registered children in West and Central Africa. In Angola, only 36 per cent of children were registered, and only 26 per cent in rural areas despite the provisions of the 2007 civil registration law for universal and free registration of births. In Rwanda, where 63 percent of children under five are reportedly registered, only one in 10 had a document proving that registration (and thus nationality). In Eritrea, the issue of a birth certificate can involve major bureaucratic hurdles and cost the equivalent of one week's average rent in rural areas of the country: the rate of registration is not available. ${ }^{8}$

4 "The child shall be registered immediately after birth and shall have the right from birth to a name, the right to acquire a nationality and, as far as possible, the right to know and be cared for by his or her parents." Convention in the Rights of the Child, 20 November 1989, Article 7(1). The African Charter on the Rights and Welfare of the Child contains the same first three elements in its Article 6.

5 Kenyan Nubian Children's Case, paragraph 42. See also the Committee's General Comment on Article 6.

6 South African Citizenship Act 1995, as amended, article 2(2).

7 Angola Lei da nacionalidade No.1/2005, article 24; Botswana Children's Act No.8 of 2009, section 12(3); Rwanda Organic Law No.30/2008 of 25 July 2008, article 25.

8 UNICEF, Every Child's Birth Right: Inequities and trends in birth registration, 2013. See also UNICEF "Information by country", available at http://www.unicef.org/infobycountry/, last accessed 4 December 2014; and concluding observations of the committee monitoring 
Single mothers may face particular difficulties registering a birth, even where constitutional and legislative provisions forbid discrimination on the basis of sex, and even where court cases have confirmed the rights of women. Similar problems face grandmothers left to care for orphaned grandchildren. In some cultures it can be shameful for the child to carry the mother's name, and impossible to give the child the father's name without his consent. ${ }^{9}$

In some countries, registration of births is not even compulsory. For example, in southern Africa, as of 2004 registration of births was as of 2004 compulsory for all children in Mauritius, South Africa, Swaziland, Zambia, and Zimbabwe; but not in Botswana, Malawi, and Tanzania. ${ }^{10}$ In Malawi and Tanzania, the requirement to register was racially based. Registration was compulsory only if one or both parents were of European, American, or Asiatic "race" or origin, and in Tanzania also if of Somali origin. ${ }^{11} \mathrm{New}$ efforts supported by UNICEF have changed this situation, but registration rates remain low. ${ }^{12}$

The problem of low birth registration rates should in principle be addressed by the provisions in several nationality codes in the civil law countries that allow for those persons who have always been treated as citizens (are in possession d'etat de national) to obtain official recognition that they are citizens by origin, without needing to establish further facts. Senegal provides that if someone has his or her habitual residence in Senegal and has always behaved and been treated as a citizen, it shall be presumed that he or she is a citizen. ${ }^{13}$ Similar provisions exist in Benin, Congo Republic, Morocco, Togo, and elsewhere.

compliance with the UN Child Rights Convention, available at http://www.ohchr.org/ EN/HRBodies/CRC/Pages/CRCIndex.aspx, last accessed 4 December 2014.

9 Rumbidzai Dube, A Right or a Privilege: Access to Identity and Citizenship in Zimbabwe, Harare: Research and Advocacy Unit, 2008; Rumbidzai Dube, Identity, Citizenship, and the Registrar General: The Politicking of Identity in Zimbabwe, Harare, Research and Advocacy Unit, 2012.

10 Klaaren and Rutinwa, "Towards the Harmonisation of Immigration and Refugee Law in SADC", pp.40-41.

11 Tanzania Births and Deaths Registration Act 1920 (Cap.108), sections 26 \& 27; Malawi Births and Deaths Registration Act 1904 (Cap.24), section 18.

12 "The Government of Tanzania launches a new national birth registration system set to massively accelerate the number of children under 5 with birth certificates", UNICEF, 23 July 2013; "In Malawi, the launch of universal birth registration guarantees protections for children”, UNICEF, 30 March 2012. However, the Tanzanian Births and Deaths Registration Act (Cap.108), dating from 1920, which made registration compulsory only for non-natives, had not yet been replaced by the end of 2014. In Malawi, the National Registration Act 2009 replaced the previous legislation dating from 1904 and made registration compulsory for all.

13 Loi nº 61-70 du 7 mars 1961 déterminant la nationalité sénégalaise (as amended), article 1. 
However, these provisions will often only benefit those who fit in with the general ethnic profile of the country, and sometimes this is made explicit. For example, Algeria's nationality code includes the common provision on the possession d'etat de national, if a person has always been treated as Algerian. In addition, it provides that nationality of origin can be claimed by showing evidence of two generations of ancestors born in the country (one parent and one of his or her parents) but only if those ancestors were Muslim, introducing religious discrimination in an apparently procedural article. ${ }^{14}$ In Chad, the provision on possession d'état de Tchadien is restricted to those of "African ancestry" (de souche africain). ${ }^{15}$

The African Centre for Statistics hosted by the UN Economic Commission for Africa launched a major initiative to improve civil registration systems in 2010, with a meeting of African ministers responsible for civil registration. ${ }^{16}$ In February 2015, the third meeting in this series launched a "decade of civil registration" recognising "the significance of CRVS as a tool to facilitate development with all that entails, from honoring human rights starting with the right to identity, to enhancing economic opportunity and Africa's commitment to regional integration." ${ }^{17}$

Based on these efforts and with the support of UNICEF, there has been progress in many countries. For example, from 2006 to 2011 birth registration rates increased in Benin from 60 to 80 percent; in Senegal, from 55 to 75 percent; in Mozambique, from 36 to 48 percent; in Namibia, from 60 to 78 percent; and in Uganda, from 21 to 30 percent. In Tanzania, the registration of children under five doubled between 1999 and 2010 - from 6 per cent to 16 per cent — but remained very low, and the proportion of those with a physical birth certificate was unchanged; further efforts were underway to secure more improvements. ${ }^{18}$

The situation in Kenya is illustrative. Kenyan law has always provided for compulsory registration of births and deaths, and the 2001 Children's Act brought wide-ranging reforms, including providing for every child to have the right to a name and nationality. Nonetheless, as of 2007, the UN Committee on the Rights of the Child noted its concern at "the restrictive measures around birth registration, the discrimination with regard to the registration of children born

14 Ordonnance No. 05-01 du 27 février 2005 revising Ordonnance No.70-86 du 15 décembre 1970 portant code de la nationalité algérienne, article 32.

15 Ordonnance no.33/PG-INT du 14 août 1962 portant Code de la nationalité tchadienne, articles 14-16.

16 See background on the initiative available at the UNECA website, http://ecastats.uneca. org/acsweb/FocusAreas/CRVS.aspx, last accessed 04 March 2014.

17 "Africa Launches Decade of Civil Registration 2015-2024", Thomson Reuters Foundation, 16 February 2015. See also website for the $3^{\text {rd }}$ Ministerial Conference on Civil Registration and Vital Statistics at http://www.uneca.org/crmc3, last accessed 17 February 2015.

18 UNICEF, Every Child's Birth Right; also UNICEF statistics on birth registration available at http://data.unicef.org/child-protection/birth-registration accessed 1 September 2014. 
out of wedlock and of non-Kenyan fathers, as well as the lack of mechanisms and infrastructure to facilitate birth registrations." ${ }^{19} \mathrm{New}$ legislation on civil registration, mobile registration units and a campaign of public outreach with the assistance of UNICEF and Plan-International had increased the percentage of children registered to 60 percent by December $2013 .^{20}$

Table 10: Birth registration rates (percentage of children under five) 21

\begin{tabular}{|c|c|c|c|c|c|c|c|}
\hline Country & Total & Urban & Rural & Country & Total & Urban & Rura \\
\hline Algeria & 99 & 100 & 98 & Madagascar & 80 & 92 & 78 \\
\hline Angola & 36 & 40 & 26 & Malawi & - & - & - \\
\hline Benin & 80 & 87 & 76 & Mali & 81 & 92 & 77 \\
\hline Botswana & 72 & 78 & 67 & Mauritania & 59 & 75 & 49 \\
\hline Burkina Faso & 77 & 93 & 74 & Mauritius & - & - & - \\
\hline Burundi & 75 & 87 & 74 & Morocco & 94 & 97 & 91 \\
\hline Cameroon & 61 & 81 & 48 & Mozambique & 48 & 51 & 47 \\
\hline Cape Verde & 91 & - & - & Namibia & 78 & - & - \\
\hline CAR & 61 & 78 & 52 & Niger & 32 & 71 & 25 \\
\hline Chad & 16 & 42 & 9 & Nigeria & 42 & 63 & 32 \\
\hline Comoros & 88 & 90 & 87 & Rwanda & 63 & 60 & 64 \\
\hline Congo Rep. & 91 & 95 & 85 & SADR & - & - & - \\
\hline Côte d'Ivoire & 65 & 85 & 54 & STP & 75 & 76 & 74 \\
\hline DRC & 28 & 24 & 29 & Senegal & 75 & 89 & 66 \\
\hline Djibouti & 92 & 92 & 84 & Seychelles & - & - & - \\
\hline Egypt & 99 & 99 & 99 & S. Leone & 78 & 78 & 78 \\
\hline Eq. Guinea & 37 & 49 & 28 & Somalia & 3 & 6 & 2 \\
\hline Eritrea & - & - & - & South Africa & 95 & - & - \\
\hline Ethiopia & 7 & 29 & 5 & South Sudan & 35 & 45 & 32 \\
\hline Gabon & 90 & 89 & 91 & Sudan & 59 & 85 & 50 \\
\hline Gambia & 53 & 54 & 52 & Swaziland & 50 & 62 & 47 \\
\hline Ghana & 63 & 72 & 55 & Tanzania & 16 & 44 & 10 \\
\hline Guinea & 43 & 78 & 33 & Togo & 78 & 93 & 71 \\
\hline G. Bissau & 24 & 30 & 21 & Tunisia & 99 & 100 & 98 \\
\hline Kenya & 60 & 76 & 57 & Uganda & 30 & 38 & 29 \\
\hline Lesotho & 45 & 43 & 46 & Zambia & 14 & 28 & 9 \\
\hline Liberia & 4 & 5 & 3 & Zimbabwe & 49 & 65 & 43 \\
\hline Libya & - & - & - & & & & \\
\hline
\end{tabular}

[less than 50\% highlighted in bold]

19 Committee on the Rights of the Child, Concluding observations: Kenya, CRC/C/KEN/ CO/2, 19 June 2007, paragraph 30; Kenya Country Report presented at the Second Eastern and Southern Africa Conference on Universal Birth Registration, Mombasa, Kenya, 26-30 September 2005.

20 See also Plan International website, https://plan-international.org/what-we-do/ protection/boosting-birth-registration-in-kenya/, last accessed 1 September 2014.

21 Source: UNICEF, Every Child's Birth Right. [-] indicates information not available. Reference years vary from 2005 to 2012. 
Even in the countries most successful at increasing birth registration rates, problems remain. In South Africa, birth registration is central to the South African citizenship regime, and explicitly required as proof of entitlement to citizenship. ${ }^{22}$ The Births and Deaths Registration Act states that birth registration is a right for all children. A major drive to improve registration rates led to an increase from less than 25 percent of under-fives registered in 1998 to 50 percent in 2001, 72 percent in 2005, 92 percent by 2009, and 95 per cent in 2012. Even so, a substantial proportion of births are registered late. ${ }^{23}$ Moreover, those who are most likely not to be registered are children whose parents cannot produce a passport or South African identity card. This means that asylum seekers, refugees, stateless persons and undocumented migrants may be unable to obtain birth registration for their children, and thus the child may be unable to claim a parent's nationality or his or her rights to South African nationality either at birth (if otherwise stateless) or if still resident in the country at majority (under recent amendments to the Citizenship Act). ${ }^{24}$ In September 2014, the government announced that the Department of Home Affairs' late registration of birth programme would come to a close at the end of 2015, after six years, alleging that it had created an avenue for foreigners "who do not deserve South African citizenship being able to bribe their way onto the NPR [National Population Register]"25.

Children with one South African parent may also face difficulties if the child is born out of wedlock. In a 2011 report, the Public Protector found that the Department of Home Affairs' failure to register the birth of a child with a South African father and non-South African mother was "procedurally and substantively flawed" and in violation of the constitution; and in a similar case the High Court ordered that the details of the South African father be entered on the birth certificate for a child born out of wedlock to a non-South African mother and the child declared to be a South African citizen. ${ }^{26}$ Home Affairs regulations also prevent a father from registering a child out of wedlock without the mother's consent and presence to acknowledge paternity, leaving children abandoned by their mothers at risk. Since the 2010 reforms to the citizenship

22 For example, though the Citizenship Act provides that citizenship is granted to a child born on the territory who would otherwise be stateless, this right is conditional on birth being documented through a birth certificate. South African Citizenship Act 1995, as amended to 2010, section 2(2).

23 The coverage and quality of birth registration data in South Africa: 1998-2005, Report no. 0603-01 (2007), Statistics South Africa, 2007; 2009 and 2013 figures from UNICEF.

24. Towards Universal Birth Registration in South Africa: A Briefing Paper, Lawyers for Human Rights, Pretoria, 2011.

25 "Gigaba blames crooked priests in immigration fraud", SAPA, 28 September 2014.

26 Report on an investigation into allegations of failure to register the birth of a child and the naturalisation of the mother by the Northern Cape Department of Home Affairs, Report No.38 of 2011, Public Protector of South Africa; Steven Sikhumbuzo Moyo and another vs Minister Home Affairs, North Gauteng High Court case number 44424/09. 
law, children born in the country of parents who are permanent residents do not get the computerised birth certificate with national ID number included, but only a handwritten version, that creates other problems in proof of identity and access to services. Though this was supposed to change, new penalties for late registration of births were likely to make further problems. ${ }^{27}$

\section{Case study from Lawyers for Human Rights, South Africa ${ }^{28}$}

Elizabeth Nthunya was born in Lesotho in 1982. Her mother was a Lesotho citizen, while her father was South African. When she was three years old, she came to stay with her paternal grandmother in South Africa. Over the years, she struggled to register as South African because she does not have a birth record from Lesotho, which is required in terms of the Births and Deaths Registration Act. Lesotho has very low rates of birth registration. Home Affairs told her to go back to Lesotho and find her mother. Eventually she returned to Lesotho for her mother's funeral. She discovered that the clinic where she was born does not have records prior to 1985. She returned to South Africa but Home Affairs still refuses to assist her. Her father and grandmother have since passed away, but she has five South African aunts and uncles willing to testify to her identity.

Elizabeth has a son born in South Africa to a South African father, but Home Affairs will not allow them to register the child's birth because Elizabeth does not have an ID. Thus her son is also unable to access his South African citizenship, even though his father has a valid South African ID document.

Elizabeth's case illustrates the generational impact that lack of documentation has on the right to a nationality. Such strict requirements - for a foreign birth certificate and for the mother's ID document result in a complete block to citizenship for Elizabeth and her son, with consequences on their economic mobility, right to work and education, and their physical and emotional health.

27 Lawyers for Human Rights, Statelessness and Nationality in South Africa, 2013, pp.41-42.The Births and Deaths Amendment Act No.18 of 2010 entered into force, together with new regulations (Government Notice R128 in Government Gazette 37373 dated 26 February 2014), on 1 March 2014. The amendment also formalised the difference between notices of births given to South African citizens and non-South African citizens.

28 Extracted from Lawyers for Human Rights, Statelessness and Nationality in South Africa, p. 25 . 


\subsection{Inaccessible, discriminatory or absent systems for proof of nationality}

In the context where many people are undocumented, access to definitive proof of nationality for those whose status is in doubt paradoxically becomes more important. In most of the civil law countries, it is assumed that this is provided by the system of national identity cards, which have been obligatory for adults since the 1960s; a national ID card will usually indicate nationality as one of the pieces of information shown on the face of the card. Identity card systems have also been introduced in many Commonwealth countries, as well as in Liberia. Nonetheless, not even in the civil law countries do all citizens carry such a card — in Guinea, for example, coverage is estimated at only around 20 percent. $^{29}$

National identity documents have a dual nature: while they are instruments of control, they are also the gateway to accessing other rights. They have different levels of evidentiary value, and in most countries are not formally proof of nationality, even in those countries where an identity card is mandatory only for nationals. Nonetheless, possession of an identity card may be key to accessing all sorts of rights restricted to citizens, including not only voting and other political rights, but also health care and education, as well as participation in the formal economy. A national identity card may also be necessary to obtain a passport. ${ }^{30}$

Given that identity card applications are usually vetted in the first instance by quite low-ranking civil servants, this gives the power to determine someone's right to evidence of nationality - for practical if not legal purposes - to a person who is in no way trained in nationality law. Although complaints mechanisms may theoretically exist within the identity card management system for those whose applications are wrongfully rejected, they are usually quite inaccessible unless the person is connected or has some legal assistance. At the same time, a large number of people may "pass" as nationals who are not entitled to do so.

In the civil law countries definitive proof of nationality is rather provided by a certificate of nationality issued by a tribunal, a process provided for in all the nationality codes; the delegation of this authority to decide if someone is a national to the courts provides both in principle and in fact some protection against arbitrary decision-making. A person whose nationality is seen as being in doubt by the personnel responsible for ID card management will be referred to the tribunal for adjudication on the case. In addition, the possibility of obtaining a nationality certificate means that there is a document that cannot be challenged at moments when conclusive proof of nationality is required for official purposes.

29 Jaap van der Straaten, Towards Universal Birth Registration in Guinea: Analysis and recommendations for civil registration reform in Guinea for Government and UNICEF, Civil Registration Centre for Development-CRC4D, December 2013.

30 For southern Africa, see Klaaren and Rutinwa, "Towards the Harmonisation of Immigration and Refugee Law", Chapter 2, Population Registration and Identification, pp.26-38. 
Since the document is delivered by a tribunal the decision is made by a person who has been trained in the law, and is tied to a fundamental standard of due process, which creates a basis for challenge of any decision. There are significant advantages over the executive-dominated system in the common-law countries.

Of course, there are problems in practice. Judges cannot overcome weaknesses in the law itself; and interpretations of the law may sometimes vary across different tribunals. It can be very cumbersome to prove all the elements required to obtain recognition of nationality. The relevant tribunal is usually located at the capital of a department or region, and may be quite remote from the areas where many people live. Administrative staff may be unhelpful, and there is substantial triage before cases reach the tribunal president, as those collecting the applications send people back who do not have the correct supporting paperwork. Outside any tribunal or other office for nationality papers will be a queue of people waiting to speak to someone to sort out their case; some of them have been returning to the same spot multiple times over several months. Applicants may have to spend many hours sorting out irregularities in their birth certificates or other documents; for example, where names on different official documents do not conform to each other in spelling (an illiterate person may be completely unaware of the significance for legal authorities of the difference between Mohamad and Mohammed). Intermediaries who assist these people may levy substantial unofficial fees. Statistics for the numbers of certificates of nationality issued are not published, but the numbers obtained from a handful of tribunals visited in West Africa were well below the numbers you would expect if most people were to have proof of nationality. For example, in Ziguinchor, capital of a department in the region of Casamance in Senegal, the departmental tribunal issued 1,895 certificates of nationality in 2013; at the tribunal de grande instance in Niamey, capital of Niger (a city with a population of a million or more), 21,692 certificates of nationality were issued from October 2012 to September 2013. ${ }^{31}$

By contrast, in the Commonwealth countries, although there may be the theoretical provision for a certificate of nationality in cases of doubt, this is delivered by the executive, and is effectively unknown in practice. ${ }^{32}$ Thus, there is no single document

31 Interviews, with court registrars (greffiers), May/June 2014.

32 For example, the Ghana Citizenship Act 2000, provides in its Section 20 that: "The Minister may, on an application made by or on behalf of any person with respect to whose citizenship of Ghana a doubt exists under Part I of this Act, certify that the person is a citizen of Ghana and a certificate issued under this section shall be prima facie evidence that the person was such a citizen at the date indicated in the certificate, but without prejudice to any evidence that he was such a citizen at an earlier date." There is a similar provision in Section 14 of the Gambia Nationality and Citizenship Act, 1965, and in Section 24 of the Sierra Leone Citizenship Act 1973; but not in Nigeria. In southern Africa, Botswana, Lesotho, Malawi, Swaziland, Zambia and Zimbabwe also have such provisions, as does Tanzania; however, the laws in Kenya and Uganda have no such provision (though the Uganda Citizenship and Immigration Control Act, 1999 does 
that provides conclusive proof of nationality: while the passport has highest status, most people do not have an international passport. In practice, a variety of documents may be accepted as proof of nationality, depending on the circumstances.

In Nigeria, for example, the law establishes no document or process that conclusively proves nationality. Constitutional provisions referring to membership of an "indigenous community" in relation to the nationality of those born before independence, reinforced by the legal framework of federalism, have created a strong emphasis on "indigeneity" that pervades identification systems and that impacts both internal migrants and those who have come from other countries. Since no law establishes another document to do so, the proof of your right to be Nigerian is effectively a certificate of indigeneity, a document that has no legal basis, and for which there are no established written criteria on the basis of which a refusal could be challenged (see below, chapter 13.1). In Sierra Leone, also, no national system of identification exists, but rather a multiplication of different forms of document, many of them created in the period of "hyperidentification" by different agencies after the end of the civil war; for many years previously the annual tax receipt issued by a chief to "heads of household" was the only identity document valid for travel within the country. ${ }^{33}$

These problems are replicated somewhat in Togo, which is one of the few francophone countries where a certificate of nationality is issued by the ministry of justice rather than a court. ${ }^{34}$ Even without the requirement for a legal procedure, a study by the Office of the UN High Commissioner for Human Rights estimated that only around 75,000 certificates were issued each year nationwide. Moreover, whereas an unproblematic request for a certificate of nationality will be fulfilled within about two months, in any case where there is a query it may take further months or even years to resolve. The law provides that if the Ministry of Justice does not supply a certificate of nationality within two months of the date of request, it is presumed that the certificate has been refused - and it is not clear if there is any appeal from this outcome. ${ }^{35}$ In practice a certificate of nationality is refused when there is any doubt about a late birth registration established by a jugement supplétif from a tribunal, the usual form of

provide in section 33 for a "duly certified citizenship certificate" to be proof of nationality it does not establish how to obtain one).

33 Mariane Ferme, "Deterritorialized Citizenship and the Resonances of the Sierra Leonean State" in Veena Das and Deborah Poole (eds.), Anthropology in the Margins of the State, Santa Fe: School of American Research Press, 2004.

34 Rapport de la Commission ad hoc chargée de réviser les textes relatifs à la nationalité et de définir les modalités pratiques des audiences foraines d'établissement de certificats d'origine et de nationalité, Lomé, 12-16 septembre 2011, on file with author. See also Rapport Alternatif de la société civile sur la mise en cuvre de la Convention relative aux droits de l'enfant, 2005-2010, Forum des organisations de défense des droits de l'enfant au Togo (FODDET), april 2011.

35 Ordonnance No.78-34 du 7 septembre 1978 portant Code de la nationalité togolaise, art 72. 
late registration in the francophone countries; thus the administrative authorities effectively question the decision of the courts. In such cases of doubt the practice is to demand a "certificat d'origine" which is awarded on the basis of an enquiry carried out in the district where the person is from; but no legal authority exists for this practice. Efforts to computerise and strengthen administration of nationality certificates created problems for those without papers who were not able to meet new standards of proof. ${ }^{36}$

Those affected by discrimination in gaining access to nationality documentation are often those who are alleged to have another nationality. Some of the most notorious cases of systematic discrimination against those who are accused of dual loyalties are discussed in Chapter 8 , but there are daily examples of the same practice even in countries not at all known for discrimination and conflict. In Botswana, for example, the introduction of a new computerised passport system in 2011 found many who had always been recognised as Botswanan suddenly denied the right to renew their passports unless they renounced another nationality that they had never claimed (in a manner very similar to what happened in Zimbabwe, see chapter 8.3). ${ }^{37}$ Meanwhile, the Bazezuru, members of an ethnic group found also in Zimbabwe, faced what was described as a "citizenship crisis" in relation to their efforts to acquire Botswanan identity cards and passports. Dual nationality is not allowed in Botswana, and government departments require them to show proof they have renounced their Zimbabwean citizenship before giving them Botswanan documents - though they have never held Zimbabwean citizenship and, indeed, would struggle to gain recognition of Zimbabwean citizenship in order to renounce it. In Botswana, a birth certificate is evidence of citizenship ${ }^{38}$, which has meant that, though government ministers urge the community to register all births, the Bazezuru even struggle to obtain this most basic of documents, preventing their children from accessing education. The minister for home affairs promised in 2013 to appoint a task force to deal with the matter, but one year later a member of the community commented:

36 Le droit à une nationalité: l'accès aux documents d'identité au Togo, UN Office of the High Commissioner for Human Rights, March 2013, in file with author.

37 Lawrence Seretse, "Thousands of Batswana become foreigners overnight", Mmegi (Gaborone), 18 November 2011. See also Francis B. Nyamnjoh, "Local attitudes towards foreigners in Botswana: An appraisal of recent press stories", Journal of Southern African Studies, Vol.28, No.4, 2002, pp.755-775.

38 Children's Act No.8 of 2009, section 12(3): “A birth certificate issued by the Registrar of Births under [the Births and Deaths Registration Act] shall be proof of the nationality of the child." Births and Deaths Registration Act, No.48 of 1968, as amended to 1998, section 10(2): "Every such certificate [of birth, still-birth or death] shall, in all courts of law and public offices within Botswana, be prima facie evidence of the particulars set forth therein." 
We appreciate the minister's intervention even though it did not bring the results we expected. Most of us still cannot get help from immigration and national registration due to the dual citizenship alleged by the officers. Our citizenship remains a mystery despite the fact that our first generation has long passed; we don't know what is expected of us because we were born and bred in Botswana. ${ }^{39}$

The impact of this lack of coordination and coherence across systems is seen perhaps most strikingly in the context of electoral registration, theoretically restricted to nationals. Most people do not have a document that is proof of nationality (even in the francophone countries where a certificate of nationality would provide such proof), so it would not be possible to hold elections if such proof were required. Thus, the required proof of identity to be registered to vote varies greatly across the region, and sometimes the systems may be effectively circular: it may be easier to obtain an electoral card than an identity card; but an electoral card may then be sufficient to serve as the basis of an application for an identity card (for example in Guinea). This lack of a systematic approach can operate both to include people on the voters' roll who should not be there; but also to exclude those who should. According to a survey by the Carter Center, some African countries "have extremely opaque and confusing laws or occasionally no accessible laws or regulations at all governing the voter identification process, allowing great discretion among election administrators and the potential for confusion for all involved". ${ }^{40}$

There are some positive initiatives to address this problem. For example, assisted by UNHCR, the Namibian government negotiated with the Angolan, Botswanan, South African and Zambian governments to undertake a joint identification exercise among undocumented populations in its border regions; the process started in 2010, and by November 2011, more than 900 persons had been naturalised or officially recognised as Namibian through this process. Among them were around 200 people of Nama and Damara heritage removed in the 1970s by the South African government from the Riemvasmaak area of the Northern Cape to what was then South West Africa, as well as people who fled from Angola to Namibia during the Angolan civil war. ${ }^{41}$

39 Sesupo Rantsimako, "Bazezuru still in citizenship predicament", Botswana Gazette, 6 February 2014; See also, Sesupo Rantsimako, "Bazezuru seek clarity on their citizenship", Botswana Gazette, 3 October 2012; Goitsemodimo Williams, "Bazezuru want minister's intervention”, Botswana Daily News (no date: 2012?); "Commissioner urges Bazezuru to register”, BOPA, 29 February 2012.

40 Tova Wang, Voter Identification Requirements and Public International Law: An Examination of Africa and Latin America, The Carter Center, 2013.

41 Information provided at UNHCR regional meeting on statelessness in Southern Africa, Mbombela, South Africa, 1-3 November 2011. 


\section{Religious discrimination in the issue of identity documents in Egypt}

Identification documents are mandatory for all Egyptians, and necessary to obtain access to employment, education, registration of births and deaths, recognition of marriage, and other state services, as well as most commercial transactions. A person who cannot produce a national ID upon request by a law enforcement official commits an offence punishable by a fine of LE100-200 (US\$18-35).

For years, the Egyptian government denied Egyptians who were not members of one of the three recognised religions-Islam, Christianity, or Judaism - the right to access such documents. Members of the small Baha'i minority in Egypt, numbering some 2,000, were those most affected by these laws. In addition, on the basis of their interpretation of Shari'a rather than any Egyptian law, government officials regularly deny those who convert from Islam to any other religion the option to change their religious affiliation on their official documentation. The courts have usually supported officials in this practice.

In March 2009, the Supreme Administrative Court overturned a previous 2006 decision and upheld the right of Egypt's Baha'is to obtain official documents, including identity cards and birth certificates, without revealing their religious affiliations or having to identify themselves as Muslim or Christian. The verdict also affirmed that, because of the complexity of the "modern civil state, every individual has the right to an identity card and that not issuing such basic documents infringes his/her basic rights stipulated in and protected by the Egyptian legal codes." ${ }^{42}$ Three days later, the Egyptian Interior Ministry accepted the ruling by issuing a decree that introduced a new provision into the Implementing Statutes of Egypt's Civil Status Law of 1994 and instructed Civil Status Department officials to leave the line for religion blank for adherents of religions other than the three the state recognises. The decree came into force on April $15 .{ }^{43}$ Despite this progress, Baha'i representatives reported ongoing problems in relation to identity documentation, especially the registration of marriages. ${ }^{44}$

42 Translation of judgment from The State of Emergency and Military Judiciary in the Egyptian Legal System, Presentation by the Department of Human Rights in the Ministry of Foreign Affairs of Egypt to the Subcommittee on Human Rights of the European Parliament, May 2010, available at http://www.europarl.europa.eu/meetdocs/2009 2014/documents/ droi/dv/201/201005/20100510 5 10comprpaper en.pdf, last accessed 31 March 2014.

43 Egypt: Prohibited Identities: State Interference with Religious Freedom, Human Rights Watch, November 2007; “Egypt: Decree Ends ID Bias Against Baha’is,” Human Rights Watch, 15 April 2009.

44 Bureau of Democracy, Human Rights and Labor, "International Religious Freedom Report for 2013: Egypt”, US State Department, 28 July 2013. 


\section{Extraordinary vetting procedures in Kenya}

Kenya's Registration of Persons Act, in effect since 1949 and repeatedly amended $^{45}$, provides for a compulsory system of national identity cards for all adults. Although rates of birth registration have improved in recent years, even those Kenyans who have birth certificates may still face problems in gaining their national identity cards once they reach adulthood. Investigations and hearings held by the Kenya National Commission on Human Rights and by a 2002 Constitutional Review Commission brought repeated complaints from marginalised ethnic groups of burdensome "vetting" processes before they could get identity cards or passports, or exercise the right to vote. ${ }^{46}$ Most of those affected by this discrimination are ethnic groups with origins in border areas, or with pastoralist lifestyles, including the Maasai, Teso, Borana and especially the Somalis. Added to these is the Nubian community based in Nairobi.These groups face additional security vetting procedures, demands for bribes or complete refusal to grant documentation; though some manage to obtain registration by paying for the privilege. Kenyan women married to nonKenyans found that their children could not obtain identity documents, even though children born in Kenya with one Kenyan parent should have had an automatic right to citizenship. ${ }^{47}$

A peculiarity of the Kenyan case is the importance that came to be given to the categories of ethnic group in the decennial census. The 1969 census categorisation listed 42 "tribes" for the purposes of recording population; persons of African ethnicity not belonging to one of these "tribes" were recorded as "other", though there were codes for whites and Asians. While the census codes have in principle no legal significance for entitlement to citizenship, they were perceived as legitimation as "Kenyan" of some groups and not of others. Having a last name that is not a name belonging to one of these "tribal codes" could be enough for the rejection of an application for an identity card. ${ }^{48}$

45 Registration of Persons Act, No. 33 of 1947, Cap.107 (entry into force 16 May 1949, most recently amended by the Security Laws (Amendment) Act 2014).

46 The People's Choice: The Report of the Constitution of Kenya Review Commission, 2002; and two reports by the Kenya National Commission on Human Rights: An Identity Crisis? Study on the Issuance of National Identity Cards in Kenya, 2007 and Out of the Shadows: Towards Ensuring the Rights of Stateless Persons and Persons at Risk of Statelessness in Kenya, 2010. See also the report by the Kenya Human Rights Commission (an NGO), Foreigners at Home: The Dilemma of Citizenship in Northern Kenya, 2009.

47 Children born outside Kenya, however, could until the 2010 constitution came into effect only obtain citizenship if their father was a citizen. 1963 Constitution, Article 90.

48 Samantha Balaton-Chrimes, "Statelessness, identity cards and citizenship as status in the case of the Nubians of Kenya", Citizenship Studies, Vol.18, No.1, 2014, pp.15-28. 
The Kenyan National Commission on Human Rights reported in 2010 on this practice. One victim, born in Kenya of two parents and four grandparents also born in Kenya, first applied for an identity document in 2003: "I filled out my father's original tribe [...].The [vetting] committee advised I return to my father's home country, which I had never been to, and to apply for any official document that that country issues. The fact that I had produced a letter of support from the chief, death certificates of my parents and a copy of my paternal uncle's Kenyan ID did not assist my application in any way". The application was eventually accepted at the office where it was filed, but then rejected in Nairobi as the tribal code was "illegal". On reapplying and filling out his mother's tribal code, he was arrested and charged with fraud when summoned to the vetting committee. Though eventually acquitted by the magistrate, who also ruled that he was a citizen, he was still waiting for his ID in September 2009.49

In 2009, the list of census enumeration codes was changed, to more than double the number of ethnic groups and sub-groups. Among them were included the Nubians for the first time, a matter of pride to those who had campaigned for the change. At the same time, "Kenyan" was for the first time listed as a possible tribe. ${ }^{50}$

\subsection{Inaccessibility of naturalisation procedures}

It is indicative of the difficulty of naturalisation that there are almost no published statistics about the numbers naturalised in most African countries. Those statistics that are available reveal that the numbers of naturalised persons vary hugely across countries, but are generally low.

In the course of research in West Africa, it was established that fewer than one hundred people had been naturalised in the course of 2013 in each of Senegal, Niger and Guinea ${ }^{51}$; in Burkina Faso, 62 were reported naturalised in 2005 in Senegal as of 2007, a total of only 12,000 people had been naturalised since independence in $1960 .^{53}$ In Niger and Guinea, the actual number naturalised was not known by the ministry of justice when interviewed in 2014 , since

49 KNHRC, Out of the Shadows, pp.15-16.

50 Samantha Balaton-Chrimes, "Counting as Citizens: Recognition of the Nubians in the 2009 Kenyan census”, Ethnopolitics Vol.10, No.2, 2011, pp 205-218.

51 Interviews with ministry of justice officials, Dakar, Niamey, and Conakry, June 2014.

52 "Burkina Faso: 62 naturalisations en 2005 » Press release from the ministry of justice reported in Sidwaya Quotidien, 11 July 2005, available at http://allafrica.com/ stories/200507120441.html, last accessed 11 December 2014.

53 "Accès à la nationalité sénégalaise : les mêmes textes pour tous les demandeurs," APA News, 13 August 2007. 
naturalisation is ultimately by presidential decree on the discretion of the president, and there was no system of feedback on individual dossiers. In Niger, if the application is not considered within one year of its submission it lapses and the applicant has to start again. In Ghana, no non-Ghanaian was granted Ghanaian citizenship by naturalisation between 1993 and 2006. ${ }^{54}$ In Nigeria, perhaps 100-200 people are naturalised each year — in a country of around 170 million - but UNHCR only knows of a single refugee or former refugee (a Rwandan) who has been included among that number. ${ }^{55}$ Even in Côte d'Ivoire a maximum of 92,000 people acquired nationality by naturalisation during the whole period from 1962 to 2013: though more than in some countries, this represented a trivial number in light of the millions of people who remained categorised in the census as "foreigners" although they had lived in Côte d'Ivoire for decades or generations. ${ }^{56}$

In north Africa, a mere 1,646 people were reported naturalised in Morocco between 1959 and 2007.57 In Algeria a more substantial 47,000 obtained nationality between 1970 and 2009, the majority French, Palestinian, Syrian and Egyptian; but naturalisation procedures were significantly tightened in 1986 — only 683 otained nationality in $2008 .{ }^{58}$ In southern Africa, the figures are similarly low, though variable. Of the nearly 20,000 foreigners who had applied for naturalisation in Swaziland since its independence until 2005, only 6,000 had been successful. ${ }^{59}$ Botswana granted 39,000 people citizenship between 1966

54 Akyeampong "Race, Identity and Citizenship in Black Africa".

55 Official figures are not published, but news stories indicate that numbers naturalised are of this order. See, for example, Emeka Anuforo, “79 foreigners get Nigerian citizenship”, The Guardian, 31 January 2007; "FEC okays 119 for Nigerian citizenship", The Nation, 5 June 2008; "FG confers citizenship on 82 nationals", NAN, 18 August 2010; Ahamefula Ogbu, "FG Uncovers 1,497 Illegal Migration Routes into Nigeria", This Day, 15 March 2012; Elizabeth Embu, "FG Grants Citizenship to 174 Foreigners, Denies 27 applicants", Daily Times, 6 November 2013; Jibrin Lumba, "As Nigerians Relocate, Foreigners Struggle For Nigerian Citizenship", Orient Daily, 26 December 2013. Included in the numbers referred to are women married to Nigerian citizens who have applied to register as Nigerians, a far less demanding process under section 26 of the constitution. Also interview, UNHCR Abuja, July 2014.

56 Following the change of government in 2011, the Ministry of Justice conducted two surveys of the Journal Officiel, where naturalisation decrees are published, which concluded that at least 32,000 and perhaps up to 92,000 people had been naturalised between 1962 and the end of 2012 (the discrepancies might be explained by different counting methods applied to the spouses and children of those naturalised). Interview, Paul Koreki, Ministry of Justice, Abidjan, June 2014; also draft report by Mirna Adjami for UNHCR on Statelessness in Côte d'Ivoire, 2014, on file with author. The 1988 census revealed approximately 51,000 people claiming to be naturalised Ivorian at that date. See below, chapter 8.7.

57 Perrin, "Citizenship struggles in the Maghreb".

58 According to a Ministry of Justice statement: “47000 étrangers ont obtenu la nationalité algérienne depuis 1970", algeria.com, 21 Octobre 2009.

59 "About 6000 foreigners may become Swazi citizens," Times of Swaziland, 17 August 2005. 
and 2004. ${ }^{60}$ Tanzania reported in 1998 that 1,000 people had naturalised in the previous four years in 1998, of whom half were Burundians. ${ }^{61}$ Only in South Africa is there an effective system in place to allow people to become South African, with thousands of people naturalising each year, with others resuming citizenship or registering citizenship by descent - though the numbers dramatically reduced after 2010 (without official explanation). ${ }^{62}$

This difficulty in naturalising is partly a matter of law but even more a matter of practice: the procedures tend to be heavy in bureaucratic requirements, and in the processing. The system for application is similar in the civil law countries: an application for naturalisation is submitted at the mairie of the commune, requiring a dossier with the birth certificate or proof of nationality from the country of origin, proof of marriage (if relevant), the birth certificates of any children included in the application, a certificate of residence, proof of a clean criminal record (casier judiciaire), and a letter of motivation. The mayor sends the application to the Direction d'administration du territoire for an inquiry into the morality of the person; and the dossier is then sent the Ministry of Justice to be verified, before it is sent on to the presidency for consideration. The final naturalisation is by decret, secondary legislation adopted by the president. In Nigeria, where naturalisation requires fifteen years' residence and fulfilment of numerous other conditions, ${ }^{63}$

60 “Over 30,000 granted citizenship," Daily News, Gaborone, 31 March 2005.

${ }^{61}$ Xinhua, 11 November 1998, available at http://www.queensu.ca/samp/ migrationnews/1998/nov.htm, last accessed 20 December 2014.

62 According to figures published in the Department of Home Affairs Annual Reports, the numbers of people naturalised each year are:

\begin{tabular}{|l|l|l|l|l|l|l|l|l|l|}
\hline $2001 / 02$ & $2003 / 04$ & $2004 / 05$ & $2005 / 06$ & $2006 / 07$ & $2007 / 08$ & $2008 / 09$ & $2009 / 10$ & $2010 / 11$ & $2011 / 12$ \\
\hline 14,108 & 20,648 & 18,107 & 19,888 & 24,671 & 9,346 & 32,627 & 37,522 & 6,102 & 1,603 \\
\hline
\end{tabular}

The 2002/03 Annual Report is not on the website (nor are earlier years) and the 2012/13 and 2013/14 Annual Reports did not contain this statistic. See http://www.dha.gov.za/ files/Annual\%20Reports/, last accessed 17 November 2014.

63 Section 27 of the 1999 Constitution provides that: "(1) Subject to the provisions of section 28 of this Constitution [requiring renunciation of any other nationality also held by naturalisation], any person who is qualified in accordance with the provisions of this section may apply to the President for the grant of a certificate of naturalisation. (2) No person shall be qualified to apply for the grant of a certificate or naturalisation, unless he satisfies the President that - (a) he is a person of full age and capacity; (b) he is a person of good character; (c) he has shown a clear intention of his desire to be domiciled in Nigeria; (d) he is, in the opinion of the Governor of the State where he is or he proposes to be resident, acceptable to the local community in which he is to live permanently, and has been assimilated into the way of life of Nigerians in that part of the Federation; (e) he is a person who has made or is capable of making useful contribution to the advancement; progress and well-being of Nigeria; (f) he has taken the Oath of Allegiance prescribed in the Seventh Schedule to this Constitution; and (g) he has, immediately preceding the date of his application, either- (i) resided in Nigeria for a continuous period of fifteen years; or (ii) resided in Nigeria continuously for a period of twelve months, and during the period of twenty years immediately preceding that period of twelve months has resided in Nigeria for periods amounting in the aggregate to not less than fifteen years." 
an application for naturalisation is made to the Ministry of the Interior, and the dossier is then reviewed by a range of different state agencies, including the State Security Service, the Immigration Service, the police, the governor of the state and chair of the local government area where the person is resident, and other agencies. Ultimately, the dossier is passed to the Federal Executive Council for review and recommendation and the final decision is made by the president. A fairly substantial percentage of those who apply are rejected (perhaps 15-20 percent, judging from press reports). In Nigeria, naturalisation is also not automatic for minor children of those whose applications are successful: in one case, the child of parents of Palestinian origin who had obtained Nigerian nationality by naturalisation was unable to obtain a Nigerian passport herself on reaching majority; a separate application had then to be made. ${ }^{64}$

In Niger, problems are created in this process particularly by the requirements that a person requesting naturalisation on the basis of ten years' residence has to provide both a certificate of nationality from the country of origin (though they are not required to renounce that nationality), and residence permits showing legal residence for ten years. However, among those requesting naturalisation are people born and brought up in the country of parents born elsewhere (who are not eligible for nationality of origin in Niger). These people have never considered obtaining a residence permit (permis de séjour), and it seems absurd to require them to obtain proof of nationality of one or other or both of their parents' countries (for which they would have to travel to that country in order to collect all the documentation and go through onerous administrative processes) in order to obtain recognition of the nationality of the country where they have always lived. Even for people who grew up in another ECOWAS country and do have evidence of nationality of that country, providing a residence permit is usually an impossible demand for those who are not operating in the formal economy and for whom West Africa is perceived as a zone of free movement. ${ }^{65}$

In Sierra Leone, after filling out the necessary forms, the applicant is required to undergo a series of interviews at the Immigration Headquarters, the Criminal Investigation Department, and the National Revenue Authority. Final interviews are before a panel chaired by the minister of foreign affairs, and including the attorney general and minister of justice, the minister of trade, and the head of immigration. This committee forwards its recommendation to the cabinet for approval and the president has the final say. There is no requirement to give any reason for the refusal of an application for naturalisation, and the decision cannot be challenged in any court. ${ }^{66}$ In 2006, procedures for naturalisation were

64 Interview, Nigerian National Immigration Service, Abuja, July 2014.

65 Interview, Abdou Hamani, Ministry of Justice, Niamey, May 2014. Moreover, thanks to a bilateral agreement, a permis de séjour is not required for nationals of Mali, meaning that they would have no proof of residence.

66 Sierra Leone Citizenship Act, 1973, section 24. 
simplified; however, according to the US Department of State 2010 human rights report, the government had approved no new naturalisations since the end of the war in 2002; moreover, a naturalised citizen must reportedly pay the equivalent of US\$3,000 for a passport. ${ }^{67}$ In 2013, President Koroma naturalised British journalist Mark Doyle and at least twenty others; still a very small number, restricted to an elite cadre of people. ${ }^{68}$

The requirement for a presidential decree is no great barrier in some countries, such as Senegal, where presidential approval is a formality after the Ministry of Justice has verified that the conditions for naturalisation are fulfilled. But in many other countries, the perception is that the naturalisation procedure is highly politicised and only approved for those who have connections; naturalisation is therefore effectively available only to wealthy individuals with the full panoply of documents required, and the ability to follow their dossier closely through the process. In Côte d'Ivoire, in particular, the naturalisation process has been much criticised, especially in the case of group naturalisations. ${ }^{69}$

In these circumstances, those who wish to become nationals and show their commitment to a new country are unable to do so. Instead, they may be forced to obtain documents illicitly. This may be done in good faith: if the perception is that nationality is generally obtained through a birth certificate, then seeking a birth certificate in the country even if not born there may be rather an effort to "naturalise" than an act of fraud. Many "ordinary people" who are long-term residents in a country where they do not have nationality papers are very hazy on what the correct procedures should be: they just want recognition as nationals in the place where their lives were centred and they have the strongest ties.

Naturalisation procedures are also often not effectively open to refugees, despite the obligation to facilitate naturalisation contained in the UN Refugee Convention, even where there are no formal legal impediments to an application (see further, chapter 11).

${ }^{67}$ Sierra Leone Citizenship (Amendment) Act No. 11 of 2006; Bureau of Democracy, Human Rights, and Labor, 2010 Country Reports on Human Rights Practices : Sierra Leone, US Department of State, 8 April 2011; "Nasser Ayoub appeals to President Koroma", Sierra Express, 15 May 2012

68 "Mark Doyle Subscribes to the oath of allegiance as Sierra Leonean", Sierra Leone presidency, 5 November 2013; “'We ExpectYou To Be Good Citizens'- President Koroma Admonishes”, Sierra Leone presidency, 11 September 2013, both available at http://www. statehouse.gov.sl/ last accessed 08 July 2014.

${ }_{69}$ For example, several thousand descendants of Mossi immigrants Burkina Faso to Bouaflé in central Côte d'Ivoire were naturalised by President Henri Konan Bedié by decree in 1995, an act that is still controversial today; many of the individuals concerned still have no documentation of nationality although supposedly covered by the decree. See «Lutte contre l'apatridie : 8.133 postulants a la nationalité ivoirienne obtiennent leur naturalisation " Government of Cote d'Ivoire 4 March 2013; and «Bradage massif de la nationalité ivoirienne: Ouattara se sert de Bédié, grosse colère au PDCI ", IvoireBusiness.net, 13 Mars 2013. 


\subsection{Conflict and loss of documents}

At the end of 2013, it was estimated that sub-Saharan Africa was host to more than 2.9 million refugees, or one quarter of the global total, primarily from Somalia $(778,400)$, Sudan $(605,400)$, DRC $(470,300)$ the Central African Republic $(251,900)$, and Eritrea $(198,700)$. There were also a total of 12.5 million internally displaced, including at least 3.3 million in Nigeria alone. ${ }^{70}$

Among the many difficulties of those affected by conflict, whether or not they cross an international border, are the loss or destruction both of personal documents and of government archives recording their issue. In the Ivorian conflict, where access to documentation was one of the key issues in dispute, civil registration records were in some cases deliberately targeted for destruction; in the Casamance region of Senegal records have also been burnt in some places. Reconstructing official databases is one of the many difficult and costly tasks that must be undertaken when peace is restored.

Refugees registered with UNHCR usually receive both a UN document and a document issued by a national refugee agency recognising their refugee status, which either state their country of nationality (or indicate that they are stateless, if that is the case). For those refugees who return home within a few years such documentation is usually sufficient to provide them both with a legal status in their country of refuge and with proof of nationality on return (though often not enough to protect them from harassment by security forces in the country of refuge who see any document that is not a national identity document as an excuse to shake someone down for money). Children born outside the country of their refugee parents may face more difficulties in establishing their nationality, depending on whether and how their birth was registered. In addition, there are those who fled into a neighbouring country and never registered as refugees as well as those whose asylum applications are rejected but are not deported and thus remain outside their country of origin.

Those who do not cross an international border may in some ways be even worse affected by lack of documents, since they are much less likely to be registered by an international or national agency at the time of displacement, but equally likely to be affected by loss or destruction of their existing documents and the dispersal of community leaders who could vouch for a person's identity. Displaced children separated from their parents are the most vulnerable of all. A survey conducted by the Danish Refugee Council in May 2013 found that 55

70 War's Human Cost: Global Trends Report 2013, UNHCR, June 2014 ; Global Overview 2014: People internally displaced by conflict and violence, Internal Displacement Monitoring Centre Norwegian Refugee Council, May 2014. The Nigerian National Commission for Refugees, Migrants and Internally Displaced Persons published official figures for the first time in 2013, calculating those displaced by violence since 2010. Sub-Saharan Africa for UNHCR encompasses all African countries except Egypt, Libya, Tunisia, Algeria, Morocco and Mauritania. 
percent of the internally displaced living in Mopti, Mali, had no documentation (ID card or birth certificate). ${ }^{71}$

A representative of persons displaced by the Casamance conflict in Senegal noted that the groups put at risk by lack of documentation were not just the refugees and internally displaced, but also those who lived in zones where civil registration records had been burnt; as well as the children of the rebels themselves, who had never been declared to any authority. His brother, also Senegalese born in Senegal, had become a refugee in Guinea Conakry, where he had married a wife from Guinea Bissau and had children. His children, who consider themselves Senegalese, have no documentation from Senegal, Guinea or Guinea Bissau; they have tried to get documents from Senegal but have not been able to do so. The procedure to obtain a jugement supplétif for late registration of birth (in this case for the children's father in the first instance) required the physical presence of five people: the person him or herself, both parents (or their death certificates) and two witnesses, which was simply too onerous to achieve. His opinion was that even if the conflict came to an end it would return again if the problems of documentation were not addressed. ${ }^{72}$

\subsection{Official and unofficial costs}

Official fees for obtaining registration of birth (whether within the set time limits or by late registration procedures), identity documentation and certificates of nationality are usually fairly modest, and birth registration fees have in some countries been reduced or eliminated altogether with the support of UNICEF. However, even a fee of a few dollars may put the process out of reach; and almost everywhere additional unofficial charges may be levied, if not by the officials themselves then by intermediaries who play an important role in explaining the system and facilitating acquisition of documents by those who do not know what the procedures are. Transport costs are a significant additional charge for those who live in remote locations and have to travel to a departmental or regional capital for nationality documentation; added to the cost of transport is the cost of lost time from income-generating activities - any centre responsible for issuing nationality or identity documents will see lines of people waiting to see the responsible official, sometimes for many hours at a time. ${ }^{73}$ Costs for

71 Cited in Forced Displacement of and Potential Solutions for IDPs and refugees in the SahelBurkina Faso, Chad, Mali, Mauritania \& Niger, UNHCR and Global Program on Forced Displacement of the World Bank, October 2013.

72 Interview with representative of IDPs, Ziguinchor, May 2014.

73 In Senegal, for example, a certificate of nationality costs CFA2300; a national identity card is now free, though until recently cost CFA1000. Birth registration is free if done within the correct time limits, if outside those limits via a jugement supplétif the charges have recently been dropped from CFA4,000 to CFA700. To get an extrait de minute du greffier confirming that a birth certificate is correct (in case of doubt) costs CFA2500, as does an annulation and reissue of a certificate. Reported "faciliation fees" paid to intermediaries 
naturalisation may be significantly higher, given the multiple documents, many of them from another country, that need to be assembled for an application.

In some cases, costs may be set to make access to citizenship more difficult for certain categories of people: in Zimbabwe, for example, as of 2008 birth registration and a birth certificate were free for those born in Zimbabwe, but the parents of a child born in South Africa must pay a deposit of ZAR 110 into the Zimbabwean consulate's bank account, and then US\$50 on submitting the required forms for the certificate noting the birth abroad issued by the registrargeneral's office in Harare. Passport costs had also increased during the general crisis over citizenship, with additional fees required to expedite endlessly delayed applications. Rules on which documents are required to prove identity may vary from branch office to branch office of the registrar-general, creating additional costs when unexpected additional documents must be supplied. ${ }^{74}$

Corruption in nationality administration may, paradoxically, both ease problems of statelessness and create them. The ability to "negotiate" the acquisition of a birth certificate, identity card or other document may enable a person to "pass" as a national for most purposes. However, the sense that the system is not reliable may also mean that the mere possession of documents will not convince others that the person concerned is indeed a "real" national, even if they fulfil all the conditions for nationality from birth or have completed all the procedures for naturalisation. It is widely reported in many West African countries that a person may seek to obtain a new birth certificate in order to change their age, in order to apply for a civil service position, scholarship or other benefit where there is an age restriction. In Guinea - where an assessment mission noted that "the administrative system suffers serious dysfunction, including related to lack of financial, human and material resources, difficulties in managing the various institutions and a generalised corruption" 75 — senior government officials freely admit that nationality documents could be obtained with little if any check on entitlement. ${ }^{76}$ While Guinea is perhaps the most extreme case, many West African countries struggle with the same issues.

In Senegal, for example, the national identity card system is in the process of

ranged from a few hundred to a few thousand francs. Interviews Dakar and Ziguinchor, May 2014. The exchange rate at the time was roughly 490 CFA francs to one US dollar.

74 Dube, A Right or a Privilege; Dube, Identity, Citizenship, and the Registrar General. Supporting documents for an ordinary passport might include (but not be limited to) any of the following: a National Identification Card, a Birth Certificate, two passport photos, a completed passport application form, the passport application fee, and a set of fingerprints. See also chapter 8.3 .

75 Rapport de mission en République de Guinée 29 octobre - 19 novembre 2011, Commissariat Général aux Réfugiés et aux Apatrides (CGRA/Belgique), de l'Office Français de Protection des Réfugiés et Apatrides (OFPRA/France) et de l'Office Fédéral des Migrations (ODM/Suisse), March 2012.

76 Interviews, Conakry, May 2014. 
being computerised, which is revealing widespread problems with duplicate or triplicate birth registrations, as the system rejects people who apply with the same number birth certificate. Often, the person in possession of such a document may have been completely unaware that the birth certificate was not valid: they simply followed the understood procedure in paying a fee. At the Niaguis commune outside Ziguinchor in Casamance, all birth registration certificates issued during a certain period were being replaced as of 2014, creating major problems for those who had innocently obtained such documents. A person with a birth certificate from Niaguis who applied for an ID document or certificate of nationality had to go back to court to have the birth certificate cancelled or confirmed by the registrar (greffier); if it was invalid, the person would then need a jugement supplétif confirming the facts of birth and a new birth certificate; and then a certificate of nationality before getting their final identity document issued. Each stage of this process had fees attached. If the identity card itself was incorrectly issued, the person would need to travel to Dakar to get it sorted out. It could take months to complete the unravelling for those trapped in this situation; or they might never do so. ${ }^{77}$

\subsection{The struggle to obtain a passport}

It is when it comes to the issue of identity and travel documents that discretion and arbitrary decision-making is most evident. In the case of passports for international travel, African jurisprudence in the Commonwealth countries has regrettably often followed the rule established in British law, which historically regarded the grant of travel documentation as being within the "crown prerogative", a privilege and not a right. ${ }^{78}$ In the 1985 Mwau case in Kenya, for example, the High Court ruled that "in the absence of any statutory provisions . . the issue and withdrawal of passports is the prerogative of the president." ${ }^{\prime 79}$ In some countries the law makes this discretion explicit: in Seychelles, the law states that the minister may deny a passport or identity certificate to any citizen if it is "in the national interest."

Exploiting these legal loopholes, one of the most common actions of repressive governments seeking to silence their critics is to stop them travelling abroad: either by denying them a passport to start off with, or by confiscating existing passports when they try to leave the country. Alternatively, certain social groups may simply find it impossible to obtain a travel document in practice. For example, the US State Department human rights reports for 2007 mentioned arbitrary denial or confiscation of passports in Chad, Djibouti, Eritrea, Sudan, and Zimbabwe; in 2013, these countries included Egypt, Eritrea, Rwanda, South

77 Interviews, Ziguinchor, May 2014.

78 See Fransman's British Nationality Law, pp.773-777 for the rules relating to British passports.

79 In re application by Mwau, 1985 LRC (Const) 444.

80 Passport Act, 1991 (Cap 155), sections 6 \& 12. 
Sudan, Sudan, Swaziland and Zimbabwe (despite the provisions of the new constitution). ${ }^{81}$

But litigation and new laws have begun to push back the tide of absolute administrative discretion: court cases in several Commonwealth countries ruled that a citizen is entitled to a passport, even though this is not provided for in legislation. In Zimbabwe, the Supreme Court confirmed in 1993 that the state had no right or power to withhold the passport of a citizen, since a passport was needed in order to exercise the constitutional right to travel; ${ }^{82}$ other cases confirmed this right in the face of repeated efforts to deny passports to citizens. ${ }^{83}$ In Nigeria, where seizure of passports from activists attempting to travel was a common practice of previous military regimes, the Nigerian Court of Appeal in 1994 upheld the fundamental right of every citizen to hold a passport and to leave the country. The judges ordered that the passport of well-known lawyer Olisa Agbakoba, seized at the airport as he was on his way to attend a conference, be returned to him. ${ }^{84}$ In Zambia, the courts have also ruled that a citizen is entitled to a Zambian passport, though this is not provided for in legislation. ${ }^{85}$ In Kenya, a 2007 ruling overturned the Mwau decision: "In Kenya the right of travel is an expressed constitutional right, and its existence does not have to depend on a prerogative, inference or any implied authority." 86

Some constitutions and legislation are also beginning to recognise this right. The 2010 Kenya constitution provides that "Every citizen is entitled to a Kenyan passport and to any document of registration and identification issued by the State to citizens". ${ }^{87}$ The South African Constitution provides for citizens to have a right to a passport, ${ }^{88}$ and the Ugandan citizenship law adopted in 1999 similarly gives all citizens the right to a passport. ${ }^{89}$ The Zimbabwe Constitution of 2013 confirmed the rights of all citizens to passports and other travel documents. ${ }^{90}$

81 Bureau of Democracy, Human Rights, and Labor, Country Reports on Human Rights Practices for 2007 and 2013, available at http://www.state.gov/j/drl/rls/hrrpt/, last accessed 6 December 2014.

82 Chirwa $v$ Registrar-General 1993 (1) ZLR 1 (H); Registrar-General v Chirwa 1993(1) ZLR 241 (S).

83 Piroro v Registrar General 2011(2) ZLR 26 (H); Trevor Ncube v. Registrar-General (HH 7316/06), 25 January 2007.

84 See Obiora Chinedu Okafor, "The fundamental right to a passport under Nigerian law: An integrated viewpoint," Journal of African Law,Vol.40, No.1, 1996.

85 Cuthbert Mambwe Nyirongo v Attorney-General (1990-1992) ZR82 (SC).

86 Deepak Chamanlal Kamani v. Principal Immigration Officer and 2 Others [2007] eKLR; see also Peter Mwaura, "Passport is a right for every citizen, not a privilege" The Nation (Nairobi), 7 July 2007.

87 Constitution of Kenya, 2010, Article 12.

88 Article 21(4), Constitution of the Republic of South Africa.

89 Citizenship and Immigration Control Act, 1999, section 39: "Every Ugandan shall have the right to a passport or other travel documents."

90 Constitution of Zimbabwe 2013, Article 35(3). 


\section{Citizens report the challenges of getting a passport}

In 2007, the BBC website ran a discussion forum asking African readers "Is a passport your right?" Respondents from across the continent and in the diaspora detailed the trials that they undergone to obtain this most critical of citizenship documents. Repeatedly, they described the bribes they had to pay, the discrimination they faced, and the difficulties of producing documentation that proved their right to nationality and to travel documentation.

Kenya: I am a Kenyan Somali. Getting my passport was not easy at all, I now treasure it because of the process. I can't say I am proud of it. It is our right to get passports, but in Kenya the process is a nightmare, it has now been politicised because of the upcoming election. Muslims in Kenya have been allocated a separate desk at the Migration. They don't need to be treated special ... but equal, like any other Kenyan.

Sierra Leone: I have a passport and very proud of it. Holding a Sierra Leonean passport is not easy, more so if you are poor or your surname belongs to the Fullah tribe, like me! It cost a lot of money (for the average Sierra Leonean), it sometimes cost up to 300,000 Leones (US\$ 100) which include "see to see" for the fast tracking of the process. I believe a better option to get is to decentralise the process as people are better known in their communities. Everybody should be treated equally always. Liberia: Getting passport in your country of birth should be a right not privilege, but in Liberia here, getting passport is being tribalised when it comes to certain ethnic groups like the Mandingo — which is unconstitutional, unjustifiable and unacceptable.

Sudan: I have my Sudanese passport though getting it wasn't easy, one has to first acquire a nationality card and then apply for it, and by the way, my fellow poor countrymen and those who have no relatives and no access to the Southern Capital, Juba (in terms of transport fee and poor roads to make it to the capital) are unable to get as it is only here in Juba in the whole South where they are issued.

Eritrea: In Eritrea getting a passport is a roller coaster. There are times when they issue passports to everyone, that is apparently when the issuing authority needs money, then they screen people when they issue exit visas. Children above ten years of age and young men and women till the age of forty five are not allowed to travel outside the country, but family members and associates of the ruling system have it easy. And yet, they travel abroad and claim asylum. ${ }^{91}$

91 Extracts (lightly edited for spelling and punctuation) from comments posted in "Is a passport your right?", BBC News Forum discussion, October 2007, no longer available online; download on file with author. 


\section{PART II}

\section{Who is a native?}

Across the world it is normal practice for foreigners to be blamed in tough economic times, scapegoated for national setbacks, or targeted for verbal or legal abuse - or worse — by politicians seeking to consolidate support among their own natural constituency. ${ }^{1}$ In the context of the weak national cohesion and weaker state structures in many African states, the temptation has proved great to use exhortations against foreigners almost as a form of "nation-building" in political discourse, uniting a core constituency around the fear of an outside threat.

At its most cynical, incitement of public anger at "strangers" in the national community was the most easily accessible tool to shore up the shaky authority of new governments struggling to deliver on the promise of independence. Yet there were also reasonable arguments for the need to ensure that those resident in the new state were loyal and committed to its future; arguments that led to the very common ban on dual nationality in the newly adopted citizenship laws, as well as measures of affirmative action to rebalance colonial distortions of the economy and foster an "indigenous" middle class of administrators and business people. And when such legal measures moved into mass expulsions and other abuses, it was easy to respond that these groups had acquired their privileged position through similar measures. But manipulation of nationality law has very often affected much more seriously people who have no connection with colonial abuses, or indeed the descendants of those who were themselves victims of colonial policies, especially of forced recruitment.

This chapter provides some case studies of the more egregious abuses of nationality law for political purposes, from the periodic mass expulsions that have convulsed some countries, to the manipulations of the law to strip individual opposition politicians or entire groups of citizenship. But it also provides evidence for the role that reform of nationality law may play in ending such conflicts. Even in the most dysfunctional state, law matters.

Zimbabwe provides perhaps the clearest example of policies of dispossession dating from the era of colonial and minority rule returning boomerang-like to give their perpetrators' descendants a knock-out blow. Yet those worst affected by the efforts to denationalise the "former oppressors" have not been white Zimbabweans but rather the African migrants from neighbouring countries who

1 This chapter is a revised, expanded and updated version of material first published in Bronwen Manby, Struggles for Citizenship in Africa, London: Zed Books, 2009. 
have travelled to Zimbabwe in search of economic opportunities. Although the government took care to give the appearance of respect for a rule of law by adopting statutes and constitutional amendments in the usual legalistic terms, the overall effect was to overturn the legal conventions and principles that are the basis of international human rights law, including as it applies to nationality. But because many of the most high-profile figures affected by citizenship discrimination were white Zimbabweans and because the citizenship issue was tied to land redistribution, the Zimbabwean government was able to gain a measure of support from across Africa, even though the most numerous victims of the policy were black Africans from neighbouring countries.

In the East African countries of Kenya and Uganda, unlike in Zimbabwe, the great majority of those whites who had acquired land and property during the period of British colonial rule left at independence. Though vast white-owned estates still exist in Kenya, they are few, and the resentment that they might perhaps have generated against whites in the post-independence era has instead been targeted at the South Asian migrants who migrated at a time when both East Africa and the Indian subcontinent were equally part of the British empire. Asians for the most part did not acquire large landed estates, but they did achieve an economic success that came to be seen to pose a threat to the autonomy of the new states. To undercut the political power that relative wealth might have given them, the new states argued that these Asian immigrants should not have the right to be full citizens —and then took action accordingly. But other communities have found themselves with similar problems, including both the Nubian Kenyans who were brought to the country by the British from what is now Sudan; and Somali Kenyans, including those whose territory was incorporated within the borders of the Kenyan state at independence. In Uganda, the Banyarwanda also faced a fight to be recognised as legitimate Ugandans.

In West Africa, migration from South Asia was less common than in the countries that came to make up the East African Community; the same role was played by the Middle Eastern migrants who came to the region under colonial rule and have remained a dominant economic force. As in East Africa, the laws governing the transition to independence were non-discriminatory on a racial or ethnic basis; but very similar sorts of discrimination in law and practice have been adopted since independence. Among the more extreme cases are the two West African neighbouring countries where freed slaves played the leading role in the early years of self-government: Liberia and Sierra Leone. In each case, the history of oppression by white people and favoured immigrants from other continents led to the adoption of laws that excluded those not of African descent from full membership of the new states. In Liberia, the constitution has, since the first version was adopted in 1847, always provided that only a "Negro" may be a citizen. Sierra Leone applies a similar rule: though it allows non-blacks to naturalise, it makes this extremely difficult in practice, and citizenship by birth is restricted to "Negro Africans", defined - until 2006 - with reference to the male line only. 
The instability and civil war that devastated Côte d'Ivoire's once-prosperous economy after 1999 , displacing some 750,000 people and causing three million to require humanitarian assistance, had some of their deepest roots in conflicts over the definition of who is a "real" citizen of the country. As one of those who took up arms stated:"We needed a war because we needed our identity cards". ${ }^{2}$ Colonial-era crossborder migration, and the failure to create an effective and widely-accepted legal regime for the integration of these people and their descendants as Ivorian citizens, sowed the seeds of today's tensions. More recent migration kept the tensions alive and ready for exploitation by unscrupulous politicians. Each step towards denial of nationality was meticulously spelled out in laws, decrees and circulars.

Together with Côte d'Ivoire, the post-independence history of the current Democratic Republic of Congo (DRC) most clearly illustrates the negative consequences for peace and security of a focus on authenticity and blood descent in citizenship matters. Congo's jus sanguinis citizenship law, with an explicit foundation in ethnicity, rendered hundreds of thousands of people who have never lived in any other country doubtful as to their rights and legal status; and this uncertainty has repeatedly been used as a justification or excuse for taking up arms. In particular, the disputed status of the Kinyarwanda-speaking populations of the provinces of North and South Kivu in eastern DRC was at the heart of the conflicts that afflicted the region with devastating consequences from the early 1990s.

Extract from : Quel est mon pays ? by Yodé et Siro (Cote d'Ivoire)

Quand je suis au Gabon on m'appelle ghanéen ;

Quand je suis au Ghana on m'appelle gabonais.

Au Burkina on dit voilà ivoirien ;

En Côte d'Ivoire voilà burkinabè.

De part et d'autre je suis reconnu mais pas en tant que tel :

Quel est mon pays, le pays du métisse ?

Ne regarde pas mon visage pour m'attribuer une nationalité ;

Mon accoutrement pour donner le nom de mon pays.

When I am in Gabon they call me Ghanaian;

When I am in Ghana they call me Gabonese.

In Burkina, they say there's an Ivorian;

In Côte d'Ivoire, there's a Burkinabè.

In every place I am recognised but not as what I am:

Which is my country, the country of the hybrids?

Don't look at my face to give me a nationality;

Or at my clothes to know the name of my country.

2 "Côte d'Ivoire: What's in a name? A fight for identity", UN Integrated Regional Information Network (IRIN), 1 November 2005.

3 Available at https://www.youtube.com/watch?v $=$ ok8a5Drvj_Y last accssed 22 November 2014. 


\subsection{Mass expulsions as "nation-building"}

When the drafters of the African Charter on Human and Peoples'Rights (working in the late 1970s) included in the Charter a specific provision forbidding mass expulsion of foreigners (see above, chapter 3.12), it was in the knowledge that mass expulsions had already become a pattern in the continent. ${ }^{4}$

Best known of these expulsions in the international media was that of the Ugandan Asians driven out of the country in the 1970s by the government of Idi Amin (see below, chapter 8.4). But the majority of episodes primarily affected people of African descent. In West Africa, for example, the role of welleducated Dahomeyans in French colonial administration was widely resented in countries where they had been deployed, and tens of thousands were expelled from other countries — including Côte d'Ivoire in 1958, Congo-Brazzaville in 1962, and Niger in 1964. ${ }^{5}$ In 1965 and 1969-1970 Ghana also expelled several hundred thousand foreigners, many of them Nigerian, including children born in the country; Ghanaians were expelled from Sierra Leone and Guinea. ${ }^{6}$ In 1982, Sierra Leone expelled Fula allegedly originating from Guinea. ${ }^{7}$ Nigeria expelled Ghanaians immediately after independence, and again in 1983 around 1.5 to 2 million foreigners, of which an estimated one million were Ghanaians; though many were readmitted within a short period. ${ }^{8}$ In the mid-1990s, an

4 On this phenomenon globally, see Nicholas van Hear, "Mass Expulsion of Minorities: An Overview", Journal of Refugee Studies Vol.6, No.3, 1983, pp.274-285.

5 Suzanne Bonzon, «Les Dahoméens en Afrique de l'Ouest " Revue française de science politique, Vol.17, No.4, 1967, pp. 718-726; Herschelle Sullivan Challenor, "Strangers as colonial intermediaries:The Dahomeyans in Francophone Africa", in William A. Shack, and Elliott P. Skinner (eds.) Strangers in African Societies University of California Press, 1979, pp.67-83 ; Alain Tirefort, "L'affaire «Daho-Togo »: Une fièvre de xenophobie en Côte d'Ivoire", in Catherine Coquery-Vidrovitch et al, Etre Etranger et Migrant en Afrique au XXe Siecle: Politiques identitaires et modes d'insertion, Vol.1, Paris : Harmattan, 2003, pp.415-452 ; Joseph Roger de Benoist, " Pogrom contre les Dahomeens et les Togolais en Cote d'Ivoire en octobre 1958 » in CoqueryVidrovitch et al, Etre Etranger et Migrant en Afrique, Vol.1, pp.437-452.

6 Margaret Peil, "The expulsion of West African aliens", Journal of Modern African Studies Vol 9, No 2, (1971), pp.203-29; Margaret Peil, "Ghana's aliens", International Migration Review Vol.8, No.3, (1974) pp.367-81; Margaret Peil, "Host reactions: aliens in Ghana", in Shack \& Skinner, (eds). Strangers in African Societies, 1979 pp.123-401; see also Rhoda E. HowardHassmann, Human Rights in Commonwealth Africa, Rowman and Littlefield, 1986, p.104.

7 Aderanti Adepoju, "The politics of international migration in post-colonial Africa, in Robin Cohen (ed.), The Cambridge Survey of World Migration, Cambridge University Press, 1995.

8 Lynne Brydon, "Ghanaian Responses to the Nigerian Expulsions of 1983", African Affairs, Vol. 84, No. 337, 1985, pp. 561-585; Roger Gravil, “The Nigerian Aliens Expulsion Order of 1983”, African Affairs, Vol. 84, No. 337, 1985, pp. 523-537; Aderanti Adepoju, "Illegals and Expulsion in Africa: The Nigerian Experience", International Migration Review, Vol. 18, No. 3, 1984, Special Issue: Irregular Migration: An International Perspective, pp. 426436; Olajide Aluko, "The Expulsion of Illegal Aliens from Nigeria: A study in Nigeria's decision making", African Affairs, Vol.84, No.337, 1985, pp.539-560. 
estimated half a million Chadian and other nationality workers were expelled from Nigeria, including among them many who had been legally established in the country for many years. ${ }^{9}$ Guinea expelled Sierra Leonean refugees en masse in 2000, an episode which was later condemned by the African Commission on Human and Peoples' Rights. ${ }^{10}$

Mass expulsions are thus certainly not a purely historical phenomenon. Gabon, which hosts many migrant workers in its oil industry and spin-off economic activities, has expelled foreigners on many occasions; almost as if it were a way of cementing Gabonese identity. There were attacks on and expulsions of Congolese in 1962, of Beninois in 1978, of Cameroonians in 1981, of Lebanese in 1985; and a general tightening of measures against foreigners thereafter, including the requirement to obtain expensive residence and work permits, with further expulsions of Nigerians and other West Africans in the late 1980s and early 1990s. ${ }^{11}$ In September 1994, Gabon further strengthened these measures, announcing that foreigners would have to regularise their status (at a cost of up to $\$ 1,200$ ) or leave the country by 15 February 1995: by March an estimated 64,000 foreign nationals left the country, and 15,000 legalised their residency; around 1,000 were detained and held in a camp before being repatriated. ${ }^{12}$

In southern Africa, Angola has carried out repeated expulsions of people of alleged Congolese origin, on economic or national security grounds, ${ }^{13}$ and the African Commission on Human and Peoples' Rights ruled against Angola for the expulsion of West Africans in 1996. ${ }^{14}$ In 2004 and 2005, Angola's Operação Brilhante led to the deportation of more than a quarter of a million alleged foreign citizens involved in artisanal diamond mining, mainly from the two Congos and West Africa, and these expulsions continued in following years; in 2011, Angola expelled more than 100,000 alleged Congolese nationals. DRC responded in 2009 with tens of thousands of expulsions of alleged Angolans from its soil. ${ }^{15}$

9 Committee on Economic, Social and Cultural Rights, Consideration of reports submitted by States parties under articles 16 and 17 of the Covenant: Concluding observations of the Committee on Economic, Social and Cultural Rights: Nigeria, 13 May 1998, E/C.12/1/Add.23.

10 Communication 249/2002, African Institute for Human Rights and Development (on behalf of Sierra Leonean refugees in Guinea) $v$ Republic of Guinea, Decided at the 36th ordinary session, December 2004, 20th Activity Report.

11 Christopher J. Gray "Cultivating Citizenship through Xenophobia in Gabon, 19601995”, Africa Today, Vol.45, No.3-4, 1998, pp.389-409.

12 “Migrants Expelled from Gabon", Migration News, Vol. 2, No. 4, University of California, Davis, March 1995.

13 Jean-Michel Mabeko-Tali, “"Congolenses ", « Congoleses ", « Zairenses » : L'immigration centr-africaine et la problématique identitaire angolaise", in Coquery-Vidrovitch et al, Etre Etranger et Migrant en Afrique, Vol.1, 2003, pp.189-206.

14 Communication No.159/96, Union Interafricaine des Droits de l'Homme and Others v. Angola, ACHPR 1997.

15 Human Rights Watch, "If You Come Back We Will Kill You": Sexual Violence and other Abuses against Congolese Migrants during Expulsions from Angola, New York, 2012;"Operation 
But, as the tit-for-tat expulsions between Angola and DR Congo showed, it is often not clear who is a foreign migrant, illegally present in another country and thus legitimately subject to expulsion (though an individual decisionmaking process would be required in law); and who is a person with (a right to) citizenship, whose expulsion even on an individual basis would be impermissible in international (and national) law. In many cases, those expelled by Angola and Congo were people of mixed parentage, or alternatively individuals who, until the date that political events turned against them, had always been treated as citizens.

In Uganda, in a much less well known episode than the expulsion of Asians in the 1970s, the government of President Milton Obote expelled a large number of Banyarwanda in the early 1980s, including some 40,000 people who claimed Ugandan citizenship and 31,000 people registered with UNHCR, forcing most of them to seek refuge in Rwanda. ${ }^{16}$ Tanzania, while often praised for its generosity to refugees from neighbouring countries, has also, in response to the politics of the East Africa region, expelled many thousands of people of Rwandan, Burundian and Congolese descent, many of whom were born in the country (which still retained its jus soli citizenship law as of 2014), and some of whom had been offered and accepted naturalisation as Tanzanian citizens (see chapter 11.2). Djibouti, too, a country of contested national identity despite its small size, expelled around 80,000 alleged foreigners of non-Somali ethnicity in 2003 (more than ten percent of the country's population), many thousands of them in fact people who should have had a right to citizenship. ${ }^{17}$

deports 270,000 foreign citizens", Angola Press Agency, 19 April 2005; “ANGOLA-DRC: Retaliatory expulsions reach a new peak", IRIN, 13 October 2009; Barry Bearak, "Congo and Angola Agree to End Expulsions" New York Times, 13 October 2009;" DRC: Humanitarians ease the plight of those expelled from Angola", UN OCHA, 14 April 2012; further reports from UNHCR available at the REFWORLD website.

16 Bonaventure Rutinwa, "The end of asylum? The changing nature of refugee policies in Africa”, Refugee Survey Quarterly, Vol. 21, Nos. 1 and 2, April 2002, p.6.

17 Samson A. Bezabeh, "Citizenship and the logic of sovereignty in Djibouti", African Affairs Vol. 110 No. 441, 2011, pp: 587-606; Simon Imbert-Vier, “Afars, Issas ... and Djiboutians: Toward a History of Denominations", Northeast African Studies, Vol.13, No.2, 2013, pp. 123-149. 


\section{Libya: A pattern of expulsions}

President Muammar Al-Gadhafi of Libya repeatedly stated a policy of welcoming Arab and African immigrants, and, among other policies, deployed the grant of citizenship as a way of recruiting fighters to the Libyan army. At the same time, a fierce Arabisation campaign denied the existence or validity of non-Arab ethnicities within Libya. Many nonArabs faced difficulties in obtaining nationality documentation, even if established in the country for many decades. ${ }^{18}$

By the early $21^{\text {st }}$ century, between 10 and 25 percent of the population of Libya was not of Libyan origin, according to government figures: among the estimated population of 5.3 million, there were around 600,000 legal migrant workers, and up to 1.2 million present illegally, either seeking work in Libya itself or in transit to Europe. ${ }^{19}$ In addition to recent migrants were many of Berber-Tuareg origin, long-term residents in the country, whose nationality was not recognised (see chapter 9.4).

Thousands of non-Arabs, including Berbers, had no official documentation attesting to their citizenship. In Libya, the main proof of citizenship is the family booklet, in which all members of the family are listed and which is presented when applying for jobs, university studies and scholarships, or when taking out a loan from the bank. While those whose families had lived in Libya since the early years of the twentieth century had mainly managed to obtain these documents, those who settled in the country 40 or 50 years ago were denied a family booklet and possess neither Libyan nor any other citizenship.

Gaddafi's government periodically mobilised hostility to immigrants for political purposes. As early as 1985, Libya expelled more than 30,000 Tunisian migrants over a period of several weeks. ${ }^{20}$ Mass expulsions became a pattern from the mid-1990s.

In early September 1995, Libya began deporting thousands of Arab workers, including some 30,000 stateless Palestinians; the move was widely interpreted as a punishment for Palestinian agreements with Israel on self-rule in the West Bank and Gaza. ${ }^{21}$ Hundreds of those refugees

18 Pierre Boilley, Les Touaregs Kel Adagh : dépendances et révoltes : Du Soudan français au Mali contemporain, Paris : Karthala 1999 ; International Crisis Group, Popular protest in North Africa and the Middle East (V): Making sense of Libya, Middle East/North Africa Report N¹07, 6 June 2011.

19 Seventeenth periodic report of States parties due in 2002, Libyan Arab Jamahiriya, 18 June 2003, CERD/C/431/Add.5; Stemming the Flow: Abuses Against Migrants, Asylum Seekers and Refugees in Libya, Human Rights Watch, September 2006.

20 Edward Schumacher, "For Tunisians in Libya, an Abrupt Homecoming", The New York Times, 23 September 1985.

21 Migration News, Vol. 3, No. 6, UNHCR, June 1996 
remained stranded in a refugee camp on the Libyan-Egyptian border for years. ${ }^{22}$ At around the same time, following clashes between the Libyan security forces and Muslim fundamentalists in Benghazi, the Libyan authorities trucked some 50,000 Sudanese to the border, and a further 300,000 were ordered to leave on the basis that they did not have work permits. ${ }^{23}$ People of Egyptian origin were also deported in the same wave of expulsions.

In September 2000, a mob of Libyans in the town of Zawiyya, west of Tripoli, clashed with foreigners primarily from Sudan and Chad, killing up to fifty people, according to press reports. Following this clash, which was followed by further outbreaks of xenophobic violence, thousands of African migrant workers, many from Ghana, Nigeria and Chad, were expelled. ${ }^{24}$

The European Commission concluded after a trip to Libya in 2004 that, "[T]he decision to return illegal immigrants to their country of origin seems to be taken for groups of nationalities rather than after having examined individual cases in detail." 25 UNHCR was more critical, expressing concern for the "minimum standards of treatment for persons who might be in need of international protection." ${ }^{26}$ In a comprehensive review of Libya's treatment of refugees and migrants published in September 2006, Human Rights Watch concluded that, partly under pressure from the European Union, Libya had "implemented a plan to arrest and forcibly return tens of thousands of foreigners who illegally enter Libya or are there without proper documentation" making "no attempt to differentiate between these people and the asylum seekers, refugees and others in need of international protection who also came". ${ }^{27}$

Despite these concerns, deportations increased, even by the government's own account. In November 2006, the Libyan authorities announced that they had deported 64,430 irregular migrants so far that year, compared to figures of 47,991 and 4,947 for 2005 and 2004 respectively. ${ }^{28}$

22 "Libya threatens to deport Palestinian refugees to Gaza", ynetnews.com, 17 March 2007.

23 Sudan News \& Views, Issue No.12, 15 September 1995.

24 Committee on the Elimination of Racial Discrimination, Consideration of Reports Submitted by States Parties under Article 9 of the Convention: Concluding Observations of the Committee on the Elimination of Racial Discrimination: Libyan Arab Jamahiriya, CERD/C/64/CO/4, 10 May 2004; Human Rights Watch, Stemming the Flow.

25 European Commission, "Technical Mission to Libya on Illegal Immigration, 27 Nov - 6 Dec 2004, Report".

26 "UNHCR Concerned Over Continued Forcible Return of Potential Refugees from Libya," UNHCR Briefing Notes, September 21, 2004.

27 Human Rights Watch, Stemming the Flow.

28 Amnesty International, "Libyan Arab Jamahiriya: Briefing to the UN Human Rights Committee”, June 2007, AI Index: MDE 19/008/2007. 
These actions were regarded with dismay south of the Sahara. It was thus not an accident that a meeting of AU ministers on immigration gathered in Tripoli in June 2005 specifically called for a protocol to the African Charter on deportations and expulsions, to address the concerns of due process and respect for human rights. ${ }^{29}$

On the fall of the Gaddafi regime in 2011, there was a mass flight across the Libyan borders from the civil conflict that followed, including not only Libyans but also migrants from Africa and further afield. There were also attacks on African migrants by Libyans, blamed for their alleged support for Gaddafi. ${ }^{30}$ Some destroyed their own identity documents, fearing that rumours about migrants being given visas to fight for Gaddafi might expose them to danger. According to IOM figures as of March 2012, the crisis resulted in some 317,000 third-country nationals who had fled to Libya's neighbouring countries (Algeria, Chad, Egypt, Niger and Tunisia) requiring evacuation to their home countries - mainly across Africa, and the largest numbers to Chad and Niger. IOM and its partners assisted more than 210,000 people to return by June 2011; and a further 38,000 stranded in the country by May 2012. ${ }^{31}$ Many more fled independently of such assistance.

\subsection{Denationalisation as censorship}

Asserting that someone is a non-citizen has a particular usefulness for a government nervous of a challenge to its hold on power. While other forms of abuse of process - such as investigations for corruption and other stratagems used not only in Africa - may also be deployed, a person accused of such an offence still has access to the courts. Where a person is simply declared never to have been a citizen, any rules of due process under the law to a decision to deprive a person of nationality may be argued not to apply; the person may be subject to deportation first, and permitted access to the courts only after already out of the country. Even if a person is not deported, he or she may be regarded as entitled — in the government's eyes, and perhaps in the courts' also — only to

29 Report on the African Union Conference of Ministers of Immigration, Ex.CL/197(VII) 28 June 2 July 2005; see also "African ministers push for protocol on deportation, mass expulsion", PANA, 30 June 2005.

30 "Libya: Stranded Foreign Workers Need Urgent Evacuation: Sub-Saharan Africans Appear at Greatest Risk", Human Rights Watch, 3 March 2011; International Crisis Group, Holding Libya Together: Security Challenges after Qadhafi, Middle East/North Africa Report No115 - 14 December 2011; Asylum Research Consultancy, Libya Country Report, Commissioned by the Office of the United Nations High Commissioner for Refugees (UNHCR), Division of International Protection, July 2013.

31 Asmita Naik, "Returnees from Libya: The bittersweet experience of coming home", Policy Brief, IOM, May 2012. 
the protections due to foreigners, not the general rights of citizens.

Abuse of nationality law has most often reached the courts in case of high profile individuals running for the presidency or other political office. ${ }^{32}$ The case studies below narrate the Kafkaesque bending of the law in Zambia to declare that Kenneth Kaunda, president of the country from 1964 to 1991, was not a citizen and thus could not run for office again; and also to exclude from power the less internationally well known politicians William Banda and John Chinula. The government of Botswana, which regularly comes top of the African league tables for good governance, tried the same strategy against John Modise after he attempted to establish an opposition party, leaving him in a no-man's land limbo for years. The same year that Kaunda was declared a non-citizen, the courts in Côte d'Ivoire annulled the nationality certificate of former Prime Minister Alassane Ouattara, on grounds that it had been irregularly issued (see chapter 8.7). These high profile cases reached the African Commission on Human and Peoples' Rights, which in every case ruled the government in violation of several articles of the African Charter (see chapter 3.12.2).

Some similar cases have been litigated or protested only at national level. In Nigeria, for example, the federal government of President Shehu Shagari in January 1980 arrested and expelled to Chad the majority leader of the opposition-controlled state legislature of the northeastern state of Borno, Alhaji Shugaba Abdulrahman Darman, alleging that he was Chadian. The Nigerian courts struck down this act as illegal, finding that Shugaba was a Nigerian citizen and that citizens were not liable to be deported from their own countries of nationality. ${ }^{33}$ Such tactics may also be used against journalists and other critics: Tanzania has attempted to strip troublesome individuals of their citizenship several times in recent years. In 2001, the government declared that four individuals were not citizens, though giving them the option of applying for naturalisation; the move was interpreted as reprisal for independent media criticism of political and economic developments in Tanzania. ${ }^{34}$ In August 2006, the government of Tanzania again stripped two journalists of nationality, accused of being "unpatriotic and enemies

32 See Beth Elise Whitaker, "Citizens and Foreigners: Democratization and the Politics of Exclusion in Africa," African Studies Review Volume 48, Number 1, April 2005, pp.109-126.

33 Shugaba Abdulrahman Darman vs. Federal Minister of Internal Affairs and 3 Others [1981], 2 Nigerian Constitutional Law Reports 459; Samuel Akanmode, The Shugaba Affair, Nigerian Council for National Awareness, 1980.

34 "Tanzania drops envoy to Nigeria over citizenship", The Guardian, Dar es Salaam, 5 February 2001. The four were Timothy Bandora (the country's then High Commissioner to Nigeria); Jenerali Ulimwengu (a leading publisher, journalist, media proprietor and chief executive of Habari Media Limited and also a former Tanzanian diplomat and member of parliament, who was born and educated in Tanzania), Anatoli Amani (the leader of the ruling Chama Cha Mapinduzi (CCM) party in the north-western Kagera region), and Mouldine Castico (a former publicity secretary of CCM in Zanzibar). 
of the state". ${ }^{35}$ In Swaziland, as described below, the default response to those who criticise the monarchy or organise to challenge the government is to accuse them of not being Swazi.

\subsubsection{Zambia: Kenneth Kaunda and others become instant foreigners}

After twenty-seven years of one party rule following independence, Zambia held multi-party presidential and parliamentary elections on 31 October 1991. The elections were won by the Movement for Multiparty Democracy (MMD), led by Frederick Chiluba. It was one of the first post-cold war transitions on the African continent, much heralded as a model for other countries.

In 1993, the MMD fulfilled a campaign pledge to review the constitution by appointing a 24-member review commission to collect views from the general public and provide proposals for the content of a new constitution. The Mwanakatwe Commission, named for its chairman John Mwanakatwe, released its report in June 1995, including a contentious recommendation for a constitutional amendment to require that both parents of any presidential candidate should be Zambians by birth. This clause would effectively disqualify former president Kenneth Kaunda, whose parents were Malawian missionaries, from standing for the presidency in the 1996 elections on the ticket of the United National Independence Party (UNIP) - the party that he had during led the independence struggle and that had been in power since 1964 until defeated by the MMD. The ruling party pushed the amendment through parliament in 1996, rather than providing for the recommendations to be agreed by a constituent assembly and subject to a referendum, as the Mwanakatwe Commission had recommended. ${ }^{36}$

The opposition Zambia Democratic Congress party unsuccessfully sought to prevent the adoption of the constitutional amendment through the courts. ${ }^{37}$

35 They were Ali Mohammed Nabwa, weekly consulting editor of Fahamu, and Richard Mgamba, a reporter with the Mwanza-based The Citizen newspaper. The Zanzibar's Immigration Department's revocation of Nabwa's citizenship came just days after his citizenship had been restored following a previous withdrawal when the Zanzibar government banned another newspaper he was heading as managing editor. "Veteran editor stripped of citizenship", The Guardian, Dar es Salaam, 8 August 2006; Ernest Mpinganjira, "Intimidation of media exposes Tanzania's fear of criticism", The Sunday Standard, 13 August 2006.

36 Constitution of the Republic of Zambia, 1991, article 34(3)(b), added by the Constitution (Amendment) Act No. 18 of 1996. The Constitution also provides in Article 7(b) that a person may not be deprived of citizenship except on the grounds that they are the citizen of another country or they have obtained citizenship by fraud. See discussion in Melvin L.M. Mbao, "Human Rights and Discrimination: Zambia's Constitutional Amendment, 1996”, Journal of African Law,Vol.42, 1998, pp.1-11.

37 Zambia Democratic Congress v. Attorney General, Appeal No. 135/96, SCZ Judgment No. 37 of 1999. The Supreme Court of Zambia ultimately (long after the elections had come and gone) ruled against the petition, declaring that the Zambian parliament had the power 
Kaunda was thus not allowed to contest the 1996 elections, which were held in an atmosphere of severe threat to all opposition candidates ${ }^{38}$; in 1997 Kaunda was detained for several months during a general crackdown following an alleged coup attempt.

Chiluba's government had already began to use citizenship and immigration law to disable its political opponents. William Steven Banda and John Lyson Chinula - both leading members of UNIP - were separately deported to Malawi in 1994 under the Immigration and Deportation Act, on the grounds that they were not citizens and were "likely to be a danger to peace and good order in Zambia". Banda fought his deportation order in the courts, arguing that he had a Zambian National Registration Card and a passport and had used these freely for many years without challenge, but the Supreme Court ultimately denied his claim and he was forcibly deported. Chinula was given no opportunity to contest his deportation order before the courts at all and was immediately deported. The Malawian courts, however, declared both deportees not to be Malawian citizens.

Amnesty International complained to the African Commission on Human and Peoples' Rights on behalf of Banda and Chinula. In 1999, the Commission found that the deportations were politically motivated and that Zambia was in contravention of the African Charter by not applying due process in the two cases. ${ }^{39}$ Chinula died in Malawi before the Commission concluded its consideration of the case; despite the ruling, the Zambian government did not allow William Banda to return until fresh elections brought the new government of President Levy Mwanawasa, still heading the MMD, in 2002.

In an ironic twist, following the 1996 elections, the dual parentage clause was invoked to challenge in court the re-election of President Fredrick Chiluba.The petitioners alleged that Chiluba's father was not Zambian by birth and therefore Chiluba did not qualify to be elected president of Zambia. This time, the Supreme Court affirmed that citizenship must not be defined in discriminatory terms and questioned the rationale of the provision in the Constitution requiring both parents of a presidential candidate to be Zambians by birth. The

to adopt the proposed amendment to the constitution without a referendum. The Legal Resources Foundation, a human rights organisation, then lodged a complaint against Zambia with the African Commission on Human and Peoples' Rights following the Supreme Court's decision: in 2001 the African Commission ruled that the Zambian government was in violation of several provisions of the African Charter. Legal Resources Foundation v. Zambia (2001).

38 Zambia: Elections and human rights in the Third Republic, Human Rights Watch, December 1996.

39 In court, the Zambian government alleged that Banda's father was Malawian; although the trial court found that there was no admissible evidence that Banda was Malawian, it also found that there was insufficient evidence that he was Zambian either.African Commission on Human and Peoples' Rights, Communication 212/98, Amnesty International v. Zambia (2000), paragraph 29. 
court held that, while the language of the amendment did not in fact exclude "non-indigenous" Zambians from the presidency, if it had it may have violated the non-discrimination provisions elsewhere in the constitution. In any event, whichever of several proposed biographies was adopted, Chiluba's ancestors came from Northern Rhodesia (what is today Zambia) and his citizenship and eligibility for the presidency could not be questioned. ${ }^{40}$

In a subsequent case heard in 1999, petitioners from the MMD requested the court once again to review Kaunda's citizenship. ${ }^{41}$ It was argued that the Zambian citizenship of Kaunda should be quashed, that Kaunda had never qualified to be elected president of Zambia, and that he should be declared to have ruled Zambia as president illegally. The High Court observed that Kaunda's own affidavit showed that he had renounced entitlement to Malawian citizenship on 21 June 1970. Thus, the High Court concluded that Kaunda had become a citizen of Malawi by descent when Malawi became independent (on 7 July 1964), but that at the time of the case he was neither a Zambian nor a Malawian citizen and thus a stateless person. Kaunda appealed to the Supreme Court, but the case was settled in 2000 and Kaunda's citizenship finally restored.

In 2001, a communication to the African Commission about the Kaunda case was finally decided. The Commission found in favour of Kaunda, finding the constitutional amendment in violation of the rights to non-discrimination (article 2) and equal treatment under the law (article 3). In relation to the state succession issues, the Commission noted that "the movement of people in what had been the Central African Federation (now the States of Malawi, Zambia and Zimbabwe $)^{42}$ was free and ... by Zambia's own admission, all such residents were, upon application, granted the citizenship of Zambia at independence. Rights which have been enjoyed for over 30 years cannot be lightly taken away. To suggest that an indigenous Zambian is one who was born and whose parents were born in what came (later) to be known as the sovereign territory of the State of Zambia may be arbitrary and its application of retrospectivity cannot be justifiable according to the Charter." 43

In 2001, the MMD split, after President Chiluba unsuccessfully sought a third term in office.Vice-president Christon Tembo formed a new party, the Forum for Democracy and Development (FDD). The government questioned the

40 Lewanika and Others v. Chiluba, 1998 ZLR 86.The Constitution at the time of independence provided in article 3(1) as follows: "3(1) Every person who, having been born in the former protectorate of Northern Rhodesia, is on 23 ${ }^{\text {rd }}$ October 1964 a British protected person shall become a citizen of Zambia on $24^{\text {th }}$ October $1964 . "$

41 Mushota and Another v. Kaunda and Another 1997/HN/357 unreported. The judgment was published in the Times of Zambia on 1 April 1999.

42 On the Central African Federation, see chapters 4.2 and 4.3.

43 Legal Resources Foundation v. Zambia, African Commission on Human and Peoples' Rights, Communication 211/98 (2001). 
citizenship of both Tembo and Dipak Patel, another member of parliament who joined the FDD, whom it alleged had not been a citizen when he first stood for election in 1991. Ironically, the MMD had refused citizenship to Majid Ticklay, a resident of Zambia since childhood but of Indian origin, to protect Tembo's own parliamentary seat when Ticklay wished to run for office in $1996 .{ }^{44}$

In April 2003, President Levy Mwanawasa, elected the previous year, appointed a fourth constitutional review commission, headed by lawyer Wila Mung'omba; and in August of the same year, a twenty-six member Electoral Reform Technical Committee (ERTC) to analyze and make recommendations regarding the legal framework of the electoral process. The eligibility criteria to run for president were relevant to both processes. The Mung'omba Commission completed its work and mandate in December 2005. Most of the petitioners who addressed the subject of the parentage clause in the qualifications for presidential candidates argued for the provision be repealed. The Commission supported this view, on the basis also that the Supreme Court had doubted the constitutional validity of the parentage clause, and recommended that the requirement should be simply for the president to be a citizen "by birth or descent" and not a dual citizen. Responding to the ERTC report, which made the same recommendation, the Zambian government indicated that it also supported the repeal of the provision on parentage. ${ }^{45}$

In 2007, President Mwanawasa proposed yet another constitution drafting process, scheduled to last five years; the process was initially boycotted by Michael Sata's opposition Patriotic Front (PF) party along with civil society organisations, who regarded the proposals as being in bad faith. A compromise was reached in June 2007, for the establishment of a new body representing different interest groups, the National Constitutional Conference (NCC). However, the process had yet to reach any conclusions by Mwanawasa's untimely death in 2008. Newly elected President Rupiah Banda, also of the MMD, was expected to continue with the NCC process. However, it was not until Sata's own election as president in September 2011 that the drive for constitutional reform continued. President Sata appointed a technical committee to draft a new constitution, which produced a first draft based largely on recommendations from the 2005 Mung'omba Commission, to be discussed at different fora around the country. The technical commission finished its work by October 2013, and the draft was formally made public one year later, just as Sata's own death prompted the need for fresh elections. The draft provided in Article 98 that "A person qualifies to be nominated as a candidate for election as President if that person - (a) is a citizen by birth or descent...."

44 Whitaker, "Citizens and Foreigners"; Sheikh Chifuwe, “Tilyenji Denounces Citizenship Law”, The Post (Lusaka), 18 October 2001.

45 Report of the Constitution Review Commission, Lusaka, Zambia, 29 December 2005. 


\subsubsection{Botswana: The case of John Modise}

John Modise was born in South Africa of Batswana parents, prior to the independence of Botswana, and brought up in Botswana. Until 1978, the year that he became a founder and leader of an opposition political party, Modise held Botswana citizenship without problems. In that year, the government of Botswana decided that Modise could not claim to have citizenship by descent, ${ }^{46}$ and the Office of the President declared Modise a prohibited immigrant. His arrest and deportation to South Africa followed soon thereafter. Even one of Africa's most stable democracies resorted to underhand means to prevent challenge to the status quo.

Modise was not given the chance to challenge the deportation in court and the deportation prevented him from following up on an application for a temporary work permit which, if granted, would have allowed him to remain in Botswana. Four days after the first deportation, Modise re-entered Botswana and was arrested, charged with illegally entering the country as a prohibited immigrant, and deported again without a hearing. After his third attempt to enter Botswana he was again arrested and charged with the same crime, but was this time sentenced to a ten-month prison term. Modise filed an appeal but before it was heard he was again deported to South Africa.

The South African government did not recognize Modise as a citizen either and he was forced to settle in the then "homeland" of Bophuthatswana, where he lived for seven years before he was again deported, this time to the no-man's land border zone between Botswana and South Africa where he lived for several months. Modise was finally allowed to re-enter Botswana on humanitarian grounds, but was forced to live on temporary residence permits which were renewed every three months at the discretion of the Ministry of Home Affairs. ${ }^{47}$

The effect on Modise of being rendered stateless, declared a prohibited immigrant, deported numerous times, and kept in a prolonged state of insecurity was to bankrupt him, disrupt his personal life, and effectively quash his political aspirations. In 1993, a complaint was filed on his behalf with the African Commission on Human and Peoples' Rights, which was finally decided in 2000 after many attempts to reach an amicable resolution. The Botswana government attempted a solution to the problem for many years by offering Modise citizenship

46 The Government alleged that because Modise was born in the Republic of South Africa and was not a subject of the British Crown at the time of Botswana's independence in 1966, because his father (who had been born in a British Protectorate) was not alive in 1966, and because he had not exercised his right to become a naturalized Botswana citizen by October 1968, he could not be considered a citizen of Botswana.

47 See African Commission on Human and Peoples' Rights, Communication No. 97/93, John K. Modise v. Botswana (2000). The judgment in the decision contradicts itself on facts of the case in paragraphs 5 and 91 ; what is stated here are believed to be the correct facts, based on information from Interights, the plaintiff's representatives. 
by naturalisation: however, though citizenship by naturalisation extends nearly all of the same rights as are conferred on citizens by descent, the constitution places limits with regard to the holding of political office. As a naturalised citizen Modise would not be eligible to hold the highest political office in Botswana - that of president. Citizenship by naturalisation would also not guarantee citizenship of his children, unless it was granted retroactively.

The African Commission ruled in favour of Modise, found Botswana to be in violation of Articles 5 and 7 of the African Charter on Human and Peoples' Rights and recommended that Botswana grant Modise citizenship. The African Commission held that "while [restrictions on holding public office] may not seriously affect most individuals, it is apparent that for Mr. Modise such is a legal disability of grave consequence. Considering the fact that his first deportation [and declaration as a prohibited immigrant] came soon after he founded an opposition political party, it suggests a pattern of action designed to hamper his political participation. When taken together with the above action, granting the Complainant citizenship by [naturalisation] has, therefore, gravely deprived him of one of his most cherished fundamental rights, to freely participate in the government of his country, either directly or through elected representatives." ${ }^{4}$ After follow-up from the Commission, the Botswana government agreed in principle to grant citizenhip by birth to Modise, but refused meaningful compensation. ${ }^{49}$

\subsubsection{Swaziland: Critics are "un-Swazi"}

Since Swaziland gained independence from the United Kingdom in 1968, its rulers have chosen to emphasise an exclusive ethnic identity for the country. Tradition has been invoked to uphold a monarchical system that has never subjected itself to the rule of law or allowed public debate on the national destiny. And in support of this system of government with no democratic limits on power, a primary weapon used by Swaziland's rulers has been to describe critics as "foreign", divisive and hostile to Swazi "tradition". Although the 1967 constitution in place during the short life of Swaziland as a "Protected State" with internal self-government (rather than a protectorate) had provided for a jus soli right to citizenship for anyone born in the territory before or after independence, the 1968 constitution of Swaziland as a fully independent

48 Modise v. Botswana, paragraph 96.

49 The government reportedly offered Modise P100 000 (around U.S.\$21,000 at the contemporary exchange rate) as compensation in 2004 for his 1978 deportation from Botswana in response to the African Commission's ruling, an offer he is said to have rejected. Donny Dithato, "State in Secret Talks with Modise," Mmegi, 25 August 2004. See also Lirette Louw, "An Analysis of State Compliance with the Recommendations of the African Commission on Human and Peoples' Rights", thesis submitted in fulfilment of the requirements for the degree of Doctor of Laws at the University of Pretoria, South Africa, January 2005. 
country provided for citizenship only to those born in or outside Swaziland from that date if the child's father was a citizen of Swaziland at the time of the birth (though existing citizens remained so). ${ }^{50}$

During the lead up to independence, King Sobhuza and his supporters had resisted the operation of political parties, already describing them as antithetical to the "traditional" systems of Swazi government. Parties were formally allowed by the independence constitution, but in the pre-independence elections no opposition candidates won a seat. In the 1972 general elections, however, the first as an independent country, an opposition political party, the Ngwane National Liberatory Congress (NNLC) gained three seats in parliament. The reaction was immediate. Before the elected candidates could be sworn in, the minister responsible for immigration issued a declaration that one of the members of the NNLC, Bhekindlela Thomas Ngwenya, was a "prohibited immigrant" under the 1964 Immigration Act and subject to deportation.

Ngwenya challenged the declaration in court, and the deportation order was set aside by the High Court in August 1972 on the grounds that the government had not shown that he was not a citizen. ${ }^{51}$ The government appealed.

While the appeal was pending, an amendment to the Immigration Act was rushed through parliament to establish a tribunal to decide cases of disputed nationality, from whose rulings an appeal could only be made to the office of the deputy prime minister, whose decision was final. ${ }^{52}$ The tribunal, whose jurisdiction was retroactive, ruled that Ngwenya was not a citizen of Swaziland. Ngwenya then challenged the competence of the tribunal in the High Court, which ruled against him in January $1973^{53}$; on appeal, however, the Court of Appeal ruled in March 1973 that the amendment to the Immigration Act removing the jurisdiction of the High Court was unconstitutional because in effect it amounted to a constitutional amendment and had not followed the correct procedures. ${ }^{54}$

On 12 April 1973, the prime minister introduced a motion in parliament abrogating the constitution, the opposition walked out, and the king later that day announced the repeal of the constitution and then the banning of political parties. ${ }^{55}$ Among the laws subsequently promulgated was an exceptionally restrictive citizenship law. This law provided that a person who had citizenship

50 Fransman's British Nationality Law, catalogue entry on Swaziland.

51 Bhekindlela Thomas Ngwenya $v$. The Deputy Prime Minister 1970-76 SLR (HC) 88.

52 Immigration (Amendment) Act No. 22 of 1972.

53 Bhekindlela Thomas Ngwenya $v$. The Deputy Prime Minister and the Chief Immigration Officer 1970-76 SLR (HC) 119

54 Bhekindlela Thomas Ngwenya v. The Deputy Prime Minister and the Chief Immigration Officer 1970-76 SLR (CA) 123.

55 See also, Thulani Rudolf Maseko, "The writing of a democratic constitution in Africa with reference to Swaziland and Uganda”, LLM thesis, University of Pretoria, 2005. 
under the 1968 constitution (including those whose citizenship under the 1967 constitution had been confirmed) would only remain so if his or her father had been a citizen at the time of the birth. The law also provided that a person who had proof issued by a Swazi chief that he or she had khonta'd, that is "been accepted as a Swazi in accordance with Swazi law and custom" could apply for registration as a citizen, without being subject to the discretionary decisionmaking process applied to other applicants; part of a general rise in the political mobilisation of Swazi ethnicity. ${ }^{56}$

Over many years, the Swazi government consistently harassed Jan Sithole, the vocal general secretary of the Swaziland Federation of Trade Unions (SFTU). Amongst the many campaigns waged against Sithole for his outspokenness, which included beatings and assault by security forces, court actions, and kidnapping, was an attack on his integrity and loyalty to Swaziland by virtue of his being a "foreigner". The authorities claimed that Sithole had no right to Swazi citizenship because his father came from Mozambique, despite the fact that he was born in Swaziland, had lived there all his life, and had a Swazi mother. Sithole had applied for citizenship in 1979 in order to comply with the 1974 legal requirements and had received no response. Subsequently, under a 1992 citizenship law, a right to Swazi nationality was conferred on persons whose mother but not father was a Swazi; but all such persons were required to seek a certificate of naturalisation from the Minister of Home Affairs.

In early June 1995, during a period of mass trade union mobilisation and national stay-aways, Sithole was served with a notice ordering him to appear before a Citizenship Board to justify his claim to Swazi citizenship. Though the hearing never took place, on 19 July the authorities wrote to him asking for "convincing proof" that he qualified as a citizen of Swaziland. Towards the end of 1995, the authorities also began investigating the citizenship status of Richard Nxumalo, the SFTU president, claiming that he was a South African. ${ }^{57}$ Sithole and other trade union leaders faced constant surveillance, repeated arrests, and multiple court cases during the same period and for many years thereafter. The citizenship allegations were one part of a more general pattern of harassment; and also part of a pattern in which those who criticised the government have been accused of being "un-Swazi" for objecting to the style of rule by their traditional leader and absolute monarch, the Swazi king.

56 Citizenships Order, King's Order in Council, 22 of 1974, section 6(2), reproduced in Fransman's British Nationality Law; see also Hugh Macmillan, "A Nation Divided? The Swazi in Swaziland and the Transvaal, 1865-1986", in Leroy Vail (ed.), The Creation of Tribalism in Southern Africa, James Currey, 1989.

57 International Labour Organisation, Committee on Freedom of Association, "Swaziland" (Case No. 1884), 23 May 1996, Report No. 306 (Vol. LXXX, 1997, Series B, No. 1) - Complaint against the Government of Swaziland presented by the International Confederation of Free Trade Unions (ICFTU). 
In late 2002, all six members of the Swaziland Court of Appeal (all South African citizens) resigned en masse, in protest at the royal family's explicit refusal to abide by two high-profile rulings the court had given; members of the legal profession went on strike in support of the judges. In April 2003, several days after the International Bar Association issued a damning report on these events and the rule of law in Swaziland, Attorney-General Phesheya Dlamini announced that the government had opened a file on prominent lawyers and others with dual citizenship, as part of a general crackdown on alleged improper conduct in the legal profession in the interests of "the security of the country and its institutions". Justifying this policy in the Senate, Minister of Home Affairs Prince Sobandla asserted - without legal basis - that dual citizenship in the kingdom was not allowed. Among those threatened with deportation was Paul Shilubane, president of the Swaziland Law Society and a vocal critic of the government, on the grounds that he had dual citizenship in South Africa. ${ }^{58}$

The 2005 constitution created a preference in favour of those "generally regarded as Swazi by descent". Meanwhile, among the provisions of the 1992 Citizenship Act, which is still in force, remains the possibility of acquiring citizenship "by ukukhonta"; that is, under customary law. Though other ways of qualifying for citizenship are also now possible in theory, in practice those who are not ethnic Swazis often find it difficult to obtain recognition of citizenship. The 2005 constitution also explicitly confirmed that a child born after the constitution came into force is a citizen only if his or her father is a citizen, one of the few recently adopted African constitutions to reaffirm gender inequality. ${ }^{59}$ Nonethnic Swazis experience lengthy processing delays when seeking passports and identity documents, including to mixed-race and white persons, who may not

58 "Enforcement of Immigration Act intensifies", The Times of Swaziland, 24 April 2003; Legalbrief Africa, Issue No 024, 21 April 2003. The Swaziland Citizenship Act 1992, the relevant legislation at the time and still in force, provides that those who have citizenship by registration may be deprived of it if they subsequently acquire another citizenship, but makes no other provisions on dual nationality. The 2005 Constitution that has since come into force does not change this position. See also Swaziland: Law, Custom and Politics: Constitutional Crisis and the Breakdown in the Rule of Law, International Bar Association Human Rights Institute, March 2003; Fact-Finding Mission to the Kingdom of Swaziland, Report of the Centre for the Independence of Judges and Lawyers, International Commission of Jurists, 10 June 2003; Swaziland: Human rights at risk $n$ a climate of political and legal uncertainty, AI Index: AFR 55/004/2004, Amnesty International, July 2004.

59 "A person who has Khontaed, that is to say, has been accepted as a Swazi in accordance with customary law and in respect of whom certificate of Khonta granted by or at the direction of the King is in force, shall be a citizen of Swaziland." Swaziland Citizenship Act No.14 of 1992, section 5. See also Constitution of Swaziland, 2005, Article 42, which provides that persons born before the constitution came into effect are citizens "by operation of law" if either parent is a citizen and also if the person is "generally regarded as Swazi by descent". Article 43 of the constitution removes this (not entirely clear) ethnic basis for children born after the constitution came into effect, but entrenches gender discrimination, providing that citizenship is only passed by a father who is a Swazi citizen. 
be considered legitimate citizens. At the same time, the government has since independence treated the thousands of ethnic Swazis living across the border in South Africa as indistinguishable from citizens and routinely grants them Swazi documentation. ${ }^{60}$

\subsection{Dual Citizenship, denationalisation and disenfranchisement in Zimbabwe}

What was then Southern Rhodesia was one of the most favoured destinations for white settlement under the British empire. Profitable commercial farms were rapidly established on the rich land expropriated from its former cultivators, and the colonial government established systems to recruit cheap labour from neighbouring Nyasaland (today's Malawi) and Northern Rhodesia (Zambia), as well as from Portuguese-held Mozambique. The nationality status of the people who came to Zimbabwe during this period (black and white) has remained under question till today.

Zimbabwe's citizenship law has roots that go back long before the attainment of universal suffrage in 1980. Southern Rhodesia was originally a British colony rather than a protectorate, and had a large measure of self-government. In 1948, it became an "independent Commonwealth country" along with the former "dominions" (including South Africa), a new status established by the British Nationality Act of 1948 (see chapter 4.2). The Southern Rhodesian Citizenship and British Nationality Act 1949, the first nationality law for the territory, was adopted in line with the planned scheme for all the independent Commonwealth countries. It conferred citizenship on a jus soli basis, with the standard exceptions relating to those whose fathers had diplomatic status or were enemy aliens, ${ }^{61}$ and, as a transitional measure, to those who were British subjects by birth, descent, naturalisation or annexation.

Despite this more distant relationship from Britain itself, the white minority government in Southern Rhodesia succeeded in arguing for its formal linking to the protectorates of Nyasaland and Northern Rhodesia within a "Central African Federation" in place from 1953 to 1963, to facilitate the import of labour for farms and mines. Southern Rhodesian citizenship was suspended during the period that the Citizenship of Rhodesia and Nyasaland and British Nationality Act was in force for the Central African Federation (see chapter 4.2); but with the dissolution of the federation, a new law was adopted, the Citizenship of Southern Rhodesia and British Nationality Act 1963, that provided for continuity of citizenship, and citizenship on a jus soli basis going

${ }^{60}$ Bureau of Democracy, Human Rights, and Labor, Country Reports on Human Rights Practices, US Department of State, entries on Swaziland over many years.

${ }^{61}$ Southern Rhodesia Citizenship and British Nationality Act 1949 (No.13 of 1949), Section 6 . 
forward, with the standard exceptions. ${ }^{62}$

White Rhodesian resistance to African enfranchisement proved irresolvable within the Commonwealth framework. Southern Rhodesia made its unilateral declaration of independence from Britain in November 1965, known as UDI, announcing that it was now the independent sovereign state of Rhodesia. The citizenship law became significantly more restrictive under the new regime. In 1967, the 1963 act was amended to create a new exception to exclude from citizenship those whose fathers were "prohibited immigrants" (in line with the South African law in force at the time). ${ }^{63}$ A new Citizenship of Rhodesia Act adopted in 1970 continued this framework, and a 1972 amendment expanded the exceptions yet again to restrict transmission of citizenship on the basis of birth in the country still further for those born after the amendment came into force, requiring the father either to be a citizen or ordinarily resident in Zimbabwe (or the mother if born out of wedlock). ${ }^{64}$

Though new foreign recruitment largely ceased with UDI, the existing workers remained, and by 1980 between a quarter and a half of farm workers were of foreign origin (though the vast majority had been born in Zimbabwe), as well as others in the mining and commercial sectors. ${ }^{65}$ An end to white minority rule came in 1980 only after a protracted war of liberation, but was ultimately negotiated through talks brokered by the British government. A new government was elected on the basis of universal suffrage, headed by Robert Mugabe (first as prime minister and from 1987 as president), the leader of the dominant liberation movement, the Zimbabwe African National Union - Patriotic Front (ZANU-PF). The newly independent state inherited the systems of economic control deployed by the minority government, but initially deployed them to effect greater distributive justice between blacks and whites.

The twists and turns of Zimbabwe's citizenship law since majority rule was attained shadowed the political history of the country. Rights based on birth in the territory were further restricted, and ever-stricter rules were applied relating to those Zimbabweans who might have a possible claim on some other citizenship — whether or not they actually held that citizenship in fact. While

62 Citizenship of Southern Rhodesia and British Nationality Act 1963 (No.63 of 1963), Sections 4-8; the same exceptions applied on jus soli citizenship.

63 Citizenship of Rhodesia and British Nationality Amendment Act No.25 of 1967.

${ }^{64}$ Citizenship of Rhodesia Act, No.11 of 1970, as amended by Act No.49 of 1972, Section 5(1)(c) and (d) (incorporated into the revised edition of the Statutes of Rhodesia 1974, Cap 23). See generally, Fransman's British Nationality Law, catalogue entry on Zimbabwe, and the history of citizenship law in Piroro vs. Registrar General of Citizenship and Others, Case No.HC 7248/10 [2011] ZWHHC 128.

${ }_{65}$ Amanda Hammar, Brian Raftopoulos and Stig Jensen, Zimbabwe's Unfinished Business: Rethinking Land, State and Nation in the Context of Crisis, Harare:Weaver Press, 2003; Angus Selby, "Commercial farmers and the state: Interest group politics and land reform in Zimbabwe", unpublished DPhil Thesis, Oxford University, 2006. 
many other African countries relaxed their rules on dual nationality, Zimbabwe moved so far in the opposite direction that it could in fact be impossible for someone with any line of descent from an immigrant to the country to be a citizen.

The 1979 Constitution of Zimbabwe provided for continuity of citizenship from previous laws, and carried into the new law restrictions on jus soli right to nationality that had first been enacted in 1967 and $1972 .{ }^{66}$ Thus, it limited the transmission of citizenship by birth to children born in the country of a father (or, if out of wedlock, of a mother) who was a citizen or ordinarily resident and legally present in Zimbabwe; while transmission of citizenship to children born outside the country was limited to one generation, through provisions that stated that only a citizen "otherwise than by descent" could pass on citizenship to a child also born outside the country. The provisions on award of citizenship by registration to adults (in other countries more usually called naturalisation), based on marriage, long residence, or other criteria, were less complex. However, in the case of marriage, only the wife of a Zimbabwean citizen had the right to acquire citizenship on that basis, but not the husband.

An additional departure from the standard model in the independence constitutions in British protectorates in Africa was that, as a protection for white interests, the constitution allowed dual citizenship. ${ }^{67}$ As in the case of constitutional provisions providing special protections for white Zimbabweans and restricting redistribution of land for the first decade of majority rule, this provision was opposed by ZANU-PF. ${ }^{68}$ Unlike the other transitional arrangements, permission to hold dual nationality had no special constitutional protection. ZANU moved quickly to address this question: in 1983, the constitution was amended to prohibit dual citizenship. ${ }^{69}$

A new citizenship law passed in 1984 confirmed this position and also introduced a comprehensive requirement that Zimbabwean citizens with an entitlement to another citizenship renounce that right by the end of 1985 or automatically lose their Zimbabwean citizenship. ${ }^{70}$ This provision was directed primarily at those white Zimbabweans with a British or other passport, or the right to another passport. Though perhaps two-thirds of the up to a quarter-million white Zimbabweans left the country during the years immediately after independence,

66 Citizenship of Rhodesia Act, Cap 23, section 5; Constitution of Zimbabwe 1979, article 5.

67 Constitution of Zimbabwe, 1979, article 8.

${ }_{68}$ Brian Raftopoulos, The State in Crisis: Authoritarian nationalism, selective citizenship and distortions of democracy in Zimbabwe. Centre for Development Research, Harare, 2001.

69 Constitution of Zimbabwe Amendment Act, No.3 of 1983.

70 Citizenship of Zimbabwe Act, No.23 of 1984, article 9. Article 4 also required naturalising citizens to renounce their other nationality; and article 11 gave extremely wide discretion to the minister to deprive a person of citizenship. 
at least twenty thousand did renounce their entitlement to a foreign citizenship before Zimbabwean officials and kept or obtained Zimbabwean passports as a result; thousands more remained in the country as permanent residents but used foreign passports. ${ }^{71}$

However, when dual citizenship was abolished, many persons of foreign origin with less access to information than the white population typically had especially farm workers - were deprived of their Zimbabwean citizenship because they had failed to sign the prescribed form renouncing their foreign citizenship. In 1990, the government provided a partial response to the excluded status of this group by adding a new provision to the constitution that extended the categories of voters entitled to vote in a presidential or parliamentary election beyond citizens to "persons who, since 31 December 1985, have been regarded by virtue of a written law as permanently resident in Zimbabwe". ${ }^{72}$ Thus, the government ensured they were not deprived of the franchise as well as their citizenship - no doubt with the hope of obtaining their votes in return. Yet farm workers were still regarded with suspicion by the government, tainted by their association with white farm owners even though they were amongst the lowest paid groups in Zimbabwe. ${ }^{73}$

Running in parallel with this racially charged debate on dual nationality was a separate (but related) argument over gender discrimination. Under Zimbabwean citizenship law, women did not have the right to pass on citizenship to their non-Zimbabwean husbands, nor to their children by a non-Zimbabwean father. Immigration law also subjected foreign husbands (but not wives) of Zimbabwean citizens to the discretion of the state in terms of their right to reside in Zimbabwe. In 1994, the Supreme Court of Zimbabwe, using its powers to interpret Zimbabwean law in light of international obligations, ruled in the Rattigan case that these restrictions violated the constitutional right of Zimbabwean women to freedom of movement. ${ }^{74}$ The government promptly

71 Brian Raftopoulos, "Nation, Race and History in Zimbabwe", in Sara Dorman, Daniel Hammett and Paul Nugent (eds.), Making Nations, Creating Strangers: States and Citizenship in Africa, Brill, 2007; A.P. Cheater, "Transcending the State? Gender and borderline constructions of citizenship in Zimbabwe", in Thomas M. Wilson and Hastings Donnan (eds.), Border Identities: Nation and State at International Frontiers, Cambridge University Press, 1998.

72 Constitution of Zimbabwe (Amendment No.11) Act, No.30 of 1990, inserting article $3(1)(b)$ to Schedule 3 of the constitution.

73 Blair Rutherford, "Shifting grounds in Zimbabwe: Citizenship and farm workers in the new politics of land", in Dorman et al, Making Nations, Creating Strangers, 2007; Sam Moyo, Blair Rutherford and Dede Amanor-Wilks, "Land Reform and Changing Social Relations for Farm Workers in Zimbabwe", Review of African Political Economy, Vol.27, No.84, 2000, pp.181-202.

74 Rattigan and others v. Chief Immigration Officer, Zimbabwe, and others, 1995 (2) SA 182 (ZS). See also Simon Coldham, "Case Note: Devagi Rattigan and others v. Chief Immigration Officer and others", Journal of African Law Vol. 38, 1994, pp.189-190. 
introduced a bill to amend the constitution to enable the restrictions on foreign husbands to be reinstated. Just as in the case of dual citizenship, although the amendment was presented as a law that would only affect "elite" women bringing husbands from overseas, most of those potentially affected were rural women living in Zimbabwe's border regions. Women's rights activists won a pyrrhic victory over the bill: the government conceded on the gender discrimination point, but the constitutional amendment was resubmitted and passed in a form that ensured that restrictions applied to foreign wives as well as husbands of Zimbabwean citizens. The final version preserved the rights based on marriage for women married to Zimbabweans before the new amendment came into effect, but moving forward removed all rights based on marriage, meaning that any spouse would be subject to a discretionary naturalisation procedure (which would naturally tend to reinforce the previous gender discrimination). ${ }^{75}$ At the same time, gender discrimination in the transmission of citizenship to children was removed for those born after the amendment came into effect; but, perhaps even more importantly, the previous right to citizenship of the child of a father ordinarily resident and legally present in Zimbabwe was not extended to a child born in wedlock of a mother with that status; instead, citizenship based on birth in Zimbabwe was restricted to children of citizens, removing any rights that came from birth in the territory (not even for foundlings). Citizenship by descent was still limited to one generation born outside the country, as it had been since 1979 (and before).

In 1999, a new opposition movement was formed, the Movement for Democratic Change (MDC), to contest upcoming elections and challenge the long dominance of ZANU-PF. The MDC campaigned against a proposed new constitution put forward by the government, which had co-opted a citizens movement for constitutional reform by creating a ZANU-PF-dominated constitutional commission to draft a new text. The draft constitution, which would have greatly strengthened the executive at the expense of parliament as well as extending the powers of the government to acquire land compulsorily without compensation, was rejected in a February 2000 referendum. In June 2000, parliamentary elections were held. The MDC won 57 seats, only just short of the 62 seats won by ZANU-PF, and took 77 per cent of the urban vote. ZANU-PF chose to attribute its losses to the MDC in the referendum and elections to the influence and finance of white Zimbabwean citizens considered anti-government, especially the approximately 4,000 white commercial farm

75 Constitution of Zimbabwe Amendment (No.14) Act of 1996; Welshman Ncube, "Defending and Protecting Gender Equality and the Family Under a Decidedly Undecided Constitution in Zimbabwe", in John Eekelaar and Thandabantu Nhlapo, (eds.) The Changing Family: International Perspectives on the Family and Family Law, Oxford, Hart Publishing, 1998, pp.509-528; Tandeka C. Nkiwane, "Gender, Citizenship, and Constitutionalism in Zimbabwe:The Fight Against Amendment 14", Citizenship Studies, Vol. 4, No.3, 2000, pp.325-338. 
owners, as well as the by now several hundred thousand farm workers and their families. In addition to mobilising violence against the opposition and other measures, steps were taken to amend the criteria for Zimbabwean citizenship, with the transparent aim of disenfranchising these groups.

In May 2000, the government warned whites they would be stripped of their Zimbabwe citizenship if they could not produce foreign documentation showing they had no entitlement to the citizenship of another country. Around 86,000 whites who had allegedly failed to renounce their British citizenship would have to turn in their Zimbabwean passports, a government newspaper advertisement stated; of these, around 30,000 were adults, able to vote. ${ }^{76}$ In accordance with this announcement, the registrar-general's office began to refuse to renew the Zimbabwean passports of many whites, arguing they should have renounced any entitlement to foreign nationality to individual foreign governments. ${ }^{77}$

At least two court cases successfully challenged these provisions. In December 2000, the Supreme Court ruled against the registrar-general, in a case brought by Robyn Carr, a businesswoman whose application to renew her passport had been refused by the registrar-general on the grounds that she must prove she had renounced her British citizenship under British law. But the Supreme Court ordered renewal because she had complied with the requirements of renunciation under Zimbabwean law by filling in a form of renunciation of citizenship, and the registrar-general had no power to require her to renounce her citizenship under British law. ${ }^{78}$ In January 2001, Sterling Purser, an eighteen-year-old born in Harare in 1982 of a British father was denied a passport on the grounds he had not renounced his British citizenship. Purser challenged the decision, arguing that he had fulfilled the legal requirements to renounce his entitlement to foreign citizenship, and the Supreme Court agreed, following its earlier ruling in the Carr case. In both cases, the Supreme Court awarded costs against the registrar-general. ${ }^{79}$

In light of these court defeats and the electoral results of 2000, the government introduced the Citizenship Amendment Act No 12 of 2001, which strengthened the provisions for renunciation drastically, including inserting a provision requiring renunciation under the relevant foreign law, and not only under Zimbabwean law: ${ }^{80}$ Section 9(7) provided that:

76 "Mugabe tries to bar whites from Zim poll", AFP, 13 May 2000.

77 The registrar-general's office is responsible for maintaining the voters' roll and other aspects of elections, citizenship, passports, births, marriages and deaths, and for national population registration and the system of national identity cards.

78 “Court Rules on Zimbabwe Citizenship",AP, 1 December 2000; Carr v. Registrar-General, 2000 (2) ZLR 433 (S).

79 "Registrar-General loses citizenship case", Daily News, 17 January 2001.

80 Citizenship Amendment Act No 12 of 2001, section 3(c), repealing section 9(7) of the Citizenship of Zimbabwe Act, chapter 4:01, and substituting the text here. The amendment act also inserted a provision in article 13 to revoke the citizenship of a person who is absent from the country for five years. 
A citizen of Zimbabwe of full age who-

(a) at the date of commencement of the Citizenship Amendment Act, 2001 , is also a citizen of a foreign country; or

(b) at any time before that date, had renounced or purported to renounce his citizenship of a foreign country and has, despite such renunciation, retained his citizenship of that country;

shall cease to be a citizen of Zimbabwe six months after that date unless, before the expiry of that period, he has effectively renounced his foreign citizenship in accordance with the law of that foreign country and has made a declaration confirming such renunciation in the form and manner prescribed.

According to the state-owned media, quoting a government official, the amendment was required because " $[\mathrm{t}]$ here are concerns that those with dual citizenship are behind efforts to discredit the Government economically and politically by enlisting foreign governments to use diplomatic and other means to topple the ZANU-PF Government." ${ }^{11}$ Information Minister Jonathan Moyo described passports as "privileges" not rights, and threatened their withdrawal from anyone involved in calls for international sanctions against Zimbabwe. ${ }^{82}$

While lawyers argued that the amendment act only required those people who actually had dual citizenship to renounce their foreign citizenship according to the laws of their respective countries, the law was applied more expansively. Registrar-General Tobaiwa Mudede placed an advertisement in a national newspaper stating that even those people with only a claim to foreign citizenship (but no citizenship in fact) had to renounce that potential citizenship. He repeatedly restated this position. ${ }^{83}$ Thus, for example, a person born in Zimbabwe of a father of Malawian descent and a mother of Mozambican origin had to renounce entitlement to Malawian and Mozambican citizenship: something virtually impossible to do. Despite protests from farm workers' organisations at this interpretation of the act, the registrar-general issued a statement confirming that "any failure by farm workers to renounce foreign citizenship in the form and manner prescribed by the foreign law will result in loss of Zimbabwean citizenship after 6th January 2002." 84 Before the 6 January deadline, the Mozambican High Commission in Harare stated that it was overwhelmed with applications for

81 Sunday Mail, quoted in the Zimbabwe Human Rights Bulletin, Issue 5, Zimbabwe Lawyers for Human Rights, September 2001.

82 "Zim threatens to take away critics' passports", The Star (Johannesburg), 17 February 2001. Moyo later argued against just this position once he left ZANU-PF to become an independent MP. See Prof Jonathan Moyo, "Constitutional madness will not save Zanu PF” NewZimbabwe.com, 26 August 2005.

83 As noted by the "Fourth Report of the Portfolio Committee on Defence and Home Affairs on the Citizenship of Zimbabwe Act", presented to Parliament 13 June 2007.

84 “Citizenship law under scrutiny", Zimbabwe Independent, 19 October 2001. 
documentary proof that persons of Mozambican descent were not eligible for Mozambican citizenship, and were unable to supply it. ${ }^{85}$ Similarly, those who could not provide sufficient details to the Malawian High Commission in Harare satisfying the consular officials that they were entitled to Malawian citizenship, were in the paradoxical situation that they could not therefore renounce that citizenship to the satisfaction of the Zimbabwean authorities. ${ }^{86}$

As Mudede confirmed, the vast majority of persons affected by the amendment were farm workers and others born in neighbouring countries or whose parents were born in neighbouring countries. ${ }^{87}$ But although the amendment was given some publicity in the urban areas of Zimbabwe, many affected citizens in the outlying areas remained uninformed until the deadline set had passed and their Zimbabwean citizenship had been lost by operation of law.

\section{Neither one thing nor the other: Testimony to the Research and Advocacy Unit, Harare ${ }^{88}$}

"I was born in Zimbabwe. My mother was Zambian and my father was from Malawi. Both my parents are late now but before they died they both had Zimbabwean birth certificates, Zimbabwean identity documents and Malawian passports. I have a short birth certificate and a Zimbabwean identity document. When my parents were still alive and we were still young they got us Malawian passports and I have always been using a Malawian passport. I took my passport in 1995 and it expired in 2000.

I tried to renew my passport and the people at the Malawian embassy processed it but refused to give it to me when I went to collect it, saying that I needed to renounce my Zimbabwean citizenship before I could get the Malawian passport. To renounce Zimbabwean citizenship I had to prove that I am an alien. Proof that you are an alien is found on the long birth certificate certifying that you are an alien; I have a short birth certificate. The Malawian embassy also asked for a letter from the village headman of the kraal from which my ancestors in Malawi came from as proof that I am of Malawian origin. I do not know anyone in Malawi and I am sure if I were to go there no one would remember me. My home is in Zimbabwe, I was born here, I grew up here and I know no other place as home but this one. I know that I also will not be able to get a Zimbabwean passport if I try because the Registrar-General's office will also require me to renounce Malawian citizenship and I will have to

\footnotetext{
85 "Zimbabwe loses second citizenship case", The Star (Johannesburg), 12 June 2002.

86 “Stateless Zimbabwe residents gain citizenship", IRIN, 21 June 2013.

87 Zimbabwe Lawyers for Human Rights submissions on the interpretation of citizenship laws to the Parliamentary Committee on Defence and Home Affairs, 7 March 2007.

88 Case history from Dube, A Right or a Privilege.
} 
prove my Malawian origin yet again. My father died with an identity card that showed that he was Zimbabwean. To make matters worse, the people at the Malawian embassy treated me badly. They refused to help me at first because I was not speaking to them in the Malawian language. I speak Shona because that is the language I have been speaking since I was born. I had to struggle to speak to them using the little I know of the Malawian language. One man was holding a long list of chiefs and headmen as he asked me where I said my ancestors came from. Other people who were there were turned away for making a mistake in identifying the correct chief or headman. Not having a passport has deprived me of my source of livelihood.

When I had a passport I used to be a cross border trader. I would go to Botswana and do piece meal jobs such as doing people's laundry, ironing and house cleaning. I could actually get enough money to buy all the things I needed to survive. Now my life is miserable. I do not have any money and I struggle just to get food on the table."

A class action suit challenging the registrar-general's interpretation of the citizenship law was filed with the High Court in October 2001 by Lesley Leventhe Petho. Initially struck out by the High Court, on the grounds that Petho's case was not sufficiently typical to be the basis of a class action (he was born in Zimbabwe, the son of Hungarians who had fled the aftermath of the 1956 uprising) the Supreme Court confirmed the possibility of bringing a class action case in October 2002, providing Petho advertised in national newspapers and on radio to let others in the same plight know he was doing this. ${ }^{89}$ The state-run Zimbabwe Broadcasting Corporation then refused to accept his advertisements, and negotiations to have the advertisements run at an affordable price never reached conclusion.

Several other cases were successfully brought in the High Court over the next year. In February 2002, the High Court ruled in a case brought by trade union and opposition leader Morgan Tsvangirai, stating that it could not be assumed that a person had a right to foreign citizenship only because his parents were born elsewhere and that a person could not be required to renounce what they had never possessed, and extending the deadline for renunciations to 6 August 2002..$^{90}$ In May 2002, the High Court found in favour of Judith Todd, daughter of former Rhodesian prime minister Sir Garfield Todd, deposed as head of government when he tried to liberalise Rhodesia's apartheid-style rule,

89 Petho v. Minister of Home Affairs, Zimbabwe and Another (07/06/02) [2002] ZWSC 80; ZWNews, 9 March 2003.

90 Tsvangirai v. Registrar General and Others (HC 12092/01) [2002] ZWHHC 29, 27 February 2002. 
and herself a high-profile opponent of the former white minority regime. In 1998, she had become a shareholder and director of Associated Newspapers of Zimbabwe, publisher of the newly established independent newspaper the Daily News. The registrar-general asserted that Judith Todd should lose her citizenship because she had not renounced any claim to citizenship of New Zealand, where her father was born. The court, however, ruled that she was still a Zimbabwean citizen, and ordered the restoration of her passport. ${ }^{91}$ She was issued a temporary passport, valid one year, and the government appealed. In June 2002, the High Court also ruled in favour of Ricarudo Manwere, a dancer of Mozambican parentage. ${ }^{92}$

Presidential elections were held in March 2002. In January, the first set of" notices of objection" issued in terms of section 25 of the Electoral Act were sent to Zimbabwean citizens who had purportedly lost their Zimbabwean citizenship because they had failed to comply with the terms of the Citizenship Amendment Act No 12 of 2001. Each notice alleged that the person affected had lost his/her Zimbabwean citizenship and therefore was no longer entitled to remain on the voters' roll. The affected voter was given seven days to appeal to the constituency registrar. There were two distinct groups of people who received notices in error: those who had in fact renounced their foreign citizenship and thus remained Zimbabwean citizens, and those who had never been Zimbabwean citizens and had always been entitled to vote as permanent residents since 31 December 1985; and a further disputed group who had failed to renounce a potential right to foreign citizenship. In a large majority of the cases the notices were received after the seven-day deadline and when individuals attempted to lodge their appeals they met with resistance and refusal by the constituency registrar and the registrar-general's office. Many affected farm labourers and rural dwellers never in fact received these notices, and were summarily struck off the voters' roll without first having had an opportunity to be heard. ${ }^{93}$

In parallel with the cases dealing with dual citizenship, the issue of the rights of permanent residents under the constitutional provision allowing both citizens and permanent residents to vote, also came into dispute in the courts. Lawyers

91 Todd v. Registrar General of Citizenship and Another (HC 55/2002) [2002] ZWHHC 76, 7 May 2002.

92 Ricarudo Manwere v. Registrar General (HH 87/02), 27 February 2002, cited in Zimbabwe Lawyers for Human Rights, "Submissions on the interpretation of citizenship laws to the Parliamentary Committee on Defence and Home Affairs", 2007; “Zimbabwe loses second citizenship case”, The Star, Johannesburg, 12 June 2002.

93 See generally, Zimbabwe Lawyers for Human Rights, "The Path to Disenfranchisement: 2002 General Elections”, Pambazuka News, Issue 58, 21 March 2002, http://pambazuka. org/en/category/rights/6599; also "More information on citizenship issues", Zimbabwe Lawyers for Human Rights, 19 April 2002, and other updates issued on citizenship, renunciation and passport issues available at http://archive.kubatana.net, last accessed 24 December 2014. 
for those who had lost their citizenship argued that those who had supposedly lost their Zimbabwean citizenship under the new rules were nevertheless entitled to be on the voters' roll and vote, because they remained permanent residents. In January 2002, in another case brought by Morgan Tsvangirai, the High Court ordered the registrar-general to restore this group of persons to the voters' roll. ${ }^{94}$ In February, however, the Supreme Court overturned this decision, holding that citizens and permanent residents were two separate statuses that could not be held at the same time, and those who had lost their citizenship were therefore not permanent residents by default and not entitled to vote. ${ }^{95}$ Other cases in the High Court followed the Supreme Court's ruling. ${ }^{96}$ Litigation on these issues was still under way as the presidential election was held on 9-11 March, including a challenge to a new statutory instrument issued on 9 March that changed the rules for disputes over the voters' roll. On the days of polling those people who had obtained orders from the magistrates' courts in favour of their right to be on the voters' roll were nonetheless denied the chance to vote.

In 2005, the government ended this argument, by passing the Constitution of Zimbabwe Amendment (No. 17) Act. Among many sections dealing with land ownership and the creation of a second chamber in the national parliament, the act also repealed the constitutional provision allowing adults with permanent residency in Zimbabwe to vote. ${ }^{97}$ The act also amended the section of the constitution dealing with freedom of movement to allow restrictions on movement imposed "in the national interest, or in the interests of defence, public safety, public order, public morality, public health, the public interest or the economic interests of the State." That is, it allowed the government to seize passports and stop MDC representatives or civil society activists from travelling outside Zimbabwe.

Among those disenfranchised by the various legislative amendments was Sir Garfield Todd, who had, somewhat ironically, previously been deprived of his passport by the government of the last Rhodesian prime minister, Ian Smith. In addition to having his citizenship revoked when the new rules came into force, Garfield Todd's name was put on a list supplied by Registrar-General Mudede to all polling stations of those not allowed to vote, even if, like his, their names were actually printed on the current voters' roll. Aged 94, he still attempted to vote,

94 Tsvangirai v. Registrar General of Elections and Another, Tsvangirai v. Registrar General of Elections and Others (HC 11843/01, HC 12015/01) [2002] ZWHHC 22, 25 January 2002.

95 Registrar General of Elections and Others v. Tsvangirai (30/2002) [2002] ZWSC 12, 28 February 2002

96 Peter Jackson and 634 Others v. Registrar-General (HC 2434/02), 7 March 2002 (unreported).

97 Constitution of Zimbabwe Amendment (No.17) Act, 2005, section 20(b), repealing schedule 3, article 3(1)(b) of the Constitution on "Qualifications and disqualifications for voters". See also, "Representations on the Bill made by the Zimbabwe Human Rights NGO Forum to the Portfolio Committee on Justice, Legal and Parliamentary Affairs", 4 August 2005. 
and was refused. ${ }^{98}$ Paying attention to symmetry, the government also refused to renew the passport of Ian Smith. ${ }^{99}$

In November 2002, the minister of justice published a cabinet-approved notice in the Government Gazette clarifying that renunciation of citizenship would not apply to a potential right to foreign citizenship, but only a to a person who is actually and presently a citizen of a foreign country. ${ }^{100}$ (In June 2007, a parliamentary committee of which MDC members formed a substantial part issued a report supporting the cabinet's 2002 notice, to no effect. ${ }^{101}$ )

Despite this, the registrar-general continued to apply the rule that renunciation applied to potential as well as actual citizenship. ${ }^{102}$ Moreover, in February 2003, the Supreme Court — which by 2002 had been augmented by judges known to support the government - considered the government's appeal against the ruling in Judith Todd's case and agreed with the government's interpretation that a potential claim to citizenship had to be renounced, as well as an actual citizenship. It examined New Zealand law and concluded that although Judith Todd had not actively sought New Zealand citizenship at any time in her life, she was nevertheless entitled to it under the foreign law, and therefore should renounce such entitlement. If she did not do so within two days, she would lose Zimbabwean citizenship. ${ }^{103}$ Todd attempted to comply with the ruling. The New Zealand authorities, however, responded in July stating that they had received Todd's application for renunciation of citizenship, but that this application could not be processed as she had never laid claim to New Zealand citizenship.

The High Court, however, the first to hear these cases, continued to rule against the registrar-general on the grounds that individuals had in fact no foreign citizenship to renounce. In June 2005, the High Court handed down a judgment in favour of lawyer Job Sibanda, whose father was born in Malawi, finding that that Sibanda was "a Zimbabwean citizen with all privileges, duties and obligations attaching such citizenship". ${ }^{104}$ In 2006, the High Court confirmed the right of lawyer Lewis Uriri, born in Zimbabwe of Mozambican parents, to obtain a birth certificate for his son. ${ }^{105}$ In January 2007, the High Court ordered the registrar-

98 Judith Todd, "When would-be heroes turn bad", Mail \& Guardian, Johannesburg, 3 May 2007.

99 Basildon Peta, "Zimbabwe strips former PM Smith of his citizenship", Independent, London, 28 March 2002.

100 General Notice 584 of 2002. See Fourth Report of the Portfolio Committee on Defence and Home Affairs on the Citizenship of Zimbabwe Act, 13 June 2007.

101 Fourth Report of the Portfolio Committee on Defence and Home Affairs on the Citizenship of Zimbabwe Act, 13 June 2007.

102 Dube, A Right or a Privilege (2008) and Identity, Citizenship, and the Registrar General (2012).

${ }_{103}$ Registrar General of Citizenship v. Todd (58/02/01) [2003] ZWSC 4, 27 February 2003.

104 Job Sibanda v. Registrar-General of Citizenship and Others (HH 3626/02); "Man born of foreign parents is Zimbabwean - Judge", Legalbrief Today, 20 June 2005.

105 "Zimbabwe Lawyers for Human Rights submissions on the interpretation of citizenship 
general to issue a passport to Trevor Ncube, owner of the independent and critical newspapers the Zimbabwe Independent and the Standard, who had been informed in December 2005 that he had forfeited his Zimbabwean citizenship because he had failed to renounce his Zambian citizenship (his father was allegedly born in Zambia). ${ }^{106}$ Ncube's passport was restored to him.

Protests from the southern African region about the Zimbabwe government's treatment of those whose parents had origins in neighbouring countries eventually led to a concession in favour specifically of migrant workers from Southern African Development Community (SADC) countries. In 2003 the Citizenship of Zimbabwe Act was amended to allow people who were born in a SADC country, but whose parents came to Zimbabwe as farm labourers, mine workers, domestic employees or "in any other unskilled occupation", to apply for "confirmation" of their citizenship of Zimbabwe and at the same time sign a form renouncing their foreign citizenship (without the need to obtain any documentation from the other SADC country). ${ }^{107}$ Although this should have substantially improved the situation of the many farmworkers who had been rendered stateless, the amendment was published after most of the people concerned had already lost their Zimbabwean citizenship, and did not have retroactive effect; while the attitude of the authorities did not seem to change in practice. ${ }^{108}$

In Mozambique, UNHCR identified hundreds of stateless individuals who were mainly returnees from Zimbabwe and who did not have either their Mozambican or their Zimbabwean citizenship recognized. These persons had difficulties in accessing basic services and were also reported sometimes to be victims of harassment by authorities, especially the police, due to their lack of documentation. ${ }^{109}$ Malawi restored citizenship to 85 persons during the period 2008 to 2011, but the process was expensive and difficult to access. An unknown number of diaspora returnees from Zimbabwe or elsewhere do not have citizenship documents. ${ }^{110}$ In South Africa, the authorities eventually responded to the crisis by adopting a twelve-month "special dispensation permit" for Zimbabweans on the basis of the 2002 Immigration Act, granting the right to legally live and work in the country (later extended several times). ${ }^{111}$

\footnotetext{
laws to the Parliamentary Committee on Defence and Home Affairs", 7 March 2007.

106 Trevor Ncube v. Registrar-General (HH 7316/06), 25 January 2007.

107 Citizenship of Zimbabwe Amendment Act, No 12 of 2003, chapter 4, article 9A(d).

108 Zimamoza Institute, Ethnic Cleansing In Zimbabwe: The origins and objectives of the Zimamoza Institute, Harare, 2007.

109 "Mozambique: UNHCR to Support Registeration of Stateless People", UNHCR, 5 October 2011.

110 Information provided at UNHCR regional statelessness meeting, 1-3 November 2011.

111 Tara Polzer, "Regularising Zimbabwean Migration to South Africa", Migration Policy Brief, May 2009, Forced Migration Studies Program University of the Witwatersrand and Consortium for Refugees and Migrants in South Africa, Johannesburg.
} 
In 2007, the Zimbabwe government introduced a bill to parliament to support the "economic empowerment of indigenous Zimbabweans". Indigenous Zimbabweans were defined in the bill as "any person who before the $18^{\text {th }}$ April 1980 was disadvantaged by unfair discrimination on the grounds of his or her race, and any descendant of such person, and includes any company, association, syndicate or partnership of which indigenous Zimbabweans form the majority of the members or hold the controlling interest". ${ }^{112}$ The law, which was adopted unchanged, required that at least 51 percent of all companies worth more than US $\$ 500,000$ (in the face of hyperinflation, the US dollar was formally adopted as Zimbabwe's currency in 2009), publicly quoted or private, should be held by indigenous Zimbabweans, and established other procedures for ensuring their economic empowerment. The law entered into force in 2010, with the deadline for disinvestment September 2011, at which time even smallholders found themselves subject to renewed harassment if they could be alleged to be "non-indigenous". ${ }^{113}$

Parliamentary and presidential elections took place in March 2008, though MDC presidential candidate Morgan Tsvangirai withdrew from the second round of the presidential elections, citing state-sponsored violence against the opposition. Mugabe was declared the winner; however, both parties agreed to take part in talks mediated by SADC. In September 2008, a power-sharing agreement known as the Global Political Agreement (GPA) was agreed.The GPA covered a wide range of issues, but at its heart was a commitment that a revised constitution should be agreed, followed by new elections. On 30 January 2009 the MDC, which by this time had split into two factions, agreed to join a twoyear unity government with ZANU-PF, paving the way for the implementation of the GPA. Tsvangirai became prime minister, a new position, while Mugabe remained president. A maximum 18-month timetable for the coming into force of a new constitution was established. Also part of the unity government was the breakaway faction of the MDC led by Arthur Mutambara (MDC-M; while those loyal to Tsvangirai's were known as MDC-T).

The constitutional amendment allowing for the installation of a government of national unity also revised the citizenship provisions. ${ }^{114}$ The amendment kept the terminology of citizens by birth and by descent, but removed the restriction on transmission of citizenship to children born outside the country, and extended rights in some circumstances to those with a grandparent who was a citizen. A child born in Zimbabwe was a citizen by birth if either parent was a citizen (of any type), or if any grandparent was a citizen by birth or descent (that is, not if the grandparent was only registered as a citizen). A child born outside

112 Indigenisation and Economic Empowerment Act No. 14 of 2007, preamble and section 2.

113 "Some are more indigenous than others", IRIN, 14 October 2011.

114 Constitution of Zimbabwe Amendment (No.19) Act, 2009. The Citizenship Act (last amended in 2003), however, continued to quote the pre-1996 version of the constitution. 
Zimbabwe was also a citizen by birth if one of the parents was a citizen (of any type) and "ordinarily resident" in Zimbabwe or working for the state or an international organisation. These provisions expanded the law to provide a right to citizenship deriving from grandparents - but did not restore the right to citizenship by birth that had existed until 1996 for children born in Zimbabwe of legal residents. A child born outside Zimbabwe was a citizen by descent if either parent or any grandparent was at the time of the birth a citizen "by birth or descent" or if either parent was a citizen by registration. In addition, the birth must be "registered in Zimbabwe in accordance with the law relating to the registration of birth". Transmission of citizenship to spouses was finally made gender-neutral, providing a right to apply on the basis of marriage and ordinary residence in Zimbabwe for at least 5 years. Naturalisation for any alien was permitted after 10 years' residence in the country.

The constitutional amendment did not prohibit dual citizenship, though it allowed legislation to do so; it also provided that legislation could provide for loss of citizenship by descent or registration (only). The Citizenship Act's existing provisions were not, however, amended, and efforts to prevent those with a potential other nationality from claiming citizenship continued. In 2011, a Canadian-based Zimbabwean whose citizenship was denied on the grounds that his father had been born in Mozambique, so that he must renounce a Mozambican citizenship, obtained an order confirming he was a citizen and instructing the registrargeneral to renew his passport. The High Court also ruled that the Citizenship Act's provisions requiring a citizen from birth with dual nationality to renounce the other nationality were in breach of the amended constitution. Judgement was reserved in a further suit that the registrar-general was in contempt of court for failing to issue a passport. ${ }^{115}$ In another case, however, the High Court failed to confirm the Zimbabwean citizenship of a white Zimbabwean and election expert who had acquired South African citizenship after being declared an "undesirable person" in 2005, on the grounds that he had himself acquired the other nationality, rejecting arguments that under the circumstances this was not a "voluntary act". ${ }^{116}$ The Supreme Court eventually overturned this ruling, deciding that a citizen of Zimbabwe by birth cannot lose citizenship and be

115 Alex Bell, "Registrar-General faces court action after refusing Zim man passport", SW Radio Africa, 26 October 2011; Piroro v Registrar General 2011(2) ZLR 26 (H); "Justice Bhunu reserves judgment in the Mudede passport case", Zimbabwe Lawyers for Human Rights (ZLHR), 27 October 2011.

116 Whitehead $v$ Registrar-General and others, HH-349-12, judgment delivered 13 September 2012, noted in Legal Resources Foundation Case Summaries, July-December 2012, available at http://www.lrfzim.com/case-summaries/, accessed 01 September 2014. The applicant was born in Southern Rhodesia of a naturalised Rhodesian father (born in South Africa) and a mother also born in the country, and had renounced any claim to South African citizenship in 2002. He had acquired South African citizenship after being declared an undesirable person in Zimbabwe in 2005, in order to avoid being stateless. 
declared a prohibited immigrant. ${ }^{117}$

Meanwhile, a flurry of government initiatives were taken to crack down on sham marriages, including the extraordinary requirement that a foreign national must produce a "certificate of no marriage" from the country of origin before marrying in Zimbabwe; ${ }^{118}$ a new register of marriage officers, and a ban on "mass weddings". ${ }^{119}$ Similarly, the Ministry of Home Affairs announced an effort to stop the issue of fake Zimbabwean birth certificates to those born out of the country, centralising the system in Harare. ${ }^{120}$

The government of national unity was shaky and often acrimonious, but the coalition finally succeeded in agreeing a new constitution after a long and much-disputed process. A final draft prepared by a parliamentary committee was published in July 2012; amendments proposed to the draft by ZANU were released in August, but not introduced into the final version adopted in January 2013. Citizenship, especially dual citizenship, was a key point of disagreement in these debates. ${ }^{121}$ The new constitution was approved by referendum in March 2013, and fresh elections held in July 2013. Mugabe's was re-elected as president and ZANU-PF gained a two-thirds majority in the parliamentary poll; the MDC rejected the election outcome, unsuccessfully challenged some results in the courts, and boycotted the opening of the new parliament in September. ${ }^{122}$

The 2013 constitution retained many of the changes on citizenship that had already been made in 2009: the provisions on citizenship by birth and descent were the same, with the distinction between citizens by birth and by descent becoming meaningful only in the context of the provisions on dual citizenship. The constitution was now silent on the question of dual citizenship for citizens by birth, leading to the presumption that dual citizenship was permitted. However, the text provides that parliament may make legislation regarding "the prohibition of dual citizenship in respect of citizens by descent or registration", enabling legislation that would restrict the ability of Zimbabweans born outside the country to retain Zimbabwean citizenship if they acquire a new citizenship, and/or require those registering as Zimbabwean citizens to renounce another

117 Silas Nkala, "Whitehead Wins Citizenship Case", The Standard, 15 September 2013.

118 "Zimbabwe clamps down on sham marriages", New Zimbabwe, 1 Feburary 2012; "Court blocks MDC-T MP's 'sham marriage"” New Zimbabwe, 10 March 2012; "Evelyn Masaiti finally marries her man”, New Zimbabwe, 29 March 2012.

119 “Zimbabwe bans mass weddings”, Nehanda Radio, 17 July 2012.

120 Eugene Majuru. "Diaspora dual birth certificates scam for children exposed", ZimDiaspora,com, 6 January 2013.

121 See Bronwen Manby, "Draft Zim constitution fails citizenship test", 11 October 2012, blog posting for the Open Society Initiative for Southern Africa (OSISA), available at http://www.osisa.org/law/blog/draft-zim-constitution-fails-citizenship-test, last accessed 1 September 2014.

122 Mmanaledi Mataboge and Takudzwa Munyaka, "MDC-T resolves to reject Zim election results”, Mail \& Guardian (South Africa), 2 Aug 2013. 
citizenship. Although generally preserving the framework introduced in 1996 (and kept in 2009) by which birth in the territory gave no rights to citizenship, the constitution did introduce for the first time a provision protecting children of unknown parents from statelessness: a child found in Zimbabwe "who is, or appears to be, less than fifteen years of age, and whose nationality and parents are not known, is presumed to be a Zimbabwean citizen by birth." ${ }^{23}$

The 2013 constitution also included an important provision aimed at redressing some of the injustices of the previous decade against persons with a parent who was a citizen of a neighbouring country. It provides that a person born in Zimbabwe before the constitution came into force of one parent who was a SADC citizen is recognised as a citizen by birth; though only if the person is "ordinarily resident in Zimbabwe" when the constitution comes into effect (however, excluding many of those who had left the country as a result of being denied citizenship, or seeking work and income elsewhere). ${ }^{124}$

Many of those who had been affected by the previous rules began to re-apply for confirmation of Zimbabwean citizenship, including many of the poorest people desperate to reassert their right to be Zimbabwean, and thus be able once again to cross the border freely, establish a bank account, get a job, rent an official trading site. Yet, despite the removal of the constitutional ban on dual citizenship (at least for citizens from birth), the registrar-general continued to deny passports to those who had acquired another citizenship even after the new constitution came into force. ${ }^{125}$ Court applications challenged this refusal: in June 2013, the Constitutional Court ruled that Mutumwa Mawere, one of Zimbabwe's richest businessmen, who had obtained South African citizenship, was entitled to be reinstated with Zimbabwean citizenship and a passport without renouncing his other nationality. ${ }^{126}$ A year later, the court confirmed the right of a Zimbabwean who had also held South African nationality since birth to reside in Zimbabwe without a residence permit. ${ }^{127}$ But, with a new Citizenship Act not yet proposed by the end of 2014, the registrar-general was still left significant latitude to apply the old rules to those seeking identity documents, unless specifically ordered otherwise in an individual case. ${ }^{128}$

123 Constitution of Zimbabwe 2013, Chapter 3 (sections 35 to 43).

124 Constitution of Zimbabwe 2013, section 43(2).

125 Alex Bell, "Zim Citizenship Rules in Chaos As Nationals Denied Documentation”, SW Radio Africa (London), 22 October 2013; "Passports for 'alien' sisters", The Zimbabwean, 17 May 2014.

126 Violet Gonda, "Mawere wins landmark dual citizenship case", SW Radio Africa (London), 27 June 2013.

127 “Constitutional Court endorses dual citizenship”, ZBC, 25 June 2014.

128 Mthulisi Mathuthu, "Confusion on Zimbabwe dual citizenship continues", Bulawayo24,com, 8 July 2014; Zvamaida Murwira, "Scramble for Zim citizenship, Enquiries flood from all over the world, RG's office overwhelmed", The Herald, 23 July 2014; “Citizenship Act Needs Realignment”, The Herald, 25 July 2014; Mthulisi Mathuthu, 


\section{4 "Asians" and other "others" in Kenya and Uganda}

Asian migration to East Africa began many centuries ago, as trading links across the Indian Ocean were developed among coastal communities in what are now Somalia, Kenya, Tanzania, Mozambique, Yemen, Oman, the Gulf States, Pakistan, India, and further afield. This contact was accelerated and brought into the interior of the continent under British colonial rule, especially in Kenya and Uganda, where thousands of people from the Indian subcontinent were either imported to work as indentured labour on the railways, or came as traders and businessmen following the economic opportunities those railways brought.

In both Kenya and Uganda, the status of the newer populations of South Asian descent, by then numbering around 175,000 (the majority in Kenya), was highly sensitive during the period leading up to and immediately after independence. ${ }^{129}$ Initially it was in Kenya in particular that the loyalty of the Asian population was in question; not just because of their greater numbers, but also because the status of (most of) the territory as a colony rather than a protectorate meant that not only Kenyans of British descent but also most Kenyan Asians (as well as Africans) had the status of citizenship of the UK and colonies rather than British protected persons, giving them (until the UK changed the law in 1968) full rights of abode in Britain.

The constitutions of both countries applied the same transitional rules for acquiring citizenship at independence: a person who had been born in Kenya or Uganda of at least one parent who was also born in the country, and who was on the date of independence either a citizen of the United Kingdom and colonies or a British protected person automatically became a citizen of the newly independent country. In addition, a person born outside the country was automatically a citizen if his father became a citizen according to these rules. Various categories of people with a connection to the country had the right to apply for citizenship by registration - a non-discretionary process intended to cater for the descendants of Asian or European immigrants — including those born in the country but caught by the exception for those whose parents were born outside the country, as well as those who had married a citizen. Registration on the basis of birth in the country was open only to those who had been British protected persons and citizens of the UK and colonies, but

\footnotetext{
“Government Delays Realignment of Laws”, SW Radio Africa (London), 29 July 2014.

129 Daniel D. C.Don Nanjira, The Status of Aliens in East Africa: Asians and Europeans in Tanzania, Uganda and Kenya, New York, Praeger Publishers, 1976; Dharam P. Ghai and Yash P. Ghai, "Asians in East Africa: Problems and Prospects", Journal of Modern African Studies, Vol.3, No.1, 1965, pp. 35-51;Y. P. Ghai, "The Kenya Council of State and the African Affairs Board of the Central African Federation:An Experiment in the Protection of Minorities", International and Comparative Law Quarterly, Vol. 12, No. 4, 1963, pp.1089-1132; Donald Rothschild, "Kenya's Minorities and the African Crisis over Citizenship", Race \& Class, Vol.9, No.4, 1968, pp.421-437. See also chapter 4.3, Transition to independence.
} 
not other non-citizens, who would follow the far more discretionary process of naturalisation. Those born after independence would acquire citizenship by the fact of birth in the territory - with the usual exceptions for the children of diplomats or enemy aliens. The constitutions also recognized Commonwealth citizens as a special category of people, but prohibited dual citizenship for adults, in line with the standard model in the newly independent Commonwealth countries of Africa. ${ }^{130}$

Both during the independence negotiations and immediately after the adoption of the new constitutions, discontent over the economically advantaged position of Asian immigrants to Kenya and Uganda led to agitation for changes in the law. Above and beyond a prohibition on dual nationality (including citizenship of the UK and colonies), the criteria for acquiring citizenship by registration became a subject of debate and dispute. In both countries, citizenship law was modified and restrictions placed on the business operations of "non-indigenous" populations; in Uganda, these changes were ultimately far more radical, and eventually led to the expulsion of the population of Asian descent.

The 1963 Kenya Citizenship Act mainly reiterated the constitutional provisions with regards to citizenship. However, section 3, on registration of citizens, introduced a requirement not present in the constitution that an applicant to be registered as a citizen had to satisfy the minister that he was of "African descent". In addition, the person had to show that either "he was born, and one of his parents was born, in a country to which this section applies", or that "he has been resident for a period of not less than ten years in a country to which this section applies and he is not a citizen of an independent state on the Continent of Africa." 131 The minister could declare the countries to which the section applied (essentially on the basis of reciprocity); the provision was rooted in a commitment to African solidarity, in an era before all African states were independent. In 1969 a new constitution was adopted that consolidated other amendments that had greatly strengthened executive power, though it repeated the provisions of the 1963 constitution on citizenship,. ${ }^{132}$ These measures were clearly aimed at Kenyans of Asian descent: the 45,000 people of European descent also resident in Kenya at the time were equally excluded by the new amendments, but it was (rightly) assumed that Britain would permit them to retain or reacquire its citizenship. ${ }^{133}$

130 Constitution of the Republic of Kenya, 1963, articles 1-12; Constitution of the Republic of Uganda, 1962, articles 7-12.

131 Kenya Citizenship Act, 1963, section 3(1)(b)(ii). The 1963 Constitution provided, in addition to the transitional provisions relating to acquisition of citizenship at independence, for citizenship by registration for Commonwealth citizens or citizens of another African country - but did not made reference to African descent.

132 Constitution of Kenya, 1969; the citizenship provisions were renumbered but otherwise unchanged.

133 Karatani, Defining British Citizenship, pp.154-163. 
But the changes also affected many of foreign origin but clearly of "African descent" resident in Kenya at independence. Among those that faced severe difficulties in obtaining recognition as Kenyan were members of the Kenyan Nubian community, who came to Kenya with the British empire. ${ }^{134}$ The Nubians were conscripted into the British army from what is now Sudan, at the time administered jointly by Britain and Egypt. They became known as the King's African Rifles, or as askaris (the Arabic/Swahili word for soldier or guard), during the British expeditions of colonisation in East Africa and in both world wars. When they were demobilized in Kenya they were not given any meaningful compensation or benefits, although many were allocated small plots of land for farming in a place known as Kibera, near Nairobi. In 1933, an official report already criticised the British government's treatment of its former soldiers: "We consider that the government had a clear duty to these ex-Askaris either to repatriate them or to find accommodation for them. They were told they might make their homes in Kibera and in our judgment they ought not to be moved without receiving a suitable land elsewhere and compensation for disturbances, and we believe that similar obligations exist in respect of their widows or sons who are already householders at Kibera". ${ }^{135}$ Yet neither citizenship nor repatriation to Sudan was offered by the British authorities, and at Kenya's independence in 1963 they remained in Kibera where they had been settled. Kibera became an enormous informal settlement, which the Kenyan government has insisted is government land; local politicians are alleged to have arranged for numerous parts of it to be given to groups of their supporters, while police and courts failed to respond to Nubian protests at the alienation of their land. ${ }^{136}$

In Uganda, meanwhile, the requirements of the 1962 independence constitution were implemented by the Uganda Citizenship Ordinance. ${ }^{137}$ The ordinance

134 A summary of the Nubian situation can be found in Maurice Odhiambo Makoloo, Kenya: Minorities, Indigenous Peoples and Ethnic Diversity, Minority Rights Group International / CEMIRIDE, 2005; Douglas H. Johnson, "Tribe or nationality? The Sudanese diaspora and the Kenyan Nubis", Journal of Eastern African Studies,Vol.3, No. 1,2009, pp.112-131;Adam Hussein Adam, "Kenyan Nubians: standing up to statelessness", Forced Migration Review, Vol. 32, 2009 (Statelessness); and also in the articles by Samantha Balaton-Chrimes: "The Nubians of Kenya and the emancipatory potential of collective recognition", Australasian Review of African Studies, Vol.32, No.1, 2011, pp.12-31; "Counting as Citizens: Recognition of the Nubians in the 2009 Kenyan census", Ethnopolitics Vol.10, No.2, 2011, pp 205-218; "Indigeneity and Kenya's Nubians: seeking equality in difference or sameness?" Journal of Modern African Studies, Vol.51, No.2,2013, pp 331-354;"'Statelessness, identity cards and citizenship as status in the case of the Nubians of Kenya", Citizenship Studies,Vol.18, No.1, 2014, pp.15-28.

135 Report of the 1933 Kenya Land Commission, known as the Carter report, quoted in Makoloo, Kenya: Minorities, Indigenous Peoples and Ethnic Diversity, p. 16.

136 It is claimed that for a long time the Kenyan maps continued to reflect Kibera as a forest where nobody lived, and this was what the successive governments continued to claim. See, for instance, "Kibera, The Forgotten City", IRIN, 13 September 2006.

137 Uganda Citizenship Ordinance (No. 63 of 1962); renamed as the Uganda Citizenship Act, Cap.65. 
provided that Commonwealth citizens or British protected persons (including most whites and Asians) could register as citizens if they applied before 9 October 1964, and satisfied the minister that they had been resident for five years, amongst other conditions. The 1962 constitution and the Citizenship Ordinance also gave the minister extensive powers to revoke citizenship granted in this way. During the parliamentary proceedings, Asian members of parliament argued unsuccessfully for an easier application and registration process and a more stringent process for revoking citizenship. By 1967, only around 11,000 of the just under 25,000 applicants for registration made within the two year time limit had been granted citizenship. ${ }^{138}$ As of 1969, the total Asian population recorded in Uganda was just under 75,000 (less than one percent of the total population of 9.5 million); of which 26,657 were Ugandan citizens (more than 11,000 of them under 11 years old), 36,593 remained British protected persons or citizens of the UK and colonies, 8,890 were Indians, and 1,768 Kenyans. The total non-citizen population was more than 500,000, mainly Kenyans and Tanzanians. ${ }^{139}$

The short-lived 1966 constitution left the citizenship regime unaltered, but the question of citizenship for Asians and other foreigners living in Uganda remained heated. The 1967 constitution removed the jus soli citizenship rights included in the standard Commonwealth independence constitution; although it extended the right to derive citizenship on the basis of descent from a grandparent as well as a parent, and removed gender discrimination for citizenship by descent (though not in marriage). Dual nationality remained prohibited. ${ }^{140}$

Both Uganda and Kenya also took measures to promote the "Africanisation" of the economy, perceived to be too dominated by businesses owned by Kenyans of European and Asian descent. Each country passed a Trade Licensing Act, in 1969 and 1977 respectively, to restrict the operations of non-African owned businesses.

138 John Jean Barya, "Reconstituting Ugandan Citizenship under the 1995 Constitution: A Conflict of Nationalism, Chauvinism and Ethnicity", CBR Working Paper No. 55, 2000, Kampala, Centre for Basic Research.

139 James S. Read, "Some Legal Aspects of the Expulsion”, in Michael Twaddle (ed.) Expulsion of a Minority: Essays on Ugandan Asians, Athlone Press, London, 1975; Vishnu D. Sharma and F. Wooldridge "Some Legal Questions Arising from the Expulsion of the Ugandan Asians", International and Comparative Law Quarterly, Vol.23, No.2. 1974, pp 397-425.

140 Constitution of the Republic of Uganda, 1967, articles 4 and 6; see also Uganda Constitutional Review Commission report, 1995. Although either parent could be a citizen in the first instance, there were restrictions on the transmission of citizenship for those born outside the country if the father had also been born outside. Citizenship by marriage was restricted to women marrying Ugandan men. 
In Kenya, these measures led to a case before the Kenyan High Court in 1968 which considered the concept of "African descent" under the Citizenship Act in order to decide if non-Africans could be deprived of property rights. ${ }^{141}$ The plaintiffs were individuals of Asian descent who had been given notices to quit the stalls they rented from Nairobi city council following a resolution on the Africanisation of commerce. They had been born in Kenya but did not qualify automatically for citizenship because their parents had not been born in the country, though they had applied for citizenship by registration and were awaiting the results. The court found that the implementation of the resolution was discriminatory in practice and that the quit notices were void - but not that the policy or the resolution were unconstitutional in themselves, on the grounds that the constitutional protection against discrimination did not apply to non-citizens. ${ }^{142}$ Effectively, the court accepted that the state's delay in processing applications for citizenship justified its actions against the very same group of people. In 1985, the exclusion was widened when the Kenyan parliament adopted a law amending the 1969 constitution to remove jus soli citizenship from those born in Kenya since independence and putting in place a pure jus sanguinis rule - with retroactive effect to the date of independence. ${ }^{143}$

In Uganda, the take-over of power by President Idi Amin in early 1971 greatly accelerated the legal and other steps taken against the Asian population. Amin stated his ambition to return the Asian-controlled businesses to "black Ugandans", on the grounds that the Asians were "sabotaging Uganda's economy and encouraging corruption". ${ }^{44}$ In December 1971, Amin announced that 12,000 outstanding applications to register for Ugandan citizenship would be cancelled, but could be resubmitted. On 4 August

141 Wadhwa and Others v. City Council of Nairobi [1968] E.A 406; see also Alan H. Smith, "Prevention of Discrimination under Kenyan Law", International and Comparative Law Quarterly, Vol. 20, No. 1, January 1971, pp. 136-142.

142 The Council argued that its resolution was not racially discriminatory since the term African should be taken to mean not a person whose forefathers were born in Africa but rather a citizen of any country on the continent of Africa, without regard to race. The judge rejected this line of argument on the grounds that the provisions on citizenship did not extend automatically to citizens of other countries in Africa, except as listed in the Citizenship Act. In a somewhat similar case heard before the Kenya High Court in 1968, Fernandes v. Kericho Licensing Court, the question of citizenship arose once again. The plaintiff was of Indian origin and was denied renewal of a liquor licence on the basis that he was not a citizen. The court found in favour of the plaintiff, on the grounds that under the relevant law (Liquor Licensing Act, Laws of Kenya, chapter 121) the liquor court had power to refuse to renew the applicant's licence only if he was suffering from one of the six disqualifications set out in the Act, and lack of citizenship was not one of them.

143 Constitution of Kenya Amendment Act No.6 of 1985.

144 See for example Mahmood Mamdani, "The Ugandan Asian Expulsion: Twenty Years After", Journal of Refugee Studies Vol.6, No.3, 1993, pp.265-273; Patrick Keatly, "Britain could face influx of 80,000 Asians", The Guardian (London), 5 August 1972. 
1972, he announced that he would demand that the British government take over responsibility for the Asian Ugandans and ensure their removal from Uganda within three months. Successive decrees cancelled all entry permits and certificates of residence issued to persons of Asian origin; these initially required that the persons involved be citizens or subjects of the UK, India, Pakistan and Bangladesh, but from October 1972 the requirement that the person hold another nationality was removed. Although the decrees did not technically apply to those holding Ugandan citizenship, a process of "verification" of citizenship by registration reduced the numbers of those recognised as Ugandan - all of whom had been required to renounce another nationality in order to obtain citizenship. ${ }^{145}$ Most Asians and many other foreigners left the country. The influx of East Africans to the UK, meanwhile, led to new legislation applying immigration controls restricting their entry to Britain (ultimately successfully challenged under the European Convention on Human Rights). ${ }^{146}$

In 1983 the new government reversed these policies, passing legislation to return confiscated property and encouraging the return of the Asian community and other foreigners and investors to Uganda ${ }^{147}$ — though the process was not a simple one and there was much controversy over ownership of the property formerly held by Asians. ${ }^{148}$

145 Immigration (Cancellation of Entry Permits and Certificates of Residence) Decree (No. 17 of 1972), 9 August 1972; Immigration (Cancellation of Entry Permits and Certificates of Residence) (Amendment) Decree (No. 30 of 1972), 25 October 1972. See Read, "Some Legal Aspects of the Expulsion".

146 Commonwealth Immigration Act 1968, Immigration Act 1971; East African Asians v. UK-Application 4403/70 [1973] ECHR 2, 14 December 1973; Richard Plender, "The Exodus of Asians from East and Central Africa: Some Comparative and International Law Aspects", American Journal of Comparative Law, Vol. 19, No. 2, 1971, pp. 287-324.

147 Uganda Expropriated Properties Act, Laws of Uganda, 2000, chapter 87, transferred the properties and businesses of Asians that had been acquired or expropriated during the military regime to the Ministry of Finance and ensured their return to former owners or their lawful disposal by government.

148 The issue led to many court cases. In Kayondo v. Asian Property Custodian Board (HCCS No. 345 of 1981), the presiding judge stated that the seizure of businesses and other properties by the military government from Asians was unconstitutional. On appeal (HCB No. 17 of 1982), however, it was held that the takeover of the property amounted to nationalisation and therefore was not a violation of the constitution. Some cases relating to ownership of formerly Asian held properties took years to resolve; others continue to be fought out in the courts. Judgments of the Ugandan courts, available at http://www.ulii.org/ (search for e.g. "custodian" since most cases named the Property Custodian Board as defendant), accessed 29 October 2014. See also, Mamdani, “The Ugandan Asian Expulsion”. 


\section{The Terminal: stateless man spends year at airport}

Sanjay Shah was born in Kitale in Kenya and later lived in Nairobi. His parents were both born in India but held British passports. His predicament began when he learnt that he was eligible for a British Overseas Citizen passport, and decided to apply for one in August 2003. After the mandatory six months wait, he got his passport, and he left to visit his sister in Britain. However, a British Overseas Citizen passport does not give the same rights as a British citizen, and at Heathrow he was detained under the Immigration Act 2002 on the grounds that he did not give satisfactory reasons for his visit. He was returned to Kenya three days later with his passport stamped "prohibited". Upon arrival in Kenya he was detained again on the grounds that, having obtained another nationality, he was no longer a Kenyan citizen. Shah spent one year at the airport unable to enter Kenya or to go to Britain, while the Indian government also refused to take him. Effectively he found himself suddenly stateless. In July 2005 it was reported that finally he was to become a citizen of Britain. ${ }^{149}$

The status of the Ugandan and Kenyan Asians gradually became a less politically sensitive problem (though still controversial), in part because many left; but the question of who qualified to be a citizen of either country remained an urgent one, increasingly with a greater impact on people of African descent. In Uganda, the constitution and law was amended to create an explicit ethnic element to citizenship; while in Kenya, though the law appeared to become more open with the adoption of a new constitution in 2010 and new citizenship legislation in 2011, detailed procedures for identification have continued to create exclusion in practice - especially as the overspill of the "global war on terror" impacted East Africa.

In Uganda, a new constitution was promulgated in 1995 following a countrywide consultative process led by a constitutional review commission (known as the Odoki Commission, after its chair). While the status of those of Asian descent had dominated the drafting of the 1962 and 1967 Constitutions, the 1994-5 constitutional debate focused on the status of African immigrants and refugees. In particular, because of the controversial status of the "Rwandese Tutsi" who had come to Uganda as refugees, as well as the fact that part of Rwanda had been ceded to Uganda in 1910, many Ugandans opposed the recognition of "Banyarwanda" as citizens. However, though a minority sought

149 Evelyn Kwamboka and Juliet Otieno, "Stateless man's agony after a year of life at the airport", The Standard, 15 June 2005; Adam Mynott, "Kenya airport dweller is British", BBC News, 12 July 2005. In the 2004 film "The Terminal" Tom Hanks played an immigrant trapped at JFK airport in New York in similar circumstances. 
a more restrictive position, many Ugandans wanted citizenship to be defined to include all people who had been in Uganda for a long period of time and wished to obtain citizenship. ${ }^{150}$

The 1995 Constitution introduced an explicit ethnic definition of Ugandan citizenship for the first time, while removing the requirement introduced in 1967 for those born in Uganda to have a parent who is a citizen. It provides for a right to citizenship by birth for two categories: first, for every person born in Uganda, "one of whose parents or grandparents is or was a member of any of the indigenous communities existing and residing within the borders of Uganda as at the first day of February, 1926"; and secondly, for every person born in or outside Uganda one of whose parents or grandparents was a citizen of Uganda by birth. ${ }^{151}$ Both categories, the former explicitly, the latter by implication, privilege the ethnic groups historically resident in Uganda, making it difficult for whites and Asians to obtain Ugandan nationality. ${ }^{152}$ A schedule listing the "indigenous communities" of Uganda generated some of the hottest debate as the constitution was adopted; Asians argued unsuccessfully that they should be regarded as an indigenous group. Fifty-six groups were eventually included, among them the Banyarwanda, as well as other cross border ethnic groups such as the Batwa, Lendu and Karamojong; in 2005, a further nine were added to the list. ${ }^{153}$ Uganda thus joined the small group of countries where the law itself makes it more difficult for those of the "wrong" race or ethnicity to become citizens with full rights. ${ }^{154}$ The 1995 constitutional provisions also reaffirmed the earlier position denying dual citizenship. Although there were submissions both for and against the issue of dual citizenship made to the Odoki Commission, the Commission, on a statistical assessment of the views submitted to it, recommended that dual citizenship be rejected. ${ }^{155}$ Implementing legislation in 1999 confirmed these rules. ${ }^{156}$

${ }^{150}$ Barya, "Reconstituting Ugandan Citizenship"; Uganda Constitutional Review Commission report, 1995.

151 Constitution of the Republic of Uganda, 1995, article 10.

152 Another article provided for those born in Uganda to obtain citizenship by registration on application, if they had been living in Uganda since 1962 and had no parent or grandparent with diplomatic status or who had been a refugee. Constitution of the Republic of Uganda, 1995, article 12.

153 Constitution of the Republic of Uganda, 1995, third schedule; Uganda Constitution (Amendment) Act, 2005.

154 In Kenya meanwhile, a draft constitution produced in 2002 after an extensive national consultation but never formally adopted, moved in the other direction, removing gender discrimination and providing much great due process protections to all. The People's Choice: The Report of the Constitution of Kenya Review Commission, September, 2002.

155 Report of the Uganda Constitutional Commission (Odoki Commission), 1993.

156 Uganda Citizenship and Immigration Control Act No.3 of 1999. 
Though the issues of loyalty and belonging remained live, the immediate concerns over the status of those with a claim on another citizenship were diluted by the dawn of the $21^{\text {st }}$ century. First Uganda (in 2005) and then Kenya (in 2010) changed the law to allow dual nationality. ${ }^{157}$

In Uganda, a new Constitutional Review Commission (CRC) was set up from 2001 to 2003 and re-examined the provisions on citizenship. The Commission noted that the majority view was that only people who were descendants of indigenous communities of Uganda should be recognized as citizens and therefore some communities, such as the Banyarwanda, should be excluded. ${ }^{158}$ Once again, the majority of responses submitted to the CRC were against dual citizenship. As during the 1995 constitutional debate, the main arguments against dual citizenship revolved around the issue of loyalty and the security and sovereignty of Uganda. Fears were also expressed that dual nationality investors would come to dominate the Ugandan economy. Proponents of dual citizenship, however, argued that it was wrong to deny people Ugandan citizenship if political or economic circumstances had forced them to acquire foreign nationalities, and that Ugandans in the diaspora contributed substantially to the Ugandan economy. The Ugandan government's proposals to the CRC argued that it was necessary to allow dual citizenship both for indigenous Ugandans living abroad and for potential foreign investors. The CRC ultimately recommended that parliament should allow dual citizenship both for Ugandans in the diaspora and for non-Ugandans. The government position was reaffirmed in a white paper responding to the CRC report. ${ }^{159}$

In 2005 legislation was finally passed to amend the constitution and allow both Ugandans and non-Ugandans to acquire dual citizenship. The act also mandated that parliament prescribe the offices of state that those with dual citizenship would be disqualified from holding. ${ }^{160}$ It took four years for parliament to pass amending legislation in May 2009, setting out the detailed rules for citizenship applications, as well as a long list of official positions that could not be held by dual citizens, including the presidency, prime minister, ministers, and senior

157 Constitution (Amendment) Act, 2005, Article 6, amending Article 15 of the 1995 Constitution; Uganda Citizenship and Immigration Control (Amendment) Act, No 5 of 2009, section 9, replacing section 19 of the principal act (also creating significant limitations on dual citizenship). Constitution of Kenya, 2010, article 16 permits dual nationality for citizens from birth; Kenya Citizenship and Immigration Act, No.12 of 2011 (Cap.172) repeats this provision in section 8 and does not require a person naturalising as a Kenyan to renounce another citizenship (section 13).

158 Uganda Constitutional Review Commission report, 10 December 2003, Page 157.

159 "Government white paper on (1) The report of the commission of enquiry (2) Government proposals not addressed by the report of the commission of inquiry," paragraph 1.11(f), available at http://www.cmi.no/pdf/?file=/uganda/doc/government-whitepaper.pdf, accessed 29 November 2014.

160 Uganda Constitution (Amendment) Act, 2005, Part III, sections 5 to 8, amending articles 14 to 17 of the 1995 Constitution. 
positions in the armed forces, intelligence services and police. The requirements for those naturalising as Ugandan who wished to retain another nationality were also drastically increased. ${ }^{161}$

Both the 1995 constitution and 1999 Citizenship and Immigration Control Act require 20 years' residence in the country before a person can naturalise, an unusually long period. ${ }^{162}$ Moreover, although children born in Uganda to noncitizens could apply for registration as citizens, children of refugees, perhaps the most likely category to need this right, were explicitly excluded. ${ }^{163}$ In 2006 a new Refugees Act was passed, incorporating the definitions of the UN and African treaties, and establishing rules that are largely in conformity with international law. In relation to naturalisation, the act states that "the Constitution and any other law in force in Uganda shall apply to the naturalisation of a recognised refugee"; but in practice refugees have struggled to gain Ugandan citizenship. ${ }^{164}$ Administration of the immigration directorate has been poor, and the Citizenship and Immigration Board provided for by the Citizenship and Immigration Control Act, which ought to have been deciding on issues of citizenship, was only finally established in 2007 , leading to vast backlogs of citizenship applications. ${ }^{165}$

In Kenya, meanwhile, a decades-long struggle by pro-democracy activists was given impetus by international intervention in response to the crisis of violence following the December 2007 elections, and finally led to a new constitution adopted by referendum in 2010. The 2010 Constitution ended gender discrimination under the law in relation to a woman's ability to pass her nationality to her child or spouse, allowed Kenyans to hold dual nationality, restricted the grounds on which nationality may be taken away, and provided for all Kenyans to have a right to a passport and identity documents. ${ }^{166}$ However, in relation to children of non-national parents, the text only added a right to Kenyan nationality for children born on the territory of unknown parents (an

161 Uganda Citizenship and Immigration Control (Amendment) Act 5 of 2009, introducing sections 19A to E in the original Act. See also Felix Osike and Mary Karugaba, "Rules set for dual citizens," New Vision (Kampala), 18 August 2008; Henry Mukasa and Catherine Bekunda, "Parliament passes dual citizenship law" New Vision, 17 May 2009.

162 Constitution of Uganda, 1995, Article 12(2)(b) and (c); Uganda Citizenship and Immigration Control Act, 1999, as amended 2009, sections 14(2)(b) and 15(5)(a).

163 Constitution of Uganda, Article 12(1)(a)(ii); Uganda Citizenship and Immigration Control Act, 1999, section 14(1)(a)(ii).

164 Refugees Act, 2006, section 45; see also Critique of the Refugees Act (2006), Kampala: Refugee Law Project; Samuel G. Walker, From refugee to citizen? Obstacles to the Naturalisation of Refugees in Uganda, Kampala: Refugee Law Project, 2011. Uganda's Control of Alien Refugees Act, adopted in 1960, was originally an ordinance of the Protectorate government that provided specifically for the refugees (mostly Tutsi) - from Rwanda, Burundi, and what is now DRC—who fled to Uganda during 1959 and 1960.

165 "Let sanity begin at immigration," The Monitor, Kampala, 12 November 2007.

166 Constitution of Kenya, 2010, Chapter III. 
improvement on the previous situation), but not those who would otherwise be stateless, or any other rights based on birth and residence. ${ }^{167}$ The African Committee of Experts on the Rights and Welfare of the Child, responsible for monitoring compliance with the African Charter on the Rights and Welfare of the Child, decided in 2011, in its first case, that the Kenyan law was still in violation of its obligations under Article 6 of the Charter, despite the reforms of the new 2010 constitution. ${ }^{168}$ The Committee noted the "devastating" consequences of statelessness for children in relation to their socio-economic rights. ${ }^{169}$

Kenya's Citizenship Act was replaced in 2011, as required by the constitution; but the new Citizenship and Immigration Act No. 12 of 2011 did not rectify this omission by providing any further rights based on birth in the territory. ${ }^{170}$ The new law did, however, include specific measures on the integration of populations that were not incorporated into the citizenship body on succession of states at independence. It provided that:

A person who does not have an enforceable claim to the citizenship of any recognized state and has been living in Kenya for a continuous period since $12^{\text {th }}$ December, 1963 , shall be deemed to have been lawfully resident and may, on application, in the prescribed manner be eligible to be registered as a citizen of Kenya... ${ }^{171}$

Similar provisions apply to "a person who has voluntarily migrated into Kenya before 12 December 1963" (the date of independence) who "does not hold a passport or an identification document of any other country". The registration in either case is subject to conditions similar to those for naturalisation, including a clean criminal record, and knowledge of Swahili or another "local dialect". The application must be made within five years of the entry into force

167 Constitution of Kenya, 2010, Chapter 3, Article 14(4). For detailed commentary on the deficiencies of the draft text of the constitution,, see "Comments on the Citizenship Provisions of the Draft Kenyan Constitution"

18 March 2010, and "Submission to the Task Force on Citizenship and Related Provisions of the Constitution"

13 April 2011, both by Citizenship Rights in Africa Initiative, available at the website http://citizenshiprightsinafrica.org/, last accessed 20 November 2014.

168 Kenyan Nubian Children's Case, paragraph 53.

169 Ibid., Paragraphs 42 and 46.

170 Kenya Citizenship and Immigration Act No12 of 2011, section 9 provides for children of unknown parents under the age of eight. In 2011, the African Committee of Experts on the Rights and Welfare of the Child, in its decision on the situation of Nubian children, found the Kenyan state in violation of its obligations under Article 6 of the African Charter on the Rights and Welfare of the Child, despite the reforms of the new constitution. See further above, chapter 3.12.1.

171 Kenya Citizenship and Immigration Act No.12 2011, section 15. 
of the act. ${ }^{172}$ Descendants of those eligible to register as citizens under these provisions are equally eligible, if born in Kenya. ${ }^{173}$

These provisions have, however, been ineffective in practice. Amongst their intended beneficiaries were the Nubian community, whose previous litigation at nationality level for recognition of citizenship had been unsuccessful. ${ }^{174} \mathrm{On}$ the one hand, Nubians were reluctant to start from the point of self-definition as stateless rather than as Kenyan; on the other, any applications for citizenship brought under this provision languished as the government officials responsible for citizenship applications remained uncertain how to process them in the absence of any regulations to give detailed guidance on the modalities of implementation of the law. ${ }^{175}$ Nonetheless, for the Nubians at least, applications for national identity cards on the normal basis did generally become somewhat easier, as the campaign for Nubian citizenship gained profile. Nubians may still be subject to vetting, or required to pay additional bribes for the privilege, but the majority now have IDs. ${ }^{176}$

172 Ibid., section 16. The two sections are headed "stateless persons" and "migrants". Although the definitions section of the act defines "stateless person" as "a person who is not recognized as a citizen by any state under the operation of the laws of any state", in accordance with the definition in the 1954 Convention relating to the Status of Stateless Persons, section 15 of the act on "stateless persons", refers rather to a person who "does not have an enforceable claim to the citizenship of any recognized state". It is not clear therefore how the courts will interpret the legislation. Nor is it clear what the distinction is with a person eligible under section 16, who "does not hold a passport or an identification document of any other country".

173 Ibid., section 17.

174 In 2003, representatives of the Nubian community brought a case to the Kenyan courts seeking confirmation of their citizenship and the right to be issued with relevant official documents. High Court civil case no. 256 of 2003, Nairobi. After more than three years of blocked progress at national level on procedural grounds, the Nubians took their case to the African Commission on Human and Peoples' Rights, requesting the premier continental human rights body to find in their favour in relation to numerous violations of the African Charter on Human and Peoples' Rights. Communication 317/06, ACHPR: The Nubian Community v. Kenya. As of the end of 2014, the final decision on the merits was still awaited.

175 Information from Nubian Rights Forum, October 2013.

176 Balaton-Chrimes, "Statelessness, identity cards and citizenship". 


\section{The daily struggles of Nubians in Nairobi ${ }^{177}$}

Khadija Hassan was born in 1979 in Kibera. She and her husband have four children and share a small home together with her brother. Khadija's life story echoes the stories of thousands of other Nubians deprived of basic necessities. Whereas she says without hesitation that she is a citizen of Kenya, she has no means of proving that. "My father, who died when I was very young, told me that I am," she says. "Nubians have a real problem getting any kind of identification documents. If you have a Muslim name it is very difficult to do anything." Khadija explains that few Nubians can afford to pay the bribes that officials demand for birth certificates, and without connections in the government it is very difficult for Nubians to get identity cards and essentially impossible to get passports. "Unlike other people here, Nubians have to go through a vetting process to get identity documents. If I wanted a passport for myself, they will ask for my parents' and grandparents' — sometimes even my great-grandfather's - birth certificates. My friend who is Kikuyu got a passport simply by showing her ID," she says. "I consider myself a Kenyan. I was born here and I don't have anywhere else to go even though people tell us "go home where you came from" all the time".

Abdalla Ali Ramadhan was born in Mlimani in Eldama Ravine in 1955. He tried to get an ID card for many years, and finally succeeded in 1992. In 2004, he lost his ID card and tried to get a replacement. However, he was told he had to produce his deceased parents' and grandparents' birth certificates to get a new one - a requirement he was unable to meet. As a result, Abdalla has virtually no access to official transactions such as opening a bank account or voting. He also cannot be formally employed without an ID card, something which significantly contributes to unemployment and poverty among Nubians. Moreover, the risk of becoming a victim of police violence is significantly larger for people without identity documents as the police frequently demand to be shown national IDs to forestall arrest - something which Abdalla has experienced on several occasions.

Mohamed Juma has a daughter who is three years old. Since autumn 2005 he has tried to get her a birth certificate and explains the bureaucratic process: "I went to Sheria House where I was given a form to fill. I filled out the form and took it back. I was told to go to City Hall. At City Hall I was asked for my wife and daughter's clinic cards. I brought these cards back but I was told that they were not stamped. I had to return to the

177 Summaries of affidavits taken in 2005 by the Open Society Justice Initiative, CEMIRIDE and the Institute for Human Rights and Development in Africa, for the communication brought to the African Commission on Human and Peoples' Rights. Names have been changed. 
hospital and get them stamped. I took the stamped cards back to City Hall but could not find the person I was dealing with. After many visits, I found the officer and he told me to fill in a form B3. The form asked the names of the child, the father, and the mother and the date of birth of the child. I filled out the form. I then had to take the form to the Chief and Sub-Chief for signatures. I returned the form to the City Hall on Tuesday 4 February 2006. I am still waiting for a response. I do not feel good about this process. The reason they are giving me all these hurdles is that I have a Nubian name."

The group perhaps at most risk of statelessness in Kenya today are the Somalis, whose long-term marginal status has been exacerbated by the impact of the "global war on terror". Kenya hosts hundreds of thousands of refugees from Somalia, mostly hosted in North East Kenya, as well as a large Kenyan Somali population. The security forces have a long history of harassment of Somalis, whether refugees or Kenyans, who are consistently suspected of support for pan-Somali unity and universal engagement in banditry. ${ }^{178}$ In the aftermath of independence a secessionist movement was suppressed with great brutality, and episodes of military abuses have recurred since then. ${ }^{179}$

In November 1989, a newly introduced "screening" procedure compelled all Kenyans of Somali origin to report with identity documents to the Kenyan authorities, for the purpose of "registration of all Kenyan Somali and to expel those found sympathetic with Somalia." ${ }^{180}$ As in the case of the Nubians, vetting committees were established, which handed out identity cards to those who satisfied them, and confiscated existing cards from those who did not. Kenyan Somalis living in other provinces were told to go back to their "home" district to register, a requirement not imposed on members of other ethnic groups. Among the sub-groups suddenly denationalised in this way were the roughly 3,500 Galje'el Somalis living in Tana River District, Coast Province.The Galje'el Somalis claim that their ancestors came from Wajir in North Eastern Province in the mid-1930s and settled along the Tana River, where they had until the 1980s been regarded as Kenyan citizens, though they lacked government-provided

178 For many years, constitutional protections for freedom of movement did not apply to restrictions imposed for "the protection or control of nomadic Peoples', among other circumstances. 1963 Constitution, article 81(3)(b). Also excluded were restrictions in the interests of defence, public safety or public order.

179 In 1984, more than a thousand Kenyan Somalis were killed by security forces in a massacre at Wagalla, North Eastern Province, for which there has to date been no accountability. See Thuo Kinyanjui, "Remembering Wagalla Massacre 30 Years Later", Kenya National Commission on Human Rights, 14 February 2014.

180 Legal Notice No.5320, Kenya Government Gazette 10 November 1989. 
schools, clinics, or drinking water points. During the 1989 screening process, they were branded non-Kenyans, their identity cards were confiscated, they were told to leave for Somalia, and many of them were displaced from their land. Although their entitlement to citizenship was eventually officially confirmed, their national identity cards were not returned. ${ }^{181}$ In 1999, the Galje'el were evicted from their main settlement and forcibly relocated some distance away, with access to few if any services. ${ }^{182}$

After the 1998 bombing of the US embassy in Nairobi, security measures were tightened. In April 2005, the minister for immigration, registration of persons and refugees stated that those non-citizens (not only Somalis) who did not possess the necessary registration documents would be considered as staying illegally in Kenya and would therefore be deported to their countries of origin. The original deadline for the registration of non-citizens in Kenya was fixed for the end of June, later extended to 15 August 2005. Using this law, security forces once again raided the Galje'el communities. The Galje'el obtained interim orders in court against the provincial administration and the attorney-general to stop any attempts to evict, harass, displace, or render the community homeless or stateless. ${ }^{183}$ But this did not change the position on the ground. A 2008 letter addressed to a member of the Galje'el community stated that an application for an identity card could not be processed "because the holder was declared to be non-Kenyan by the ... Task Force of 1989." 184

The global politics of terrorism also impacted on the Kenyan Arab minority living in the coastal areas who, unlike the Somalis, had not historically faced discrimination or challenge to their right to citizenship. In early 2005, the minister for immigration announced on the radio that any late (i.e., longer than six months after birth) registration of births in the coastal areas would have to be vetted by the central government. The justification given was that many terrorists come to the coastal regions and acquire Kenyan birth certificates illegally, and then easily get other relevant national documents and pass themselves off as Kenyans. In practice, the policy made it harder for coastal Muslims to obtain identity documents, and was received with anger by a population already resenting a general atmosphere of suspicion against them. ${ }^{185}$

181 Letter from the Office of the President to the District officer of the Kiunga Division, Lamu, dated 29 July 1992 (on file with CEMIRIDE, the Centre for Minority Rights Development, Nairobi, shared by Adam Hussein Adam).

182 Alamin Mazrui, Banditry and the Politics of Citizenship: The Case of the Galje'el Somali of Tana River, MUHURI, Mombasa, 1999, cited in Adam Hussein Adam, "Making of Stateless People - The Kenyan Style".

183 Miscellaneous Civil Application No. 28 of 1999 in Mombasa (on file with CEMIRIDE).

184 Letter from National Registration Bureau, 28 March 2008, cited in Adam Hussein Adam, "Making of Stateless People - The Kenyan Style", 2008 (on file with author).

185 "Kenya: National registration process leaves minorities on the edge of statelessness", Bulletin, Refugees International, 23 May 2008. 
In 2013, following the Westgate shopping mall terrorist attack in which at least 67 people were killed, there were calls for the expulsion of all Somalis in Kenya and the closure of the Dabaab refugee camp; arbitrary arrests of many Somalis followed, as well as dismissals of immigration officials for issuing "Kenyan identity documents to illegal immigrants, thereby endangering national security". ${ }^{186}$ In November 2013, Kenya, Somali and UNHCR signed a tripartite agreement for the return of refugees to Somalia; though it stressed that repatriation should be voluntary, there was no matching provision for any to have permanent settlement in Kenya. ${ }^{187}$ In late 2014, a controversial new security law amended already stringent provisions in the Public Order Act, the Prevention of Terrorism Act and other legislation. Amongst other draconian measures, the law amended both the Registration of Persons Act to allow the government to cancel the registration and revoke the identity card of any person on the basis of misrepresentation, fraud, multiple registration or "any other justifiable cause", and the Citizenship and Immigration Act to increase the powers of the government to regulate the presence of foreigners, including to widen the grounds on which permanent residence may be lost, and provide for compulsory registration of a foreign national resident in Kenya for more than three months. The Refugees Act was amended to restrict the "permitted number of refugees and asylum seekers in Kenya" to 150,000 people. ${ }^{188}$ The 1966 Preservation of Public Security Act remained in force and allowed for special public security measures to restrict free movement (into, out of, or within Kenya). ${ }^{189}$ The issue of national ID cards was suspended in the three counties located in the former North Eastern Province bordering Somalia (Garissa, Wajir and Mandera Counties, created by the 2010 Constitution), meaning that those without IDs cannot travel out of that zone, and effectively lose the reality of citizenship rights — without the need for the

186 "Kenya Calls for Somalis to Leave World's Largest Refugee Camp", AllAfrica.com, 26 October 2013.

187 Tripartite Agreement between the Government of the Republic of Kenya, the Government of the Federal Republic of Somalia and the United Nations High Commissioner for Refugees, governing the voluntary repatriation of Somali refugees living in Kenya, 2013.

188 The Security Laws (Amendment) Act, 2014, sections 18, 25 and 75-84. Available at the website of the Kenyan presidency http://www.president.go.ke/the-security-lawsamendment-act-2014/, last accessed 22 December 2014. See also "Kenya Security Bill Tramples Basic Rights: Lawmakers Should Reject Amendments", Human Rights Watch and Amnesty International, 14 December 2014.

189 Preservation of Public Security Act, chapter 57, section 4(2)(b). The Outlying Districts Act and the Special Districts (Administration) Act were repealed by the Statute Law (Repeals and Miscellaneous Amendments) Act, No.10 of 1997. Although the Preservation of Public Security Act was also amended in 1997 to remove the provisions relating to detention of persons, the other provisions remained in force. Special regulations are set out for the North-Eastern Province and contiguous districts, allowing for the control of movement of specified ethnic nationalities or into "prohibited zones". Legal notices No. 264 of 1966 and No. 185 of 1967; The Public Security (Control of Movement) Regulations, L.N.43, 1967. 
government to undertake any legal proceedings to deprive them of that status. ${ }^{190}$

\subsection{The "Lebanese" of Sierra Leone}

The kernel for the British Colony of Sierra Leone was founded in 1787, when several hundred immigrants, made up largely but not only of London's "poor blacks" supported by funds from the abolitionist movement, arrived in the territory and established the first new settlement. In 1792, bolstered by the arrival of ex-slaves from Nova Scotia, the settlers established Freetown, and were joined there by other "returnees" from Jamaica and America. Then, from the date of the abolition of the slave trade by the British Parliament in 1807, the British navy began intercepting slave ships travelling from Africa to the Americas, and landed thousands of freed slaves in Freetown, where a naval base had been established. The Colony previously managed by the private Sierra Leone Company was surrendered to the British crown in the same year. Though contacts both peaceful and military between the Colony and the interior then steadily increased, it was not until 1896 that a British Protectorate was declared over the full territory of Sierra Leone.

During the last decade of the nineteenth century, migrants from what are now Syria and Lebanon but was then the Ottoman Empire began arriving in Freetown, which had become a thriving port, and set up businesses as traders. By the date of independence, around 3,000 individuals of Middle Eastern descent, known collectively as "Lebanese", were living within the borders of either the Colony or the Protectorate; among 18,300 estimated to be in West Africa as a whole. ${ }^{191}$ Lebanese nationals also came to settle more recently, especially during the civil war in Lebanon, though the numbers were always substantially less than one percent of Sierra Leone's estimated five to six million population; and the numbers reduced again during the civil war. Many "Lebanese" resident in Sierra Leone today have parents and grandparents born in Sierra Leone, speak Sierra Leonean languages, and some have intermarried and actively participated in the political, social and economic life of the country. At the same time, a strong Lebanese identity is retained by some (and exacerbates resentment of their social isolation), through institutions such as the Lebanese International

190 Bronwen Manby, "You can't lose what you haven't got: citizenship acquisition and loss in Africa", contribution to EUDO Citizenship Observatory debate The Return of Banishment: Do the New Denationalisation Policies Weaken Citizenship?, October-December 2014, available at http://eudo-citizenship.eu/commentaries/citizenship-forum/citizenshipforum-cat/1268-the-return-of-banishment-do-the-new-denationalisation-policiesweaken-citizenship, last accessed 23 December 2014.

191 H. L. van der Laan, The Lebanese Traders in Sierra Leone: Change and Continuity in Africa, The Hague: Mouton, 1975; Neil O. Leighton, "The political economy of a stranger population: The Lebanese of Sierra Leone", in Shack and Skinner (eds.) Strangers in African Society, p.87; Andrew Arsan, Interlopers of Empire: The Lebanese Diaspora in Colonial French West Africa, London and New York: Hurst and Oxford University Press, 2014. 
School in Freetown. ${ }^{192}$

The Lebanese in Sierra Leone, as elsewhere in West Africa, are for the most part businesspeople, dominating commerce in the large towns, and the diamond trade in particular. In the context of the drive to "Africanise" the economy common to most post-independence African states, resentment of the Lebanese role as middlemen and supporters of the colonial government meant that they were early targets of efforts to reduce their privileged economic position and formalise their status as "strangers" in the new state. Yet Lebanese money was freely drawn on by political parties to support their own efforts to gain office.

In 1961, the independence constitution of Sierra Leone created a single nationality, without any distinction by race, ethnic group or sex. "Every person" born in the former colony or protectorate who was a citizen of the United Kingdom and colonies or a British protected person on 26 April 1961 became a citizen of Sierra Leone on 27 April 1961, unless neither of his or her parents nor any of his or her grandparents was born in Sierra Leone; those born outside the country became citizens if their father became a citizen under this provision. Others born in the country, but whose father and grandfather were not, could apply to register as citizens, a non-discretionary form of naturalisation. In addition to these transitional provisions, the constitution provided for jus soli citizenship to everyone born in the country after the date of independence (with the standard exception for children of diplomats), and for the child of a Sierra Leonean father born outside the country. ${ }^{193}$ The 1961 constitution also had an extensive bill of rights including a non-discrimination provision (with some exclusions in relation to customary law). Dual citizenship was forbidden for adults, in line with usual African and international practice at that time. Legislation was adopted to provide details on citizenship by naturalisation and registration and on renunciation and deprivation of citizenship. ${ }^{194}$

Within a year after independence, Sierra Leone's constitutional provisions on citizenship were amended three times to become more restrictive and discriminate against individuals on the basis of race and sex. ${ }^{195}$ First, an act deleted

192 Lina Beydoun "Lebanese migration to Sierra Leone: Issues of transnationalism, gender, citizenship, and the construction of a globalized identity", unpublished $\mathrm{PhD}$ thesis, Wayne State University, 2005; Lina Beydoun, "The Complexities of Citizenship among Lebanese Immigrants in Sierra Leone", African Conflict \& Peacebuilding Review Vol.3, No.1, 2013, pp.112-143; Michael Humphrey, "Lebanese identities: between cities, nations and trans-nations", Arab Studies Quarterly Vol.26 No.1, 2004, pp.31-50; Chris Bierwirth, "The Lebanese communities of Côte d'Ivoire", African Affairs Vol.98, 1999, pp.79-99.

193 Constitution of Sierra Leone, 1961, section 1, 2 and 4.

194 Sierra Leone Nationality and Citizenship Act, No.10 of 1962.

195 Constitution (Amendment) Act, No.11 of 1962; Constitution (Amendment) (No.2) Act, No.12 of 1962; and Constitution (Amendment) (No.3) Act, No.39 of 1962. The amendments were subsequently consolidated in the Constitution (Consolidation of Amendments) Act, No.52 of 1965. 
the transitional provisions of the constitution providing for non-discretionary registration of those excluded from automatic acquisition of citizenship for lack of a parent or grandparent born in the country. ${ }^{196}$ Then, the words "of negro African descent" were inserted immediately after the words "every person" in relation both to those who automatically became citizens at independence and those born on the territory after independence, to apply retroactively from the date of independence. At the same time, the restriction on jus soli citizenship for those whose father held diplomatic status or was an enemy alien was lifted - so a person of negro African descent born in Sierra Leone would become a citizen, whatever the status of the parents. Finally, the non-discrimination clause that prohibited any law that is "discriminatory of itself or in its effect", was amended to exclude laws relating to the limitation of citizenship to persons of negro African descent. Individuals who were not of "negro African descent" but who had acquired citizenship by virtue of the 1961 Constitution were thus stripped of their citizenship of Sierra Leone after less than a year, and many more who should have been able to opt for citizenship by a simple application process had that right taken away. Moving forward, no person born on Sierra Leonean territory not of negro African descent would be a citizen by birth. ${ }^{197}$ In these amendments, Sierra Leone draw on the tradition in neighbouring Liberia, where the constitution has, since the first version was adopted in 1847, always provided that only a "Negro" could be a citizen, whatever the other circumstances. ${ }^{198}$

The 1962 constitutional amendments defined "person of negro African descent" as follows: "a person whose father and his father's father are or were negroes of African origin", introducing both racial and gender discrimination at one step. Even if a person was born in Sierra Leone of a "negro African" mother,

196 Whereas Section 2(1) of the 1961 Constitution had provided that "Any person who, but for the proviso to subsection (1) of section 1 of this Constitution [relating to the exclusion from citizenship of those without a parent or grandparent born on the territory] would be a citizen of Sierra Leone by virtue of that subsection shall be entitled, upon making an application before the $27^{\text {th }}$ day of April $1963 \ldots$ to be registered as a citizen of Sierra Leone." (Emphasis added). This subsection was repealed by the Constitution (Amendment) Act 1962, No.11 of 1962, and although the Sierra Leone Nationality and Citizenship Act, No.10 of 1962, dealt generally with registration and naturalisation as a citizen, this particular provision was not re-enacted. All of these amendments were deemed to have come into effect on the date of independence.

197 In Britain, meanwhile, the 1962 Commonwealth Immigrants Act introduced for the first time restrictions on immigration to Britain for citizens of former colonies. Though not explicitly racial in its language, the new provisions were aimed at non-white immigrants from the newly independent countries of Africa and the Caribbean; the effect was to leave some residents of former British colonies with no right of citizenship in any country.

198 Amos Sawyer, The Emergence of Autocracy in Liberia: Tragedy and Challenge, San Francisco: Institute for Contemporary Studies Press, 1992; Konia T. Kollehlon, "On Race, Citizenship and Property in Liberia", The Perspective, Atlanta, Georgia, 19 March 2008; Jessie Tannenbaum, Analysis of the Aliens and Nationality Law of the Republic of Liberia, American Bar Association Rule of Law Initiative, 2009. 
that person could not qualify for citizenship by birth if that person's father and grandfather were not of negro African descent. The amendments also provided that a person whose mother (but not father or grandfather) was a negro of African descent could apply to be registered as a citizen, though only on a discretionary basis. ${ }^{199}$ However, a registered citizen did not qualify to become a member of the House of Representatives or of any local elected body, unless he or she had been resident in Sierra Leone or served in the army for twenty-five years. ${ }^{200}$ Nor did the law provide how registration should be done; the new Citizenship Act did not take account of this further amendment to the constitution.

Subsequent laws restricted the rights of non-citizens to acquire property both in the Western Area (the historic Colony of Sierra Leone, comprising Freetown and the surrounding area) and in the provinces (though it did not take any right away from those non-citizens who had already purchased property in the Western Area). ${ }^{201}$ From 1965 and 1966, the government introduced successive acts restricting non-citizens' ability to own and profit from retail trade, and promoting citizen participation in commerce. In 1969 a new government introduced a further trade act that widened the scope of restrictions, barring non-citizens from trading in 38 consumer goods, rather than the eight previously listed, except by special licence from the minister. The restrictions - which to a large extent allowed money to be extorted from those affected, rather than preventing businesses operating altogether - were also extended to other Africans resident in Sierra Leone, and not just Lebanese and Europeans; affecting in particular the large community of Fula traders, many originating from neighbouring Guinea. ${ }^{202}$ Another act required all non-citizens to register their presence, and gave the government extensive powers to expel non-citizens in the interests of the "public good". 203

These legal changes took place against a turbulent political background. They were motivated not only by resentment of Lebanese and other foreign dominance of the commercial economy, but also by political considerations. In particular,

199 "Any person, either of whose parents is a negro of African descent and who would, but for the provisions of subsection (3) [requiring the father and father's father to be negroes of African origin] have been a Sierra Leone citizen, may... be registered as a citizen of Sierra Leone, but such person shall not be qualified to become a member of the House of Representatives, or of any District Council or other local authority unless he shall have resided continuously in Sierra Leone for twenty-five years after such registration or shall have served in the civil or regular Armed Services of Sierra Leone for a continuous period of twenty five years".

200 Sierra Leone Constitution (Amendment) (No.2) Act, No. 12 of 1962, section 2(b).

201 The Non-Citizens (Interests in Land) Act of 1966.

202 Non-Citizens (Restriction of Retail Trade) Act, 1965; Non-Citizens (Restriction of Trade and Business) Act, 1965; Non-Citizens (Trade and Business) Act 1969. A 1966 Act was repealed the same year. See also Alusine Jalloh, African Entrepreneurship: Muslim Fula Merchants in Sierra Leone, Ohio University Press, 1999, pp.85-86.

203 Non-Citizens (Registration, Immigration and Expulsion) Act, 1965. 
the initial aim was to narrow the set of candidates eligible to contest elections due to be held in 1962, by depriving Lebanese and mixed-race Sierra Leoneans of the political rights conferred by citizenship.

In 1964, Sir Milton Margai, leader of the Sierra Leone People's Party (SLPP) and the new state's first prime minister, died and was succeeded by his brother Sir Albert Margai. In closely contested elections in March 1967, Siaka Stevens, candidate of the All People's Congress (APC), was declared winner over Margai - only to be ousted in a coup within a few hours. A year of military rule by successive groups was ended with a return to civilian rule in 1968 under Siaka Stevens. Though further disturbances and attempted coups followed, Stevens retained power for the next seventeen years, first as prime minister and then, after a republican constitution was adopted in 1971, as president.

John Joseph Akar, a prominent mixed-race Sierra Leonean with political ambitions, became the best known case of those affected by the changes to citizenship law and the face of efforts to reverse them. Akar's mother was a black Sierra Leonean; his father was of Lebanese origin and thus not "of negro African descent", though he had never visited Lebanon. When Sierra Leone became independent on 27 April 1961, Akar automatically became a citizen by operation of the constitution, as both he and one of his parents had been born in Sierra Leone. With the 1962 amendments, however, he lost his citizenship by birth; though he did apply for and was granted citizenship by registration. He challenged the amendments in court. In his application, he contended that the true intention of the amendments was to exclude persons not of negro African descent from being elected to the House of Representatives. He succeeded in the High Court, but the Court of Appeal subsequently reversed the decision. Akar appealed to the Privy Council in England (then the highest court for Sierra Leone). In 1969 the Privy Council reversed the Court of Appeal and declared that the amendment was of no effect, though on different grounds from the judge at first instance. ${ }^{204}$

The victory was short lived. The Siaka Stevens government disregarded the judgment and re-enacted the discriminatory provisions in the Sierra Leone Citizenship Act 1973. ${ }^{205}$ The government also established its own Supreme

204 Akar v. Attorney General, Sierra Leone Supreme Court, 1967; Attorney General v. Akar, Court of Appeal Decision, 1968; Akar v. Attorney General, Privy Council Appeal No.20/68, June $30^{\text {th }}$ 1969. See African Law Reports Sierra Leone Series 1967-68; "John Joseph Akar v. Attorney General", Journal of African Law,Vol.12, No.2 (Summer 1968), pp.89-109; "John Joseph Akar v. Attorney General”, Journal of African Law, Vol.13, No.2 (Summer 1969), pp.103-116. Akar was appointed ambassador for Sierra Leone to the United States while the appeal was still pending.

205 Sierra Leone Citizenship Act, No. 4 of 1973. The 1971 Constitution did not include provisions on citizenship, except in that it repeated the exclusion of limitations on citizenship from the non-discrimination article. There was therefore a two year hiatus, before the adoption of new legislation in 1973, in which the citizenship provisions were 
Court in Sierra Leone through the 1971 constitution, removing the right of appeal to the Privy Council.

The 1973 Citizenship Act provided for two categories of citizenship: by birth and by naturalisation. Citizenship by birth was granted to anyone born in Sierra Leone before 19 April 1971, or resident in Sierra Leone on 18 April 1971, provided that his or her father or grandfather was born in Sierra Leone and he or she "is a person of negro African descent". Dual citizenship was excluded. Persons entitled to apply for naturalisation under the 1973 Act were foreign women married to citizens, other persons of negro African descent born in Sierra Leone, and persons of negro African descent continuously resident for a period of not less than eight years. ${ }^{206}$ Persons who were afro-Lebanese (i.e. those whose mothers were black Sierra Leonean but whose fathers were not "negro African") could in principle apply to be naturalised under this provision, though no procedures to do so were initially established. The 1973 Act does not define who is a negro African, relying on the 1971 Interpretation Act, which stated: "'negro African descent' used in relation to any person means that his father and paternal grandfather were African negroes", adding some extra confusion by its slight variation from the 1962 constitutional amendment. ${ }^{207}$ The presumption was that the phrase meant black African, reducing the essential condition for the acquisition of citizenship to the colour of the person's skin. Thus a black man's children by a Sierra Leonean black woman were citizens by birth wherever they are born. A white or mixed-race man's children by a Sierra Leonean woman could only acquire Sierra Leonean citizenship by naturalisation. The 1983 Births and Deaths Registration Act reinforced this discrimination by requiring the officer registering a child's birth to include the race of the child's parents in the birth certificate. ${ }^{208}$ In 1974, the constitution was amended to provide greater restrictions on access to public office by naturalised and non-negro African citizens. ${ }^{209}$

Those without a parent of negro African descent did not even have a right to naturalise until an amendment to the Citizenship Act came into force in 1977, which allowed for individuals over 21 years of age and without a parent of negro African descent to apply for naturalisation based on a residence period of fifteen years, renunciation of any other citizenship, and other criteria. ${ }^{210}$ Those under

entirely unclear.

206 Sierra Leone Citizenship Act, 1973, sections 7 and 8.

207 Interpretation Act, No.8 of 1971.

208 Act No.11 of 1983. Although the birth certificate was later amended to require the parents' nationality (rather than race) to be stated, "Lebanese" may be recorded in cases where the parents are of Lebanese origin, even though the nationality of the parents is not Lebanese. Jamesina King, Africa Discrimination and Citizenship Audit: Report on Sierra Leone, Open Society Justice Initiative, 2005.

209 Constitution (Amendment) Act, No. 6 of 1974.

210 "Every person of full age and capacity, neither of whose parents is a person of negro 
21 could apply to naturalise only if one of their parents was already naturalised: the children of naturalised citizens were issued with Sierra Leonean passports, but as soon as the children were 18 years old the Immigration Department required these passports to be returned. Persons of "negro-African descent" born in Sierra Leone, however, could apply for naturalisation at any time, with no further requirements; and those with a parent of negro African descent not born in the country could apply for naturalisation after only eight years. The minister was not required to give any reason for the refusal of any application for naturalisation and his decision on any such application could not be challenged in any court. ${ }^{211}$ The minister also had very wide powers to revoke the grant of citizenship by naturalisation. A person whose certificate is revoked ceases to be a Sierra Leonean and may be subject to expulsion. ${ }^{212}$ Naturalisation became progressively more nearly impossible to obtain, except by payment of a bribe.

The Citizenship Act was further amended in 1976 to exclude naturalised persons from holding a wider range of public offices. ${ }^{213}$ After a period of 25 years, the restrictions could be lifted; but only by parliamentary resolution passed by a twothirds majority. In 1978, a referendum approved a new constitution that did not include provisions on citizenship, but provided that a two-thirds majority would be needed to change the citizenship $l_{a w}^{214}$; it also made the country a one-party state. Despite these restrictions, Lebanese commercial interests were central to the increasing corruption and "privatisation" of the Sierra Leonean state under the Stevens government, and especially to the exploitation of Sierra Leone's important alluvial diamond industry. The trade acts were used rather as a source

African descent who is resident in Sierra Leone and has been continuously so resident for a period of not less than fifteen years may on application being made by him in the manner prescribed, be granted a certificate of naturalization if he satisfies the Minister that he is qualified for naturalization under the provisions set for the in the Third Schedule". Sierra Leone Citizenship Amendment Act, No. 13 of 1976, amending section 8(3) of the principal act. The third schedule and section 9 of the act set out requirements related to a clean criminal record, knowledge of an indigenous Sierra Leonean language, oath of allegiance, and payment of fees.

211 Sierra Leone Citizenship Act, 1973, section 24; see also Beydoun, Lebanese migration to Sierra Leone.

212 In April 1998, following the restoration of the elected government of President Kabbah, 22 people, mostly Lebanese, were expelled from Sierra Leone because of their activities during the rebel regime. See Sierra Leone Web News Archive, available at http://www. sierra-leone.org/Archives/slnews0498.htm, last accessed 19 November 2014.

213 Sierra Leone Citizenship Amendment Act, No.13 of 1976, section 8(5); Constitution (Consequential Provisions) Act, 1976. See also Constitution of Sierra Leone, 1991, article $76(1)$.

214 Constitution of Sierra Leone, 1978, Article 158: "The Provisions of the Constitution (Consequential Provisions) Act 1976 of any Act relating to Citizenship shall not be amended, repealed, re-enacted or replaced unless the Bill incorporating such amendment, repeal re-enactment or replacement is supported at the final vote thereupon by the votes of not less than two-thirds of the Members of Parliament." 
of revenue for the government than to restrict non-citizens' ability to operate businesses in practice. $^{215}$

At the same time as these amendments aimed at those who were not "negro Africans", other efforts were also aimed at restricting what was seen as the disproportionate economic and political influence of the educated Krio (Creole) elite, descendants of various groups of freed slaves landed in Freetown in the eighteenth and nineteenth centuries (and estimated to form about three percent of the population today). Since they were indisputably of "negro African descent", other means had to be found to limit their rights than restrictions on non-citizen property ownership.

The distinction between the Colony and Protectorate of Sierra Leone had existed throughout the period of British rule, creating different legal regimes and different rights and treatment of the residents of each zone, including in relation to taxation: residents of the Colony were British subjects (after 1948, citizens of the UK and colony), subject to versions of the law applied in the UK; those in the Protectorate were subject to the jurisdiction of the Native Courts, which — in the standard language also used in other British colonies — applied "native law and custom, so far as it is not repugnant to natural justice, equity and good conscience" ${ }^{216}$, particularly in matters of personal law. Legislation dating from 1927 (and still in force) drew a distinction between "natives" and "nonnatives" in relation to land-owning, aimed at preserving the control of "tribal authorities" in the interior. A "non-native" can only acquire a leasehold interest in the land in the Provinces, as the former Protectorate was renamed, subject to the approval of a "tribal authority". A "native" is still subject to tribal authority in the Provinces, but can hold and use land for any period and anywhere, including in the Western Area, the former Colony of Sierra Leone. ${ }^{217}$ "Non-natives", even if they are living outside the Western Area, are not subject to customary law. These distinctions remain relevant, and were among the resentments that led to the civil war, as the Krio elite dominated politics and the economy; just as the Americo-Liberians did in next door Liberia.

The definition of "native" went through several contortions during the 1970s, according to the drift of the political tides at any one moment. At the date of independence:

215 See the literature on "conflict diamonds"; for example, Lansana Gberie, "Sierra Leone: Diamonds, Corruption and the Lebanese Connection", Occasional Paper \#6, 2002, Diamonds and Human Security Project, Partnership Africa Canada.

216 Native Courts Ordinance, 1933, consolidated as Cap.8 Laws of Sierra Leone, 1960.

217 The Protectorate Land Ordinance, 1927, as amended, Cap.122 Laws of Sierra Leone 1960. See also Ade Renner-Thomas, Land Tenure in Sierra Leone: The Law, Dualism and the Making of a Land Policy, AuthorHouse 2010. 
"native" means any person who is a member of a race, tribe or community settled in Sierra Leone (or the territories adjacent thereto) other than a race, tribe or community -

(a) which is of European or Asiatic origin; or

(b) whose principal place of settlement is in the Colony"

"non-native" means any person other than a native. ${ }^{218}$

This definition was retained in legislation passed in 1961 and 1965 (with the substitution of Western Area for Colony, in line with new terminology). ${ }^{219}$ Although the exclusion from "native-ness" of any "race, tribe or community" whose principal place of settlement was in the Western Area could be interpreted to include the Krio, this was placed beyond doubt in 1971, when a new law added a reference to American origin to the list in subparagraph (a). ${ }^{220}$

The legislation regulating land holding in the provinces was also amended in 1972 to provide a specific definition of "non-native" in the context of land ownership in the former Protectorate. Henceforward, a "non-native", rather than simply being "any person other than a native" as generally applied, was for the purposes of land ownership in the Provinces "any person not entitled under customary law to rights in land in a Province". ${ }^{221}$

The Sierra Leone Citizenship Act of 1973 then re-amended the definition, removing the question of settlement in the Western Area, though retaining the American connection and also introducing a citizenship requirement. ${ }^{222}$ The 1976 amendments to the Citizenship Act reintroduced the exclusion for those settled in the Western Area and set the definition which is still in force as:

"native" means a citizen of Sierra Leone who is a member of a race, tribe or community settled in Sierra Leone, other than a race, tribe or community -

218 Interpretation Ordinance 1945, as amended, consolidated as Cap.1 Laws of Sierra Leone 1960.

219 Interpretation Act 1961, No.46 of 1961; Interpretation Act 1965, No.7 of 1965.

220 "'native' means any person who is a member of a race, tribe or community settled in Sierra Leone (or the territories adjacent thereto) other than a race, tribe or community - (a) which is of European or Asiatic or American origin; or (b) whose principal place of settlement is in the Western Area." Interpretation Act 1971, No.8 of 1971.

221 Laws (Adaptation) Act 1972, No.29 of 1972, amending the Provinces Land Act Cap.122 (as renamed, consequent on independence).

222 “" native' means a citizen of Sierra Leone who is a member of a race, tribe or community settled in Sierra Leone, other than a race, tribe or community which is of European or Asiatic or American origin or of mixed European and Asiatic American origin." Sierra Leone Citizenship Act, No.4 of 1973, section 29(3), amending the Interpretation Act, 1971. There is no "or" between Asiatic American in the final phrase in the version of the act published in the official gazette. 
(a) which is of European or Asiatic or American origin; or

(b) whose principal place of settlement is the Western Area. ${ }^{223}$

These word-games would in principle permit restrictions not only on the activities of Krio from the Western Area but also on other groups persistently regarded as not citizens, such as the Fula merchants seen as migrants from neighbouring Guinea rather than "settled" in Sierra Leone.

Siaka Stevens retired from office in 1985, and installed Joseph Saidu Momoh as his successor. Pulled by the tide of reform that swept across Africa with the end of the cold war, Momoh instituted a constitutional review process. A new constitution was adopted in 1991 that provided for multi-party elections but did not address the citizenship questions, endorsing the discrimination established in the citizenship acts. ${ }^{224}$

In March 1991, fighters from a group calling itself the Revolutionary United Front (RUF) entered Sierra Leone from Liberia, launching a rebellion to overthrow the APC government. The outbreak of the war brought fresh instability to Sierra Leone's politics. In 1992, Momoh was overthrown in a military coup by Captain Valentine Strasser, whose National Provisional Ruling Council (NPRC) ruled until it was itself overthrown in 1996, by his deputy, Brigadier Julius Maada Bio. Later in 1996, multi-party elections were held and won by Ahmad Tejan Kabbah, head of the SLPP, who pledged to bring about an end to the war. Peace negotiations failed, and in May 1997, President Kabbah was himself overthrown in a coup led by army major Johnny Paul Koroma, heading the Armed Forces Revolutionary Council (AFRC), which then invited the RUF to join them in the new government. Regional intervention by West African troops reinstated President Kabbah as president in March 1998. Only in 1999 was a peace agreement signed, and only in 2002, following the deployment of a large UN peacekeeping force, was the conflict finally declared over. Elections held the same year returned President Kabbah's SLPP to office for a second term.

When the NPRC took power, they launched a process to reform the 1991 constitution, with the professed aim of addressing the corruption of APC rule. Ahmed Tejan Kabbah, Solomon Berewa, and Banda Thomas (subsequently president, vice-president and minister of internal affairs, respectively) were all members of the National Advisory Council appointed to lead the review process. The draft new constitution published in 1994 proposed removing citizenship

223 Sierra Leone Citizenship (Amendment) Act, No.13 of 1976, section 3, re-amending the Interpretation Act, 1971. For a discussion of unsuccessful attempts to unify a definition of "native" in British southern and eastern Africa in the 1930s, and the differing weights given to descent and culture, see Joon-Hai Lee "The 'Native' Undefined".

224 The provisions of the non-discrimination clause in the 1991 constitution are stated not to apply to laws affecting non-citizens, registered or naturalised citizens, and laws limiting rights to citizenship. Constitution of Sierra Leone, 1991, article 27(4). 
discrimination based on race or ethnicity and granting citizenship by birth to any person born to parents who were ordinarily resident in Sierra Leone for a continuous period of fifteen years. It also provided equal rights to naturalise, due process protections for the revocation of citizenship (by naturalisation only), and excluded naturalised citizens from only the very highest offices of state. ${ }^{225}$ These reforms were never implemented, as governments came and went and civil war wracked the country during the 1990s.

With the restoration of a stable civilian government since 2002, there were some steps towards repealing the discriminatory provisions. In October 2006, a law was adopted to amend the 1973 citizenship act to remove gender discrimination in citizenship by descent. But at least one parent or grandparent still has to be "of negro-African descent", even though it can now be the "mother or grandmother" as well as "father or grandfather". ${ }^{226}$ Dual citizenship was also permitted for the first time. The strict requirements for naturalisation of those not "of negro African descent" by the new definition were, however, left unchanged. ${ }^{227}$ In 2004, the 1969 Non-citizens (Trade and Business) Act was repealed, freeing up foreign-owned business, though not addressing the underlying question of who is a foreigner. ${ }^{228}$ In 2001, the immigration department announced that, in an effort to combat corruption, all Sierra Leonean passports had to be replaced by new, machine-readable passports. ${ }^{229}$ The Law Reform Commission has also put forward proposals for a more thorough-going reform of citizenship law: the draft of a new Citizenship Act presented to the government in 2007 would finally do away with the racial and gender provisions of the existing law. ${ }^{230}$

There was reportedly a total of only about 115 naturalised citizens in Sierra Leone in 2005, almost all of Lebanese descent. ${ }^{231}$ No naturalisations were carried out under the Sierra Leone Peoples' Party government in office between 1996 and 2007, although it was alleged by the subsequent All People's Congress government that the SLPP's predecessors, the military National Provisional Ruling Council, had carried out "mass naturalisation", especially of Chinese and Korean nationals. ${ }^{232}$ Only in 2013 did President Koroma carry out the first

225 Jamesina King, Africa Discrimination and Citizenship Audit: Report on Sierra Leone, Open Society Justice Initiative, 2005.

226 Sierra Leone Citizenship (Amendment) Act, No.11 of 2006.

227 With the exception of an additional right to appeal from the minister's decision in case of deprivation of citizenship by naturalisation.

228 Article 20, Investment Promotion Act, 2004.

229 Immigration and Refugee Board of Canada, Responses to Information Requests, SLE40893.FE, 14 January 2003.

230 Draft Sierra Leone Citizenship Bill, dated 22 November 2007.

231 According to the Immigration Department in Sierra Leone, cited in King, Report on Sierra Leone. See also chapter 7.3.

232 "Immigration unveils Naturalization and Citizenship Application Forms", Awoko, 4 May 2011. 
officially reported naturalisations in perhaps 20 years, conferring nationality on British journalist Mark Doyle and around twenty others. ${ }^{233}$ Nonetheless, despite the continued racial basis of the law and popular sentiment opposing Lebanese participation in politics, both President Kabbah and President Koroma appointed ministers of partial Lebanese ancestry. ${ }^{234}$ Lebanese money remained important for the funding of political parties, even as their membership of the state remained questionable.

In 2011, the UN Human Rights Council adopted a decision on the Universal Periodic Review of Sierra Leone which included a recommendation that the government should "Urgently address, the anomaly — accepted by the Government — regarding citizenship status for residents of non-African descent". The government formally accepted the recommendation. ${ }^{235}$ However, the Sierra Leonean government had yet to table a new law in parliament by the end of 2014.

\section{Lebanese Sierra Leoneans tell their stories ${ }^{236}$}

Abraham Bamin came to Sierra Leone in the 1800s as one of the first Lebanese settlers in the country. He naturalised in his newfound home on 23 April 1907. His son Elias, born in the country, was at the forefront in the country's struggle for independence from Britain, and was jailed for his efforts. Despite his contribution, he was deprived of Sierra Leonean citizenship by the postindependence amendments to the Citizenship Act.

233 "Mark Doyle Subscribes to the oath of allegiance as Sierra Leonean", Sierra Leone presidency, 5 November 2013; “’We ExpectYou To Be Good Citizens'- President Koroma Admonishes”, Sierra Leone presidency, 11 September 2013, both available at http://www. statehouse.gov.sl/ last accessed 08 July 2014.

234 For example, Joe Blell, deputy minister of defence under President Kabbah, and John Saad, Minister of Housing and Infrastructural Development under President Koroma. "President Kabbah's Sixth Cabinet and Deputy Ministers, May 2002 - September 2007", Sierra Leone Web, at http://www.sierra-leone.org/cabinet-kabbah6.html, last accessed 20 November 2014; "Calibre of Koroma's Cabinet is Impressive So Far", Awareness Times, 9 October 2007.

235 Report of the Working Group on the Universal Periodic Review: Sierra Leone, A/ HRC/18/10, 11 July 2011, endorsed by Human Rights Council Decision 18/108, Outcome of the Universal Periodic Review: Sierra Leone, A/HRC/DEC/18/108, 18 October 2011; see also Addendum: Views on conclusions and/or recommendations, voluntary commitments and replies presented by the State under review,A/HRC/18/10/ Add.1,13 September 2011.

236 Based on text and interviews by Umaru Fofana for the Open Society Justice Initiative, Freetown, April 2008; Lila’s story extracted from Lina Beydoun, "Lebanese migration to Sierra Leone: Issues of transnationalism, gender, citizenship, and the construction of a globalized identity", PhD thesis, Wayne State University, submitted 1 January 2005. 
Elias's own son, Tommy, also born in Sierra Leone over sixty years ago, still lives in Freetown. He has not been granted citizenship. He has never been to Lebanon, does not speak a word of Arabic and speaks flawless Krio, Sierra Leone's lingua franca. Three generations on, his grown-up children can also not become Sierra Leoneans otherwise than by naturalisation. They use British passports, the country their grandfather resisted, because they cannot obtain Sierra Leonean documents.

A Lebanese lawyer opines that the legal changes and political appointments are all just a fig leaf, emphasising that "there is still legal and official xenophobia against people of Lebanese ancestry... and it will stay forever until governments become more sincere with themselves". Moreover, although the 2006 Citizenship Amendment Act has removed the gender discrimination, another member of the Lebanese community argues that nothing has changed: "It is the race clause that should be expunged from the law books."

Others complain that extortion at the hands of law-enforcement agencies is commonplace, simply because the Lebanese are perceived as non-citizens. "If we refuse to bribe law enforcement officers, we will pay far more to settle the courts", one businessman laments. His mother is a native of Sierra Leone, which under the amended citizenship law makes him a citizen by birth; but he says his skin colour still draws all sorts of prejudices against him by other citizens.

"In 2002, Lila, a second-generation Lebanese woman, who had become a naturalised citizen in 1990, applied for a new passport [under the requirement to acquire a machine-readable version]. Her application was denied because, after scrutiny, the Immigration Office found that she had naturalised "illegally" when she was over the age limit of 21 . She could not, however, have obtained naturalisation before the age of 21 , because she had to wait for her father to take the Oath [of allegiance]. To qualify for a new passport, she had to take the Oath herself, but the President at the time had suspended the process of naturalisation. On the surface, Immigration Officers seemed concerned about implementing Immigration Laws, but underlying that façade was a hidden message: By showing that the law cannot be used to facilitate renewal of the passport, the bribe expected is higher than would be if the law had applied. An Officer suggest that Lila change her birth certificate to make the nationality of one of her parents Sierra Leonean, i.e. of Negro African descent. This way, she could obtain citizenship based on the amended [law] that states that one of her parents should be Sierra Leonean at her birth. After bribing the staff, she then took her falsified birth certificate to immigration, bribed the Immigration Officer and received a new passport." 


\subsection{The Banyarwanda of Eastern Democratic Republic of Congo}

The two Congo wars, from 1996 to 1997 and from 1998 to 2003, involved most of the neighbouring countries and some further afield, ${ }^{237}$ killed perhaps hundreds of thousands of people in direct violence, may have indirectly caused the deaths of more than five million, and displaced millions more - hundreds of thousands of them across international borders. ${ }^{238}$ Civil war in the east has continued virtually unabated since then. In all this conflict, the question of who belongs to Congo and when they arrived has been one of the central issues, laying open the arguments that had already seen successive laws set the "date of origin" for Congolese citizenship variously at 1885, 1908, 1950, and 1960. The argument over who is an indigenous (autochtone) Congolese linked comparatively local disputes over resources to national and regional wars.

The DRC, with a population estimated, in the absence of any census for several decades, to be around 60 million, ${ }^{239}$ comprises several hundred ethnic groups: it is one of the most diverse countries in Africa. In North and South Kivu, among the most troubled provinces over the past fifteen years, the majority ethnic groups are the "indigenous" Nande (North Kivu), Bashi and Barega (South Kivu), with substantial minority populations made up of other "indigenes", including Batwa ("pygmy") groups, and many speakers of Kinyarwanda, the language of Rwanda. Known collectively as Banyarwanda, they are mainly Hutu, with a minority Tutsi. While Tutsi are traditionally regarded as pastoralists, and Hutu and the "indigenous" groups have been cultivators, most have always raised cattle when they can. As in many parts of Africa, disputes over land ownership and use both among and between pastoralists and cultivators have often been the trigger for wider conflict.

237 Amongst those whose troops became directly involved were Angola, Burundi, Chad, Namibia, Rwanda, Uganda, and Zimbabwe.

238 The International Rescue Committee conducted surveys of "excess mortality" in DRC, and estimated that during the period 1998 to 2007 there were 5.4 million excess deaths attributable to the war, more than two million of them after the formal end of the war in 2002: Mortality in the Democratic Republic of Congo: An Ongoing Crisis, International Rescue Committee, 2007. However, these figures were considered an exaggeration by other surveys: see Human Security Report 2009/2010: The Causes of Peace and The Shrinking Costs of War, Human Security Report Project, Simon Fraser University, Canada, "Chapter 3: The Death Toll in the Democratic Republic of the Congo". In 2003, the UN Special Rapporteur on the DRC reported 2.7 million displaced persons: Interim report of the Special Rapporteur on the situation of human rights in the Democratic Republic of the Congo, UN Doc. A/58/534, 24 October 2003. The UN High Commissioner for Refugees reported more than 600,000 refugees from DRC in neighbouring countries in 1996, reducing to 200,000 by 2005 : 2005 UNHCR Statistical Yearbook: Dem. Rep. of the Congo.

239 Population Division of the Department of Economic and Social Affairs, World Population Prospects: The 2006 Revision, United Nations, 2007. A new census was planned for 2015, but postponed till after elections could be held. 
The origins of the Banyarwanda in DRC are diverse and much argued-over. Some Congolese argue that there are in fact no indigenous Banyarwanda in Congo. However, parts of the territory that is now DRC were prior to colonisation subject to the Rwandan king and already occupied by rwandophone populations. These people (the Banyabwisha) became de facto Congolese citizens in February 1885, with the recognition of the Belgian King Leopold II's "private" Congo Free State by the Berlin Conference. In 1908 the Congo Free State was taken over by the Belgian government and became a colony of the Belgian state. In a 1910 agreement between Germany, Belgium and Britain, new borders were established, ceding some parts of what had been Congo Free State territory to the German colony of Rwanda, and other portions to the British colony of Uganda. Following the first world war, the German colonies of Rwanda and Burundi (whose language and ethnic make-up is close to that of Rwanda) were mandated to Belgium by the League of Nations in 1922, and in 1925 Belgium annexed them under the name Ruanda-Urundi to the Belgian Congo (following the second world war, these mandated territories became instead trust territories under the aegis of the United Nations). ${ }^{240}$

The Belgian colonial administration then established a policy of organised transplantation of tens of thousands of Banyarwanda, both Hutu and Tutsi, from the already densely-populated and famine-prone Rwanda and Burundi to districts in what is now North Kivu in eastern Congo (especially Masisi and Rutshuru). These transplantés, brought by the Mission d'immigration des Banyarawanda (MIB) in place from 1937 to the mid-1950s, formed a source of labour (often forced) for agricultural plantations of coffee and other export crops and for mines established by the colonial authorities. Large tracts of land were expropriated by the Comité national du Kivu both for these purposes and for national parks, a process deeply resented by local populations. In Masisi, an accord for the cession of around 350 square kilometres from the Bahunde collectivity was signed with the Bahunde chief. ${ }^{241}$ Many others migrated independently of this programme; estimates of the total number of immigrants by the time of the dissolution of the MIB ranged up to several hundred thousand, making them a very significant proportion of the population, a majority in places such as Masisi. At the same time, the colonial authorities opposed the expansion of "Tutsi" pastoralist modes of production: cattle-keeping was closely regulated, and - as a deliberate act to distinguish eastern Congo from the contemporary Tutsi hegemony in Rwanda - the colonial authorities appointed Hutu leaders as chiefs for their administrative purposes. ${ }^{242}$

240 A comprehensive history of the legal changes related to nationality is set out in Célestin Nguya-Ndila Malengana, Nationalité et citoyenneté au Congo/Kinshasa: Le cas du Kivu, Paris: L'Harmattan, 2001.

241 Jean-Pierre Pabanel, «La question de la nationalité au Kivu » Politique africaine, No.41, 1991, pp.32-40.

242 Jean-Claude Willame, Banyarwanda et Banyamulenge: Violences ethniques et gestion de l'identitaire au Kivu, Bruxelles : Institut africain (Cahiers africains No.25, March 1997) / 
One sub-group of the Banyarwanda today in DRC are for the most part descendants of Tutsi pastoralists who migrated to the area around Mulenge in what is now the province of South Kivu from Rwanda, Burundi and Tanzania; mainly in the eighteenth and nineteenth centuries, but some of them perhaps earlier. From the 1970s, this group began to use the term "Banyamulenge" (people of Mulenge) to describe themselves, as part of a conscious effort by their leaders to affirm a separate identity from other South Kivu ethnic groups in the battle to increase their influence in regional and national politics and to distinguish themselves as autochtones from other, more recently arrived, Banyarwanda. From the mid-1990s, the term Banyamulenge often came to be used to mean "Congolese Tutsi" in general. ${ }^{243}$

Since independence, the Kivu provinces ${ }^{244}$ have also taken in other Banyarwanda economic migrants as well as refugees fleeing violence in Rwanda and Burundi. In 1959, thousands of Tutsi fled to Congo during the pre-independence Hutu uprising against the prior Belgian-supported Tutsi dominance in Rwanda; and more refugees arrived in further outbreaks of violence in the early 1960s, 1973 (from Rwanda), in 1972 and 1978 (from Burundi), and in the early 1990s (from both Rwanda and Burundi), before the major influx — of hundreds of thousands - following the Rwandan genocide of Tutsi by extremist Hutu that began in April 1994. All those fleeing Rwanda after independence were Tutsi until July 1994, when Tutsi rebel forces advancing from Uganda overthrew the Hutu extremist Rwandan government and ended the genocide. The ethnicity of those crossing the border then changed, and western television screens became filled with startling images of massed Hutu refugees flooding into DRC; provoking an immediate relief effort where the genocide itself had notably failed to receive the attention it deserved.

The first law that governed nationality in Congo was an 1892 decree of King Leopold, which provided that Congolese nationality was obtained by "birth on the territory of the state of Congolese parents" as well as by naturalisation, by presumption of law and by option. ${ }^{245}$ The decree provided that children born on the territory of parents who were legally unknown or stateless were presumed

Paris : L'Harmattan, 1997 ; Nguya-Ndila Malengana, Nationalité et citoyenneté au Congo/ Kinshasa, pp.29-54 and 124-125.

243 Willame, Banyarwanda et Banyamulenge, pp.76-99 ; Koen Vlassenroot, "Citizenship, Identity Formation \& Conflict in South Kivu:The Case of the Banyamulenge", Review of African Political Economy Vol. 29 No. 93/94, 2002, pp. 499-515.

244 Except for a couple of years from 1962, when many new provinces were briefly established, there was only one Kivu Province until 1987, when it was split into North and South Kivu and Maniema.

245 «La nationalité congolaise s'acquiert : par la naissance sur le territoire de l'Etat de parents congolais, par la naturalisation, par la présomption de la loi, et par l'option ». Décret du 27 décembre 1892 sur la nationalité Congolaise (reproduced in full in Nguya-Ndila Malengana, Nationalité et citoyenneté au Congo/Kinshasa), article 1. 
Congolese, as were foundlings. ${ }^{246}$ Those born on the territory of foreign parents could opt for Congolese nationality at majority, and were presumed to have done so if resident on the territory for the three previous years. ${ }^{247}$ Naturalisation was possible by application; and in practice the Belgian authorities treated those from the neighbouring colonies of Afrique équatoriale française or Angola as Congolese after residence in Congo for more than five years. While the provisions related to unknown parents and foundlings had their origins in Belgian law at the time, the provision on children of stateless parents was an innovation for Congo. The law was broadly drafted as part of an effort to recruit as many as possible to come under the jurisdiction of the Congo Free State - where they could contribute their labour to the colonial project. Another royal decree of 1904 provided that any indigène congolais residing in the territory remained Congolese and subject to Congolese law even if he or she claimed to have acquired another nationality; a Congolese leaving the territory and in possession of another nationality must indicate that this is the case, or the obligations of Congolese nationality would remain in place. ${ }^{248}$

From 1908, the date of the transformation of the Congo Free State into the Belgian Congo, Congolese nationality no longer existed and Congolese became Belgian nationals, though deprived of the civil and political rights accorded to the white residents of the colony. The decree of 1892 remained in force for the purposes of determining nationality of those resident in the territory. As in other European colonies, residents of the Belgian Congo were firmly divided into categories, according to race and civil status. ${ }^{249}$

246 «Est congolais l'enfant né sur le sol de l'Etat de parents légalement inconnus ou sans nationalité déterminée. L'enfant trouvé sur ce sol congolais est présumé, jusqu'à preuve contraire, né sur ce sol. L'enfant naturel dont la filiation est établie pendant sa minorité, suit la condition de son père si la reconnaissance par ses auteurs résulte d'un seul et même acte ; sinon il suit la condition de celui de ses parents qui le premier l'a reconnu. » Décret sur la nationalité Congolaise, Article 4.

247 «L'enfant né sur le sol de l'Etat, d'un étranger, peut, dans l'année qui suit l'époque de sa majorité, requérir la qualité de Congolais par une déclaration expresse de son intention à cet égard. Si l'enfant a été domicilié au Congo durant l'année qui suit l'époque de sa majorité et pendant les trois années précédentes l'intention d'acquérir la qualité de Congolais est présumée exister à la fin de ce terme, sauf déclaration contraire de volonté.» Décret sur la nationalité Congolaise, article 5.

248 Nguya-Ndila Malengana, Nationalité et citoyenneté au Congo/Kinshasa, p.58-59.

249 See generally Nguya-Ndila Malengana, Nationalité et citoyenneté au Congo/Kinshasa, pp.54-73. Article 6 of the 1892 decree provided that full civil rights were enjoyed by those who had naturalised as Congolese; those whose birth or other recognition of civil status had been registered by the authorities; those who were married before the civil authorities; and those who had obtained from the authorities recognition of their entry into the registers of the civilised population" ("qui auront obtenu de l'autorité publique leur immatriculation aux registres de la population civilise." Décret sur la nationalité Congolaise, article 6). The continued existence of a Congolese nationality was, however, implied by the wording of some laws applied to the territory; see Maurice Verstraete, $L a$ 
Among these categories, the transplantés and other immigrants from RuandaUrundi had a unique status. The League of Nations mandates established over the former German territories specifically prohibited the grant of nationality en masse to the populations of the mandated territory by the relevant European power (though individual naturalisation was possible). ${ }^{250}$ The immigrants from the Ruanda-Urundi territories in Congo were themselves arguably stateless, since they had lost German nationality, but Belgium could not grant them nationality as a group; and they were given identity cards of a different type from the rest of the Congolese population; whereas immigrants from other neighbouring countries were given the same cards as Congolese. ${ }^{251}$

The lack of a new and more comprehensive law on access to Belgian nationality for those outside Belgium created real confusion on who in fact qualified to be Congolese/Belgian (exacerbated by the absence of consistency in whether those concerned were called Congolese or Belgian in other laws). The possibility of adopting a law that would formally recreate "Congolese nationality" as a type of Belgian nationality, and who exactly would qualify for it, was under debate among Belgian scholars right up to the moment when the question became irrelevant. ${ }^{252}$ The status of the Banyarwanda of eastern Congo was therefore already unclear and controversial during the lead-up to independence of what became the Republic of Congo in 1960. Unlike the situation in the French and British colonies, there was no considered period of handover (however short, and however inadequately managed by the colonial powers); rather, the Belgians retreated precipitately, as disturbances broke out in both Congo and RuandaUrundi, without adopting a legal framework to govern the transition.

In 1959, the governor-general of Congo had adopted an ordinance permitting those from Ruanda-Urundi to vote and stand for office for newly created local government structures, on the same conditions as "Congolese", if they had been resident for ten years in Congo. ${ }^{253}$ This left unclear the nationality of those concerned. The immigrant Rwandans protested the ten-year requirement; but there was heavy resistance from other ethnic groups to any grant of the right to vote to the rwandophone immigrants, whose arrival had changed the ethnic calculations among other political players. The 1960 "Brussels Round Table" that negotiated the terms of independence was held just months after the arrival

nationalité congolaise. Bruxelles : Académie Royale des Sciences d'Outre-Mer, 1959.

250 Resolution on the Nationality of B and C Mandated Territories, Council of the League of Nations, 22 April 1923; Weis, Nationality and Statelessness, pp.20-25.

251 Nguya-Ndila Malengana, Nationalité et citoyenneté au Congo/Kinshasa, pp.68-69 ; Melone, "La nationalité des personnes physiques » pp.84-85.

252 André Durieux, Nationalité et citoyenneté, Bruxelles: Académie Royale des Sciences Coloniales, 1959 ; Maurice Verstraete, La nationalité congolaise. Bruxelles : Académie Royale des Sciences d'Outre-Mer, 1959.

253 Ordonnance legislative No.25/554 du 6 novembre 1959, cited in Nguya-Ndila Malengana, Nationalité et citoyenneté au Congo/Kinshasa, p.79. 
of tens of thousands of Tutsi refugees from the pre-independence violence in Rwanda. Resolution No. 2 of the Round Table adopted in February 1960 ultimately left the determination of nationality of Congo's "inhabitants" to the law; meaning that the existing law — the 1892 decree on nationality — would remain in force for the meantime. ${ }^{254}$ A law on elections, adopted the following month, provided again, separately from the question of nationality, that Rwandan immigrants resident for ten years would be able to vote but not stand for office in forthcoming national elections. ${ }^{255}$ However, in principle the descendants of the transplantés born on the territory were citizens under the previous law, since they would either have acquired nationality on a jus soli basis as the children of stateless parents; or by presumption within a year of majority as the children of foreign parents if born on the territory and resident for three years previously.

Article 6 of the "Luluabourg" Constitution of 1964 - the first constitution of the new state and the first legal determination of nationality - declared to be "Congolese as of 30 June 1960 all persons one of whose ancestors was or had been a member of a tribe or part of a tribe established in the Congo before 18 October 1908", ${ }^{256}$ the date on which the Belgian Congo was created. This position, which radically changed the previous assumptions, was confirmed in the decret-loi of 18 September 1965, which provided for naturalisation and loss of nationality (not dealt with in the constitution), and finally also abrogated the previous law, while providing for its own entry into force to date back to the date of independence. ${ }^{257}$ No reference was made to those who had migrated prior to independence (and their descendants) and who had a status recognised by the previous law. The Banyarwanda (and others) who had migrated to Congo

254 «Le Congo, dans ses frontières actuelles, constitue à partir du 30 juin prochain, un Etat indépendant dont les habitants auront aux conditions que la loi déterminera une même nationalité sur le territoire duquel ils pourront se déplacer et s'établir librement et où les marchandises aussi pourront circuler sans entrave ». Résolution No.2 relative à l'organisation de l'Etat du Congo. The loi fondamentale (as the interim constitution of the new state was called) of 19 May 1960 stated that all laws in effect at that date remained in force until changed.

255 Loi du 23 mars 1960 ("Article 1 : Pour être électeur pour la Chambre des Représentants, il faut répondre aux conditions suivantes : 1. être de statut congolais, ou être né de mère congolaise, ou être ressortissant du Ruanda-Urundi résidant au Congo depuis dix ans au moins .... Article 10 Sont éligibles ... des personnes qui 1. sont de statut congolais ou sont nées de mères congolaises... "), cited in Nguya-Ndila Malengana, Nationalité et citoyenneté au Congo / Kinshasa, pp.80-81. See also Isidore Ndaywel è Nziem, "La nationalité congolaise à l'épreuve du séisme des Grands Lacs » in Pamphile Mabiala Mantuba-Ngoma (ed.), La Nouvelle Histoire du Congo : Mélanges euroafricains offerts à Frans Bontinck, Cahiers africains, Nos. 65-66-67, Paris : L'Harmattan, 2004, pp.407-427.

256 «Il existe une seule nationalité congolaise. Elle est attribuée, à la date du 30 juin 1960, à toute personne dont un ascendant est ou a été membre d'une tribu ou d'une partie de tribu établie sur le territoire du Congo avant le 8 octobre 1908. » Constitution of 1 August 1964, Article 6.

257 Décret-loi du 18 septembre 1965. 
after 1908 were thus not citizens of the new state; which left their status as citizens of any state uncertain, since there was no possibility for many of them of returning to their country of origin. Arguments that the presence of some Banyarwanda on Congolese territory before 1908 meant that all could claim citizenship were not accepted.

In the years after independence there were outbreaks of violence in eastern Congo and elsewhere, as the political structures and coherence of the fragile new state came under immediate stress. The southern provinces of Katanga and Kasai began secessionist struggles. The 1963 division (reversed in 1965) of existing provinces into smaller units heightened indigene-settler divides all over the country. In Kivu, it took the form of resentment of the Banyarwanda who opposed the creation of a North Kivu province, rather wishing the Banyarwanda majority territories to be attached to a proposed Central Kivu territory. ${ }^{258}$ A period of national instability and civil war followed, ended in November 1965 by a Belgian and United States-backed coup putting Joseph-Désiré Mobutu in power. During this period, a rebellion led by Pierre Mulele, formerly a minister in the cabinet of murdered prime minister Patrice Lumumba, broke out in Kivu and Orientale provinces in 1964. The Mulelist rebels espoused a variant of communist philosophy, though support for their cause from the dominant Bashi ethnic groups in South Kivu was rather based on personal and ethnic alliances than ideology; the Banyamulenge sided with the then-Congolese National Army to crush the revolt. In North Kivu, meanwhile, politicians of the "indigenous" ethnic groups mobilised supporters by labelling as foreigners even those Banyarwanda who could trace their ancestry to the Congolese side of the colonial borders from before 1908. From 1963 to 1965, fighting known as the "Kanyarwanda war" pitted the Banyarwanda (Tutsi and Hutu) of the newly created North Kivu against the indigenous Nande, Hunde and Nyanga as each group agitated for creation of new districts where they would be in control. Not insignificantly, the Kanyarwanda war centred on Masisi, the location of the largest number of Banyarwanda transplantés. Even before the war broke out, Banyarwanda were accused of obtaining fake Congolese identity documents in order to participate in the planned referendum that would vote on the creation of the new provinces; meantime, indigenous Hunde lost no time in replacing Banyarwanda in all notable administrative positions. In October 1965, the North Kivu authorities adopted a "résolution-loi" directed at the expulsion of all Banyarwanda for "collusion with the rebels"; various Banyarwanda leaders were arrested and transferred to Leopoldville (the future Kinshasa). ${ }^{259}$ The nationality

Willame, Banyarwanda et Banyamulenge, p.48

259 Willame, Banyarwanda et Banyamulenge; Frank van Acker, « La « Pembenisation » du HautKivu : Opportunisme et droits fonciers revisités ", in L'Afrique des grands lacs Annuaire 19981999; Stephen Jackson, "Sons of Which Soil? The Language and Politics of Autochthony in Eastern D.R. Congo", African Studies Review Vol.49, No.2, 2006, pp. 95-123; Angele N. Makombo, "Civil Conflict in the Great Lakes Region:The Issue of Nationality of the 
provisions of the constitution of 1964 and décret-loi of 1965 were drafted amidst these disturbances, before the assumption of power by Mobutu, and played their own role in heightening tensions.

Following Mobutu's accession to power and the end of active hostilities, a commission of inquiry was then sent by the central government to Kivu province to inquire into the vexed question of the nationality of the Banyarwanda. The Tewen Commission presented its report in October 1966, and classed the Banyarwanda of the Kivus into four categories, of which only members of the first were considered Congolese: (1) those who freely immigrated from the $17^{\text {th }}$ century and were present on the territory as of 1885; (2) fugitives from famine and political disturbances in Rwanda who arrived between then and around 1918; (3) the transplantés brought by the Belgians as labour; (4) the refugees of 1959 following the deposition of the Rwandan king during the independence of Rwanda (of which others went to Tanzania or Uganda). ${ }^{260}$ This interpretation became the dominant official view on those who were entitled to be Congolese, albeit with some variation on dates of origin between 1885 and 1908.

A new constitution was adopted in 1967 that stated that the law would provide for nationality, leaving in place the rules of the 1964 constitution and the décretloi of 1965 (1974 and 1978 revisions did not affect these provisions). ${ }^{261}$ However, under the influence of powerful Banyarwanda close to Mobutu, including Barthélémy Bisengimana, a Tutsi from North Kivu appointed to be director of the president's office from 1969 and thus a figure of power in the government, laws were adopted to favour the position of the Banyarwanda. ${ }^{262}$ Mobutu's party, the Mouvement Populaire de la Révolution (MPR) created in 1967 and merged with state structures so that they became indistinguishable, recognised the Banyarwanda of Masisi (forming "85 percent of the inhabitants of the region") as citizens of right, and confirmed — perhaps more significantly — their chief as the administrative authority of their territory. This recognition was argued to be justified by their contribution to the development of the region through their labour, and the fact that the Belgians had brought them against their will, and then recognised them as equal to other inhabitants on the eve of independence. ${ }^{263}$

Banyarwanda in the Democratic Republic of the Congo", African Yearbook of International Law, Vol.5, 1997, pp.49-62.

260 Nguya-Ndila Malengana, Nationalité et citoyenneté au Congo/Kinshasa, pp.40-41 and 91.

261 Constitution du 24 juin 1967, Article 46 : « La loi fixe les règles concernant [...] La nationalité, l'état et la capacité des personnes, les régimes matrimoniaux, les successions et les libéralités ; ... » Article 49 : «La loi électorale, la loi sur la nationalité et les lois auxquelles la présente Constitution confere le caractère de lois organiques ne sont adoptées par l'Assemblée nationale qu'à la majorité absolue de ses membres. Elles sont modifiées dans les mêmes conditions."

262 Willame, Banyarwanda et Banyamulenge, pp.53-55.

263 Nguya-Ndila Malengana, Nationalité et citoyenneté au Congo/Kinshasa, pp.96-98, quoting the minutes of a meeting of the Bureau politique of the MPR, 29 July 1970 and 
An ordinance-law adopted in 1971 by Mobutu specifically addressed the situation of persons originating from Rwanda and Burundi, providing that if they were established in Congo before 30 June 1960 they had Congolese nationality. ${ }^{264}$ In 1972, a general nationality law voted by parliament soon after the change of the country's name to Zaire first reaffirmed the basic principle of the 1964 constitution based on date of arrival before 1908, but, after hearing from Bisengimana on the decision of the MPR, provided an exception for persons originating from Rwanda or Burundi who had taken up residence before 1 January 1950. ${ }^{265}$ These highly controversial laws thus aimed to give citizenship by origin to those Banyarwanda who had arrived in the country after 1908 (though the 1972 law would exclude only the Tutsi refugees of 1959, no subsidiary legislation implementing the 1972 law was adopted). In principle the collective naturalisation of the Banyarwanda by this process would completely change the balance of political power in North Kivu: in Masisi, according to the 1970 census, out of a total population in the Masisi district of 273,920, 193,428 were "foreigners". 266

At the same time, Bisengimana favoured his ethnic group in official appointments, using the process of "zairianisation" of the civil service and economy for this purpose; while an equally controversial land law was adopted in 1973 and used to benefit Tutsi elites at the expense of more traditional forms of land-holding: most of the colonial-era plantations in the Kivus confiscated from Europeans then ended up in Banyarwanda hands. The increasing corruption of the state meant that national identity cards were easily available for those who could buy them, even if they did not fulfil the provisions of the newly generous law. It was during this period that the question of the status of the Banyarwanda in general and Tutsi in particular, and their access to land, was elevated from a regional preoccupation to an issue of general national concern. ${ }^{267}$

Bisengimana's address to parliament.

264 "Les personnes originaire du Ruanda-Urundi établies au Congo à la date du 30 juin 1960 sont réputées avoir acquis la nationalité congolaise à la date susdite. » Ordonnanceloi no.71-020 du 26 mars 1971 rélative à l'acquisition de la nationalité congolaise par les personnes originaires du Ruanda-Urundi établies au Congo au 30 juin 1960, seul article.

265 Loi no.72-002 du 5 janvier 1972 relative à la nationalité zaïroise : Article 1 : «Il existe une nationalité zaïroise. Sont zä̈rois ... à la date de 30 juin 1960 toute personne dont un des ascendants est ou a été membre d'une des tribus établies sur le territoire de la République du Zaïre dans ses limites du 15 novembre 1908 et telle que modifiées par les conventions ultérieures. » Article 15 : « Les personnes originaires du Ruanda-Urundi qui étaient établies dans la province du Kivu avant le $1^{\text {er }}$ janvier 1950 et qui on continué à résider depuis lors dans la République du Zaïre jusqu'à l'entrée en vigueur de la présente loi on acquis la nationalité zaïroise à la date du 30 juin 1960."

266 Willame, Banyarwanda et Banyamulenge, p.54, citing 1970 census figures quoted in Léon de Saint Moulin Atlas des collectivités du Zaire, Kinshasa : Presse universitaire du Zaire, 1976.

267 The 1973 Loi foncière - which is still in force - greatly enhanced state control over land and thus allowed for award of land to favoured individuals for political reasons; van Acker, 
Bisengimana fell from power in February 1977, perhaps after one too many accusations of personal benefit from his activities. The nationality question immediately returned to the table, with a series of memoranda and countermemoranda addressed to Mobutu as head of state. A commission of inquiry was appointed to look into the issues, composed of members of the central committee of the MPR. In 1981, a new code of nationality was adopted by the Zairian parliament which reversed the changes of the 1970 s, created the most exclusionary rules yet implemented, and effectively denationalised a large segment of the Banyarwanda population. Law No.2 of 29 June 1981 provided nationality only for "any person one of whose ancestors was a member of one of those tribes established in the territory of the Republic of Zaire as defined by its frontiers of 1 August 1885", the date on which the borders of the Congo Free State were officially recognised. ${ }^{268}$ This law took the date at which an ethnic group could claim to be "indigenous" back to its furthest yet; though it did allow a Congolese woman married to a foreigner to transmit her nationality to her child. The law also provided that the grant of nationality could be only individual and not collective (thus cancelling the provisions of the law of 1972 relating to the Banyarwanda), and that those naturalised were subjected to significant constraints in relation to the holding of political office for a period of fifteen years. Individual naturalisation had in any event been rarely granted: only 28 cases could be traced in the period 1973 to 1993 by Célestin NguyaNdila Malengana in his comprehensive consideration of nationality issues in Congo. ${ }^{269}$ In implementation of the law, a 1982 ordinance explicitly annulled the certificates of nationality issued under the law of 1972, leaving these people stateless unless they applied for naturalisation; it made use of such a certificate punishable by six months of penal servitude. ${ }^{270}$

Although some of the Banyarwanda could trace the arrival of their ancestors to a date preceding 1885, proof was difficult to establish and in practice they were treated as denationalised: they were prevented from participating in local elections during the 1980s, and many were expelled. ${ }^{271}$ At the same time, however,

"La « Pembenisation » du Haut-Kivu »; Stanislas Bucyalimwe Mararo, "Land, Power, and Ethnic Conflict in Masisi (Congo-Kinshasa), 1940s-1994", International Journal of African Historical Studies, Vol. 30, No. 3, 1997, pp.503-538; José Mvuezolo Bazonzi, "Crise identitaire et lutte de leadership dans la région des grands lacs : Lecture des principaux conflits fonciers et armés du Kivu 1900-2005”, in Bahru Zewde (ed.) Society, State, and Identity in African history, Addis Ababa: Forum for Social Studies, 2008, pp.218-230.

268 "Est zaïrois ... à la date du 30 juin 1960 toute personne dont un des ascendant est ou a été membre d'une des tribus établies sur le territoire de la République du Zaïre dans ses limites du $1^{\text {er }}$ août 1885 , telle que modifiées pas les conventions subséquentes ». Loi No.81-002 du 29 juin 1981, article 4.

269 Nguya-Ndila Malengana, Nationalité et citoyenneté au Congo/Kinshasa, p.112.

270 Ordonnance No.82-061 of 15 May 1981, quoted in Nguya-Ndila Malengana, Nationalité et citoyenneté au Congo/Kinshasa, pp.99-100.

271 Uganda also displaced a large number of Banyarwanda in the early 1980s, including some 
a Banyarwanda elite still held wealth and land amassed from official patronage during the 1970s, an economic dominance that continued to fuel resentment of their position and enabled them to get past the rules that supposedly now applied. It was even alleged that powerful individuals from or even based in Rwanda acquired land and used the local Banyarwanda or imported Rwandans as labour; many were alleged to have documents showing nationality of both countries. Local elections scheduled for 1987, then postponed to 1989, were never held in North Kivu, due to the impossibility of identifying who was entitled to vote. ${ }^{272}$

During the early 1990s, the regime of Joseph-Désiré Mobutu weakened under international pressure and the end of United States support to his government with the end of the Cold War, and he was forced to agree to the creation of a "sovereign national conference" (Conférence nationale souveraine, CNS) to debate the future structures of government in what was still Zaire. The prospect of elections and new political arrangements encouraged ethnic mobilisation to control political space, using the language of autochthony where it was useful, or simple political deal-making where it was not: alliances formed and reformed in different locations according to local politics. A 1991 population census to identify and register citizens in advance of anticipated elections contributed to the raising of tensions, since the voting power of the Banyarwanda, if recognised as nationals, would have a significant effect on the electoral outcomes. ${ }^{273}$ Ultimately, Banyarwanda were largely (though not completely) excluded from the sovereign national conference itself, as a Commission de verification et de validation des mandats de la CNS refused to recognise delegates decided to be representing "foreigners"274; though a stipulation that delegates should be "indigenous" also affected other ethnic groups straddled between provinces within Zaire's borders (such as "Kasaians" in Shaba Province). A sub-commission of the national conference adopted a report proposing four categories of Banyarwanda - autochtones (from before 1885), transplantés, refugees, and clandestins (undocumented immigrants) — with only the first entitled to citizenship. ${ }^{275}$ The final text adopted by the CNS on nationality was more moderate, however, recommending an approach that "preserved the integrative vocation of the Congolese state" while "avoiding the creation of statelessness that would put our country among the ranks of human rights violators". ${ }^{276}$

40,000 people who claimed Ugandan citizenship and 31,000 people registered with UNHCR as refugees, forcing most of them to seek refuge in Rwanda. See Rutinwa, "The end of asylum", p.6.

272 Willame, Banyarwanda et Banyamulenge ; Pabanel, «La question de la nationalité au Kivu ».

273 Stanislas Bucyalimwe Mararo, "La guerre des chiffres: Une constante dans la politique au Nord-Kivu”, L'Afrique des Grands Lacs Annuaire 1999-2000.

274 Willame, Banyarwanda et Banyamulenge, pp.62-63.

275 Jackson, "Sons of Which Soil?".

276 "La question délicate de la nationalité à été abordée avec les précautions qui s'imposent pour à la fois concilier le souci de préserver au Congo sa vocation de pays intégrateur, métissé sans ostracisme outrancier d'aucune sorte, et celui de faire respecter les lois 
As these debates were going on in Kinshasa, the politics of Rwanda and Burundi also impacted dramatically and negatively on the situation in the east. The Uganda-based Rwandan Patriotic Front (RPF) began its military campaign to overthrow the Hutu-controlled and discriminatory Rwandan government in 1990, and also organised and recruited among the Congolese Tutsi. Meanwhile, the Rwandan government similarly formed links with and supported Hutu groupings within Congo's eastern provinces. In October 1993, a Tutsi-led coup in Burundi accompanied by massacres sent thousands of Hutu refugees across the borders.

In March 1993, the already tense situation escalated from occasional confrontations into generalised violence in North Kivu. Electoral arithmetic, coupled with tensions over land use, had generated a coalition of "indigenous" groups (led by the largest, the Nande) and Tutsi against the Hutu, especially in Masisi, where Hutu were the majority. The "Masisi war", in which the provincial authorities encouraged attacks on Hutu in the region, began a process of "ethnic cleansing" that has continued to date, with previously mixed-ethnicity communities becoming exclusively Hutu, Nande, Hunde, Nyanga, Tutsi and so on. But the configuration of ethnic conflict was not fixed. In some areas, the Tutsi fought as part of a general Banyarwanda group; in others Hutu (describing themselves as autochtones) attacked Tutsi, in yet others they were outside the local conflict. In the short term, the Masisi war caused political damage to the Nande, as Governor Jean-Pierre Kalumbo Mbogho, a Nande, was removed from office in July 1993; to the profit of the Tutsi. ${ }^{277}$

Hostilities had hardly begun to die down under efforts to negotiate peace, symbolised by the arrival of Mobutu in the region with his presidential guard, when, from April 1994, the Rwandan civil war and genocide spilled over into Zaire. Rwandan Hutu extremists murdered nearly one million Rwandan Tutsi and Hutu who opposed the policy, in a government-organized campaign of violence that was unleashed just as negotiations to end the increasingly powerful RPF rebellion had seemed to reach a conclusion. First Rwandan Tutsis, and then, following the military success in Rwanda of the Tutsi-dominated RPF, several hundred thousand Hutus, including both innocent civilians and perpetrators of the genocide, fled across the border. They were then held in refugee camps placed largely among local Hutu communities, thus further blurring the distinction between Congolese and Rwandan Hutu and potentially drastically altering the ethnic calculus of regional politics.

nationales en matière d'immigration, de résidence ou de naturalisation, tout en évitant de plonger des catégories de citoyens dans l'apatridie qui mettrait notre pays au banc des pays violateurs des droits de l'homme ". Final report of the travaux of the conference, cited in Willame, Banyarwanda et Banyamulenge, p.63.

277 Stanislas Bucyalimwe Mararo, "Le Nord-Kivu au cœur de la crise congolaise", L'Afrique des Grands Lacs Annuaire 2001-2002. 
Hutu militia continued their violence against Zairian Tutsi after crossing the border, and divisions between Zairian Tutsi and Hutu were stirred into renewed violence. In some cases, Hunde, Nande and Nyanga militia joined with Hutu interahamwe militia from the Rwandan genocide to attack Tutsi Banyarwanda; elsewhere Hutu militia attacked the "indigenous" groups. Zairian government forces either stood by or actively assisted the Hutu militia in this violence against Tutsi, including by providing weapons; but other official comments supported "indigenous" groups in efforts to expel all Banyarwanda. Tens of thousands of Tutsi people moved from Congo to Rwanda during late 1994 and 1995, mainly chased from their lands in the Masisi area, and their cattle stolen or killed. ${ }^{278}$

On 28 April 1995, the transitional parliament (le Haut Conseil de la RépubliqueParlement de transition) adopted a "resolution on nationality" describing all Banyarwanda, including groups such as the Banyamulenge and Banyabwisha who claimed autochthony, as foreigners "who have acquired Zairian nationality fraudulently". The resolution included a list of people to be arrested and expelled, the cancellation of any sale or transfer of assets, the replacement of existing governors and commanders with new officials, and the removal of all "Rwandan and Burundian refugees and immigrants", but also other foreigners, from all administrative and other posts. ${ }^{279}$ This resolution led to a challenge in the Supreme Court by two members of the transitional parliament, Mutiri Muyongo and Kalegamire Nyirimigabo, requesting that it set aside a decision to exclude them on grounds of doubt about their nationality. The court annulled the decision of the transitional parliament on both procedural and substantive grounds, ruling that the Congolese nationality of the two parliamentarians was sufficiently proved by the certificates of nationality or identity cards that they had obtained from the Ministry of the Interior; though it declined to award any damages. ${ }^{280}$

278 Human Rights Watch, Forced to Flee: Violence Against the Tutsis in Zaire, July 1996, citing UNHCR.

279 " $[\mathrm{L}]$ 'annulation de tout acte de vente, d'acquisition ou d'attribution de titres fonciers ou immobiliers au bénéfice des immigrés et transplantés ayant acquis frauduleusement la nationalité zairoise ainsi que tout acte de nomination de réfugiés et immigrés rwandais et burundais dans les fonctions publiques". Le Haut Conseil de la Republique - Parlement de Transition, "Résolution sur la nationalité", Kinshasa, 28 April 1995, cited in NguyaNdila Malengana, Nationalité et citoyenneté au Congo/Kinshasa, p.101; and in Jackson, "Of 'Doubtful Nationality". See also "Briefing on the conflict in South Kivu", IRIN, 10 July 1996.

280 Mabanga Monga Mabanga, Le contentieux constitutionnel congolais, Editions Universitaires Africaines, Kinshasa, 1999, pp.56-58. The 1965 and 1972 nationality laws required that evidence of Congolese nationality must include "proof of all the conditions established by the law." However, a court could also take into account "weighty, precise and corroborating presumptions" (présomptions graves, précises et concordantes) as evidence of nationality, drawing inferences from known to unknown facts. This provision was not included in later versions of the law (neither that of 1981, which set the date of ethnic qualification for citizenship 
Those without the status of parliamentarians were not so fortunate. In South Kivu, the district commissioner of Uvira ordered in September 1995 an inventory of all property and land owned by the Banyamulenge. Evictions of South Kivu Banyamulenge from their homes became common, as were deportations to Rwanda or Burundi, escalating during 1996. Ultimatums were issued for the Banyamulenge to leave the country, and slogans adopted supporting ethnic cleansing: "Opération rendre les rwandais au Rwanda"; "Bukavu et Uvira villes propres". ${ }^{281}$ In early September, "indigenous" ethnic militia, supported by government soldiers, began attacking Banyamulenge villages, killing and raping, and forcing survivors to flee. On 8 October 1996 the deputy governor of South Kivu decreed that all Banyamulenge must relocate to temporary camps within a week. On 31 October 1996, the transitional parliament announced the expulsion of Rwandan, Burundian and Ugandan nationals. Scores of Banyamulenge were arrested and reports of executions and disappearances were widespread.Violence against Tutsi escalated throughout the eastern regions and many more refugees fled over the borders; many had their Zairian identity cards confiscated by guards at the border and destroyed. ${ }^{282}$

In response to these physical and rhetorical attacks on their presence in Congo, from around September 1996 the South Kivu Banyamulenge organised and armed themselves both to rebel against the central government and to defend themselves from the militia now operating in their territory; allegedly including some who had returned from fighting with the Rwandan army. ${ }^{283}$ In midOctober four groups (including both Banyamulenge and other indigenous ethnic groups) came together in an alliance of convenience to form the Alliance des Forces Démocratiques pour la Libération du Congo-Zaïre (AFDL). This became the catalyst for a regional war in which the AFDL rebels, who came to be led by Laurent-Désiré Kabila, a former Lumumbist originally from Katanga, were backed by both Rwanda and Uganda, whose troops crossed the border into Zaire in late 1996, and later by Angola. The Rwandan government stated that it was seeking to eliminate the organised Hutu militia that still raided into Rwanda

as 1885 , nor its replacement of 2004), which state only that evidence of nationality is provided by an official certificate of nationality supplied by the correct state authority.

281 "Operation return the Rwandans to Rwanda"; "Bukavu and Uvira clean cities": from Declaration de la communauté banyamulenge à la conference sur la paix, la sécurité et le développement au Nord et au Sud Kivu, January 2008 (copy obtained by author at the meeting).

282 For the sequence of events, see reports by Human Rights Watch: Rearming with Impunity: International Support for the Perpetrators of the Rwandan Genocide, May 1995; Forced to Flee: Violence Against the Tutsis in Zaire, July 1996; Zaire: 'Attacked By All Sides', March 1997; Zaire: Transition, War and Human Rights, April 1997; What Kabila is Hiding: Civilian Killings and Impunity in Congo, October 1997; Transition and Human Rights Violations in Congo, December 1997.

283 Willame, Banyarwanda et Banyamulenge, pp.93-94 ; Human Rights Watch, What Kabila is Hiding. 
from the refugee camps in Zairian territory, while also mobilising ideas of a "Greater Rwanda"; though Congolese largely regarded this argument as simply an excuse for Rwandan violation of Congolese territorial sovereignty and extraction of Congolese resources. By late 1996 a large percentage of the Hutu refugees had been driven back into Rwanda; AFDL soldiers were responsible for extensive and systematic massacres in this process. The rebels eventually ousted President Mobutu from power in May 1997 and installed Kabila as president in Kinshasa; as well as instituting their own administration in much of the east. The country was renamed the Democratic Republic of Congo. ${ }^{284}$

Kabila's support among the Banyamulenge was effectively ended in August 1998 when he decided to expel Rwandese and Ugandan contingents from his army. A new and even more deadly war broke out in the east, in which the rebel Rassemblement Congolais pour la Démocratie-Goma (RCD-Goma), with the active backing of Rwanda, stated that it championed the cause of the Banyamulenge and Congolese Tutsi more generally. Among the disputed objectives of the RCD-Goma during the war (and in the negotiations that ended it) was the establishment of the specific administrative territory of Minembwe, where Banyamulenge would be in the majority. ${ }^{285}$ Rwanda itself again sent troops across the border, again justifying its presence in DRC as self-defence, as well as part of an effort to protect the Banyamulenge communities. ${ }^{286}$ Kabila also armed both "Mai-Mai" and Congolese Hutu militia in response to the Rwandan army's supply of weapons to RCD-Goma. ${ }^{287}$ In 1999, the nationality law of 1981 was reaffirmed, replacing the name Zaire with that of Congo. ${ }^{288}$

284 Human Rights Watch, What Kabila is Hiding; United Nations, Report on the Situation of Human Rights in Zaire by the Special Rapporteur, Mr. Robert Garretón, in accordance with Commission resolution 1996/77, UN Doc. E/CN.4/1997/6/Add.1; Emmanuel Lubala Mugisho, "La situation politique au Kivu:Vers une dualisation de la societé", L'Afrique des Grands Lacs Annuaire 1997-98, pp.307-333 ; Jean-Claude Willame, "Kivu : La poudrière » in Colette Braeckman et al. Kabila prend le pouvoir, Brussels : Groupe de recherche et d'information sur la paix et la sécurité (GRIP), 1998, pp.31-46.

285 The territory was in fact created by a departmental arrêté (No.001/MJ/DAT/MB/ ROUTE/1999) in September 1999, though of shortlived legal validity. Cited in PaulRobain Namegabe Rugarabura, "Traditional Chieftaincy and Decentralisation in the Democratic Republic of Congo: Opportunities and Challenges", Unpublished PhD thesis, Libera Università Internazionale degli Studi Sociali, Rome, October 2008. See also International Crisis Group, Understanding Conflict in Eastern Congo (I): The Ruzizi Plain, Africa Report N²06, 23 July 2013.

286 In early 2002, RCD-Goma officer Patrick Mazunzu rejected the rebel movement's authority and took many supporters with him, causing a continuing split in the Banyamulenge community. RCD-Goma troops tried unsuccessfully to suppress Masunzu's group. Rwandan government soldiers then joined in attacking the Banyamulenge, a people whose security had once been a pretext for the Rwandan army presence in Congo. See Human Rights Watch, World Report 2003: Democratic Republic of Congo, New York, 2003.

287 Human Rights Watch, Rearming with Impunity; Forced to Flee.

288 Décret-loi no.197 du 29 janvier 1999. 
For the Tutsi Banyarwanda of eastern Congo, including the Banyamulenge, the consequence of these events was that - whatever the reality for each individual and despite the claims to autochthony of the Banyamulenge in particular they were presumed by the Zairian/Congolese government and many of its people to be supporters of the Rwandan invaders and of the armed groups that the Rwandans were backing. The fact that Banyarwanda refugees often fled to Rwanda or Burundi for safety seemed to confirm conspiracy theorists' views that their true loyalties were over the border. Illegal extraction of Congo's resources by foreign interests - whether Rwandan, Ugandan or from further afield - increased the general resentment of "non-indigenous" involvement in the region. Hate speech leaflets multiplied denouncing Banyarwanda invaders and their puppets who allegedly sought to assert the domination of central African Tutsi (or Banyarwanda in general; the categories slip). ${ }^{289}$ In 1998, hate speech was particularly virulent: among other official statements, Foreign Minister Abdulaiye Yerodia Ndombasi publicly asserted that Tutsi were "vermin" worthy of "extermination", allegedly leading directly to massacres of those targeted. ${ }^{290}$

After the assassination of Laurent-Désiré Kabila in January 2001, his son Joseph took over power. Joseph Kabila quickly began steps to end the war, and peace meetings were held in Lusaka, Zambia and Sun City, South Africa, culminating in a "global and all-inclusive agreement on the transition in the DRC" signed on 17 December 2002. A transitional government was formed in 2003, and elections held in 2006. The transitional constitution negotiated at Sun City provided, as a critical element of the effort to find a permanent solution to the discrimination that had contributed to the recent wars, that "The ethnic groups and nationalities whose representatives and territories made up what became the Congo at independence should enjoy equal rights and equal protection of the law as citizens." 291

Nonetheless, violence among Banyarwanda populations and the "indigenous" groups continued in North and South Kivu provinces, and between the supposedly newly integrated armed forces (Forces Armées de la République

289 The discredited colonial-era "Hamitic hypothesis" in which "Nilotic" pastoralist invaders were said to have dispossessed Bantu cultivators throughout much of east and central Africa, still has much currency in the discourse of difference today, despite the lack of evidence to support it. For a discussion, see Edith R. Sanders, "The Hamitic Hypothesis: Its origin and functions in time perspective", Journal of African History, Vol.10, No.4, 1969, pp.521-31; Jan Vansina, Paths in the Rainforest : Towards a History of Political Tradition in Equatorial Africa, London: James Currey 1990.

290 Prosecutors in Belgium issued a international arrest warrant for Yerodia in 2000 in connection with these statements, accusing him of breaches of the Geneva Conventions and crimes against humanity (in 2002 the International Court of Justice ruled that Belgium had violated international law in issuing the warrant against a serving minister). See Pieter H.F. Bekker, "World Court Orders Belgium to Cancel an Arrest Warrant Issued Against the Congolese Foreign Minister”, ASIL Insights, February 2002.

291 Constitution de la Transition, 5 April 2003, article 14. 
Démocratique du Congo, FARDC) and dissidents who refused to accept the settlement and rejected the government's control over the eastern parts of DRC. ${ }^{292}$ Among those who returned to the bush were two officers of the RCDGoma, General Laurent Nkunda (a Tutsi from North Kivu) and Colonel Jules Mutebusi (a member of the Banyamulenge community). During 2004, thousands of settlers from Rwanda crossed the border into DRC with Rwandan military support, and cleared land for farming in the Virunga National Park, a UNESCO World Heritage Site. Though the Rwandan government alleged the operation was defensive, reports suggested that influential Rwandan businessmen intended to reap financial benefit from the new agricultural land. ${ }^{293}$ Oil exploration also heated up in the region following the signing of memoranda of understanding between Heritage Oil and the Congolese and Uganda governments in 2002, creating higher stakes for control of territory. ${ }^{294}$

In November 2004, a new nationality law was adopted, after heated debate in the transitional parliament, which returned the foundation date for nationality to 1960, as it had been in the decree of 1971. But this law still founded Congolese nationality on ethnicity, rather than on birth, residence or other objective criteria, giving nationality by origin to "every person belonging to the ethnic groups and nationalities of which the individuals and territory formed what became Congo at independence." 295 No further guidance was given on which ethnic groups are included in this description. (Moreover, the upper house of parliament (the Senate) did not approve this critical article; though under the transitional constitution the views of the lower house took precedence.)

A law on electoral registration, meanwhile, provided for a range of different forms of proof of nationality, including, in the absence of any form of documentation,

292 After the entry into force in 2002 of the treaty establishing an International Criminal Court, the Kabila government referred the situation in the DRC to the ICC; several cases are under investigation from Ituri Province, north of the Kivus, in relation to atrocities committed by different ethnic militia (including Tutsi militia) as well as the army, and arrest warrants issued. Updates on the investigation into the situation in DRC are available on the website of the International Criminal Court, http://www.icc-cpi.int, accessed 3 September 2014.

293 Stefan Lovgren, “'Gorillas in the Mist'Park Slashed by Squatters”, National Geographic News, 12 July 2004; Finbarr O'Reilly, "Mountain gorilla region under threat”, The Scotsman, 23 August 2004; see also C. Nellemann, I. Redmond, and J. Refisch (eds). The Last Stand of the Gorilla - Environmental Crime and Conflict in the Congo Basin. A Rapid Response Assessment, UN Environment Programme, 2010, and other information at the website for the Great Apes Survival Project, at http://www.un-grasp.org/ accessed 3 September 2014.

294 International Crisis Group, Black Gold in the Congo: Threat to Stability or Development Opportunity? Africa Report N¹88, 11 July 2012.

295 «Est Congolais d'origine toute personne appartenant aux groupes ethniques et nationalités dont les personnes et le territoire constituaient ce qui est devenu le Congo (présentement la République Démocratique du Congo) a l'indépendance. " Loi nº4/024 du 12 novembre 2004 relative a la nationalité congolaise, article 6. 
the testimony of five witnesses who had already been registered and were resident for at least five years in one constituency. ${ }^{296}$ Although this process did not define citizenship on an ethnic basis, de facto discrimination remained pervasive. Many still argued that because the Banyarwanda are not regarded as having a "territory" within Congo, they were not included within the 2004 law; meanwhile, the failure of the Congolese state to recognise Banyarwanda "customary" claims to land remained one of the principal complaints of the Banyarwanda themselves.

A referendum in December 2005 overwhelmingly approved a new constitution, which came into force in 2006. Article 10 again recognises members of ethnic groups who were present in the territory of the state at the time of independence in 1960 as nationals of origin of the DRC. ${ }^{297}$ The 2004 law remained in effect, with the new constitution providing an intended final settlement of the question of which groups are to be considered indigenous. In theory, the great majority of Banyarwanda should be included within these groups, but the wording of the law left a dangerous level of ambiguity in its interpretation. The rights of naturalised citizens were also substantially improved in the same legal reforms, and exclusions of naturalised citizens from public office - which had been extremely broad - restricted to only the very highest posts. The law excluded from naturalisation people who are guilty of economic crimes or have worked for the profit of a foreign state, common accusations against the Banyarwanda.

Dual nationality remains prohibited under the law, though in early 2007 the newly elected National Assembly hastily adopted a resolution purporting to bring in a six-month moratorium on the enforcement of the provision, after it emerged that a large number of politically important (and non-Banyarwanda) members of the Assembly in fact held two passports. A special committee was appointed to propose a solution to the problem. ${ }^{298}$

In the context of the continued weakness of the central Congolese state and the presence of massive natural resources in eastern Congo, the temptation to

296 Loi n 04/028 du 24 decembre 2004 portant Identification et enrôlement des électeurs en République Démocratique du Congo, article 10 : «Pour justifier l'identité et l'âge de l'électeur, sera prise en considération l'une des pièces ci-après: le certificat de nationalité ou l'attestation tenant lieu de certificat de nationalité ; la carte d'identité pour citoyen ; le passeport national ; le permis de conduire national sécurisé ; le livret de pension congolais délivré par l'Institut National de Sécurité Sociale ou par toute autre institution congolaise légalement reconnue en tenant lieu ; la carte d'élève ou d'étudiant ; la carte de service. A défaut de l'une ou l'autre de ces pièces, sera pris en considération le témoignage fait devant le bureau du Centre d'Inscription par cinq témoins déjà inscrits sur la liste des électeurs du même Centre d'Inscription et résidant depuis 5 ans au moins dans le ressort du centre d'inscription. "

297 Constitution de la République démocratique du Congo, 2006. However, the constitution did not repeat the term "nationalités" from the 2004 law.

298 "Un moratoire accordé aux personnes concernées par la double nationalité ", Agence Congolaise de Presse, 13 February 2007. 
manipulate the ethnic and citizenship issues for political or economic gain is likely to remain irresistible to some. In May 2006, during the election campaign, AbdoulayeYerodia, by then one of Congo's four vice-presidents in the transitional government and a supporter of presidential candidate Joseph Kabila, once again verbally attacked Congolese Tutsi at a rally in Goma, saying they should leave the country. In August 2007, hundreds of people rioted and attacked UN staff in the town of Moba, Katanga province, after rumours of the return to their homes of displaced Banyamulenge. ${ }^{299}$

The 2006 election confirmed the political eclipse of the Tutsi-dominated RCDGoma: from being one of the four political forces governing the country during the transition period, it was wiped out electorally and fell to having virtually no political significance at the national level. A short-lived effort to recreate a united Hutu-Tutsi coalition had also failed. And the Banyamulenge demand for Minembwe to be a territory of its own for the elections was denied. Laurent Nkunda, a Rwandan-trained Congolese Tutsi who had been a commander for the RCD in North Kivu and one of those who had refused to disarm in 2004, then returned to arms under the name Congrès National pour la Defense du Peuple (CNDP). Despite regional efforts to secure peace through a Great Lakes pact among all Congo's neighbours signed in 2006, ${ }^{300}$ active hostilities resumed in late 2006 and 2007 between the CNDP and the new Congolese army; and with a predominantly Rwandan Hutu group, known as the Forces Démocratiques de Liberation du Rwanda (FDLR), some of whose leaders had participated in the 1994 genocide in Rwanda. ${ }^{301}$

At January 2008 peace talks in Goma, provincial capital of North Kivu, the status of the Congolese Tutsi and the return of Congolese Tutsi refugees from Rwanda remained one of the most difficult issues to resolve: Tutsi representatives at the talks complained of continued daily discrimination against their community, including exclusion from public office; ${ }^{302}$ while "indigenous" groups made clear that they regarded them as still immigrants, without a real claim on the land, and possibly working on behalf of the Rwandan government. Later the same year, CNDP forces with Rwandan backing once again went on the offensive, killing thousands, displacing hundreds of thousands, and threatening to overwhelm the UN forces protecting Goma.

299 "DR Congo: Refugees urge resumption of repatriation to Moba; UNHCR waits", UNHCR, 8 Oct 2007.

300 Pact on Security, Stability and Development for the Great Lakes Region, December 2006. The signatories were Angola, Burundi, Central African Republic, Congo, DRC, Kenya, Rwanda, Sudan, Tanzania, Uganda and Zambia; in 2012, the new state of South Sudan joined the pact.

301 Human Rights Watch, Renewed Crisis in North Kivu, October 2007.

302 «Déclaration de la communauté banyamulenge à la conférence sur la paix, la sécurité et le développement au Nord et au Sud Kivu ", January 2008. 
At the end of 2008, the political landscape changed dramatically in eastern Congo with a new and unexpected alliance between the governments in Kinshasa and Kigali; which, however, brought a further deterioration of the situation in the Kivus, with increased killings and displacement. President Kabila struck a deal with Rwandan President Paul Kagame, allowing Rwandan soldiers to enter eastern Congo for several weeks of joint military operations with the Congolese army against the FDLR. In return, Rwanda arrested Laurent Nkunda, the leader of the CNDP, who had previously enjoyed Rwandan support. ${ }^{303}$

On 23 March 2009, the CNDP signed an agreement with the Kinshasa government providing for the integration of its supporters into national political and security structures. The DRC army then allied with the CNDP to fight the FDLR, as well as mai-mai militias who refused integration into the army, with the usual consequences for the long-suffering civilian population. New CNDP leader Bosco Ntanganda was made a general in the Congolese army and deputy commander of military operations in the east - despite his indictment by the International Criminal Court (ICC) for crimes committed as a rebel leader in Ituri province between 2002 and 2004. Other CNDP officers were awarded senior ranks, and ordinary CNDP cadres - at least some of them later admitted to be Rwandan nationals - were incorporated into the Congolese army and given a leading role in the joint Congolese-Rwandan military operation, known as Umoja Wetu ("Our Unity" in Kiswahili). Despite the purported integration of forces, the CNDP was effectively allowed to maintain a parallel chain of command and to retain considerable control over areas it occupied. ${ }^{304}$

The CNDP administrative authorities in North Kivu used intimidation and the application of the 1973 land law (never harmonized with customary practices), to assert control of lucrative mining zones in Masisi, Walikale, Kalehe, and Mwenga, as well as the key farming and cattle areas of Rutshuru and Masisi.Yet the influence gained by the CNDP risked backfiring in the long run, as it created renewed resentment through its exclusion of non-Banyarwanda (Hutu or Tutsi) from control of land and economic opportunities. One of the demands of the CNDP in their accord with the Kinshasa government was for the découpage of North Kivu - the carving out, in the context of a general decentralisation policy, of a long-demanded new province specifically designed for the Banyarwanda

303 Negotiations between Rwandan and Congolese officials began from October 2008, and led to the preparation of a joint military plan to disarm the FDLR endorsed by the foreign ministers of both countries at a public ceremony in Goma on 5 December, though the text and details of the plan remained confidential. Negotiations for the implementation of the plan continued over the following weeks. See International Crisis Group, Five Priorities for a Peacebuilding Strategy, Africa Report N¹50, 11 May 2009.

304 Jason Stearns, North Kivu: The background to conflict in North Kivu province of eastern Congo, London: Rift Valley Institute, 2012; Jason Stearns, From CNDP to M23: The evolution of an armed movement in eastern Congo, London: Rift Valley Institute, 2012; International Crisis Group, A Comprehensive Strategy to Disarm the FDLR, Africa Report №151, 9 July 2009. 
community. This proposal was strongly resisted by the autochtones, in the same way as the proposal for a new "territory" of Minembwe for the Banyamulenge in South Kivu; but also by those opposed in principle to the idea of ethnicallybased administrative units. ${ }^{305}$

The renewed military operations resulted in the killing of many hundreds of civilians and the displacement of hundreds of thousands more in North and South Kivu. ${ }^{306}$ A second phase of military operations received backing from UN peacekeepers, who hoped thereby — incorrectly as it turned out —- to reduce civilian casualties. A third phase of operations by the Congolese army in the Kivus began in early 2010, also supported by UN forces, but with stronger UN efforts to ensure that the most abusive commanders were not involved, and that the operations specifically targeted FDLR command bases in order to reduce the impact on the general population. Nonetheless, many thousands more civilians fled their homes. ${ }^{307}$

In the renewed fighting, the constant remained the cross-border themes of citizenship and belonging. The FDLR, which fought with Congolese government forces during 2008, but was attacked by them in 2008 and 2009, claimed to be seeking greater political representation for ethnic Hutus in Rwanda. The CNDP, the most recent of three different Rwandan-backed Congolese Tutsi rebel groups, portrayed itself as the defender of the rights of persecuted ethnic Congolese Tutsi, including the Banyamulenge.

The 23 March agreement had placed an emphasis on the return of refugees and displaced persons, but this process had been — inevitably — highly controversial. In early 2010, a tripartite agreement was signed between UNHCR and the governments of DRC and Rwanda for the repatriation of tens of thousands of Congolese refugees who fled to Rwanda during the 1990s: at that time, UNHCR reported that there were 55,000 Congolese refugees living in Rwanda and 69,800 Rwandan refugees in the Kivus. Local committees were supposed to be established to regulate the process, but "spontaneous" returns soon caused disruption. In early 2011, the governor and provincial assembly of North Kivu raised the alarm over the identification of Banyarwanda "returning" in an

305 As with the other debates on these issues, the internet is alive with detailed postings by Congolese who have strong views. For example, "Non au découpage de la Province du Nord-Kivu : Réflexion d'un originaire non-rwandophone ", 17 April 2009, available at http://www.benilubero.com/index.php?option=com content\&task=view\&id=1424\&Itemid=64; " The UN and Kabila Illegally endorse Minembwe ", http://www.laconscience.com/The-UN-and-Kabila-Illegally-endorseMinembwe.html, both accessed 26 March 2014.

306 Human Rights Watch, You Will Be Punished: Attacks on Civilians in Eastern Congo, December 2009; Always on the Run: The Vicious Cycle of Displacement in Eastern Congo, September 2010.

307 International Crisis Group, No Stability in Kivu despite Rapprochement with Rwanda, Africa Report N¹65, 16 November 2010. 
unplanned manner to Lubero and Rutshuru; in July the CNDP imposed the resettlement of 2,400 families from Rwanda in Masisi. UNHCR, meanwhile, had not repatriated a single Congolese refugee from Rwanda to the DRC, because of ongoing insecurity but above all "the impossibility of identifying with any degree of certainty the individuals whom the Rwandan authorities present as refugees." ${ }^{308}$ There was little or no effort to create meaning for the commitments made in the agreement through confidence-building measures, or even to implement specific agreed actions. There were many reports that Rwandans were among the "Congolese refugee" returnees, highlighting once again how the lack of effective and legitimate civil administration - and accompanying documentation of facts that would prove birth and residence on the territory — is a critical part of the wider conflict around rights to nationality and access to land and other resources.

In November 2011, presidential and legislative elections were held as scheduled. Hate speech was rife once again during the election period, despite the commitments of all major political parties to a code of conduct forbidding incitement to violence. ${ }^{309}$ But there were also many allegations that the CNDP was forcing people in Kivu to vote for Kabila and its own candidates, as well as registering Rwandans. ${ }^{310}$ Voter registration was one way of obtaining an identity document that provided a presumption of nationality and could allow the holder to use it to travel in the region. ${ }^{311}$ International observers reported widespread irregularities, though Kabila's dubious victory in the presidential elections was confirmed by the Supreme Court. In the new National Assembly, 98 political parties were represented, of which 76 had five or fewer seats; the elections in Masisi, North Kivu, were among several constituencies annulled by the election commission on grounds of fraud, but the elections were not re-held in those locations. ${ }^{312}$

The flawed elections did nothing to cement peace. Under international pressure, in April 2012, the Congolese authorities finally ordered the arrest of CNDP leader Bosco Ntaganda, indicted by the ICC in 2006. Ntaganda promptly

308 International Crisis Group, Eastern Congo: Why Stabilisation Failed, Africa Briefing Nº91, 4 October 2012.

309 "DR Congo: Candidates Should Not InciteViolence", Human Rights Watch, 28 October 2011.

310 Letter dated 12 October 2012 from the Group of Experts on the Democratic Republic of the Congo addressed to the Chair of the Security Council Committee established pursuant to resolution 1533 (2004) concerning the Democratic Republic of the Congo, 15 November 2012, UN document S/2012/843; Carter Center, Presidential and Legislative Elections in the Democratic Republic of the Congo November 28, 2011: Final Report, 30 October 2012.

311 International Crisis Group, The Electoral Process Seen from the East, Africa Briefing No80, 5 September 2011.

312 Carter Center, Presidential and Legislative Elections 2011: Final Report; International Crisis Group, Eastern Congo: Why Stabilisation Failed, Africa Briefing Nº91, 4 October 2012. 
mutinied from the army to create the M23 rebel movement - referring to the peace agreement between the government and the CNDP of 23 March 2009 and joined with other suspected war criminals to create the new force.The UN's revelation of $\mathrm{R}$ wandan support for M23 heightened tensions between $\mathrm{R}$ wanda and DRC, ${ }^{313}$ while also bringing the first serious Western condemnation of the Rwandan role in the Congolese war and the suspension of some aid, including by the UK. ${ }^{314}$ The combined impact of the government's alliance with the CNDP in 2009 and incorporation of CNDP regiments within the FARDC, followed by the Rwandan support for the M23 rebellion, was to increase anti-Rwandan and anti-Rwandophone resentment in the Kivus, with threats and attacks on Banyarwanda communities, especially Tutsis. ${ }^{315}$ At the end of 2012, Goma, capital of North Kivu, fell to the M23 rebels.

The latest crisis provoked a renewed international effort to try to resolve the regional conflict: on 24 February 2013, meeting in Addis Ababa under UN auspices, the governments of Congo, Rwanda, Uganda and other members of the International Conference on the Great Lakes Region (ICGLR) established following the 2006 Great Lakes pact, and the Southern Africa Development Community (SADC) signed a framework agreement for peace, security and cooperation. The agreement also provided for the creation by the UN Security Council of an intervention brigade to neutralise armed groups in the area, its first ever "offensive" force, with substantial contributions from SADC countries. ${ }^{316}$ In March 2013, Ntaganda, who had been sheltering in Rwanda, handed himself over to the US Embassy in Kigali, and was subsequently transferred to the ICC in the Hague. By the end of the year, M23 had suffered comprehensive military defeat by the Congolese army, as Rwanda finally withdrew its support. M23 "renounced its rebellion" and committed itself to pursue its objectives through the "Kampala dialogue" facilitated by the ICGLR. It was promised that M23 members would be included in national structures responsible for refugee issues $^{317}$ — but no proposal for identification and verification of nationality was yet on the table.

313 "Letter dated 26 June 2012, from the Chair of the Security Council Committee established pursuant to Resolution 1533 (2004) concerning the Democratic Republic of Congo addressed to the President of the Security Council", UN Security Council, S/2012/348/ add.1, 27 June 2012.

314 “UK stops $f^{21 \mathrm{~m}}$ aid payment to Rwanda”, BBC News, 30 November 2012.

315 International Crisis Group, Eastern Congo: Why Stabilisation Failed.

316 "Peace, Security and Cooperation Framework for the DRC: hopes and challenges", Institute for Security Studies (South Africa), 8 March 2013. “'Intervention Brigade' Authorized as Security Council Grants Mandate Renewal for United Nations Mission in Democratic Republic of Congo: Resolution 2098 (2013) Enables 'Offensive' Combat Force to 'Neutralize and Disarm' Congolese Rebels, Foreign Armed Groups”, UN Security Council, SC/10964, 28 March 2013.

317 Declaration of Commitments by the Movement of March 23 at the Conclusion of the Kampala Dialogue, 12 December 2013. 


\subsection{Côte d'Ivoire's war of conjunctions: The "and" and the "or"}

Historical explanations for the crisis of ethnic identification in Côte d'Ivoire can be traced back to the 1930s and the population movements imposed by the then colonial power France. The French assessed the rich and well-watered land of Côte d'Ivoire, first created as a colony in 1893, to be ideal for agricultural development, especially coffee and cocoa cultivation, but underpopulated. Meanwhile, the much drier savannah territory to the north, known by the French as Haute Volta (Upper Volta; future Burkina Faso) and under military governorship when it was created in 1919, had a high population density. The obvious answer was to move the "surplus" labour south. ${ }^{318}$

In 1933 France modified the administrative borders within AOF, including between Côte d'Ivoire and UpperVolta. The new zone of Haute Côte d'Ivoire brought together three quarters of the territory of Haute Volta and the northern parts of Côte d'Ivoire. A program of forced movement of agricultural workers to plantations further south was instituted and, as part of this process, the French established by decree a number of "colonial villages" in central Côte d'Ivoire, where recruits from Haute Volta were housed in new settlements that took on the names of the towns of origin of the workers further north. ${ }^{319}$ Forced

318 There is a vast literature on migration and the question of identity in Côte d'Ivoire. In addition to the works cited specifically below, see: Sylvie Bredeloup, « La Côte d'Ivoire ou l'étrange destin de l'étranger " Revue Européenne des Migrations Internationales Vol.19, No.2, 2003,pp.85-113;Bruno Losch,(ed.) “Dossier:Côte d'Ivoire, la tentation ethnonationaliste”, Politique africaine No. 78, 2000 ; Daouda Gary-Tounkara, Migrants soudanais/maliens et conscience ivoirienne: Les étrangers en Côte d'Ivoire 1903-1980, L'Harmattan, 2008 ; Richard Banégas, "Côte d'Ivoire: Patriotism, ethnonationalism and other African modes of selfwriting”, African Affairs,Vol.105, No.421, 2006, pp.535-552 ; Richard Banégas and Ruth Marshall-Fratani, "Côte d'Ivoire: Negotiating Identity and Citizenship", in Morten Boas and Kevin C. Dunn (eds.), African Guerrillas: Raging Against the Machine, Lynne Rienner, 2007, pp. 81-111; Maya Collett, "Ivorian identity constructions: Ethnicity and nationalism in the prelude to civil war", Nations and Nationalism, Vol.12, No.4, 2006, p.613-629 ; Fabrice Courtin, Florence Fournet and Philippe Solano, "La crise ivoirienne et les migrants burkinabés : L'effet boomerang d'une migration internationale", Afrique contemporaine No.236, 2010, pp.11-27 ; Karen Morris, "Avoiding vagabond nationality: The emergence of ivoirité in 1990s Côte d'Ivoire", in Brian D. Behnken and Simon Wendt (eds.), Crossing Boundaries: Ethnicity, race and national belonging in a transnational world, Lexington Books, 2012, pp.161-183 ; Giulia Piccolino, "Ultranationalism, democracy and the law: insights from Côte d'Ivoire", Journal of Modern African Studies,Vol.52, No.1, 2014, pp.45-68; Jeanne Maddox Toungara, "Ethnicity and Political Crisis in Cote d'Ivoire", Journal of Democracy, Vol.12, No.3, 2001, pp. 63-72; Yéo O. Emma, Idéologie politique et conflit en Côte d'Ivoire : Une analyse du discours politique sur l'identité nationale, Centre de Recherche et d'Action pour la Paix (CERAP)/ Consortium for Development Partnerships (CDP) Research Report No.3, 2008.

319 By 1934, three colonial villages were established in the area surrounding Zuénoula that were named Ouagadougou, Kaya, and Koudougou; and four villages surround the Ivorian town of Bouaflé: Koudougou, Garango, Koupéla, and Fankodogo. See Chikouna Cissé, 
labour was ended in 1946, by which time around 420,000 migrants had been registered, ${ }^{320}$ and the Haute Côte territory was re-divided between Côte d'Ivoire and Haute Volta in 1947; but the policy of encouraging migration continued. A private labour recruiting consortium known as the Syndicat inter-professionel pour l'acheminement de la main-d'oeuvre (SIAMO) was formed to recruit labour, in conjunction with the French West African labour inspectorate (Inspection $d u$ travail de l'AOF) that had been created in 1932. ${ }^{321}$ By independence in 1960 SIAMO had imported more than 250,000 workers. ${ }^{322}$ Many others had migrated voluntarily - from Haute Volta, but also from Mali, Guinea, and other parts of $\mathrm{AOF}$ - to take up cocoa and coffee farming in their own right on land ceded by southern Ivorian ethnic groups. The majority of the migrants were Muslims from the Malinké ethno-linguistic group, itself a sub-group of the Mandé, though other groups were also represented. ${ }^{323}$

The development of the coffee economy also promoted internal migration within the territory, especially by the east-central Baoule, related to the Akan of Ghana. Though some coffee was grown in the southern parts of their territory, Baoule themselves were internal migrants to the cocoa growing areas of the south east and south west. As in the case of the migrants from UpperVolta, many of these became established as farmers in their own right. Independence leader Félix Houphouët-Boigny, himself a Baoulé, in fact came to political prominence as leader of the Syndicat agricole africain (SAA), defending the interests of smallscale African farmers against European domination of the plantation economy and protesting the use of forced labour. ${ }^{324}$

Migration et Mise en Valeur de la Basse Côte d'Ivoire (1920-1960), Harmattan, 2013, pp. 120123.

320 Statistics on historical migrant numbers from the Recensement Général de la Population et de l'Habitat, 1988 :Tome 2, Répartition Spatiale de la Population et Migrations, Analyse des résultats définitifs, République de la Côte d'Ivoire, 1992 (hereafter Recensement Général,Vol.2, 1988).

321 Vincent Bonnecase, Les étrangers et la terre en Côte d'Ivoire à l'époque coloniale, Montpellier : Institut de Recherche pour le Développement (IRD), Document de l'Unité de Recherche 095, N² 2001.

322 Recensement Général,Vol.2, 1988.

323 The ethnic make-up of the migrants was of course more complex: among the Burkinabè, a large percentage were Mossi from Burkina Faso's central plateau, not one of the Mandé groups; many Mossi are also not Muslim. Among the northern ethnic groups in current Côte d'Ivoire are also the Senoufo, whose members include those who follow Muslim, Christian or traditional religions. See Mike McGovern, Making War in Côte d'Ivoire, University of Chicago Press, 2011, chapter 1 for a good summary of autochthonous and migrant ethnic groups, the fluidity of the definitions, and the different pre-colonial political and membership arrangements within each group.

324 Jean-Pierre Dozon, "L'étranger et l'allochtone en Cote d'Ivoire", in Bernard Contamin and Harris Memel-Fotê (eds), Le modèle ivoirien en questions : Crise, réajustements, récompositions, Karthala, 1997. 
The French administration also made use of many (better educated) Dahomeyans and Senegalese in the Ivorian civil service, and as early as the 1930s there was an Association de défense des intérêts des autochtones de Côte d'Ivoire protesting this tendency. In October 1958, less than a month after the referendum on the constitution of the Communauté française that gave internal self-government to Côte d'Ivoire and other French territories, popular riots forced around seventeen thousand Dahomeyans, Togolese and others to leave the country. ${ }^{325}$

Many of the current problems relating to nationality in Côte d'Ivoire can be traced back to the failure of the transitional provisions adopted at the time of the dissolution of French West Africa to define clearly who became "Ivorian of origin" on the date of independence.As was the case across AOF, the independence constitution of Côte d'Ivoire adopted in 1960 left the details of nationality law to be determined by legislation, leaving a gap that created ambiguity across the region, but nowhere more than in Côte d'Ivoire. In 1961, Article 6 of the new Ivorian nationality code gave "nationality of origin" to every person born in Côte d'Ivoire unless both of his or her parents were foreigners (étrangers). ${ }^{326}$ Those born outside Côte d'Ivoire would be Ivorian if they had one Ivorian parent. ${ }^{327} \mathrm{~A}$ child born in Côte d'Ivoire of foreign parents and resident there for five years could, however, acquire nationality "by declaration" on majority; this applied equally to those born before or after independence, but was dependent on the birth being formally registered. ${ }^{328}$ In addition, as a transitional provision,

325 Challenor, "Strangers as colonial intermediaries: The Dahomeyans in Francophone Africa”; Tirefort, "L'affaire Daho-Togo ”; de Benoist, « Pogrom contre les Dahomeens et les Togolais ".

326 Article 6 of the Code de la nationalite 1961, stated in its original form under "nationality of origin" that: "Est ivoirien tout individu né en Côte d'Ivoire, sauf si les deux parents sont étrangers ". After 1972, this article was amended to impose a discrimination based on birth in or outside marriage, stating that the following persons are "ivorian of origin": «1L'enfant légitime ou légitimé, né en Côte d'Ivoire, sauf si ces deux parents sont étrangers; 2- L'enfant né hors mariage, en Côte d'Ivoire, sauf si sa filiation est légalement établie à l'égard de ses deux parents étrangers ou d'un seul parent également étranger. "

327 Article 7, Code de la nationalité 1961 : «Est ivoirien, l'individu né hors de Cote d'Ivoire d'un parent ivoirien ». The difference between the wording of Articles 6 and 7 is puzzling. However, Article 7 appears to requires proof that one parent is Ivorian, while Article 6 requires proof that both parents are foreigners. That is, not only that they do not have Ivorian nationality, but that they do have nationality elsewhere: which would mean that children of unknown or stateless parents would be Ivorian based on birth in the territory. This would also make sense of the drafting of Article 9 of the 1961 Nationality Code, which created a presumption of birth on Ivorian soil for abandoned children of unknown parents found in Côte d'Ivoire, but not also a presumption that at least one parent was ivorian. See discussions on the 1961 Ivorian code in Zatzépine, Le Droit de la Nationalité, and Decottignies and de Biéville Les nationalités africaines.

328 Articles 17-23 Code de la nationalité 1961. The requirement for birth registration, « to the exclusion of all other forms of proof » was introduced by the National Assembly, « in order to avoid abuses ». Procès-verbal de la séance du mercredi 8 novembre 1961, Commission 
those who had their permanent residence in Côte d'Ivoire before independence could also be naturalised as citizens without further requirements if they applied within one year. ${ }^{329}$ Otherwise, a regular naturalisation process was set up in law, providing for discretionary grant of nationality to those who fulfilled a range of conditions, including five years legal residence, but also satisfactory health and police reports and other hurdles. ${ }^{330} \mathrm{~A}$ final article, introduced by the National Assembly, provided that all those established in the territory who did not acquire Ivorian nationality could remain in the territory and continue to benefit from all their acquired rights (though not the right to vote or be elected). ${ }^{331}$

The convoluted language on acquisition of nationality of origin, drafted in a way that at first sight appeared to be - and was indeed understood to be founded on jus soli rights based on birth in the territory ${ }^{332}$, plus the lack of a definition of étranger, meant that in many cases it was more or less impossible to know if a person's parents were "foreign" under the law and therefore if further action was needed or not. All those living in French West Africa had previously had French nationality, and a large number of people had been forcibly brought to Côte d'Ivoire by the French. It would be possible to argue that none of those who made up the population of the country at independence were "foreigners", unless they had the nationality of a country that had not previously been under French control. Equally, it could be the case that all those attributed the nationality of another country were not Ivorian. If they knew of the new law's provisions at all, many potentially affected may have assumed that if they had come from another formerly French territory then they were not "foreign"; or that there was no need to make a choice of nationalities, given their continued right to stay in Côte d'Ivoire if already established in the country. The law included no definition that created clarity on the attribution of Ivorian nationality by operation of law on those who might potentially have the claim on the nationality of one of the other newly created states. As a matter of fact, not a single person applied for naturalisation during the one-year transitional period, while the right of option was only accessed by two people before it was abolished in 1972..$^{333}$

des Affaires Générales et Institutionnelles, Assemblée Nationale.

329 Article 105, Code de la nationalité 1961.

330 Articles 25-32 Code de la nationalité 1961

331 Article 106, Code de la nationalité 1961 ; Procès-verbal de la séance du mercredi 8 novembre 1961.

332 Exposé des motifs de la Loi de 1961 portant Code de la nationalité ivoirienne, présenté par le Président de la République ("l'article 6 consacre comme principe de la nationalité d'origine, le premier critère, à savoir la naissance sur le sol »); see also Procès-verbal de la séance du mercredi 8 novembre 1961, and Procès-verbal de la séance du mercredi 24 novembre 1961. All three texts reproduced in the Recueil des textes législatifs et réglementaires relatifs au droit de la nationalité ivoirienne, prepared by the Ministry of Justice of Cote d'Ivoire with UNHCR support, 2014.

333 Exposé des motifs, Projet de loi portant dispositions particulières en matière d'acquisition 
However, for some years these drafting ambiguities were not significant. While ensuring that no ethnic group was completely left out in his management of the political chessboard, President Houphouët-Boigny and his Parti Démocratique de la Côte d'Ivoire (PDCI) were also clearly politically allied with northerners and migrants to Côte d'Ivoire, as well as internal migrants, including the Baoule, who shared many of the same interests. In the context of a strong post-independence economic boom, the PDCI continued to encourage economic migration from neighbouring African states, as well as from north to south of the country, and adopted an expansionary attitude towards both the pre-independence and more recent migrants, without ever directly addressing the question of citizenship. In December 1965, Houphouët-Boigny even proposed granting automatic reciprocal rights of nationality to citizens of neighbouring countries ${ }^{334}$, a proposal defeated by parliament in a rare moment of independence from the executive, and abandoned by Houphouët-Boigny with the acknowledgement that Ivorians "suffered from an inferiority complex" in relation to their better educated neighbours. ${ }^{335}$ In the interests of building electoral support in the north and centre of the country, as well as satisfying a need for labour to increase export earnings from commercial crops of coffee and cocoa in plantations in the south, Houphouët-Boigny promoted both the migration-friendly policy that "the land belongs to those who work it" (la terre appartient à celui qui la met en valeur $)^{336}$, and the liberal grant of identification documents and political rights. Fom 1980, the electoral law provided that non-Ivorians of African origin would be allowed to register and vote in national elections. ${ }^{337}$

Tensions related to migration were already evident: as early as 1970, a Bété uprising in the south-western plantation country briefly declared an independent

de la nationalité par déclaration, (No.2013-653 du 13 septembre 2013).

334 Benin, Niger, and Burkina Faso (and later Togo) members of the Conseil de l'Entente created in 1959 by Houphouët-Boigny as a counterbalance to Senegal's union with Mali during the final phases of the French Community. Cooper, Citizenship between Empire and Nation, pp.420-421.

335 Quoted in Bonzon, «Les Dahoméens en Afrique de l'Ouest ».

336 Widely cited, though with some variants in phrasing; see for example, Alfred Babo, "The Crisis of Public Policies in Côte d'Ivoire: Land law and the nationality trap in Tabou's rural communities", Africa,Vol.83, Special Issue 01, 2013, pp 100-119.

337 Article 57 of Loi No.80 - 1039 du 1er Septembre 1980 relative à l'élection des députés à l'Assemblée nationale: «Pour les élections de 1980, pourront prendre part au vote les nonivoiriens d'origine africaine inscrits sur les listes électorales ». See also Loi. No.80-1038 portant modification des articles 10 et 29 de la Constitution; (however, Article 5 of the 1960 constitution still reserved the right to vote to "Ivorian nationals"). This decision was in line with the ECOWAS discussions on establishing a "community citizenship", though not implemented in other countries, nor required by the Protocol on the Definition of Community Citizen adopted by ECOWAS in 1982. See also Reynald Blion and Sylvie Bredeloup "La Côte d'Ivoire dans les stratégies migratoires des burkinabès et des sénégalais", in Contamin et Memel-Fotê (eds.), Le modèle ivoirien en questions; Epiphane Zoro-Bi, Juge en Côte d'Ivoire : Désarmer la Violence, Paris : Karthala, 2004, p. 81. 
state, whose demands included the departure of migrants. The uprising was brutally suppressed..$^{338}$

In 1972 the nationality code was amended to "correct the too great liberalism" of the existing law by removing the right of those born in the country of foreign parents to opt at majority for Ivorian nationality; as well as introducing distinctions between those born in or out of wedlock, with the requirement to establish descent by the formal process of law. Even the right to nationality for an abandoned infant found in Côte d'Ivoire was repealed. ${ }^{339}$ Since the original law had, unlike the other AOF countries, not provided for double jus soli, birth in the country now provided no rights to nationality in any circumstances. Foreign nationals of whatever origin could in theory still acquire Ivorian citizenship by naturalisation in the normal way, ${ }^{340}$ but this discretionary process was only readily accessible to those working in the formal economy, with full proof of legal residence and a range of other documentation. Although, for the most part, an ideology of welcome to fellow-Africans was accepted by the host populations, who saw that increasing prosperity depended on their labour, ${ }^{341}$ a lack of clarity over the status of the newcomers created the conditions for future problems.

By 1988, the census showed a population of foreign origin of more than three million (half of them of Burkinabè origin), forming just over $28 \%$ of a total population of 10.8 million; up from 17.5 percent in 1965. At least 45 percent of these "foreigners" had been born in the country and more than 60 percent of the remainder had been resident for more than five years and thus theoretically eligible to naturalise. ${ }^{342}$ Yet only just over 51,000 people were identified as formally naturalised as Ivorian. ${ }^{343}$ Ten years later, the 1998 population census revealed that of the approximately 15 million inhabitants of the country just over a quarter were non-citizens, once again almost half of them had been born in the

338 See McGovern, Making War in Côte d'Ivoire, for an account of this revolt.

339 Cote d'Ivoire Loi no. 72-852 du 21 décembre 1972 ; quote on the need to " corriger le trop grand libéralisme » from the Exposé des motifs. The law deleted the second paragraph of the original Article 9 that provided for children of unknown parents to be presumed born in Cote d'Ivoire (and, thus, Ivorian, on the basis that étranger did not include an unknown parent). The first paragraph, requiring all facts related to birth and descent to be proved by civil registration procedures, remained in place. There was no explanation for the removal of the provision on children of unknown parents in the exposé des motifs for the 1972 law.

340 Articles 25-26 of Loi no. 61-415 du 14 décembre 1961 portant Code de la nationalité ivoirienne, modifiée par loi no. 72-852 du 21 décembre 1972.

341 Ousmane Dembélé, "La construction économique et politique de la catégorie "étranger" en Côte d'Ivoire ", in Marc Le Pape and Claudine Vidal (eds.) Côte d'Ivoire : L'année terrible, 1999-2000, Paris : Karthala, 2002.

342 Recensement Général,Vol.2, 1988.

343 Recensement Général de la Population et de l'Habitat, 1988 : Tome 3, Caractéristiques socio-culturelles et économiques de la population, République de la Côte d'Ivoire, 1992, table 2.3. 
country, and only 88,714 were identified as naturalised. ${ }^{344}$

By the late 1980s, the modele ivoirien, supposedly an exception to instability in the West African region, was in crisis. ${ }^{345}$ Large falls in the global price of cocoa and coffee were twinned with increasing pressure on land in the southern plantation territories. State guarantees of prices paid to producers were no longer sustainable, and a structural adjustment programme forced retrenchment of the public workforce and an end to regulated prices, including reform of the Comité de gestion de la filière café-cacao responsible for marketing coffee and cocoa on the international markets (and an important source of funds for the PDCI) ${ }^{346}$ With the changes in eastern Europe and the end of one-party regimes elsewhere in Africa, the PDCI was also forced to concede a return to multiparty democracy, just as economic recession was exacerbating, in the classic way, popular resentment against immigrants. Long-standing but previously suppressed tensions came to the fore and were exploited for political purposes by the opposition to the PDCI. In the 1990 elections, the main opposition party, the Front Populaire Ivoirien (FPI) led by Laurent Gbagbo (a Béte from the southwest, the area most affected by in-migration, who also had close links to the French Socialist Party) mobilised around a campaign that accused the PDCI of favouring foreigners.

Houphouët-Boigny died in 1993. His successor as PDCI leader and president, Henri Konan Bédié, also a Baoulé, abandoned the PDCI's unofficial allegiance with migrant groups (internal and from outside the country), and canvassed a new political definition of the concept of ivoirite ("Ivorian-ness"). A group of PDCI intellectuals devised a manifesto promoting a highly restrictive interpretation of Ivorian citizenship, limiting it to those whose parents were both members of one of the "autochthonous" ethnic groups of Côte d'Ivoire. ${ }^{347}$ This

${ }^{344}$ By these statistics, Côte d'Ivoire is one of the top twenty countries in the world receiving migrants: United Nations, Department of Economic and Social Affairs, Population Division Trends in International Migrant Stock: The 2013 Revision, United Nations database, POP/DB/MIG/Stock/Rev.2013, Table 3. However, the methodology for counting does differ among countries, so the figures are not always comparable. The estimate of international migrants (persons born abroad) as a percentage of the population, was 14.4 in 1990 , dropping to 12.5 percent in 2010 , with total population increasing from 12.6 million to 19 million over the same period. See also Georges Photios Tapinos, " La population étrangère ", in Georges Photios Tapinos, Hugon Philippe et Vimard Patrice (eds.) La Côte d'Ivoire à l'aube du XXIe siècle. Défis démographiques et développement durable, Paris: Karthala, 2001, reporting that the highest percentage of persons born abroad was reached in the 1980s, at 16.4 percent of the total population.

345 Bernard Contamin and Harris Memel-Fotê (eds), Le modèle ivoirien en questions : Crise, réajustements, récompositions, Karthala, 1997.

346 See McGovern, Making War in Côte d'Ivoire, chapter 5, for a discussion of the role of the filière "slush fund" in Ivorian politics, and the failure of privatisation to create a transparent and accountable system.

347 "L'ivoirité, ou l'esprit du nouveau contrat social du Président H. K. Bédié", 1996, 
new interpretation, creating an anthropological definition of nationality in the absence of a satisfactory legal one, ${ }^{348}$ effectively defined those whose forebears had migrated before independence as foreigners (including those who had moved or been moved when the Ivorian borders encompassed a much larger territory); and, by extension, those who were their ethnic kin but had always lived within the borders of Côte d'Ivoire. Eventually these unofficial documents became official policy, as the National Economic and Social Council described the "tolerable threshold" of immigration as being "long overstepped". ${ }^{349}$ Those with "foreign" names by these interpretations, known pejoratively as "Dioula" (derived from the Malinké word for trader), or with one parent who was a foreigner, faced ever-increasing difficulties in obtaining the identity cards and certificates of nationality necessary to claim their other rights, especially to vote and to hold land. Bédié also strengthened programmes for the ivoirisation of the workforce - a Ministère du travail et de l'ivoirisation des cadres was established as early as 1978, but had originally been aimed at French and other foreign personnel in senior civil service positions - turning the programme, some said, into an agenda of baoulisation. ${ }^{350}$

From 1990, a new law required all foreigners, including citizens of ECOWAS States, to obtain and carry as proof of identity a carte de séjour, a type of residence permit. ${ }^{351}$ However, the general law on identity cards adopted after independence remained in force, and only required production of a birth certificate to get an ID card, with formal proof of nationality needed only at the discretion of the administrative official. ${ }^{352}$ In 1998, a new law on identification was adopted, stating

published by the Cellule Universitaire de Recherche et de Diffusion des Idées et Actions Politiques du Président Henri Konan Bédié (CURDIPHE), extracted in Politique africaine No.78, June 2000 : "L'individu qui revendique son ivoirité est supposé avoir pour pays la Côte d'Ivoire, né de parents ivoiriens appartenant à l'une des ethnies autochtones de la Côte d'Ivoire".

348 Epiphane Zoro Bi, "Je suis un Sidibé de Tiémélékro : L'acquisition de la nationalité ivoirienne à titre originaire : Critère juridique ou critère anthropologique?" in JeanBernard Ouédraogo and Ebrima Sall (eds.) Frontières de la citoyenneté et violence politique en Côte d'Ivoire. Dakar, CODESRIA, 2008.

349 Rapport du Conseil économique et social (octobre 1998) «Immigration en Côte d'Ivoire: le seuil du tolérable est largement dépassé ", republished in Politique africaine, No.78, 2002.

350 Dembélé, "La construction économique et politique de la catégorie "étranger" en Côte d'Ivoire "; Jean-Pierre Dozon, "La Côte d'Ivoire entre démocratie, nationalisme et ethnonationalisme", Politique africaine, No.78, June 2000, pp.45-62 ; Arnim Langer, "Horizontal Inequalities and Violent Conflict: Côte d'Ivoire Country Paper", Occasional Paper 2005/32, UNDP Human Development Report Office.

351 Loi No. 90-437 du 29 mai 1990 relative à l'entrée et au séjour des étrangers en Côte d'Ivoire. I am indebted to Mirna Adjami for sharing the draft of her report on Statelessness and Nationality in Côte d'Ivoire, prepared for UNHCR in 2014, for the detailed account of identification procedures.

${ }^{352}$ Loi No. 62-64 du 20 février 1962 portant institution de la Carte Nationale d'Identité ; Décret No. 67-86 du 10 mars 1967, fixant les modalités d'application de la Loi No. 62- 
that Ivorian nationals would be identified inside the country by the national identity card, and distinguishing among ECOWAS and non-ECOWAS nationals for residence permits; ${ }^{353}$ a new decree created more onerous requirements for applications, including that a certificate of nationality be submitted in all cases. ${ }^{354}$

The emphasis on ivoirité was designed both to undercut the FPI's ethnonationalist demands and to exclude Bédié's strongest opponent for the presidency, Alassane Dramane Ouattara, a Muslim from the north of Côte d'Ivoire. Ouattara had been prime minister under Houphouët-Boigny (1990-1993) but left the PDCI on Boigny's death to become the leader of a new opposition party, the Rassemblement des Républicains (RDR), which drew heavily on support from the largely Muslim north. Bédié accused Ouattara of not being a native Ivorian citizen, since one or both parents were in fact from Burkina Faso, an assertion Ouattara himself strenuously denied. ${ }^{355}$ The fact that Ouattara had spent most of his professional life outside the country working for the World Bank and International Monetary Fund, and was responsible for the application of austerity programmes in Côte d'Ivoire as elsewhere in Africa, did not help his case.

Under the independence constitution and the electoral law in effect until the death of Houphouët-Boigny, the holders of the highest national offices — president of the republic and president or vice-president of the National Assembly - had, simply, to be Ivorian citizens. Bédié's administration changed the electoral law in December 1994 to forbid individuals from running for these offices unless both their father and mother were "Ivorian by birth" (ivoirien de naissance), of two

64 du 20 février 1962, modifiée par Décret No. 71-63 du 6 février 1971 ; Circulaire No. 1138 du 13 juin 1962. See also the historical overview of identification in Côte d'Ivoire, at the website of the Office national d'identification: http://www.oni.ci/?q=content/ historique, last accessed 7 November 2014. A temporary substitute for an identity card was created, under Décret No.94-348 du 22 juin 1994, which allowed witness evidence to be submitted by to obtain an attestation administrative d'identité valid only for the 1995 elections.

353 Loi No. 98-448 du 4 août relative à l'identification des Personnes et au Séjour des Etrangers en Côte d'Ivoire. Article 1: «L'identification des ivoiriens âgés de plus de 16 ans s'établit à l'intérieur du territoire national par la Carte nationale d'identité."

354 Décret No. 98-471 du 12 août 1998 modifiant et complétant le décret No. 67-h86 du 10 mars 1967 fixant les modalités d'application de la loi no. 62-64 du 20 février 1962 instituant une carte nationale d'identité. All persons submitting a first-time request to obtain an Ivorian ID card were required to submit as documentary proof not only a copy of a birth certificate or jugement supplétif, but also a certificate of residence, a certificate of nationality, and copies of the national ID cards of at least one of the person's parents or a copy of a parent's decree of naturalisation. The 1998 changes, however, were never implemented because all identification operations were suspended with the military coup led by General Robert Guéi on 24 December 1999.

355 Ouattara's account of his origins, as given at a 2001 national reconciliation forum, is quoted extensively in Francis Akindès The Roots of the Military-Political Crises in Côte d'Ivoire, Nordiska Afrikainstitutet, Uppsala, Research Report No.128, 2004, pp.37-39. 
parents also Ivorian by birth, and must never have held another nationality. The same requirements were adopted with regards to the eligibility requirements to be a candidate for member of parliament. ${ }^{356}$ The term ivoirien de naissance did not exist in the nationality law; moreover, since Ivorian nationality had not existed before 1960, and the transitional provisions had not clarified this point, while to be eligible for president a person had to be a minimum of 45 years old, it was hard to know what this amendment meant as a matter of law. Nonetheless, the requirement was clearly aimed at Ouattara, and he did not stand for president in the 1995 elections, which were won by Bedié. The 1995 electoral law also restricted the right to vote to citizens alone, a reversion to the pre-1980 position that immediately greatly increased the importance of citizenship to long-term migrants. During 1999, the government instituted a judicial investigation into Ouattara's nationality certificate, and it was annulled by a court on 27 October 1999 on the grounds of irregularity in its issue. Protests and riots followed, for which several RDR politicians were convicted under laws allowing organisers of demonstrations to be held responsible for violence. In November 1999, an arrest warrant for Ouattara was issued while he was staying abroad, on the grounds of alleged use of forged documents to support his eligibility to run in the elections in October 2000.

The changes in the law brought to the fore the lack of legal clarity on who in fact was a "foreigner", especially for those whose ancestors arrived in the country before independence. Questions about the status of the descendants of the migrants from the 1930s settled in the "colonial villages", some of whom were prominent people, did lead to an effort to resolve their particular situation. In 1995, Bédié signed a decree accepting the requests for naturalisation presented by "persons of original Burkinabè nationality of the villages of Garango, Koudougou, Koupela, Tenkodogo, in Bouaflé Department, and the villages of Kaya, Koudougou, Ouagadougou, in Zuénoula Department." 357 A list of the 8,133 individuals affected was attached. Despite this apparent resolution of the situation for at least one group of people, those named still struggled to obtain national ID cards and nationality certificates; and their children, who should under the law have been automatically Ivorian, were often not recognized as such. ${ }^{358}$ The decision to naturalise these individuals as a group was still controversial twenty years later, when many of those listed in the decree, and their descendants, still had no documentation of nationality. ${ }^{359}$

356 Loi No. 94-642 du 13 décembre 1994 du 13 décembre 1994 portant Code Électoral, Articles 3, 49-50, and 77-78 ; Décret no 94-662 du 21 décembre 1994 déterminant les modalités d'établissement, de révision et de refonte de la liste électorale.

357 Décret No. 95-805 du 26 septembre 1995.

358 Adjami, Statelessness and Nationality in Côte d'Ivoire.

359 See, for example, «Lutte contre l'apatridie : 8.133 postulants a la nationalité ivoirienne obtiennent leur naturalisation " Government of Cote d'Ivoire, 4 March 2013; and «Bradage massif de la nationalité ivoirienne: Ouattara se sert de Bédié, grosse colère au 
Bediés administration also changed the land law to introduce a system of written evidence of title to land rather than the unregistered systems of tenure that had existed up to then. ${ }^{360}$ Since the pre-colonial period, the dominant system in the south of the country had been the customary law system known in French as the tutorat, in which "autochthonous" landholders ceded the use of land for cocoa and coffee plantations in exchange for a range of cultural and economic obligations, including payment in labour and cash. Prior to the promulgation of the new law in 1998, existing legislation only recognised land transactions carried out in the presence of a notary, while customary law had not historically provided for absolute individual title to land; but there was an increasing ambiguity as to the nature of the rights ceded, following the rhetoric of Houphouët-Boigny and as a cash economy became more dominant. Local communities had developed a range of systems for the regulation of land use by "strangers" to the area, including written documentation and adjudication by traditional courts or village councils. The 1998 law — backed by opposition as well as government members of the national assembly — did not recognise the validity of these hybrid systems, instead opting for a "re-traditionalisation" of land tenure, reasserting the overriding claims of the "autochthonous" southern populations to the land since ceded on various terms to "stranger" farmers. The law provided for the transformation of customary rights into formalised individual private ownership over a period of ten years. Rights of land users not suitable for transfer into exclusive title had no status under the new law, making the ambiguous status of many existing rights immediately more critical. Most controversially of all, the 1998 land law provided that only the state, public entities and Ivorian nationals (personnes physiques ivoiriennes) had rights to own land in rural areas (except for existing owners of formal title deeds, which covered less than two percent of the land, largely in urban areas); other users could only hold a long-term lease. ${ }^{361}$

The surface intention of the amended law was positive - to provide greater security of tenure for customary rights holders - and the changes were supported by the World Bank and other development partners since they appeared to

PDCI ", IvoireBusiness.net, 13 March 2013.

360 Loi no. 98-750 du 23 décembre 1998 relative au Domaine foncier rural. See also JeanPierre Chauveau, "Question foncière et construction nationale en Côte d'Ivoire”, Politique africaine, No.78, June 2000, pp.94-126; Jean-Pierre Chauveau, « La Loi Ivoirienne de 1998 sur le Domaine Foncier Rural et l'Agriculture de Plantation Villageoise: Une Mise en Perspective Historique et Sociologique " in Land Reform: Land Settlement and Cooperatives (FAO), 2002, pp.62-78 ; Barbara McCallin and Marzia Montemurro, Whose land is this? Land disputes and forced displacement in the western forest area of Côte d'Ivoire, Norwegian Refugee Council / Internal Displacement Monitoring Centre, October 2009.

361 A decade later, the African Commission on Human and Peoples' Rights found both the restrictive provisions on standing for election as president and the 1998 land law to be in violation of non-discrimination provisions of the African Charter on Human and Peoples' Rights. See above, chapter 3.12.2. 
provide a more "modern" market in land. However, the law also responded to the increasingly xenophobic national mood, and provided a basis for attacks on northern and foreign migrants farming in their own right or working on others' land in the south and west of the country. During September 1999, perhaps up to 20,000 people, mainly Burkinabè migrants and northerners, were expelled from their land and villages in the south-west without any intervention to protect them by the police, administrative or political authorities. ${ }^{362}$ Similar incidents continued into 2000.

It was against this background that General Robert Guéi, Bédié's retired chief of army (a Yacouba from the far west of the country) led Côte d'Ivoire's first coup d'état on 24 December 1999. Initially, it seemed that the new regime would roll back some of the political exclusion of the previous five years. Guéi formed a broad-based administration which included ministers from leading opposition parties, including the RDR and the FPI. He pledged to clean up corruption, rewrite the constitution, and hold fresh elections. These stated ambitions were, however, soon diverted. The manipulation of identification intensified rather than decreased. In 2000, Guéi issued a decree creating a highly discretionary model for issuing national ID cards, foreseen as a two-year temporary measure. According to this decree, the normal requirements for obtaining a national ID card were suspended. Instead, Ivorians could go to their "village of birth or origin" to obtain a national ID card on the basis of less stringent requirements. Although this appeared to be a relaxation of normal provisions, it effectively instituted a period of entirely discretionary issue of identification documents. ${ }^{363}$

362 Babo, "The Crisis of Public Policies in Côte d'Ivoire". The south-west territory of the Bétés had been integrated rather later than the Agni south-east into the cocoa growing economy, and had seen particularly rapid alienation of land in favour of Dioula or immigrants. For a detailed historical treatment of this issue, see Jean-Pierre Chauveau and Jean-Pierre Dozon, “Au cœur des ethnies ivoriennes : L'Etat, l'économie de plantation et les ethnies en Côte d'Ivoire”, in Emmanuel Terray (ed.) L'Etat contemporain en Afrique, Paris : Harmattan, 1987.

363 Décret No. 2000-419 du 31 mai 2000 fixant les modalités d'application de la Loi No. 62-64 du 20 février 1962 instituant la carte nationale d'identité. According to this decree, the normal requirements for obtaining a national ID card as most recently defined in 1998 (Decree 98-471) were suspended. Instead Ivorians could go to their "village of birth or origin" to obtain a national ID card. Those individuals who did not possess the required documents relating to the birth and nationality of their parents, could present whatever documents they actually held and appear with two witnesses before a mobile team (équipe itinérante), including a magistrate and various other officials, advised by the local chiefs and notables. This mobile team could issue an identity card and certificate of nationality. General Guéi also signed two ordinances that allowed as a temporary measure for individuals to present informal administrative certificates or receipts issued by local municipalities in place of identification through documents otherwise required by law. Ordonnance $\mathrm{n}^{\circ} 2000-504$ du 26 juillet 2000 instituant une attestation administrative d'identité tenant lieu de carte de résident; Ordonnance $n^{\circ} 2000-502$ du 26 juillet 2000 instituant une attestation administrative d'identité. 
In late July 2000, a flawed referendum was held to approve a new constitution which, among other things, inserted into the constitution itself the requirements of Bediés electoral laws that candidates for the presidency must be "Ivorian by origin", born to a father and a mother who are themselves both Ivorian by origin. ${ }^{364}$ Although the phrasing ivoirien d'origine could be argued to be simply a paraphrase of the nationality code's reference to "nationality of origin" as opposed to "nationality by acquisition" (by marriage, naturalisation etc), the provision effectively implied a new constitutional concept of ivoirité. The nationality code states that an individual has Ivorian "nationality of origin" if born to one parent who is a citizen; and it still did so after the 2000 constitution was adopted. Yet the anchoring of the right to run for elected office in a requirement to prove "Ivorian-ness of origin" by both paternal and maternal lineage enshrined in law the arguments of the proponents of ivoirité that to be Ivorian required something deeper than birth in the territory of a citizen parent. Rather, it confirmed the idea already in popular circulation of a pure ancestry connected to Ivorian soil "from time immemorial". A revised electoral code adopted in August endorsed these eligibility criteria for the presidential office in Côte d'Ivoire. ${ }^{365}$ though it eased the eligibility criteria for parliamentary candidates. ${ }^{366}$ Following the referendum, the government of General Guéi led an "identification campaign" during which many who had previously believed themselves to be Ivorian were designated foreigners. ${ }^{367}$

With the new constitution and electoral code in place, presidential and parliamentary elections were held in October and December 2000. On 6 October, the Supreme Court, which had been dissolved and reconstituted following the 24 December coup and was widely believed to have been hand-picked by Guéi himself, disqualified fourteen of the nineteen presidential candidates, including Ouattara and Bédié. ${ }^{368}$ Nonetheless, the coup leaders did not obtain the "right" result. After early results showed Laurent Gbagbo leading in the 22 October presidential polls, General Guéi dissolved the National Electoral Commission and proclaimed himself the winner. Massive popular protests were met with

364 Article 35, Constitution of Côte d'Ivoire, 2000 : « Le Président de la République ... doit être ivoirien d'origine, né de père et mère eux-mêmes ivoiriens d'origine. Il doit n’avoir jamais renoncé à la nationalité ivoirienne. Il ne doit être jamais prévalu d'une autre nationalité." The significance of the change in language from ivoirien de naissance in the 1994 electoral code to ivoirien d'origine in the new constitution was not clear, but did bring the law into closer line with the nationality code.

365 Article 48, Loi No. 2000-514 du 1er Août 2000 portant Code Electorale.

366 Article 71 requires that candidates for the National Assembly be at least 25 years old, be "Ivorian by birth" "Ivoirien de naissance " and have never renounced Ivorian nationality.

367 Ruth Marshall-Fratani, "The war of 'Who is Who': Autochthony, Nationalism and Citizenship in the Ivorian Crisis", in Dorman, Hammett and Nugent (eds.), Making Nations, Creating Strangers.

368 Cour Suprême, Chambre constitutionnelle, Liste définitive des candidats à l'élection du Président de la République du 22 octobre 2000, Arrêt No.E 0001-2000 du 6 octobre 2000. 
a violent response, but General Guéi ultimately fled the capital and Gbagbo declared himself president. Ouattara's RDR demanded fresh elections, leading to further fighting characterized by religious and ethnic divides, as security forces and civilians supporting President Gbagbo clashed with the mostly Muslim northerners who formed the core of support for the RDR. President Gbagbo imposed a curfew and state of emergency; amongst other abuses, around sixty RDR supporters were killed by security forces in the "charnier du Youpougon" on 29 October. ${ }^{369}$ On 30 November 2000, the Constitutional Council barred Ouattara from standing in the parliamentary elections scheduled for 10 December, again because of questions about his citizenship. ${ }^{370}$ Nonetheless, the parliamentary election went ahead, boycotted by the RDR. The FPI won a slight majority, with 96 seats, followed by the former ruling party, the PDCI, which won 94 seats. ${ }^{371}$

In March 2001, local elections were held, which the RDR contested, winning more constituencies than any other party. President Gbagbo immediately instituted a new process of national identification, claiming that most of those on the electoral roll were not citizens and therefore not eligible to vote. ${ }^{372} \mathrm{By}$ the time of departmental elections in July 2002, some 20 percent of potential voters had not obtained their new registration cards; others attempting to register found themselves given a foreign resident's card in place of a national identity document. When individuals attempted to register in their place of residence, they faced demands based on the new rules for identity documents that they return to their "village of origin" to establish their identity, or produce local witnesses from their "village of origin" to testify to their citizenship. The director of the newly established Office Nationale d'Identification (ONI) ${ }^{373}$ publicly endorsed these demands, stating that "whoever claims to be Ivorian must have a village. Whoever has done everything to forget the name of his village or who is incapable of showing he belongs to a village is a person without bearings and is so dangerous that we must ask him where he comes from" ${ }^{374}$ Those unable to

369 Human Rights Watch The New Racism: The Political Manipulation of Ethnicity in Côte d'Ivoire, 2001.

370 Conseil constitutionnel, Arrêt No.E 10-2000 du 30 novembre 2000 relatif aux 227 requêtes en contestation d'éligibilité des députés à l'Assemblée nationale.

371 See results posted on African Elections website, http://africanelections.tripod.com/ ci.html, last accessed 26 August 2014.

372 Loi No. 2002-03 du 3 janvier 2002 also reinstated the use of the term cartes de séjour as the standard terminology for all residence permits to be acquired by all foreigners, including ECOWAS citizens; in relation to nationals however, Décret No.2002-331 du 13 juin 2002 removed the compulsory requirement established by the 1998 decree that an applicant for a national identity card had to have a nationality certificate.

373 Established by Décret $n^{\circ}$ 2001-103 du 15 février 2001; see history of identification in Côte d'Ivoire at the website of the ONI, http://www.oni.ci/?q=content/historique, last accessed 12 November 2014.

374 Notre Voie 28 July 2002, cited in Fratani, "The war of "Who is Who"”. 
produce proper documentation faced heavy fines and security force harassment; ethnic violence in the mixed neighbourhoods of Abidjan and elsewhere escalated in this atmosphere of official permission. Nonetheless, Alassane Ouattara himself was given a new certificate of nationality in June 2002.

\section{Testimony of Abdou Houabou Bah ${ }^{375}$}

My name is Abdou Houabou Bah. I was born in Bouaké, Republic of Côte d'Ivoire, on 27 April 1961. My parents are of Guinean origin, themselves born in Côte d'Ivoire. I am the last in a family of seven children, all born in Côte d'Ivoire.

I went to school in Bouaké at the Military Camp School for my primary school, then college and high school in Bouaké, where I got my Baccalaureate A1 in 1985, after a break of four years due to the distractions of adolescence. After that, I moved to the University of Abidjan Faculty of Law, where I obtained my degree in private law in 1990 and my masters in public law in 1991.

I note that since my birth, I had always and exclusively held Ivorian nationality, until it was contested in 2001, under the circumstances which I will summarize briefly.

In short, after my completion of the competition for entry to the magistracy in 1998 - the training lasted two years, that is to say, from January 1999 to December 2000 - I was unpleasantly surprised to find, during the assignment of magistrates to their courts in September 2001, that my nationality was doubtful, because my name was foreign sounding. They asked me to prove that I was really Ivorian; I fulfilled all that was asked. But, despite my efforts, the then authorities (the Laurent Gbagbo regime) found that the papers of my mother (illiterate, of mixed Ivorian and Guinean descent), were not regular. This is the source of all my problems that continue to this day.

As previously stated, I finished my training at the magistrates' college, where I obtained my diploma to practice as a magistrate. But, from 18 September 2001, the day assignments to positions were made, to date, I have tried everything but not succeeded. That includes judicial, administrative, and human approaches.

When it comes down to it, since I live in in a xenophobic or "Ivoritarian" regime, my efforts were unlikely to succeed. On reading my case, you

375 Testimony of Abdou Houabou Bah to the African Commission on Human and Peoples' Rights, March 2011, French original in possession of and English translation by the author. 
will perhaps not be surprised to know why we had the rebellion in Côte d'Ivoire that lasts to this day.

I did not choose my parents nor the place of my birth. It has been nearly a decade since I have lived in a state of quasi-unemployment caused by power-hungry politicians and administrators who are zealots and careerists.

I do not wish to write a book about my life, but if the story of my experience of denial of citizenship can be used to help rectify the situation, then I remain ready to tell you of my painful journey.

In August 2002, facing pressure from the European Union and other international actors, President Gbagbo announced a government of national reconciliation, with representation of the four principal political parties in his cabinet. However, an attempt to demobilize many of the soldiers who had been brought into the army by General Guéi led to a rebellion by some of those affected. Calling themselves the Mouvement Patriotique de la Côte d'Ivoire (MPCI), they launched an attempted coup d'état on 19 September 2002. Though they failed to topple the central government, the rebels took control of the northern Ivorian town of Korhogo and the central town of Bouake, engaging in fierce fighting with government soldiers. A short-lived ceasefire from mid-October gave way to further fighting in which the mid-west cocoa capital of Daloa saw heavy combat. The south-west also burst into conflict between and among autochthonous and immigrant groups; many immigrants or northerners were driven out. MPCI leader Guillaume Soro emphasised the foundation of the war in the right to nationality: "Give us our identity cards and we hand over our Kalashnikovs", 376

The French government swiftly intervened with military force, launching Operation Licorne in September 2002 to reinforce troops already based in Côte d'Ivoire. Though controversial, because seen as self-interested and (in the first instance) hostile to Gbagbo's government, the intervention eventually helped to establish an often misnamed "zone of confidence" in the main areas of tension. ${ }^{377}$ The French were soon joined by West African soldiers mandated by ECOWAS, and from early 2003, the joint forces were authorised to act to re-establish security by the United Nations Security Council ${ }^{378}$; a year later, a UN peace keeping force was established, supported by French troops operating under their

376 Quoted in Christian Bouquet, «La crise ivoirienne par les cartes », Géoconfluences, 4 June 2007, available at http://geoconfluences.ens-lsh.fr/doc/etpays/Afsubsah/AfsubsahDoc5. $\underline{\mathrm{htm}}$, last accessed 7 November 2014.

377 Pierre Weiss, "L'Opération Licorne en Côte d'Ivoire : Banc d'essai de la nouvelle politique française de sécurité en Afrique', Annuaire français de relations internationales, Vol.V, 2004.

378 Resolution 1464 (2003), Adopted by the Security Council at its 4700th meeting, 4 February 2003. 
own command. ${ }^{379}$ Active fighting gradually gave way to a de facto partition of the country into two separate zones, controlled by the government of Gbagbo in the largely Christian south (including the south-west, retaken by government forces), and by the rebel "New Forces" 380 led by Soro in the Muslim north.

The French also instituted a succession of peace negotiations and agreements that attempted to find a permanent solution to the conflict, variously under the auspices of the French government, ECOWAS, the African Union and the United Nations. Throughout these negotiations and in successive agreements, the question of citizenship as well as of land ownership was central. In January 2003, the Linas-Marcoussis agreement signed in France by all major political parties failed to end active hostilities in Côte d'Ivoire, but set the framework followed in subsequent talks (Accra I, II, III; Pretoria I, II). ${ }^{381}$ Amongst other provisions aiming at the formation of a new government with jurisdiction over all the territory of Côte d'Ivoire it established the principle of a general revision of citizenship law, including that the conditions for eligibility to senior public offices should be that candidates hold Ivorian citizenship and a father or - not and - a mother who held Ivorian nationality of origin. On that basis and under pressure from South Africa's then president Thabo Mbeki, who played a role in facilitating talks, President Gbagbo confirmed in April 2005 that all signatories of the Marcoussis agreement (which included Ouattara) would be able to run for office in the next presidential elections. ${ }^{382}$

Economic interests affected by the war also intervened to ensure some changes to the 1998 land law in relation to the rights of non-citizens. Amendments adopted in August 2004 recognised the rights of those non-citizens who could prove legal title to land dating before the 1998 land law, including the right to pass title to others; though with the requirement that these rights only took effect if the owners were specifically listed in a decree of the Council of Ministers. ${ }^{383}$ The amendments did not change the situation of those who did not have written evidence of ownership, and only just over one hundred non-citizens actually benefited from this legislation, out of which more than a third were French agri-businesses. The vast majority of non-citizen land holders were still left with no secure tenure.

379 Resolution 1528 (2004), Adopted by the Security Council at its 4918th meeting, 27 February 2004.

380 Formed by an amalgamation in March 2003 of the MPCI with the Mouvement Populaire Ivoirien du Grand Ouest (MPIGO) and the Mouvement pour la Justice et la Paix (MJP), both based in the south-west.

381 Accord de Linas-Marcoussis, 24 January 2003, Annex « Programme du gouvernement de réconciliation ".

382 “La présidentielle envisagée par Gbagbo pour fin 2007”, L'Humanité, 8 August 2007.

383 Loi no. 2004-412 du 14 août 2004 portant amendement de la loi n $98-750$ du 23 décembre 1998 relative au Foncier Rural (amending Article 26). 
Two laws adopted in late 2004 in application of the agreement at Linas-Marcoussis revised the nationality code and established temporary special naturalisation procedures that on the face of it partially addressed some of the nationality problems. The revisions to the nationality code made it possible for the first time for a man marrying an Ivorian woman to acquire Ivorian nationality, rather than having to naturalise by the procedures applicable to any foreigner. ${ }^{384}$ In addition, the amendments introduced explicit restrictions on the exercise of public office by naturalised citizens, clearly in light of the second law. ${ }^{385}$

The law creating temporary special naturalisation procedures applied to all those who had been allowed to claim nationality from 1961 either during the transitional period of one year or until the procedures for acquisition by declaration were repealed by the amendments to the nationality code in 1972 (that is, those aged under 21 at the date of independence and born in Côte d'Ivoire of foreign parents, those born in Côte d'Ivoire of foreign parents between 1960 and 1973, and those who habitually lived in Côte d'Ivoire before independence). The law established that people in these categories could, during a limited period, apply for naturalisation with written evidence in the form of an original birth certificate or a jugement supplétif, a form of late certification of birth from a tribunal. In addition, an applicant was required to provide proof of renunciation of nationality of origin — something difficult or impossible to do, for those who had lost any connection to the country of their parents' birth - as well as proof of residence and a criminal record check. ${ }^{386}$ At the same time, restrictions on "foreign" participation in the formal workforce were also strengthened, and the law on identification of foreigners was again adjusted. ${ }^{387}$

384 Loi no. 2004-662 modifiant et complétant la loi 61-415 portant Code de la nationalité. Under the 1961 nationality code as in force to that date, a foreign woman marrying an Ivorian man had automatically acquired nationality on marriage; the amendments changed this rule to a right for the woman to opt for Ivorian nationality at the time of marriage; but for a man marrying an Ivorian woman only to be able to do so after a two year delay. Presidential decisions 2005-03/PR of 15 July 2005 and 2005-09/PR of 29 August 2005 reduced and then removed the discrimination based on sex, and made it possible for either a man or a woman marrying an Ivorian national to acquire nationality by option at the time of marriage.

385 Loi no.2004-662 initially amended the provisions on loss of nationality to provide for automatic loss of nationality if a person exercised office in a foreign country; presidential decision 2005-03 restored the previous situation, where loss would be dependent on government action to deprive the person by decree.

386 Loi no.2004-663 du 17 décembre 2004 portant dispositions spéciales en matière de naturalisation. See also Habibou Bangré, “Côte d'Ivoire : révision du code de la nationalité et de la naturalisation ; Les amendements apportent des progrès mitigés", 21 December 2004, available at http://www.afrik.com/article7981.html, last accessed 7 November 2014.

387 Arrêté n 1437 du 19 février 2004 portant modification de l'arrêté n 4810 du 21 avril 1997 relatif à la réglementation du recrutement et des frais de visa du contrat de travail des personnels non ivoiriennes ; Loi No.2004-303 du 3 mai 2004 portant modification 
The law on special naturalisation procedures was modified twice by presidential decisions in 2005 clarifying and redefining the categories of people to which it applied and adjusting the procedures for application. ${ }^{388}$ The implementing decree was only finally adopted by the Council of Ministers in May 2006, starting an initial one year period for those who wished to apply for naturalisation under its provisions. ${ }^{389}$

The government then implemented a programme of late registration of birth through special hearings by departmental tribunals travelling away from their usual seat (audiences foraines). ${ }^{390} \mathrm{~A}$ birth certificate is an essential first step to gaining recognition of nationality through a certificate of nationality or national identity card, as well as for applying for naturalisation under the special procedures. The civil war had caused birth registration rates to fall from 72 per cent in 2000 to 58 per cent by $2006,{ }^{391}$ and the process aimed to provide those who had not been registered at birth with a jugement supplétif, that is, with court approval for late registration of birth (as provided for in the civil status law ${ }^{392}$ ). Applying for recognition of nationality was then a second step of the process. The special identification process was repeatedly postponed by Gbagbo and interrupted by his supporters: in July-August 2006 the FPI's Jeunes Patriotes (Young Patriots) militia responded to a party leadership call to arms and brought the hearings to a halt by staging violent demonstrations and attacking foreigners and opposition party organisers. ${ }^{393}$ As a result of these issues, in the end, not a single naturalisation was actually approved as a result of the special measures on naturalisation. ${ }^{394}$

de la Loi No.2002-03 relative à l'identification des personnes et au séjour des étrangers en Côte d'Ivoire.

388 Décision no. 2005-04/PR du 15 juillet 2005 and Décision no.2005-10/PR du 27 décembre 2005.

389 Décret No.2006-76 du 31 mai 2006 portant modalités d'application de la loi no.2004663 du 17 décembre 2004, which again re-adjusted the precise definition of those who were eligible to benefit, to bring the law precisely into line with the original provisions in the 1961 nationality code, repealed in 1972.

390 A 2004 decree had tasked the ONI with the mission of modernizing the civil registration system and organizing such mobile court hearings. Article 13, Décret No. 2004-28 du 15 janvier 2004 portant modification du décret No. 2001-103 du 15 février 2001 portant création de l'Office Nationale d'Identification.

391 Every Child's Birth Right: Inequities and trends in birth registration, UNICEF, 2013.

392 Loi no.64-374 du 07 octobre 1964, sur l'état civil telle que modifiée par les lois no.83-799 du 02 août 1983 et no.99-691 du 14 décembre 1999. This system of jugement supplétifs (or déclaratifs) is the standard procedure in the francophone countries.

393 See, for example, "Abidjan paralysée par les Jeunes Patriotes hostiles aux audiences foraines ", IRIN, 19 July 2006. Also Situation des droits de l'homme en Côte d'Ivoire: Rapport No.6, mai-juin-juillet-août 2006, Mission des Nations Unies en Côte d'Ivoire ; Rapport du Président de la Commission sur la situation en Côte d'Ivoire, African Union Peace and Security Council, PSC/AHG/3(LXIV), 64th meeting, 17 October 2006.

394 Explanatory memorandum for Law No.2013-653 du 13 septembre 2013. 
While this process was still blocked, Gbagbo and Soro finally signed an agreement in March 2007 in Ouagadougou, creating a government of national reconciliation. Gbagbo was to be president and Soro prime minister. Further measures agreed for the reunification of the country included the redeployment of administrative authorities throughout the country, the demobilisation of militias, the disarmament of former combatants, the organisation of fresh democratic elections within one year; and first of all, a process of identification of the population, with renewed audiences foraines, the reconstitution of civil registries damaged in the crisis, a new identity card system and a new electoral register. ${ }^{395}$ A "Flame of peace ceremony" was held in Bouaké, in central Côte d'Ivoire, on 30 July 2007, to symbolise the end of the war and the beginning of the reconciliation process.

The Ouagadougou Accord provisions on identification were implemented through the adoption of a decree providing new procedures under the 1962 law requiring all nationals to hold an identity card. Under this decree there were two ways of obtaining an ID card: either by "ordinary identification" or by registering to vote. To obtain a card by "ordinary identification" it was required for the first time that a person must produce not just a birth certificate, but also a certificate of nationality; but those who were registered to vote need only produce a birth certificate to get a card - and a certificate of nationality was not needed in order to be entered on the voters roll. ${ }^{396}$ The requirement for ECOWAS nationals to hold a carte de séjour was repealed. ${ }^{397}$

The identification process resumed, with modified procedures, ${ }^{398}$ and by mid-May 2008, when it was declared completed after time extensions, the audiences foraines had issued more than 600,000 jugements suppletifs. ${ }^{399}$ Following an extension, the UN reported that 750,000 people had received late registration of birth by 25 September 2008; even so, the numbers were lower than they might have been, since the central administration had yet to be re-established in many parts of the north of the country. ${ }^{400}$ However, the "ordinary identification" process was not

395 Accord Politique de Ouagadougou, March 2007.

396 Décret No. 2007-647 du 20 décembre 2007 portant conditions d'établissement, d'obtention et de forme de la Carte Nationale d'Identité, articles 4 and 5.

397 Ordonnance No.2007-604 du 8 novembre 2007 portant suppresion de la Carte de Séjour.

398 Décision No.2007-14/PR du 21 septembre 2007 portant Dispositions spéciales en matière d'audiences foraines.

399 See Statement of the Ministry of Justice and Human Rights on the mobile court process at http://www.audiencesforaines.gouv.ci/faq4.php, last accessed 7 November 2014; Seventeenth Progress Report of the Secretary-General on the United Nations Operation in Cote d'Ivoire, UN Security Council Document S/2008/451, 10 July 2008.

400 Eighteenth Progress Report of the Secretary-General on the United Nations Operation in Côte d'Ivoire, UN Security Council Document S/2008/645, 13 October 2008; In addition, 250,000 civil registry entries had been reconstituted; Rapport Final : Election Présidentielle 31 octobre - 28 novembre 2010, Mission d'Observation Electorale de l'Union Européenne, 25 January 2011. 
yet re-instituted, with the focus on the second form of identification, based on the voters' roll.

Inevitably, there were also extended delays and confusion over the process of voter identification and registration — in which the rights of those with contested nationality (who would be expected to vote against Gbagbo) was the principal issue at stake. The 2000 electoral code remained in force, as modified in 2008 to provide for "elections to exit the crisis" ${ }^{401}$ Voters were Ivorian nationals and those who had acquired nationality by naturalisation or marriage. ${ }^{402}$ The criteria to stand for president or for the national assembly established in 2000 remained in place. Elections were repeatedly postponed, as the protagonists argued over the identification of those eligible to vote.

Responsibility for the voter identification process, officially launched in September 2008, was split between five entities, led by the Independent Electoral Commission (Commission électorale indépendante, CEI) and the National Commission for Supervision of Identification (Commission nationale de supervision de l'identification), highly disorganised, plagued with problems of cross-checking, and lacking a clear framework for operations. Registration drives were often disrupted by attacks, particularly in the highly insecure west of the country, in which armed men intimidated those waiting registration at centres, or confiscated registration papers that had been completed. In late 2009, two electoral lists were published after many delays and "cross-checking" of lists: the "white list" of 5.3 million people who were in principle accepted for the electoral roll; and the "grey list" with an additional 1.1 million "doubtful" cases of people who were required to show further proof of their right to vote, that is, of their nationality. Militants from the Jeunes patriotes sought the removal of many other names on the "white list"; Gbagbo himself did not miss an opportunity to emphasise the distinction between Ivorians and foreigners throughout the campaign; and dissolved and reconstituted the CEI in February 2010. ${ }^{403}$ A new "provisional electoral list" was published in July 2010, after further additions and deletions, and the final definitive list of 6 September 2010 numbered 5.7 million people. Although accepted by the UN as credible, it was rather the product of agreement between the parties than a verified process. The full final list was never distributed to voting stations, while the nationality status of 601,322 persons who remained on the grey list was never clarified. ${ }^{404}$

401 Ordonnance no.2008-133 du 14 avril 2008 portant ajustements au Code Electoral pour les élections législatives de sortie de crise ; Décision no. 2008-15/PR du 14 avril 2008 portant modalités spéciales d'ajustements au Code Electoral.

402 "Sont électeurs les nationaux ivoiriens de deux sexes et les personnes ayant acquis la nationalité ivoirienne soit par naturalisation soit par mariage "

403 See International Crisis Group reports: Ensuring Credible Elections, Africa Report N ${ }^{\circ} 139$, 22 April 2008; What's Needed to End the Crisis, Africa Briefing Nº2, 2 July 2009; Securing the Electoral Process, Africa Report N¹58, 5 May 2010.

404 Numbers on the different lists taken from Rapport Final, Mission d'Observation Electorale 
Presidential elections were finally held in two rounds in October and November 2010. Given the context in which they were held, challenges to the validity of the results were hardly surprising; but victory for Ouattara against all the odds and without the benefits of incumbency was more unexpected. On 1 December, the CEI announced that Ouattara had taken 54.1 percent in the run-off vote, with 45.9 percent to Gbagbo. On 3 December, however, the Constitutional Council ruled that the results announced by the CEI were invalid in seven northern constituencies supportive of Ouattara, and that Gbagbo had won with 51.45 percent of the vote. By the end of 2010, the country was back in full scale crisis. ${ }^{405}$ Both presidential candidates began appointing a government, and Côte d'Ivoire was suspended from both ECOWAS and the African Union, which urged Gbagbo "to respect the results of the election and to facilitate, without delay, the transfer of power to the President-Elect, in the best interests of Côte d'Ivoire, the region and Africa as a whole." ${ }^{406}$ At least one thousand people were killed in renewed conflict over the next five months. ${ }^{407}$

Ultimately, a military offensive from the Ouattara side led to the arrest of Laurent Gbagbo in Abidjan, facilitated by French and UN support. On 21 May 2011, Alassane Ouattara was finally inaugurated as president. ${ }^{408}$ Legislative elections were held on 11 December 2011, ${ }^{409}$ the first since 2000, just two weeks after Gbagbo's transfer to the International Criminal Court in The Hague. The elections were boycotted by Gbagbo's party, the FPI, and on a turnout of only around one third of those on the electoral register established the previous year, the RDR and PDCI took 122 and 76 seats each, with the remainder of the 255 seats going to smaller parties and independents. ${ }^{410}$

Among the many critical issues for the new administration and legislature to address, including national reconciliation, measures of accountability for war crimes, and the reconstruction of the economy, was the continued crisis over nationality and identification. Even before a new National Assembly was in place,

de l'Union Européenne; also Adjami, Statelessness and Nationality in Côte d'Ivoire.

405 International Crisis Group, Finally Escaping the Crisis? Africa Briefing $N^{\circ} 77,25$ November 2010; Is War the Only Option? Africa Report Nº171, 3 March 2011; Human Rights Watch, "That Land Is My Family's Wealth" Addressing Land Dispossession after Côte d'Ivoire's PostElection Conflict, 2013.

406 Communique of the $252^{\text {nd }}$ Meeting of the Peace and Security Council of the African Union (AU), on the situation in Côte d'Ivoire. 9 December 2010.

407 "Death toll in Ivorian post-election violence surpassed 1,000 - UN", UN News Centre, 26 May 2011.

408 Amnesty International, They Looked at his Identity Card and Shot him Dead: Six Months of Post-Electoral Violence in Côte d'Ivoire, AFR 31/002/2011.

409 Also governed by the 2000 electoral code, with further modifications for the 2011 legislative elections. Ordonnance $n^{\circ} 2011-352$ du 24 octobre 2011 ; Ordonnance $n^{\circ}$ 2011 $\square 382$ du 10 novembre 2011.

410 Results as posted at http://africanelections.tripod.com/ci.html\#2011 National Assembly Election, last accessed 12 November 2014. 
President Ouattara adopted an ordinance in September 2011 to facilitate the late registration of births that had taken place since 2002. ${ }^{411}$ A new law adopted in 2013 further extended the deadlines, allowing late registration up to the end of July 2014. ${ }^{412}$ After some consultation and study of the existing procedures, in October 2013 the Council of Ministers authorised the ONI to start the process for "ordinary identification" provided for under the Ouagadougou Political Accord and resume the issuing of identity cards, based on the requirement that a person have a certificate of nationality. ${ }^{413}$

The new legislature also adopted two new laws on nationality: as in 2004, one modified the nationality code, and the other provided temporary special naturalisation procedures. The law amending the nationality code made acquisition of nationality on marriage once again automatic (rather than requiring an option), but now automatic for either a man or a woman marrying an Ivorian national (rather than only a woman marrying an Ivorian man, as it had been at independence). ${ }^{414}$ The new law on special naturalisation procedures was targeted at the same people as the 2004 law; that is, those who could have benefited from the transitional provision on naturalisation for those habitually resident in 1961, and for those born in the territory before January 1973 and still resident as adults. ${ }^{415}$ But the law and its implementing decree made the procedures to access nationality significantly easier by providing for non-discretionary acquisition of nationality by declaration (if the conditions were met) rather than the highly discretionary naturalisation envisaged in the normal framework of the nationality code, from which few had benefited, and the 2004 special procedures, which had reached nobody at all. ${ }^{416}$ Declaration forms were distributed by the Ministry

411 Ordonnance No.2011-258 du 28 septembre 2011 relative à l'Enregistrement des naissances et des décès survenus durant la crise.

${ }^{412}$ Loi No.2013-35 du 25 janvier 2013 portant modification de l'article 2 de l'Ordonnance No. 2011-258 du 28 septembre 2011 relative à l'Enregistrement des naissances et des décès survenus durant la crise.

413 Projet de Communiqué du Conseil des Ministres du Mercredi 02//10/2013 ; in 2014 a new decree was adopted to authorise the issuing of identity cards : Communique du Conseil des ministres du mercredi 04 juin 2014 ; also Adjami, Statelessness and Nationality in Côte d'Ivoire.

${ }^{414}$ Loi No.2013-654 du 13 septembre 2013. Although the automatic acquisition can be problematic (for example, if the other country does not allow dual nationality), it does mean that a person does not have to be aware that a positive step must be taken in order to acquire nationality.

415 Loi No.2013-653 du 13 septembre 2013. However, with some confusion on the categories (especially the application to descendants of those initially entitled) created by different wording in the law, its implementing decree and an interministerial circular. See Adjami, Statelessness and Nationality in Côte d'Ivoire.

416 Loi No.2013-653 du 13 septembre 2013, and its explanatory memorandum; Décret No.2013-848. The declaration procedure also meant that the person acquiring nationality was not subject to the limitation of political rights placed on those who have naturalised. Following the change of government in 2011, the Ministry of Justice conducted at 
of Justice to the relevant tribunals of first instance, as well as to the offices of the administration. At the same time, the National Assembly also adopted a law approving Côte d'Ivoire's accession to the two statelessness conventions. ${ }^{417}$ By the end of 2014, approximately 60,000 declarations requesting nationality had been submitted, though none yet officially approved. ${ }^{418}$

But these measures, while important, only addressed the situation of those born before 1973, leaving a very large number of people resident in Côte d'Ivoire in doubt as to their nationality as Ivorian. These included not only the descendants of the pre-independence migrants, but also those born since 1972 of foreign parents, and their own children (not covered by the special naturalisation procedures), members of some ethnic groups found in remote border areas and un- or under-counted in the census, children of unknown parents, the children of refugees and the internally displaced, and anyone whose nationality had been questioned in the past, including some 600,000 people on the "grey list" for the elections of $2010 .{ }^{419}$ The main provisions of the nationality law on the acquisition of nationality of origin for those born in Côte d'Ivoire remained highly restrictive, and no revision to this law was in sight. And with a limited mandate after parliamentary elections boycotted by the main opposition, the government of President Ouattara was hardly in a strong position to fix these problems.

least two comprehensive surveys of the archives of the Official Journal, where decrees of naturalisation are published. The first review estimated that at 31 December 2012, 32,819 individuals had been naturalized since 1962 by the signing of 7,121 decrees. These numbers do not include minor children who would have acquired subsidiary Ivorian nationality through the naturalization of their parents. Another review conducted by the Ministry of Justice in 2013 concluded that 14,793 naturalization decrees had been signed concerning 92,760 beneficiaries, over the same period. The discrepancies may have been the result of different counting techniques with respect to inclusion of subsidiary acquisition of Ivorian nationality by spouses and minor children. Adjami, Statelessness and Nationality in Côte d'Ivoire, based on internal report of the Ivorian Ministry of Justice to UNHCR submitted in February 2012.

417 Loi No.2013-647 du 13 septembre 2013 and Loi No.2013-649 du 13 septembre 2013 authorising the president to ratify the 1954 and 1961 Conventions.

418 Information from UNHCR Côte d'Ivoire, email 2 February 2015.

419 Adjami, Statelessness and Nationality in Côte d'Ivoire. 
Tiken Jah Fakoly : Où veux-tu que j'aille ${ }^{420}$

Où veux-tu que j'aille? (bis)

Pourquoi veux-tu que j'm'en aille?

Où veux-tu que j'aille?

T'as brûlé ma maison d'Abidjan

Parce que je ne suis pas de ton clan

Mon grand-père t'a tout donné

Mon papa a tant sué

Moi je suis né là,

Pourquoi veux-tu que j'm'en aille?

Front la racaille !

Où veux-tu que j'aille?

Où veux-tu que j'aille? (bis)

Pourquoi veux-tu que j'm'en aille?

Où veux-tu que j'aille?

...

Nous sommes tous nés là

Exilés sans autre choix

Nos grands-pères se sont sacrifiés (tirailleurs!)

Nos papas se sont intégrés

Même si on nous traite d'étrangers

Pourquoi veux-tu qu'on s'en aille?

Front la pagaille

Où veux-tu qu'on aille? (bis)

Mais où veux-tu que j'aille?

Pourquoi veux-tu qu'on s'en aille?

Où veux-tu qu'en aille?

Dans les années soixante

On a fait appeler là nos frères

Rappelés au bord de la mer !

Bukinabés, maliens et africains

Pourquoi veux-tu qu'ils s'en aillent,

compatriotes?

Pour quoi tu en as honte?

Où veux-tu qu'on aille?

Pourquoi veux-tu que j'm'en aille?

Où veux-tu qu'on aille?
Where do you want me to go ?

Why do you want me to go?

Where do you want me to go?

You burnt my house in Abidjan

Because I am not from your clan

My grandfather gave you everything

My father sweated so much for you

Me, I was born here,

Why do you want me to go?

Rabble rousers!

Where do you want me to go ?

Where do you want me to go ?

Why do you want me to go?

Where do you want me to go?

$\cdots$

We were all born here

Exiled without any choice

Our grandfathers were sacrificed (tirailleurs ${ }^{421}$ !)

Our fathers were integrated

Even if we are treated as strangers

Why do you want us to go?

Coalition for chaos

Where do you want us to go ?

But where do you want me to go?

Why do you want us to go?

Where do you want us to go?

In the $1960 \mathrm{~s}$

We called our brothers here called them to come down to the sea!

Burkinabés, Malians and Africans

Why do you want them to go, compatriots?

Why are you ashamed of them?

Where do you want us to go?

Why do you want me to go?

Where do you want us to go?

${ }^{420}$ Available at https://www.youtube.com/watch?v=ASF-GELkmzg, last accessed 22 November 2014.

421 African soldiers fighting for the French army. 



\section{State succession since independence and its impact on nationality}

Africa's colonial history, like that of other zones of former empire, has made the rules governing the transition to independence - the rules of state succession - particularly sensitive in the context of nationality law. Many of the most well-known cases of individuals or groups deprived of nationality relate to the status of those who were recognised as colonial subjects but whose presence is resented today, to the inhabitants of regions whose borders were altered during the colonial period, or to the determination of where someone belongs whose parents came from another part of a common colonial territory and who migrated as part of colonial policy.

The case studies of the previous chapter frequently revolve around the rules governing nationality at the succession of states: the content of these laws are central to Kenneth Kaunda's alleged citizenship of Malawi or Alassane Ouattara's of Burkina Faso and to the general status of the "Dioula" in Côte d'Ivoire or of the Banyarwanda in eastern DRC; their implementation (or lack of it) to the status of Asians in East Africa or Lebanese in West Africa. There are many other issues at stake of course, some of them unconnected to legal frameworks, most importantly questions of economic and political power; but the problematic nature of some transitional provisions on nationality, and their openness to wilful misinterpretation in others, mean that law has been a key tool in national politics around the nature of belonging.

More recent cases, long after the departure of the European colonial powers, illustrate that the rules governing transitions in state authority are always critical: deeply political even when they seem most tediously technical; and with the potential to cause problems long after the rules were first adopted. ${ }^{1}$

The most damaging example so far in the post-colonial history of the continent has been around the secession of Eritrea from Ethiopia - itself never colonised. In 1998, former comrades in arms against dictatorship in Ethiopia's central government, who had together successfully overthrown that regime and then, to the world's admiration, peacefully managed the process of creating a new state of Eritrea along Ethiopia's northern border, decided to turn their guns on each other instead. The brutal war that followed between the Ethiopian and Eritrean armies, fought out in an arid mountainous version of World War I trenches,

1 The information in this chapter is based on material first published in Struggles for Citizenship in Africa; in two publications on Sudan published by the Open Society Foundations in 2011 and 2012; and in Nationality, Migration and Statelessness in West Africa. 
devastated the lives of tens of thousands: not only the soldiers who were killed and injured and their families; but of all those who became instant suspected traitors in the land of their birth. The conflict rendered people born of parents from the "wrong" side of the border of what had been one country open to treatment as foreigners and subject to deportation.

The case of the secession of South Sudan may yet have even more serious consequences, as the issue of citizenship lurks to destabilise both halves of the former single country. The determination of successive governments of Sudan to define the Sudanese state as Arab and Muslim - the adoption of shari'a law as the basis of the legal system, the insistence on Arabic language law and education, and other measures - was a major driver of the two long civil wars that afflicted the country after independence in 1956. Nonetheless, the idea of Sudanese nationality in itself had not been questioned until the final secession of the south to form a new Republic of South Sudan in 2011. The failure of the parties to agree a joint definition and a joint mechanism to adjudicate cases in doubt left many former citizens of the united Sudan for the first time at risk of denial of their rights as continuing citizens of the Republic of Sudan and some at risk of statelessness, excluded from both the successor states.

A particular category of border population most affected by doubts around nationality are those affected by border disputes; and in particular those where administration of territory has been transferred as a result of a ruling by the International Court of Justice (ICJ). The best known of these cases, and the one affecting the most people, awarded the Bakassi peninsula bordering Nigeria and Cameroon to Cameroon; but other cases relate to disputed frontiers between territories formerly administered as part of AOF, where boundary determination had never been a priority during the colonial period. Often the populations affected by such border disputes have long had limited contact with the central administrations of either country, and thus are likely to have few documents of an existing nationality; in addition, they may be members of minority ethnic groups, or of nomadic or semi-nomadic lifestyle, making them more vulnerable to doubts about their nationality, whether or not any dispute is resolved. The ICJ - following recognised principles of international law - notably fails either to take into account the wishes of the inhabitants of these territories in relation to their nationality or to make any ruling on the steps that should be taken to ensure that those affected have a recognised nationality after the transfer of territory.

\subsection{Eritrea/Ethiopia: State succession and mass expulsion}

Ethiopia remained independent throughout the period of European colonial government in Africa, under the rule of the Amharic emperors, though its external borders were established by the conquest of neighbouring territories by the Italians, French and British. It was thus the first sub-Saharan African country to have its own nationality law, adopted in 1930. The 1930 law was based on jus 
sanguinis, providing that: "Any person born in Ethiopia or abroad, whose father or mother is Ethiopian, is an Ethiopian subject.” Although the law was genderneutral at first sight, the provisions setting out the arrangements through which children born of mixed marriages could establish their Ethiopian nationality, also stated that: "Every child born in a lawful mixed marriage follows the nationality of its father." 2 Thus, children of Ethiopian women and foreign men were not regarded as Ethiopian - either in law or in popular understanding - even if they were born and had lived all their lives in Ethiopia. ${ }^{3}$ In relation to marriage, the law also discriminated, allowing a man to pass nationality to his wife, but not vice versa. ${ }^{4}$ These laws already created a problem of statelessness in Ethiopia: many Arabs, Italians, Greeks, Armenians, and others lived in Ethiopia from the late 19th century, and many married Ethiopians, and had children born and raised in Ethiopia. If the father was foreign, these children did not have the right to Ethiopian nationality (see chapter 4.1 for a discussion of the history of Ethiopian nationality law).

Though Ethiopia was never formally colonised, Eritrea was an Italian colony from the late nineteenth century till 1941, when British troops advancing from Sudan defeated the Italians during World War II. Following a period of British military administration, the United Nations adopted a resolution in 1950 designating Eritrea an autonomous unit federated to Ethiopia. In 1962, Ethiopian Emperor Haile Selassie unilaterally annexed Eritrea and declared it a province of Ethiopia; residents of Eritrea without another nationality were declared to be Ethiopian nationals. The Eritrean People's Liberation Front (EPLF) began an armed struggle against Ethiopian rule; following the 1974 overthrow of the emperor by the brutal military government known as the Derg, they joined with the Tigrayan People's Liberation Front (TPLF) of northern Ethiopia and other ethnically based armed groups in the alliance known as the Ethiopian Peoples' Revolutionary Democratic Front (EPRDF).

2 Ethiopia Nationality Law, July 1930, sections 1 and 6.

3 "A child born in a lawful marriage of an Ethiopian mother with a foreigner is always able to recover the benefit of Ethiopian nationality, provided he lives in Ethiopia and proves he is completely divested of the paternal nationality" (section 7); "If the lawful marriage according to the national law of the foreign father is posterior to the birth of the child issued from his relations with an Ethiopian woman, the child legitimated through this subsequent marriage follows the nationality of his foreign father only on condition that the national law of the latter confers upon him the foreign nationality with all inhering rights. Otherwise, the child preserves his Ethiopian nationality" (section 8). Ethiopia Nationality Law, July 1930, sections 7 and 8 .

4 "A lawful marriage [in Ethiopia or abroad] of an Ethiopian [man] with a foreign woman confers Ethiopian nationality upon her", "a lawful marriage contracted abroad of an Ethiopian woman with a foreign [man] deprives her of Ethiopian nationality if her marriage with the foreigner gives her the nationality of her husband." Ethiopia Nationality Law, July 1930, sections 2 and 4. 
In 1991, the EPRDF finally defeated the Derg, and the new Ethiopian transitional government immediately approved — as promised within the alliance - a referendum on the status of Eritrea. All individuals identifying themselves as Eritrean, including those living within the borders of what would become Ethiopia, were allowed to register and vote, provided they obtained an "identification card" issued by the Eritrean provisional government. More than 1.1 million people registered; including more than 300,000 outside the country, 60,000 of whom were in Ethiopia. The referendum was held in 1993 under UN supervision; the vote was 99 percent in favour of independence, and a new state was formed. The two governments agreed that "until such time that the citizens of one of the sides residing in the other's territory are fully identified and until the issue of citizenship is settled in both countries, the traditional right of citizens of one side to live in the other's territory shall be respected." 5

In Eritrea, the Nationality Proclamation of 1992, on the basis of which eligibility to register in the independence referendum was determined, provided that Eritrean nationals are those born of a father or mother "of Eritrean origin"; and defined "Eritrean origin" to mean (descent from) a person who was resident in Eritrea in $1933 .{ }^{6}$ Despite the apparent reference to ethnic origin, the definitions in in the law in fact based citizenship on the international norm of habitual residence, while providing a cut-off date for automatic citizenship that was far in the past and avoided giving nationality to recent arrivals in the territory. Those who entered and resided in Eritrea between 1934 and 1951 are also entitled to a certificate of nationality on application. Any person who arrived in Eritrea in 1952 or later — including Ethiopians — must apply for naturalisation in the same way as any other foreigner, showing a ten-year residence in Eritrea before 1974, or a twenty-year residence thereafter, and must renounce any other nationality. They must also not have "committed anti-people acts during the liberation struggle of the Eritrean people". ${ }^{7}$ Though restrictive — the 1933 date is very long ago, while the 20 year regular naturalisation period is very long - those who obtained Eritrean nationality in 1993 included many people of mixed parentage, descendants of Europeans who had come to Eritrea during the colonial period, members of groups who had somehow stayed in Eritrea while en route to or from Mecca for the Haj, and so forth.

5 "Agreement on Security and Other Related Matters between the Ministries of Internal Affairs of the governments of Ethiopia and Eritrea", Addis Ababa, 13 May 1994, article 2.3. Cited in Human Rights Watch, The Horn of Africa War: Mass Expulsions and the Nationality Issue (June 1998-April 2002), January 2003; see also (from the Eritrean perspective) Natalie S. Klein, Report on the Deportation of Eritreans and Ethiopians of Eritrean origin from Ethiopia, June - August 1998, Embassy of Eritrea, Washington DC, 1999.

${ }_{6}$ Eritrean Nationality Proclamation (No. 21/1992). A 1933 Italian colonial decree had defined as Eritrean "subjects" all persons (with the exception of Italian "citizens"), residing in the country before the end of 1933.

7 Eritrean Nationality Proclamation No.21/1992, articles 2-4. 
Ethiopia, meanwhile, adopted a new constitution in 1994, that provided a right to a nationality for all children and granted Ethiopian citizenship to "any woman or man either of whose parents is an Ethiopian citizen", in principle creating gender neutrality. A general provision on the right to equality, also provided, among other things, for non-discrimination on the basis of sex. While silent on dual citizenship, the constitution further stated that "no Ethiopian citizen shall be deprived of his or her Ethiopian citizenship against his or her will", and that marriage of an Ethiopian, male or female, to a foreigner does not result in the loss of Ethiopian nationality unless he or she chooses to take the nationality of his or her spouse. ${ }^{8}$

The statute law in force, however, remained the Ethiopian Nationality Law of 1930, which stated that any Ethiopian citizen who acquired another nationality would lose his or her Ethiopian citizenship (as well as discriminating on the basis of gender in granting citizenship in general). ${ }^{9}$ Nonetheless, as late as 1996, Ethiopia still affirmed that additional procedures were required for those who wished to substitute their Ethiopian with Eritrean nationality, in an agreement with Eritrea that Eritrean-Ethiopians should be made to choose between their two possible nationalities. ${ }^{10}$ Implementation of this agreement was postponed, however, until other issues were resolved.

Despite initial harmony between the governments of the two territories, there was popular resentment within Ethiopia at the perceived privileged status and economic dominance of people of Eritreans descent living in the country (as well as at the dominance of Tigrayans in the Ethiopian government). Tensions between the two governments began to develop also, especially on trade (newly landlocked Ethiopia relied heavily on access to the sea through Eritrea's Red Sea ports of Massawa and Assab) and agreement of the border between them. In 1998, war erupted over the formal demarcation of the route of that border. Fighting continued over the following two years at varying levels of intensity, until repeated attempts to negotiate a truce eventually culminated in a comprehensive peace agreement in December 2000.

At the outbreak of the war, there were still around half a million people of Eritrean origin living in Ethiopia, including approximately 200,000 living in the Tigray border region. An estimated 100,000 Ethiopians were living in Eritrea.

8 Constitution of the Federal Democratic Republic of Ethiopia, 8 December 1994, articles 6, 25, 33, 35 and 26. Article 6 provides that: "(1) Any person of either sex shall be an Ethiopian national where both or either parent is Ethiopian. (2) Foreign nationals may acquire Ethiopian nationality. (3) Particulars relating to nationality shall be determined by law."

9 Ethiopian Nationality Law, 1930, article 33(1). The 2003 Proclamation on Ethiopian Nationality removed the gender discrimination, but still prohibits dual nationality.

10 Agreed minutes of the Fourth Ethio-Eritrean Joint High Commission Meeting, 18-19 August 1996, paragraph 4.3.4. Cited in Human Rights Watch, The Horn of Africa War. 
In June 1998, approximately one month after the war began, Ethiopia issued a policy statement that the " 550,000 Eritreans residing in Ethiopia" could continue to live and work in the country, although politically active individuals were ordered to leave the country and those in "sensitive" jobs were told to take a mandatory leave of one month. ${ }^{11}$ Despite this reassurance, the very next day saw the first wave of arrests and expulsions of prominent individuals of Eritrean origin, including those working for intergovernmental organisations based in Addis Ababa, and dismissals of those in government jobs. As the arrests and expulsions continued into 1999 and 2000, those affected were increasingly ordinary people with no particular status to attract the authorities' attention. Almost all those expelled from urban areas were detained in harsh conditions, often for weeks, before being transported in bus convoys on a several day journey to the border. Rural people affected by the campaign were ordered to leave, and usually had to travel on foot, without their personal possessions. Ultimately, the Ethiopian authorities arrested, detained and deported some 75,000 people of Eritrean origin without any attempt at due process of law.

In July 1999, the Ethiopian authorities issued a press release stating that the Ethiopians of Eritrean origin who had registered to vote in the 1993 referendum on Eritrea's independence had thus assumed Eritrean citizenship; though that was clearly not the interpretation that any party put on the process at the time. ${ }^{12}$ A month later all those who had registered for the referendum were required to register for alien residence permits with the Security, Immigration and Refugee Affairs Authority, to be renewed every six months. Business licences for these individuals were revoked, and assets frozen; despite procedures that were supposed to be in place to allow the appointment of others to oversee their property, many suffered huge losses.

The Eritrean government organised quickly to assist the expellees, registering them as refugees in the same way as other Eritrean exiles returning from abroad. Nonetheless, although the more economically and educationally advantaged integrated relatively quickly, many still reside in a UNHCR-administered camp in Eritrea and some still have no permanent identity papers, though others are reported to purchase Eritrean documents. ${ }^{13}$

During the first phase of the conflict, there was no official Eritrean policy of expulsion of Ethiopians, though Ethiopians were subject to popular abuse and

11 "Government says never to change policy on relations with Eritreans", Press Digest, Vol.V, no.25, 18 June 1998, quoting the Ethiopian Herald of 13 June 1998. Cited in Human Rights Watch, The Horn of Africa War.

12 “Eritrea's baseless accusations", Ethiopia Office of Government Spokesperson, 9 July 1999.

13 Canada: Immigration and Refugee Board of Canada, Eritrea: Prevalence of fraudulent national identity cards, 8 July 2008, ERI102852.E, available at: http://www.refworld.org/ docid/49b92b4b0.html, last accessed 18 December 2014. 
official harassment, and many were in fact prevented from leaving by denial of the required exit visas. As the war continued, Eritrea's policy became more hostile. From August 1998 to January 1999, during a period of relative calm in the war, around 21,000 Ethiopians left Eritrea with the assistance of the International Committee of the Red Cross (ICRC). The Eritrean authorities claimed the departures were voluntary, though some intimidation was nonetheless reported by those concerned. In July 1999, Ethiopia asserted that some 41,000 of its citizens had been deported from Eritrea. A major Ethiopian offensive in May 2000 caused perhaps one third of Eritrea's three million people to flee their homes. In early June 2000, Ethiopian citizens living in Asmara were told to register with the authorities "in preparation for repatriation". Soon after, the Eritrean government admitted holding 7,500 Ethiopian nationals in detention pending deportation, and started expelling batches of several hundred across the border. Property was also confiscated, affecting especially the large Ethiopian community in the port city of Assab. Figures collated by the ICRC and UN ultimately indicated that around 70,000 people were expelled or repatriated from Eritrea to Ethiopia, just less than the mirroring figure, despite the Eritrean government continuing to deny it had any policy of expulsion. ${ }^{14}$ Individuals of Ethiopian descent still living in Eritrea who had not sought nationality by the time the war broke out in 1998 are considered aliens, dealt with according to the normal rules applicable to citizens of other countries living in Eritrea.

Those of Eritrean descent who were not expelled and remain in Ethiopia (an estimated 150,000) were not considered Ethiopians, but had not acquired another nationality. They were excluded from exercising citizenship rights, such as voting and faced lack of access to employment and education, and remain potentially subject to deportation. A 2002 law which bestowed special rights and privileges on "foreign nationals of Ethiopian origin", singled out Eritreans who forfeited Ethiopian nationality and expressly excluded them from enjoying the new rights and privileges. ${ }^{15}$

In 2003, a comprehensive reform to the nationality law should have significantly improved the situation. The 2003 Proclamation on Ethiopian Nationality removed gender discrimination, providing that an Ethiopian national of either sex may pass nationality to his or her spouse, and also that "any person shall be an Ethiopian national by descent where both or either of his parents is Ethiopian." The proclamation also eased restrictions on naturalisation and provided that "all Ethiopian nationals shall have equal rights and obligations of citizenship regardless of the manner in which nationality is acquired." 16 The immigration

14 Human Rights Watch, The Horn of Africa War.

15 Proclamation to Provide Foreign Nationals of Ethiopian Origin with Certain Rights to be Exercised in their Country of Origin (270/2002), 5 February 2002. See above, chapter 6.5.1.

16 Proclamation 378/2003 on Ethiopian Nationality, sections 3, 5, 6 and 18. 
authorities also adopted an internal directive on the residence status of Eritrean nationals living in Ethiopia. ${ }^{17}$

But although many people of Eritrean origin living in Ethiopia were able to reacquire citizenship under the new proclamation, especially those of mixed descent, the law was not stated to have retroactive effect, and in practice it seemed that those with non-Ethiopian fathers still found it difficult to obtain recognition of a right to nationality on equal terms. Problems were still reported in obtaining national identification cards, including delays of several years and interrogation by immigration officials. Moreover, the immigration directive stated that a residence permit may be cancelled "where the bearer ... is found to be an undesirable foreigner". An Ethiopian of Eritrean descent interviewed in early 2008 observed that "the gap between law and implementation is like the space between the sun and the moon, and no one knows how to close it". ${ }^{18}$ Among those affected by these issues are individuals who were expelled from Ethiopia to Eritrea in 1998, but have since then fled Eritrea's highly repressive government and returned to Ethiopia. The 2003 law provides that "[a] person who was an Ethiopian national and who has acquired foreign nationality by law shall be readmitted to Ethiopian nationality if he: returns to domicile in Ethiopia; renounces his foreign nationality; and applies to the Authority for re-admission", and those whom the Ethiopian government expelled on the grounds that they had acquired Eritrean nationality should be eligible to reacquire Ethiopian nationality under this provision. However, none of those who have applied to the Security, Immigration and Refugee Affairs Authority to exercise this right have been successful, with the rejection being based on the grounds that they were a "security threat". ${ }^{19}$ Ethiopians of Eritrean origin in other countries have also been unable to reacquire Ethiopian documents. ${ }^{20}$

17 Directive issued to determine the residence status of Eritrean nationals residing in Ethiopia, 2004.

18 Maureen Lynch and Katherine Southwick, Ethiopia-Eritrea: Stalemate Takes Toll on Eritreans and Ethiopians of Eritrean Origin, Refugees International, 30 May 2008. This report also noted that travel between Eritrea and Ethiopia was prohibited, there was no interstate phone system, and Ethiopians had reportedly been jailed for communicating with friends and relatives in Eritrea via the internet. At the same time, Ethiopia did accept refugees fleeing political repression and military conscription in Eritrea; a camp on the border housed almost 18,000 people as of early 2008. See also Katherine Southwick, "EthiopiaEritrea: Statelessness and state succession", Forced Migration Review, Vol. 32 (Statelessness), 2009.

19 Amsale Getnet Aberra, "Ethiopians in Limbo: from statelessness to being a refugee in one's own country”, ECADF Ethiopian News, 14 February 2014, available at http://ecadforum. com/2014/02/14/ethiopians-in-limbo-from-statelessness-to-being-a-refugee-in-onesown-country/, accessed 03 November 2014.

20 See, for example, Louise Thomas, Refugees and Asylum Seekers from Mixed Eritrean-Ethiopian Families in Cairo, FMRS, American University in Cairo, June 2006. 
In 2004, the independent Claims Commission established under the December 2000 peace agreement adjudicated on the nationality of the citizens of Ethiopia and Eritrea after the splitting of the two countries in 1993. Ethiopia had tried to justify the de-nationalizations and forced population transfers during the war by arguing that those Ethiopians who registered as Eritreans for the referendum in 1993 had thereby lost their nationality. Eritrea argued that they could not have done so because there was no Eritrea in existence at that point. The Claims Commission found that, under the "unusual transitional circumstances" around the creation of Eritrea, those who qualified to participate in the referendum in fact acquired dual nationality. ${ }^{21}$ The outbreak of the war did not of itself suspend this dual nationality, and Ethiopia's action in denying nationality of the dual nationals had been arbitrary and unlawful. ${ }^{22}$

\section{Expelled-Never to Return ${ }^{23}$}

Ethiopian nurse B.H. was working for a humanitarian agency in Addis Ababa when war broke out between Ethiopia and Eritrea in May 1998. Then in her mid-fifties, she had lived in Ethiopia's capital all of her adult life. She traced her ancestry to Ethiopia's former province of Eritrea, which won its independence in 1993. She was widowed in 1989 from her Ethiopian husband — who had no Eritrean heritage - after more than twenty years of marriage. She had lived and raised her two children in Ethiopia.

In June 1998, Ethiopia authorities set in motion a campaign to round up, strip of all proof of Ethiopian citizenship, and deport Ethiopians of Eritrean origin from the country. Along with as many as 75,000 others, B.H. was taken into custody, denied her Ethiopian nationality, separated from her children, and deported to a purported homeland with which she had only distant ties. In Eritrea, parallel roundups of Ethiopian nationals ensued later in the course of the war. [...]

21 Award of the Eritrea-Ethiopia Claims Commission in Partial Award (Civilian Claims: Eritrea's Claims 15, 16, 23 \& 27-32), 44 ILM 601 (2005) (award of 17 December 2004) at para.51, available at the website of the Permanent Court of Arbitration, which acted as registry for the process. "Taking into account the unusual transitional circumstances associated with the creation of the new State of Eritrea and both Parties' conduct before and after the 1993 Referendum, the Commission concludes that those who qualified to participate in the Referendum in fact acquired dual nationality. They became citizens of the new State of Eritrea pursuant to Eritrea's Proclamation No. 21/1/1992, but at the same time, Ethiopia continued to regard them as its own nationals."

22 See also Sean D. Murphy, Won Kidane and Thomas R. Snider, Litigating War: Mass Civil Injury and the Eritrea-Ethiopia Claims Commission, Oxford University Press, 2013, especially pp.311-319.

23 Extracted from: The Horn of Africa War: Mass Expulsions and the Nationality Issue (June 1998-April 2002), Human Rights Watch, January 2003, p.3. 
In September 1998 police sought out B.H. at her work in Addis Ababa and took her to the local police station for questioning by a "processing committee". As they asked her questions, the members of the committee took down information. B.H. noticed that an agent had marked down her nationality as "Eritrean"- - although he had never asked her to state her nationality:

"I asked him "what was that?"

He said "nationality."

"Why don't you ask me?” I told him.

He just laughed."

B.H. said that during her entire ordeal she never doubted that the whole thing was a "terrible mistake" on the part of the Ethiopian authorities. She believed that the expulsion bureaucracy would "soon" discover its mistake and allow her to return to her family; indeed, she said that she patiently waited for that moment to arrive even as she was being transported to the border in a convoy of trucks and buses with 1,500 other deportees.

Five months after her expulsion, B.H. said it was still difficult for her to accept her rejection as an Ethiopian. What was most painful at the time of the interview, however, was her forced separation from her Ethiopian children.

Ethiopian nurse B.H. and tens of thousands of others were expelled en masse as enemy aliens, in groups of up to thousands at a time. Most were trucked or bussed to the border with Eritrea. Documents proving Ethiopian nationality were confiscated, property rights were cancelled, and travel papers in many instances were marked "Expelled-Never to Return". There was no opportunity for judicial review-or even for appeal of rulings through administrative processes. Thousands were detained for periods from a few days to a few months in difficult conditions; many were ill-treated at the time of their arrest or while in detention awaiting transit to Eritrea. Many endured great suffering while in detention and during gruelling journeys to the border.

\subsection{Sudan and South Sudan}

A British-Egyptian condominium was imposed over Sudan from 1899 to 1956, following the defeat of the Mahdist nationalist and Islamic state created in rebellion against Turko-Egyptian rule in the 1880 s. $^{24}$ The condominium

24 This section is based on Bronwen Manby International Law and the Right to Nationality in Sudan, and The Right to Nationality and the Secession of South Sudan: A Commentary on the Impact of the New Laws, Open Society Foundations, 2011 and 2012. 
was headed by a governor-general theoretically appointed by the Egyptian khedive with British consent, but was under effective British control. Egyptian independence in 1922 led to the withdrawal of Egyptian troops from Sudan, although the condominium continued (as did the presence of British troops in Egypt). From 1924 onwards, Sudan was governed as two separate provinces, kept administratively quite segregated, with controls on movement between them. The Arabic language and Islam were dominant in the north; in the south, the British permitted Christian missionaries to operate, but failed to develop any educated cadre of southern Sudanese. From the mid-1940s, as a degree of self-government was given to Sudan, and a legislative assembly and executive council were established in 1948, the south began to be integrated into the central government's administrative and political structures — in which southern politicians complained of marginalisation. ${ }^{25}$

Under the British-Egyptian condominium, a Sudanese was any person who was subject to Sudanese jurisdiction. From 1948, the Definition of Sudanese Ordinance defined a Sudanese as "every person of no nationality [thus excluding British, Egyptian and other nationals] who ... is domiciled in Sudan and (i) has been so domiciled since 31 December 1897, or else whose ancestors in the direct male line since that date have all been so domiciled" or who is the wife or widow of such a person. ${ }^{26}$

The 1952 Egyptian revolution led to the abrogation of the condominium treaty with Britain, followed by an Anglo-Egyptian agreement for a process leading to Sudanese self-government; Sudanese nationalists in turn unilaterally declared their own independence in late 1955. The proposed self-government statute was hastily adopted as the Sudan Transitional Constitution 1956.

A year later the Definition of Sudanese Ordinance was replaced with the first real citizenship law, the Sudan Nationality Act 1957, which, amended several times ${ }^{27}$, remained in effect until 1993. The 1957 Act provided that a person was Sudanese if he (sic) was born in Sudan or his father was born in Sudan and he or his direct male ancestors had been resident in Sudan since 31 December 1897, prior to the defeat of the Mahdist forces. Naturalisation was possible based on a 10-year residence period and other conditions, including adequate knowledge of Arabic and renunciation of any other nationality; a child born after the act came into

25 Douglas H. Johnson, The Southern Sudan, London: Minority Rights Group, Report No. $78,1988$.

26 Definition of "Sudanese" Ordinance, 15 July 1948, Laws of the Sudan 1956,Vol.1, Title 1, sub-title 5 . For the purposes of British nationality law, Sudan was simply a foreign country, with no protectorate or other status giving the British government extra-territorial jurisdiction over British subjects (although some condominium passport holders were treated as British protected persons, this was as a matter of royal prerogative rather than statutory right). Fransman's British Nationality Law, catalogue entry on Sudan.

27 In 1959, 1970, 1972, 1963, 1970, 1972, 1973 and 1974. 
effect was a citizen if his or her father was a citizen (whether naturalised citizen or by descent); and a woman married to a Sudanese man could naturalise based on two years residence. ${ }^{28}$ The provisions of the law thus provided a jus sanguinis rule with an emphasis on male line descent, but based on a starting point of place of birth rather than ethnic origin of an ancestor.

Even before the ink was dry on Sudan's declaration of independence, southern army officers rebelled against the Khartoum government. Though the mutinies were quickly suppressed, they date the start of a civil war that took off for real in the early 1960s (after southern demands for a federal system were decisively rejected by Khartoum in 1958), and continued to 1972. A period of military rule from 1958 to 1965 gave way to an unstable series of civilian governments dominated by divisions over the nature of the state, including proposals for the creation of a more Islamic system of government. In 1969 a military coup brought Col. Gaafar Nimeiri to power, proposing a socialist secular state. Initially harsh political repression softened somewhat, and in 1972 the Addis Ababa peace agreement temporarily ended the civil war, with the grant of a degree of autonomy to the south, enshrined in a new 1973 constitution for Sudan. The 1957 Nationality Act was also amended in 1972 to change the date of origin for residence in Sudan to 1 January 1924, when Sudan was reorganised administratively into two provinces by the British; thus creating an understanding of nationality at least somewhat based on a political recognition of South Sudan.

In 1983, the war was reignited as the Nimeiri government responded to pressure from the Muslim opposition parties by abandoning its former socialist and liberal allies and adopting a policy of Islamicisation, including the adoption of shari'a law in the north, as well as the splitting of the southern region into three, revoking its autonomous powers. Nimeiri was overthrown by another coup in 1985, which created a fifteen-man transitional military council, succeeded by a series of elected civilian governments under Prime Minister Sadiq el-Mahdi of the Umma party, which, despite a commitment to an Islamic state, agreed to suspend the application of shari'a law and entered into negotiations to end the renewed civil war. In 1989 a new coup d'état brought Omar al-Bashir to power as chairman of the Revolutionary Command Council for National Salvation, a body with both legislative and executive powers. The new government suspended political parties and re-introduced the shari'a laws. In 1993, the Revolutionary Command Council was replaced by an appointed Transitional National Assembly (TNA), made up of members of the National Islamic Front (NIF), which had been founded in the 1960s by Dr. Hassan al-Turabi; Bashir became president of the new government.

28 Sudanese Nationality Act 1957, Section 5(1) and Section 9. A two-year residence in Sudan was required, although the President of the Republic, upon the recommendation of the Minister of Interior, was entitled to exempt alien women married to Sudanese nationals from the residence requirement. 
In 1993, the military government under President Bashir replaced the 1957 Nationality Act with a new law, adopted as a provisional decree; the 1993 decree was amended by the Transitional National Assembly in 1994 and then confirmed into law. ${ }^{29}$

Despite the initiatives to Islamicise Sudan in other ways, the new nationality law of 1993 was very similar to the 1957 law in relation to the grant of nationality by birth, providing that a person born before the act came into effect was a national from birth if he or his father was born in Sudan and he or his paternal ancestors were resident in Sudan since 1924. The law was relatively liberal in the changes it made to the 1957 act, limiting the grounds on which citizenship could be taken away by the executive, reducing the period required for a resident in Sudan to become a naturalised Sudanese citizen from ten years to five years, and removing the prohibition on dual citizenship. ${ }^{30}$ The amendments made before the 1993 provisional decree became the 1994 law also included a change to the applicable date for a claim to nationality by birth based on domicile of a male ancestor from 1924 to 1 January 1956, the date of independence, a date that would make significantly more people eligible for Sudanese nationality. ${ }^{31}$ The law retained gender discrimination in the transmission of citizenship to children and to spouses. ${ }^{32}$ While naturalisation was permitted under the 1994 law, it remained discretionary (including conditions related to mental competency and good moral character, as well as residence, though not to knowledge of Arabic). ${ }^{33}$ The amendments added back in some of the grounds for depriving

29 Provisional Decree No. 19 (or 18; both numbers are used) of 18 August 1993, amended and approved by Transitional National Resolution No.59 of 3 May 1994, and signed into law by the president on 17 May 1994.

30 Sudanese Nationality Law 1993, sections 4, 7, 10, and 11.

31 Sub-section 4 (b) (ii) of the 1994 Act.

32 Section 4(1): "With regard to persons born before the coming into force of this Act, a person shall be a Sudanese by birth: (a): if he or she has acquired a certificate of Sudanese nationality by birth before the entry into force of the 1994 Act; (b) (i) if he or she was born in Sudan or his or her father was born in Sudan, and (ii) if he or she was resident in Sudan at the time of coming into force of this Act and he/she or his/her ancestors in the male line have been domiciled in Sudan since 1 January 1956; (2) A person born after the coming into effect of this Act shall be a Sudanese by birth if at the time of his birth his father was a Sudanese citizen by birth; (3) [added in 2005: see below]; (4) A person born to parents who are Sudanese by naturalization shall be a Sudanese by birth if his or her parents have obtained the Sudanese nationality by naturalization before his or her birth"; Section 5: "A person first found as deserted infant shall, until the contrary is proven, be deemed to be a Sudanese by birth." Section 8 deals with marriage. Note that the available English translation of the 1994 law is based on an incorrect version in Arabic that had an critical omission in section 4(2), stating that "a person born after the ratification of this act shall become a citizen by birth at the time of his birth". The official Arabic version makes clear that the father must be a citizen.

33 According to some, this was in order to facilitate naturalisation of international Islamists who took up residence in Sudan during the 1990s. 
a person of (naturalised) citizenship, including "an act or words outside Sudan showing his non-allegiance or hatred of Sudan." 34 The 1994 law also removed adopted children from the definition of children; this was the only provision overtly relating to government adherence to Islamic legal principles, which do not recognise adoption in its modern form. ${ }^{35}$

Despite all these changes, there was little dispute over who was a Sudanese. ${ }^{36}$ Although the various laws setting out the rules for citizenship of Sudan were discriminatory on the basis of gender, the definition of a citizen was founded on the idea of birth and residence in the country rather than race, ethnicity or religion.

In 1998 a new constitution was adopted, following a process that allowed for some public debate, though the final draft was closely edited by the executive. The TNA became an elected National Assembly, and the NIF created the National Congress Party (NCP), headed by President Bashir, as its formal political arm and the only legally recognised party in the country. In relation to the right to nationality, the constitution represented a step towards a more inclusive idea of citizenship, in particular - and remarkably - by removing gender discrimination. Article 22 provided that "Everyone born of a Sudanese mother or father has the inalienable right to Sudanese nationality, its duties and obligations. Everyone who has lived in Sudan during their youth or who has been resident in Sudan for several years has the right to Sudanese nationality in accordance with the law." This commitment to gender equality, was not, however, translated into an amended version of the 1994 nationality law, which continued to discriminate on the basis of gender in relation to citizenship founded on residence in the territory before independence.

The civil war continued with brutal effects, exacerbated by efforts to exploit oil deposits discovered in the south. Peace negotiations resumed in 2002 and finally brought the war to an end in 2005, with the adoption in Kenya first of the Machakos Protocol, outlining the terms of a peace treaty, and subsequently a

34 Section $11(1)(d)$.

35 Nasredeen Abdulbari, "Citizenship Rules in Sudan and Post-Secession Problems", Journal of African Law Vol.55, No.2, 2011, pp.157-180.

36 Abdulbari, "Citizenship Rules in Sudan and Post-Secession Problems", quoting Alex de Waal. See also Nasredeen Abdulbari, "Identities and citizenship in Sudan: Governing constitutional principles", African Human Rights Law Journal, Vol.13, 2013, pp.383-414; Amir Idris, "Rethinking Identity, Citizenship, and Violence in Sudan", International Journal of Middle East Studies, Vol. 44, No.2, 2012, pp 324-326; Jennifer Smith and Joel R. Charny, Sudan: Preventing Violence and Statelessness as the Referendum Approaches, Refugees International, June 2010; Ahmad A. Sikainga, "Citizenship and Identity in Post-Secession Northern Sudan", Bulletin of the Association of Concerned Africa Scholars, Issue 86, November 2011, pp.11-19; Elena Vezzadini, "Genealogies of Racial Relations: The Independence of South Sudan, Citizenship and the Racial State in the Modern History of Sudan," Bulletin of the Association of Concerned Africa Scholars, Issue 86, November 2011, pp.30-46. 
detailed Comprehensive Peace Agreement (CPA). The CPA provided for a five year transition period, during which the south would have a degree of autonomy, followed by a referendum on independence. A separate protocol provided for the disputed territory of Abyei (see chapter 10.1.1). Meantime, however, a further rebellion had broken out in 2003 in Darfur, in the west of northern Sudan.

The 2005 Comprehensive Peace Agreement provided that "the people of South Sudan have the right to self-determination". This right was also enshrined in the interim constitutions for Sudan and Southern Sudan that followed the peace agreement. But who were "the people of South Sudan"? The Interim Constitution for Southern Sudan and the legislation establishing the eligibility for individuals to vote in the referendum on the independence of South Sudan provided two parallel definitions, one based on ethnicity, thus permitting "southerners" resident in the north — whether displaced by the war, or employees in the Sudanese state or economy - or in other countries to vote; the other on residence, thus allowing those (many fewer in number) "northerners" resident in the south to be heard also.

The Interim Constitution for Southern Sudan provided that :

For purposes of the referendum ... a Southern Sudanese is: (a) any person whose either parent or grandparent is or was a member of any of the indigenous communities existing in Southern Sudan before or on January 1,1956; or whose ancestry can be traced through agnatic or male line to any one of the ethnic communities of Southern Sudan; or (b) any person who has been permanently residing or whose mother and/ or father or any grandparent have been permanently residing in Southern Sudan as of January $1,1956 \ldots{ }^{37}$

The Southern Sudan Referendum Act 2009 repeated these provisions in very similar language, but removed the reference to agnatic (patrilineal) descent, providing that:

The voter shall meet the following conditions:

1) be born to parents both or one of them belonging to one of the indigenous communities that settled in Southern Sudan on or before the 1st of January 1956, or whose ancestry is traceable to one of the ethnic communities in Southern Sudan; or,

2) be a permanent resident, without interruption, or any of whose parents or grandparents are residing permanently, without interruption, in Southern Sudan since the 1st of January $1956 ; \ldots{ }^{38}$

37 Interim Constitution of Southern Sudan, Article 9.

38 Southern Sudan Referendum Act, 2009, section 25, unofficial translation. The other criteria are: "3) have reached 18 years of age; 4) be of sound mind; 5) be registered in the Referendum Register". Similar criteria are provided for the referendum on the status of Abyei: see further 10.1.1. 
Category (1) of these criteria reflected an understanding of citizenship based on descent and ethnicity. Category (2) expanded this understanding in line with the provisions of the Sudanese nationality law, to include people who are or have been permanently resident in the territory, providing an important less discriminatory basis for recognition as a voter in the South Sudanese referendum and future citizen: "northerners" who were long-term residents in the South were accepted as having a voice.

In relation to Sudanese citizenship during the transitional period, the Interim National Constitution of Sudan 2005 repeated the gender-neutral rules of the 1998 constitution for the transmission of citizenship to children, and continued to allow dual nationality, but delegated rules on naturalisation to legislation. ${ }^{39}$ The 1994 nationality law was also amended in 2005, in response to the CPA and the adoption of the Interim National Constitution, and for the first time gave the child of a Sudanese woman and foreign father the right to apply for nationality (although not the automatic conferral of nationality by operation of law, as for the child of a Sudanese father). ${ }^{40}$

The issue of citizenship was among the most difficult issues to settle in the process leading to the secession of the Republic of South Sudan from the Republic of Sudan. The decision on criteria that would result in Sudanese citizens keeping their nationality of the Republic of Sudan or becoming citizens of the new state of South Sudan was not merely a technical matter, but went to the heart of the vision that the National Congress Party and the Sudan Peoples' Liberation Movement (SPLM), the ruling parties in each entity, each had for the continued existence of a smaller Sudanese state, and for the new state of South Sudan.

The question of how the Sudanese nationals would be allocated to the citizenship of either Sudan or South Sudan was supposed to have been resolved in negotiations between the NCP and SPLM in advance of the referendum on independence, which took place on 9 January 2011; or, at the latest, before the 9 July 2011 official independence of South Sudan after the positive referendum vote. Extensive suggestions to resolve the question of nationality of those who might have a claim to belong to either state were made to the parties by advisers working with UNHCR and the AU High Level Implementation Panel (AUHIP)

39 Article 7 of the 2005 Interim National Constitution of Sudan: (1) Citizenship shall be the basis for equal rights and duties for all Sudanese; (2) Every person born to a Sudanese mother or father shall have an inalienable right to enjoy Sudanese nationality and citizenship; (3) The law shall regulate citizenship and naturalization; no naturalized Sudanese shall be deprived of his/her acquired citizenship except in accordance with the law; (4) A Sudanese national may acquire the nationality of another country as shall be regulated by law.

40 The 2005 amendment added subsection (3) to Section 4 of the Nationality Act, to provide that: "A person born to a mother who is a Sudanese by birth shall be eligible for the Sudanese nationality by birth provided that he or she submits an application to become a Sudanese national by birth". 
led by former president Thabo Mbeki of South Africa. ${ }^{41}$

These recommendations were based on the International Law Commission's Draft Articles on nationality in the context of succession of states (see chapter 3.7), and in particular the section relating to the type of state succession when there is "separation of part or parts of the territory" while the predecessor state continues to exist - as is the case in the Sudans. Article 25 provides that the predecessor state shall withdraw its nationality from those of its former nationals qualified to acquire the nationality of the successor state, if they are resident in the successor state and under certain other circumstances. However, it may not withdraw nationality from persons who have their habitual residence in its territory. Article 26 states that

Predecessor and successor States shall grant a right of option to all persons concerned $[. .$.$] who are qualified to have the nationality of both the$ predecessor and successor States or of two or more successor States. ${ }^{42}$

In relation to those persons who had the nationality of the predecessor state but are not-resident in the territory whose sovereignty is transferred, the customary law position is not clear, but it is suggested that "the successor State may, subject to acquiescence by the State which exercises territorial jurisdiction over them, confer its nationality on them, if they reside outside the transferred territory, unless it is held that such imposition of nationality requires - under a rule of international law — the consent of the individual concerned." ${ }^{43}$

However, the parties failed to reach any agreement. The legal drafting issues were quite technical, but fundamentally the problem was lack of political will; and closely linked to other blockages about the sharing of oil revenue and the national debt, and the status of the Abyei region. ${ }^{44}$

While negotiations were supposed to resume post-independence, both states moved separately to introduce laws and procedures on nationality. South Sudan passed a new Nationality Act, 2011; and Sudan adopted amendments to the existing Sudan Nationality Act, 1994, providing for loss of Sudanese nationality by those who have acquired the nationality of South Sudan.

Although the criteria to vote in the referendum reflected an instinctive understanding of many people in Sudan of the nature of nationality, there was no reason in law why the criteria for attributing nationality in either state following secession of the South should follow the rules established for the right to vote.

41 The author was one of these advisers.

42 ILC, Draft Articles on Nationality of Natural Persons in relation to the Succession of States.

43 Weis, Nationality and Statelessness, p.149.

44 See reports of the AU High Level Implementation Panel (chaired by Thabo Mbeki) on the AU Peace and Security web portal at http://www.peaceau.org/en/resource/118theme-auhip, last accessed 18 February 2014. 
Both laws, however, drew on the referendum legislation in determining who the citizens of each state should be, and thus questions of ethnic identity have formally entered into Sudanese nationality law (of north and south) for the first time.

The Transitional Constitution of South Sudan, adopted in 2011 pending the appointment of a commission to draft a final constitution, did not in fact include transitional provisions on nationality, but echoed the wording of the 1998 and 2005 constitutions of Sudan that "Every person born to a South Sudanese mother or father shall have an inalienable right to enjoy South Sudanese citizenship and nationality", thus providing for a gender-neutral descent-based citizenship regime. It explicitly permitted dual nationality. ${ }^{45}$

Article 8 of the new South Sudanese Nationality Act (SSNA), adopted in June 2011, just before the secession of South Sudan, in turn provided that:

An individual will be considered a South Sudanese national if such person meets any of the following requirements:

(a) Any parents, grandparents or great grandparents on the male or female line were born in South Sudan;

(b) Such person belongs to one of the indigenous tribal communities of South Sudan;

(c) Such person, at the time this bill came into force, has been domiciled in South Sudan since 1.1.1956; or

(d) Such person has acquired and maintained the status of a South Sudanese national by an uninterrupted domicile.

The law also provides for acquisition of citizenship by naturalisation based on 10 years' residence (longer than the five years applied in the north since 1994) and other conditions.

The ethnic definition of citizenship in the second paragraph could create problems for the future in the South: which groups in fact form the "indigenous tribal communities of South Sudan"? Do they include cross-border groups, pastoralists who spend only part of the year in the South, descendants of immigrants from other parts of Africa? Nonetheless, by drawing on Sudan's traditions of nationality law and international law principles to add other criteria based on residence and

45 Transitional Constitution of the Republic of South Sudan, Article 45: (1) Every person born to a South Sudanese mother or father shall have an inalienable right to enjoy South Sudanese citizenship and nationality. (2) Citizenship is the basis of equal rights and duties for all South Sudanese. (3) Every citizen shall enjoy all the rights guaranteed by this Constitution. (4) The law shall regulate citizenship and naturalization; no naturalized citizen shall be deprived of his or her acquired citizenship except in accordance with the law. (5) A South Sudanese national may acquire the nationality of another country as shall be prescribed by law. (6) A non-South Sudanese may acquire the nationality of South Sudan by naturalization as shall be prescribed by law. 
birth on the territory, the law should mean that at least in theory almost anyone who has a strong link to South Sudan and desires recognition of South Sudanese nationality would in principle be able to get it. Notably, the removal of gender discrimination departed from the SPLM's previous efforts to define membership of Southern Sudan. ${ }^{46}$ In practice, however, those with only weak links to South Sudan (including those individuals of mixed parentage with a South Sudanese mother who have always lived in the north of Sudan) may have difficulty in proving entitlement to South Sudanese nationality and obtaining the relevant documentation. ${ }^{47}$

As problematic as the inclusion of an ethnic definition of South Sudanese, is the wording of the SSNA that "An individual will be considered a South Sudanese national..." whatever the circumstance of the person concerned. The law makes no distinction between people born and habitually resident in South Sudan and those born or resident abroad, including in Sudan, for whom an alternative wording such as "has the right to opt for South Sudanese nationality" would be more appropriate. Indeed, depending on its interpretation in practice and the regulations implementing the law, it could be argued to be in conflict with international norms prohibiting the en masse conferral of nationality on residents of neighbouring states. ${ }^{48}$

46 In 2003, the SPLM adopted a Nationality Act as one of the Laws of the New Sudan, applied in the areas under its control. The Act provided that a person born before 2003, the date of the entry into force of the Act, was a New Sudan national by descent if he or she was or his/her parents or his/her grand and great grandparents were born in the New Sudan provided that he or she belonged to one of the "tribes of the New Sudan". A person could also be a New Sudan national by descent if he or she, at the time of coming into force of the new Nationality Act, was domiciled since April 1994 and his or her ancestors in the direct male line had all been domiciled in the New Sudan. Alternatively, a person could be a New Sudan national by descent if he or she had acquired and maintained the status of a New Sudan national by uninterrupted domicile. In addition, persons born after the ratification of the New Sudan Nationality Act would be also New Sudan nationals by descent if their fathers were New Sudan nationals by naturalization at the time of their birth. The Act provided that deserted infants or of unknown parents would be presumed nationals by descent until the contrary was proved. There had been heavy resistance to the idea of gender equality in a citizenship law for the new state, but under international pressure, the (male) leaders of the SPLM were obliged to accept that they could not justify a male-line legal regime. The 2011 nationality law was barely debated in the national assembly.

47 Mike Sanderson, "Key Threats of Statelessness in the Post-Secession Sudanese and South Sudanese Nationality Regimes", Tilburg Law Review,Vol. 19, 2014, pp.236-247.

48 See Recommendation 11 of the Bolzano/Bozen Recommendations on National Minorities in Inter-State Relations adopted by the OSCE in June 2008; also Enrico Milano "The Conferral of Citizenship En Masse by Kin-States: Creeping Annexation or Responsibility to Protect?" in Francesco Palermo and Natalie Sabanadze (eds.), National Minorities in Inter-State Relations, Leiden: Nijhoff, 2011; McDougal et al, "Nationality and Human Rights", at pp.918-922. 
The broad attribution of nationality by South Sudan immediately created the threat of denationalisation for those "South Sudanese" resident in the North. On 19 July 2011, the National Assembly of the Republic of Sudan adopted amendments to the Sudan Nationality Act 1994. New section 10(2) provided that:

An individual will automatically lose his Sudanese nationality if he has obtained, de jure or de facto, the nationality of South Sudan.

A minor child of an affected parent would also lose his or her nationality.

An additional Article 16 was also added, which stated that: "Without prejudice to Article 10(2), the president may reinstate nationality to any individual who has lost his/ her nationality ... when s/he applies for it." The law provides no process to allow a person to argue that he or she has not obtained the nationality of South Sudan (or even to renounce any such right in order to remain a citizen of the Republic of Sudan).

The paradox was that the very broad terms of the South Sudanese law, which appeared to attribute nationality automatically to those eligible even if they were resident outside the territory of South Sudan, allowed Khartoum to argue that a very large number of people (anyone with one great-grandparent born in South Sudan) were "really" South Sudanese and thus automatically lost their Sudanese nationality. ${ }^{49}$

The government of Sudan stated that southerners resident in the north must "regularize their status" in Sudan by 8 April 2012, nine months after the date of the 9 July 2011 referendum. However, the means for doing so were wholly unclear. While some senior government officials stated that "there are absolutely no deportation plans for Southerners after April", ${ }^{50}$ others threatened expulsion of those identified as "unwanted". 51

Southerners resident in the north then began to be dismissed from employment in the civil service and in the private sector, while their children were refused registration in school and treatment in public health clinics. ${ }^{52}$ Under the Interim National Constitution of Sudan 2005 (still in force), the right to property is only protected for citizens, ${ }^{53}$ and people of southern origin faced difficulties in buying

49 In similar circumstances, however, the Eritrea-Ethiopia Claims Commission, set up by the comprehensive peace agreement of December 2000 that ended the war between the two countries, found that individuals became dual national, even though Ethiopian law did not allow dual nationality: see chapter 9.1.

50 Al-Obeid Murawih, spokesman for the Ministry of Foreign Affairs, quoted in "SudanSouth Sudan: Southerners running out of options”, IRIN, 16 February 2012.

51 Vice President al-Haj Adam Yusif quoted by al-Jareeda, 7 March 2012.

52 "Sudan - South Sudan: Southerners running out of options", IRIN, 16 February 2012.

53 "Every citizen shall have the right to acquire or own property as regulated by law." Interim National Constitution of Sudan, 2005, Article 43 (1). 
or selling immovable property — hindering their ability to remain in Sudan, but also to realise funds to relocate to South Sudan, should they wish. Official rhetoric surrounding the status of "southerners" was hostile, even if active plans to follow through were not in place. Khartoum State announced that it was establishing evacuation camps for moving "foreigners who live illegally in Khartoum", while the popular committees at neighbourhood level were instructed to draw up lists of foreign residents and report violators. ${ }^{54}$ Officials indicated that those "southerners" still in Sudan as of 9 April would be dealt with as foreigners, whether or not the "four freedoms" agreement was concluded. ${ }^{55}$

The status of the Ngok Dinka of Abyei - ethnically "southern" but living in territory claimed by both north and south — was also in some doubt. Officials of the Republic of Sudan issued public statements to the effect that the Ngok Dinka of Abyei would continue to be treated as Sudanese citizens; ${ }^{56}$ but the amendments to the Sudan Nationality Act did not explicitly protect the citizenship rights of the Ngok Dinka. SPLM leaders from Abyei, meanwhile, criticised as "shameful" the idea that the Ngok Dinka might not be South Sudanese citizens. ${ }^{57}$ Whatever the final status of Abyei, Ngok Dinka resident in Sudan outside the disputed territory face the same risks as other people of southern Sudanese origin of being treated as having automatically become South Sudanese nationals with the secession of South Sudan. ${ }^{58}$

Khartoum also adopted a new civil registration law and biometric identity card for its citizens. In principle, this was a welcome step to improve birth registration and documentation of citizens. In practice, the process of application for the new ID cards appeared to be used to deprive southerners in the north of their status there: an Arabic language daily newspaper reported in January 2012 that the Khartoum North Court had sentenced a man and woman with a Sudanese father and South Sudanese mother who had sought to obtain identity cards to one month imprisonment and a fine for providing incorrect information regarding their nationality, on the grounds that they were no longer entitled to Sudanese documents since they had become South Sudanese. ${ }^{59}$

On 13 March 2012, representatives of the two governments signed a longawaited "Framework Agreement on the Status of Nationals of the Other State

54 "Camps to Evacuate Illegal Foreigners in Khartoum State", Al Sudani, 1 February 2012; Al-Sahafa, 23 February 2012.

55 Al-Ray al-Aam, 2 April 2012.

56 Hassan Berkia, "Ngok Dinka citizenship falls through cracks of post-split Sudan", The Niles, 8 August 2011.

57 Luka Biong Deng, “Are Ngok Dinka of Abyei South Sudanese?” Sudan Tribune, 1 March 2013.

58 Minority populations in South Kordofan and Blue Nile states may also be at risk of being alleged to be southerners, even though their Sudanese nationality nor that of their territory is not theoretically in question.

$59 \quad$ Al Intibaha, 4 January 2012. 
and Related Matters" in the presence of former president of Burundi Pierre Buyoya representing the African Union. The agreement, modelled on a similar 2004 agreement between Sudan and Egypt known as the "four freedoms" agreement, provided that :

In accordance with the laws and regulations of each State, nationals of each State shall enjoy in the other State the following freedoms:

(a) Freedom of residence;

(b) Freedom of movement;

(c) Freedom to undertake economic activity;

(d) Freedom to acquire and dispose of property.

The agreement would establish a "joint high level committee" to "oversee the adoption and implementation of joint measures relating to the status and treatment of nationals of each State in territory of the other State". The parties also committed to further negotiations to elaborate on these freedoms, which could in principle greatly improve the situation of "southerners" in Sudan, in particular by removing the requirement to obtain specific permission to remain in the country on an individual basis. However, very poor relations between the two governments further worsened in late March, with the outbreak of open hostilities between the two states in the oil-rich border territory of Heglig. A signing ceremony for the four freedoms agreement by the presidents of the two republics, due to take place in Juba, the capital of South Sudan, on 3 April, was cancelled.

On 10 April 2012, the Ministry of the Interior of South Sudan issued a press release announcing, "in response to procedures issued by the Government of the Republic of the Sudan concerning the status of South Sudanese in the Republic of Sudan", that "all nationals of the Republic of Sudan are declared foreigners as of $9^{\text {th }}$ April 2012", and those entering South Sudan would require visas. ${ }^{60}$ The press release also stated that Sudanese nationals would be given temporary stay documents free of charge, and time to regularise their status. There remained a lack of clarity on who actually would be considered to be Sudanese.

Faced with this situation, several hundred thousand people of southern origin had already headed south since the date of the referendum, on their own or with the assistance of the UN; tens of thousands of others who had made the first steps to returning, selling their homes and many of their possessions, found themselves stuck in temporary camps without the means to continue their journey. South Sudanese were dismissed from employment, and a new identity card system in Sudan saw many with the right to Sudanese nationality under the constitution denied registration. ${ }^{61}$

\footnotetext{
60 "Status of Sudanese Nationals in the Republic of South Sudan", Press Release, Ministry of the Interior, Republic of South Sudan, 10 April 2012.

61 "Sudan's split takes shape of exclusion as Khartoum fires southerners in private sector",
} 
The Four Freedoms Agreement was finally signed by the presidents of both sides in September 2012 in Addis Ababa, included as one of eight protocols to a general cooperation agreement between north and south. But the agreement did not address citizenship, nor does it prevent loss of citizenship. Section 4 (2) provided that "A person who has already exercised any of the freedoms conferred by this Agreement shall not be deprived of that freedom by reason of the amendment or termination of this Agreement," but it kicked the detail into the future by proposing that the AUHIP negotiate a further agreement to "elaborate" the freedoms. ${ }^{62}$

No further progress was made before the breakdown of the South Sudanese government in late 2013 put an end to all further negotiations between the two sides. Tens of thousands of people displaced from the fighting once again streamed into the north - but this time as cross-border refugees, rather than as internally displaced, as they had been prior to 2011. More than 300,000 people living in Sudan of southern Sudanese origin were assessed by UNHCR at that time to be at risk of statelessness. ${ }^{63}$

\subsection{The Bakassi Peninsula}

The resource-rich Bakassi peninsula lies on the boundary between what are now Nigeria and Cameroon, but was previously the British Protectorate of Southern Nigeria and what was first German Kamerun and subsequently known as the Southern Cameroons, mandated to Britain by the League of Nations after the First World War. The precise delimitation of the boundary in the peninsula zone had not been important, since the mandated territory was administered from Nigeria. At independence, the Southern Cameroons voted in a referendum to join Cameroon, the former French-mandated part of German Kamerun (while the Northern Cameroons voted to join Nigeria). While the Bakassi peninsula continued to be administered from Nigeria (and is listed as one of 774 local government areas in the 1999 Constitution), Cameroon contested ownership, and by the early 1990 s the dispute had escalated into confrontations between the military forces of the two states.

In 1994, Cameroon referred the dispute over the Bakassi peninsula, as well as territory further north towards Lake Chad on the border with the former Northern Cameroons, to the International Court of Justice. The ICJ issued its

The Niles, 7 July 2011;“South-bound but stranded in Sudan”, UNHCR, 16 January 2012; Munzoul A. M. Assal, "Struggles of Citizenship in Sudan" in Isin and Nyers Routledge Handbook of Global Citizenship Studies.

62 Framework Agreement on the Status of Nationals of the Other State and Related Matters between The Republic of the Sudan and The Republic of South Sudan, Addis Ababa, 27 September 2012.

632014 UNHCR Country Operations Profile - Sudan; "Number of South Sudanese refugees in Sudan set to double", UNHCR, 24 July 2014. 
final judgment in the case in 2002, and granted sovereignty over the peninsula and other territory to Cameroon. ${ }^{64}$ In accordance with established international law, the court case did not consider the wishes of the people living in the territory affected (who had largely considered themselves Nigerians), but rather the historical exercise of sovereignty over the territory. ${ }^{65}$ Nor did the court rule on the nationality of those living in the transferred territory; though, in accordance with international norms which base nationality in case of succession of states on habitual residence, it was presumed that Bakassi residents would become Cameroonian. ${ }^{66}$ The number of people affected was also disputed between Cameroon and Nigeria, but was alleged by Nigeria to be more than 150,000 people. $^{67}$

Nigeria rejected the judgement, stating that "For Nigeria, it is not a matter of oil or natural resources on land or in coastal waters, it is a matter of the welfare and well-being of her people on their land." ${ }_{68}$ UN Secretary General Kofi Annan facilitated further meetings on the implementation of the judgment, leading to the establishment of a Cameroon-Nigeria Mixed Commission to negotiate further. In 2006, a bilateral agreement was reached at Greentree, New York, between the two countries, by which Cameroon guaranteed fundamental rights and freedoms to Nigerian nationals living in the peninsula; and in particular promised not to force Nigerian nationals living in the Bakassi Peninsula to leave the zone nor to change their nationality. ${ }^{69}$ The territory was formally handed

64 Land and Maritime Boundary between Cameroon and Nigeria (Cameroon v. Nigeria: Equatorial Guinea intervening), ICJ Judgement of 10 October 2002. For a detailed history of the dispute, the court case and its aftermath, see Hilary V. Lukong, The Cameroon-Nigeria Border Dispute: Management and Resolution, 1981-2011, Langaa Research and Publishing Common Initiative Group, Cameroon / African Books Collective, 2011.

65 "The Court finds that the evidence before it indicates that the small population of Bakassi already present in the early 1960s grew with the influx from Nigeria in 1968 as a result of the civil war in that country. Gradually sizeable centres of population were established. The Parties are in disagreement as to the total number of Nigerian nationals living in the peninsula today, but it is clear that it has grown considerably from the modest numbers reported in the 1953 and 1963 population censuses. Nor is there any reason to doubt the Efik and Effiat toponomy of the settlements, or their relationships with Nigeria. But these facts of themselves do not establish Nigerian title over Bakassi territory; nor can they serve as an element in a claim for historical consolidation of title, for reasons already given by the Court." Ibid. para 221.

66 ILC, Draft Articles on Nationality of Natural Persons in relation to the Succession of States, article 5.

67 Statement of Mrs. Nella Andem-Ewa, Attorney-General of Cross River State, to the ICJ, 28 February 2002, transcript available at http://www.icj-cij.org/docket/files/94/5005, last accessed 29 August 2014.

68 Statement of the Federal Government of Nigeria on the Judgement of the International Court of Justice at The Hague (Cameroon vs. Nigeria, Equatorial Guinea intervening), 23 October 2002.

${ }^{69}$ Article 3(2) states that "Cameroon shall : a) Not force Nigerian nationals living in the 
over to Cameroon on 14 August 2008, though a Nigerian presence remained during a five-year transitional period. The understanding was that at the end of the transitional period, Bakassi residents could become Cameroonian with the right to Cameroonian identity documents; but could also remain Nigerian with resident alien status in Cameroon; or leave Bakassi and resettle in Nigeria. ${ }^{70}$

The legal authority to enable these outcomes on either side of the border was left unclear. Cameroon would have to adopt specific legislation to grant nationality as a group to the Bakassi residents affected by the transfer of territory; however, it has promised not to force them to change their nationality, so the law would need to provide for an option rather than automatic attribution, as well as specifying the right of the Bakassi residents to keep Nigerian nationality and the terms on which they could obtain resident alien status. Naturalisation as Cameroonian would be theoretically available after five years' legal residence (presumably completed at the end of the transitional period), but is highly discretionary and hard to obtain in practice. In Nigeria, the nationality status of Bakassi residents is complicated by their status as former residents of what has now been decided was part of the Southern Cameroons: special provisions on the nationality of the residents of the Northern Cameroons were introduced into the Federal Constitution of 1960 by the Nigeria Constitution First Amendment Act of 1961, following the referendum which led to the Northern Cameroons becoming part of Nigeria. ${ }^{71}$ There would be the need for an explicit constitutional amendment to provide similarly for the Nigerian nationality of residents of the Southern Cameroons - that is, natives of Bakassi - who have moved to Nigeria. Neither the ICJ judgment nor the Greentree Agreement made any provision to ensure the resolution and ongoing monitoring of these issues.

There have thus been problems in establishing nationality both for those Bakassi residents who remained in their homes, in what is now Cameroon, and for those who relocated to the Nigerian side of the border in Cross Rivers State.

Bakassi Peninsula to leave the zone or to change their nationality ...". See also, AlainDidier Olinga, L'Accord de Greentree du 12 juin 2006 relatif à la presqu'île de Bakassi, Paris: L'Harmattan, 2009; Kevin Ngang, "Understanding the Bakassi Conflict: A Showcase of Conflict Prevention in Practice", EPU Research Papers Issue 04/07, European University Centre for Peace Studies (EPU), Stadtschlaining, Austria. There was no similar agreement in relation to the populations living in the disputed border area towards Lake Chad whose territory was allocated to Cameroon; similar problems may exist in relation to the recognition of the nationality of those living there, but there has been much less attention drawn to them (even before the current insecurity in the region).

70 "Bakassi - more than one place, more than one problem", IRIN, 13 November 2007; Le temps des realisations: Bulletin mensuel bilingue d'informations $N^{\circ} 14$, Special Edition on Bakassi, Government of Cameroon, August/September 2013.

71 ArthurV.J. Nylander, The Nationality and Citizenship Laws of Nigeria, Lagos: University of Lagos, 1973, “Annotated Text of the Citizenship Legislation”. 
Within Cameroon, at the end of the transitional period on 14 August 2013, Nigerians had to apply either for a residence permit or for Cameroonian citizenship if they wished to remain. ${ }^{72}$ A registration drive was promised but had not yet taken place by the end of the year. ${ }^{73}$ Without special dispensation, Bakassi residents would first require a Nigerian passport to acquire residence permits as aliens. ${ }^{74}$ In addition, under the Cameroonian system, a birth certificate is in principle required to obtain any official papers of this type - which very few Bakassi residents hold; a jugement supplétif from a tribunal would be required to obtain late registration of birth, a time-consuming and potentially costly process. While the Cameroonian government gave assurances to the ICJ that the Bakassi residents would be made as welcome as other Nigerians in Cameroon, ${ }^{75}$ the situation of those who are living where they have always lived is significantly different from those who have moved to Cameroon for other purposes. ${ }^{76}$ Without national identity documents, Bakassi residents are vulnerable to extortion at police checkpoints in Cameroon. While the Greentree Agreement principle that Nigerians should not have to change their nationality was no doubt well-intentioned, the more useful commitment (from the point of view of the Bakassi residents) would be that they be guaranteed the right to Cameroonian nationality, unless they chose not to take it.

Meanwhile, several thousands of Bakassi residents relocated to the other side of the Nigerian border. The Cross Rivers government purported to carve out a new local government area for the Bakassi displaced - though it had no constitutional authority to do so - and granted or facilitated some humanitarian assistance. ${ }^{77}$ At the federal level, no agency took charge of resolving the situation

72 "Le Cameroun retrouve la plénitude de sa souveraineté sur la presqu'île de Bakassi ", Présidence de la République du Cameroun, 14 August 2013 ;"Bakassi residents to pay tax under Cameroon sovereignty”, BBC News, 15 August 2013 ; "Press Statement on Bakassi Peninsula Developments”, SC/11094 AFR/2680, UN Security Council, 15 August 2013.

73 Email communication from Leanne Johansson, doctoral candidate, University of Oxford, 19 February 2014.

74 There is an argument that Bakassi residents could be considered as being in possession d'état d'originaires de Cameroun occidental.Article 45 of the 1968 Cameroon nationality code provides that a person will be considered as holding this status if one of his or her parents was born in Western Cameroon (ie former Southern Cameroons), even if the person him or herself was not born there. Since the ICJ has held that Bakassi was in fact in Western Cameroon, the nationality would change with the transfer of territory; reinforcing the usual presumption in relation to nationality and succession of states. The Greentree Agreement, however, contradicts this presumption, which is only a presumption and not a binding rule.

75 Cameroon v. Nigeria, ICJ Judgement of 10 October 2002, paragraph 317.

76 See generally, Fongot Kini-Yen Kinni, Bakassi: Or the Politics of Exclusion and Occupation? Langaa Research and Publishing Common Initiative Group, Cameroon / African Books Collective, 2013.

77 The National Commission for Refugees, Migrants and Internally Displaced Persons was reported by the Cross River State government to have distributed relief supplies to more than 
of the Bakassi displaced; and in particular there was no effort to document them, and thus provide them with proof of Nigerian citizenship. As a consequence, they were also denied the right to vote in various elections, since the locations where they were registered no longer exist; there was litigation by the Independent National Electoral Commission on this point. ${ }^{78}$ In February 2014, the Nigerian Attorney General of the Federation and Minister of Justice, Mr. Mohammed Adoke, speaking at the opening of the 32nd Session of the Mixed Commission, stated that those affected by the judgment who wished to be Nigerian should simply "apply for Nigerian citizenship" showing a rather alarming disregard for the difficulty of doing so under the Nigerian constitution, but also implying that they need to naturalise, rather than obtain recognition of ongoing nationality from birth (see further sections 7.2 and 13.1). ${ }^{79}$ Lobbying continued in Nigeria for the government to retake control of the peninsula; but not, despite the professed concern of the Nigerian government for its people rather than for the oil that may be beneath the peninsula, to ensure reintegration of the Bakassi residents into the Nigerian polity.

\subsection{The Tebu and the "Aouzou strip" between Chad and Libya}

The Tebu (also Toubou or Tabu and other spellings in English) are an ethnic group (or a collection of related smaller groups) speaking a language of the diverse Nilo-Saharan language family and following a semi-nomadic lifestyle in what is now southern Libya, northern Chad and northeastern Niger. They were known for their resistance to French colonial encroachments. Since independence of all the countries concerned, they have also played a sometimes controversial role in the politics of the region, as Tebu politician Goukouni Oueddei became president of Chad between 1979 and 1982, with Libyan backing against the French-backed Hissène Habré (also a Tebu, from another branch).

During the 1970s, Libya under Colonel Gaddafi invaded what became known as the "Aouzou Strip", a uranium-rich region contested between Chad and Libya. Libya registered the inhabitants of the strip as nationals and issued them with documents; many Tebu who were resident in other parts of Libya and had previously held documents issued by other local administrative authorities came to hold papers issued from Aouzou. ${ }^{80}$ After President Oueddei was overthrown

1,500 households in two local government areas in the state. See "Bakassi,Akpabuyo Refugees Get Relief from Refugees Commission" Cross Rivers State government, 29 July 2013.

78 Jude Okwe, "INEC - Bakassi May Not Participate in 2015 Elections", This Day, 4 April 2014; interview with Chidi Anselm Odinkalu, chair Nigerian National Human Rights Commission, July 2014; Chidi Odinkalu, "Stateless in Bakassi: How a Changed Border Left Inhabitants Adrift”, Open Society Justice Initiative, 2 April 2012.

79 Dele Ogbodo, "Greentree Agreement: FG Advises Bakassi Indigenes to Apply for Nigerian Citizenship", This Day, 3 February 2014

80 Laura van Waas, The Stateless Tebu of Libya? Tilburg Law School Legal Studies Research Paper Series No. 010/2013. 
by Habré in a 1982 coup, there were several years of conflict over the Aouzou strip, ended on 31 August 1989, with the signature in Algiers of a framework agreement (accord-cadre) on the peaceful settlement of the dispute; but without a definitive outcome, the two countries jointly referred the dispute to the ICJ in September 1990. In its 1994 judgment, the ICJ awarded the territory to Chad, on the basis of a "Treaty of Friendship and Good Neighbourliness" concluded by the French Republic and the Kingdom of Libya in 1955. After further talks, an agreement was signed on 4 April 1994 establishing the practical modalities for the implementation of the judgment. Among other things, the agreement provided for the withdrawal of the Libyan administration and forces from the Aouzou Strip, removal of mines, the establishment of crossing points, the demarcation of the boundary, further cooperation and notification of the agreement to the United Nations. ${ }^{81}$

Despite Gaddafi's support for the Tebu in Chad, arabisation policies in Libya meant that they were also not accepted by his government as fully Libyan; and with the handover of the Aouzou strip to Chad, they were further ostracised. In 1996, a decree declared that "Those who carry the ID of that area [Aouzou] are considered as foreigners and all come under the jurisdiction of the law relating to foreigners". ${ }^{82}$ In December 2007, the Libyan government issued a directive that the Tebu were not Libyans but Chadians. Local authorities barred Tebu from access to ration books, education and health care services, and refused to renew or extend passports and identity cards to members of this minority, or to register births of Tebu children. In November 2008, up to 33 people died in Kufra, during five days of fighting between the official security forces and the Tebu, and the local government continued to evict Tebu people from their residential areas. ${ }^{83}$ In his final months in power Gaddafi reportedly annulled the 1996 decree, and recognised holders of documents issued from Aouzou as nationals once again. ${ }^{84}$ However, after the fall of the Libyan regime, the Tebu were seen as pro-Gaddafi foreigners. ${ }^{85}$ In 2012, the Carter Center reported that

81 Territorial Dispute (Libyan Arab Jamahiriya/Chad), ICJ Judgment of 3 February 1994. See also information on the United Nations Aouzou Strip Observer Group, available at http:// www.un.org/en/peacekeeping/missions/past/unasog.htm, last accessed 4 December 2014.

82 Decree No.13(1485), cited in van Waas, The Stateless Tebu, pp.6-7.

83 Summary prepared by the Office of the High Commissioner for Human Rights in accordance with paragraph 15 (c) of the annex to Human rights Council resolution 5/1: Libyan Arab Jamahiriya, A/ HRC/WG.6/9/LBY/3, 15 July 2010 (summary of submissions from nine organisations, including the Society for Threatened Peoples, for Libya's Universal Periodic Review).

${ }_{84}$ Van Waas, The Stateless Tebu, p.8.

85 International Crisis Group, Popular Protest in North Africa and the Middle East (V): Making Sense Of Libya, Middle East/North Africa Report N¹07 - 6 June 2011; Jamestown Foundation, "Arab-Tubu Clashes in Southern Libya's Sabha Oasis", Terrorism Monitor, Vol.10, No.7, 6 April 2012, available at: http://www.refworld.org/docid/4f8550982.html, last accessed 4 December 2014. See also Asylum Research Consultancy, Libya Country 
the district court in Kufra had removed 1,085 names from the voters' list on the basis that they were inhabitants of the Aouzou area, and thus not Libyan nationals ${ }^{86}$; while "in Murzuq, an area said to be currently controlled by the minority Tubu community, a large percentage of the population do not have documents." 87

Although the situation of the Tebu community in Libya is not directly caused by the decision of the ICJ on the Aouzou strip - other non-Arab minorities in Libya have faced not dissimilar discrimination - it illustrates the lack of certainty that remains for many ethnic groups found in remote border areas that were never clearly delineated during the colonial period, nor provided for at the time when sovereignty was transferred, and whose nationality status is not considered when territory changes hands. The Libyan authorities, having issued the Tebu with documents from the Aouzou administrative zone, then failed to recognise the holders as Libyan once the zone was handed to Chad, even if they had their main residence elsewhere in Libya.

\subsection{Other ICJ rulings in border disputes}

In a judgment from 1986 adjudicating a frontier dispute between Burkina Faso and Mali, the ICJ noted the difficulty of "ascertain[ing] where the frontier lay in 1932 in a region of Africa little known at the time and largely inhabited by nomads, in which transport and communications were very sketchy." ${ }^{\text {" }}$ Affirming the principle of uti possedetis (by which territory remains with the possessor), the court noted that: "At first sight this principle conflicts outright with another one, the right of peoples to self-determination. In fact, however, the maintenance of the territorial status quo in Africa is often seen as the wisest course, to preserve what has been achieved by peoples who have struggled for their independence and to avoid a disruption which would deprive the continent of the gains achieved by much sacrifice." 89 The court emphasised the decision of African states to respect colonial borders, and focused on the delimitation and exercise of administrative power during the colonial period (and the dissolution in 1932 and reconstitution in 1947 of the French colony of UpperVolta), without considering any evidence related to the wishes of those living in the territory affected. Their nationality was presumed to be allocated with the territory itself.

In southern Africa, the ICJ has ruled on a dispute between Namibia and Botswana on the ownership of an island in the Chobe river forming the boundary between the two states along the southern border of the Caprivi Strip — itself one of the

Report, Commissioned by the Office of the United Nations High Commissioner for Refugees (UNHCR), Division of International Protection, July 2013.

86 "Carter Center Congratulates Libyans for Holding Historic Elections", 9 July 2012.

87 "Libyan minority rights at a crossroads", IRIN, 24 May 2012.

${ }_{88}$ Frontier Dispute (Burkina Faso/Mali), ICJ Judgment of 22 December 1986, paragraph 64.

89 Ibid., paragraph 25. 
most ludicrous examples of colonial-era border determination. ${ }^{90}$ Although there was discussion of the occupation of the territory by members of the Masubia ethnic group originating from the Namibian side of the border, this aspect was, according to the usual precedents, found by the majority to be irrelevant to the ultimate decision to award the island to Botswana. ${ }^{91}$

Two other cases more recently decided by the ICJ relate to boundaries between Niger and its neighbours. In 2002, Benin and Niger jointly referred to the court the disputed ownership of 25 islands along a $150 \mathrm{~km}$ stretch of the River Niger where it forms the border between the two countries. The largest island, Lété, is "fertile, with rich pastures, and is permanently inhabited; according to information supplied by Niger, its population numbered some 2,000 in the year 2000 "; 92 it had been disputed between the two countries dating right to the early days of independence, a conflict that provided the spark leading to the expulsion of some 16,000 Dahomeyans from Niger in late 1963 and early $1964 .{ }^{93}$ In its ruling of 2005 the ICJ awarded Niger sovereignty over 16 of the islands, including Lété, the remainder going to Benin. The judgment contained no commentary or ruling on the nationality status of the populations currently living in or using the resources of the islands. ${ }^{94}$ The two groups affected by the decision were, first, the Fulani nomads who have traditionally moved from one country to the other with their livestock, many of whom had no nationality documentation from either of the countries (but who have paid taxes to both); and, secondly, the fishermen and agriculturalists who live on the islands for some or all of the year. One of the islands allocated to Benin, the Ile aux oiseaux, is occupied temporarily during the dry season — but the inhabitants relocate to one side of the river or the other (Niger or Benin) when the island is flooded. The semi-nomadic nature of the populations makes their documentation difficult since they have no settled residence; many have no identity papers, and no access to public services. A community that had moved to Benin when Lété island (allocated to Niger) was flooded in 2012, were accommodated in a village in Karimama commune — tellingly named Sabon Gari ("strangers' quarter") — but Beninois nationality had not been offered or confirmed; and a large percentage also have no birth registration. One of them commented: "Because no country recognises us, we live as if we were in prison"; without documents they are subjected to extortion from the security forces of both countries. ${ }^{95}$

90 Case concerning Kasikili/Sedudu Island (Botswana/Namibia), ICJ Judgment of 13 December 1999.

91 Three minority judgments disagreed; but not on the basis of the wishes of the people using the island.

92 Frontier Dispute (Benin/Niger), ICJ Judgment of 12 July 2005, paragraph 19.

93 Bonzon, «Les Dahoméens en Afrique de l'Ouest».

94 See also, "BENIN-NIGER: International Court rules that main disputed island belongs to Niger not Benin”, IRIN, 12 July 2005.

95 Information and interview from UNHCR mission to the region, May 2014. 
After several decades of failed attempts to finalise the line between their two states, Burkina Faso and Niger referred their border disputes to the ICJ in 2010; in 2013, the court handed down its judgement. In its ruling determining the boundary, the ICJ expressed its wish that "each Party, in exercising its authority over the portion of the territory under its sovereignty, should have due regard to the needs of the populations concerned, in particular those of the nomadic or semi-nomadic populations, and to the necessity to overcome difficulties that may arise for them because of the frontier." 96 In a separate opinion, Judge Cançado Trindade elaborated on concerns with the local populations, also welcoming the common concern expressed by Burkina Faso and Niger for the local populations (on both sides of their border and constantly moving across it), focusing on territory and their inhabitants together. ${ }^{97}$ But there was no specific ruling or expression of views on the nationality of those affected by the judgment; it being presumed that nationality would transfer with the transfer of territory. There has been no further bilateral agreement or national action to confirm the nationality of those affected.

Other border disputes rumble on without referral to the ICJ and without resolution of the status of those living in the affected territory. For example, there is a border dispute between Guinea and Sierra Leone about Yenga town, in a zone close also to the Liberian frontier that is inhabited (on both sides of the river forming the boundary) by the Kissi people. Yenga was historically administered as part of Kailahun district of Sierra Leone. After it became a source of diamond production, Yenga was a base for the Revolutionary United Front (RUF) during the Sierra Leonean civil war, and in 1998 Guinea sent troops into the town to assist in evicting the RUF and defend itself against incursions from the rebel forces; but these soldiers then remained based in the town, as Guinea claimed the territory. This situation continued despite several agreements over the following years for their withdrawal, most recently in 2012, when Sierra Leone and Guinea — both now with elected governments agreed to demilitarise the zone and Guinea recommitted to withdrawing its troops. ${ }^{98}$ However, tensions remained high, administrative infrastructure weak, and the identity documentation of those living in the district very limited.

96 Frontier Dispute (Burkina Faso/Niger), ICJ Judgment of 16 April 2013, paragraph 112.

97 Frontier Dispute (Burkina Faso/Niger), Opinion of Judge Cançado Trindade.

98 "GUINEA-SIERRA LEONE: Guinea hands back disputed border village", IRIN, 7 September 2004; Sheikh Bawoh, "The Yenga Dispute Hinders Border Economic Prospects", Borderlines (magazine published as part of the Regional Youth Initiative of the World Bank Civil Society Fund) Edition 1, January 2008; Lansana Gberie, "The GuineaSierra Leone border dispute: Time for ECOWAS to intervene", Pambazuka No.446, 3 September 2009; Lt Col. (Rtd) Sim Turay, "Yenga Border Dispute Sierra Leone/Guinea", Awoko, Freetown, 29 September 2009; "Guinea, Sierra Leone demilitarize Yenga", Press Release, Sierra Leone Presidency, 27 July 2012. 



\section{Nomadic and "indigenous" populations}

The modern state system is peculiarly ill-adapted to accommodate people whose lifestyle is not sedentary. The entire system of international and most domestic law on citizenship (and other) issues has grown up around the idea that individuals have their "home" in one fixed place. Modern lifestyles in the rich world challenge this assumption, with the super-rich and their multiple homes, or even the visiting professor who splits her time between two universities. These individuals may garner little sympathy for any problems of uncertain identity; but those least accommodated by the fundamental framework of nationality law are members of traditionally nomadic populations. As a consequence, these groups are often at risk of statelessness and lack even the theoretical protection that is provided by belonging to a state, however dysfunctional. There is an almost total lack of international law or national precedent relating to the determination of the nationality of those who are not "habitually resident" in any particular place - even in Africa, where migratory pastoralism is very common.

This paucity of law and jurisprudence is reflected in the difficulties that pastoralist groups whose seasonal grazing territory is transboundary or close to national borders have had in establishing citizenship in any particular country. Other communities dependent on a hunter-gatherer lifestyle face the same questions. Many of these communities live, in effect, outside the legal framework of citizenship and its attendant rights and responsibilities. While they may be envied for this so long as it is their choice, many find that statelessness is an unwelcome condition once they have contact with the authorities claiming territorial control of the place they live.

At international level, these groups have often found a space to voice their concerns within the framework of the debate around the rights of "indigenous peoples"; although their particular situations vary greatly and often do not fit easily into the same pattern as that of aboriginal populations in other continents. The terminology around indigenous peoples sits uneasily in Africa, and African states have objected to UN recognition of particular rights for the "indigenous"; the emphasis on "who was here first" is indeed problematic in the African context.

\subsection{Nomadic pastoralism and nationality in Africa}

There is a very large and longstanding literature on pastoralism in Africa. ${ }^{1}$ Very

1 See for example, Ian Scoones, Sustainable pastoralism in Africa: an annotated bibliography, International Institute for Environment and Development, 1988; bibliography annexed 
little of it deals with the rights of pastoralists to a nationality; and indeed nomadic pastoralists often choose to live under the radar of formal state interactions, though problems with identity papers or possession of multiple passports may be mentioned in passing. ${ }^{2}$

Yet nomads have faced consistent difficulty with nationality in African states. Anxiety over the role of the Tuaregs in the Sahel and their doubtful loyalties led to them being treated with suspicion across the region, both north and south of the Sahara. Traditional cattle-rearing groups such as the Fulani (Peul) in West Africa have consistently faced problems in recognition as nationals in countries across the Sahel region. In Uganda, the pastoralist Basongora, returnees from the DRC and Tanzania who originally left the country to escape the conflict in the north, have found their former lands occupied and are now referred to as "strangers". 3

There have been quite extensive state efforts to address issues related to crossborder pastoralism, with bilateral and multi-lateral agreements to facilitate cross-border movement, especially in West Africa, under the aegis of the Economic Community of West African States (ECOWAS). In addition to the usual ECOWAS framework on freedom of movement, there have been quite extensive state efforts to address issues related to cross-border pastoralism, with bilateral and multi-lateral agreements to facilitate cross-border movement. ${ }^{4}$ Since 2000 pastoralists have been issued livestock passports for their animals, international transhumant certificates (ITC) and handbooks for travel. The ITC is essentially a pass which is issued to transhumant pastoralists and their herds to manage the departure of herds, ensure sanitary protection of local herds, and provide inhabitants of reception zones with advance information on the arrival of transhumant herds. The eight states of the West African Monetary Union (Union économique et monétaire ouest africaine, UEMOA) have also adopted policies

to Roger Blench, "You can't go home again": Pastoralists in the new millennium, Overseas Development Institute, 2001; papers of the Pastoral Development Network available on the Overseas Development Institute website at http://www.odi.org.uk/work/projects/ pdn/papers/index.html, last accessed 24 February 2014.

2 For example: John Markakis, Pastoralism on the Margin, Minority Rights Group International, 2004; Ekuru Aukot, “Am I stateless because I am a nomad?” Forced Migration Review,Vol. 32 (Statelessness), 2009.

3 Report on the African Commission's Working Group on Indigenous Populations/Communities' Research and Information Visit to the Republic of Uganda, 14-17 and 24-29 July 2006,ACHPR and IWGIA, 2009, pp.64-66.

4 See for example, Loi n ${ }^{\circ} 01-004 /$ du 27 fevrier 2001 portant Charte pastorale en République du Mali; Agreement Concerning Transhumance between the Republic of Mali and the Islamic Republic of Mauritania, 19 September 1989; Loi n² 2000-044 portant Code pastoral en Mauritanie; Decret No.97/007 PRN/MAG/EL du 10 janvier 1997 fixant statut des terroirs d'attache des pasteurs (Niger); Réglementation de la transhumance entre les états membres de la CEDEAO Décision A/DEC.5/10/98 of 1998 and C/ REG.3/01/03 of 2003. 
on the regulation of the free movement of animals. ${ }^{5}$ Learning from these efforts, the Common Market for Eastern and Southern Africa (COMESA) released a draft Regional Policy Framework for Food Security in Pastoralist Areas in 2009. The African Union also adopted a Policy Framework for Pastoralism in Africa in 2010 which endorsed the ECOWAS framework and created strategic objectives relating to the recognition of pastoralism in development. ${ }^{6}$

However, these documents do not address the issue of nationality of the pastoralists themselves - and are focused on facilitating the conflict-free movement of the livestock rather than the people concerned.

\subsubsection{The status of the Misseriya in Abyei}

The nationality and rights of cattle-rearing nomads moved centre stage in Sudan in the debate over the status of the territory of Abyei, on the border between the territories of north and south, and illustrates the problems in determining nationality of such groups.

The long and complex history of Abyei, which at different times had been administratively positioned on either side of the north-south line between northern and southern Sudan, meant that the Abyei Area was accorded "special administrative status" by a protocol to the 2005 Comprehensive Peace Agreement (CPA) between the Sudan People's Liberation Army/Movement (SPLA/M) and the government of Sudan that ended the second Sudanese civil war. ${ }^{7}$ The Abyei Area was at that time considered part of the larger Abyei District within the nowabolished state of West Kordofan. Under the terms of the Abyei Protocol, the Abyei Area was declared, on an interim basis, to be simultaneously part of the states of South Kordofan (in northern Sudan) and northern Bahr el Ghazal (in southern Sudan).

The Abyei Protocol to the CPA and the Abyei Area Referendum Act 2009 provided for a separate referendum for the Abyei area, to determine whether it should remain a special administrative region of north Sudan or become part of South Sudan. Those who could vote in this referendum were to be:

5 See, for example, Règlement Nº07/2007/CM/UEMOA Relatif a la sécurité sanitaire des végetaux, des animaux et des aliments dans l'UEMOA.

6 See also "Legislation to Support Crossborder Livestock Mobility", COMESA Policy Brief Number 14, February 2010. Policy Framework for Pastoralism in Africa: Securing, Protecting and Improving the Lives, Livelihoods and Rights of Pastoralist Communities, African Union, Department of Rural Economy and Agriculture October 2010.

7 Protocol on the resolution of Abyei conflict, Kenya, 26 May 2004. 
(a) Members of the Ngok Dinka Community;

(b) Other Sudanese residing in Abyei Area in accordance with the criteria of residency, as may be determined by the Commission according to section 14(1) of this Act [establishing the powers of the Abyei Area Referendum Commission]; ... ${ }^{8}$

An Abyei Boundary Commission made up of experts nominated by both sides had been established by the Abyei Protocol, tasked by the parties with the responsibility of evaluating historical and conflicting claims to the land and demarcating a border between the groups. The final report of the Commission was completed in July 2005, but was rejected by the government of Sudan. In 2008, the government of Sudan and the SPLM referred the dispute to the Permanent Court of Arbitration (PCA) in The Hague, which constituted a five member arbitral tribunal to have the final word. In its 2009 award the tribunal ruled on the borders of the Abyei Area, deciding that the best way of determining the Abyei Area was in a "predominantly tribal manner" rather than a "predominantly territorial approach" based on the 1905 provincial boundary, which could split the Ngok Dinka community, depending on the outcome of the referendum. ${ }^{9}$ The boundaries it decided on were thus defined primarily by the area of "permanent habitation" of the Ngok Dinka. (In this approach, the PCA tribunal notably departs from the uti possedetis rule applied by the International Court of Justice in settling border disputes: see chapter 9 on its rulings in the Bakassi peninsula and other cases.)

In practice, the people whose "residence" was most controversial for the purposes of the Abyei referendum were the mainly pastoralist Misseriya Arabs, who traditionally migrate to Abyei for a part of every year though the "home base" for most of them is in North Sudan. The Sudanese government argued that the Misseriya were residents of Abyei for the purposes of the referendum; but their status was disputed by the SPLM and the Ngok Dinka community, who make up the majority of the settled community in Abyei. The Ngok Dinka are members of the large southern Sudanese Dinka ethnic group that has historically led the SPLM.

Thanks to ongoing deep political disagreements between the negotiating parties, the Abyei Area Referendum Commission was never set up, so that the further residence criteria were never established; nor other issues related to

8 Abyei Area Referendum Act, 2009, Section 24. As for the referendum on the status of the rest of South Sudan, the other criteria are "(c) Not less than 18 years of age; (d) Of sound mind; (e) Registered in the Referendum Register."

9 The Government of Sudan / The Sudan People's Liberation Movement/Army (Abyei Arbitration), Final Award, 22 July 2009, paragraphs 595-596, available at the PCA website http://www.pca-cpa.org/showpage.asp?pag id=1306 accessed 03 September 2014. 
border demarcation, wealth sharing and voter registration agreed. ${ }^{10}$ Accordingly the Abyei referendum was not held in January 2011 at the time of the general referendum on the status of South Sudan. In 2012, the AU Panel on Sudan chaired by ex-president Thabo Mbeki made a further proposal on the final status of Abyei, proposing it retain a special status whether part of north or south, in which each government would recognise the historic role or claim of the Misseriya and Ngok Dinka, including the right of both the Ngok Dinka and "Misseriya residing in the Area" to "civic and political participation in Abyei State and the protection of the individual rights of all persons". ${ }^{11}$ The proposal endorsed the concept of "soft borders" and the rights of the Misseriya to historical grazing pastures, as endorsed in the Abyei Protocol. On eligibility to vote in the referendum, which it proposed for October 2013, the proposal elaborated on the existing criteria to provide an unqualified right to vote for Ngok Dinka who are "residents", and for "other Sudanese" based on "permanent abode within the Abyei Area". ${ }^{12}$

In October 2013, as the chance for a formally approved referendum retreated with the further deterioration of relationships between the two communities in Abyei and between the two governments either side of the border, Ngok Dinka leaders held a "community referendum", in which the result was announced to be 99.9 percent in favour of union with South Sudan. Both the

10 The Abyei Protocol also provided for the delineation of Abyei to be undertaken by an international panel of experts, the Abyei Boundary Commission. A Commission was formed and submitted its report to the Sudanese government in 2005, which, however, refused to accept them. The SPLM agreed in 2008 to the referral of the issue to the Permanent Court of Arbitration (PCA) in The Hague. In July 2009, the PCA redrew the boundaries of Abyei. The ruling was accepted by both parties.

11 AU High Level Implementation Panel for Sudan (AUHIP), Proposal on the Final Status of the Abyei Area, 21 September 2012. Article 6 states: "Depending on the outcome of the Referendum: a. the Republic of Sudan shall recognise the definition of Abyei Areas as the historic land of the Ngok Dinka, and the predominant role of the Ngok Dinka in Abyei Area, their right to civic and political participation in Abyei State and the protection of the individual rights guaranteed to all persons; and, b. the Republic of South Sudan shall recognise the historic role of the Misseriya in the Abyei Area, including the right of Misseriya residing in the Area to civic and political participation in Abyei State and the protection of the individual rights guaranteed to all persons." See also Interim Report of the African Union High-Level Implementation Panel on the Matters Detailed in the 24 April 2012 Communiqué of the Peace and Security Council, AU Peace and Security Council, PSC/PR/2(CCCXXXIX), 24 October 2012.

12 Proposal on the Final Status of the Abyei Area, paragraphs 26-28: "26. The residents of the Abyei Area shall be eligible to vote in the Referendum. The residents of the Abyei Area are: a. members of the Ngok Dinka community; and, b. other Sudanese residing in the Abyei Area. 27. The criterion for qualifying under Paragraph 26(b) shall be permanent abode within the Abyei Area. 28. The Abyei Area Referendum Commission (AARC) shall compile the voters roll based on the criterion identified." 
UN and the African Union expressed concern at "unilateral actions". ${ }^{13}$ Both the governments of Sudan and South Sudan also condemned the vote, for their own reasons - largely to do with resolving ongoing disagreements over the flow of oil from the South through the territory of Sudan to the Red Sea. ${ }^{14}$ By 2014, clashes between Ngok Dinka and Misseriya had broken out in northern Abyei. ${ }^{15}$

\subsubsection{The Tuareg, Fulani and other West African pastoralists}

Nomadic or transhumant pastoralism is a way of life and means of livelihood for many millions of people in West Africa, especially among the Tuareg and Fulani, including Fulani sub-groups such as the Mbororo. Although some pastoralists are settled or semi-settled, or move only between two poles of migration in response to the seasons (transhumance), others have no fixed place of settlement and move freely across the region, in response to climate variations over the long term and other priorities. Attempts to "encourage" nomadic pastoralists to settle or submit to centralised political organisation have created tensions in both colonial and post-colonial eras. ${ }^{16}$

Many, perhaps most, of these pastoralists do not have identity documents: they can cross borders without any papers, while state institutions may barely exist in the remote rural regions. In any event, even with the correct papers or they may be subject to extortion at border points.

The status of the Sahelian Tuaregs has been doubtful within contemporary African states. Tuareg are nomadic inhabitants of the Sahara, spread mainly among Algeria, Libya, Mali and Niger, and speaking a dialect of the Berber language (Amazigh). Demands for self-determination date back to the 1950s, and Tuareg leaders wrote to French President Charles de Gaulle in 1957, in the lead up to the independence of African countries, stating that they did not want to be included either in Arab North Africa or in sub-Saharan black Africa but have their own Sahelian state. Though in part this sentiment was fuelled by the 1956 discovery of oil in southern Algeria and was supported by certain French interests anxious to preserve access to these resources, it was also based on real fear of the impact of independence on the Tuaregs. Tuaregs have since then been actors both in their own continuing demands for autonomy in their desert zone, and in broader geopolitics of the region. It was well known that many Tuareg were given nationality papers easily in Libya under Ghadafi's

13 "Abyei: Security Council 'gravely concerned' about highly volatile situation" UN News Centre, 26 October 2013; AU Peace and Security Council Communique, PSC/PR/ COMM.(CDIII), 26 October 2013.

14 "What they're saying about Abyei", IRIN, 1 November 2013.

15 "Update on Abyei", Human Security Baseline Assessment for Sudan and South Sudan (HSBA), 16 May 2014.

16 Charles Frantz, "West African Pastoralism: Transformation and Resilience", in Carl Salzman and J. G. Galaty (eds). Nomads in a Changing World. Naples, Instituto Universitario Orientale, 1990. 
government, and recruited into the Libyan army for deployment in both the Arab and sub-Saharan African theatres of Libyan foreign policy. ${ }^{17}$ Anxiety over the role of the Tuaregs in the Sahel and their doubtful loyalties led to them being treated with suspicion especially by Algeria, which responded at various times both by expulsion of refugees from conflicts in neighbouring countries, but also with efforts to mediate Tuareg rebellions in Niger and Mali in the 1960s and 1990s. ${ }^{18}$ The collapse of the Ghadafi regime in Libya in 2011 greatly destabilised the countries to the south, including by fuelling Tuareg discontent with and challenges to the Malian state, and by providing weapons to support those demands. A regional and global Islamist agenda then profited from this resurgence of Tuareg demands — with appalling knock-on effects, including for those Tuaregs who had no wish to support an independent Tuareg state, but whose exclusion from the Malian state was only intensified. ${ }^{19}$

Documentation is a critical problem for many Tuaregs who have no proof of identity or nationality even though they have been resident in country many years, and sometimes generations. As one Nigerien commented, "it outrages them" (ça les révolte) that they have no documentation from the Nigerien state, symptomatic of a generalised neglect: "it is only when Boko Haram comes that they notice us." ${ }^{20}$ While Tuareg leaders freely admit that part of the problem is a lack of awareness of the need for or usefulness of birth registration and other documents, it is also the case that birth certificates and other documents have been difficult to obtain. Only with a recent push for birth registration supported by UNICEF has birth registration become more widespread among the Tuaregs in Niger. But until two generations had been born in Niger birth registration did not help, those who had themselves moved, and their children "remain foreigners for ever" (restent éternellement des étrangers) as a Tuareg activist lamented. ${ }^{21}$ Equally, Tuareg refugees in Niger from the conflict in Mali reported that many among them had no documentation, including birth registration, since they did not see the need. Even though an identity card should in principle enable problem-free travel within Mali or across the border between Niger and Mali (their traditional zones of migration), police at the borders or at routine checkpoints would expect money in any event. Access to schools and other

17 Boilley, Les Touaregs Kel Adagh; Bruce S. Hall, A history of race in Muslim West Africa, 1600-1960, Cambridge University Press, 2011, chapter 8. A French law established the Organisation Commune des Régions Sahariennes in 1956, but this took the form of a development agency rather than political structure, as originally envisaged, and was dissolved n 1962.

18 See commentary by Mohand Salah Tari, "Tuareg :The tragedy of a forgotten people", no date, http://www.amazighworld.org/studies/articles/forgotten poeple.php, accessed 24 February 2014.

19 See, for example, International Crisis Group, Mali: Avoiding Escalation, Africa Report N¹89, 18 July 2012.

$20 \quad$ Interview, Niamey, May 2014.

21 Interview, Albarka Saliha of Timidria, Tillaberi, Niger, May 2014. 
public facilities was so poor for the nomadic communities that there was little point in going through the procedures of registering births. Only in the refugee camp itself were births being systematically registered. ${ }^{22}$

Members of the Fulani (known as Peul in French) ethnic group also find themselves treated as presumptively "foreign" across the West African region, and report difficulties in obtaining passports and other documents. ${ }^{23}$ Though the Fulani have historically followed a nomadic lifestyle of transhumance with herds of cattle, and many still do so, others are settled for several generations in the same location, or migrate only within the borders of one country, yet still face resistance to the idea that they are nationals of that country. Fulani have also been the target of mass expulsions, often in response to clashes over land use rights: for example, in 1982, Sierra Leone expelled Fulani allegedly originating from Guinea; and Ghana expelled Fulani pastoralists in 1988/89 and again in 1999/2000; Senegal expelled Fulani also in 1989. ${ }^{24}$ The Mbororo Fulani sub-group found in Cameroon and as far as Sudan face similar difficulties. ${ }^{25}$ Of the approximately 70,000 people expelled by the Mauritanian government in 1989/1990, the majority were cattle herders of Fulani ethnicity from the Senegal River Valley (site of the most fertile land in Mauritania); though civil servants, military officers and activists from other black African ethnic groups were included (see also chapter 11.5).

22 Interviews, refugee camp, Ayorou, Niger, May 2014.

23 The nomenclature used for this widely dispersed West African ethnic group (itself made up of several sub-groups) is complex: in Commonwealth countries they are usually known as Fula or Fulani; in countries of the Francophonie as Peul. The language may be known as Fulfulde or Pulaar, and those who speak it are sometimes also known as Halpulaar(en). The variations in terminology are complex and not consistently used. For a discussion of the issues, see the thread on "Names for African peoples \& language" on the H-Africa log for December 2007, available at http://www.h-net.org/ africa/, accessed 27 June 2014.

24 Adepoju, "The politics of international migration in post-colonial Africa, in Cohen (ed.), The Cambridge Survey of World Migration; Steve Tonah, "The Politics of Exclusion: The expulsion of Fulbe pastoralists from Ghana in 1999/2000", Working Paper No. 44, Max Planck Institute, 2002.

25 Michaela Pelican, "Mbororo Claims to Regional Citizenship and Minority Status in North-West Cameroon" Africa, Vol.78 No.4, 2008. pp 540-560; Sam Hickey, "Caught at the crossroads: citizenship, marginality and the Mbororo Fulani in northwest Cameroon", in Dorman et al Making Nations, Creating Strangers; Nicodemus Fru Awasom, "From Migrants to Nationals and from Nationals to 'Undesirable Elements': The case of the Fulani (Mbororo) in the North West Province of Cameroon", in Catherine CoqueryVidrovitch et al, Etre Etranger et Migrant en Afrique, Vol.1, pp.403-414; Rogers Tabe Egbe Orock, "The Indigene-Settler Divide, Modernisation and the Land Question: Indications for Social (Dis) order in Cameroon", Nordic Journal of African Studies, Vol. 14, No. 1, 2005, p. 68. Even during the period of British rule in Cameroon there was discussion over whether the Fulani-Mbororo were "natives" ("a person originating from the area where he is living") for the purpose of 1927 Land and Native Rights Ordinance. 
Outside the context of such crisis moments, those who are victims of discrimination on the grounds they have a Fulani last name may eventually be able to establish documentation through payment of bribes, or with the assistance of intermediaries who will vouch for them; others may be able to establish documentation of a country "of origin" different from that where they currently live. ${ }^{26}$ But the poorest and most marginalised members of such communities are certainly at a consistent risk of statelessness.

Others of traditionally nomadic lifestyle face similar problems. In October 2006, the Nigerien minister of the interior threatened to expel Mahamid Arabs understood to be of Chadian origin, though settled in Niger in the Diffa region bordering Chad since at least the 1970s: the Mahamids are nomadic camel keepers, and the expulsion was provoked by conflicts over access to water points - conflict that dated back to the 1990s and included the use of firearms. Numbers cited in the media of up to 150,000 Mahamids settled in Niger and a similar number of camels were clearly fanciful, but many thousands of people were potentially affected by the threats. Among the Mahamids many were in possession of Nigerien national identity cards or birth certificates, though there were frequent allegations by neighbouring communities that such proof of nationality had been fraudulently obtained. With the intervention of the UN and other agencies, as well as protests from nine Arab members of the Nigerien National Assembly, the threat of expulsion was eventually withdrawn. A group of national human rights organisations called for the nationality status of the Mahamid Arabs to be clarified through a commission of inquiry. ${ }^{27}$ In 2009 , the UN Committee on the Rights of the Child stressed the particular need for registration of the births of Mahamid Arab children, since absence of birth registration left them at risk of statelessness. ${ }^{28}$

This exclusion is not just based on ethnic or religious prejudice. Nationality law in most countries of the world is very poorly adapted for the situation of those who have no fixed home. For example, in Niger, the core principle is that of double jus soli - birth in the country of one parent also born there. However, many Tuaregs who are long-term migrants from Mali (over several decades) and wished to obtain Nigerien nationality have presented themselves to the audiences foraines established to provide late registration of births, on the understanding that the process to obtain nationality starts with acquiring a birth

26 For example, Fulani in Ghana interviewed in a focus group by UNHCR and IOM in August 2013 (transcript shared with author).

27 Rapport mission HCR au Niger : La situation des mahamides, 27 octobre au 02 novembre 2006 ; « Niger says it will expel nomadic Arabs to Chad », AFP, 26 October 2006 ;"NIGER: Govt expulsion order will fuel instability, Arabs warn", IRIN, 26 October 2006; " Le statut civil des Arabes mohamids du Niger, encore mal défini, selon la société civile », APA 12 December 2006.

28 UN Committee on the Rights of the Child, Observations finales: Niger, CRC/C/NER/ CO/2, 18 June 2009. 
certificate. They were bemused that they had been rejected, believing that this showed discrimination against them. Yet the tribunal was simply applying the rules. For someone who is not familiar with the system, it is not at all clear why you can obtain a birth certificate only from the country where you are born, but nationality documents only from the country where you have a claim to nationality, which could be a different country - and what would be the appropriate procedures in each case. Nobody had directed those same people towards an application for naturalisation - which would be initiated at the mairie rather than the tribunal responsible for the process of late birth registration; but which would also require proof of another nationality as the basis for acquisition of Nigerien nationality, and thus an almost insurmountable burden of document collection (see chapter 7.3 ). ${ }^{29}$

\subsection{Africa and the UN Declaration on the Rights of Indigenous Peoples}

The situation of nomadic groups in Africa has become interlinked with the international debates around the status of "indigenous peoples', despite the frequent lack of obvious fit between the two sets of issues. These discussions were especially heated during the period leading up to the adoption in September 2007 of the UN Declaration on the Rights of Indigenous Peoples. The response of the African Group at the UN to that exercise was not welcoming, in the context of the increased use of claims to indigeneity or autochthony in many African countries and the violence that has been linked to these claims.

The question of indigenous peoples had been brought to the African Commission on Human and Peoples' Rights as early as 1999, based especially on the engagement of the Denmark-based International Working Group on Indigenous Affairs, collaborating with partner groups in Africa, as well as other international NGOs such as the London-based Minority Rights Group. ${ }^{30}$ The ACHPR established a Working Group on the Rights of Indigenous Populations/ Communities in 2001, which reported extensively on the situation of particular "indigenous populations", and prepared a consolidated report in 2005. ${ }^{31}$

Within the framework of these debates, and meetings considering the rights of indigenous peoples in Africa, those self-identifying as "indigenous" have included the forest-dwelling Batwa ("Pygmy") populations of Central Africa, the traditionally hunter-gatherer Khoi-san ("Bushmen") of southern Africa,

29 Interviews, Tillaberi, Niger, May 2014.

30 Kealeboga Bojosi and George M. Wachira (2006). "Protecting indigenous peoples in Africa: an analysis of the approach of the African Commission on Human and Peoples' Rights", African Human Rights Law Journal,Vol.6, No.2, pp.382-406.

31 The documents of the Working Group are available at the website of the African Commission, http://www.achpr.org/mechanisms/indigenous-populations/, last accessed 17 October 2014. 
and nomadic pastoralists across the Sahel and East Africa. ${ }^{32}$ This is a diverse set of groups, and while the Batwa and Khoisan may fit more easily into the international understanding of "indigenous peoples", the problems faced by nomadic pastoralists are for the most part - though not entirely — rather different. ${ }^{33}$ There is not, however, any similar international advocacy framework for debate on the rights of pastoralists, whereas the label of "indigenous people" creates important opportunities. This point was recognised also by the Movement for the Survival of the Ogoni People (MOSOP) in the Niger Delta of Nigeria, whose spokesman Ken Saro-Wiwa (later executed by the military government) brought their cause to international attention through skilful mobilisation of the opportunities created by the UN Year of Indigenous Peoples in 1993. ${ }^{34} \mathrm{Up}$ to that point, nobody had thought of the Ogoni as an "indigenous people" in the international sense.

During the process of finalising the text of the draft UN Declaration, the African Group at the UN circulated a "Draft Aide Memoire" expressing concerns at the potential of the declaration to "create tensions amongst ethnic groups and instability within sovereign states". 35 The African Group was particularly troubled by the lack of a definition of the term "indigenous peoples" in the draft declaration, ${ }^{36}$ as well as by the provision of a general right of self-determination for indigenous peoples "threatening the political unity and the territorial integrity of any country", and by support for the right to "land, territories and resources which they have traditionally owned, occupied or otherwise used or acquired". They noted that "The current borders of African countries were artificially drawn by colonial powers. The borders cut across or divide members of the same tribal communities. There is a real danger therefore that this clause can be interpreted to mean that tribal communities can choose to belong to one

32 The ACHPR working group has issued reports on Congo, DRC, Burundi, Rwanda, CAR, Gabon, Uganda, Botswana, Namibia, Niger and Libya.

33 For the Khoisan case, see Robert K. Hitchcock, “'We are the First People': Land, Natural Resources and Identity in the Central Kalahari, Botswana", Journal of Southern African Studies, Vol. 28, No. 4, 2002, Special Issue: Minorities and Citizenship in Botswana, pp. 797-824. On the Batwa, see Geschiere, Perils of Belonging, chapter 4.

34 See the profile for the Ogoni at the website of the Unrepresented Nations and Peoples Organisation http://www.unpo.org/members/7901, last accessed 17 October 2014, and other documentation at that site; the situation of the Ogoni and the trial and execution of Ken Saro-Wiwa has also been extensively covered by groups such as Human Rights Watch and Amnesty International.

35 Draft Aide Memoire : African Group : United Nations Declaration on the Rights of Indigenous People, 9 November 2006.

36 Compare Peter Geschiere's notes on the confusion in Canada over the Dutch usage of the term "autochthony" to describe the situation of "native" Dutch people, rather than restricting it to the usage in the UN debate as the translation for "indigenous" in the context of aboriginal groups of traditional lifestyle threatened by marginalisation within a colonised society. Geschiere, The Perils of Belonging. 
country whilst they are inhabitants of another." 37

Although this intervention was seen as wholly negative by many commentators, ${ }^{38}$ its basic positions were not at all intellectually hollow. Though African states were and are far from practising what they preached in their aide memoire, in essence they were holding to a non-discriminatory framework for human rights, and highlighting potentially dangerous fallout from the idea of segmented rights for particular groups.

The AU Assembly of Heads of State and Government commissioned the African Commission on Human and Peoples' Rights to produce an advisory opinion on the point. The Commission did as requested and concluded that, in relation to the definition of indigenous people, "in Africa, the term indigenous populations does not mean 'first inhabitants' in reference to aboriginality as opposed to nonAfrican communities or those having come from elsewhere. This peculiarity distinguishes Africa from the other Continents where native communities have been almost annihilated by non-native populations. Therefore, the ACHPR considers that any African can legitimately consider him/herself as indigene to the Continent." (The Commission did not, however, address the vexed question of who is an "African" for these purposes.) Generally, the Commission rejected the idea that the concept of indigenous populations created "a hierarchy between national communities", rather asserting that it tries to "guarantee the equal enjoyment of the rights and freedoms on behalf of groups, which have been historically marginalized." 39 Specifically on citizenship, the Opinion stated (paragraph 31) that "trans-border identification of indigenous communities or nations has not resulted in any challenge to the question of citizenship or nationality being governed by the internal laws of each country." On this basis, and faced with international pressure on the issues, most African states eventually agreed to sign the declaration, with abstentions only from Burundi, Kenya and Nigeria among the African states. ${ }^{40}$

37 Draft Aide Memoire, op. cit.

38 See, for example, "Response Note to the Draft Aide Memoire of the African Group on the UN Declaration on the Rights of Indigenous Peoples Presented by an African Group of Experts", 21 March 2007, and other documents available at http://www.converge.org. nz/pma/indig.htm, last accessed 9 October 2014.

39 Advisory Opinion of the African Commission on Human and Peoples' Rights on the United Nations Declaration on the Rights of Indigenous Peoples, Adopted by the African Commission on Human and Peoples' Rights at its 41st Ordinary Session held in May 2007 in Accra, Ghana.

40 The Declaration was adopted by a majority of 144 states in favour, 4 votes against (Australia, Canada, New Zealand and the United States) and 11 abstentions (Azerbaijan, Bangladesh, Bhutan, Burundi, Colombia, Georgia, Kenya, Nigeria, Russian Federation, Samoa and Ukraine). See generally on these debates, Felix Mukwiza Ndahinda, Indigenousness in Africa: A Contested Legal Framework for Empowerment of "Marginalized" Communities, The Hague: Springer, 2011. 
In February 2010, the African Commission adopted a decision on a complaint against Kenya by the Endorois community affected by expropriation of land that significantly developed this thinking. It noted "that there is a common thread that runs through all the various criteria that attempts to describe indigenous peoples - that indigenous peoples have an unambiguous relationship to a distinct territory and that all attempts to define the concept recognise the linkages between people, their land, and culture" and found that Endorois culture, religion, and traditional way of life are intimately intertwined with their ancestral lands - Lake Bogoria and the surrounding area. It agreed that Lake Bogoria and the Monchongoi Forest were central to the Endorois' way of life and that without access to their ancestral land, the Endorois were "unable to fully exercise their cultural and religious rights, and feel disconnected from their land and ancestors". The Commission also "accepts that self-identification for Endorois as indigenous individuals and acceptance as such by the group is an essential component of their sense of identity," and concluded by stating that "The African Commission is satisfied that the Endorois are a 'people', a status that entitles them to benefit from provisions of the African Charter that protect collective rights. The African Commission is of the view that the alleged violations of the African Charter are those that go to the heart of indigenous rights - the right to preserve one's identity through identification with ancestral lands." ${ }^{41}$ This ruling was taken into account in the drafting of the 2010 Kenyan constitution, which in its definition of "marginalised communities" included "an indigenous community that has retained and maintained a traditional lifestyle and livelihood based on a hunter or gather economy." ${ }^{42}$

Although broadly welcomed as a breakthrough for indigenous peoples' rights, and as a basis for justice for those whose lands had been expropriated, the decision of the African Commission has potentially problematic implications for other contexts, including the very different meaning of the rights of the "indigenous" in other countries (see chapter 13.1 on "indigeneity" in Nigeria). Though it is the opposite of what is intended, the concept of "indigenous peoples" creates the serious risk of exacerbating resource competition based on identity - unless the entitlement to membership of the "people" is treated in national law in an unusually complex way, based on multiple possible connections and not just ethnicity. And, by the definition applied, which is significantly expanded from the UN usage, virtually any African ethnic group could claim to be an "indigenous people". ${ }^{43}$

41 Decision in Centre for Minority Rights and Development (CEMIRIDE) and Minority Rights Group International on behalf of Endorois Welfare Council v. Kenya, Communication 276/2003, February 2010, paragraphs 154, 156, 157 and 162; see also Elizabeth Ashamu, "Centre for Minority Rights Development (Kenya) and Minority Rights Group International on Behalf of Endorois Welfare Council v Kenya: A Landmark Decision from the African Commission" Journal of African Law, Vol.55, No.2, 2011, pp.300 - 313.

42 Constitution of Kenya 2010, article 260.

43 For a critique of the decision, see Gabrielle Lynch, "Becoming indigenous in the pursuit 
A better approach would be adopt the arguments of those Nigerian activists arguing for "indigeneity" to be based on residence rather than ethnicity: though indigeneity is a powerful word in Nigeria, its connotations are quite different from those intended by the UN Declaration. Pastoralists and other "indigenous peoples" share the likelihood of problems with nationality status, and status within different zones inside a state, thanks to their often quite literally marginal situation on the frontiers of national territories; and, for communities like the Batwa or Khoisan, their existence outside the recognition of state structures. Attention to this point rather than whether they qualified as "indigenous" would better assist in resolving the problems of access to national resources in the African context. The UN Declaration, however, offers little help. It states, in Article 6, that "Every indigenous individual has the right to a nationality", but does not provide any guidance on the resolution of issues that may arise when persons belonging to such groups lack documentation or live in remote regions where borders are ill-defined and little monitored. ${ }^{44}$ On the one hand, there should be no requirement to force documents on people who do not want them; but on the other, those who seek integration in the modern state should have the ability to do so.

of justice: The African Commission on Human and Peoples' Rights and the Endorois", African Affairs, Vol.111, Issue 442, 2012, pp. 24-45.

44 For examples of provisions that do attempt to grapple with these issues, see Gabon's law on those born in border areas, unique in Africa, discussed in chapter 6.1.2; also several Latin American countries have taken these issues into account. Colombia's constitution, for example, provides that "Members of the indigenous peoples who share border areas" are nationals by adoption (por adopción; implying a process equivalent to naturalisation), on the basis of reciprocity with other countries; in addition, dual nationality is allowed and no naturalised citizen is required to renounce another nationality (Constitution 1991, amended 1997, Article 96:"Son nacionales colombianos: [...] 2. Por adopción: [...] c) Los miembros de pueblos indígenas que comparten territorios fronterizos, con aplicación del principio de reciprocidad según tratados públicos.[...].» The matching provision in the nationality law has been declared enforceable by the Colombian Constitutional Court : Sentencia C-893/09, Diciembre 2; Bogotá D.C., available at http://www.corteconstitucional.gov. co/RELATORIA/2009/C-893-09.htm, last accessed 25 November 2014). In Ecuador, the constitution states that citizens by birth include "Persons belonging to communities, peoples or nations recognized by the State living in border areas." (Constitution Article 7. "Son ecuatorianas y ecuatorianos por nacimiento: 1. Las personas nacidas en el Ecuador. 2. Las personas nacidas en el extranjero de madre o padre nacidos en el Ecuador; y sus descendientes hasta el tercer grado de consanguinidad. 3. Las personas pertenecientes a comunidades, pueblos o nacionalidades reconocidos por el Ecuador con presencia en las zonas de frontera. ") 


\section{Between a rock and a hard place: Access to citizenship for refugees}

In the language of the UN refugee system, there are three "durable solutions" to the situation of individuals who have crossed an international border seeking refuge from persecution or from civil war: voluntary repatriation, local integration in the country of first asylum, or resettlement in a third country. ${ }^{1}$ Although voluntary repatriation to their home country is, in principle, the best outcome, the reality for many refugees is that repatriation is not possible because of continued insecurity. Resettlement in a third country is only ever going to be possible for a small minority of those affected. Policies to facilitate the local integration into the country of refuge of refugees in a "protracted" situation defined by UNHCR to mean those who have been in exile for more than five years without immediate prospects for implementation of durable solutions are thus urgently needed. ${ }^{2}$

UNHCR estimated in 2004 that there were approximately 2.3 million people living in a protracted refugee situation in sub-Saharan Africa, fleeing 22 separate conflicts; the largest numbers were of Congolese and Burundians in Tanzania, Somalis in Kenya, Sudanese in Uganda and other countries, and Liberians in several neighbouring countries. ${ }^{3}$ Since that date, under pressure both from donor governments to UNHCR and from some of the countries of origin of the refugees (especially Rwanda), there have been efforts to resolve some of these protracted situations by invoking the "cessation clauses" from the 1951 Refugee Convention, which set out the situations in which refugee status may properly come to an end. These situations may be based on actions by the refugee him or herself (such as voluntarily returning to the country concerned, or naturalisation in another country), but in cases where the reason for ending refugee status is that the situation in the country of origin has changed sufficiently to make

1 This chapter is mainly based on material first published in Manby, Struggles for Citizenship in Africa, and Bronwen Manby, Nationality, Migration and Statelessness in West Africa, UNHCR and IOM, forthcoming, 2015.

2 Conclusion on Protracted Refugee Situations, No. 109 (LXI) - 2009, EXCOM Conclusions, 8 December 2009. Alexandra Fielden, "Local integration: an under-reported solution to protracted refugee situations," New Issues in Refugee Research: Research Paper No. 158, UNHCR, June 2008; Jeff Crisp, "No Solution in Sight: The Problem of Protracted Refugee Situations in Africa”, Refugee Survey Quarterly, Vol.22, No.4, 2003, pp.114150. For a bibliography see http://www.prsproject.org/protracted-refugee-situations/ bibliography/, last accessed 3 July 2014.

3 Protracted Refugee Situations, Executive Committee of the High Commissioner's Programme, EC/54/SC/CRP.14, 10 June 2004. 
return possible, there is a process for a statement to be made by UNHCR and the authorities of the country in question that, as a group, refugees from that country no longer have a well-founded fear of being persecuted (though individuals may rebut the presumption). ${ }^{4}$

The cessation clauses have been invoked four times in the continent, relating to the situation in Sierra Leone (at the end of 2008), Angola and Liberia (in 2012) and Rwanda (in 2013). On invocation of the cessation clause, the refugees become simply foreigners with the same status (and requirements to regularise their status) as any other foreigner. UNHCR thus enters into agreements with the countries of refuge and origin on measures for the voluntary repatriation or local integration of the former refugees; or for individual exemption from the cessation clause on the grounds of a need for continued international protection. Resettlement in a third country is highly unlikely to be available at the moment the cessation clause is invoked.

In principle, refugees are usually eligible to naturalise under each country's nationality laws (whether or not the cessation clause has been invoked). However, some countries specifically exclude periods of residence as a refugee from the qualifying period, while in all countries naturalisation can be very difficult to obtain (see chapters 6.6 and 7.3), especially without the assistance of UNHCR. Refugees may also have a desire to retain the principal identity of their country of origin, even in the context where dual nationality is allowed, and even though this decision may leave their children vulnerable. ${ }^{5}$

In practice, as the office of the UN High Commissioner for Refugees (UNHCR) put it, with restraint:"Progress has been rather modest in terms of local integration throughout the continent." ${ }^{\prime \prime}$ Even where refugees make progress in economic and social integration, there is often no possibility of converting refugee status into a more permanent legal status, whether that of permanent residence or citizenship.

In Kenya, host to about half a million refugees and 20,000 stateless persons

4 “The Cessation Clauses: Guidelines on their Application”, UNHCR, Geneva, April 1999; "Implementation of the Comprehensive Strategy for the Rwandan Refugee Situation, including UNHCR's recommendations on the Applicability of the 'ceased circumstances' Cessation Clauses", UNHCR, 31 December 2011. The invocation of the cessation clauses for Rwanda in particular was controversial, see Rwanda: Cessation of Refugee Status is Unwarranted Memorandum of Fact and Law, FAHAMU, 22 September 2011; Barbara Harrell-Bond and Guillaume Cliche-Rivard, "Rwandan refugees face no choice but repatriation", OpenDemocracy.Net. 10 May 2012; "No consensus on implementation of cessation clause for Rwandan refugees" IRIN, 12 July 2013.

5 Jennifer Byrne, "Should I Stay or Should I go? National identity and attitudes towards local integration among Liberian refugees in Ghana", Refugee Survey Quarterly, 2013, Vol.32, No.1, pp.50-73.

6 United Nations Secretary-General, Assistance to refugees, returnees and displaced persons in Africa, report to the General Assembly, A/61/301, 29 August 2006. 
recognised by UNHCR as of $2012,{ }^{7}$ the government has not accepted the idea of local integration, and assistance to the many thousands of Somali refugees resident in camps is managed by UNHCR. Until 2006 there was no refugee law in Kenya, and refugees were subject to the same requirements as any other foreigners under the Immigration Act and the Aliens Restriction $\mathrm{Act}^{8}$ in obtaining entry to the country, work permits and registration of place of abode. A Refugee Act adopted in 2006 finally brought Kenyan law largely into line with international standards of refugee protection, but the act did not give refugees the right to work, nor did it contain any explicit right to naturalise as a Kenyan citizen. ${ }^{9}$ Although a new constitution and citizenship act adopted in 2010 and 2011 placed no barriers on access to citizenship, in practice Kenyan nationality remains virtually impossible to obtain for refugees (see also chapter 8.4). ${ }^{10}$

In Zambia, a new refugee law was presented to parliament in 2002 with the encouragement of UNHCR, which would, among other things, facilitate the acquisition of nationality by long-staying refugees, including many Angolans. ${ }^{11}$ However, the bill was withdrawn from parliament after strong opposition, and the legislation still in force remains the 1970 Refugees Control Act, which does not conform to the provisions of the 1951 or 1984 conventions and makes no provision on local integration of any kind. Following the cessation of refugee status for Angolans in 2012 and Rwandans in mid-2013, Zambia agreed to the local integration of an estimated 10,000 Angolans and a much smaller number of Rwandans; some 4,200 eligible Angolan candidates resident in Zambia since the 1960s applied for residency permits in 2013. ${ }^{12}$ Naturalisation, however, was not offered on the grounds that it was "not their right". ${ }^{13}$

7 "Refugees, asylum-seekers, internally displaced persons (IDPs), returnees (refugees and IDPs), stateless persons, and others of concern to UNHCR by country/territory of asylum, end-2012", UNHCR, Statistical Yearbook, 2012 (annex, table 1).

8 Kenya Immigration Act, Laws of Kenya, chapter 172, 1968 (amended 1984); Kenya Aliens Restriction Act, Laws of Kenya, chapter 173, 1977 (amended 1985)

9 Refugee Act, No. 13 of 2006.

10 Constitution of Kenya, 2010, articles 15 and 18; Kenya Citizenship and Immigration Act No.12 2011, section 15, where the conditions include "has been a resident under the authority of a valid permit" (which may well not be obtained by an asylum seeker) and "has been determined, through an objective criteria, and the justification made, in writing, that he or she has made or is capable of making a substantive contribution to the progress or advancement in any area of national development within Kenya".

11 UN High Commissioner for Refugees, "Zambia Initiative Launched," Briefing notes, 27 August 2002.

12 UNHCR, "2014 regional operations profile - Southern Africa”, available at http://www. unhcr.org/pages/49e485ba6.html, last accessed 31 March 2014.

13 "Zambia says won't give Angolan refugees citizenship because it's not their right", Zambian Watchdog, 22 June 2012. See also Oliver Bakewell, "Repatriation and Self-Settled Refugees in Zambia: Bringing Solutions to the Wrong Problems", Journal of Refugee Studies, Vol 13, No. 4, 2000, pp.356-373. 
Botswana's national legislation, the 1967 Refugee (Recognition and Control) Act, ${ }^{14}$ adopts only the basic definition of a refugee set forth in the $1951 \mathrm{UN}$ Convention and not the expanded definition in the OAU Convention. It also specifically provides that a refugee recognised by Botswana is not regarded as being ordinarily resident in Botswana for the purposes of any written law other than a taxation law, and thus excludes refugees in Botswana from normal naturalisation procedures. ${ }^{15}$ As a limited exception to this rule, the 2003 tripartite agreement for the repatriation of Angolan refugees provided for 850 recognised refugees not wishing to return to Angola to have the right to apply for citizenship, though only a minority were reported to have been naturalised as a result of this offer. ${ }^{16}$

Uganda adopted a groundbreaking new Refugee Act in 2006 to replace the tellingly-named 1960 Control of Alien Refugees Act. Whereas the former legislation had - as in Botswana - excluded any period spent in Uganda from counting as residence for the purposes naturalisation, the new version simply stated that the normal law applied to the naturalisation of a refugee. ${ }^{17}$ While the 1995 constitution excludes refugees from the easier process of registration as a citizen for those born before independence, it delegates the provision of terms for naturalisation to legislation. ${ }^{18}$ The Uganda Citizenship and Immigration Control Act of 1999 provides no exclusion for refugees from the provisions on naturalisation, though the residence period required for anyone to naturalise is very long, at 20 years, and other conditions apply. ${ }^{19}$ Nevertheless, some remaining ambiguities (including the fact that persons born in Uganda of refugee parents or those who did not themselves "legally and voluntarily" immigrate to Uganda are excluded from the non-discretionary process of registration), have led Ugandan officials to interpret the law to mean that refugees may not naturalise. Forms and procedures used as of 2011 still referred to the long-repealed 1964 Citizenship Act. $^{20}$

The situation of the Angolan displaced illustrates the complex problems that may exist both in gaining official recognition in countries of exile, but also for

14 Botswana Refugees (Recognition and Control) Act, Laws of Botswana, chapter 25:01.

15 Klaaren and Rutinwa, "Towards the Harmonisation of Immigration and Refugee Law in SADC", pp.90-91.

16 "Botswana/Angola sign repatriation deal", Mmegi, 6 June 2003;"183 Angolan refugees get citizenship," Government of Botswana Daily News Online, 2 November 2006.

17 Control of Alien Refugees Act 1960, Art 18; Refugee Act, 2006 Article 45.

18 Uganda Constitution, 1995, Article 12(1), 12(2)(b) and 13.

19 Uganda Citizenship and Immigration Control Act, 1999, section 16.

20 Walker, From refugee to citizen?. Article 14 of the Citizenship and Immigration Control Act 1999, as amended 2009, provides for various categories of person to be registered as a citizen on application, including a person born in Uganda who has lived continuously in Uganda since 1962 unless neither parent nor any grandparent had diplomatic status or was a refugee; and a person who has legally and voluntarily migrated to and has been living in Uganda for at least ten years. The "legal and voluntary" caveat does not apply to naturalisations under Article 16; but in that case twenty years' residence is required. 
those who have returned and those who never left. Those remaining in exile no longer have refugee status, since the cessation clause was invoked in 2012, but many will not have accessed the limited naturalisation prcesses in neighbouring countries. Those returning, whether formerly recognised as refugees or not, and their children born in exile, find it difficult to have their Angolan nationality recognised. $^{21}$ Many returnees are still without any documentation, most importantly the cedula pessoal, or "personal record" that ensures access to schooling for children, and other rights, and is the basis for issue of a passport or national identity card. ${ }^{22}$ Even the internally displaced who never left the country have faced problems in establishing their identity. ${ }^{23}$ Meanwhile, UNHCR has been engaged in finding legal solutions for children born in the Democratic Republic of Congo of mixed Angolan and Congolese parentage denied recognition as Congolese citizens despite nationality legislation granting citizenship of the DRC to a child with one Congolese parent. ${ }^{24}$ Equally, UNHCR has advocated for the naturalisation in Angola of a group of up to 15,000 Congolese refugees from Katanga Province who have lived in Angola for more than three decades and have achieved "a significant level of socio-economic integration in the country". 25

This chapter highlights difficulties — and some progress — in obtaining recognition of legal status and nationality for Sierra Leonean and Liberian refugees in Guinea, for Rwandans and Burundians in Tanzania, for Palestinians in Egypt, for Sahrawis in Algeria, for Mauritanians in Senegal (and for those who have returned), and for refugees from across the continent in South Africa.

\subsection{Former Liberian and Sierra Leonean refugees in Guinea}

The cessation clause came into effect for Sierra Leonean refugees at the end of 2008. At that time, the vast majority of the hundreds of thousands of refugees who had at one time fled the civil war had already returned home, with or without the assistance of UNCHR. The total number of remaining Sierra Leonean refugees worldwide was estimated at 43,000, the great majority in neighbouring countries. ${ }^{26}$ At the time the cessation clause came into effect for Liberia, on 30 June 2012, almost 67,000 Liberian refugees were still registered with UNHCR

21 Evaluation of UNHCR's returnee reintegration programme in Angola, August 2008; MabekoTali, “" Congolenses ", "Congoleses ", "Zaïrenses »; and see above paragraph on Zambia.

22 Though the government's "Eleven Commitments for Children", which include birth registration should assist with this problem. Steve Felton, "With free birth registration, Angola promotes a child's right to legal identity”, UNICEF, 10 August 2010.

23 Human Rights Watch, Struggling through Peace: Return and Resettlement in Angola, August 2003.

24 UN High Commissioner for Refugees, Africa Newsletter, third quarter 2006.

25 UNHCR, 2011 Regional Operations Profile for Southern Africa.

26 "Applicability of Ceased Circumstances Cessation Clauses to Refugees from Sierra Leone", UNHCR, 2 June 2008. 
in nine West African countries, with the largest populations in Côte d'Ivoire $(23,650)$, Ghana $(11,295)$, Guinea $(9,972)$, and Sierra Leone $(8,046) .^{27}$

In Guinea, home to a large number of this remaining caseload, several thousand Sierra Leonean and Liberian refugees applied for continued international protection, many in the hope that resettlement might still be possible. ${ }^{28}$ Those who had lost everything or were afraid to return (because they had themselves committed crimes, or because the killers of their loved ones are now in power) also stated that they were afraid to stay in Guinea, citing the attacks on refugees in 2000-2001 by the government of Lansana Conte in which an unknown number of people were killed. ${ }^{29} \mathrm{With}$ ethnic tensions high in Guinea, and many refugees coming from the two main ethnic groups that form the most powerful blocs in Guinea (the Mandingo and Peul/Fulani), there was a fear that such violence could easily return. In addition, the Sierra Leoneans and Liberians do not speak French nor are they familiar with the government structures in a civil law country (life is easier in Guinea in that respect for refugees from Cote d'Ivoire). This is as much true of children born in Guinea as for those who were already adults. Schooling was provided in the refugee camps, but it was provided by teachers from their home countries, according to the curriculum of those countries - on the grounds that they would eventually return. ${ }^{30}$

In the case of those who opted for repatriation or local integration, UNHCR negotiated with the governments of Sierra Leone and Liberia to issue either travel documents allowing the former to return home, or passports on the basis of which the latter could obtain a residence permit in the country of asylum. ${ }^{31}$ This assistance with papers had already been provided for some refugees even before the invocation of the cessation clause: for example, in 2007, agreements between UNHCR, the Economic Community of West African States (ECOWAS), and the governments of Nigeria, Liberia, and Sierra Leone provided for more than 7,000 refugees from Sierra Leone and Liberia resident in Nigeria to be issued

27 "Protracted refugee situations in Liberia and Angola to finally end", UNHCR 29 June 2012.

28 Among all the Liberians in West African countries, around 13 percent (6,172 individuals) applied for exemption from the cessation clause. Information from UNHCR, June 2014.

29 Human Rights Watch, Refugees Still at Risk: Continuing Refugee Protection Concerns in Guinea, 2001; Decision of the African Commission on Human and Peoples' Rights in Communication 249/02 Institute for Human Rights and Development in Africa (on behalf of Sierra Leonean refugees in Guinea) / Guinea, 2006. For background on the politics of ethnicity in Guinea, see Robert J. Groelsema, "The Dialectics of Citizenship and Ethnicity in Guinea”, Africa Today Vol.45, Nos.3-4, 1998, pp.411-421.

30 For the attitudes of those in the camps, see Lacey Andrews Gale, "The Invisible Refugee Camp: Durable Solutions for Boreah 'Residuals' in Guinea”, Journal of Refugee Studies, Vol. 21, No. 4, 2008, pp.538-552.

31 Strangely, therefore, the criteria for determination of nationality were more stringent for those seeking local integration outside Liberia or Sierra Leone (who required a passport) than for those seeking to return home (on the basis of a simple one-way travel document). 
passports by their home governments, while Nigeria undertook to ensure that these refugees would enjoy the entitlements of ECOWAS citizenship, including the right to work and access to education and health care on the same terms as Nigerians. ${ }^{32}$

In Guinea, the Guinean government established a system to review the applications for exemption from the cessation clause on the basis of the need for continued protection, which were first considered by officials, and then appealed to a three-person panel of magistrates. The overwhelming majority of requests for continued protection were rejected, with the rejection letters on appeal giving no reasons for the rejection. Others among both the Sierra Leoneans and the Liberians simply did not engage with the process at all, rejecting the two options on offer and holding out for resettlement, and/or not understanding the need to apply for continued protection. In addition to the former refugees, there are people who never applied for refugee status though they left Sierra Leone or Liberia because of the wars, and who were not therefore included within the processes surrounding the invocation of the cessation clause; although IOM did facilitate the acquisition of documents from their home country for some in this category.

It seems that the process for considering the Sierra Leonean applications was quite problematic: certainly the former refugees themselves believed so. There was quite generalised misunderstanding of the process at that time; and others did not hear of it, despite widespread publicity. During 2013, a group of around 200 former Sierra Leonean refugees protested first at the UNHCR office and then at an encampment of several weeks outside the US Embassy in Conakry, in both cases eventually being dispersed by police and gendarmes, with some injured as a result. As of June 2014 they were sheltering in a one-room shed at a church near the US Embassy, itself a very basic structure catering just to a Sierra Leonean congregation. Other Sierra Leoneans remained in the former refugee camps in Kissidougou and Nzerekore in Guinea Forestière; as did some Liberians, apparently cut off from all contact with the Guinean administration. ${ }^{33}$

The Liberian government sent vetting missions to the various countries to verify the Liberian citizenship of those seeking these documents. Although the process was still incomplete as of mid-2014, it seemed, from lists submitted to UNHCR, that just under 10 percent of the original applicants for Liberian passports (around 900 individuals) who had been registered as refugees for decades by UNHCR and mostly claimed birth in Liberia of parents also born there, had been rejected as non-Liberian by the vetting missions (coded red on the lists), but on very unclear criteria. Among those rejected were individuals who had spent a long time out of the country, having left as children, and who

32 "Liberian, Sierra Leonean refugees to settle in Nigeria," Reuters, 7 August 2007.

33 "Rapport de mission à Kissidougou du 2 au 6 juin 2013 ", Commission nationale pour l'integration et le suivi des refugiés, Conakry : 2013 ; interviews, Conakry, June 2014. 
no longer spoke Liberian English or any national language fluently. Given that only 5 percent of births are registered in Liberia, official proof of birth in the country (which should automatically give Liberian citizenship, provided the child is "negro African") is rare. With no knowledge of the villages they came from and no documentation to prove a connection to Liberia, a registration with UNHCR as a Liberian refugee apparently did not confirm their Liberian nationality. For those never registered as refugees, the evidence of a Liberian connection was sometimes even more difficult to show. ${ }^{34}$

Liberian women who had children with Guinean soldiers who were part of the ECOMOG peacekeeping forces in Liberia and had returned with them to Guinea, so never requested asylum; only to be rejected by the families of those soldiers, "and now they cannot find their way home." Others included non-Liberians married to Liberian citizens, who would under Liberian law be required to naturalise formally to obtain Liberian citizenship; and at least one person who held a voter's card in another country (in this case, Nigeria), which under Liberian law results in automatic loss of Liberian nationality. ${ }^{35}$

Altogether perhaps a number in the low thousands of former Sierra Leonean and Liberian refugees remained in Guinea with no legal status as of 2014. ${ }^{36}$ They had neither Guinean documents, nor any documents proving nationality of their home country, nor any continuing refugee status. Their lack of valid documentation meant they had no access to health care and their children were not in school; the assistance that UNHCR used to provide had ended and as non-nationals they could not access Guinean public health facilities or schools. Without Guinean papers, they were also subject to constant extortion by police, which severely curtailed their freedom of movement. Even the most menial jobs are difficult to access in such circumstances. While their children born in Guinea would, under the law, acquire Guinean nationality at majority, that right might depend on their being registered at birth, and since UNHCR ceased facilitating registration, many children were not being registered. At the same time, if they "returned" to Sierra Leone or Liberia many would struggle to be recognised as nationals, as the "red-coding" of Liberians indicated. Guinea has no process to provide a status to stateless persons.

Other countries of West Africa also provide little realistic chance of naturalisation

34 Telephone interview, IOM Accra, July 2014. For those born abroad, although the constitution provides that a child of a Liberian father or mother is Liberian, the nationality law only grants nationality to those whose fathers are nationals, and they must take an oath of allegiance before they are 23. Liberia Constitution Art 28; Aliens and Nationality Law, Article $\mathbb{2} 20.1(\mathrm{~b})$.

35 Interviews with former Liberian refugees Conakry, Guinea; Commission naitonale pour l'Intégration et le Suivi des Réfugiés (CNISR) Guinea; and UNHCR Nigeria, June and July 2014.

36 According to UNHCR and CNISR unofficial estimates - but no audit had been done to determine the numbers. 
for refugees. In Ghana as of 2014, UNHCR had no information that any refugee or former refugee had been able to naturalise. Even the far less numerous former Rwandan refugees faced difficulties: in Niger, for example, a group of Rwandan refugees had already submitted naturalisation requests even before the cessation clause was invoked, with no success; an application lapses and must be resubmitted if no reply has been received within a year. The exception, ironically enough, appeared to be Liberia, which offered to naturalise several thousand Sierra Leonean former refugees based on long residence in the country. ${ }^{37}$

\section{Former refugees in Guinea ${ }^{38}$}

Lamin Koroma: I was born in Freetown in 1970, both my parents were Sierra Leonean. I was a news presenter and I was declared wanted when the rebels attacked. I left Freetown in March 1999 and came to Guinea by the boat. We were met by the Red Cross and I have been here since then. I was given a document by the Red Cross in 1999, and then an attestation de réfugié when they snapped [photographed] me in 2005, which enabled me to go to hospital and also to travel around Guinea. In 2008 they told me there were three options - return to Sierra Leone, stay in Guinea or further international protection. I chose further international protection. Then they gave me an appointment and an interview but I was rejected. I appealed, but that was also rejected. They gave me no reasons for the rejection but they said the refugee status was removed. They gave me another slip that gave me just one year more of refugee status. They told me that from 1 January 2010 I could no longer be a refugee. There are too many problems in this country. They will not give me a job as a foreigner, even a cleaning job - there is too much discrimination. My brother went home to Freetown, but he was killed there. I am with an Ivorian woman who is also a refugee; she came here in 2006. She recently gave birth to my son, just three weeks ago, but they would not see her at the hospital. We went there at midnight and said we were refugees and they said "we have no place for you people", so we went home and she gave birth there. We have not registered the birth of the baby - you have to have the hospital slip to be able to register a baby, that is how it works. Without the slip you cannot go to the commune. I have no documents to prove my nationality so that we can get a birth certificate saying the child is Sierra Leonean.

Maria Gaye was born in 1968, in Grand Gedeh county, Liberia, of two parents also born in Liberia. She fled Liberia in 1990, and spent the next

37 Manby, Nationality, Migration and Statelessness in West Africa; Mirna Adjami, Statelessness and nationality in Liberia, UNHCR, forthcoming 2015.

38 Interviewed in Conakry, June 2014; Names have been changed. 
five years in refugee camps in Sierra Leone, then crossing the border to Guinea in 1996, spending a year in Forecariah camp, and travelling to Conakry in 1997. She had no documents in Liberia other than a school enrolment card, which she has lost. In Sierra Leone she had a refugee card from UNHCR and a ration card. In 1997 she received an attestation de refugié from UNHCR and the Guinean Commission nationale d'éligibilité. She has four children: two born in Sierra Leone and two born in Guinea, as well as two grandchildren born in Guinea; though all the children and both grandchildren have birth certificates, they have no nationality documentation in any country. Her husband was killed in the attacks against Sierra Leonean refugees incited by the government of Lansana Conté in 2000-2001. Maria opted for local integration when the cessation clause was invoked and the refugees were given the option to choose between local integration or voluntary repatriation, and completed the application to receive a Liberian passport, on the basis of which she could regularise her status in Guinea. The latest renewal of her refugee card was valid from February to June 2013 and has now expired; she also has a temporary carte de séjour valid for one year - due to expire at the end of June 2014. Just a few weeks from the expiry of that card she had yet to receive a passport, though others who had gone through the same process had done so.

Without a Liberian passport, Maria Gaye will be stateless and, in the absence of any procedure for recognising and documenting stateless persons, unable to regularise her status in Guinea.

\subsection{Tanzania: Naturalisation stalled by regional politics}

Tanzania is one of the African countries that has made the most positive efforts to grant citizenship to refugees, especially refugees it has received from Rwanda and Burundi over the years. Tanzania also was one of the few Commonwealth countries not to take steps to amend the provisions of the independence constitution granting citizenship to (almost) all children born on the territory. Tanzania's policy has been in marked contrast to that of the DRC, and it has reaped the benefits in social peace.

Yet the situation is complex. Official policy towards refugees has gone through marked swings in practice, with failings in the implementation of policy commitments and periodic mass expulsions at times of political tension. Moreover, although the independence constitution provisions attributing citizenship to a child born in the country were preserved in the 1995 Citizenship Act, officials came to interpret the confusingly drafted exceptions relating to the child of a father with diplomatic status (if the mother was not a citizen) to require that one 
parent must be a citizen. ${ }^{39}$ Nevertheless, naturalisation was in theory possible for refugees on the same terms as other foreigners, provided another nationality was renounced. Dual nationality remained prohibited for adults, requiring (in principle) an option for either citizenship at majority for those born in Tanzania of foreign parents, but in practice interpreted to mean that a person with a claim on another citizenship did not become Tanzanian.

Just as in Congo, many Kinyarwanda-speaking people were already resident in Tanzania at the date the colonial borders were drawn. Also as in Congo, Tanzania saw major outflows of (largely Tutsi) refugees from Rwanda fleeing the immediate pre- and post-independence violence in Rwanda. In 1980, refugees who came to Tanzania from Rwanda and Burundi in 1959 and during the 1960s were given the right to Tanzanian citizenship on a group basis in which normal application procedures and fees were waived. Once the naturalisation process was complete, former refugee camps became normal Tanzanian villages, integrated into state structures in every way. Though a commitment entirely in line with Tanzania's commitment to a pan-African ideal, in practice certificates of naturalisation were slow to be issued, and years later many former refugees were still waiting for their documents. ${ }^{40}$ Uneasiness around definitions of citizenship was also reflected in renewed official discussions on how to determine who was an "indigenous Tanzanian" in the context of efforts to reduce the dominance of the economy by people of Arab and Indian ethnicity. ${ }^{41}$

The large influxes of refugees to Tanzania from both Rwanda and Burundi in the mid-1990s put a strain on the policy of integration. Already there had been expulsions of Burundians in 1987 and 1991, while camps in Tanzania became militarised, as those driven from their homes organised to return, creating genuine security concerns for the Tanzanian government. In 1993, several hundred thousand Hutu Burundians fled an upsurge of violence in October of

39 Tanzanian Citizenship Act, 1995, Articles 5-9 and second schedule. Article 5 provides: “(1) Subject to the provisions of subsection (2), every person born in the United Republic on or after Union Day shall be deemed to have become and to have continued to be a citizen of the United Republic with effect from the date of his birth [...]. (2) A person shall not be deemed to be or to have become a citizen of the United Republic by virtue of this section if at the time of his birth: (a) neither of his parents is or was a citizen of the United Republic and his father possesses the immunity from suit and legal process which is accorded to an envoy of a foreign sovereign power accredited to the United Republic; or (b) any of his parents is an enemy and the and the birth occurs in a place then under occupation by the enemy."

40 Charles P. Gasarasi, "The Mass Naturalization and Further Integration of Rwandese Refugees in Tanzania: Process, Problems and Prospects", Journal of Refugee Studies, Vol.3, No. 2, 1990, pp.88-109.

41 Ned Bertz, "Educating the Nation: Race and Nationalism in Tanzanian Schools" in Dorman, Hammett and Nugent, Making Nations, Creating Strangers, p.179; Bruce Heilman, "Who Are the Indigenous Tanzanians? Competing Conceptions of Tanzanian Citizenship in the Business Community." Africa Today Vol. 45, Nos.3-4, 1998, pp.369-387. 
that year. In 1994, hundreds of thousands of Rwandans crossed the border, as in Congo; first of Tutsi and then Hutu ethnicity. In late 1996, just as Rwandan refugees were driven back to their country from DRC, the Tanzanian army also drove several hundred thousand Rwandan refugees back across the border; though most were recent arrivals, some had been resident in Tanzania since the 1960s. The Rwandan border remained closed until 1998, though Tanzania still accepted refugees from DRC and Burundi (as of 2008, perhaps 25,000 Rwandan refugees from the 1994 outflow still remained in Tanzania). ${ }^{42}$ In late 1997, the government ordered the army to round up all foreigners living outside refugee camps; this time the bulk of those affected were Burundian, and included many born in Tanzania. ${ }^{43}$

In 1998, a new Refugee Act was passed, incorporating the UN and OAU refugee definitions into national law, though still requiring refugees to live in designated sites, with no emphasis on local integration or naturalisation, and providing significant restrictions on refugees' rights; in 2003, a National Refugee Policy was adopted, which cast "local settlement" as a temporary solution. Nevertheless, in June 2003 the government announced that it would look favourably upon the request forTanzanian citizenship from Somali refugees in Chogo settlement in the north-eastern part of Tanzania, and in May 2005 granted citizenship to the first 182 of around 3,000 Somalis of Bantu ethnicity, who had fled persecution by the Siad Barre regime in Somalia and the civil war that followed his fall from power. ${ }^{44}$ Yet at the same time, expulsion of the far more numerous Rwandan refugees continued on an intermittent basis. ${ }^{45}$

Then in 2007, Tanzania offered naturalisation to Burundian refugees resident in the country since 1972 and their descendants; of those eligible, 80 percent, or 162,000 people, expressed their desire to remain in Tanzania, and the remaining 20 percent were to receive assistance with repatriation from March 2008. The European Commission, announcing support for the processing of the applications in August 2008, described the decision as "a unique and unprecedented act of generosity and humanity." ${ }^{6}$ Nonetheless, the

42 Bonaventure Rutinwa, “The Tanzanian Government's Response to the Rwandan Emergency”, Journal of Refugee Studies, Vol.9, No. 3, 1996, pp.291-302; Human Rights Watch, In the Name of Security: Forced Round-ups of Refugees in Tanzania, July 1999; Charles P. Gasarasi, "The Question of the Recent Expulsion of Rwandans from Tanzania”, Journal of African Conflicts and Peace Studies Vol. 1, No.1, 2008, pp.111-125.

43 International Crisis Group Burundian Refugees in Tanzania: The Key Factor to the Burundi Peace Process, Central Africa Report N 12, 30 November 1999.

44 "Somalia-Tanzania: Government grants Somali refugees citizenship", IRIN 20 June 2005; UNHCR, Finding a Home on Ancestral Land: Somali Bantu refugees gaining citizenship in Tanzania, Dar es Salaam, 2010.

45 Charles P. Gasarasi, "The Question of the Recent Expulsion of Rwandans from Tanzania”, Journal of African Conflicts and Peace Studies, Vol. 1, No.1, 2008, pp.111-125.

46 "EU funds naturalisation of Burundians," Daily News (Dar es Salaam), 19 August 2008; UNHCR, Global Report 2007. 
process was not without its own issues: among them the exclusion of more recent refugees from Burundi, disagreements over the status of those born in Tanzania (some of whom according to the principles of Tanzania's jus soli law should automatically have citizenship) or married to Tanzanians, and problems with documentation of their existing status. Because dual nationality was not permitted, those wishing to naturalise had to renounce their Burundian citizenship, with no possibility of retaining refugee status without naturalising. Just as in the case of the naturalisation offered to Rwandan refugees in 1980, many of those who had applied for naturalisation and been named in lists published of those approved for citizenship did not obtain their certificates of naturalisation. The naturalisation procedure was stalled when almost complete, leaving thousands in limbo; while thousands of others who had not applied for citizenship were expelled from Tanzania in 2013, even though many of them were likely entitled to recognition as citizens, based on their birth in the country. ${ }^{47}$ As of late 2014, the process of issuing naturalisation certificates had reportedly resumed again. ${ }^{48}$

The case of Tanzania shows how difficult it may be to provide for naturalisation in a context where new refugee flows and political considerations disrupt efforts to normalise the situation of long-term settled refugee populations. Tanzania's expulsion of refugees has been affected by regional politics not only in relation to the internal crises of its neighbours, but also its positioning in the most important regional political and economic body, the East African Community. Whereas the expulsion of Rwandan refugees in the early 2000s appeared linked to opposition to Rwanda joining the EAC, those in 2012 and 2013 tracked somehow the closer alliances being formed between Kenya, Uganda and Rwanda to the exclusion of Tanzania. Individual refugees were thus caught up in wider regional issues. ${ }^{49}$ The Tanzania case also shows the critical importance of documentation procedures, including birth registration and the issue of identity documents, in providing confidence for both refugees and hosts on the good faith of integration efforts; as well as the role that UN

47 See reports by the International Refugee Rights Initiative, Kampala: Going Home or Staying Home? Ending Displacement for Burundian Refugees in Tanzania, 2008; Resisting Repatriation: Burundian Refugees Struggling to Stay in Tanzania; An urgent briefing on the situation of Burundian refugees in Mtabila camp in Tanzania, 2012; 'I can't be a citizen if I am still a refugee': Former Burundian Refugees Struggle to Assert their new Tanzanian Citizenship, 2013; From refugee to returnee to asylum seeker: Burundian refugees struggle to find protection in the Great Lakes region, 2013.

48 "Tanzania Grants Citizenship to 162,000 Burundian Refugees in Historic Decision", UNHCR, 17 October 2014.

49 See reports of International Refugee Rights Initiative, cited above; also Gasarasi, "The Question of the Recent Expulsion of Rwandans from Tanzania"; Giles Muhame, "Rwanda, Tanzania Tensions Threaten Regional Integration", Chimpreports (East African news service), 20 August 2013; Dismas Nkunda, "Tanzania must learn to be a good neighbour", The Observer (Kampala), 15 September 2013. 
agencies can play in supporting these efforts and the importance of coordinated regional responses. ${ }^{50}$

Tanzania's neighbours in Central Africa indeed recognised the importance of a regional response to nationality and statelessness as one of the issues addressed by the creation of the International Conference on the Great Lakes Region. ${ }^{51}$ The Conference's 2004 Dar-es-Salaam Declaration committed states to "Adopt a common regional approach for the ratification and implementation of the UN Conventions on Statelessness, harmonize related national laws and standards, and provide refugees and displaced persons with identification documents enabling them to have access to basic services and exercise their rights". ${ }^{52}$ Implementation of this commitment has, however, been lacking in practice.

\subsection{Palestinians in Egypt}

Egypt, host to at least 250,000 refugees and asylum seekers in $2013^{53}$, fails to make any serious provisions for refugee integration, condemning many longterm refugees to statelessness: the Egyptian government treats the position of refugees as temporary, allowing only two solutions: repatriation or resettlement in a third country. There is no specific refugee law, and though the constitution recognises the concept of political refugee, this status has been granted only to a few high profile individuals. For the rest, Egypt has effectively passed on the execution of its obligations under the UN refugee convention to the UNHCR Cairo office. Moreover, Egypt placed reservations to its ratification of the international instruments, relating to refugees' access to employment, state education, and public relief and assistance or rationing. Refugees in Egypt and their children face a near impossibility of obtaining Egyptian nationality, unless they are married to or have a parent who is an Egyptian citizen; they

50 International Refugee Rights Initiative, "Citizenship and Forced Migration in the Great Lakes Region", Report of a Consultation on the Feasibility of a Collaborative NetworkBuilding Project Linking Research with Program and Policy Development, co-hosted by the Social Science Research Council and the International Refugee Rights Initiative, Kampala, Uganda, 6-8 April 2005.

51 The ICGLR held its first meeting in 2004 and was formalised in 2006 with the signing of a Pact on Security, Stability and Development in the Great Lakes Region. The member states are: Angola, Burundi, Central African Republic, Republic of Congo, Democratic Republic of Congo, Kenya, Uganda, Rwanda, Republic of South Sudan (joined 2012), Sudan, Tanzania, and Zambia. See http://www.icglr.org/.

52 Dar-es-Salaam Declaration on Peace, Security, Democracy and Development in the Great Lakes Region, 2004. See also The Great Lakes Pact and the rights of displaced people: A guide for civil society, Internal Displacement Monitoring Centre and International Refugee Rights Initiative, September 2008.

53 An increase of more than 100,000 in five years, largely made up of Syrians. See UNHCR country operations profile - Egypt, 2014, available at http://www.unhcr.org/ pages/49e486356.html, last accessed 28 November 2014. 
do not qualify for naturalisation as Egyptians regardless of the length of their residence in the country. ${ }^{54}$ Very few people have been recognised as stateless, even though there are likely many thousands of stateless people in Egypt, facing significant hardships because of their status. ${ }^{55}$

The majority of refugees in Egypt have historically come from Palestine, making up some 70,000 of the total 100,000 refugees and asylum seekers in the country as of the early 2000s; Sudanese and Somalis made up most of the remainder, while there are also several million Sudanese migrants to Egypt. Unlike other refugees, Palestinians are to some extent integrated in Egyptian society and have preferential treatment with regards to accessing work. However, they are completely excluded from the possibility of obtaining citizenship, thanks to a 1959 decision of the Arab League - reinforced by the 1963 Casablanca Protocol for the treatment of Palestinians in Arab states - that the Palestinian diaspora should not be given citizenship in other Arab countries, as a way of preserving their identity and political cause. ${ }^{56}$ Although children born in Egypt of Egyptian mothers and unknown or stateless fathers had, under the 1975 citizenship law, the right to Egyptian nationality, they were deprived of this right if their fathers were Palestinian. There are no available statistics on how many children of such marriages were stateless as a result. ${ }^{57}$

In 2004, an amendment to the 1975 nationality law for the first time allowed the children of Egyptian women and foreign men to obtain nationality, ${ }^{58}$ and those born before the changes to the law came into effect (in November 2005) were given the right to apply for their citizenship to be recognised. The application of the law places considerable constraints in terms of access to the provision. Applicants for citizenship have to provide, among other documents, the birth certificates of both parents, the mother's identity card and her father's birth certificate, and the marriage contract. The process of

54 CMRS, Africa Citizenship and Discrimination Audit: The Case Study of Egypt, Open Society Justice Initiative, 2005; Mulki Al-Sharmani, "Livelihood and identity constructions of Somali refugees in Cairo," Forced Migration and Refugee Studies Working Paper No. 2, American University in Cairo, July 2003.

55 Pierrot, UNHCR and statelessness in Egypt; Kelly A. McBride and Lindsey N. Kingston, "Legal Invisibility and the Revolution: Statelessness in Egypt", Human Rights Review, Vol.15, No.2, 2014, pp.159-175.

56 League of Arab States Decree, No.1547 of 1959; Protocol for the Treatment of Palestinians in Arab States (Casablanca Protocol), League of Arab States, 11 September 1965.

57 See generally, works by Oroub El-Abed: The Palestinians in Egypt: An Investigation of Livelihoods and Coping Strategies, Forced Migration Refugee Studies Program, The American University in Cairo, 2003; FMO Research Guide: Palestinian Refugees in Egypt, Forced Migration Online, 2004; "Palestinian Refugees of Egypt: What Exit Options Are Left for Them?” Refuge,Vol.22, No.2, 2005.

58 Law No. 154 of 2004 amending some provisions of Law No.26 of 1975 concerning Egyptian nationality, Official Gazette, Vol.28, 14 July 2004. See also http://www. learningpartnership.org/egypt, last accessed 4 March 2014. 
obtaining an identity card and passport can be long and frustrating, even for members of the educated elite. Nonetheless, thousands of people immediately applied for Egyptian citizenship under the new law, and by 2006 it was estimated that 17,000 people had obtained citizenship, most of them born of Sudanese or Syrian fathers. More were then expected to apply, as the Ministry of the Interior announced that applicants for Egyptian citizenship would be exempted from the fee previously required. ${ }^{59}$

However, the authorities continued to refuse nationality to children born to a Palestinian father and Egyptian mother before the entry into force of the law; though a number successfully challenged the discrimination in court. With the 2011 fall of the Mubarak regime this policy changed. In May 2011, in direct response to public protests by women affected, the Ministries of Interior and Foreign Affairs issued a decree allowing Egyptian women married to Palestinian men to transmit their nationality to their children. Applications for nationality rapidly increased, with 893 obtaining documents by late October, of which the vast majority were children of Palestinian fathers ${ }^{60}$ At the same time, refugee and stateless populations also faced increasing xenophobia under the Muslim Brotherhood government of Mohammed Morsi; and a no less uncertain future when his government was in turn deposed in 2013 by the military led by General Abdel Fattah el-Sisi. Following el-Sisi's confirmation as president by election, a cabinet committee revoked nationality from 800 people, including Palestinians, apparently on national security grounds. ${ }^{61}$ Prospects for local integration for migrants generally remained "bleak". ${ }^{62}$

59 Reem Leila, “Citizenship costs less," Al Ahram Weekly Online, Issue 806, 3-9 August 2006.

60 "Egypt to grant citizenship to kids of Palestinian dads", Jerusalem Post, 8 May 2011; "Post-Revolution, Egypt Establishes the Right of Women Married to Palestinians to Pass Nationality to Children", the Arab Women's Right to Nationality Campaign in Lebanon, 13 May 2011, available in English at http://www.learningpartnership.org/lib/ post-revolution-egypt-establishes-right-women-married-palestinians-pass-nationalitychildren-1, last accessed 27 November 2014; Gianluca Parolin, "New policy on Egyptian citizenship for children of Palestinian fathers", EUDO Citizenship Observatory, http:// eudo-citizenship.eu/search-results/530-new-policy-on-egyptian-citizenship-forchildren-of-palestinian-fathers, last accessed 27 November 2014.

61 "Egyptian nationality stripped from 800, including Palestinians", Egypt Independent, 29 October 2014; Sonia Farid, "Stripping Egyptians of citizenship: a new punishment?", $A l$ Arabiya News, 23 October 2014.

62 Kelsey P. Norman, "Migrants in post-revolution Egypt”, Washington Post, 7 January 2015. 


\section{"Participatory research" on Palestinian refugees in Egypt ${ }^{63}$}

"Throughout my time doing research on Palestinian refugees in Egypt, I experienced interference from the Egyptian security authorities. This has now culminated in being held at Cairo airport when on the way from my home in Amman, Jordan to present a paper in Cairo on the unprotected Palestinians in Egypt. Later I was refused entry to Egypt and deported.... Of the many people who were in the waiting room, [one case] drew my attention: A Palestinian, holding an Egyptian travel document was denied entry to Egypt since he overstayed his return visa. His mother is Egyptian and he was raised in Egypt where he remained until 15 years ago when he decided to leave and look for work elsewhere. Today, he works in Tanzania and was hoping to spend his holidays with his family in Cairo. The Egyptian authorities, denying him entry, told him to seek a visa for another country. Through contacts of his wife, he was waiting for a visa from Russia. He was not sure when he would leave, but he had hopes of receiving his visa in another five days."

\subsection{Western Sahara}

The Western Saharan refugees in Algeria constitute one of the largest and longest standing populations of unintegrated refugees in Africa. Like the Palestinians refugees in Egypt, they are trapped in a citizenship black hole, thanks to a political failure to resolve the fundamental questions of state existence that first led to their flight; though unlike the Palestinians they do at least have the possibility in principle of returning to Morocco. The status of Western Sahara has been disputed between the Kingdom of Morocco and the Polisario Front ${ }^{64}$ independence movement for more than 30 years. While this dispute has remained unresolved, with Morocco in occupation of the territory, more than 150,000 Western Saharans, known as Sahrawis, have lived as stateless refugees in Algeria.

Western Sahara is a former Spanish territory on the western edge of North Africa, bordered by Morocco, Algeria and Mauritania. Historically, it was on the margins of the Berber kingdom in the western Mediterranean that subsequently became a Roman province, was later conquered by Muslim Arab forces, and ultimately formed the basis of the Moroccan kingdom. In 1884 a Spanish royal order declared the territory to be a Spanish protectorate on the basis of agreements with the leaders of the population. Treaties between Spain and France, which established a protectorate over the Morocco kingdom and most of the

63 Extracted from, Oroub El-Abed, "Deportation from Cairo", 5 March 2004, available at http://www.achr.eu/newen35.htm, last accessed 26 August 2014.

64 The Frente Popular para la Liberación de Saguia el-Hamra y de Río de Oro (Frente POLISARIO), named after the two former Spanish provinces making up the territory. 
Mediterranean zone from 1912, recognised Spanish control of that part of the Atlantic coast south of Morocco. In 1958, the territory was integrated into Spain, and the residents of the two provinces were recognised as Spanish nationals. The Spanish government accordingly stated to the UN that: "Spain possesses no non-self-governing territories, since the territories subject to its sovereignty in Africa are, in accordance with the legislation now in force, considered to be and classified as provinces of Spain." 65

A liberation movement emerged in the 1960s and 70s and a series of UN resolutions called on Spain to hold a referendum on self-determination for Western Sahara, but only in 1974, in the last year of Franco's government, did Spain concede the principle of a referendum and begin compiling a census of the population. King Hassan II of Morocco, however, announced that Morocco would not accept a referendum that included an option for independence; Mauritania also claimed the territory. At the request of Morocco, the UN General Assembly referred the situation to the International Court of Justice for an advisory opinion: in October 1975, the ICJ ruled that "the materials and information presented to it do not establish any tie of territorial sovereignty between the territory of Western Sahara and the Kingdom of Morocco or the Mauritanian entity"; that is, that the principle of self-determination of the territory should be respected. ${ }^{66}$

Just days after the ICJ ruling, Moroccan armed forces crossed the border and occupied most of the northern part of the Western Sahara territory; followed by a "green march" of several hundred thousand Moroccan civilians to "reclaim" the region for Morocco. Spain then signed an agreement in Madrid with Morocco and Mauritania that agreed a temporary tripartite administration of the territory; in April 1976, Morocco and Mauritania subsequently agreed a partition between just their two states. Meanwhile, Polisario proclaimed the creation of the Sahrawi Arab Democratic Republic (SADR) on 27 February 1976, following Spain's formal withdrawal the day before. Mauritania renounced its claims to the territory in 1979 and withdrew its forces, following losses in fighting with Polisario; but Moroccan forces remain until today in occupation of most of the former Spanish colony, with only a small strip in the east under the control of the Polisario/SADR.

As a result of the Moroccan takeover, around half of the native population fled the territory: by mid-1976 there were 40,000 refugees, growing to 80,000 by the end of 1977. According to the government of Algeria, it hosts today an estimated 165,000 Saharawi refugees, though the number is contested. ${ }^{67}$ Most of these people are still in four camps near Tindouf, a historic oasis town in

65 ICJ, Western Sahara: Advisory Opinion of 16 October 1975, paragraph 34; Tony Hodges, Western Sahara: The Roots of a Desert War, New York: Lawrence Hill \& Co, 1983.

${ }_{66}$ ICJ, Western Sahara: Advisory Opinion of 16 October 1975, paragraph 162.

67 UNHCR, Statistical Yearbook 2012, Table 1. 
southern Algeria. Though the camps are poor, the Sahrawi refugees have access to some health, education and other services, thanks to infrastructure established by Polisario with support from the UN, European Union and other countries, as well as solidarity groups in Spain and elsewhere. Initial close control of the camps by Polisario has opened up to a somewhat freer system; and, though the Polisario and Algerian authorities have checkpoints on the roads leaving the camps, including to the border posts, in practice camp residents seem to be largely free to leave on trips of short or longer duration. Travel within Algeria beyond Tindouf, however, may require permission from the Algerian authorities. ${ }^{68}$

A UN-sponsored ceasefire was agreed between Morocco and Polisario in 1991, based on a peace plan that provided for the establishment of a United Nations mission (known as MINURSO) to organise a referendum on independence or other status for the territory. ${ }^{69}$ To date, no referendum has been held. Among the key points of contention are the eligibility criteria to vote in the referendum, the options available to be voted for, and the return of refugees from Algeria. Morocco has continued to put forward proposals by which Western Sahara would remain within its control, but with some level of devolution of power to locally elected bodies and officials. In January 2000, after interviewing almost 200,000 applicants, the Identification Commission of MINURSO published a list of just over 86,000 persons eligible to vote in the referendum $(48,000$ living under Moroccan control and 38,000 in the refugee camps), based on the Spanish census of 1974; Morocco, however, lodged more than 120,000 appeals on behalf of the settler population in the territory. UNHCR also prepared an unpublished list of refugees to be repatriated. The total population in the area under Moroccan control is today close to $400,000 .{ }^{70}$ In 2007 , Morocco presented a new plan for Western Saharan autonomy to the UN.

In 1984, the support of Algeria and (at that time) Libya won the SADR recognition from the Organisation of African Unity (OAU), following the failure

68 Pablo San Martin, "Nationalism, Identity and Citizenship in the Western Sahara", Journal of North African Studies, Vol.10, No.3-4, (Sept-Dec 2005); Human Rights Watch, Human Rights in Western Sahara and in the Tindouf Refugee Camps, December 2008; telephone interview with Francesco Bastagli, former Special Representative of the UN SecretaryGeneral for Western Sahara, May 2008.

69 See website of the UN Mission for a Referendum in Western Sahara (MINURSO), available at http://www.un.org/Depts/dpko/missions/minurso, last accessed 4 March 2014. The "Settlement Plan", based on a framework initially proposed by the OAU in 1983, was originally put forward by the UN and agreed to in principle by the parties in 1988. It was ultimately approved by UN Security Council Resolution 690 of 29 April 1991. For background on the peace negotiations, see Issaka K. Souaré, "Western Sahara: Is there light at the end of the tunnel?" ISS Paper 155, Institute of Security Studies, South Africa, November 2007.

70 San Martin, "Nationalism, Identity and Citizenship in the Western Sahara", footnotes 7 and 47; Human Rights Watch, Human Rights in Western Sahara and in the Tindouf Refugee Camps, December 2008, p.23. 
of OAU peace brokering efforts to reach a successful conclusion. Morocco then withdrew from membership of the continental body. ${ }^{71}$ Algeria remains the SADR/Polisario's main supporter. At different times, more than 70 states have recognised the SADR, most of them in Africa and Latin America, though in more recent years several African countries have cancelled or "suspended" their recognition, following the latest Moroccan offer of a form of autonomy to the territory - and Moroccan incentives for a change of position. As of late 2014, around forty countries recognised the republic. ${ }^{72}$ Morocco has never been recognised as the "administering power" of the territory by the United Nations under the legal framework providing for "non-self-governing territories". ${ }^{73}$

The SADR constitution provides for the national council to adopt legislation on nationality ${ }^{74}$; though this has never been done, and the criteria for who would be considered nationals of a future state remain vague. In the meantime, the SADR issues national identity cards to those Sahrawis living in the refugee camps and the territories under SADR control, and those who wish to travel abroad are granted Sahrawi passports, with which they can travel to the countries recognising the Sahrawi Republic, including Mauritania (where many have family ties). The government of Algeria issues short-term passports to Sahrawi refugees who need to travel - usually for reasons of medical treatment, family unification, and so on - to countries that do not recognise the SADR. These passports are obtained by applying to the Algerian authorities via the SADR bureaucracy, but are only travel documents and do not imply recognition of the refugees as Algerian citizens. ${ }^{75}$ Group permit schemes also allow many thousands of Sahrawi children to travel each year to Spain, Venezuela, Cuba, Italy and other countries to be hosted by families offering solidarity with the refugees. An unknown number of Sahrawis also have citizenship in Mauritania, where many have family or other ties.

71 For background, see Sidi M. Omar, "The right to self-determination and the indigenous people of Western Sahara", Cambridge Review of International Affairs, Vol.21, No.1, March 2008.

72 A referenced list is maintained on Wikipedia, though with many contestations, at: http:// en.wikipedia.org/wiki/Legal status of Western_Sahara, last accessed 26 November 2014.

73 This position was confirmed in a 2002 opinion by the UN Legal Counsel, which recalled that Spanish Sahara was included in 1963 in the list of non-self-governing territories under Chapter XI of the UN Charter, and that the transfer of administrative authority over the territory to Morocco and Mauritania in 1975 did not transfer sovereignty nor affect the international status of Western Sahara as a non-self-governing territory. Letter dated 29 January 2002 from the Under-Secretary-General for Legal Affairs, the Legal Counsel, addressed to the President of the Security Council, UN Document S/2002/161.

74 Sahrawi Constitution 1999, Article 104, available (in French) at http://arso.org/03const.99.htm, last accessed 26 November 2014.

75 In 2007, the Spanish Supreme Court ruled in favour of a Sahrawi refugee who had applied to be recognised as stateless by the Spanish authorities, even though she had travelled to Spain on an Algerian passport granted to enable her to seek medical treatment seven years earlier. Case of Ms. Khadijatou Bourkari Dafa, Recurso Casacion Num: 10503/2003. 
In 1976, Spain adopted a decree giving natives of former Spanish Sahara the option during a period of one year to opt for Spanish nationality, under certain conditions. ${ }^{76}$ However, because of the nature of the Western Sahara legal status - in which the International Court of Justice rejected Morocco's claim to any legal tie to the territory, while the UN does not recognise Morocco as the administering power - the general principles in case of succession of states (attribution on the basis of habitual residence or an individual choice) do not apply.

Nonetheless, those Sahrawis living in the area under Moroccan occupation are under Moroccan law Moroccan nationals eligible for travel and other documentation; moreover, the Moroccan nationality code does not allow for an individual to renounce Moroccan citizenship except as authorised by decree. ${ }^{77}$ Since 1977, the inhabitants of the Western Saharan territories occupied by Morocco have also been able to participate in Moroccan national and regional elections. Many Sahrawis, however, reject Moroccan nationality and continue to protest Moroccan administration of the territory; there were new waves of protest in 1999 and 2005. In practice, civil liberties are still restricted in Moroccan-administered Western Sahara, though the human rights situation has greatly improved in recent years. Many Sahrawis were among the hundreds of "disappearances" that took place in Morocco from the mid-1960s to the early 1990s. Moroccan legislation prohibits attacks on the kingdom's "territorial integrity", and activists for Western Saharan independence still face harassment, including deprivation of travel and nationality documents. ${ }^{78}$ For example, Brahim Sabbar, a human rights activist documenting violations in Western Sahara, spent a decade in prison in the 1980s, and from 2000 to at least 2007 was denied a passport. ${ }^{79}$ A group of Sahrawis were deprived of their passports for several years after they attempted to travel to Geneva to participate in UN human rights activities in 2003, though they were later permitted to travel again. ${ }^{80}$

76 Decree 2258 of 10 August 1976.

77 Code de la nationalité marocaine, chapitre IV.

78 In 1998, the Moroccan Supreme Court declared itself unable to rule on the nationality of Abraham Serfaty, who, though not a Sahrawi, had spent seventeen years in prison for advocating self-determination for Western Sahara, from 1974 to 1991, and after his release was expelled from the country on the grounds that he was not Moroccan. Serfaty, who is Jewish, was born in Morocco, worked for years as a high-ranking civil servant and lived there until his expulsion. He was not given the opportunity to challenge the expulsion in court before he was forced into exile. He was, however, eventually allowed to return to Morocco. Morocco/Western Sahara: "Turning the page": Achievements and obstacles, Amnesty International, 4 August 1999, Index Number: MDE 29/001/1999, and annual report sections on Morocco/Western Sahara.

79 Amnesty International, Morocco/Western Sahara: Stop the judicial harassment of Sahrawi human rights defenders, 5 February 2007, Index Number: MDE 29/003/2007.

80 Human Rights Watch, Letter to King Mohammed VI on the Trial of Sahrawi Human Rights Defenders in the Western Sahara, 8 December 2005. 
A satisfactory resolution of the Sahrawis' plight may have to wait for a political settlement. In the meantime, some have managed to obtain citizenship of the countries where they find themselves, including Algeria; but most living in the refugee camps have access only to the SADR identity documentation, recognised by very few internationally, and Algerian travel documents on an ad hoc basis.

\subsection{Mauritanian refugees and returnees}

The territory that today forms Mauritania, to the south of both the French and Spanish protectorates in what is now Morocco or Western Sahara, and previously a dependency of the Moroccan kingdom, was gradually conquered by the French during the European expansion into sub-Saharan Africa in the $19^{\text {th }}$ century, and eventually formed part of Afrique occidentale française (French West Africa, AOF).

The territory is today inhabited by three principal groups: people speaking Hassaniya Arabic and of mixed Berber-Arab ancestry (collectively known as Beydanes or White Moors ${ }^{81}$ ); those of dark skin colour who also speak Arabic (a group known as Haratines, descended from former slaves to the Berber-Arabs, many still in servile roles); and dark-skinned people who belong to sub-Saharan African ethnic groups (mainly the Fulani/Peul, Wolof, Soninké and Bambara, herders and cultivators who mostly live in the south of the country, along the Senegal river valley). During the colonial era, when Mauritania formed part of AOF, blacks who led a more settled life were able to take greater advantage of educational opportunities and came to dominate the lower levels of the administrative structure; although, by contrast with other AOF countries, the French also relied on the traditional emirs of the Beydanes, in a system more similar to the British "indirect rule". Since independence, political and economic power has been in the hands of the Beydanes.

In 1958, Mauritania gained semi-autonomy with other AOF territories as part of the short-lived Communauté française, and, with the other AOF countries, was given its full independence in 1960. Mauritania adopted a nationality law the year following independence, which entered into force on 13 June 1961 (as in many French territories, there was a gap between independence and the first nationality law that created room for ambiguity on who became a national of the new state). The transitional provisions of the law allowed any person habitually resident in Mauritania who did not fulfil the general criteria to opt for Mauritanian nationality, but did not attribute nationality automatically based on residence. Generally, the law provided for nationality to be attributed by paternal descent (with rights to the mother's nationality if the father was stateless or of unknown nationality) and on the basis of double jus soli. All facts relating to place of birth and parentage had to be established on the basis of the civil register, but the conditions for double jus soli were presumed fulfilled on the basis of possession

81 Beydane means "white" in Hassaniya Arabic; Moor derives from the Roman name for the people of the western North African region. 
d'etat, of long-standing treatment as a national - though the criteria were not defined, facilitating later discrimination. ${ }^{82}$

The first President, Moctar Ould Daddah, quickly established a one-party authoritarian government and was re-elected, unopposed, in 1966, 1971 and 1976. From the mid-1970s, the government inaugurated a policy of Arabisation: Arabic replaced French as the official language and other measures were taken to identify the state as Arab. ${ }^{83}$ This policy was continued by President Maaouya Ould Sid'Ahmed Taya who seized power in 1984 (and was himself displaced by a 2005 coup). Mauritanians whose mother tongue was not Arabic protested these measures and political tensions rose. Economic tensions also increased over control of the fertile land of the Senegal river valley. A 1983 reformulation of the land law stated that "the land belongs to the whole nation and any Mauritanian can become an owner without discrimination in conformity with the law", a provision that opened up the redistribution of land in the valley. ${ }^{84}$ Pressure on land was also increased by immigration from Senegal, across the river border.

In 1989/1990 the Mauritanian government expelled tens of thousands of people, claiming that they were of foreign nationality illegally present in the country. The expulsions followed a dispute over grazing rights in the Senegal river valley, which erupted into communal violence in the capitals of Dakar and Nouakchott. Under intense international pressure to prevent further bloodshed, Maurtania and Senegal then agreed to repatriate the other's citizens. The Mauritanian government seized the repatriation process as an opportunity to begin systematic removal of black Mauritanian citizens: ultimately 60-65,000 were expelled to Senegal and 10-15,000 to Mali, while a few others fled to Chad. ${ }^{85}$

Among those expelled, there were no doubt some who held Senegalese or Malian nationality documents and others whose fathers had held such documents (and thus were entitled themselves to that nationality); the role of Senegal as the capital of French West Africa meant that many Mauritanians had links in Senegal, while the river had previously been a uniting rather than dividing factor. However, the great majority had previously been recognised as Mauritanians and had no entitlement to another nationality, even if they had family links across the river. Mauritanian identity documents were systematically destroyed in the course of the expulsions.

82 Loi No.61-112 du 12 juin 1961 portant Code de la nationalité mauritanienne ; see also Zatzepine, Le droit de la nationalité des républiques francophones, pp.22-23.

83 Ambroise Queffélec and Bah Ould Zein, «La 'Longue Marche' de l'arabisation en Mauritanie", Le français en Afrique, $\mathrm{n}^{\circ}$ 15, 2001, available at http://www.unice.fr/bcl/ ofcaf/15/15.html, last accessed 7 December 2014.

${ }_{84}$ Ordonnance $\mathrm{n}^{\circ}$ 83-127 du 5 juin 1983 portant réorganisation foncière et domaniale, Article 1 : "La terre appartient à la nation et tout Mauritanien, sans discrimination d'aucune sorte, peut, en se conformant à la loi, en devenir propriétaire, pour partie."

85 Human Rights Watch, Mauritania's Campaign of Terror: State-Sponsored Repression of Black Africans, New York, 1994; David Stone, Enhancing livelihood security among Mauritanian refugees in Northern Senegal: a case study, UNHCR, 2005. 
Most of the expelled refugees were pastoralists and peasant farmers, but the policy also targeted soldiers, civil servants and senior executives. Many expellees were black Mauritanian government employees suspected of opposing the Arabisation policy. These events began a "campaign of terror" in which the Mauritanian army occupied its side of the Senegal river valley: several hundred villages were entirely emptied of their largely Fulani inhabitants before being renamed and taken over by Moors (as landowners) and Haratines (as labourers) - some of them from among those expelled from Senegal during the "repatriation" process. Those dispossessed were forced to relinquish their identity cards and then transported in trucks, with or without their families, with few or no possessions. Others who were not themselves physically expelled fled the country to escape massacres and political persecution which continued throughout 1989 and over the next two years. In late 1990 and early 1991 several hundred political detainees were tortured and killed. ${ }^{86}$

From 1994, after a détente with Senegal, the Mauritanian government invited the deportees to return, and approximately 30,000 refugees did go back between 1994 and 1997. However, many returnees later left again for exile because they could not get back their lost properties, regain their jobs, or obtain national identity cards to replace those destroyed during the deportation in 1989. By the mid-1990s, when it ceased providing material assistance to the refugees in Senegal, UNHCR stated there were 25,000 people who had not repatriated from Senegal and Mali, though other estimates were 45,000 to 60,000. ${ }^{87}$

In 2000, the African Commission on Human and Peoples' Rights found that the expellees had been arbitrarily deprived of their nationality, were entitled to return to Mauritania, and should have their identity documents and property restored, and that they and other victims should also received compensation for the harm done. ${ }^{88}$ This decision was not implemented by President Taya's government, but prospects for the repatriation and restoration of citizenship to the deportees greatly improved after the Ould Taya government was overthrown in a coup d'état in 2005, initiating a period of democratic opening that resulted in the election of a new government in April 2007. Freshly elected President Sidi Mohamed Ould Cheikh Abdallahi announced that the government intended to repatriate, restore to citizenship and compensate the refugees. ${ }^{89}$

86 Human Rights Watch, Mauritania's Campaign of Terror; see also Human Rights Watch, World Report 1989 and 1990.

87 "Global Review of Statelessness:Africa", in Maureen Lynch, Lives on Hold: The Human Cost of Statelessness, Refugees International, February 2005, p.29; Human Rights Committee, "Concluding observations of the Human Rights Committee: Mali", CCPR/CO/77/ MLI, 16 April 2003.

88 African Commission on Human and Peoples' Rights, Communications 54/91, 61/91, 98/93, 164-196/97 and 210/98, Malawi African Association and others v. Mauritania (2000).

89 "Refugees cautiously optimistic about new initiative", IRIN, 10 July 2007; Kissy Agyeman, "Exiled Mauritanians Begin Tentative Retreat Back to Homeland after 18 Years", Global 
The Mauritanian government then sent a delegation to visit the refugees camps in Senegal; UNHCR carried out a census of refugee households in Senegal and issued a call for support for donor funds to finance the repatriations. A tripartite agreement between Senegal, Mauritania, and UNHCR was signed in October 2007. ${ }^{90}$ Mauritania undertook to restore the citizenship rights of the refugees, return their properties and reinstate former civil servants. Senegal undertook to provide all documents needed for the resettlement of returnees, as well as to facilitate the integration of Mauritanians who opted to remain in Senegal. The first refugees returned, with UNHCR assistance, in January 2008. A majority were resettled on their original property, and after some weeks' delay those in the first wave received Mauritanian identity cards. The entire process of repatriation was expected to take eighteen months. ${ }^{91}$ Mauritanian refugees in Mali were also expected to return to Mauritania, under the same UNHCR repatriation operations, though there was no formal memorandum with the government of Mali.

By the end of July 2008, more than 4,500 deportees had returned to Mauritania under this programme. But on 6 August the government was overthrown in a fresh military coup. Though the new government stated that it would continue the repatriation process, its future was thrown into doubt, and the more inclusive policies of the previous government appeared under threat. ${ }^{92}$ After a resumption, the process was suspended again from December 2010 for one year, when the Mauritanian government decided that the issue of all national identity documents would be put on hold as the national population register was replaced with a new biometric version (always a point of danger for the creation of statelessness). ${ }^{93}$ Discrimination during the census process led to the creation of a protest movement, Touche pas à ma nationalité, which called for the adoption of a "neutral and representative census system to create a reliable civil status registry in a coordinated legal framework". ${ }^{94}$ Demonstrations against the delays

Insight Daily Analysis, 11 July 2007.

90 Tripartite Accord: UNHCR and the governments of Senegal and Mauritania, November 2007; "Tripartite agreement on return of Mauritanian refugees", UNHCR Briefing Notes, 13 November 2007.

91 "Thousands of Mauritanians to Return Home From Senegal With Help of UN Agency", UN News Service, 13 November 2007; “Is Mauritania ready for its refugees?” IRIN, 16 November 2007.

92 Briefing paper on the return of expelled Mauritanians to the Islamic Republic of Mauritania following the August 6, 2008 coup, Institute for Human Rights and Development in Africa, October 2008.

93 "Mauritania: a single integrated system", at the website of MORPHO, no date (approx. July 2010), http://www.morpho.com/references/identite-125/mauritania-a-singleintegrated-system, last accessed 3 July 2014.

94 "Ladoption d'un système de recensement neutre et représentatif pour un état-civil fiable dans un cadre juridique concerté ". Memorandum sur le recensement en cours : Recensement a vocation d'etat-civil ou volonté dépuration ethnique ? Touche pas à ma 
in restoring papers to those who had already been repatriated led to violent clashes with police in Nouakchott in late 2011. ${ }^{95}$

Eventually repatriation was resumed, and more than 24,000 refugees had returned under the voluntary repatriation agreement by March 2012, when the programme was declared completed. ${ }^{96}$ However, many still faced difficulties in reestablishing their Mauritanian nationality, as the Mauritanian government insisted on evaluating eligibility on a case by case basis. Although the government stated that 90 percent of the 24,000 who returned under the voluntary repatriation agreement had received identity documentation, refugee representatives in Senegal asserted that only 8,000 had recovered Mauritanian documents as of mid-2014 (leaving some with the paper approving their voluntary repatriation as their only identity document); and even fewer had recovered land and other property. ${ }^{97}$ Several hundred of the repatriated Mauritanians staged a march from the Senegal Valley to Nouakchott in May 2014 to protest their situation. ${ }^{98}$

Meanwhile, a 2010 amendment to the nationality law removed all jus soli provisions (including both double jus soli and the right to opt based on birth and residence till majority) to create a pure jus sanguinis regime, with the exception only of foundlings, making it much more difficult for those without proven Mauritanian ancestry back to independence to claim Mauritanian nationality; at the same time, the languages required for a person to naturalise were redefined to remove from the list French and Bambara (spoken among the groups living in the east, towards Mali). The law also amended the standard provision that facts relating to birth and parentage must be established by an entry in the civil registry to remove the possibility of late registration by court judgement, and the presumption that the conditions for double jus soli were fulfilled if a person was in possession d'état de mauritanien. ${ }^{99}$ These changes would undoubtedly make it

nationalité, 16 October 2011.

95 "Répression violente du mouvement «Touche pas à ma nationalité "” FIDH and AMDH, 28 septembre 2011; Sebastian Kohn, "Fear and Statelessness in Mauritania”, Open Society Justice Initiative, 3 October 2011; "Black Mauritanians in 'Racist' Census Protest", AFP, 24 September 2011; "Police Arrest 56 in Mauritania Over Census Protests”, AFP, 30 September 2011; "Police Disperse Mauritanian Blacks in 'Racist' Protest”, AFP, 28 November 2011.

96 UNHCR, Stratégie d'intégration locale et moyens de subsistance des refugies Mauritaniens au Sénégal, 2011; "UNHCR completes repatriation of more than 24,000 Mauritanians", UNHCR, 27 March 2012.

97 Interviews, Dakar, May 2014 ; Information from UNHCR Nouakchott, August 2014.

98 "Répression à Nouakchott d'une marche des rapatriés mauritaniens du Sénégal ", APA 5 May 2014 ; "Société : Régler les problèmes des ex-réfugiés mauritaniens au Sénégal », PANA 12 May 2014 ; «Le gouvernement mauritanien s'engage à régler les problèmes des réfugiés rapatriés ", PANA, 21 May 2014.

99 Loi. No. 2010-023 du 11 février 2010 abrogeant et remplaçant certaines dispositions de la loi 61-112 du 12 juin 1961 portant Code de la nationalité mauritanienne, especially deletion of article 9 and amendments to articles 13,19 and 58. 
more difficult for returnees to establish their Mauritanian nationality, especially in the context of the new identity card system.

As of 2014, Senegal still hosted some 13,700 Mauritanian refugees, and Mali more than 12,000, of whom some 8,000 had expressed the wish to return home. The plan was for UNHCR and the governments of Mauritania and Senegal to complete the repatriation of 7,500 Mauritanians in 2014. ${ }^{100}$

Those who have opted to stay in Senegal still retain refugee status, since the cessation clause has not been invoked. The refugees are eligible for naturalisation under Senegalese law, and the Senegalese authorities have repeatedly confirmed that naturalisation is available; however, representatives of the Mauritanian community in Senegal state that they do not wish for naturalisation, but either resettlement in a third country or repatriation to Mauritania with full restoration of nationality, property and other rights. At the same time, it is clear that many persons of Mauritanian origin in Senegal have obtained Senegalese identity cards. While a Senegalese identity document is not proof of nationality (which is provided only by a certificate of nationality issued by a tribunal), it enables those who hold them to function more easily in Senegal: the Mauritanian refugees belong to the same ethnic groups as those who live on the Senegalese side of the river, and those born in Senegal are effectively indistinguishable from Senegalese nationals. In the long run, it seems likely that, while those who themselves fled the persecution in Mauritania will continue to reject the options available, the descendants of the refugees who have stayed in Senegal will blend into the Senegalese population; under the double jus soli rule, the grandchildren of those who fled will be automatically attributed nationality under the law. ${ }^{101}$

The nationality status of those who have returned to Mauritania, where racial policies of discrimination continue, may be more precarious.

\subsection{South Africa: the difficulties of bringing practice into line with the law}

South Africa, home of the most extreme version of the settler-native divide embodied in the notion of apartheid, had furthest to go to dismantle the inherited system of discrimination, and has achieved the greatest transformation of its legal system. In place of a baroque multiplication of different classes of citizenship based on race and ethnicity - both given an entirely inappropriate "scientific" basis — the 1996 constitution created a single united citizenship, and the rights of all citizens are equal. Moreover, of the extensive list of rights in

100 UNHCR, “2014 regional operations profile: West Africa” and "2014 country operations profiles”, Mauritania and Mali, available at http://www.unhcr.org/pages/49c3646c206. html, last accessed 03 July 2014.

101 Interviews with Senegalese officials, representatives of the Mauritanian refugee community, and human rights activists, Dakar, May 2014. 
the South African constitution, including comprehensive socio-economic rights, only four rights are limited to citizens: the citizenship right itself, political rights (to vote and stand for office), the right to residence, and rights to freedom of trade, occupation and profession. The courts have confirmed that all others are applicable to non-citizens, arguably including even those who are not legally present in the country. ${ }^{102}$

The new government also sought to address the economic and political legacy of the past by offering citizenship to many long term migrants brought to South Africa under apartheid labour policies; and by measures of affirmative action and economic empowerment for black people, rather than by denying the rights of those who had previously held power to be citizens at all. There was a wholesale review of the legal framework for citizenship, immigration and refugees.

In the first five-year administration of the new regime, a series of immigration amnesties were offered to particular groups of foreigners from the region: contract mine workers (1995); a broader category of people from the SADC region who had lived in South Africa for at least five years and had economic or family ties in the country (1996); and finally Mozambicans displaced by the civil war in that country who had been refused refugee status by the apartheid government (1999). An estimated 1 to 1.5 million people became eligible for South African citizenship in this way, but many did not access the process, and others were rejected for administrative reasons: only 51,000 applications were received from miners, and just over 200,000 from others from the SADC region. ${ }^{103}$

Also included within the flood of reforming legislation that followed during the first decade of the post-apartheid government were new citizenship, refugee and

102 The Supreme Court of Appeal ruled in the 2003 Watchenuka case that asylum seekers were entitled to work and study while awaiting the determination of their applications. The Constitutional Court in the Khosa case upheld the right of permanent residents to receive social security. In the case of $S v$ Manuel, the High Court held that the right to legal aid that is recognised in section $35(3)(\mathrm{g})$ of the Constitution applies to foreigners without correct immigration papers who are accused in a South African court. Minister of Home Affairs and Others $v$ Watchenuka and Another, 2004(4) SA 326(SCA); Khosa and Others v Minister of Social Development and Others; Mahlaule and Another v Minister of Social Development and Others, 2004(6) SA 505(CC); S v Manuel 2001(4) SA 1351(W). See also Larbi-Odam and Others $v$ Member of the Executive Council for Education (North-West Province) and Another, 1998 (1) SA 745 (CC).

103 Jonathan Crush andVincent Williams (eds.), The New South Africans? Immigration Amnesties and their Aftermath, Cape Town, Idasa, 1999; Human Rights Watch, Prohibited Persons: Abuse of Undocumented Migrants, Asylum Seekers and Refugees in South Africa, New York, March 1998; Bronwyn Harris, "A Foreign Experience:Violence, Crime and Xenophobia during South Africa's Transition”, Violence and Transition Series, Vol. 5, South Africa, Centre for the Study of Violence and Reconciliation, August 2001; Tara Polzer, Local Government and Migration Management in Border Areas - Challenges and Opportunities for Public Service Provision, Johannesburg: Forced Migration Studies Programme, University of the Witwatersrand, 2007. 
immigration laws. ${ }^{104}$ The post-apartheid constitution provides that "Every child has the right to a name and a nationality from birth" 105 , a promise completed by the Citizenship Act, which provides that a child born in South Africa obtains nationality from birth if "he or she does not have the citizenship or nationality of any other country, or has no right to such citizenship or nationality". ${ }^{106}$ Up until amendments enacted in 2010, the child born in South Africa of two parents who were permanent residents was a citizen from birth; 2010 amendments to the law only gave the child the right to retroactive recognition of citizenship from birth on reaching majority. ${ }^{107}$ The same 2010 amendments also added the right for any child born in South Africa of two foreign parents to apply to naturalise as a South African on reaching majority. ${ }^{108}$ In all cases, these rights are subject to the child's birth being registered in accordance with the Births and Deaths Registration Act. ${ }^{109}$

New refugee and immigration laws drew a clear distinction between asylum seekers and refugees and other migrants, and established a bureaucratic apparatus to deal with applications for refugee status. South Africa's system also provides for a transfer of status from refugee to permanent residence and then naturalised citizenship. After five years of continuous residence in South Africa from the date that asylum was granted, the Immigration Act allows for the granting of (permanent) residence to a refugee if the Standing Committee for Refugee Affairs provides a certificate that he or she will remain a refugee indefinitely. Five years after that, a permanent resident can apply for citizenship by the usual rules. ${ }^{110}$ The Immigration Act also allows the minister for home affairs discretion to grant persons permanent residence, and while these discretionary powers have

104 South African Citizenship Act (No. 88 of 1995); South Africa Refugees Act (No. 130 of 1998); South Africa Immigration Act (No. 13 of 2002).

105 South African Constitution, 1996, Article 28. See also Raylene Keightley, “A child's right to nationality and the acquisition of citizenship in South Africa", South African Journal on Human Rights, Vol.14, 1998, p.411-429; Jonathan Klaaren, "Constitutional citizenship in South Africa”, International Journal of Constitutional Law, Vol.8, No.1, 2010, pp. 94-110.

106 South African Citizenship Act, 1995, as amended to 2010, section 2(2).

107 South African Citizenship Act, 1995, as amended to 2010, section 2(3). The 2010 amendments came into force on 1 January 2013. Up to 2010, the Department of Home Affairs in fact granted citizenship from birth to children with only one parent who was a permanent resident. Jonathan Klaaren, "Post-Apartheid Citizenship in South Africa", in A. Aleinikoff (ed.) From Migrants to Citizens: Membership in a Changing World (Brookings Institution Press, 2000) pp.221-252.

108 South African Citizenship Act, 1995, as amended to 2010, section 4.

109 From 2010, children of permanent residents began to be given handwritten "foreigner" birth certificates rather than computerised certificates with a national ID number, creating problems for them in accessing other services. Information presented by Lawyers for Human Rights at UNHCR regional statelessness meeting 1-3 November 2011.

110 Immigration Act (No. 13 of 2002), section 27(d), read with the Refugees Act (No. 130 of 1998), section 27(c). 
not been much used, there has been some litigation in this area. ${ }^{111}$

However, the new system has struggled to cope. By 2012, around 65,000 people had been granted refugee status in South Africa; but there was a backlog of almost a quarter of a million people who had applied for asylum. ${ }^{112}$ Acknowledged refugees also struggled to gain the necessary identity documents that should follow. Despite the various provisions for the reduction of statelessness in the law, many individuals seemed to fall through the cracks, mostly those in the usual vulnerable groups: orphans and unaccompanied children, populations in border areas, children of migrants generally, children of South African citizens born abroad, and asylum seekers or migrants from particular countries, including Zimbabweans (see chapter 8.3), Congolese (chapter 8.6), Ethiopians of Eritrean origin (chapter 9.1), Rwandan and Burundian refugees born in Tanzania (chapter 11.2), DRC or other countries, as well as descendants of Mozambican, Swazi, or Basotho parents, in certain circumstances. It took litigation to force the government to recognise the South African citizenship of a child born in the country of Cuban parents who could not transmit their nationality to their child born abroad. ${ }^{113}$ Birth registration for children of foreign parents, especially refugees, became steadily more difficult, as concerns grew over fraudulent acquisition of nationality. ${ }^{114}$ Victims of ID fraud, potentially affecting several hundred thousand duplicate IDs discovered by the Department of Home Affairs in 2011, created risks for those who did not have another proof of nationality than their identity document. ${ }^{115}$ Dual nationality restrictions introduced in 2010

111 On 7 March 2008 the High Court handed down judgement in the Transvaal Provincial Division in the matter of Kamelia Tcherveniakova v. The Minister of Home Affairs and Others granting the applicant along with her husband and minor child an exemption for permanent residence in terms of section 31(2) (b) of the Immigration Act, based on their individual circumstances to remain in South Africa. The applicant came to South Africa from Bulgaria in 1996, prior to there being a legislative framework to deal with asylum seekers and refugees. In 2003, after the refugee status of the applicant and her family was denied, they brought an application for exemption to the minister, which was only finalised in November 2006. In awarding permanent residence, the court took into account the length of time taken for the process to be finalised in accordance with just administrative action. Communication from Lawyers for Human Rights, who brought the case, 14 May 2008.

112 UN High Commissioner for Refugees, Statistical Yearbook 2012 (annexes, table 1).

113 "High Court recognises child as stateless and declares her to be a SA citizen", Lawyers for Human Rights (Pretoria), 8 July 2014; Order of court in DGLR and KMRG $v$ The Minister of Home Affairs and others (unreported), 3 July 2014.

114 See, for example, "Gigaba blames crooked priests in immigration fraud", SAPA, 28 September 2014; "Arrest of ID Syndicate Welcomed", Parliament of South Africa Portfolio Committee on Home Affairs 1 December 2014; "16 Days: Stateless in South Africa”, 4 December 2014, at Realising Rights blog, https://realisingrights.wordpress. com/2014/12/04/16-days-stateless-in-south- africa/, last accessed 4 December 2014.

115 Jessica P. George and Rosalind Elphick, Statelessness and Nationality in South Africa, Pretoria: Lawyers for Human Rights, 2013. 
for counties not permitting dual nationality could also pose problems for refugees seeking to naturalise ${ }^{116}$; as did the requirement that the Standing Committee must confirm that the refugee will need asylum for the foreseeable future. ${ }^{117}$

South Africa illustrates, also, the limits of legal definitions in building a national community. National human rights organisations have reported ever more serious worries about xenophobia among the native South African population toward incomers. ${ }^{118}$ In May and June 2008, attacks on foreigners surged in a wave of violence across major other urban centres, leaving more than 60 dead and displacing tens of thousands. ${ }^{119}$ Tangled up with the resentment and competition for resources that led to violence was the strong sense of ordinary, poor, South Africans that they had been excluded from the great wealth of the country, despite the transition of 1994, and often overtaken by the newcomers. Apparently endemic corruption among officials of the Department of Home Affairs and police meant that even those who did hold South African residence or nationality documents might not be believed. More than a quarter of South Africans stated that they wanted a total ban on immigration. Yet hostile feelings were more complex than a generalised resentment of foreigners, being moderated by race, gender, ethnicity and economic status. Somehow, it seemed that South Africa's history of pass laws and population control still had a grip on the popular imagination; and the ANC government's failure to deliver constitutionallypromised rights and efforts at black empowerment had exacerbated tensions between citizens and non-citizens while failing to quell long-standing antagonisms among different (racial) categories of citizens. ${ }^{120}$ At the same time,

116 For example, from Congo. Email communication, Lawyers for Human Rights, 4 November 2014.

117 Requirements to apply for permanent residence for a refugee set out at the website of Immigration South Africa (a private legal firm): http://immigrationsouthafrica.com/ permanent-residence-for-refugee-status/, last accessed 4 December 2014.

118 Anthony Minaar and Mike Hough, Who Goes There? Perspectives on clandestine migration and illegal aliens in southern Africa, Pretoria, HSRC, 1996; Loren B. Landau, The Laws of (In)Hospitality: Black Africans in South Africa, Forced Migration Working Paper Series No.7, 2004, University of the Witwatersrand; Francis B. Nyamnjoh, Insiders and Outsiders: Citizenship and Xenophobia in Contemporary Southern Africa, Codesria/Zed Books, London, 2006; John O. Oucho and Jonathan Crush, "Contra Free Movement: South Africa and the SADC Migration Protocols", Africa Today Vol.8, No.3, 2001, pp.139-158.

119 Jean Pierre Misago with Loren B. Landau and Tamlyn Monson, Towards Tolerance, Law, and Dignity: Addressing Violence against Foreign Nationals in South Africa, Johannesburg: International Organisation for Migration, 2009; Jonny Steinberg, "South Africa's Xenophobic Eruption”, ISS Paper 169, Institute for Security Studies, Pretoria, 2008.

120 Citizenship, Violence and Xenophobia in South Africa:Perceptions from South African Communities, Human Sciences Research Council, Pretoria, June 2008; see also Daniel Hammett, "The challenge of a perception of 'un-entitlement' to citizenship in post-apartheid South Africa”, Political Geography,Vol.27, No.6, 2008, pp.652-668; Francis B. Nyamnjoh, "From Bounded to Flexible Citizenship: Lessons from Africa" Citizenship Studies, Vol.11, No.1, 2007, pp. 73-82. 
the decision of the government to respect the ANC's historical commitment to inclusivity in citizenship provided hope that the future integration of migrants and refugees would remain a reality.

\section{The Freedom Charter}

We, the People of South Africa, declare for all our country and the world to know: That South Africa belongs to all who live in it, black and white, and that no government can justly claim authority unless it is based on the will of all the people....

Adopted at the Congress of the People, Kliptown, South Africa, 26 June 1955. 


\section{Orphans and vulnerable children}

In all actions concerning the child undertaken by any person or authority the best interests of the child shall be the primary consideration.

- Article 4(1), African Charter on the Rights and Welfare of the Child, 1990

The longer it takes to establish a legal identity the more difficult it becomes. Those who are adults before they attempt to prove their origins and nationality may find it impossible to do so; or they may only succeed at great effort and cost. Those vulnerable children who are in situations of difficulty, and remain completely undocumented, are thus greatly at risk of statelessness. Paradoxically, their stories often become known only once they have resolved their situation, because of assistance given - but those who never receive assistance remain invisible. For these children, lack of a nationality may not be their most obvious or urgent problem; but a total lack of documentation means that statelessness is a real risk, and likely to be a more important issue the older they become. ${ }^{1}$

Unlike the other groups at risk of statelessness discussed in preceding chapters, these children are not necessarily identifiable as a group. Though being a member of a marginalised ethnic group certainly increases the risk to a child who is at the margins of the marginalised, children from any part of society may find themselves in this category, where the law and its implementation do not provide them with a secure legal identity at birth. It goes without saying that children are more likely to be left stateless in countries where gender discrimination is most pronounced, in law or in practice.

Among this group of the most vulnerable are:

- children born out of wedlock, as well as children of unknown parents (both abandoned babies and older children separated from their families, for example by war) and children of mentally ill or intellectually disabled mothers (also almost certainly born out of wedlock).

- children working away from their families, whether trafficked or voluntary migrants, including domestic workers (largely girls) and agricultural workers (mainly boys).

- children entrusted under a system of guardianship, which may include some domestic workers, but also children enlisted for Koranic education.

- girls who are forcibly married before they attain majority, especially across borders, and their children.

1 This chapter is primarily based on information first published in Manby, Nationality, Migration and Statelessness in West Africa, and is thus mainly restricted to West Africa. 
Trafficking in children exacerbates all such problems, and is widespread in subSaharan Africa, mostly to other African countries. ${ }^{2}$ More than two-thirds of countries in West and Central Africa surveyed in 2003 identified trafficking in persons, especially children, as a critical problem; as did one-third in East and Southern Africa. ${ }^{3}$ The main flows identified include trafficking in children within and across countries primarily for farm labour and domestic work, but also in the mining, fishing and other sectors; and trafficking in women and young persons for sexual exploitation, both inside and outside the continent. ${ }^{4}$ Reports of trafficking in babies for childless couples also regularly surface, with repeated occurrences in Nigeria. ${ }^{5}$ Many other children are transferred to the care of persons other than their parents in circumstances which may not amount to trafficking, including under traditional systems of guardianship (confiage) that are in principle a system of protection rather than exploitation, but nonetheless potentially leave the children exposed to the risk of complete invisibility to the state and its systems of documentation.

Where children separated from their parents come to the attention of children's rights organisations, especially those running drop-in or residential centres, one of the first tasks of those organisations may be to establish identity documentation: in the francophone countries a birth certificate is often a requirement to obtain the court order giving authority to look after the child. The difficulty of doing this varies by country: for example, in West Africa it is fairly easy in Guinea, where the presumption is that such a child is Guinean; and much harder in countries that are more particular about documentation, such as Senegal, or where documentation barely exists. Nevertheless, advocacy by children's rights groups, and the UN system, for the principle of the "best interests of the child" to govern state interaction with children has made an impact, and most officials — judges or others responsible — will seek to provide a child with the documentation needed, even if initially on a provisional basis.

There are well-established networks of children's rights organisations across the

2 UNODC, Global Report on Trafficking in Persons, 2012

3 Trafficking in human beings, especially women and children, in Africa, UNICEF Innocenti Research Centre, 2003.

4 Aderanti Adepoju, "Review of Research and Data on Human Trafficking in subSaharan Africa" in Frank Laczko and Elzbieta Gozdziak (eds.), Data and Research on Human Trafficking: A Global Survey, IOM, 2005 (Special Issue of International Migration, Vol. 43 Nos.1\&2); Global Report on Trafficking in Persons, UNODC, 2012; Claire Healy, Counter-Trafficking: Baseline Assessment, FMM West Africa, 2013; Alexis Aronowitz, Human Trafficking, Human Misery: The global Trade in Human Beings, Praeger Publisher, Westport, 2009.

5 See, for example, "Arrestations au Niger dans une affaire de trafic de bébés ", RFI, 26 June 2014 ; Monica Mark, "Wives of top Niger politicians held over child trafficking", The Guardian (London), 27 June 2014; Al Chukwuma Okoli, "Commercialism and Commodification of Illicity: A Political Economy of Baby Buying/Selling in South East of Nigeria", International Journal of Liberal Arts and Social Science, Vol. 2 No. 2 March, 2014. 
continent and its sub-regions. Among the major efforts of these networks is to reunite street children, trafficked children, and others, with their birth families. Although the question of proof of the nationality of the child is not usually a priority, it may become relevant if a child in difficulty comes from another country. Even in these cases, the main concern is to obtain a document enabling the child to travel. A member of the network will contact a partner organisation for assistance in tracing the family of the child concerned, or travel to the country themselves with the children involved. It can take months or years to make these connections, and they are not always successful. Where the birth family is traced, national authorities of the child's country of residence and/or origin will provide the children with a safe conduct pass (sauf conduit) to enable to return to the family; however, this is only a travel document, and does not prove the child's nationality or legal identity. If the family is not traced, the child may be left without documentation entirely.

Those children who do not come to the attention of any social welfare agency - certainly a very large number - will not receive such assistance in getting documents: the procedures are time-consuming, require an understanding of the system, and depend on the child having free time and permission to travel, and an advocate to speak for them. Those who do not receive such assistance are likely to remain undocumented and at high risk of statelessness. These children, of course, become adults, and, depending on the law of the country where they live, may pass their undocumented status to the next generation.

\subsection{Abandoned babies, orphaned children and children born out of wedlock}

A majority of African nationality laws provide for a foundling (new born infant) or, more generously, a child of unknown parents to be presumed to be a national; but more than a dozen do not (Botswana, Côte d'Ivoire, Equatorial Guinea, Gambia, Lesotho, Liberia, Malawi, Mauritius, Namibia, Nigeria, Seychelles, Sierra Leone, South Africa, Tanzania, Togo, and Zambia; see above, chapter 6.1.4). Provisions in the nationality code are reinforced in some countries by the Code de la famille or a specific children's law setting out procedures for children of unknown parents. In Senegal, Niger, and Guinea, for example, a system exists to declare an abandoned infant to the state authorities, and the child will then be given a provisional birth certificate and name, which can later be confirmed if no parents are found; and the child will obtain nationality with no further difficulties. In Senegal, however, this provision is restricted to abandoned newborn infants, excluding children who are found at an older age but are still unable to identify or trace their parents.

In Côte d'Ivoire, where no foundling provision exists, provisional identity documents are sometimes issued to children who are fortunate to come into contact with child services agencies; however, this may not resolve the risk of statelessness when such children are obliged to acquire identity documents at 
majority, and questions can be raised if the birth certificate mentions that the parents are unknown. ${ }^{6}$ In Zimbabwe, where the law contained no provisions on children of unknown parents until a new constitution was adopted in 2013, UNICEF urged the authorities to take action on identification papers for street kids whose lack of documentation made it impossible to integrate into the formal economy. ${ }^{7}$

However, even where the legal frameworks are in place, the practice may be different. A point of difficulty is often where a birth certificate needs to be established.There is a theoretical commitment to universal birth registration across West Africa, and in principle either the father or mother or another interested party may declare the child. But in practice there are many challenges: not only with poor coverage of the territory and lack of accessibility of registration, but also in relation to the details that are required to be completed in the registration form and the training of staff in relation to those details. In the case of abandoned babies or children born out of wedlock (often the same children), the indication on the form that both parents' names should be noted means that in some cases registration of a child "without" a father may be refused. This refusal can be based on good intentions: the social prejudice against a child born out of wedlock is very strong in some countries and a child that carries only its mother's name may be subject to permanent stigma; but it still leaves the child at risk. To obtain late registration of the birth of an orphaned child it may first be necessary to establish both a birth and death certificate for the child's own parents (or at least the father), which can be near-impossible in practice.

For example, in Niger, the usual naming system is patronymic and a person cannot have a female last name; so if the father does not acknowledge the child, and an uncle or grandfather cannot be found to give the child his name, the child may simply not be registered - even if the mother seeks to do so. Since giving a name to a child may carry implications in relation to inheritance, it is not so easy just to give the child another name; the lack of a Code de la famille or children's code and the wide variety of customary rules (custom is recognised as a source of law in Niger, but not further defined or codified), means that there is widespread confusion about the validity and consequences of different decisions. ${ }^{8}$ Similarly, to establish birth registration and other papers for a child whose parents have died may require yet further time-consuming procedures, first to establish death certificates for the parents, and then to establish a connection with a male relative or other figure who will give the child his name. In one case, a centre for children in Niamey tried to assist the child of a mother who had been detained in a facility for the mentally disabled: the mother, who was not even able to identify herself, let alone the father, fled the facility, leaving the child with no

6 Interview Dignité et Droits pour les Enfants en Côte d'Ivoire, Abidjan, June 2014.

7 Paul Ndlovu, "RG office urged to give street kids IDs", The Zimbabwean, 22 August 2011.

8 Interview, Abdourahaman Chaibou, advocate, Niamey, May 2014. 
identity — and a doubt as to whether her nationality was of Niger or Nigeria. The child remained without papers years after she first came to the attention of the centre. Another child of around eight years old had come to the centre having fled abuse from his father, a Cameroonian; the child believed his mother remains in Cameroon but had no documents of any kind, and no knowledge of the place where his mother might be. ${ }^{9}$

If a baby or child is likely to be adopted, adoptive parents will usually sort out legal identity and documents. In some countries, however, the nationality law makes no provision for adopted children (see chapter 6.2.1). In all countries, children in the "hard to adopt" category, including disabled children, may be left without documentation of any kind. Some children's homes (such as SOS Children's Villages) ensure that every child has a personal file compiling every aspect of their known identity, and ensure that state documents are acquired, including late birth registration if needed. Other children may not be so lucky even if they are in a children's home. With persistence, most children that are helped will eventually find some documentation; but many never find help.

\section{Ziguinchor, Senegal: Two children in difficulty ${ }^{10}$}

Abdoul, aged about 6 or 7, was brought to the attention of Future au Present, a centre for children in difficulty in Ziguinchor, Senegal, by other children who pointed him out as a child who slept sometimes in the streets, and needed medical attention for an injured foot. His father was from Guinea, much older than his mother, who was from Guinea-Bissau; the father had decided to return to Guinea, leaving the child with the mother. The mother had died and he was staying with his uncle, who worked in the market. Abdoul's birth had not been registered, and the one of the first actions of the children's centre was to try to get him documented: a birth certificate is necessary for the juge pour enfants to give the centre the ordonnance de garde that provides legal authority for their custody of any child. It was a huge struggle to find witnesses who could give evidence as to his parentage, given the demands on time to attend court, transport costs etc, but eventually they were able to establish a birth certificate for Abdoul, and he is enrolled in school and doing well. However, Abdoul will not be entitled to Senegalese nationality on majority, since neither of his parents is Senegalese, nor born in Senegal. He has no contact with any family in either Guinea or Guinea Bissau; even if he may be able, on the basis of a birth certificate, to establish nationality of one of those countries, it will effectively be useless to him since his life is clearly established in Senegal.

9 Interview, Soeur Brigitte Marie, Fraternité Notre Dame, Niamey, May 2014.

10 Interviews, Futur au Present, Ziguinchor, Senegal, May 2014. Names have been changed. 
Mohammed was found by the centre sleeping rough at night in the bus station in Ziguinchor, where he'd been portering and doing other tasks in return for pocket money and food. He had left Guinea at the age of about 12 with his older brother, with the intention of earning money to look after his mother. They had arrived together at Kolda, inland from Ziguinchor, and his older brother had stayed there, but Mohammed had decided to travel on. The centre eventually managed to trace his brother, but they both refused the idea of returning to Guinea until they had attained their objective of earning some money. Mohammed was too old to be enrolled in school, but accepted the idea of obtaining training in a skill, and was learning to be a tailor. But it had been impossible to establish a birth certificate for him. Only because the juge pour enfants was sympathetic to the situation was it possible to get a provisional ordonnance de garde without a birth certificate; and no contact has been established with his family in Guinea. Mohammed is at real risk of remaining without any documents proving his nationality when he reaches adulthood. He will not be eligible to be Senegalese under Senegalese law.

\subsection{Child workers}

Children working away from their families, especially those who have crossed borders, are also often completely undocumented in the country where they have work; many of them also have no birth registration in their country of origin. For example, a Human Rights Watch report on girls working as domestic servants in Guinea, among whom some came from neighbouring countries, noted that most girls crossing the border from Mali to Guinea entered the country without documentation (neither identity documentation, nor documentation indicating that the adult in whose care they were at the time was authorised to be so). ${ }^{11} \mathrm{~A}$ report by Anti-Slavery International on children working in the cocoa plantations in Côte d'Ivoire similarly reported that many crossed borders without any identity documents. ${ }^{12}$ This lack of documents not only leaves the children vulnerable to trafficking and exploitation, but also will prevent them from establishing their nationality once they become adults. As in the case of adult migrants, even if they return to their home countries, many are ashamed to return to their families - who could confirm their identities — because they would be returning "with empty hands".

11 Human Rights Watch, Bottom of the Ladder: Exploitation and Abuse of Girl Domestic Workers in Guinea, June 2007.

12 Anti-Slavery International, Ending Child Trafficking in West Africa: Lessons from the Ivorian cocoa sector, 2010. 


\subsection{Enfants talibés}

Across Muslim West Africa, there are hundreds of thousands of children in the care of imams or marabouts (holy men) who promise to teach them the Koran. In many cases these children, known as enfants talibés (in the francophone countries) or almajiris (in Nigeria) are willingly entrusted to the marabouts by poor parents who believe that their sons will be looked after and receive an Islamic education, as well as being fed and clothed. However, a traditional system has become subject to modern abuse, and some of the children receive little to no education in the Koran, and are rather exploited as income generators through a practice of forced begging. Many, perhaps most, of these children are without any documentation of their identity or origins; including the many children who have crossed borders, some of them trafficked. While there have been measures to regulate the system and prohibit child begging in several countries, these efforts have not always had significant impact: the phenomenon of forced begging has been eradicated in Gambia, but in neighbouring Senegal it continues despite widespread condemnation from within and without the country. ${ }^{13}$

In Senegal, centres housing children in difficulty note that they are required to obtain a guardianship order (ordonnance de garde) from the children's court (tribunal pour enfants), within one week of a child coming into their care, which requires first of all that a birth certificate and legal identity be established for the child. These rules are not applied, however, to the enfants talibés in the daaras (Koranic schools), who are allowed to remain in the custody of the marabouts without any legal authority. While such centres do not intervene in the daaras, it does happen that children flee abuses they suffer there, and in that context the formally regulated children's centres often face difficulty in establishing papers for the boys concerned. ${ }^{14}$

\subsection{Child wives of "servile" origin and their children}

Across the Sahel region, historical systems of slavery and caste discrimination persist in contemporary forms, perhaps most of all in Mauritania. ${ }^{15}$ In Niger,

13 In Senegal, it is estimated that there are tens of thousands of children living in Koranic schools, perhaps as many as 100,000. In Nigeria, the Ministerial Committee on Madrasah Education estimated in 2010 that there were about 9.5 million almajiris. See, "Sur le dos des enfants "Mendicité forcée et autres mauvais traitements à l'encontre des talibés au Sénégal, Human Rights Watch, April 2010 ; Time for Change: A call for urgent action to end the forced child begging of talibés in Senegal, Anti-Slavery International, 2011 ; Enfants mendicants dans la region de Dakar, International Labour Organization, UNICEF, World Bank, Understanding Children's Work Project Working Paper Series, 2007; 2012 Findings on the Worst Forms of Child Labor, US Department of Labour; National Framework for the Development and Integration of Almajiri Education into UBE Scheme, Nigerian Universal Basic Education Commission, 2010.

14 Interviews, Dakar and Ziguinchor, May 2014.

15 See, for example, the information at the website of Anti-Slavery International, http://www. 
the anti-slavery group Timidria has reported on the practice of men taking additional wives beyond the four permitted in Islam, provided those additional wives are of "servile" origin. These women, known as wahayu (singular wahaya), are bought and sold, including between Niger and Nigeria, in Niger especially in the Tahoua region. ${ }^{16}$ Typically they are sold even before puberty, and may remain in servitude their entire lives. Timidria assisted one woman, Hadidjatou Mani Koraou, who was imprisoned simply for marrying the man of her choice after being freed by her "master" (who wished to marry her legally himself), to bring a landmark successful case to the ECOWAS Court of Justice. ${ }^{17}$ But many others remain hidden. Women who are "additional wives" in the wahaya system are usually completely undocumented, crossing borders (where they do so) without any identity papers; their children, who, in Niger, are not regarded as legitimate children of the "master" and remain as domestic servants to the family (and if girls may themselves be sold as wahayu), are also likely to be unregistered at birth and undocumented thereafter. ${ }^{18}$

antislavery.org/english/slavery today/descent based slavery/slavery in mauritania.aspx, and at SOS Esclaves, Mauritania, http://www.sosesclaves.org/, last accessed 04 July 2014.

16 Galy Kadir Abdelkader and Moussa Zangaou, Wahaya: Domestic and sexual slavery in Niger, Timidria and Anti-Slavery International, 2012.

17 Hadidjatou Mani Koraou vs. Republic of Niger, ECOWAS Court of Justice, Arrete ECW/ CCJ/JUD/06/08, 27 October 2008; see also Helen Duffy, "Hadijatou Mani Koraou v Niger: Slavery Unveiled by the ECOWAS Court", Human Rights Law Review, 2009, Vol.9, No.1, pp.151-170.

18 Interview, Habibou Ibrahim, President Timidria, Niamey, May 2014. In Nigeria, however, the children may be regarded as legitimate, and inherit property (or even ruling titles). 


\section{A stateless victim of internal trafficking in Côte d'Ivoire ${ }^{19}$}

Ibrahima was born in 1981 in Abengourou in the east of Côte d'Ivoire. He doesn't know his parents, but he grew up among the Burkinabè community there and speaks Mooré. At six years old, he was taken away from the family where he was living by an "aunt", and taken to Bapleu in the west of Côte d'Ivoire. The "aunt" left him with a man who subsequently entrusted him to another man, for whom he worked for seven years on a cocoa plantation, until he was 14 years old. At that age, he went back to see the first man, an important business person in Bapleu, asking to be reunited with his family; but, instead, he was threatened and worked a further seven years. In 2012, Ibrahima travelled alone to Abengourou to look for his parents, using as an identity document a Burkinabè consular card lent to him by the father of the young man it had belonged to, now deceased. He stayed three months in Abengourou, but failed to find his parents, and returned to Bapleu. According to the information he obtained from the chief of the Burkinabè community in Abengourou, it was believed that Ibrahima's mother was Burkinabè, but nobody knew the real identity of the father, or had any information about the current whereabouts of his mother. The "aunt" who had taken him away had essentially stolen the boy and sold him for his labour; but she has now died. Ibrahima has recently tried to obtain a genuine Burkinabè consular card, on the basis of the information he had found out about his origins, but the Burkinabè consular authorities had refused to give him one because he had no documentary proof of his birth or parentage.

\footnotetext{
19 Interview by Mirna Adjami, Duékué, July 2014. Name has been changed.
} 



\section{Internal citizenship in a federal state}

Internal rules of belonging can be as important to individual rights as citizenship at the national level; and this can be as true in states whose constitutions are formally unitary, as the experience of DRC, Kenya and others has shown. ${ }^{1}$

Three states in Africa have responded to the challenges of multi-ethnicity by adopting explicitly federal constitutions. Nigeria has had a federal structure since independence, though the federating units have rapidly multiplied, making the individual units paradoxically less powerful; Ethiopia has adopted a federal constitution more recently, as a response to the highly-centralised structure of both the Ethiopian kingdom and the military rule of the Derg that followed it. The Ethiopian constitution remarkably provides for any self-defined group to make a bid for self-determination to the point of independence. Tanzania, which does not have a federal constitution in its mainland territory, has given a semi-autonomous status to Zanzibar, with its separate political and cultural history. In both Ethiopia and Nigeria, the federating units are designed to a large extent around ethnicity, with borders aimed at uniting the most homogenous population achievable within that area; though in both countries homogeneity is not even close to being achieved in areas of great diversity, while the definition of what is a single ethnicity can shift according to the political circumstances. In Zanzibar, the criteria to be recognised as a Zanzibari are more open, allowing for residence to play a role and not only ethnicity or "nativeness".

Although both the Nigerian and Ethiopian federal systems have brought advantages in terms of decentralisation and local ownership of government, both have also brought their own problems. As the case studies below indicate, the Nigerian system in particular has inadvertently created a population of millions who are not regarded as holding full rights in the area where they live. The Ethiopian effort to give full realisation to minority rights has had similar results, including the displacement of large numbers of people from areas now "owned" by another group when the new constitution came into effect. Much as the creation of government structures that aim to resonate with popular loyalties and understanding may have many advantages, the two case studies indicate the importance of careful design of the details in relation to the entitlements of all citizens of the country, wherever they may live. By contrast, the definition of Zanzibari has been drafted in such a way as to enable those of different origins to "become Zanzibari"; even while ethnicity remains a factor and the acquisition

1 For Kenya, see, for example, Ndegwa, S.N., "Citizenship and Ethnicity: an Examination of Two Transition Moments in Kenyan Politics", American Political Science Review, 1997, Vol.91, No.3, pp.599-616. 
of a Zanzibari identity document has been subject to close political control.

As has been widely noted, an opening of the political system in African states has often led to increased ethnic conflict, leading to discussions on the need for sequencing of institution-building and electoral competition. ${ }^{2}$ Decentralisation and devolution has exacerbated this trend in some countries to emphasise autochthony and the prior rights of the "native" at local levels - globally as well as in Africa - which call into question the very notion of citizenship at the national level. ${ }^{3}$ Yet the post-colonial efforts at nation-building remain (even more) relevant for all that. There are many complex reasons for these problems, and complex solutions will also be needed. To date, there has not yet been been a serious effort to advocate for formal written rules for belonging at the sub-national level that both recognise the reality of regions and localities that may have greater popular meaning than the "nation-state", but also avoid "instinctive" definitions (which tend to a reliance on "blood and soil") and create the possibility for a person to change his or her place of belonging.

\section{1 "Indigeneity" in Nigeria}

Nigeria demonstrates within its own borders a concentrated microcosm of many of the problems of citizenship and identity that exist across Africa. Nigeria's four constitutions since independence ${ }^{4}$ have all grappled with the problem of ensuring an appropriate balance of power between the three largest ethnic groups that dominated the three original regions, and the remaining several hundred ethnic groups that are represented in the country. In these provisions, a legal and policy focus on "indigenes" to an area has emerged, leading to the creation of a massive population of Nigerians who are "non-indigenes" in the area where they live, without the rights and benefits enjoyed by the "indigenes" of that place. Though these distinctions were in part originally designed to protect smaller ethnic groups from domination by the larger, it is today often difficult to find justification for them, and even to distinguish in historical terms between those whose ancestors were allegedly "originally" in a place and those who supposedly came later.

The territory of what is now Nigeria is made up of what were initially three separate units under British control: the Colony of Lagos in the south west; the Protectorate of Southern Nigeria (the rest of the southern half of the country);

2 Jack L. Snyder, From voting to violence: Democratization and nationalist conflict, New York: Norton, 2000; Edward D. Mansfield and Jack L. Snyder Electing to fight: Why emerging democracies go to war, Cambridge, Mass.: MIT Press, 2005.

3 Bayart, Geschiere and Nyamnjoh (eds.), Critique internationale (Special issue " J'étais là avant "); Geschiere, The Perils of Belonging.

4 These were adopted in 1960,1963,1979 and 1999. A 1989 constitution never came into force. 
and the Protectorate of Northern Nigeria. ${ }^{5}$ From 1914, when the protectorate of Northern Nigeria was joined to the south for administrative purposes, the entire area was known as the Colony and Protectorate of Nigeria. At the date of cession of the Colony of Lagos to the British crown in 1861, the territory became part of the "crown's dominions" (see chapter 4.2) and the inhabitants became British subjects. Those born in the colony after that date became British subjects on the basis of their place of birth, with the same status as those born in Britain. This regime did not apply in the protectorates, though from 1914 British protected persons could naturalise locally as British subjects within the Colony of Lagos under certain conditions. From 1948, British subjects in the Colony of Lagos became citizens of the UK and colonies, in line with the 1948 British Nationality Act; those born in the protectorates had the status of British protected persons, formally defined for the first time.

A unified framework for citizenship was only created from independence in 1960. The transitional provisions for the assignment of nationality at independence followed the standard template for Commonwealth countries, providing for the grant of citizenship by operation of law for those born in the territory who were British protected persons or citizens of the UK and colonies, provided that one parent or grandparent was also born there, and for those born outside the territory if their father had been born in the territory. Those born after the entry into force of the new constitution obtained Nigerian nationality on a jus soli basis (based purely on birth on the territory, with the usual exceptions for children of fathers who were diplomats), or on the basis of their father's nationality if born outside the country. The Nigerian Citizenship Act 1960 and the Nigerian Citizenship Act 1961 provided greater detail on provisions for registering or naturalising as a citizen and for loss of citizenship. ${ }^{6}$

The 1963 constitution made no significant changes on citizenship, ${ }^{7}$ but in 1974 an amendment decree adopted by the military government replaced chapter II of the constitution and repealed the Citizenship Acts of 1960 and 1961. The new provisions somewhat restricted the categories of those entitled to citizenship, both retrospectively for those born before independence, and for those born since. The basic scheme remained the same, but with an exclusion from citizenship if any parent or grandparent had lost his citizenship by any means (i.e. including by acquiring another nationality), unless one parent was a citizen. Those born in the

5 Added to these were (part of) the western section of the German colony of Kamerun, mandated to Britain in 1922.

${ }^{6}$ See generally, Arthur V.J. Nylander, The Nationality and Citizenship Laws of Nigeria, University of Lagos Press, 1973; Fransman's British Nationality Law, catalogue entry on Nigeria; K. C. Okoli, "Nigerian Citizenship Law: A Current Perspective", Journal of African Law,Vol.34, 1990, pp.27-41.

7 The 1960 independence constitution chapter on citizenship was reproduced with minor amendments in the 1963 republican constitution, and was unaffected by the suspension of certain provisions following the 1966 military coup. 
country with one parent who was a citizen by registration or naturalisation were also citizens, and those born outside if both parents were citizens by registration or naturalisation. ${ }^{8}$

The 1979 constitution then fundamentally altered this scheme, introducing an ethnic dimension to citizenship (a revision argued to be necessary to take account of the fact that many communities in Nigeria are separated from their ethnic kin by arbitrary colonial borders'); at the same time it completely removed any element of jus soli citizenship, granting no right to nationality based on birth in the country. Article 23(1) of the 1979 constitution provided for citizenship by birth for:

(a) every person born in Nigeria before the date of independence, either of whose parents or any of whose grandparents belongs or belonged to a community indigenous to Nigeria: Provided that a person shall not become a citizen of Nigeria by virtue of this section if neither of his parents nor any of his grandparents was born in Nigeria; (b) every person born in Nigeria after the date of independence either of whose parents or any of whose grandparents is a citizen of Nigeria; and (c) every person born outside Nigeria either of whose parents is a citizen of Nigeria.

The 1979 constitution also made provision for citizenship by registration for a woman married to a Nigerian man (but not for a foreign man married to a Nigerian woman); naturalisation on the basis of fifteen years' residence in the country (a very long period by international standards) and other conditions; for deprivation of citizenship; and for prohibition of dual nationality. These provisions on citizenship were repeated largely unaltered in the 1999 constitution, still in force. The one significant change made was that the prohibition on dual citizenship for Nigerian citizens from birth was removed; however, those wishing to naturalise as Nigerian were required to renounce any other naturalised citizenship. ${ }^{10}$ Provisions relating to renunciation of citizenship were also added. Unusually, instead of providing for additional rules on citizenship to be set out in legislation, both the 1979 and 1999 constitutions rather delegated authority to the president to make regulations; something which has never been done, leaving a lack of detail that allows for a high degree of discretion in implementing the constitutional framework.

8 Constitution (Amendment) Decree, No.33 of 1974. See E.I. Nwogugu, "Recent Changes in Nigerian Nationality and Citizenship Law", International and Comparative Law Quarterly, Vol.25, 1976, pp 423-439.

9 O. Adigun. "Nationality and Citizenship: The Legal Problematic of Transborder Ethnic Communities in Nigeria", in A.I. Asiwaju and P.O. Adeniyi (eds.) Borderlands in Africa: A Multidisciplinary and Comparative Focus on Nigeria and West Africa, Lagos: University of Lagos Press, 1989.

10 Constitution of the Republic of Nigeria, 1979, article 23; Constitution of the Republic of Nigeria, 1999, article 25. 
Those born after independence are equally citizens by birth if the parent or grandparent on which they base their claim is a citizen by naturalisation or a citizen from birth, thus avoiding in principle a permanent ethnic discrimination in citizenship (as in the case of 1995 constitution of Uganda). However, the first clause implies a need for "indigeneity" which is also reflected in Nigeria's domestic practice, in the distinctions between the different units that make up the federation. ${ }^{11}$ And for the second and third clause to provide effective access to citizenship for "non-indigenes", naturalisation procedures should be functional and accessible; something that is far from being the case (see chapter 7.3).

In an effort to grapple more successfully with the challenges of managing a multi-ethnic state, the 1979 constitution also introduced a new concept of "federal character": the idea that government positions at national level should be shared equitably among those coming from the different units that made up Nigeria's federal system. The "Fundamental Objectives and Directive Principles of State Policy" provided that:

(3) The composition of the Government of the Federation or any of its agencies and the conduct of its affairs shall be carried out in such manner as to reflect the federal character of Nigeria and the need to promote national unity, and also to command national loyalty thereby ensuring that there shall be no predominance of persons from a few States or from a few ethnic or other sectional groups in that government or in any of its agencies. (4) The composition of the Government of a State, a local government council, or any of the agencies of such government or council, and the conduct of its affairs shall be carried out in such manner as to recognise the diversity of the peoples within its area of authority and the need to promote a sense of belonging and loyalty among all the peoples of the Federation. ${ }^{12}$

These requirements were also repeated in the 1999 constitution; and the idea of federal character is reflected in other provisions. For example, the president is required to "appoint at least one minister from each state, who shall be an indigene of the state". ${ }^{13}$ The membership of the executive of any registered political party must also "reflect the federal character of Nigeria", and this will be deemed to be the case "only if the members thereof belong to different States not being less in number than two-thirds of all the States of the Federation and the Federal Capital Territory, Abuja." ${ }^{14}$ The interpretation section then provides that "belong to", "when used with reference to a person in a state refers to a

11 See Human Rights Watch, "They Do Not Own This Place”: Government discrimination against "non-indigenes" in Nigeria, April 2006.

12 Constitution, 1979, article 14; repeated verbatim in Constitution of the Federal Republic of Nigeria, 1999, article 14.

13 Constitution of the Federal Republic of Nigeria, 1999, article 147(3).

14 Constitution, 1999, article 223(2)(b). 
person either of whose parents or any of whose grandparents was a member of a community indigenous to that state" ${ }^{15}$

In 1996 the Federal Character Commission Decree was adopted by the military government led by General Sani Abacha, establishing a commission with the responsibility to elaborate, monitor and enforce the provisions on federal character. The 1999 constitution included the Federal Character Commission in its list of "certain federal executive bodies", but the decree has not been revised since the restoration of civilian rule. ${ }^{16}$ Among the Commission's functions are to work out "an equitable formula ... for the distribution of all cadres of posts in the civil and the public services of the Federation and of the States, the armed forces, the Nigeria Police Force and other security agencies, bodies corporate owned by the Federal or a State Government and Extra-Ministerial Departments and parastatals of the Federation and States"; as well as "for distribution of socioeconomic services, amenities and infra structural facilities" and "modalities and schemes, subject to the approval of the President, for redressing the problems of imbalances and reducing the fear of relative deprivation and marginalisation in the Nigerian system of federalism as it obtains in the public and private sectors". ${ }^{17}$

The Commission adopted Guiding Principles and Formulae for the Distribution of all Cadres of Posts in 1997. These principles establish, among other things, that "the indigenes of any State of the Federation shall not constitute less than 2.5\% or more than $3 \%$ of all officers including junior staff at the head offices of any national institution, public enterprise or organisation." 18 Where the number of posts are too few to respect this formula, the Commission established criteria based on the six geographic zones of Nigeria, or a simple north-south division; and it has also established rules to apply at state and local government level, even though it is a federal body. The principles include a definition of "indigene" at each level of government, which is entirely circular and adds no substantive content, though it clearly prohibits claims of "dual indigeneship":

10. (1) An indigene of a local Government means a person:

i. either of whose parents or any of whose grandparents was or is an indigene of the local Government concerned; or

ii Who is accepted as an indigene by the Local Government:

Provided that no person shall lay claim on more than one Local Government.

15 Constitution, 1999, article 318(1). The only section in which the phrase "belong to" is used, however, is section 223 on political parties.

16 Constitution 1999, article 153.

17 Federal Character Commission Decree, No.34 of 1996, section 4(1)(a) and (d).

18 Guiding Principles and Formulae for the Distribution of all Cadres of Posts, Part III, section 3, SI 23 of 1997, available at http://federalcharacter.gov.ng/guidingprinciplesdef. php, last accessed 10 March 2014. 
(2) An indigene of a state shall be a person who is an indigene of one Local Government in that state.

Provided that no person shall claim to more than one state or to a state and the Federal Capital Territory.

(3) An indigene of the Federal Capital Territory

a. is a Nigerian citizen, other than by naturalization, who cannot lay claim to any state of the Federation; or

b. is a person born in the Federal Capital Territory and whose descendants lived in the area now constituting the Federal Capital Territory before 26th February, 1976 and has continued to reside in the Federal Capital Territory after that date.

11. A married woman shall continue to lay claim to her state of origin for the purpose of implementation of the Federal Character formulae at the national level. ${ }^{19}$

Under this regime, a "certificate of indigeneity", issued by the chair of a person's local government area "of origin", is required for many official and unofficial purposes, including applications for civil service positions, government scholarships, election to public office and many other official interactions. An entire infrastructure of personnel and form-filling exists to supply such certificates. Yet this document has no basis in law, and there are no established written criteria on the basis of which a refusal could be challenged. A certificate of indigeneity is usually available only to those whose father is an indigene, despite constitutional prohibitions on gender discrimination. Although in some places the criteria applied may be more flexible, based on residency and assimilation, there is no equivalent of the naturalisation provisions in relation to citizenship at the national level. Since there is no legal framework, the process is effectively at the discretion of the local government chair. In practice, such certificates can be obtained with money and connections, but it is hard to recommend such a workaround as a matter of public policy. ${ }^{20}$ Being labelled as a "non-indigene" of a state has serious consequences. No requirements related to ethnicity or indigeneity are placed by the law on the right to run for election or be appointed to public office in any state in the federation. Yet many states refuse to employ non-indigenes in their civil services; non-indigenes are charged higher fees at state universities and are usually not eligible for academic scholarships; nonindigenes may have difficulty in accessing any number of other government services, including police protection in case of ethnic violence. A non-indigene

19 Guiding Principles and Formulae for the Distribution of all Cadres of Posts, Part II, sections 10 and 11 .

20 For a report on the criteria applied for certificates of indigeneity, see, "Indigeneity, Belonging, \& Religious Freedom in Nigeria: Citizens'Views from the Street”, Nigeria Research Network, Policy Brief No.5, University of Oxford / Development Research and Project Centre Kano, 2014. 
may vote, but will find it very hard to run for office in the area where he or she is resident. ${ }^{21}$

This interpretation echoes back to the definitions of "native" adopted by Britain for the Nigerian protectorate (in similar terms to language used in other British territories). Historical provisions can have long shadows. The 1939 Interpretation Act defined "native of Nigeria" to mean "any person whose parents were members of any tribe or tribes indigenous to Nigeria and the descendants of such persons, and includes persons one of whose parents was a member of such tribe." A "native foreigner" is a "person (not being a native of Nigeria), whose parents are members of a tribe or tribes indigenous to some parts of Africa and the descendants of such person, and shall include any person any of whose parents is a member of such tribe"; and a "non-native" was someone who was neither a native of Nigeria nor a native foreigner. ${ }^{22}$ These definitions were based on ethnic identity, and like the current practice, did not allow for assimilation of others into the idea of "native" of a particular place, nor did they create any definition of the length of time needed before a tribe could be considered as "indigenous". At the same time, they blurred the distinctions between British nationals (whether citizens of the UK and colonies or British protected persons) and aliens in the pre-independence era: a native foreigner could be a citizen of the UK and colonies (a child of Ghanaian parents born in Lagos); whereas a native of Nigeria could be an alien (a child born in Dahomey (Benin) of a Yoruba mother who was a British protected person and a Yoruba father who was a French subject). At national level, therefore, those who became Nigerian by operation of law on 1 October 1960 were not necessarily therefore "natives" of Nigeria; and not all "natives" qualified as citizens, leaving room for much confusion on who did in fact become Nigerian. ${ }^{23}$

The requirements on federal character have been complemented and complicated by the multiplication of federal units and sub-units. At independence, Nigeria comprised three regions: Northern, Western and Eastern, each dominated by

21 For discussion of the indigene-settler question in Nigeria and efforts to resolve it, see: Chidi Anselm Odinkalu, "Natives, subjects, and wannabes: Internal citizenship problems in post-colonial Africa", in Rhoda E. Howard-Hassmann and Margaret Walton-Roberts (eds.) The Human Right to Citizenship: A Slippery Concept, University of Pennsylvania Press, forthcoming, 2015; Uchenna Emelonye, (ed.) Nigeria: Peace Building through Integration and Citizenship, International Development Law Organization, 2011; Daniel C. Bach, "Federalism, Indigeneity and Ethnicity in Nigeria" in Larry Diamond, Tom Bierstecker, A.H.M. Kirk-Greene and Oye Oyediran (eds.), Transition without End ; Nigerian Politics and Civil Society under Babangida, Lynne Rienner : Boulder, 1997, pp.333-350; Ijeoma Nwachukwu, "The Challenge of Local Citizenship for Human Rights in Nigeria" African Journal of International and Comparative Law Vol.13, 2005, pp.235-261; Olufemi Taiwo, "Of Citizens and Citizenship", in Okon Akibá (ed.), Constitutionalism and Society in Africa, Aldershot, UK: Ashgate, 2004, pp. 55-78.

22 Interpretation Ordinance No.27 of 1939.

23 Nylander, The Nationality and Citizenship Laws of Nigeria, pp.2-4. 
one major ethnic group, the Hausa-Fulani, ${ }^{24}$ Yoruba and Igbo, respectively. The sub-national units have been repeatedly divided, and the three original regions have become 36 states today; while the 301 local government areas created in 1976 as part of a comprehensive reform led by the military government have become 774 listed in the 1999 Constitution (plus two sub-divisions of the Federal Capital Territory, Abuja).

Doubts about the value of such subdivisions date back to the pre-independence period: during the debates in the constitutional conference that was established in 1953 to decide the form of the future independent state, the British government appointed a commission of inquiry to advise on safeguards for minority rights. This commission, known as the Willink Commission after its chair, Henry Willink, reported in 1958. The Commission considered each region of Nigeria (Northern, Western and Eastern) and the demands for state creation from minorities. In each case, it rejected the idea of new states on the grounds that: "it is seldom possible to draw a clean boundary which does not create a fresh minority; the proposed state had in each case become very small by the time it had been pared down to an area in which it was possible to assert with confidence that it was desired." 25

With the repeated creation of new states and local government areas, Nigerians are indigenes of ever smaller units of territory; and with the constitutional changes that have created these units, millions have found themselves instantly transformed into "foreigners" in the only place of residence they have ever known. An indeterminate but undoubtedly large number of Nigerians are now in the situation where they can claim indigeneity in no state of the federation, leaving them in practice excluded from the benefits of citizenship in the only country to which they have any possible claim to those rights. To make matters worse, increasing ethnic tensions between "indigenes" and "settlers" in many states, coupled with pressure on jobs and economic opportunities, have resulted in more stringent enforcement of the rules discriminating against non-indigenes in recent years. At the same time the formulae proposed by the Federal Character Commission do not ensure that marginalised minorities in fact obtain equitable access to federal or state level posts, since only the "state of

24 Another complex ethnonym, used only in Nigeria: Technically two ethnic groups, the Hausa being the sedentary population conquered during the $19^{\text {th }}$ century by Fulani pastoralists who went on to establish the emirates in the north of what is now Nigeria and to speak Hausa rather than Fulfulde.

25 Report of the Commission Appointed to Enquire into the Fears of Minorities and the Means of Allaying Them, Presented to Parliament by the Secretary of State for the Colonies, July 1958, Chapter 14, paragraph 3. On the other hand, however, comparative research indicates that federal systems made up of a few large regions tend to be less stable than those with many parts. See, for example, Stefan Wolff, "Conflict Management in Divided Societies:The many uses of territorial self-governance" International Journal on Minority and Group Rights (2013) Vol.20(1), pp.27-50. 
origin" and no other criteria are taken into account in determining who is to benefit from these affirmative action measures (that is, members of a dominant majority within the particular state may access most of the benefits assigned to indigenes). Provisions originally intended in good faith to address the challenges of maintaining equitable distribution of benefits in a highly diverse society have become diverted from their original purpose. The ambiguity of what it means to be an "indigene" or to "belong to" a political unit of the federal system is at the heart of these problems.

Moreover, the question of indigeneity also has implications for Nigerian nationality itself. Since no law establishes another document to do so, and since indigeneity must be proved to obtain any number of official documents, the proof of the right to be Nigerian is effectively a certificate of indigeneity: among the documents for which a certificate of indigeneity is required is a passport. ${ }^{26}$

Yet at the same time as this elaborate framework of distinctions among nationals from different parts of the territory has been constructed, the constitutional bill of rights states that "Every citizen of Nigeria is entitled to move freely throughout Nigeria and to reside in any part thereof..." (Article 41). Article 42 provides unusually explicit protections in relation to disabilities or advantages imposed or accorded to citizens by the government, but in the final clause the article is removed of any force in relation to the law on appointments to state office:

(1) A citizen of Nigeria of a particular community, ethnic group, place of origin, sex, religion or political opinion shall not, by reason only that he is such a person:- (a) be subjected either expressly by, or in the practical application of, any law in force in Nigeria or any executive or administrative action of the government, to disabilities or restrictions to which citizens of Nigeria of other communities, ethnic groups, places of origin, sex, religion or political opinions are not made subject; or (b) be accorded either expressly by, or in the practical application of, any law in force in Nigeria or any such executive or administrative action, any privilege or advantage that is not accorded to citizens of Nigeria of other communities, ethnic groups, places of origin, sex, religion or political opinions.

(2) No citizen of Nigeria shall be subjected to any disability or deprivation merely by reason of the circumstances of his birth.

(3) Nothing in subsection (1) of this section shall invalidate any law by reason only that the law imposes restrictions with respect to the appointment of any person to any office under the State or as a member of the armed forces of the Federation or member of the Nigeria Police Forces or to an office in the service of a body, corporate established directly by any law in force in Nigeria. ${ }^{27}$

26 Interview, Nigerian Immigration Service, Abuja, July 2014.

27 Constitution 1999, article 42. 
A range of Nigerian civil society organisations, including the Citizens' Forum for Constitutional Reform, have lobbied for years for an end to the official and unofficial policies of discrimination in effect on the basis of indigeneity, including drafting specific constitutional amendments to ensure this result. In 2004, a group of Nigerian senators sponsored a Residency Rights Bill that would have prohibited discrimination against non-indigenes who had lived and paid taxes in their state of residence for at least five years (with an exception related only to "traditional heritage"; such matters as chieftaincy titles). ${ }^{28}$ The bill was never adopted, and lapsed with the election of new National Assembly in 2007.

These issues remain under constant debate. In 2014, President Goodluck Jonathan established a "National Conference" of 500 delegates drawn from different interest groups and different parts of the country, producing a 10,000 page report with recommendations on the structure of the federal system and the way in which power and resources are devolved. A committee on "citizenship, immigration and related matters" produced its own report, recommending the removal of gender discrimination in transmission of citizenship by marriage, while noting the "overwhelming need to liberalise the path to naturalised citizenship". On the question of "indigeneship and residency", debates were especially heated, between the need for non-discrimination and the protection of the rights of "indigenes". In its final report the committee lamented the lack of definition of indigene, and the discrimination that resulted from the constitutional provisions, undermining national integration. It recommended that section 15(3) of the 1999 constitution, requiring the federal government to "secure full residence rights for every citizen in all parts of the Federation" be made justiciable, and a new provision inserted to read "The right of every Nigerian citizen to be resident or domiciled in any part of Nigeria should be recognised. Such a resident shall enjoy all the rights, privileges and facilities in the place of his/her choice, provided that such a person meets his/her basic civic obligations.'The committee also adopted the 2007 UN Declaration on the Rights of Indigenous Peoples, a document adopted to address a very different context (see chapter 10.2), as one of only four "reference documents" for the committee (the others being Nigerian texts) and endorsed the Declaration as a guide to national law and policy. ${ }^{29}$ But the proposals did not address the basic problems in Nigeria's exclusively descent-based citizenship law, on which the internal discrimination is in turn founded.

28 Human Rights Watch, "They Do Not Own This Place”, p. 63; for other suggestions see Abimbola O. Adesoji and Akin Alao, "Indigeneship and Citizenship in Nigeria: Myth and Reality” Journal of Pan African Studies,Vol.2, No.9, 2009, pp.151-165.

29 Report of the Committee on Citizenship, Immigration and Related Matters, The National Conference, 14 May 2014 on file with author; media coverage and interviews with participants in the committee, Abuja, June 2014. See also http://www. nigerianationalconference2014.org/, last accessed 10 November 2014. 
The costs of the emphasis on "indigeneity" for ordinary citizens were dramatically highlighted by moves, in the context of the terrorist threat from Boko Haram, from governors of some south-eastern states, including Imo and Abia, to register all "non-indigenes" resident in their states. The clear threat was for "deportations" of northerners if the security situation deteriorated; though people from neighbouring states were also potentially affected by these moves. Various northern lobby groups then threatened to expel southerners in return, and bills were submitted to several northern state assemblies for the registration of southerners. The National Council of State held an emergency meeting in July 2014 in response to these threats, which discussed the questions of discrimination around indigeneship more widely and acknowledged, under the shadow of the Biafran war, that the threat of registration and deportation "was capable of disrupting the unity of the country". The Council set up a committee made up of one governor from each of the six zones of Nigeria, to "identify discriminatory practices in all states of the federation and in all the local government areas and then this committee to submit report to council in the next two months". ${ }^{30}$

\subsection{Nations, Nationalities and Peoples in Ethiopia}

Within Africa the only state with a more fully developed federal structure than Nigeria is Ethiopia, though all countries of course have decentralised administrative structures at different levels (regional and/or local), and an increasing number of states have elements of devolution (political representation and autonomy) at sub-national levels. Nigeria's federal system is less elaborated in law than Ethiopia's, since the constituent states of the Nigerian federation do not have their own constitutions, but rely on the national constitution to establish their powers; whereas in Ethiopia all of the nine regional states have their own constitutions.

Ethiopia's 1994 constitution, adopted after Eritrea was already independent, declares the state to be a "Federal Democratic Republic". ${ }^{31}$ The preamble states

30 "Council of State moves to \$stop citizens' registration, deportation", The Citizen, 1 August 2014; Ugochukwu Onyeocha, "Terrorism Might End By December- Council Of State", Daily Times, 1 August 2014; Safiya I. Dantiye, "Government and the registration of non indigenes" Daily Trust, 25 July 2014; Obiora Ifoh, George Oji, Wole Oladimeji, Omeiza Ajayi,Tordue Salem and Ubong Ukpong "Deportation of non-indigenes, threat to North, South", National Mirror, 24 July 2014.

31 This section draws especially on Christophe Van der Beken "Ethiopia: Constitutional Protection of Ethnic Minorities at the Regional Level", Afrika Focus Vol.20, Nos.12, 2007, pp.105-151 and Assefa Fiseha, "Ethiopia's Experiment in Accommodating Diversity: 20 Years' Balance Sheet”, Regional \& Federal Studies, Vol.22, No.4, 2012, pp.435473; see also Christophe van der Beken, Unity in Diversity - Federalism as a Mechanism to Accommodate Ethnic Diversity: The Case of Ethiopia, monograph, Lit Verlag, 2012; Paul H. Brietzke, "Ethiopia's Leap in the Dark: Federalism and Self-Determination in the New 
that "the Nations, Nationalities and Peoples of Ethiopia" proclaim "full respect of individual and people's fundamental freedoms and rights", and the operative articles provide protections for both individual and group rights. Article 39(5) defines a "Nation, Nationality or People", without distinction among the terms, as "a group of people who have or share a large measure of a common culture or similar customs, mutual intelligibility of language, belief in a common or related identities, a common psychological make-up, and who inhabit an identifiable predominantly contiguous territory." The country is divided into nine regional states, essentially on the basis of language and ethnicity, each with "equal rights and powers" within a federal structure; and any "nation, nationality or people" within those states is given the right to a self-governing entity within a regional state, to demand a new state within the federation, or even to claim the right to secede (hence the requirement in Article 39(5) for a contiguous territory). The power of self-determination has only been used once, to create a separate administrative zone for the Siltie in the Southern Nations and Nationalities Region following a referendum in 2001. ${ }^{32}$ The regional states were given wide-ranging political and administrative powers, including the power to "determine their respective working languages". ${ }^{33}$ At the federal level, the House of Peoples' Representatives has a guaranteed number of seats for "minority nationalities and Peoples'; and all nations, nationalities and peoples have a right to be represented in the second chamber, the House of the Federation, elected by the regional parliaments. Unlike the interim constitution of 1991, the 1994 constitution contains no provisions that guarantee representation for different ethnic groups in the federal executive. However, in practice, the most important government positions are generally distributed across members of different ethnic groups.

Ethiopia has more than 80 ethnic groups, but only nine regional states: five are named after the dominant ethnic group in that region (Amhara, Oromo, Tigray, Afar and Somali) but also have substantial minorities; the Southern Nations and Nationalities Region alone comprises almost 60 different "nations, nationalities

Constitution", Journal of African Law, Vol. 39, No. 1, 1995, pp. 19-38; Jon Abbink, "Ethnicity and Constitutionalism in Contemporary Ethiopia", Journal of African Law, Vol. 41, No. 2, 1997, pp. 159-174; Asnake Kefale Adegehe "Federalism and ethnic conflict in Ethiopia : a comparative study of the Somali and Benishangul-Gumuz regions", Doctoral Thesis, Leiden University, 2009; Berhanu Gutema Balcha, "Restructuring State and Society: Ethnic Federalism in Ethiopia”, Doctoral Thesis, Aalborg University, 2007; Fantahun Haile Michael, "The Roots of Nationality Problems and the Challenge to Nation-building in Ethiopia”, DERAP Working paper Issue 250, Chr. Michelsen Institute, 1989.

32 Lahra Smith, "Voting for an ethnic identity: procedural and institutional responses to ethnic conflict in Ethiopia", Journal of Modern African Studies, Vol. 45, No.4, 2007, pp.565594. See also Lahra Smith, Making Citizens in Africa: Ethnicity, Gender, and National Identity in Ethiopia, Cambridge University Press, 2013.

33 Preamble and Articles 5, 39 and 47 of the Constitution of the Federal Democratic Republic of Ethiopia, 1994. 
and peoples"; two are divided mainly between two groups (Benishangul-Gomuz and Gambella); and the final state is centred on the city of Harrar.

The regional state constitutions vary in their definitions for membership of that region, though all reflect the federal constitution in their general provisions on individual and group rights. The Amhara regional constitution states that "The supreme power of the national regional state resides in and belongs to the peoples of the Amhara region"; whereas that of Oromia is more exclusive, stating that "sovereign power in the region resides in the people of the Oromo Nation". The Somali regional state has similar provisions to those of Oromia. In some states, a degree of autonomy is given to minorities through the three-tier system of local government within each regional state (the zone or "nationality administration", wereda and kebele). However, this is not uniform across the regions: the Amhara region provides for nationality administrations for the Himra, Awi and Oromo ethnic groups, the Southern Nations region has numerous ethnically defined nationality administrations, and Benishangul-Gomuz has five ethnically determined zones; but Oromia provides no territorial or other form of autonomy for non-Oromo residents of the state. ${ }^{34}$ The federal constitution also requires "equitable representation" of minorities in regional governments, ${ }^{35}$ and many regions have a quota system in the regional parliament or special rights for ethnic administrations in the appointment of judges.

Minority groups are explicitly classified as "indigenous" or "non-indigenous" in some regional constitutions, while the distinction is made in practice in others. Even in the case of those regions providing special rights for minorities, these nationality administrations and other rights (such as ethnic quotas) are limited to the "indigenous" ethnic groups, with no provision for those who are migrants from other parts of Ethiopia.The Benishangul-Gomuz constitution, for example, lists only five ethnic groups as indigenous, even though almost 50 percent of the population is made up of members of other groups who have migrated to the region in the past. The Gambella constitution similarly refers to "founder" nations. ${ }^{36}$ Both constitutions ensure the right of non-indigenous populations to live and work in the regions, but not to hold public office. Harrar city state, similarly, is politically completely dominated by the Harrar ethnic group, even though they form only ten percent of the population. ${ }^{37}$

The various constitutions do not establish how it is determined whether a particular individual is in fact a member of any particular ethnic group. Ethnic identity is basically a matter of choice: as an individual you are required to state

34 Van der Beken "Constitutional Protection of Ethnic Minorities at the Regional Level".

35 Constitution, Article 39.

36 Yonatan Tesfaye Fessha and Christophe van der Beken, "Ethnic Federalism and Internal Minorities: The legal protection of internal minorities in Ethiopia", African Journal of International and Comparative Law (2013) Vol.21, No.1, pp.32-49.

37 Fiseha, "Ethiopia's Experiment in Accommodating Diversity". 
your preferred ethnicity for identity documents and there are no fixed rules on the criteria for acceptance as belonging to that ethnicity. In terms of the law, the only references are to language and culture rather than descent. A federal proclamation requires candidates for regional government to speak regional languages. ${ }^{38}$ However, in practice it is not so easy: even a person who is fluent in the language of a region which is not his or her "home" region may not be accepted as eligible for public office. Often, the rules are informal in character, and thus difficult to establish for certain. ${ }^{39}$ In 2000, three Amharic-speakers whom the National Electoral Board had ruled ineligible to stand for election in the Benishangul-Gomuz regional state challenged the decision before the House of Federation (the second chamber of the Ethiopian parliament, responsible in Ethiopia's unique system for interpreting the constitution). The House of Federation held that an electoral law that makes the right to stand for election conditional on speaking the working language of the region is constitutional, but ruled that the particular individuals concerned were eligible to stand for office, since Amharic is the working language of the region (as it is of the federal government), even though it is not the language of one of the "indigenous" groups of Benishangul-Gomuz. ${ }^{40}$

The constitution also includes a bill of rights with non-discrimination provisions, including in relation to freedom of movement, voting and holding political office. ${ }^{41}$ Nevertheless, across Ethiopia, individuals who do not live in their "home" states, ethnic minorities within any state with a dominant ethnic group (especially those that are designated as non-indigenous, which include groups that were forcibly removed during the Derg era), and minorities that are dispersed across geography, do not find real protection within the constitutional system at either federal or regional level. This effective political discrimination is particularly striking in cities, which tend to be highly multi-ethnic but governed by members of the ethnic group that "owns" the region or zone, despite recent efforts to introduce a level of autonomy for city administrations. ${ }^{42}$ The adoption of the federal constitution itself led to a wave of internal displacement: in some parts of the country, individuals who did not belong to the dominant ethnic group in the region felt unwelcome and left, taking refuge in Addis Ababa and other major towns. Similar incidents have continued to occur: Amharas resident in Oromia, for example, have been expelled following conflicts over control of land. ${ }^{43}$

38 Response of the Government of the Federal Democratic Republic of Ethiopia to questions raised by the Committee on the Elimination of Racial Discrimination, United Nations, CERD/C/ETH/CO/15/Add.1 (2008).

39 Correspondence with Christophe Van der Beken, March 2013.

40 Fessha and van der Beken, "Ethnic Federalism and Internal Minorities", p.42.

41 Constitution, Articles 25, 32 and 38.

42 Fessha and van der Beken, "Ethnic Federalism and Internal Minorities".

43 Fiseha, "Ethiopia's Experiment in Accommodating Diversity". 
The Ethiopian federal structure has considerable strengths in terms of its ambition to empower previously neglected or oppressed ethnic groups. However, the lack of a system of internal "naturalisation" has - as in Nigeria - created a class of people who are not regarded as having full rights in the region in which they live, even though they are Ethiopian citizens.

\subsection{The status of Zanzibari in Tanzania}

Tanzania has a partially federal structure, with the islands of Zanzibar (Unguja and Pemba) enjoying a substantial degree of autonomy from mainland Tanzania. At the time of European colonisation of Africa, Zanzibar was under the rule of the Sultanate of Oman, then becoming a British protectorate; while mainland Tanzania initially became a German colony known as Tanganyika, and then, after the German defeat in 1918, a British protectorate. A decree on Zanzibari nationality was adopted as early as 1911, to "Declare what Persons are Zanzibar Nationals and to Provide for the Naturalization of Aliens". The decree provided that "Zanzibari' shall mean one of our [i.e the Sultan's] subjects" and that a person was Zanzibari by birth if born (anywhere) of a Zanzibari father born in Zanzibar, or if born in Zanzibar to an alien father born in Zanzibar or of unknown or stateless parents; while a child born in Zanzibar of alien parents could claim the status of Zanzibari subject at majority; and aliens could naturalise or women acquire nationality through marriage to a national. ${ }^{44}$ In 1952 , this was replaced with a decree that provided for nationality on the basis of jus soli for those born in the sultan's dominions, as well as nationality by descent through the father for those born outside, and the possibility of naturalisation and acquisition by registration for wives. ${ }^{45}$ The population of the island was highly diverse, but prior to independence dominated by people of Arab and Asian ethnicity. Membership was always going to be controversial once the sultanate and colonial government was removed. ${ }^{46}$ Zanzibar gained independence from Britain on 10 December

44 The Zanzibar Nationality and Naturalization Decree 1911. Cap 27. Article 3: "The following persons are Zanzibaris by birth: (a) The child, whether born in our Dominions or not, of a Zanzibari father who was born in our Dominions or became our subject by naturalization. (b) The child born in our Dominions of parents unknown or whose nationality is unknown. (c) The child born in our Dominions of an alien father born in our Dominions." Article 4: Every person born within our Dominions may, during the three years next ensuing from the date of his ceasing to be a minor, claim the status of a Zanzibari subject upon compliance and in accordance with the Rules in the Schedule hereto."

45 Zanzibar Nationality Decree 1952, article 3(1) "Every person born (whether before or after the $27^{\text {th }}$ December 1952) within the Dominions of His Highness the Sultan shall be a Zanzibar subject by birth"; article 4 provided that a person born outside the Zanzibari territories was a Zanzibar subject by descent if his father was a Zanzibar subject at the time of the birth (with a limitation on transmission of nationality outside of Zanzibar for a further generation).

46 Marie-Aude Fouéré, “Fixing Zanzibari-ness on Paper: Sorting Out the Internal Alien and 
1963; a month later a revolution overthrew the Arab-dominated independence government, and established a "People's Republic" under the single party rule of the Afro-Shirazi Party (ASP). Some 7,000 people of Arab or Asian descent were expelled, and further anti-Asian measures continued; in 1968 it was announced that Comorans would also be deprived of citizenship unless they renounced their status as French subjects. ${ }^{47}$

Tanganyika had already become independent from Britain on 9 December 1961, and, following the revolution in Zanzibar, the two territories merged in April 1964 to become the United Republic of Tanzania. The 1964 Constitution of the United Republic provided for Zanzibar to have a large degree of autonomy, including its own elections and government, provisions which remained largely in place under the 1977 Constitution in force as of 2014; Zanzibar also had its own constitution, with the current version dating from 1984; a constitutional review process was likely to result in a new constitution in 2015.

At independence, Tanganyika adopted the standard Commonwealth provisions on jus soli citizenship in its constitution and 1961 Citizenship Act; Zanzibar continued to apply the 1952 Zanzibar Nationality Decree which was also based on jus soli. Both laws were amended in 1964 to take into account the creation of the United Republic, and the 1961 Tanganyika Citizenship Act then recognised as citizens those born prior to union in Tanganyika or Zanzibar and those born after union in any part of the United Republic. ${ }^{48}$ Following the adoption of the 1984 constitution, which created a new definition of Zanzibari, the 1952 Zanzibar Nationality Decree was replaced in 1985 by the Zanzibari Act. The citizenship law for the Union was amended and re-enacted by the 1995 Tanzania Citizenship Act.

At sub-national level, competition for control of the Zanzibar government between the Civic United Front (CUF) and the mainland-based Chama Cha Mapinduzi (CCM) party (in power in Zanzibar since its 1977 merger with the ASP) made the question of Zanzibari citizenship and eligibility to vote in Zanzibar a perennial and conflictual debate. Notably, however, the 1984 constitution and 1985 Zanzibari Act did not base the criteria for Zanzibari status on an ethnic definition: under the act, a Zanzibari is a person who is a Tanzanian citizen according to the Tanzania Citizenship Act and who resided in Zanzibar prior to 12 January 1964 (the date of the revolution); or who was a Zanzibari citizen before 26 April 1964 (the date of Union) and has not lost his or her

Driving out the Invading Other", paper presented at the African Studies Association of the UK annual conference, Leeds, 6-9 September 2012.

47 Howard-Hassmann, Human Rights in Commonwealth Africa, p.102; Iain Walker, "Identity and citizenship among the Comorians of Zanzibar, 1886-1963" in Abdul Sheriff \& Engseng Ho (eds.), The Indian Ocean: Oceanic Connections \& Creation of New Societies London: Hurst \& Co, 2014.

48 Fransman's British Nationality Law, catalogue entry on Tanzania. 
Tanzanian citizenship; or who was born in Zanzibar and at least one of his or her parents was a Zanzibari; or who is a citizen of Tanzania and has at least one parent with Zanzibari status according to the other provisions. ${ }^{49}$ Naturalisation as a Zanzibari is also possible on application, on the basis of fifteen years' residence and other criteria very similar to those applied to people wishing to naturalise as Tanzanian.

Land redistribution had been a prime objective of the 1964 revolution, and all land in the islands was nationalised by the Confiscation of Immovable Property Decree of 1964, which was used to remove the valuable spice plantations from their Indian and Arab landlords, and then redistributed under the Land Distribution Decree of 1966. In 1989 a Commission for Lands and Environment was established to make recommendations on land tenure reform and land management, and for greater tenure security. Among the new laws passed was the Land Tenure Act of 1992, which established a new land tenure regime, within which two types of interest in land were established: a right of occupancy which is held in perpetuity and can only be held by a Zanzibari (as defined by the Zanzibari Act); and a leasehold which can be owned by both Zanzibaris and others. $^{50}$

The 1984 Constitution states that every Zanzibari who has attained the age of eighteen years old is entitled to vote in elections held in the country; these conditions are repeated by the 1984 Zanzibar Election Act. ${ }^{51}$ Restrictions on eligibility to vote in Zanzibar were increased from 1995, when a requirement of five years' residence on the islands was introduced. ${ }^{52}$ After heavily criticised 2000 general elections, in which the voter registration process in Zanzibar was condemned by independent observers, ${ }^{53}$ these restrictions were modified. Under amendments to the Election Act introduced in 2002, more specific criteria for residence were introduced, together with a reduction in the period required from five to three years: a person became eligible to register to vote if he or she is "ordinarily resident" in a constituency and has in fact lived there for the period of not less than thirty-six months consecutively prior to the registration day. ${ }^{54}$

49 Zanzibari Act No. 5 of 1985, section 3. See also Markku Suksi, Sub-State Governance through Territorial Autonomy: A Comparative Study in Constitutional Law of Powers, Procedures and Institutions, Chapter 4.4, "Zanzibar:Appeasing internal conflict by uniting for sub-state status", Springer, 2011.

50 Land Tenure Act, No.12 of 1992, Sections 7-18 and 46-54.

51 Constitution of Zanzibar 1984, section 7(1); Zanzibar Election Act. No. 11 of 1984, Section 12(1).

52 Section 11 of the Zanzibar Election Act 1984, as amended by Zanzibar Election Amendment Act 1995; see Zanzibar Wave of Violence: A fact finding Report on Police Brutality and Election Mismanagement in Zanzibar, Legal and Human Rights Centre (LHRC) and International Federation for Human Rights (FIDH), 2001.

53 Tanzania Election Monitoring Committee (TEMCO), Interim Statement on the General Elections in Tanzania, 2 November 2000; see also LHRC \& FIDH, 2001.

${ }^{54}$ Zanzibar Election Act, Section 12 (as amended by the Zanzibar Election (Amendment) 
Exceptions to these rules provided for students, security officers, government employees and people serving in international organizations.

From 2005, those seeking to register to vote also had to produce a Zanzibar identity card issued under the Registration of Zanzibari Residents Act (No. 7 of 2005). This act provides that every Zanzibari who is resident in Zanzibar is required to obtain a Zanzibar identity card (ZAN ID) on reaching majority. Obtaining a Zanzibar identity card is quite expensive: the independent Tanzania Election Monitoring Committee (TEMCO) estimated the total cost of obtaining a ZAN ID in 2009 as in the region of TShs.32,000 (about US \$22), and also time consuming, taking a couple of days for follow up.

There were also plentiful allegations that the CCM has dominated the process of defining who is an eligible voter, to its own advantage, through the manipulation of the local leaders known as shehas, who have to provide a letter as a prerequisite for the issue of a ZAN ID. The shehas are government-appointed and are often seen to be acting as CCM party cadres, creating difficulties for the recognition of the Zanzibari and Tanzanian citizenship of those with perceived "foreign" ancestry. ${ }^{55}$ Tense relationships between the CCM and the CUF were resolved with the creation of a national unity government in October 2010; which also led some Zanzibaris to feel betrayed. A new constitution proposed for 2015 would once again adjust the relationships between the component parts and the federation, with rules for membership of Zanzibar delegated to its own constitution.

Fundamental membership issues are also by no means resolved: in August 2009, the Zanzibar immigration authorities revived the 1968 decision that Zanzibaris of Comorian origin should renounce French nationality, by announcing that they would start confiscating the passports of Zanzibaris of Comorian origin on the grounds that they had failed to naturalise as Tanzanian citizens. ${ }^{56}$

The case of Zanzibar on the one hand shows how it is possible to introduce an objective, non-descent based, residence requirement for voter (and candidate) eligibility at sub-national level, while addressing anxieties about domination of politics by recent migrants and ethnic "ownership" of political rights; though it also demonstrates that a ruling party determined to manipulate such criteria may still be able to do so if strong procedural safeguards are not provided. Zanzibari identity politics has remained highly charged.

Act, No.12 of 2002).

55 Mohammed Bakari and Alexander Makulilo "Beyond polarity in Zanzibar? The 'silent' referendum and the government of national unity", Journal of Contemporary African Studies, Vol.30, No.2, (2012), pp.195-218; Tanzania Election Monitoring Committee, "Voter Registration and Updating of the Permanent Voter Register in Zanzibar", TEMCO Newsletter, Issue No.2, February 2010; Ben Rawlence, "Briefing: The Zanzibar Election" African Affairs, Vol.104, No.416 (July 2005), pp. 515-523.

56 Walker, "Identity and citizenship among the Comorians of Zanzibar". 



\section{PART III}

\section{Citizenship law as problem and solution}

It may be true that the law cannot make a man love me, but it can keep him from lynching me, and I think that's pretty important. - Martin Luther King, Jr.

Nationality is not just a legal concept but also a profoundly political question of self-definition, periodically the focus of controversy anywhere in the world. The history of Africa has exaggerated these controversies. The carving up of the continent by European powers without respect for pre-existing political or even geographical boundaries, the temporary creation of large zones of free movement, the forced recruitment of labour from one region to another, the adjustment of borders and jurisdictions among the colonial powers, followed by an often troubled and hasty transition to independence and reimposition of smaller political units, not to mention ongoing irredentist demands for new states (some of them successful), have all made membership a fraught affair. There are libraries of books on these problems, their fundamental causes, and proposals for their resolution.

Those communities within Africa whose members find that their legal right to belong to the national community is contested are generally of three main types. Firstly, descendants of people who migrated, or were forced to move, during the colonial period, when administrative borders among territories of one colonial power were open. This set divides in turn into two main sub-categories: those whose ancestors came from outside the continent (from Europe, Asia or the Middle East); and — less well advertised, but far more numerous - those whose ancestors came from elsewhere in Africa (farmworkers in Zimbabwe, tenant farmers on cocoa plantations in Côte d'Ivoire, Nubian soldiers in Kenya, and many others). Secondly, ethnic groups whose pre-colonial boundaries cross modern borders, so those speaking the same language now find themselves in two (or more) different states. Among these groups are pastoralists whose nomadic lifestyle may take them across multiple borders; as well as populations affected by transfers of territory in the resolution of border disputes. Thirdly, African states face the same contemporary challenges of migration as do states in other parts of the world in this era of globalisation: the conundrum of how to integrate new migrants and refugees (and their children) into the national polity.

Sometimes these three categories overlap: in eastern Congo, some of the ancestors of the Banyarwanda (speakers of the language of Rwanda) were always in the territory of modern-day DRC, and a contemporary international border 
has cut through a historical state; others came as forced or voluntary labour on Belgian plantations; added to these are massive outflows of refugees fleeing preand post-independence violence in Rwanda and Burundi, and those in search of fertile unoccupied land.

But to what extent does formal legal citizenship play a role in these difficulties; and thus to what extent does citizenship law reform provide a possible route out of them? African politicians have manipulated and mobilised ethnic identity without any recourse to citizenship law (Rwanda); countries with blameless citizenship laws have also seen crises based on ethnic divisions (Chad); other countries have seen identity-based violence that owes nothing to membership of the national polity, but rather a lower-level administrative-political unit (Nigeria); the African Union has a major strand of work around "managing diversity" coming out of the surveys of governance carried out by the African Peer Review Mechanism (APRM), yet analysis of these surveys does not find it necessary to mention citizenship laws. ${ }^{1}$ While citizenship law has been studied in some of the most egregious cases, such as Côte d'Ivoire or Zimbabwe, most scholars have not found the provisions of the law relating to membership to be highly relevant ${ }^{2}$ - though there are exceptions. ${ }^{3}$ Some have argued that we should indeed move away from the "sovereign temporal and spatial framework" in theorising citizenship. ${ }^{4}$

Yet I do not think it is a coincidence that those countries with particularly problematic citizenship provisions have also been the site of some of the most intractable identity-based crises. And even in some of the cases where nationality seems not to be the main issue, connections with the law on nationality and documentation of identity are there: in Nigeria, the basis of identity in "indigeneity" (see chapter 13.1) derives from constitutional provisions on citizenship at the national and internal levels with legal roots that reach back to the colonial period; while in Rwanda, the ethnicity-specific identity cards first

1 See Diversity Management in Africa: Findings from the African Peer Review Mechanism and a Framework for Analysis and Policy-Making, UNECA, 2011.

2 For example, a recent study explicitly focusing on this issue notes the need to "reinsert the state into examinations of autochthony" and mentions citizenship law in one or two places, but does not consider the content of the laws referred to: Morten Bøås and Kevin Dunn, Politics of Origin in Africa: Autochthony, Citizenship and Conflict, London, Zed Books, 2013, p.33.

3 For example, Jeffrey Herbst, "The Role of Citizenship Laws in Multiethnic Societies: Evidence from Africa", in Richard Joseph (ed.), State, Conflict and Democracy in Africa, Lynne Rienner, 1999; Jeffrey Herbst, States and Power in Africa: Comparative Lessons in Authority and Control, Princeton University Press, 2000, Chapter 8: "The Politics of Migration and Citizenship"; and for a detailed study in the colonial period, Cooper, Citizenship between Empire and Nation.

4 Aolileann Ní Mhurchú, "Citizenship beyond state and sovereignty" in Isin and Nyers (eds.) Routledge Handbook of Global Citizenship Studies, pp.119-127. 
introduced by the Belgians played a notorious role in the 1994 genocide. ${ }^{5}$

Returning to the three headings in chapter 2 - citizenship or nationality; citizens' rights or human rights; and the right to a nationality - I hope it has been made clear that nationality in the international law sense remains foundational to the exercise of citizenship rights, as the term is used by sociologists and political scientists, the right to participate in public affairs, to be a full member of a community. Also, that the international human rights regime does not begin to guarantee the greater range of rights that flow to a person from holding a particular nationality; nor could it be required to do so. Therefore, that the right to a nationality should receive a great deal more attention from the human rights community - and the influence of nationality law on the politics of belonging in Africa from academic scholarship.

It is also the case, of course, that sometimes it is difficult to distinguish chicken and egg: rather than citizenship law creating a problem, politicians in countries with particularly severe identity-based divisions find nationality law a useful tool; perhaps without it, they would have found another way of preventing the participation of which group they wish to exclude. Even if this is true to an extent, however, I think provisions in the law have clearly exacerbated existing tensions or facilitated their exploitation - or helped to heal them. The law still provides a tool that can be used to resolve or increase such problems: I return to that possibility in the final chapter.

\subsection{Citizenship law as andependent variable}

Let us start with a comparison between two francophone countries for an indication of how provisions in the law can make a difference in their own right: Côte d'Ivoire, the subject of extended treatment in this book (chapter 8.7); and Senegal, as a counter-example. Though both within the same French legal tradition in terms of the way the law and procedure was shaped, the substantive difference in the law was significant.

In West Africa, the countries of AOF almost all — with the exception of Côte d'Ivoire - adopted versions of the standard provisions of nationality law in force in France at that time: in particular they provided for the automatic grant of nationality at birth on the basis of double jus soli, and the later automatic attribution of or right to opt for nationality to a child born in the country and still resident there at majority. In Senegal, the nationality code provided and provides in its first article that any person born in Senegal (before or after independence) of one parent also born there is Senegalese (no further conditions); and that a person who has always been treated as Senegalese (is in possession

5 Timothy Longman, "Identity cards, ethnic self-perception and genocide in Rwanda", in Jane Caplan and John Torpey (eds.) Documenting Individual Identity: The Development of State Practices in the Modern World, Princeton University Press, 2001. 
d'état de sénégalais) is regarded as fulfilling this requirement and can go to court to obtain a certificate of nationality in case of any doubt. ${ }^{6}$ As a transitional provision at independence, an additional right to opt for Senegalese nationality was given to anyone who was a member of the government of Senegal or an elected representative at any level, or any person married to a Senegalese or originating from a country in Africa formerly under the jurisdiction of France or neighbouring Senegal. ${ }^{7}$

By contrast, in Côte d'Ivoire, the law gave "nationality of origin" to every person born in Côte d'Ivoire unless both of his or her parents were foreigners (étrangers); those born in the country of foreign parents could opt for nationality at majority, but almost nobody did so. The lack of a definition of étranger, and the incorporation of a large part of what is now Burkina Faso into Côte d'Ivoire for some of the colonial period, meant that it was often impossible to know if a person's parents were "foreigners" under the law. As in Senegal, systems for registration as a national were established for those born in the territory of "foreign" parents or ordinarily resident there at independence, but the default rules did not create a presumption of progressive integration. Both in Senegal and in Côte d'Ivoire many of those who could have registered under transitional provisions would not have found out about these requirements within the time limits applicable. The gaps in the Ivorian law brought a lack of clarity on who was Ivorian and who was not, that both built up resentment against those "of doubtful nationality" and also created the possibility of suddenly denying the right to belong to people who had been born and brought up in the country, often of one or both parents also born in the country, and who had since independence been treated as Ivorian. Ultimately, those excluded in this way took to arms to defend their position.

Côte d'Ivoire already had a large immigrant population at independence,

${ }_{6}$ Loi n 61-70 du 7 mars 1961 déterminant la nationalité sénégalaise, Article premier: « Est Sénégalais tout individu né au Sénégal d'un ascendant au premier degré qui y est luimême né. Est censé remplir ces deux conditions celui qui a sa résidence habituelle sur le territoire de la République du Sénégal et qui a eu de tout temps la possession d'état de Sénégalais. La possession d'état dans le sens du paragraphe précédent consiste dans le fait pour celui qui s'en prévaut : $1^{\circ}$ ) De s'être continuellement et publiquement comporté comme un Sénégalais; $2^{\circ}$ ) D'avoir été continuellement et publiquement traité comme tel par la population et les autorités sénégalaises. " Foundlings and children of parents who are stateless or of unknown nationality are also Senegalese; though gender discrimination applied to the children of Senegalese mothers. Ibid.Articles 3 and 5. Gender discrimination was removed in 2013.

7 Ibid., Articles 28-31. «Article 29 : «Peut opter pour la nationalité sénégalaise: $1^{\circ}$ ) Toute personne originaire de l'un des Etats issus des anciens groupes de territoires d'Afrique occidentale française et d'Afrique équatoriale francaise, du Togo, du Cameroun et de Madagascar qui, à la date d'entrée en vigueur de la présente loi, a sa résidence habituelle au Sénégal;(Loi du 7 mars 1961). $2^{\circ}$ ) Toute personne mariée à une Sénégalaise depuis 5 ans. La même option est ouverte aux originaires des territoires limitrophes du Sénégal.» 
so that these nationality law choices could be argued to be the result rather than the cause of problems of integration; but contemporary commentary at independence regarded the Ivorian code as being fundamentally based on a jus soli principle, with a liberal attitude to integration, and foresaw no such problems, even though they noted definitional issues. ${ }^{8}$ Moreover, Senegal, which had been the administrative centre of AOF, also had a large immigrant stock: many had come from across the region for training and higher education; as well as labour for plantations in the Senegal river valley and the building of the DakarBamako railroad. Many Guineans fled to Senegal during the repressive years of Sekou Touré's rule in Guinea, and from Guinea-Bissau during that country's war of independence in the early 1970s. Yet, the UN figures for foreigners as a percentage of the population were 1.6 percent for Senegal in 2010, against 12.5 percent for Côte d'Ivoire: these figures are not arrived at on the same basis in each country, but they indicate the official understanding of the situation. ${ }^{9}$ Despite its own separatist movement in southern Casamance, Senegal has been one of the most stable African countries since the 1960s; nor is there the sense of a subterranean issue ready for exploitation in bad economic times. Senegalese are proud of their reputation for non-discrimination. It is surely plausible that at least one of the significant variables in this difference was the content of the law.

There is an interesting contrast to the Commonwealth countries. The former British colonies, with their standard terms on citizenship mostly incorporated into the new constitutional provisions and carefully drafted to ensure statelessness was avoided, had much greater formal legal clarity on the status of all those resident in each country as the new governments took over. The transitional provisions placed weight on double jus soli, by providing an automatic right to citizenship on the date of succession of states for those born in the country of one parent also born there. In principle, the situation after independence was also extremely clear, since the laws all provided for a jus soli acquisition of citizenship based simply on birth in the territory with very limited exceptions. However, in the context of the continuing economic dominance of the descendants of immigrants, a right to citizenship based only on birth in the territory proved unacceptable to the "indigenous" populations and thus politically untenable. Birthright citizenship was removed and replaced with a jus sanguinis system, founding nationality on the basis only of descent from a citizen; in the case of Sierra Leone and Uganda,

8 Decottignies and de Biéville, Les nationalités africaines, pp.178-181; Zatzepine, Le droit de la nationalité, pp.12-13 and 39-41. Also Procès-verbal de la séance du mercredi 8 novembre 1961, Commission des Affaires Générales et Institutionnelles, Assemblée Nationale.

9 United Nations, Department of Economic and Social Affairs, Population Division Trends in International Migrant Stock: The 2013 Revision, United Nations database, POP/DB/ MIG/Stock/Rev.2013, Table 3. The notes to the tables indicate that the data sources for Côte d'Ivoire encompass both foreign-born persons and foreign nationals; whereas those for Senegal include only foreign-born persons and refugees recorded by UNHCR. Who is a foreign national has of course been a matter of interpretation in Côte d'Ivoire. 
an explicit racial or ethnic element was also introduced, targeted at Lebanese or Asian immigrants respectively; and in Nigeria a link to "indigeneity" that operates to create similar discrimination (though also to include potential aliens who can claim a link to an "indigenous" group). Moreover, though the ability of those born and resident in the territory at independence to register as citizens was supposedly non-discretionary, those who applied were often left waiting for years - a strategy used in Uganda in particular - leaving them sometimes stateless and always with a very uncertain status in the place they were living. ${ }^{10}$

Ghana, whose political economy is in many ways similar to that of Côte d'Ivoire - mining and plantation-based, dependent on migrants from the north of the country and neighbouring states — at one time looked as though it might follow the same trajectory as its neighbour. The transitional provisions of the 1957 Ghana Nationality and Citizenship Act adopted the framework that became standard for other Commonwealth countries gaining independence, excluding from automatic citizenship at the date of independence those born in the country who did not also have a parent or grandparent born in the country, although those born in the country were able to register as citizens; jus soli was initially enacted for those born on the territory moving forward. Within a year or two of independence, politicians amended the citizenship laws to limit jus soli access to citizenship even for those born after independence, and to facilitate deportations (aimed at "foreigners" involved in opposition parties). Soon after, all "aliens" were required to obtain residence permits, the government adopted official policies to promote economic advancement of "indigenous" businesses, and by the late 1960s the position of migrant populations had become precarious: more than 200,000 people were expelled from the country in 19691970, most of them migrants from other West African countries. But the policy changed. Politicians started to mobilise the votes of the descendants of foreign migrants, rather than to incite violence against them; the "stranger" populations themselves organised to engage in politics, and were permitted to do so. The 1979 constitution relaxed the citizenship provisions to expand the category of persons eligible for nationality to those with a grandparent as well as a parent who is or was a citizen; and since 2002 Ghana has accepted dual citizenship (see box, chapter 5.1) Ghana is certainly not free of ethnic tensions, nor from politicians seeking to use an appeal to xenophobia, and nor is its law as inclusive as it might be; but the contrast with Côte d'Ivoire today could hardly be stronger.

The clearest example of later problems being generated by a failure to create a comprehensive and clear solution at independence itself is that of the Democratic Republic of Congo (chapter 8.6). In Congo, the nature of the

10 And often as important as substantive law are the procedural requirements and the level of state discretion; the rules in the majority of francophone countries that provide for the courts to adjudicate on nationality of origin are significantly preferable to the executive discretion established in Commonwealth countries: see chapter 7.2. 
colonial state and the rapidity and unplanned nature of the Belgian departure meant that there was no proper clarification of the legal status of those tens, probably hundreds, of thousands of people of Rwandan or Burundian origin imported to the country as labour on the plantations established for export crops. There was no detailed agreement on nationality and only a hastily adopted law on who could vote in the independence elections. The citizenship status of the Banyarwanda brought to Congo by the Belgians was complicated by the fact that Ruanda-Urundi had been mandated to Belgian administration by the League of Nations, and thus Belgium was expressly disallowed from imposing its nationality on the inhabitants of those territories (who, when brought to Congo, were therefore given distinctive identity cards from the existing populations and other immigrants). Yet their children could also be argued to obtain nationality automatically on a jus soli basis under an expansive 1892 law aimed at bringing as many as possible within Belgian jurisdiction. The uncertainty surrounding their status during the panicky simultaneous withdrawal of Belgium from Congo, Rwanda and Burundi, amid an outbreak of violence in Rwanda that drove refugees into Congo at the critical moment of independence, left the issue open as a running sore in DRC till today. The state succession provisions were then compounded by the initial decision of the new state to create a new basis for citizenship on ethnic identity, requiring an ancestor who "was or had been a member of a tribe or part of a tribe established in the Congo". This focus on "tribe" (later "ethnic group" or "nationality"), meant that forever after the political discussion has been about the date of arrival of some pristine forebear, rather than the means of integrating populations who as a matter of fact are now living in the territory and have nowhere else to go.

\subsection{The political utility and disutility of manipulating citizenship law}

It is easy to see the utility of discriminatory legal provisions or administrative policies in countries such as Côte d'Ivoire, Uganda or DRC for politicians with an uncertain power base looking to shore up their support among one interest group or another. Denial of (proof of) nationality has been a tool used above all against those who are believed to be supporters of a political opponent; one reason, perhaps, why identity-based manipulation of the law has so notably flared since the widespread (re)introduction of multiparty elections. In the Congo, the relatively privileged position of the Banyarwanda under Mobutu was in part based on the calculation of an autocratic leader that the loyalty to their protector of henchmen from a marginalised ethnic group would be greater; with Mobutu's death as the era of one-party rule ended, the benefit to politicians reversing this policy was all the more obvious.

In some countries, the pre-colonial history almost guaranteed that the independence leaders would flip over the discrimination the "natives" previously faced, as part of the process of sealing their own legitimacy. In the phase immediately after independence, denial of access to nationality was a 
way of clipping the wings of those whose economic and political power had been unfairly increased by the colonial regime. Algeria is perhaps the paradigm example. During the colonial period, only around ten thousand of five million Muslim Algerians had achieved full French citizenship rights, and at the cost of renouncing their Muslim personal status. As independence approached, the mass exodus of the pieds noirs after the peace agreement ending the war confirmed the belief of the new government that the former masters could not be trusted with equal legal status in the new era. The new nationality code, though nondiscriminatory at first glance, defined "Algerian" as a person of Muslim religion whose father and father's father was born in Algeria, making clear that neither Christian nor Jewish Algerians would be fully regarded as part of the national community. Later changes to the law reinforced this understanding, removing an already limited double jus soli provision. A similar logic, combined with the strong heritage of both the Ottoman empire and the Muslim umma, was at play in the other north African countries that included provisions discriminating on grounds of religion in their new laws.

In Sierra Leone and Uganda, the law was modified to exclude "non-Africans" from birthright citizenship, aimed at the economically powerful communities of Lebanese and Asian descent; in Liberia, the founders were clear that only "negroes" would have access to economic or political power. In Zimbabwe, it was rather the provisions on dual nationality that became a tool of disenfranchisement. The incoming government in 1980 had been forced to accept the possibility of dual nationality in the new law that would come into effect on majority rule - alone among all the Commonwealth countries whose independence constitutions were negotiated in this way. This was changed before long, but implemented in a straightforward manner to start off with. When the government's hold on power started to look shaky at the turn of the millennium, a "legal" method was found to shore up its control — and also to bolster support among "indigenous" Zimbabweans - by applying extremely formalist interpretations to foreign laws in relation to the attribution of nationality to children born outside the country. Potential voters for the first opposition party to challenge the independence leadership's hegemony could be made to vanish at the stroke of the registrargeneral's pen.

Access to nationality and identity documentation has been central to several recent African political agreements, including not only the 2003 LinasMarcoussis Accord and 2007 Ouagadougou Political Agreement between the Ivorian political opponents ${ }^{11}$, but also the less well-known August 2006 Togolese Global Political Accord (also signed in Ouagadougou) which envisaged

11 Chapter I of the OPA was headed "General identification of the population"; Chapter II was on the electoral roll. Reproduced in UN Security Council document S/2007/144, 13 March 2007. 
the issue of identity cards along with electoral cards. ${ }^{12}$ Citizenship was one of the five issues that created the stumbling blocks to a political agreement between South Sudan and Sudan on the terms of the secession (see chapter 9.2).

The political utility of nationality laws is perhaps most obvious in the case of individuals whom the government in power considers to be troublesome (chapter 8.2). The most notorious cases in Africa where nationality law has been abused to sideline high profile politicians are those of Kenneth Kaunda in Zambia and Alassane Ouattara in Côte d'Ivoire - a former president and a former prime minister - who were both denied the right to run for office on the grounds that their citizenship had been recognised in error. Other less well known cases included in this study encompass not only politicians, but union leaders, journalists and academics whose opinions and activities have troubled the government of the day. Denial of nationality is an especially powerful tool, because it puts the person outside the realm of those who have a right to share in the state's resources and to participate in the state's political institutions. Above all, it can be used to remove the person from the country, out of reach of political ambitions: most dramatically in the case of John Modise, who was deprived of nationality by birth when he became a candidate for the Botswanan presidency — though offered naturalisation, a naturalised citizen cannot be president in Botswana.

Similarly, where urban "strangers" have been denationalised or deported in one of the periodic waves of expulsion that have convulsed some countries in Africa since independence, the economic consequences have sometimes been severe, but the political utility to the government in power none the less for that. Idi Amin's expulsion of Ugandan Asians, for example, had a severe impact on the economy, but was welcomed by many as a challenge to the Asian dominance of commerce in the country (chapter 8.4). Moreover, when those affected clearly have some means available and the right to another nationality (as the Ugandan Asians did, until the British closed the door), there may very well be gross human rights violations during the process of their expulsion, but ultimately most will be able to return or move to that other country. They will not, therefore, linger in the territory where they are not welcome and thereby create a long-term threat to the polity. This was above all true of the European colonisers themselves: whites in Kenya, Zimbabwe, Algeria or elsewhere.

Much more damaging to the stability of the state itself has been the wholesale denial of the right to nationality to long term migrant populations settled in rural areas with established usage rights to farm or graze the land. ${ }^{13}$ The

12 Clause 1.2.5 Accord Politique Global, Ouagadougou, 20 August 2006.

13 In addition to the country-specific references cited where relevant in each section above, see, for example, the articles collected in Christian Lund and Catherine Boone (eds.) Africa Vol. 83, Issue 1, February 2013 (Land politics in Africa); V. Adefemi Isumonha, "Migration, Land Tenure, Citizenship and Communal Conflicts in Africa", Nationalism and Ethnic Politics, Vol.9, No.1 2003, pp.1-19. 
most notable cases of such discrimination have been in Côte d'Ivoire and the DRC, where the decision to define - or redefine - the "nation" to exclude a very large percentage of the people living in the country (or in a particular region in the case of the Kivus in DRC) has been a recipe for disaster for government and state alike. In the end, a policy of xenophobia poses severe risks to the consolidation of government power or even to the long-term career of an individual politician. The existence of large populations of unintegrated and unintegratable marginalised "foreigners" of precarious legal status becomes, sooner or later, a highly destabilising feature of any polity.

The most recent cases of state succession in Africa - the secession of South Sudan, and the transfer of territory between Nigeria and Cameroon (sections 9.2 and 9.3) - have created, right from the outset, similar problems to those that exist in Côte d'Ivoire and DRC. In principle, the negotiators for Sudan and South Sudan could and should have negotiated transitional provisions that avoided statelessness related to the succession of states; in practice, this turned out to politically impossible, thanks to disagreements on the allocation not only of people, but also of oil and other resources, between the two countries. In the absence of an agreement, people with South Sudanese heritage in Sudan — including those with one (north) Sudanese parent, who under the Sudanese constitution have the "inalienable right" to Sudanese nationality - have been stripped of their identity cards and left potentially stateless, or live in a grey zone where their nationality may be challenged at any time. It seems sadly likely that a crisis of citizenship will unfold at some time or another. The transfer of the Bakassi Peninsula from Nigeria to Cameroon threatens similar problems, in a context where those affected have never moved from where they and their ancestors have lived. No constitutional or legislative amendments have been adopted in either country to provide clarity on the nationality status of those affected by the judgment of the International Court of Justice. Others living in zones affected by ICJ decisions are similarly in a legal "prison" of lack of documents; an issue which the ICJ does not consider in its judgments.

Denial of national citizenship has its mirror image in denial of the right to belong at the level of other administrative units within the so-called nationstate; and such policies are equally destabilising. At the provincial or local level, those excluded are often members of ethnic groups whose "home base" is in another part of the country. The consequence in some places has been violence in which many thousands of people have died: such as the pre- and post-election violence that has afflicted Nigeria, Kenya, DRC, Côte d'Ivoire and many other countries. It may be only in federal states that the legal definitions of membership of the federal units come to the fore, as considered in this study for Ethiopia, Nigeria and Zanzibar in particular; but administrative policies and political habits everywhere have similar impacts. In Nigeria, the link between domestic "indigeneity" and Nigerian nationality is made explicit by the requirement to produce a "certificate of indigeneity" in order to obtain a passport (chapter 13.1). 
But the problem with a focus on "indigeneity" or "autochthony" (according to local linguistic usage) is that once you choose that route, the necessary level of indigeneity to quality as "one of us" can be endlessly redefined. Since the political liberalisation of the early 1990s, ethnic violence and conflict over who "really" owns the land and the right to its resources have escalated, as politicians have succumbed to the temptation to "play the communal card". ${ }^{14}$ As Peter Geschiere and others have noted, in weak states where resources have come to be allocated on the basis of personal patronage, democratisation and decentralisation have often made a claim to autochthony the most accessible way to make a priority claim on those resources. ${ }^{15}$

\subsection{Not just an elite issue}

High profile cases such as those of Kaunda and Ouattara, and the targeting of those of European descent in Zimbabwe or Algeria, Asians in Uganda, or Lebanese in Sierra Leone, have encouraged a view that challenges related to nationality law are fundamentally a problem of the elites. Similarly, the campaigns in many countries to amend the law to allow dual nationality have come from the diasporas of African countries now living in Europe, the US or far afield; rather than from those with a parent from a neighbouring country. For ordinary people, the argument goes, nationality is - except in extreme cases of manipulation of the law such as Côte d'Ivoire or Zimbabwe - an abstract concept of little relevance to day-to-day life; if indeed it is a concept recognised at all by those living in a peasant or pastoralist economy far from the reach of the modern state. The tenor of those opposing dual nationality reforms is that those who are impacted by restrictions on dual nationality are individuals with political ambitions, international businessmen and the super-rich of probably dubious moral and social worth, and members of the increasingly numerous African diaspora who betrayed their own country to gain access to new passports but want the best of both worlds and wield their economic power to get it. ${ }^{16}$

14 Cynthia G. Brown and Farhad Karim (eds.), Playing the "Communal Card": Communal Violence and Human Rights, Human Rights Watch, 1995.

15 See references at chapter 2, footnote 4. See also, on the idea of autochthony in the intellectual relationship of Africa and the rest of the world, Achille Mbembe, " À propos des écritures africaines de soi ", Politique africaine, No.77, March 2000, pp. 16-45.

16 For just one example, quotes from discussion in the Constituent Assembly debating a new constitution for Tanzania: "Mr Louis Majaliwa proposed total deletion of dual citizenship in the constitution, saying 'They (Tanzanians in Diaspora) insulted us and we don't need them either."” Masato Masato, "Kadhi Court, Union, Citizenship Debate Rock CA", Tanzania Daily News, 10 September 2014. "Dr Mary Mwanjelwa said single citizenship was the key indicator of a person's trust, patriotism and obedience to their country. 'The issue here should not be dual citizenship but why people denounced their Tanzanian nationality in the first place'." Masato Masato, "Katiba Debate Nears Finishing Line", Tanzania Daily News, 11 September 2014. 
Lack of documentation is in part just one symptom of more general weaknesses in the state. A very large number of people in Africa have no access to documents because they don't see the point of having documents, and because they are costly in time and money to obtain. The first point of need is often when a child should enter school or needs to take an exam, but if schools are inaccessible or worthless, then what need for birth registration? If you remain entirely in the informal sector, a peasant farmer or transhumant pastoralist, then identity documents are not required; if the police demand money when you cross a border or an internal checkpoint whether or not you have the right documents, then a passport or identity card does not serve even its most basic use of proving your right to be present or to travel. If your strongest allegiance is not to a state but rather to an ethnic group, why obtain documents of such little emotional value. If, in addition, obtaining documentation requires a journey to the nearest administrative centre, a long wait to be seen, a mixture of official and unofficial fees, and at least a day's lost income, the cost-benefit analysis looks untempting.

But this is an underestimate of the extent to which lack of nationality impacts all but the most isolated communities - and, even more, the degree to which a lack of documents proving nationality is due to the provisions of the law (or lack of them) rather than simple prejudice, corruption or administrative ineptitude at the level of the individual civil servants responsible for processing applications.

Most obviously, identity documents and proof of nationality are needed for those crossing borders - or internal checkpoints. There is testimony in every human rights report investigating a national state of emergency anywhere in the world about the arbitrary use of identity documents in selecting individuals for "taxation" or, in the worst case, death. Even in less critical moments, the lack of a national identity document is an excuse for any state official to extract money or more from those who do not have them. An identity document was the most immediate need expressed in a survey of 172 migrants by UNHCR and IOM in 2013 in Niger and Togo - 60 percent mentioning documentation as a more urgent requirement than transport, food, health care, shelter and other needs. ${ }^{17}$

However, identification documents are, as others have noted, a tool of empowerment as well as of control, and also much-understudied as a basis for the consolidation or fragmentation of identities. ${ }^{18}$ The laws on which the identity documents are based - especially the nationality laws, but also related laws such as those on national identity cards or birth registration - are perhaps even more understudied by scholars. The narratives throughout this book show just how

17 Silvère Konan, Migrants en détresse: Analyse de situation et cadre de protection: Le cas du Niger et $d u$ Togo, UNHCR and IOM, July 2013.

18 Edward Higgs, The Information State in England: The Central Collection of Information on Citizens, 1500-2000, Palgrave Macmillan, 2004; Jane Caplan and John Torpey (eds.) "Introduction" in Documenting Individual Identity: The Development of State Practices in the Modern World, Princeton University Press, 2001. 
important nationality law is for "ordinary people" as they seek to access services and opportunities in even the most dysfunctional of states. For Sierra Leonean and Liberian former refugees in Guinea (chapter 11.1), children separated from their parents or taken in by children's homes across the continent (chapter 12), women and children trapped in a vacuum caused by gender discrimination (chapters 5.2 and 6.1.5), Nubian and Somali Kenyans (chapter 8.4), people of South Sudanese origin denied access to Sudanese nationality (chapter 9.2), Tuareg or Fulani nomads in West Africa (chapter 10.1), and many others, inability to access nationality documents has daily consequences for themselves and their children. Gender discrimination, whether enshrined in law or simply the norm in practice, ensures that those affected are not confined to particular geographies and members of specific ethnic groups, but spread throughout the population among the descendants of those who have rejected primordial attachments by "marrying out". Again, this is not just a question of elite women with nonAfrican husbands - though, thanks to their means, these are the cases that have mostly reached the courts — but just as much of the "market women" crossing African borders on foot on a daily basis. ${ }^{19}$

Everywhere across Africa, offices issuing identity cards are besieged with people trying to obtain proof that they belong. It is paradoxically often easier to register to vote than it is to obtain whatever document is required for national identity - even though voting is supposed to be restricted to nationals. Those who do not qualify find themselves unable to go to school, to open a bank account, to get a job in the civil service (from primary school teacher to customs official to magistrate) or in the formal economy, to qualify for scholarships at the national or local levels, or, of course, to organise politically and stand for office. For a young child, recognition of nationality may not be needed to access public services - childhood immunisations, primary school education and the like but just as soon as there is question of government scholarships or fee-waivers for secondary school or university, or of any access to the formal economy, or travel within or without the country, papers proving nationality start to become necessary.

It is of course possible to cross a border or exist in a remote area or live in an urban slum without paperwork, and it is certainly possible to resolve some problems of paperwork with money; but only so much can be achieved through

19 A.P. Cheater, "Transcending the State? Gender and borderline constructions of citizenship in Zimbabwe", in Thomas M. Wilson and Hastings Donnan (eds.), Border Identities: Nation and State at International Frontiers, Cambridge University Press, 1998; A. P. Cheater and R. B. Gaidzanwa, "Citizenship in Neo-Patrilineal States: Gender and Mobility in Southern Africa”, Journal of Southern African Studies, Vol. 22, No. 2, 1996, pp. 189-200; Rudo Gaidzanwa, "Citizenship, Nationality, Gender, and Class in Southern Africa", Alternatives: Global, Local, Political,Vol. 18, No. 1, 1993, Feminists Write International Relations, pp. 3959. 
bribing officials. ${ }^{20}$ Those applying the law are in the end charged with policing the boundaries of the system and ensuring that those who do not qualify do not get papers. Corruption is widespread, but if officials transgress too far beyond the limits of the law, they are likely in most places eventually to be found out. In particular, they may face difficulties if they go beyond simply taking money as an unofficial fee to issue a document that should be free, to supplying documents to those who are not "obviously" nationals. The money most people have to offer is not enough to overcome the risk of exposure in situations where such questions are critical; and many officials either want to do their job properly or have limits to the extent to which they will bend the rules, even for money (certainly, the amounts of money that poor people have to offer). This is true especially in the civil law system where the final adjudicators on nationality matters are judges; but it is also true of ordinary police officers, consular officials, and immigration ministry clerks.

Moreover, if documents are known to be obtained corruptly, they are mistrusted; and, if a person becomes prominent in some way — or is faced with hostile armed men at a roadblock in a moment of national crisis - will not be believed as proof of nationality. In any event, if a document is revealed as a fraud, those who obtained them will have to start again. Ivorian refugees in Guinea, all too aware of the importance of proof of nationality, and the difficulty of reestablishing it, had run with nothing but the clothes they stood up in - and their documents. ${ }^{21}$ In DRC, the lack of any system for distinguishing between recently arrived and long-standing Banyarwanda residents, and the lack of a law that provides the second generation with automatic access to nationality, has facilitated the demonisation of all. Even in South Africa, a far more functional state, corruption at the Department of Home Affairs has meant that official documents are not trusted as proof that a person has in fact the right to be in South Africa, or to be South African (chapter 11.6).

So people take the measures they need to exist, and a situation of doubtful nationality may simply mean the payment of a bigger bribe to obtain the documents required or to pass without documents, but the more difficult it becomes to get round such problems, the greater the level of exclusion. At the extreme ends of such practices, individuals find themselves dismissed from their jobs or driven from their homes; or just left in limbo, unable to progress with their plans for their lives. Law matters, even in some of the most dysfunctional states; and it matters more the greater the state's level of functionality - and for positive reasons of access to services and the political space reserved to citizens, not just because the state's ability to exert control over those who have papers is stronger. It is very easy for those who have the luxury of an uncontested

20 For a discussion of this issue in the Asian context, see Kamal Sadiq, Paper Citizens: How Illegal Immigrants Acquire Citizenship in Developing Countries, Oxford University Press, 2009.

21 Interviews, Conakry, May 2014. 
nationality in a functional state to argue that nationality law is essentially irrelevant; or that imposing the concepts of nationality and identity documents on those who live in remote areas is simply an act of repression. Even those who dispute the right of a state to exist will first of all need recognition of the nationality of that state to make the point without taking up arms. Those whose nationality is in doubt have to stay beneath the radar and hope that a defect such as the lack of a parent's birth certificate isn't noticed. We may wish this was not so; but individuals facing these challenges need recognition of their right to belong by the official processes administered by the state.

\subsection{Marginal citizens}

One characteristic of the policy debates around citizenship and statelessness is that it is often assumed that a state knows who is its national and who is not; that the line between citizen and alien is clear - even if there is also an intermediate category of legal resident and there may be some anomalous cases at the margins (for whom the category of stateless person has been created). There are major debates in citizenship studies about the citizenship behaviours of undocumented migrants in Europe or North America, the ways in which the undocumented exert rights within the civic space of the countries they now live, ${ }^{22}$ but much less ink is spilt on the rights of those who have never moved from where they and their parents were born and grew up and who believe themselves to be citizens.

Yet, in most if not all African countries there is a large number of people in this category, whose status as citizens is not clear; even though both officials and those nationals whose own membership of the state is unproblematic will frequently say that Nigerians or South Sudanese or Angolans or Senegalese "know who they are" and so there is no real problem with legal categories. Indeed, it is only when an application is made for paperwork at the lowest administrative levels - a national identity card or other document, even a birth certificate - that a person may first become aware that his or her nationality is seen as doubtful. This lack of clarity is not just because the law is being misapplied or implemented in a racially discriminatory or corrupt way, but inherent in the legal and administrative framework of the nationality law. While this category of "marginal citizens" exists in other regions around the world, the number of people with an unclear status, often marginal in geography but also marginal in terms of participation in the broader rights of citizenship, may be highest in the African continent.

22 For example, Parts I and II in Isin Nyers (eds.) Routledge Handbook of Citizenship Studies; Anne McNevin. "Undocumented Citizens? Shifting Grounds of Citizenship in Los Angeles" in Peter Nyers and Kim Rygiel (eds.) Citizenship, Migrant Activism and the Politics of Movement, New York and London: Routledge, 2012, pp. 165-183; Mae M. Ngai, Impossible Subjects: Illegal Aliens and the Making of Modern America, Princeton University Press, 2004. 
Thus, many people exist in a blurred zone between clearly having a nationality and clearly being stateless. It may be the case that some members of a community have some (but not all) documents related to nationality where they live (just a birth certificate, just a national identity card, just an electoral card - but were rejected or never applied for a nationality certificate or passport); whereas others were never registered at birth and applications for all other documents have been rejected; others have obtained documents by paying bribes to intermediaries; and others have travelled to a different "home" country to obtain documents there because they cannot get them where they currently live (or because they prefer to keep that affiliation). It is only in the effort of seeking documents that it will become apparent if a person is "considered as a national by any state under the operation of its law"23: that is, if he or she is stateless. Each person has his or her own narrative, and his or her own particular circumstances (of parentage, place of birth and childhood, marriage partner, habitual residence, autonomy of social status, access to connections and money) that will explain these outcomes - but cumulatively a lack of documents will fulfil the definition of stateless person.

This lack of clarity complicates the debate and leaves dangerous loopholes for the politically unscrupulous, since it is always possible for a government or political party to claim that it has no problem in principle with the right to nationality of a particular individual or group, while denying access to citizenship in practice through the deployment of administrative obstacles. Or for a politician to say that of course third generation children born in the country have the right to nationality — but as a matter of fact the documents members of a particular ethnic group produce to show this is the case are fraudulently acquired. Yet at the basis of these problems is usually not fraud among officials, but the letter and administration of the law, meaning that many are just as excluded from nationality where they live if they produce an original and genuine example of every document requested.

\subsection{Africa is not unique; politicians can choose to change direction}

There is a temptation to regard African states as unique in the difficulty of such issues. Yet while it is true that the violence of Africa's introduction to its European colonisers, the irrationality of the bordres created for African states and the abruptness of the departure of the colonisers, creates particular challenges, it is also the case that borders everywhere have been established by war, that post-imperial hangovers have given every continent headaches, and that contemporary migration threatens the equilibrium of even those states whose citizenship rules seem most stable. Eugen Weber reminds us that the creation of a common French identity was a surprisingly recent effort, ${ }^{24}$ while T.H.

23 Article 1(1), Convention relating to the Status of Stateless Person, 1954.

24 Eugen Weber Turning Peasants into Frenchmen, Stanford University Press, 1976; see also Weil, Qu'est-ce qu'un français. 
Marshall's classic work on the development of citizenship rights highlights property qualifications necessary to vote and thus to become a "citizen" that are perhaps not so different from the issues in Côte d'Ivoire (and many other African countries) over whether those who are tenants on others' land should have the right to participate in the national (and local) polity. ${ }^{25}$

Some African countries illustrate that there is an alternative; that politicians can choose to step back from an ideology of exclusion to one of inclusion. It is certainly easiest to make such changes at moments of major transition: in South Africa, for example, a series of legal reforms aimed to provide citizenship to historical migrants brought to South Africa under the harsh apartheid labour regime, while a wholesale reform of refugee and citizenship law provided new rights to South African citizenship for those born in the country who would otherwise be stateless (chapter 11.6). But law reforms can also be achieved more incrementally. Even after the initial glow of post-apartheid legal reform had faded, amendments to the South African Citizenship Act adopted in 2010 created rights to apply for citizenship for those born in the country and still resident there at majority; though it took litigation to force the government to recognise the right for a child born in South Africa to obtain citizenship if not eligible for any other, and access to birth registration has become more difficult for some. A large group of countries have removed gender discrimination, and most now allow dual nationality. Kenya's 2010 constitution creates the possibility of improved access to nationality for some historically excluded groups. The biggest hurdle still to overcome is the reversal of changes that have created rules based purely on descent, and the reform of naturalisation procedures, to create the genuine possibility of changing nationality as an adult. That is, to draft laws based on a range of what the International Law Commission calls "appropriate connections", that both allow a person to obtain recognition of nationality in the place where they have the strongest links, and also provide comfort to the existing population that those who have recognition of nationality have a real connection to the country of their nationality, and are not just "electoral cattle" herded in for their votes, or businessmen or criminals who have bought their papers.

Of course, this is not just a matter of legal drafting and state capacity; access to nationality goes to the heart of political and economic power. Recognition as a national (or member of a sub-national unit) is tied up with access to property, especially land, and with economic power more generally, as well as the right to vote and participate in public affairs. In times of economic and political insecurity, the "stranger" is always likely to be suspect. Politicians around the world have found other means than nationality law to stir up identity-based violence. Yet law reform can surely make a difference.

25 T.H. Marshall, Citizenship and Social Class (1950), as extracted in, for example, Gershon Shafir (ed.), The Citizenship Debates: A Reader, University of Minnesota Press, 1998. 



\section{The Right to a Nationality}

It remains to consider the legal and administrative reforms that could help to resolve the problems addressed in this book. I would not, of course, argue that law reform, least of all nationality law reform alone, will fix everything: there are many other variables that have been factors in individual exclusion and group conflict in Africa. You can't wave a legal wand and make everything better. I make the more modest case that there are legal provisions that can be adopted that will significantly help individuals currently excluded from nationality; more ambitiously, that such reforms may also make a contribution to the broader effort to ground the stability of African states and to create a consensus on who has the right to belong and participate in those states. These issues of legal definition of the members of the community should receive more attention from scholars interrogating conflicts of autochthony than they have so far.

In addition, I argue that the current international legal framework - while improving — is often unhelpful to address the realities on the ground. Developing the international regime may assist states to frame their own national laws in ways that are more helpful, and national advocates to put pressure on their own governments to adopt such reforms. Moreover, international law on nationality, including the presumption that statelessness should be avoided, was developed as a means of reducing friction between states, a way of assigning responsibility and ownership of persons, physical or legal, and their assets. The application of stronger rules for the grant of nationality may also be a way of reducing friction within states, of ensuring national security through ensuring human security. ${ }^{1}$ The nationality concerned should be the nationality of the place where the individual has the strongest connections, where he or she lives and intends to continue to make a life. There will always be people for whom that country is not clear, and people whom no country wants to accept; but that is no reason to avoid the challenge.

\subsection{A balancing act between consent and attribution}

The limited legitimacy of African states themselves has favoured (though not universally) the development of concepts of belonging rooted in a jus sanguinis understanding of ethnic identity - against even the pre-colonial traditions of African polities. Paradoxically, this trend has been most pronounced in many of the countries that inherited the pure jus soli rules in the Commonwealth countries from British law.

1 For discussion of the usefulness (or otherwise) of a "human security approach" in this context, see Alice Edwards and Carla Ferstman (eds.), Human Security and Non-Citizens: Law, Policy and International Affairs, Cambridge University Press, 2010. 
There is a political requirement to move towards some idea of membership that has the consensus support of the existing recognised body of citizens, while creating conditions for admission to that group that are rigorous enough not to be seen as an open door policy, and accessible enough that those who wish to be recognised as members of a state are not condemned to a decades-long or multi-generational limbo. The idea of mutual consent to citizenship, dating back to the early citizenship debates in Europe, still has relevance. At the same time, the requirements both of human rights norms and of national security mean that the mutuality of consent should not entail the exclusion of individuals or populations who have nowhere else to go, and cannot rationally be argued to have no rights in the territory where they find themselves. A way must be found to define who is a national that does not depend on purity of blood: the history of $20^{\text {th }}$ century Europe shows only too clearly in which direction that leads; as do the case studies in this book.

The question for the state and its politicians (and not only in Africa) is to find the policies that allow "strangers" to become "natives" in a way that neither leaves people vulnerable to perpetual exclusion nor creates a backlash among populations that see themselves as the hosts. And above all to make these rules clear and transparent to all: the dangers of a lack of clarity on the means by which nationality can be obtained are particularly obvious in those countries where citizenship issues have led to the greatest conflict. It is not unreasonable, and may be necessary or even desirable, to provide for distinctions between citizens and others, since the idea of greater rights for nationals than foreigners is fundamental to the idea of a "nation"; thus for the coherence of states and for social peace to be maintained. But there must be pathways from one status to the other. If no gates are open those inside the fence will find their privileged status itself under attack.

\subsection{Law, policy and process}

This law and policy reform approach does not ignore the fact that African states have many deep problems relating to citizenship and nationality - under any of the various definitions of these terms - due to their post-colonial origins and often hyper-diverse populations that are not necessarily related to nationality law in itself. In mapping out the pathways to citizenship, it seems there is no short cut through the political process. Top down legal reforms are important, but must have resonance and respond to the legitimate concerns of the affected populations.

It is thus certainly not the case that reforming nationality law will in itself solve the "native-settler", "autochthon-allochthon" conflicts in Africa. Moreover, the meaningfulness of discussions about membership of the national community depends also on the perceived legitimacy of those who are doing the discussing: on the nature of elections and effectiveness of public institutions; and even on the legitimacy of the state itself (most recently highlighted in the case of 
the secession of South Sudan). But the approach works on the basis that the state is an entrenched feature of the African geo-political landscape, whatever the utopian vision for some of a pan-African supra-national polity, despite the occasional successful creation of new state, and however much others may reject the concept of the modern state at all as purely an instrument of repression in Africa. Which is not to say that the movement towards regional or panAfrican citizenships is misconceived: far from it. But there are, as a matter of fact, political entities of which people need to be members, whose institutions even in the worst governed state may be useful as well as repressive, and in the best-governed are essential providers of public services and options for political voice. The building of regional citizenships will (almost?) inevitably depend on recognition of a person as a national citizen first of all. It is more useful to focus on establishing rules of due process and non-discrimination that can effectively sort people into one or another (or several) of those countries, and to emphasise practical solutions to people's everyday problems, than to agonise over the existential problems of statehood. And the law itself has an influence on popular perceptions about the problematic of the state.

Two continental movements have shown the power of persistent lobbying in changing the law related to nationality — but also in changing the minds of others in the national community on the nature of the problem: the campaigns for an end to gender discrimination, and for dual nationality to be allowed.

Since the mid-1990s, as civil society activity expanded into the space opened up by progressive democratisation, women's rights groups have successfully ensured that gender equality in nationality law has become the norm. About two-thirds of African states now ensure the right of a woman to transmit her nationality to her children; more than half allow a husband to acquire nationality on the same terms as a wife of a national (chapter 5.2). These reforms have been won country by country, legislative reform by legislative reform. Law reform may seem far from the day to day concerns of ordinary people, and respect in practice can remain a struggle, but these changes represent real gains in the daily lives of women; an insight well-understood by feminist legal scholars and activists. ${ }^{2}$

2 See for example, Fareda Banda, Women, Law and Human Rights: An African Perspective, Oxford: Hart, 2005, Chapter 8: Conclusion; Kafui Adjamagbo-Johnson, "Les lois, une expression " officielle " des rapports de genre", in Thérèse Locoh et Koff N'Guessan (ed.). Genre, population et développement en Afrique de l'Ouest, ENSEA, FNUAP, 1999; Celestine Nyamu-Musembi, "Addressing Formal and Substantive Citizenship: Gender Justice in Sub-Saharan Africa" in Maitrayee Mukhopadhyay and Navsharan Singh, (eds.) Gender Justice, Citizenship and Development, Zubaan, New Delhi and International Development Research Centre, Ottawa, 2007; also the research and publications of Women and Law in Southern Africa (WLSA) or Women in Law and Development in Africa (WILDAF). But, for a critique of "legal centralism", see Ambreena S. Manji, "Imagining Women's 'Legal World': Towards a Feminist Theory of Legal Pluralism in Africa”, Social \& Legal Studies Vol.8, pp. 435-455, 1999. 
During the same period as the campaigns for gender equality, a parallel lobbying effort largely from the African diaspora — but also from those advocating gender equality - has meant that a majority of African states now allow dual nationality also, a major change from the situation in the 1960s (chapter 5.3).

There is a need for a similar campaign around rights based on birth and residence - both in a state, and within sub-national units - in addition to those based on descent. A debate over the rules by which membership in the state (or other sub- or trans-national units) are determined, and the practicalities of proving the required conditions, may be a more fruitful way to resolve some of the most difficult questions of "who belongs" than a discussion of who historically owned the land or who arrived first. Rather than asking: who, culturally speaking, is a "real" member of the national (or local) community, or how has the post-colonial nation-state been constructed in Africa, or what in practice are the sub- or supra-national allegiances of individual residents of the state, there can be a counter-argument for criteria that are based on contributions made and ties created through birth, residence and place of work, and not only descent. Focusing on the provisions of the law creates a way of escaping from an understanding of membership based on ascription and perception; just as in the case of the campaign to remove gender discrimination, law reform cannot immediately resolve questions of discrimination in broader society, but it can provide real relief for people who are currently denied recognition by the state, and influence societal perceptions in the longer run.

The process of debating a new law or policy is itself an important exercise in public (and politician) education, even if there are many setbacks along the way; it is a contribution to the process of "imagining" the national community. ${ }^{3}$ Of course, creation of national citizenship must go well beyond legal formalism to the everyday building of trust in institutions, and will depend also on the "acts of citizenship" that in themselves create the fact of belonging. ${ }^{4}$ But the agitation for the legal right to citizenship — even when it involves taking up arms - is in itself an act of citizenship, an enactment of the claim to belong; and if individuals and groups are persistently denied the legal status to claim their rights, the lack of respect for a right to belong can undermine the state itself.

\subsection{A focus on "statelessness" may not be the most useful approach}

The international law on nationality and statelessness, as drafted and interpreted by states, does not tend to recognise the reality of the many millions of "marginal citizens" whose status is not clear. Rather than insisting on the need

3 Benedict Anderson, Imagined Communities: Reflections on the origin and spread of nationalism, Verso, London, 1991.

4 Engin F. Isin, and Greg M. Nielsen (eds.), Acts of Citizenship, New York: Palgrave Macmillan, 2008; also essays in Peter Nyers and Kim Rygiel (eds.) Citizenship, Migrant Activism and the Politics of Movement, New York and London: Routledge, 2012. 
for functional nationality systems, international law in this area focuses on first proving a negative (lack of nationality) and then providing protection. This is true first of all of the 1954 Convention relating to the Status of Stateless Persons; but, perhaps more importantly, of the key provision in the 1961 Convention on the Reduction of Statelessness, as well as the African Charter on the Rights and Welfare of the Child, that a child who is "otherwise stateless" should have the nationality of the state where he or she is born. This provision requires the (parents of) the child to prove that he or she is not a national of another state. In the circumstances where the parents may be refugees or second generation immigrants with no possibility of obtaining recognition of the citizenship of the state from which they originated despite a claim that on the face of it seems valid in law, but equally no proof that they cannot obtain that citizenship, this leaves everyone in doubt.

Some people who are blighted by lack of nationality where they live may in fact not be stateless in the literal sense. If they were to "return" to the country of their parents (of their father, above all), they may very well be able to re-establish documents in that place. Burkina Faso, for example, was prepared to recognise the nationality of many of those fleeing Côte d'Ivoire's policies of ethno-nationalism on the basis of their ancestral connection to Burkina Faso, or to grant consular cards to those who remained in Côte d'Ivoire, and others were able to bribe their way to papers, despite lack of documentation of parentage and place of birth. Nevertheless, those born and brought up in Côte d'Ivoire "were received with scepticism in Burkina Faso because of their perceived 'Ivorian' upbringing, language and behaviour, and were forced to face new forms of stigmatisation and exclusion". ${ }^{5}$ Moreover, a nationality in a country "of origin" is useless if the person has no intention of living in the other state, no continued connections to that place; and no expectation of consular or diplomatic protection should it be needed in their country of current residence. The status of "stateless person" may be even less useful.

Let us consider the former Liberian and Sierra Leonean refugees in Guinea who opted for "local integration" on the invocation of the cessation clause. They were offered the opportunity to apply for passports from their "home" country, though for them the very point of choosing local integration was to establish links to what was a new home. While not technically stateless (if the passport was issued - which for some it was not), and thus no longer a "statistic" for the purposes of UNHCR, they had many reasons for not wishing to return to their country of origin (or that of their parents), and their real need was for recognition of

5 Jesper Bjarnesen "Diaspora at Home? Wartime Mobilities in the Burkina Faso-Côte d'Ivoire Transnational Space", Uppsala Studies in Cultural Anthropology no 53, University of Uppsala, 2013, abstract and p.23. See also, Blion and Bredeloup "La Côte d'Ivoire dans les stratégies migratoires "; Benjamin Zanou and Siaka Lougue, Impact de la crise ivoirienne sur les migrations de retour au Burkina Faso, Paper presented at the XXVI IUSSP International Population Conference, Marrakech, 2009. 
Guinean nationality — which Guinean nationality law should theoretically have permitted by naturalisation. Without a Guinean identity document they faced serious daily challenges in accessing public services - or simply in moving about, even at a local level (chapter 11.1).

\section{4 "Undetermined nationality" and "de facto statelessness"}

In 2006, UNHCR responded to the difficulty of applying the rules on statelessness to ensure protection to vulnerable groups by deciding to make stronger efforts to identify both stateless populations and populations with undetermined nationality; ${ }^{6}$ but this decision had not been reflected in the agency's statistical reporting as of 2014, and there was no guidance on what "undetermined nationality" might include. ${ }^{7}$ In a parallel initiative, the agency reconsidered the concept of "de facto statelessness" that appears nowhere in any international treaty, but was mentioned in the Final Act of the conference leading to the adoption of the 1961 Convention on the Reduction of Statelessness and has attained quite widespread usage to deal with the situation of people whose status is not clear. Resolution I of the Final Act stated that "persons who are stateless de facto should as far as possible be treated as stateless de jure to enable them to acquire an effective nationality". There was no definition of de facto statelessness, but the implication was that it referred to a person without an effective nationality. UNHCR developed a working definition of de facto stateless persons as "persons outside the country of their nationality who are unable or, for valid reasons, are unwilling to avail themselves of the protection of that country"; that is, persons both without an effective nationality and in a "refugee-type" situation. ${ }^{8}$

However, this definition does not address the situation of those people who are inside the only country where they might claim nationality, but are unable to obtain proof of that nationality. It has been heavily criticised, ${ }^{9}$ is frequently used with different meanings ${ }^{10}$; and, if further developed, could provide the

6 UNHCR ExCom Conclusion on Identification, Prevention and Reduction of Statelessness and Protection of Stateless Persons No. 106 (LVII), 6 October 2006.

7 Laura van Waas, Amal de Chickera and Zahra Albarazi, The World's Stateless, Institute on Statelessness and Inclusion (The Netherlands), December 2014.

8 See discussions in Hugh Massey, UNHCR and De Facto Statelessness, UNHCR, Division of International Protection, LPPR/2010/01, April 2010; UNHCR, Prato Conclusions; UNHCR, Statelessness Determination Procedures and the Status of Stateless Persons (The "Geneva Conclusions"), December 2010.

9 Alison Harvey, "Statelessness: The 'de facto' Statelessness Debate”, Immigration, Asylum and Nationality Law, Vol.24, No.3, 2010, pp.257-264; Guy S. Goodwin-Gill, Definitions, Statelessness, and Stateless Persons: Some notes on some of the issues, Senior Research Fellow, All Souls College, Oxford, Professor of International Refugee Law, 2010 (unpublished manuscript on file with the author); and by this author and others at meetings.

10 For example, the discussion of "de jure", "de facto" and "effectively" stateless in Jacqueline Bhabha (ed.) Children without a state : A global human rights challenge, Cambridge, Mass.: MIT Press, 2011, introduction. 
opportunity for states to assert that a person is not "really" stateless, but only de facto, and thus not deserving of international protection; or alternatively that a person is not one of their nationals but actually de facto stateless, and thus avoid their obligations to provide recognition of nationality. The definition and use of the term de facto stateless was backed away from by UNHCR in Guidelines on Statelessness adopted in 2012 and compiled into a Handbook on Protection of Stateless Persons, published in 2014. ${ }^{11}$ The Handbook emphasises instead the common sense position that the key factor in determining if a person is stateless is factual state recognition of a person as a national.

On the definition of "stateless person", the UNHCR Handbook notes that "care must be taken that those who qualify as 'stateless persons' under Article 1(1) of the 1954 Convention are recognised as such and not mistakenly referred to as de facto stateless persons". ${ }^{12}$ Referring thereafter only to "stateless persons" (without qualification as de jure or de facto), the Handbook states that "establishing whether an individual is not considered as a national under the operation of its law ... is a mixed question of fact and law", thus:

[E]xamining an individual's position in practice may lead to a different conclusion than one derived from a purely objective analysis of the application of nationality laws of a country to an individual's case. A State may not in practice follow the letter of the law, even going so far as to ignore its substance. The reference to "law" in the definition of statelessness in Article 1(1) therefore covers situations where the written law is substantially modified when it comes to its implementation in practice. ${ }^{13}$

This elaboration of the definition is definitely helpful. However, it still does not address the question of which state is obliged to grant a stateless person its nationality; and more particularly, what are the obligations of states to grant nationality to someone whose entire life is based in that state, even where a person does not fulfil the definition of statelessness according to this interpretation. UNHCR adopted a separate Guideline which elaborated on the avoidance of stateless among children, but, like the other guidelines, and based as it had to be on UNHCR's mandate to interpret the provisions of the 1961 Convention, the analysis concentrates on the situation of children who would be "otherwise stateless", and the meaning of that phrase, rather than on the right to a nationality more broadly. ${ }^{14}$

11 UNHCR, Guidelines on Statelessness No. 1: The definition of "Stateless Person" in Article 1(1) of the 1954 Convention relating to the Status of Stateless Persons, HCR/GS/12/01, 20 February 2012; subsequently compiled into the Handbook on Protection of Stateless Persons under the 1954 Convention Relating to the Status of Stateless Persons, UNHCR, 2014.

12 Handbook, para 7.

13 Handbook, para.24.

14 UNHCR, Guidelines on Statelessness No. 4: Ensuring Every Child's Right to Acquire a 


\subsection{The right to change nationality}

This book has underlined the links between migration - historical or contemporary - and the risk of statelessness across the African continent. Even as widespread migration is permitted or even facilitated (as in the ECOWAS space), African states have been unable or unwilling to adopt or adapt or implement laws that allow migrants and their children to integrate in their new countries and become full nationals. Because the ways these laws are drafted allow in most cases for the unlimited attribution of nationality to generations of nationals born outside their country "of origin", the descendants of migrants in a new country are, over multiple generations, very often argued not to be "stateless", and rather simply to be "foreign".

The UNHCR Handbook attempted to deal with this problem of persons alleged to hold a nationality that is in practice ineffective by arguing that the status of a person as stateless is not purely a question of legal interpretation but also a question of fact, and whether a person can as a matter of obtain recognition of nationality in the country "of origin". But is it not time, rather, to take more seriously the third and often passed-over element of the Universal Declaration on Human Rights' Article 15 on nationality: the right of every person to change his or her nationality?

Commonly, the right to change nationality is interpreted in a limited sense to mean that a state should not prevent a national from renouncing nationality, provided that statelessness is not a result. It has not, to date, been found by any international authority to include the duty of a state to provide access to nationality for a person who as a matter of fact has the closest connections to that state, but may have the (even theoretical) right to another nationality. At the same time, it has been found in international tribunals that a state cannot force a change of nationality on a person in order to be able to exercise jurisdiction over him or her (most notoriously in the case of the mass imposition of German nationality on persons living in territories occupied by Germany during the Second World War). ${ }^{15}$ This prohibition seems, at first glance, reasonable where the attribution of nationality is compulsory with no possibility of opt-out, especially where a territory is under military occupation, or where acquisition of another nationality results in automatic loss of the nationality of origin.

But, on another look, there are countering arguments. There are also multiple national and international decisions on nationality in the context of colonialism, finding that the persons living in a conquered territory have acquired the nationality of the annexing power. More generally, practice in the context of succession of states, as well as the proposal in the ILC Draft Articles on the

Nationality through Articles 1-4 of the 1961 Convention on the Reduction of Statelessness, HCR/GS/12/04, 21 December 2012.

15 McDougal et al, "Nationality and Human Rights", at pp.920-921. 
Nationality of Natural Persons in relation to the Succession of States, is for nationality to be attributed on the basis of habitual residence, with a right of option to those who are qualified to have the nationality of both the predecessor and successor states.

Nationality law was originally developed for the convenience of states and not on the basis of human rights principles. Moreover, despite inroads on state discretion, international law has a lingering tolerance towards the highly restrictive criteria and arbitrary decision-making processes that are regularly applied to persons wishing to adopt the nationality of a new country, however long they have been resident and contributed to the life of that country, even where such residence has been well known to the authorities and those concerned have lost any effective connection to the state where they were born. The process of bringing naturalisation procedures within the frame of human rights, legitimate expectation and due process has not even begun in African states (with some very few and limited exceptions; see chapter 6.6). ${ }^{16}$

The right to change nationality should surely apply, however, not only to those who have themselves migrated, but above all to their children. In relation to nationality at birth, there is no ban on compulsory attribution of nationality: compulsory attribution is the norm. Indeed, the $19^{\text {th }}$ century move in European nationality law away from jus soli towards a jus sanguinis rule on nationality was to some extent based on the notion that it was more plausible to impute the "consent" of an infant to the nationality of his father (sic) than to the country of his birth (see chapter 2.3). The interpretation in many African states — both in law and in popular perception (influenced by the law) is that the attribution of nationality to the children of nationals born outside the country means that they should not be attributed nationality on the basis of the location of their birth. Yet a large majority of African states now allow dual nationality of origin, for example in the case of children with one parent who is a foreigner (even if they forbid it for those who naturalise or for those who voluntarily acquire another nationality). Though this move has been driven largely by diaspora Africans, it responds also to the lack of legitimacy of African borders, as they cut through members of the same linguistic or other community. Even where they do not, dual nationality as a child may be allowed (see chapter 6.4). Whereas creating processes of naturalisation as of right may be challenging, it should surely be possible at least to move to a more legal regime that is less discretionary and more easily accessed; while it is not too hard to believe that those African states that do not already do so may be prepared to concede a right to acquire a nationality based on birth and residence in the territory until majority (or for a shorter period). Indeed, they have signed up to such an obligation through the African and international human rights treaties.

16 For a discussion in the European and North American context, see Joppke, Citizenship and Immigration, pp.45-47. 


\subsection{The most inclusive citizenship law may be less stable than a median position}

The African laws in force at independence that had the strongest theoretical protections against statelessness for those born in their countries were those in the Commonwealth states, where the inclusion of comprehensive transitional citizenship provisions in the independence constitutions themselves, and the adoption of a pure jus soli regime for those born in the country after independence coupled with citizenship by descent for those born outside, in theory created a complete legal envelope assuring a nationality for everyone with a connection to each state. In practice, these rules were very quickly found to be politically unacceptable: Britain itself removed the pure jus soli rule in 1983. Similarly, the decision of the Belgian administration in the Congo to allow all Banyarwanda to vote in pre-independence elections, thus implying - without resolving in law - that they held the nationality of the soon-to-be-recognised state, did not address the concerns of those who might hope to hold positions of authority in that new state as to who would have the right to hold them to account. In Côte d'Ivoire, the policies of Félix Houphouët-Boigny that created access for foreigners to the rights of Ivorian nationals without even requiring them to obtain nationality resulted in a serious backlash, the adoption of rules based only on descent, and highly discriminatory application of those rules.

The problem has been that in rejecting what was perceived to be over-inclusive rules, the laws have instead reverted to a purely descent-based position, in which it is impossible for a "non-indigene" to acquire "indigeneity" on any basis; neither by naturalisation, nor by successive generations being born in the territory. The repeal of jus soli provisions was not accompanied by any intermediate rules for access to nationality on the basis of a stronger (but not exclusively descent-based) connection. By contrast, the francophone and lusophone countries that adopted double jus soli - birth on the territory and one parent also born there gives an automatic right to nationality — have seen a great deal more stability; both in their nationality laws, and also in their identity politics. Though an intermediate generation may still face substantial difficulties, there are no communities facing multi-generational exclusion with no way to access the right to participation in the life of the country where they live. Of course there are exceptions, such as in the case of Mali, where the double jus soli rule applies, but has not proved to work to integrate the nomadic Tuareg populations in the desert north of the country.

These more inclusive provisions for access to nationality are not only of benefit for the individual, but also for the state. Minimalist protections against statelessness that rely first of all on the proof of statelessness rather than the right to recognition of nationality by operation of law are not effective. There is no need to reinvent the wheel: though African traditions of membership and belonging can and should play a role in defining the content of nationality today, the experience from elsewhere is that the rules that create stability and inclusion are reasonably 
clear and remarkably similar. Essentially they are that the state where the person has the strongest links should recognise that person as a national. This level of connection should be presumed on the basis of two generations born in the country; and also in the case of a child born in the country and still resident there at adulthood, who should at minimum have a non-discretionary right to acquire citizenship of that country by declaration. Requiring a person to prove their lack of nationality elsewhere is an impossible demand to place, especially in the African context, and especially when nationality laws are frequently drafted to allow indefinite transmission of nationality for generations born outside the country. The argument that it is illegitimate for a person who has never even visited another country to have no rights at all where they are in fact settled is a strong one. Only the most racist politicians can argue indefinitely against rules that state that children born in a country of parents and grandparents also born in the country should not have the right to membership of the political community of that country, which is also where those children anticipate spending their entire lives and themselves having children.

As important as the substantive law is the establishment of procedures that reduce absolute executive discretion and create a greater role for the courts in adjudicating doubtful cases, with the possibility of accepting a variety of forms of proof of the connection to that state (also, of course, a strengthening of civil registration systems). The record in Africa also shows that provisions on access to nationality that require a positive action by the person concerned have not been effective: but while automatic attribution may be problematic in some cases where these issues are politically sensitive, the burden should at least be on the state to inform the person at the first opportunity (for example, on application for an ID card) that they need to opt for nationality, and - in the context of widespread ignorance of the rules on nationality - time limits should not exclude such an option in the way that they currently do so within a year or two of majority.

\subsection{Towards the right to a nationality in Africa}

Many millions of people in Africa live in a country that is not the one where they were born, and many millions more in a country that is not the one where their parents were born. Most of them have their origins in another African country; many have established new lives and intend to remain indefinitely in the "new" country, which may be the country of their birth. Despite this, it is very difficult to acquire the nationality of another country as an adult; and a number of African countries provide almost no possibility for the descendants of migrants to obtain the nationality of the country where they were born, even over multiple generations. Nationality law is also very poorly adapted to provide for those who do not live a settled existence. There are no definitions of "habitual" or "ordinary" residence allowing for habitual residence in more than one place (in case of naturalisation or state succession; but also at national level 
for voter registration and other events); and laws mainly based on location of birth may not be so relevant to those who consistently move about. Africa has a large percentage of its population following nomadic or transhumant lifestyles, yet its laws take no account of this fact.

The mirrored issues of nationality and statelessness have begun to take greater prominence within the institutions of the African Union; partly as a result of advocacy by the UN agencies and human rights groups, but also as governments themselves have realised the need to provide a stronger legal framework. In addition to initiatives to come to agreements on migration and documentation, two separate advocacy initiatives have brought results in the development of stronger standards on the right to a nationality for children and for adults.

\subsubsection{The implications of the drive to continental integration}

The decision to transform the OAU into the African Union revived interest in the immediate post-independence project to move rapidly to continental political integration. In September 1999, African heads of state and government meeting in Libya under the auspices of the OAU issued a declaration calling for the establishment of an African Union, in order to "rekindle the aspirations of our peoples for stronger unity, solidarity and cohesion in a larger community of peoples transcending cultural, ideological, ethnic, and national differences". ${ }^{17}$ Thanks to the same divisions that had existed in the 1960s, the African Union that was eventually launched in 2002 aspires to an architecture more similar to that of the European Union than a close political federation. Further discussions from 2006 at head of state level on the route "Towards a United States of Africa" have not resulted so far in any such grandiose outcomes. However, the debates surrounding these issues have relaunched the discussion of a common African citizenship that had flourished decades earlier; in 2002, a high-level meeting adopted a consensus statement urging that "Africa should move towards a common citizenship, through the initial steps of harmonizing citizenship, naturalisation, immigration and employment laws, and through progressively removing restrictions on travel." ${ }^{18}$ In 2004 and 2005, further meetings endorsed the idea of an African passport. ${ }^{19}$ In 2007, an African diplomatic passport was actually launched, for staff and representatives of the AU structures; a small step towards the longer term aim. At sub-regional level, discussions have also progressed on freedom of movement, requiring attention also to the integration

17 Sirte Declaration, Fourth Extraordinary Session of the Assembly of Heads of State and Government, 8-9 September 1999, EAHG/Draft/Decl. (IV) Rev.1.

18 Symposium on the African Union: Statement of Consensus, African Development Forum III: Defining Priorities for Regional Integration, Addis Ababa, Ethiopia, 3 March 2002.

19 Strategic Plan of the Commission of the African Union, 2004 - 2007; Report of the First Conference of Intellectuals of Africa and the Diaspora, Dakar, Senegal, 6-9 October 2004; Report on the African Union Conference of Ministers of Immigration, African Union Executive Council Seventh Ordinary Session 28 June - 2 July 2005, EX.CL/197 (VII). 
of those populations. ${ }^{20}$

The question of statelessness also began to enter into AU discussions, in part with the encouragement of UNHCR, but also as the AU institutions have come to see the importance of the question. The AU Migration Policy Framework adopted in $2006^{21}$ as well as the AU Border Programme ${ }^{22}$ both urged measures to address statelessness; and a meeting convened by the Department of Political Affairs in 2012 focused on the role of statelessness in conflict situations and urged African States to "develop an African regional instrument on statelessness that reflects African realities and context such as nomadic, historical migrations and border dimensions of the phenomenon". ${ }^{23}$ In 2007, African national human rights institutions also discussed the question of statelessness in the context of conflict and displacement, and adopted a resolution calling on states to reform their nationality laws. ${ }^{24}$

20 The Economic Community of West African States has had a sub-regional passport and internal freedom of movement since 1979, as well as rules intended to make it easier to establish businesses across the regional borders (see Manby, Migration, Nationality and Statelessness in West Africa for an outline of these rules). The revived East African Community has created a free movement regime among the five countries that make it up, with a common internal passport. Within the Southern African Development Community, however, disagreements over the content of a protocol on free movement led to a much watered-down version being adopted by the SADC summit in 2005, that provided very few additional rights to those already held. Other regional communities are further behind.

21 The Migration Policy Framework included among its other recommendations that AU Member States should "incorporate key guidelines as recommended in the 1954 and 1961 Statelessness Conventions", and "develop national legislative and policy frameworks to counter statelessness, particularly in cases of long-term residents, by reforming citizenship legislation and/or granting rights similar to those enjoyed by foreigners residing in the country." Migration Policy Framework for Africa, EX.CL/276 (IX), AU Executive Council, Ninth Ordinary Session, 25 - 29 June 2006, Banjul, The Gambia, Paragraph 3.7.

22 Experts meeting within the framework of the African Union Border Programme in June 2007 in Addis Ababa, Ethiopia, urged the States concerned by problems with the delimitation and demarcation of their boundaries to "take the necessary steps to protect the rights of the affected populations, notably where there is a risk of loss of nationality [statelessness], of real property or of forced displacement". Conference of African Ministers in charge of Border Issues, Report of the Meeting: Preventing Conflicts, Promoting Integration of the Preparatory Meeting of Experts on the African Union Border Programme, 4-5 June 2007, Addis Ababa, Ethiopia, BP/EXP/RPT (II); Declaration on the African Union Border Programme and its Implementation Modalities, Addis Ababa, 7 June 2007 BP/MIN/Decl.(II).

23 Recommendation 8 of the African Union Symposium on Citizenship in Africa: Preventing Statelessness, Preventing Conflicts, Nairobi / Kenya, 22-24 October 2012.

24 The Sixth Conference of African National Human Rights Institutions took place in Kigali, Rwanda in October 2007, on the theme of the "Role of National Institutions in the Protection of Refugees, Internally Displaced Persons and Stateless Persons", with the participation of UNHCR. Participants adopted a communique in which, "concerned 


\subsubsection{General Comment of the Committee of Experts on the Rights and Welfare of the Child}

A group of African child rights organisations led advocacy with the African Committee of Experts on the Rights and Welfare of the Child for the adoption of a General Comment on Article 6 of the African Children's Charter, which provides for the right to a name, birth registration and a nationality. The Committee organised a debate on the issues during its 20th ordinary session held in Addis Ababa, Ethiopia, in November 2012, including presentations from the AU Commission, UNICEF, UNHCR, Plan International and Save the Children, as a result of which it decided to draft a General Comment on the obligations of states parties. ${ }^{25}$ A draft of the General Comment was prepared during 2013, under the supervision of Prof. Julia Sloth-Nielsen, South African member of the Committee, and discussed at a technical review meeting held in Nairobi in January 2014, with the participation also of Prof. Maya Sahli Fadel, member and special rapporteur on refugees, asylum seekers and internally displaced persons for the African Commission on Human and Peoples' Rights. After revisions, the General Comment was formally adopted by the Committee at its April 2014 ordinary session, ${ }^{26}$ and provides the strongest elaboration in any international legal standard of the obligations of particular states in relation to children born or found on their territory (see chapter 3.12.1).

\subsubsection{A Protocol to the African Charter on Human and Peoples' Rights}

The African Commission on Human and Peoples' Rights has heard many cases in which the right to a nationality is relevant, and has repeatedly found that the right to nationality is implied within Article 5 of the Charter, on the right to dignity and a legal identity (see chapter 3.12). Founding their advocacy on these decisions, a group of human rights organisations under the banner of the Citizenship Rights in Africa Initiative (CRAI) ${ }^{27}$ conducted advocacy over several years for the Commission to establish stronger guidelines on the issues by drafting a protocol to the African Charter on the right to a nationality. A

about the intractable problems of refugees, IDPs and stateless persons in Africa", they recommended that African States should "evaluate and review existing legislations on citizenship and nationality and ensure that they do not create situations that could lead to statelessness" and work with international and regional organisations, including the African Union, for the "promotion, protection of rights of refugees, IDPs and stateless persons in Africa". "Kigali Declaration" issued by the Sixth Conference of African National Human Rights Institutions, Kigali, Rwanda, 8-10 October 2007.

25 Report of the African Committee of Experts on the Rights and Welfare of the Child, 12-16 November 2012, Addis Ababa, Ethiopia, ACERWC/RPT (XX), page 13.

26 African Committee of Experts on the Rights and Welfare of the Child, General Comment on Article 6 of the African Charter on the Rights and Welfare of the Child, ACERWC/GC/02 (2014), adopted by the Committee at its twenty-third Ordinary Session, 7-16 April, 2014.

27 Website of the Citizenship Rights in Africa Initiative (CRAI), at http:// citizenshiprightsinafrica.org/, last accessed 26 January 2015. 
private hearing during the $9^{\text {th }}$ extraordinary session of the Commisison in 2011 provided expert inputs from the African, European and Inter-American systems. In April 2013, the African Commission on Human and Peoples' Rights adopted a resolution which reaffirmed the right to a nationality as implied within Article 5 of the Charter, on human dignity and legal status, ${ }^{28}$ and delegated the task of drafting a study on the right to nationality on the continent to the special rapporteur on refugees, asylum seekers and internally displaced persons in Africa, Prof. Sahli Fadel. ${ }^{29}$ A May 2013 meeting between the African Commission on Human and Peoples' Rights and the AU Commission agreed the establishment of a working group on the issues. The Special Rapporteur sent out a questionnaire to states asking for information on nationality and statelessness, receiving responses from 15, as well as some national human rights institutions and civil society organisations. Based on these responses and other information, the Special Rapporteur presented a draft version of the study to the Commission in November 2013; a revised version of this draft was then presented, in April 2014, to a group of independent experts, legal professionals, researchers and members of civil society in Midrand, South Africa, to gather their comments and suggestions on the study contents and its recommendations. The final text of the study was reviewed and adopted by the African Commission during its 55th ordinary session, held in Luanda, Angola in April/May 2014. ${ }^{30}$ The resolution approving the study assigned the task of drafting a protocol to the special rapporteur. ${ }^{31}$

The next steps will be to convene an expert meeting to draft the text of the protocol, which is planned for early 2015, with the hope that a version will be ready for adoption by the Commission during 2015. Subsequently, the process would move to the level of state experts, ministers and finally adoption by the AU Assembly before it would be open for signature and ratification by member states.

28 African Charter Article 5: "Every individual shall have the right to the respect of the dignity inherent in a human being and to the recognition of his legal status. All forms of exploitation and degradation of man, particularly slavery, slave trade, torture, cruel, inhuman or degrading punishment and treatment shall be prohibited"

29 Resolution No 234 on the Right to Nationaltity, adopted at the $53^{\text {rd }}$ Ordinary Session, in Banjul, The Gambia, 9-23 April 2013.

30 The Right to Nationality in Africa, Study undertaken by the Special Rapporteur on the Rights of Refugees, Asylum Seekers and Internally Displaced Persons, pursuant to Resolution 234 of April 2013 and approved by the Commission at its 55th Ordinary Session, May 2014; which also includes a description of the history of the process leading to its adoption.

31 Resolution 277, on the drafting of a Protocol to the African Charter on Human and Peoples' Rights on the Right to Nationality in Africa, adopted at the $55^{\text {th }}$ Ordinary Session, 28 April - 12 May 2014, Luanda, Angola. 


\subsection{Recommendations for law reform}

The failure to create rights based on birth in the territory and to resolve issues of conflict of laws and dual nationality, allowing for the manipulation of the idea that a person "really" has the nationality of another country, have been the lead culprits in the creation of statelessness. The creation of rights based on birth and residence, including effective naturalisation procedures as well as access to nationality for children, must be central to their resolution.

The recommendations below are condensed version of the essential recommendations in previous studies, including the more detailed elaboration presented in Citizenship Laws in Africa: A Comparative Study. ${ }^{32}$ They also form the basis of the proposed draft text of a protocol to the African Charter. These highlighted points are the core recommendations that should form the basis of any reform effort.

\subsubsection{Removal of discrimination}

- Remove discriminatory provisions from domestic legislation in relation to the transmission of nationality to a spouse or child, including on the basis of sex, birth in or out of wedlock, race, religion, ethnic group or other criteria listed in the African Charter.

\subsubsection{Rights based on birth in the country}

- Ensure that every child has the right to a nationality, and that nationality shall be attributed at birth or as soon as possible thereafter, including through provisions that :

- Incorporate the safeguards against statelessness that are contained in the statelessness conventions and international and regional human rights treaties, as interpreted by the General Comment on Article 6 of the African Charter on the Rights and Welfare of the Child, including protection for foundlings and "otherwise stateless" children.

- Adopt the rule of double jus soli, that a child born on the territory of one parent also born there is automatically attributed nationality at birth.

- Provide that a person born in the country who remains there during childhood has the right to the nationality of that country either automatically or by option, at the latest at majority, and create the obligation for state institutions to inform the person of that right at the first opportune moment, with no time limit within which the option must be exercised.

\footnotetext{
32 Open Society Foundations, $2^{\text {nd }}$ edition 2010; $3^{\text {rd }}$ edition forthcoming 2015.
} 
- Ensure that domestic legislation on nationality creates a right to nationality, and systems to provide documents to prove it, for vulnerable children, including abandoned infants and children of unknown or deceased parents.

\subsubsection{Adaptation of rules for nomadic populations}

- Review laws to ensure that they are adapted to the contemporary African realities, including laws and regulations that provide systems for access to nationality for nomadic and border populations.

- In particular, adopt definitions of habitual residence and other connections to the state that allow for nomadic lifestyles and those whose communities are divided by an international border, and, if dual nationality is not permitted, create the right to opt (without time limits) for one or other nationality of persons who are habitually resident in or have strong connections to more than one country.

\subsubsection{Access to naturalisation}

- Establish conditions and procedures for naturalisation that are not overly onerous or subject to discretionary decision-making processes, and that are clearly advertised and accessible to all. Devise rules around proof of residence that, in the context of zones of free movement (such as in West Africa) do not insist on evidence based on participation in the formal economy but have some more flexible rules around the nature of "legal residence" and the burden of proof. Naturalisation should be facilitated for refugees and stateless persons.

\subsubsection{Dual nationality}

- While international law does not require recognition of dual nationality, some clarifications that relax the rules should be required. The law should either allow dual nationality in all cases; or make clear that dual nationality of origin is permitted for children and provide for the right to opt for another nationality at majority, but with the rebuttable presumption that nationality is maintained where the person is habitually resident.

\subsubsection{Civil registration, evidence and proof of nationality}

- Provide in law for judicial procedures to establish conclusive proof of nationality, including the right to appeal in case of rejection.

- Integrate efforts to upgrade civil registration systems with discussions on reform and implementation of nationality law, so that design and application of birth registration requirements do not inadvertently create statelessness.

- Allow for other forms of proof where documentary evidence (such as civil registration documents) is not available. 


\subsubsection{Due process}

- Reduce discretion in nationality procedures by providing objective criteria in laws and regulations, publishing the conditions that must be fulfilled and providing for administrative and judicial appeals in all cases.

\subsubsection{Protection and integration of stateless persons}

- Establish bi- and multi-lateral commissions with neighbouring states to determine the nationality of those whose status is in doubt and issue documents accordingly.

- Institute procedures for the determination of statelessness and the protection of stateless persons, including through providing pathways to obtain the nationality of the country where the person is resident.

\subsubsection{Internal citizenship}

- Adopt rules on internal citizenship of the units of federal states that conform to the same principles. The international norm is for eligibility for subnational benefits, to run for office at that level etc, to depend on "habitual residence" or similar criterion, whether or not a minimum period is set. 


\section{Valorisation Addendum for: Citizenship and Statelessness in Africa: The law and politics of belonging}

This thesis addresses a subject that has been of critical importance to African states since most attained independence in the 1960s: how to build a national identity and functioning polity out of highly diverse populations with no political history of government within the borders established by the colonial powers. It does so through the prism of nationality law, arguing that the role of the formal rules on membership of the polity in supporting or undermining the stabilisation of the modern state in Africa is both important and has been too little studied to date. On the basis of its findings the thesis makes recommendations that are of direct policy relevance to individual states, to the African Union and its institutions and to the work of UNHCR and other international agencies.

This book pulls together comparative legal analysis across all 54 African states and more than a dozen case studies of individual country situations in into one volume, sets them in a theoretical framework and in the context of the history of nationality law in Africa dating back to the pre-colonial period, and draws on the lessons of this history to inform its conclusions about the laws in effect today and their likely future impact.

This subject is of relevance not only in Africa but also globally, especially in the context of the current surge in transcontinental migration caused by conflict, in the Middle East and elsewhere, and by the increasing globalisation of the economy. How can those who flee or seek a better life, and especially their descendants, be best integrated into the states where they eventually find themselves - especially if it turns out that they are unable to go "home"? To what extent would a failure to provide these migrants and refugees a route to integrate in their new countries undermine the stability of those states in turn?

The research results will be of interest to policy-makers in a wide range of fields, including: law-makers and officials responsible for drafting and adopting nationality laws; oversight bodies examining the respect of particular states for their obligations under the international and African human rights treaties; human rights activists working at the national and global levels, especially those with a focus on children's or women's rights, as well as the rights of refugees and migrants; UNHCR policy units and field offices responsible for implementing the mandate of the agency on statelessness; and other UN and international agencies, including IOM. It will also be a resource for immigration lawyers outside the continent advising clients from Africa who may have a claim to protection as stateless persons. 
There is a wide range of fields of scholarship for which this book may be relevant, grouped under three main headings: the international and comparative law of nationality and statelessness; the origins of and solutions to conflict based on ethnicity and identity in Africa and elsewhere; and the citizenship (in its broader sense of participation) and integration of migrant populations more generally around the world.

In terms of academic impact, the thesis has two main aims: first, to urge scholars in political science and sociology to take more seriously the provisions of the law as having a real impact on popular understanding of "autochthony" and who belongs; secondly, to argue that international law should shift away from a focus on statelessness (proving a negative) and towards a focus on the right to a nationality in the country where a person has the closest connections, and on the design of functional laws and systems to provide nationality and legal identity.

There is no other book that tries to do the same thing as this work: that is, to integrate a comprehensive examination of Africa's nationality laws with a discussion of their impact in practice. There is in general little comparative scholarship on African nationality laws, and while there is a very large literature on the nature of the African state and on identity conflicts related to ethnicity and religion, very little of it pays more than glancing attention to the role of nationality laws in exacerbating or reducing such conflicts. There are some exceptions at the level of national studies (notably Côte d'Ivoire, DRC and Zimbabwe), but there is nothing that brings these studies into a cross-continental comparison dating back to the colonial period.

This research for this thesis was of three main types:

- The compilation of a comprehensive database of the nationality laws of all 54 African states, both historical and currently in effect (now made available to UNHCR's Refworld database), and the development of detailed comparative tables on the provisions currently in force. The first product of this research was a report published by the Open Society Foundations in 2009; but the content has been completely updated and expanded for this thesis.

- Wide-ranging reading in secondary sources about the history of nationality law in Africa, including of the British and French (and other) colonial powers as well as of the independent African states, and on conflicts since independence in which nationality was in question -matching this history with a chronology of amendments to the different laws and highlighting the ways in which the law was instrumentalised for political effect; or in which the law had political impacts that were not originally intended.

- Field work research conducted in the preparation of studies and conduct of advocacy for UNHCR and the Open Society Foundations. 
In addition to the thesis itself, the research will be published in a third edition of the OSF book on comparative African nationality laws (to be freely available as a PDF download); in a book that will focus rather on the country case studies and argument on the impact of law in practice, provisionally accepted for publication by Cambridge University Press; and in advocacy submissions in a range of contexts in Africa as the need arises. The recommendations in the thesis for reform to nationality law exist in more detailed form in a number of other publications.

Perhaps most importantly, the research on which the thesis is based has already informed and will continue to be used for a campaign for the adoption of a Protocol to the African Charter on Human and Peoples' Rights on the Specific Aspects of the Right to a Nationality and the Eradication of Statelessness in Africa. The African Commission on Human and Peoples' Rights adopted the text of the draft protocol at an extraordinary session in August 2015, and the campaign has moved to the other institutions of African Union and AU member states, with the aim that it will be adopted by the AU Assembly of Heads of State and Government and enter into force as a binding treaty. 



\section{Citizenship Bibliography}

\section{General}

Anderson, Benedict (1983 \& 1991). Imagined Communities: Reflections on the origin and spread of nationalism, London:Verso.

Annoni, Alessandra and Serena Forlati (eds.) (2013). The Changing Role of Nationality in International Law, Routledge, London and New York.

Arendt, Hannah (1958). The Origins of Totalitarianism, Meridian.

Batchelor, Carol A. (1995). "Stateless Persons: Some Gaps in International Protection”, International Journal of Refugee Law, Vol.7, No.2, pp.232-259.

Batchelor, Carol A. (1998). "Statelessness and the Problem of Resolving Nationality Status," International Journal of Refugee Law, Vol.10, No. 1/2, pp.156-183.

Batchelor, Carol A. (2006). "Transforming International Legal Principles into National Law:The Right to a Nationality and the Avoidance of Statelessness", Refugee Survey Quarterly, Vol. 25, No.3, pp.8-25.

Bauböck, Rainer (2005). "Expansive Citizenship: Voting beyond Territory and Membership, PS: Political Science and Politics,Vol. 38, No. 4, pp. 683-687.

Bauböck, Rainer (2006) Migration and citizenship: legal status, rights and political participation, IMISCOE / Amsterdam University Press

Bauböck, Rainer and John F. Rundell (1998). Blurred boundaries: Migration, ethnicity, citizenship European Centre for Social Welfare Policy and Research. Aldershot : Ashgate.

Benhabib, Seyla (2004). The rights of others: Aliens, residents, and citizens, Cambridge University Press.

Benhabib, Seyla and Judith Resnik (eds.) (2009). Migration and Mobilities: Citizenship, Borders and Gender NYU Press.

Bhabha, Jacqueline (ed.)(2011). Children without a state : A global human rights challenge, Cambridge, Mass.: MIT Press.

Blackman, Jeffrey L. (1998). "State Successions and Statelessness: The Emerging Rights to an Effective Nationality under International Law", Michigan Journal of International Law,Vol. 19, No. 3, pp.1141-1194.

Blench, Roger (2001). "You can't go home again": Pastoralists in the new millennium, Overseas Development Institute.

Blitz, Brad K. (2009). "Statelessness, protection and equality", Forced Migration Policy Briefing No.3, Refugee Studies Centre, University of Oxford.

Blitz,Brad K. and Maureen Lynch (2009). Statelessness and the Benefits of Citizenship: A Comparative Study, Geneva Academy of International Humanitarian Law and Human Rights.

Blitz, Brad K., Maureen Lynch, Rajith Lakshman and Samantha Balaton Chrimes (2011). The Cost of Statelessness: A Livelihoods Analysis, A project 
funded by the Bureau of Population, Refugees and Migration, United States Department of State.

Boll, Alfred Michael (2007). Multiple nationality and international law, Martinus Nijhoff Publishers.

Borella, François (1958). L'évolution politique et juridique de l'Union française depuis 1946, Paris: Librairie générale de droit et de jurisprudence

Bosniak, Linda (2006). The Citizen and the Alien: Dilemmas of Contemporary Membership, Princeton University Press.

Brown, Cynthia G. and Farhad Karim (eds.) (1995). Playing the Communal Card: Communal Violence and Human Rights, Human Rights Watch / Yale University Press.

Brubaker, Rogers (1992). Citizenship and Nationhood in France and Germany, Harvard University Press.

Bruschi, Christian (1987/88). "La nationalité dans le droit colonial”, Procès : Cahiers d'analyse politique et juridique, No.18.

Caplan, Jane and John Torpey (eds.) (2001). Documenting Individual Identity: The Development of State Practices in the Modern World, Princeton University Press.

Castles, Stephen, and Alastair Davidson (2000). Citizenship and Migration: Globalization and the politics of belonging, Macmillan.

Ceuppens, Bambi and Peter Geschiere (2005). "Autochthony: Local or Global? New Modes in the Struggle over Citizenship and Belonging in Africa and Europe" Annual Review of Anthropology, Vol. 34, pp.385-407.

Chan, Johannes M.M. (1991). "The Right to a Nationality as a Human Right: The Current Trend Towards Recognition", Human Rights Law Journal, Vol. 12, No.1-2, pp.1-14.

Costamagna, Francesco (2013). "Statelessness in the context of state succession: an appraisal under international law", in Annoni and Forlatti (eds.) The Changing Role of Nationality in International Law.

Crawford, James R. (2006). The Creation of States in International Law, 2nd Ed., Oxford University Press.

de Chickera, Amal (2010). Unravelling Anomaly: Detention, Discrimination and the Protection Needs of Stateless Persons, London: Equal Rights Trust.

de Dominicis, Felice (1916). Commento alla legge sulla Cittadinza Italiana del 13 giugno 1912, Torino: Unione Tipografico-Editrice Torinese.

de Groot, René (2011). Preventing Statelessness among Children: Interpreting Articles 1-4 of the 1961 Convention on the Reduction of Statelessness and Relevant International Human Rights Norms, background paper for joint UNHCR / Open Society Justice Initiative Expert Meeting on Preventing Statelessness among Children, Dakar, Senegal 23-24 May 2011.

de Groot, René (2013). Avoiding Statelessness resulting from Loss and Deprivation of Nationality: Interpreting Articles 5-9 of the 1961 Convention on the Reduction of Statelessness and Relevant International Human Rights Norms, background paper prepared for UNHCR Expert Meeting, Tunis, 31 October - 1 November 2013. 
de Vattel, Emmerich (1758). The Law of Nations or the Principles of Natural Law. Doek, Jaap E (2006). "The CRC and the Right to Acquire and to Preserve a Nationality”, Refugee Survey QuarterlyVol.25, pp.26-32

Donner, Ruth (1994). The Regulation of Nationality in International Law, 2nd Ed, Transnational Publishers, Inc.

Earnest, David C. (2003). Noncitizen Voting Rights: A Survey of an Emerging Democratic Norm, paper prepared for delivery at the 2003 annual convention of the American Political Science Association, Philadelphia, Pennsylvania.

Edwards, Alice and Carla Ferstman (eds.) (2010). Human Security and NonCitizens: Law, Policy and International Affairs, Cambridge University Press.

Edwards, Alice and Laura van Waas (eds.) (2014). Nationality and Statelessness under International Law, Cambridge University Press.

Faist,Thomas and Peter Kivisto (eds.) (2007). Dual Citizenship in Global Perspective: From Unitary to Multiple Citizenship, Houndmills, UK: Palgrave Macmillan.

Fielden, Alexandra (2008). "Local integration: an under-reported solution to protracted refugee situations," New Issues in Refugee Research: Research Paper No. 158 , UNHCR.

Fransman, Laurie (2011). Fransman's British Nationality Law, Third Edition, Bloomsbury Professional.

Geschiere, Peter (2009). The Perils of Belonging: Autochthony, Citizenship, and Exclusion in Africa and Europe. Chicago, IL: University of Chicago Press.

Gey van Pittius, EFW (1930). Nationality within the British Commonwealth of Nations, London: PS King \& Son.

Gohin, Olivier (2002) “La citoyenneté dans l'outre-mer français”, Revue française d'administration publique, No.101, pp.69-82.

Goldston, James A. (2006). "Holes in the Rights Framework: Racial Discrimination, Citizenship, and the Rights of Noncitizens", Ethics and International Affairs, Vol.20, No.3, pp.321-347.

Goodwin-Gill, Guy S. (2010). Convention Relating to the Status of Stateless Persons, UN Audiovisual Library of International Law.

Goodwin-Gill, Guy S. (2010). Definitions, Statelessness, and Stateless Persons: Some notes on some of the issues, Senior Research Fellow, All Souls College, Oxford, Professor of International Refugee Law (unpublished manuscript, on file with author).

Gorman, Daniel (2002). "Wider and Wider Still?: Racial Politics, Intra-Imperial Immigration and the Absence of an Imperial Citizenship in the British Empire", Journal of Colonialism and Colonial History, Vol.3, No.3, pp.1-24.

Gorman, Daniel (2007). Imperial Citizenship: Empire and the Question of Belonging, Manchester: Manchester University Press.

Hannum, Hurst (1995). “The Status and Future of the Customary International Law of Human Rights: The Status of the Universal Declaration of Human Rights in National and International Law", Georgia Journal of International and Comparative Law, Vol. 25, pp. 287-397. 
Hansen, Randall (1999). "The Politics of Citizenship in 1940s Britain:The British Nationality Act", Twentieth Century British History, Vol.10, No.1, pp.67-95.

Harvey, Alison (2010). "Statelessness: The 'de facto' Statelessness Debate", Immigration, Asylum and Nationality Law,Vol.24, No.3, pp.257-264.

Higgs, Edward (2004). The Information State in England: The Central Collection of Information on Citizens, 1500-2000, Palgrave Macmillan.

Howard-Hassmann Rhoda E., and Margaret Walton-Roberts (eds.) (2015). The Human Right to Citizenship: A Slippery Concept, University of Pennsylvania Press.

Internal Displacement Monitoring Centre (2014). Global Overview 2014: People internally displaced by conflict and violence, Norwegian Refugee Council.

Isin, Engin F. and Greg M. Nielsen (eds.) (2008). Acts of Citizenship, New York: Palgrave Macmillan.

Isin, Engin F., and Peter Nyers (eds.) (2014). Routledge Handbook of Global Citizenship Studies, London and New York: Routledge.

Joppke, Christian (2010). Citizenship and Immigration, Cambridge: Polity Press.

Karatani, Rieko (2002). Defining British citizenship : Empire, Commonwealth and modern Britain London, England, Portland, OR : Frank Cass.

Kastoryano, Riva (2005). "Citizenship, Nationhood, and Non-Territoriality: Transnational Participation in Europe", PS: Political Science and Politics, Vol. 38, No. 4, pp. 693-696.

Klusmeyer, Douglas B. and Alexander Aleinikoff (2000). From Migrants to Citizens: Membership in a Changing World, Washington, DC: Carnegie Endowment for International Peace.

Klusmeyer, Douglas B. and Alexander Aleinikoff (2001). Citizenship Today: Global Perspectives and Practices, Washington, DC: Carnegie Endowment For International Peace.

Klusmeyer Douglas B. and Alexander Aleinikoff (2002). Citizenship policies for an age of migration, Washington, D.C.: Carnegie Endowment for International Peace.

Knop, Karen and Christine Chinkin (2001)."Remembering Chrystal MacMillan: Women's Equality and Nationality in International Law”, Michigan Journal of International Law,Vol.22, No.4, pp.523-586.

Kymlicka, Will (1995). Multicultural Citizenship: A Liberal Theory of Minority Rights, OUP.

Lewis, Martin Deming (1962). "One Hundred Million Frenchmen: The 'Assimilation' Theory in French Colonial Policy" Comparative Studies in Society and History, Vol. 4, No. 2, pp. 129-153.

Lynch, Maureen (2005). Lives on Hold: The Human Cost of Statelessness, Washington, Refugees International.

Mandal, Ruma (2010). The definition of "Stateless Person" in the 1954 Convention relating to the Status of Stateless Persons: Article 1(1) - The Inclusion Clause, UNHCR, 19 May 2010. 
Manly, Mark (2014). "UNHCR's mandate and activities to address statelessness", in Edwards and van Waas (eds.) Nationality and Statelessness under International Law.

Mansfield, Edward D., and Jack L. Snyder (2005). Electing to fight: why emerging democracies go to war, Cambridge, Mass.: MIT Press.

Markakis, John (2004). Pastoralism on the Margin, Minority Rights Group International.

Marshall, T.H. (1950). Citizenship and Social Class and Other Essays, Cambridge University Press.

Massey, Hugh (2010). UNHCR and De Facto Statelessness, UNHCR, Division of International Protection, April 2010.

Moura Ramos, Rui Manuel (2013). Estudos de Direito Português da Nacionalidade, Lisbon : Coimbra Editora.

McDougal, Myres S., Harold D. Lasswell and Lung-chu Chen (1974). “Nationality and Human Rights: The Protection of the Individual in External Arenas", Yale Law Journal Vol.83 No.5, pp.900-998.

McNevin, Anne (2012). "Undocumented Citizens? Shifting Grounds of Citizenship in Los Angeles" in Peter Nyers and Kim Rygiel (eds.) Citizenship, Migrant Activism and the Politics of Movement, New York and London: Routledge, 2012, pp. 165-183.

Mhurchú, Aolileann Ní (2014). "Citizenship beyond state and sovereignty" in Isin and Nyers (eds.) Routledge Handbook of Global Citizenship Studies, pp.119127

Milano, Enrico (2011). “The Conferral of Citizenship En Masse by Kin-States: Creeping Annexation or Responsibility to Protect?" in Francesco Palermo and Natalie Sabanadze (eds.), National Minorities in Inter-State Relations, Leiden: Nijhoff.

Murray, Colin R.G. (2011). "In the Shadow of Lord Haw Haw: Guantánamo Bay, Diplomatic Protection and Allegiance”, Public Law, No.1, pp.115-138.

Nanz, Patricia (2009). "Mobility, Migrants and Solidarity: Towards an Emerging European Citizenship" in Benhabib and Resnik (eds.), Migrations and Mobilities.

Ngai, Mae M. (2004). Impossible Subjects: Illegal Aliens and the Making of Modern America, Princeton University Press.

Nyers, Peter and Kim Rygiel (eds.) (2012). Citizenship, Migrant Activism and the Politics of Movement, New York and London: Routledge.

Noiriel, Gérard (1995). "Socio-histoire d'un concept. Les usages du mot " nationalité " au XIXe siècle”, Genèses, Vol.20, pp. 4-23.

Parry, Clive (1957). Nationality and citizenship laws of the Commonwealth and of the Republic of Ireland, London : Stevens.

Pocock, JGA (1992). "The Idea of Citizenship Since Classical Times”, extracted in Gershon Shafir (ed.) The citizenship debates: A reader, University of Minnesota Press (1998).

Robinson, K. E. (1950). "The Public Law of Overseas France since the War", 
Journal of Comparative Legislation and International Law, Vol. 32, No. 3/4, pp. 37-57.

Saada, Emmanuelle (2007/2012). Les enfants de la colonie: Les métis de l'Empire français entre sujétion et citoyenneté / Empire's Children: Race, Filiation and Citizenship in the French Colonies, La Découverte / University of Chicago Press.

Sadiq, Kamal (2009). Paper Citizens: How Illegal Immigrants Acquire Citizenship in Developing Countries, Oxford University Press.

Shafir, Gershon (ed.)(1998). The citizenship debates: A reader, University of Minnesota Press.

Sloane, Robert D. (2009). "Breaking the Genuine Link: The Contemporary International Legal Regulation of Nationality", Harvard International Law Journal,Vol.50, No.1.

Smith, Rogers and Peter Schuck (1985). Citizenship without consent: Illegal aliens in the American polity, New Haven ; London :Yale University Press.

Snyder, Jack L. (2000). From voting to violence: Democratization and nationalist conflict, New York: Norton.

Southwick, Katherine, and Maureen Lynch (2009). Nationality Rights for All: Global Survey on Statelessness, Refugees International.

Soysal, Yasemin Nuhoğlu (1994). Limits of Citizenship: Migrants and Postnational citizenship in Europe, University of Chicago Press.

Spiro, Peter J. (2010). "Dual Citizenship as Human Right", International Journal of Constitutional Law,Vol.8, No.1, pp.111-130.

Spiro, Peter J. (2011). “A new international law of citizenship”, American Journal of International Law Vol.105, No.4, pp.694-746.

U.S. Committee for Refugees and Immigrants (various). World Refugee Survey (annual).

U.S. Government (various).

Country Reports on Human Rights Practices, Bureau of Democracy, Human Rights and Labor, Department of State (annual).

International Religious Freedom Report, Bureau of Democracy, Human Rights and Labor, Department of State (annual).

Findings on the Worst Forms of Child Labor, US Department of Labour (annual). van Hear, Nicholas (1993). "Mass Expulsion of Minorities: An Overview", Journal of Refugee Studies Vol.6, No.3, pp.274-285.

van Waas, Laura (2009). Nationality Matters: Statelessness under International Law School of Human Rights Research/Intersentia.

van Waas, Laura (2014). "The UN Statelessness Conventions”, in Edwards and van Waas (eds.) Nationality and Statelessness under International Law.

van Waas, Laura, Amal de Chickera and Zahra Albarazi (2014). The World's Stateless, Institute of Statelessness and Inclusion, The Netherlands.

Vermeer-Kunzli, Annemarieke (2013). "Nationality and diplomatic protection", in Annoni and Forlati (eds.), The Changing Role of Nationality in International Law. 
Verwilghen, Michel (1999). "Conflits de nationalités, Plurinationalité et apatridie", Recueil des cours Vol.277, Hague Academy of International Law, Martinus Nijhoff.

Vonk, Olivier (2015). Nationality Law in the Western Hemisphere: A Study on Grounds for Acquisition and Loss of Citizenship in the Americas and the Caribbean, Leiden/Boston: Brill Nijhoff.

Walzer, Michael (1983). Spheres of Justice: A Defense of Pluralism and Equality, New York: Basic Books.

Wang, Tova (2013). Voter Identification Requirements and Public International Law: An Examination of Africa and Latin America, The Carter Center.

Weber, Eugen (1976). Turning Peasants into Frenchmen, Stanford University Press.

Weil, Patrick (2002). Qu'est-ce qu'un français: histoire de la nationalité française depuis la Révolution Paris: Grasset

Weil, Patrick (2011). "From conditional to secured and sovereign: The new strategic link between the citizen and the nation-state in a globalised world", International Journal of Constitutional Law Vol.9, Nos.3-4, pp.615-635.

Weis, Paul (1979). Nationality and Statelessness in International Law (2nd Ed.), Kluwer.

Weissbrodt, David and Stephen Meili (2010). "Human Rights and the Protection of Non-Citizens: Whither Universality and Indivisibility of Rights?” Refugee Survey Quarterly Vol.28, No.4, pp.34-58.

Wilson, Robert R. and Robert E. Clute (1963). "Commonwealth Citizenship and Common Status", American Journal of International Law, Vol. 57, No. 3, pp. 566-587.

Wolff, Stefan (2013). "Conflict Management in Divided Societies: The many uses of territorial self-governance" International Journal on Minority and Group Rights (2013) Vol.20(1), pp.27-50.

Ziemele, Ineta (2014). "State succession and issues of nationality and statelessness" in Edwards and van Waas (eds.) Nationality and Statelessness under International Law.

\section{UN documents}

Committee on the Elimination of Discrimination Against Women (various), Concluding observations, state reports and other documents available at http:// www.ohchr.org/en/hrbodies/cedaw/pages/cedawindex.aspx, last accessed 26 January 2015.

Committee on the Elimination of Racial Discrimination (various), Concluding observations, state reports and other documents available at http://www. ohchr.org/EN/HRBodies/CERD/Pages/CERDIndex.aspx, last accessed 26 January 2015.

Committee on the Rights of the Child (various). Concluding observations, state reports and other documents available at http://www.ohchr.org/EN/ HRBodies/CRC/Pages/CRCIndex.aspx, last accessed 26 January 2015. 
Human Rights Committee (various). Concluding observations, state reports and other documents available at http://www.ohchr.org/EN/HRBodies/ CCPR/Pages/CCPRIndex.aspx, , last accessed 26 January 2015.

International Law Commission (1999). Draft Articles on Nationality of Natural Persons in relation to the Succession of States, with commentaries (Annex to UNGA Res. 55/153, 12 Dec. 2000).

UN Department of Economic and Social Affairs (various). World Population Prospects (periodic revisions).

UN Department of Economic and Social Affairs (various). Trends in International Migrant Stock (periodic revisions).

UNHCR (2008). Statelessness: An Analytical Framework for Prevention, Reduction and Protection

UNHCR (2009). Extracts of selected General Comments and Recommendations of the United Nations Human Rights Treaty Bodies relating to nationality and statelessness.

UNHCR (2010). The Concept of Stateless Persons under International Law (The "Prato Conclusions").

UNHCR (2010). Statelessness Determination Procedures and the Status of Stateless Persons (The "Geneva Conclusions").

UNHCR (2011). Interpreting the 1961 Statelessness Convention and Preventing Statelessness among Children (The "Dakar Conclusions").

UNHCR (2013). Interpreting the 1961 Statelessness Convention and Avoiding Statelessness resulting from Loss and Deprivation of Nationality (The "Tunis Conclusions").

UNHCR (2012). Guidelines on Statelessness No. 1: The definition of "Stateless Person" in Article 1(1) of the 1954 Convention relating to the Status of Stateless Persons, HCR/GS/12/01, 20 February 2012.

UNHCR (2012). Guidelines on Statelessness No. 2: Procedures for Determining whether an Individual is a Stateless Person, HCR/GS/12/02, 5 April 2012.

UNHCR (2012). Guidelines on Statelessness No. 3: The Status of Stateless Persons at the National Level, HCR/GS/12/03 17 July 2012.

UNHCR (2012). Guidelines on Statelessness No. 4: Ensuring Every Child's Right to Acquire a Nationality through Articles 1-4 of the 1961 Convention on the Reduction of Statelessness, HCR/GS/12/04, 21 December 2012.

UNHCR (2014). Handbook on Protection of Stateless Persons under the 1954 Convention Relating to the Status of Stateless Persons (incorporating Guidelines 1-3).

UNHCR (2013). Revised Background Note on Gender Equality, Nationality Laws and Statelessness.

UNHCR (various). Global Trends Report (annual).

UNHCR (various). Statistical Yearbook (annual).

UNHCR and World Bank (2013). Forced Displacement of and Potential Solutions for IDPs and refugees in the Sahel - Burkina Faso, Chad, Mali, Mauritania \& Niger.

UNICEF (2003). Trafficking in human beings, especially women and children, in Africa. UNICEF (2013). Every Child's Birth Right: Inequities and trends in birth registration. 
United Nations (2011). The United Nations and Statelessness: Guidance Note of the Secretary-General.

UNODC (2009). Global Report on Trafficking in Persons.

\section{General Africa}

Adejumobi, Said (2001). "Citizenship, Rights and the Problem of Conflicts and Civil Wars in Africa”, Human Rights Quarterly, Vol.23, No.1, pp.148-170.

Adejumobi, Said (2005). "Identity, Citizenship and Conflict: The African Experience", in W. Alade Fawole and Charles Ukeje, The Crisis of the State and Regionalism in West Africa: Identity, Citizenship and Conflict, CODESRIA, Dakar.

Adepoju, Aderanti (1995). "The politics of international migration in postcolonial Africa, in Robin Cohen (ed.), The Cambridge Survey of World Migration, Cambridge University Press.

Adepoju,Aderanti (2005). "Review of Research and Data on Human Trafficking in sub-Saharan Africa" in Frank Laczko and Elzbieta Gozdziak (eds.), Data and Research on Human Trafficking: A Global Survey, IOM (Special Issue of International Migration, Vol. 43 Nos.1\&2).

Adjamagbo-Johnson, Kafui (1999). "Les lois, une expression " officielle " des rapports de genre", in Thérèse Locoh et Koff N'Guessan (ed.). Genre, population et développement en Afrique de l'Ouest, ENSEA, FNUAP.

Aronowitz, Alexis (2009). Human Trafficking, Human Misery: The global Trade in Human Beings, Westport: Praeger, 2009.

Austen, Ralph (2010). Trans-Saharan Africa in World History, OUP.

Ayittey, George B.N. (1991). Indigenous African institutions, Ardsley-on-Hudson, NY:Transnational Publishers.

Banda, Fareda (2005). Women, Law and Human Rights: An African Perspective, Oxford: Hart.

Banda, Fareda (2008). "Protocol to the African Charter on the Rights of Women in Africa," in Malcolm Evans and Rachel Murray (eds), The African Charter on Human and Peoples' Rights: The System in Practice 1986-2006, Cambridge University Press, $2^{\text {nd }}$ edition.

Bayart, Jean-François, Peter Geschiere and Francis Nyamnjoh (2001). "Autochthonie, démocratie et citoyenneté en Afrique", Critique internationale (Special issue "J'étais là avant »: Problématiques politiques de l'autochtonie ), Vol.10, pp.177-194.

Bayart, Jean-Francois, Stephen Ellis and Beatrice Hibou (1999). The Criminalization of the State in Africa, James Currey.

Bøås, Morten and Kevin Dunn (2013). Politics of Origin in Africa: Autochthony, Citizenship and Conflict, London, Zed Books.

Bojosi, Kealeboga, and George M. Wachira (2006). "Protecting indigenous peoples in Africa: an analysis of the approach of the African Commission on Human and Peoples' Rights", African Human Rights Law Journal Vol.6, No.2, pp.382-406. 
Chabal, Patrick \& Jean-Pascal Daloz (1999). Africa Works: disorder as political instrument. Oxford: James Currey.

Chabal, Patrick (1992). Power in Africa: An essay in political interpretation, London: Macmillan.

Charrad, Mounira (2007). "Unequal Citizenship: Issues of Gender Justice in the Middle East and North Africa", in Maitrayee Mukhopadhyay and Navsharan Singh, (eds.), Gender Justice, Citizenship and Development, Zubaan, New Delhi/ International Development Research Centre, Ottawa. http://www.idrc.ca/ openebooks/339-3/

Cooper, Frederick (2005). "The politics of citizenship in colonial and postcolonial Africa” Studia Africana,Vol.16, pp.14-23.

Cooper, Frederick (2014). Citizenship between Empire and Nation: Remaking France and French Africa, 1945-1960, Princeton University Press.

Coquery-Vidrovitch, Catherine, Odile Goerg, Issiaka Mande \& Faranirina Rajaonah (eds.) (2003). Etre Etranger et Migrant en Afrique au XXe Siecle : Enjeux identitaires et modes d'insertion. Vol. I : Politiques migratoires et construction des identités; Vol. II : Dynamiques migratoires, modalités d'insertion urbaine et jeux d'acteurs. Paris : L'Harmattan

Crisp, Jeff (2003). "No Solution in Sight: The Problem of Protracted Refugee Situations in Africa”, Refugee Survey Quarterly, Vol.22, No.4, pp.114-150.

Cutolo,Armando and Peter Geschiere (eds.) (December 2008). "Dossier: Enjeux de l'autochtonie", Politique africaine, No.112.

da Ponte, Bruno (1974). The Last to Leave, Portuguese Colonialism in Africa, London: International Defence and Aid Fund.

de Benoist, Joseph-Roger (1979). La balkanisation de l'Afrique occidentale française, Dakar : Nouvelles éditions africaines.

de Donno, Fabrizio (2006), "La Razza Ario-Mediterranea : Ideas of Race and Citizenship in Colonial and Fascist Italy, 1885-1941", Interventions : International Journal of Postcolonial Studies, Vol. 8, No. 3, pp.394-412.

de Frouville, Olivier (2007). "Affaire Ahmadou Sadio Diallo (République de Guinée c. République Démocratique du Congo). Exceptions préliminaires : Le roman inachevé de la protection diplomatique", Annuaire français de droit international, Vol.53, pp.291-327.

Decottignies, Roger, and Marc de Biéville (1963). Les nationalités africaines, Collection du Centre de Recherches, d'Etudes et de Documentation sur les Institutions et la Législation Africaines, No.4, Paris.

Dorman, Sara, Daniel Hammett and Paul Nugent (eds.)(2007). Making Nations, Creating Strangers: States and Citizenship in Africa, Brill.

Dowden, Richard (2004). "The State of the State:The past, present and future of the nation state in Africa", New Economy, Institute for Public Policy Research (London), Vol.11, No.3.

Duffield, Ian (1984). "Pan-Africanism since 1940” in J. D. Fage, Michael Crowder, and Roland Oliver (eds.), The Cambridge History of Africa, Volume 8. 
Durieux, André (1955). Essai sur le statut des indigènes portugais de la Guinée, le l'Angola et du Mozambique, Bruxelles : Académie Royale des Sciences Coloniales.

Dutoit, Bernard and Denis Masmejan (1991). La nationalité de la femme mariée : Vol. 2 Afrique : Supplément 1976-1990 Librairie Droz, Geneva.

Dutoit, Bernard, Daniel Dumuse,Yves Gonset and Hélène Marie de Riedmatten (1976). La nationalité de la femme mariée : Vol. 2 Afrique Librairie Droz, Geneva.

Falola, Toyin and Kwame Essien (eds.)(2014). Pan-Africanism and the politics of African citizenship and identity, New York: Routledge.

Fawole W.Alade, and Charles Ukeje (2005). The Crisis of the State and Regionalism in West Africa: Identity, Citizenship and Conflict, CODESRIA, Dakar.

Fischer, Georges (1958). "L'indépendance de la Guinée et les accords francoguinéens" Annuaire français de droit international,Vol.4, pp.711-722.

Genova, James E. (2004). “Constructing Identity in Post-War France: Citizenship, Nationality, and the Lamine Guèye Law, 1946-1953”, International History Review, Vol.26, No.1, pp.56-79.

Geschiere, Peter (2005). "Autochthony and Citizenship: New Modes in the Struggle over Belonging and Exclusion in Africa", Forum for Development Studies, Vol.32, No.2, pp.371-384.

Geschiere, Peter and Stephen Jackson (2006). "Autochthony and the Crisis of Citizenship:Democratization,Decentralization, and the Politics of Belonging”, African Studies Review (Introduction to Special Issue: Autochthony and the Crisis of Citizenship), Vol.49, No.2, pp.1-7.

Gonidec,P.F.(1959)."Note sur la nationalité et citoyennetés dans la Communauté”, Annuaire française de droit international, Vol.5, pp.748-761.

Gonidec, P.F. (1961). «La nationalité dans les Etats de la Communauté et dans les Etats 'marginaux' " Annuaire français de droit international,Vol.7, pp. 814-835.

Halisi, CRD., Paul J. Kaiser, and Stephen N. Ndegwa (1998). “Guest Editors' Introduction: The Multiple Meanings of Citizenship: Rights, Identity, and Social Justice in Africa", Africa Today (Special issue: Rethinking Citizenship in Africa), Vol. 45, No. 3/4, pp. 337-349.

Herbst, Jeffrey (1999). “The Role of Citizenship Laws in Multiethnic Societies: Evidence from Africa", in Richard Joseph (ed.), State, Conflict and Democracy in Africa, Lynne Rienner.

Herbst, Jeffrey (2000). States and Power in Africa: Comparative Lessons in Authority and Control, Princeton University Press, Chapter 8:"The Politics of Migration and Citizenship".

Howard-Hassmann, Rhoda E. (1986). Human Rights in Commonwealth Africa, Rowman and Littlefield, Chapter 5: "State Formation and Communal Rights".

Iheduru, Okechukwu C. (2011). "African states, global migration, and transformations in citizenship politics", Citizenship Studies, Vol.15, No.2, pp181-203. 
Ishemo, Shubi (1995). "Forced labour and migration in Portugal's African colonies", in Robin Cohen (ed.), The Cambridge Survey of World Migration, pp.162-165.

Isumonha, V. Adefemi (2003). "Migration, Land Tenure, Citizenship and Communal Conflicts in Africa", Nationalism and Ethnic Politics, Vol.9, No.1, pp.1-19.

Keese, Alexander (2007). Living with ambiguity : integrating an African elite in French and Portuguese Africa, 1930 - 61, Stuttgart : Steiner.

Lampué, Pierre (1957). "L'étendue d'application du statut personnel des autochtones dans les territoires français d'outre-mer " Civilisations Vol.7, No.1, pp.1-15.

Louw, Lirette (2005). An Analysis of State Compliance with the Recommendations of the African Commission on Human and Peoples' Rights, doctoral thesis, University of Pretoria, South Africa.

Lugard, F.D. (1922). The Dual Mandate in British Tropical Africa, Blackwood \& Sons.

Lund, Christian and Catherine Boone (eds.) (2013). Africa Vol.83, No.1 (special issue on land politics in Africa).

Mamdani, Mahmood (1996). Citizen and Subject: Contemporary Africa and the Legacy of Late Colonialism, Princeton University Press.

Mamdani, Mahmood (2001). "Beyond Settler and Native as Political Identities: Overcoming the Political Legacy of Colonialism", Comparative Studies in Society and History, Vol.4, No.4, pp.651-664.

Manby, Bronwen (2009). Struggles for Citizenship in Africa, Zed Books, London

Manby, Bronwen (2010). Citizenship Law in Africa: A Comparative Study, $2^{\text {nd }}$ Edition, Open Society Foundations.

Manby, Bronwen (2014). "The historical development of citizenship law in Africa", in Isin and Nyers (eds.) Routledge Handbook of Global Citizenship Studies.

Manji, Ambreena S. (1999). “Imagining Women's 'Legal World': Towards a Feminist Theory of Legal Pluralism in Africa", Social \& Legal Studies Vol.8, pp. 435-455.

Mann, Gregory (2009). "What Was the Indigénat? The 'Empire of Law' in French West Africa”, Journal of African History, Vol. 50, No. 3, pp. 331-353.

Mann, Kristin and Richard Roberts (1991). Law in colonial Africa, Portsmouth, $\mathrm{NH}$ / London: Heinemann Educational Books / James Currey.

Mbembe, Achille (2000). "À propos des écritures africaines de soi ", Politique africaine, No.77, pp. 16-45.

Melone, Stanislas (1982). "La nationalité des personnes physiques », Encyclopédie juridique de l'Afrique : Vol VI, Droits des personnes et de la famille, Dakar : Nouvelles éditions africaines.

Ndahinda, Felix Mukwiza (2011). Indigenousness in Africa: A Contested Legal Framework for Empowerment of "Marginalized" Communities, The Hague: Springer. 
Neuberger, Benyamin (1976). “The African Concept of Balkanisation”, Journal of Modern African Studies, Vol. 14, No. 3, pp. 523-529.

Nugent, Paul (2004). Africa Since Independence: A Comparative History, Palgrave Macmillan.

Nyamnjoh, Francis B. (2007). "From Bounded to Flexible Citizenship: Lessons from Africa” Citizenship Studies, Vol.11, No.1, pp. 73-82.

Nyamu-Musembi, Celestine (2007). "Addressing Formal and Substantive Citizenship: Gender Justice in Sub-Saharan Africa" in Maitrayee Mukhopadhyay and Navsharan Singh, (eds.) Gender Justice, Citizenship and Development, Zubaan, New Delhi and International Development Research Centre, Ottawa.

Nzongola-Ntalaja, Georges, (2004). "Citizenship, political violence, and democratization in Africa”, Global Governance,Vol. 10 No.4, pp.403-407.

Ouraga, Obou (2007). "Le droit à une nationalité en Afrique subsaharienne " Revue ivoirienne de droit, No.38.

Parolin, Gianluca P. (2009). Citizenship in the Arab world: Kin, Religion and Nation State, Amsterdam University Press, Amsterdam.

Ranger, Terence (1983). "The Invention of Tradition in Colonial Africa", in Eric Hobsbawm and Terence Ranger (eds.), The Invention of Tradition, Cambridge University Press.

Rutinwa, Bonaventure (2002). "The end of asylum? The changing nature of refugee policies in Africa", Refugee Survey Quarterly, Vol. 21, Nos.1 \& 2, pp.12-41.

Scoones, Ian (1988). Sustainable pastoralism in Africa: an annotated bibliography, International Institute for Environment and Development

Seely, Jennifer C. , Emma Diambogne Diouf, Charlotte-Anne Malischewski, Maria Vaikath and Kiah Young-Burns (2013). "Second-class citizens? Gender in African citizenship law”, Citizenship Studies,Vol. 17, Nos.3-4, pp.429-446.

Shack, William A. and Elliott P. Skinner (eds.) (1979). Strangers in African Societies University of California Press.

Ukiwo, Ukoha (2012). "Ethnicity and citizenship in Africa: Some reflections" in Helen Lauer and Kofi Anyidoho (eds.) Reclaiming the human sciences and humanities through African perspectives Vol.2, Sub-Saharan Publishers, pp.11421153. [SOAS U300/753843]

UNECA (2011). Diversity Management in Africa: Findings from the African Peer Review Mechanism and a Framework for Analysis and Policy-Making.

Whitaker, Beth Elise (2005). "Citizens and Foreigners: Democratization and the Politics of Exclusion in Africa", African Studies ReviewVol. 48, No. 1, pp.109-126.

Whitaker, Beth Elise (2011). "The Politics of Home: Dual Citizenship and the African Diaspora”, International Migration Review,Vol.45, No.4, pp.755-783.

Widner, Jennifer A. (1995). "States and Statelessness in Late Twentieth-Century Africa”, Daedalus, Vol. 124, No. 3, pp. 129-153.

Zatzépine, Alexandre (1963). Le droit de la nationalité des républiques francophones d'Afrique et de Madagascar, Paris : Pichon et Durand-Auzias. 


\section{AU Documents}

African Commission on Human and Peoples' Rights (2005). Report of the African Commission's Working Group of Experts on Indigenous Populations/Communities, and research reports available at http://www.achpr.org/mechanisms/ indigenous-populations/, last accessed 26 January 2015.

African Commission on Human and Peoples' Rights (2007). Advisory Opinion on the United Nations Declaration on the Rights of Indigenous Peoples.

African Commission on Human and Peoples' Rights (2014). The Right to Nationality in Africa.

African Committee of Experts on the Rights and Welfare of the Child (2014). General Comment on Article 6 of the African Charter on the Rights and Welfare of the Child, ACERWC/GC/02.

Draft Aide Memoire: African Group: United Nations Declaration on the Rights of Indigenous People, 9 November 2006.

African Union, Policy Framework for Pastoralism in Africa: Securing, Protecting and Improving the Lives, Livelihoods and Rights of Pastoralist Communities, Department of Rural Economy and Agriculture October 2010.

African Union, Migration Policy Framework for Africa, EX.CL/276 (IX), AU Executive Council, Ninth Ordinary Session, 25 - 29 June 2006, Banjul, The Gambia, Paragraph 3.7.

\section{North Africa}

Al-Sharmani, Mulki (2003)."Livelihood and identity constructions of Somali refugees in Cairo," Forced Migration and Refugee Studies Working Paper No.2, American University in Cairo.

Asylum Research Consultancy (2013). Libya Country Report, UNHCR.

Ben Achour, Souhayma (2005). "L'étranger et la nationalité tunisienne : Le droit tunisien de la nationalité, est-il discriminatoire ?", paper presented at International Colloquium on "L'étranger", Faculté de droit et des sciences politiques de Tunis.

Bendeddouche, Jacqueline (1982). Notion de nationalité et nationalité algérienne, $2^{\text {nd }}$ Ed, Algiers: Société Nationale d'Édition et de Diffusion.

Boilley, Pierre (1999). Les Touaregs Kel Adagh : dépendances et révoltes : Du Soudan français au Mali contemporain, Paris : Karthala.

Bourouba, Samia (2013). Jurisprudence and Human Rights Standards in Arab Courts: Algeria - Iraq - Jordan - Morocco - Palestine, Raoul Wallenberg Institute.

Center for Migration and Refugee Studies (CMRS), American University in Cairo (2005). Africa Citizenship and Discrimination Audit: The Case Study of Egypt, prepared for the Open Society Justice Initiative.

El-Abed, Oroub (2003). The Palestinians in Egypt: An Investigation of Livelihoods and Coping Strategies, Forced Migration Refugee Studies Program, The American University in Cairo. 
El-Abed, Oroub (2004). "FMO Research Guide: Palestinian Refugees in Egypt", Forced Migration Online http://www.forcedmigration.org/guides/fmo028/

El-Abed, Oroub (2005). "Palestinian Refugees of Egypt: What Exit Options Are Left for Them?” Refuge Vol.22, No.2.

Elmadmad Khadija (2008). "Maroc: La dimension juridique des migrations", in Mediterranean Migration Report 2007-2008, Euro-Mediterranean Consortium for Applied Research on International Migration, European University Institute.

Elmadmad, Khadija (2002). Asile et Réfugiés dans les pays afro-arabes, Casablanca : Editions EDDIF.

European Commission (2005). Technical Mission to Libya on Illegal Immigration, 27 Nov - 6 Dec 2004, Report.

Hodges, Tony (1983). Western Sahara: The Roots of a Desert War, New York: Lawrence Hill \& Co.

Human Rights Watch (2006). Stemming the Flow: Abuses Against Migrants, Asylum Seekers and Refugees in Libya.

Human Rights Watch (2007). Egypt: Prohibited Identities: State Interference with Religious Freedom.

Human Rights Watch (2008). Human Rights in Western Sahara and in the Tindouf Refugee Camps.

Institute for Human Rights and Development in Africa (2008). Briefing paper on the return of expelled Mauritanians to the Islamic Republic of Mauritania following the August 6, 2008 coup.

International Crisis Group (2011). "Popular protest in North Africa and the Middle East (V): Making sense of Libya", Middle East/North Africa Report $N^{\circ} 107$.

Joseph, Suad (ed.) (2000). Gender and Citizenship in the Middle East, Syracuse University Press.

Julien, Charles André (1952). L'Afrique du Nord en Marche: Nationalismes musulmans et souveraineté française, Paris : $\mathrm{R}$. Julliard.

McBride, Kelly A. and Lindsey N. Kingston (2014). "Legal Invisibility and the Revolution: Statelessness in Egypt", Human Rights Review, Vol.15, No.2, pp.159-175.

Naik, Asmita (2012)."Returnees from Libya: The bittersweet experience of coming home", Policy Brief, IOM.

Omar, Sidi M. (2008). "The right to self-determination and the indigenous people of Western Sahara", Cambridge Review of International Affairs, Vol. 21, No.1, pp.41-57.

Perrin, Delphine (2007). "Identité et transmission du lien national au Maghreb : Etude comparée des codes de la nationalité”, L'Année du Maghreb 2007, pp.479-497.

Perrin, Delphine (2009). "Beyond the borders: Dual nationality in Western Mediterranean Countries", in I. Schäfer and J. R. Henry (eds.), Mediterranean policies from above and from below, Nomos, Baden-Baden, pp.537-561. 
Perrin, Delphine (2011). Immigration and Citizenship Law in the Maghreb: Turning Aliens into Citizens, EUI Working Papers, RSCAS 2011/40 Robert Schuman Centre For Advanced Studies and EUDO Citizenship Observatory.

Perrin, Delphine (2014). "Citizenship struggles in the Maghreb”, in Isin and Nyers, Routledge Handbook of Global Citizenship Studies.

Pierrot, Eirwen-Jane (2013). "A responsibility to protect: UNHCR and statelessness in Egypt”, New Issues in Refugee Research, Research Paper No. 250, UNHCR.

San Martin, Pablo (2005). "Nationalism, Identity and Citizenship in the Western Sahara", Journal of North African Studies, Vol.10, No.3-4, pp.565-592.

Souaré, Issaka K. (2007)."Western Sahara: Is there light at the end of the tunnel?" ISS Paper 155, Institute of Security Studies, South Africa.

United Nations (2010). Summary prepared by the Office of the High Commissioner for Human Rights in accordance with paragraph 15 (c) of the annex to Human rights Council resolution 5/1: Libyan Arab Jamahiriya,A/HRC/WG.6/9/LBY/3.

van Waas, Laura (2013). The Stateless Tebu of Libya? Tilburg Law School Legal Studies Research Paper No.10/2013.

van Waas, Laura and Zahra Albarazi (2014). "Transformations of nationality legislation in North Africa”, in Isin and Nyers Routledge Handbook of Global Citizenship Studies.

Weil, Patrick (2003). Le statut des musulmans en Algérie coloniale: Une nationalité française dénaturée, EUI Working Paper, HEC No. 2003/3, European University Institute.

\section{Sudan and South Sudan}

Abdulbari, Nasredeen (2011). "Citizenship Rules in Sudan and Post-Secession Problems" Journal of African Law Vol.55, No.2, pp.157-180.

Abdulbari, Nasredeen (2013). "Identities and citizenship in Sudan: Governing constitutional principles”, African Human Rights Law Journal, Vol.13, pp.383414.

Assal, Munzoul A. M. (2011). Nationality and Citizenship Questions in Sudan after the Southern Sudan Referendum Vote, Christian Michelsen Institute.

Assal, Munzoul A. M. (2014). "Struggles of Citizenship in Sudan" in Isin and Nyers Routledge Handbook of Global Citizenship Studies.

Idris, Amir (2012). "Rethinking Identity, Citizenship, and Violence in Sudan", International Journal of Middle East Studies, Vol. 44, No.2, pp 324-326.

Johnson, Douglas H. (1988). The Southern Sudan, London: Minority Rights Group, Report No. 78.

Manby, Bronwen (2011). International Law and the Right to Nationality in Sudan, Open Society Foundations.

Manby, Bronwen (2012). The Right to Nationality and the Secession of South Sudan: A Commentary on the Impact of the New Laws, Open Society Foundations.

Sanderson, Mike (2014). "Key Threats of Statelessness in the Post-Secession 
Sudanese and South Sudanese Nationality Regimes", Tilburg Law Review, Vol. 19, pp.236-247.

Sikainga,Ahmad A. (2011)."Citizenship and Identity in Post-Secession Northern Sudan”, Bulletin of the Association of Concerned Africa Scholars, Issue 86, pp.1119.

Smith, Jennifer and Joel R. Charny (2010). Sudan: Preventing Violence and Statelessness as the Referendum Approaches, Refugees International.

Vezzadini, Elena (2011). "Genealogies of Racial Relations: The Independence of South Sudan, Citizenship and the Racial State in the Modern History of Sudan," Bulletin of the Association of Concerned Africa Scholars, Issue 86, pp.3046.

\section{East \& Horn of Africa}

Abbink, Jon (1997). "Ethnicity and Constitutionalism in Contemporary Ethiopia", Journal of African Law, Vol.41, No.2, pp.159-174.

Adam, Adam Hussein (2009). "Kenyan Nubians: standing up to statelessness", Forced Migration Review, Vol. 32: Statelessness.

Adam, Hussein Adam (nd: 2008). Making of Stateless People - The Kenyan Style. Adegehe,Asnake Kefale (2009). "Federalism and ethnic conflict in Ethiopia : a comparative study of the Somali and Benishangul-Gumuz regions”, Doctoral Thesis, Leiden University

Ashamu, Elizabeth (2011). "Centre for Minority Rights Development (Kenya) and Minority Rights Group International on Behalf of Endorois Welfare Council v Kenya: A Landmark Decision from the African Commission" Journal of African Law, Vol.55, No.2, pp.300 - 313.

Aukot, Ekuru (2009). “Am I stateless because I am a nomad?” Forced Migration Review, Vol. 32: Statelessness.

Bakari, Mohammed and Alexander Makulilo (2012). "Beyond polarity in Zanzibar? The 'silent' referendum and the government of national unity", Journal of Contemporary African Studies, Vol.30, No.2, pp.195-218.

Balaton-Chrimes, Samantha (2011). "Counting as Citizens: Recognition of the Nubians in the 2009 Kenyan census", Ethnopolitics Vol.10, No.2, pp 205-218.

Balaton-Chrimes, Samantha (2011). "The Nubians of Kenya and the emancipatory potential of collective recognition", Australasian Review of African Studies, Vol.32, No.1, pp.12-31.

Balaton-Chrimes, Samantha (2013). "Indigeneity and Kenya's Nubians: seeking equality in difference or sameness?" Journal of Modern African Studies, Vol.51, No.2, pp 331-354.

Balaton-Chrimes, Samantha (2014). "Statelessness, identity cards and citizenship as status in the case of the Nubians of Kenya", Citizenship Studies, Vol.18, No.1, pp.15-28.

Balcha, Berhanu Gutema (2007), "Restructuring State and Society: Ethnic Federalism in Ethiopia", Doctoral Thesis, Aalborg University. 
Barya, John Jean (2000). "Reconstituting Ugandan Citizenship under the 1995 Constitution: A Conflict of Nationalism, Chauvinism and Ethnicity", CBR Working Paper No. 55, Kampala, Centre for Basic Research.

Bertz, Ned (2007). "Educating the Nation: Race and Nationalism in Tanzanian Schools" in Dorman et al, Making Nations, Creating Strangers.

Bezabeh, Samson A. (2011). "Citizenship and the logic of sovereignty in Djibouti”, African Affairs Vol. 110 No. 441, pp: 587-606.

Brietzke, Paul H. (1995). "Ethiopia's 'Leap in the Dark': Federalism and SelfDetermination in the New Constitution", Journal of African Law, Vol.39, No.1, pp.19-38.

Citizenship Rights in Africa Initiative (2010). Comments on the Citizenship Provisions of the Draft Kenyan Constitution.

Citizenship Rights in Africa Initiative (2011). Submission to the Task Force on Citizenship and Related Provisions of the Constitution.

Constitution of Kenya Review Commission (2002). The People's Choice: The Report of the Constitution of Kenya Review Commission, Nairobi.

Fessha,Yonatan Tesfaye and Christophe van der Beken (2013). "Ethnic Federalism and Internal Minorities: The legal protection of internal minorities in Ethiopia", African Journal of International and Comparative Law Vol.21, No.1, pp.32-49.

Fiseha, Assefa (2012). "Ethiopia's Experiment in Accommodating Diversity: 20 Years' Balance Sheet”, Regional \& Federal Studies, Vol.22, No.4, pp.435-473.

Fouéré, Marie-Aude (2012). "Fixing Zanzibari-ness on Paper: Sorting Out the Internal Alien and Driving out the Invading Other", paper presented at the African Studies Association of the UK conference, Leeds, 6-9 Sept.

Fouéré, Marie-Aude (2014). "Julius Nyerere, Ujamaa, and Political Morality in Contemporary Tanzania”, African Studies Review,Vol.57, No.1, pp. 1-24.

Gasarasi, Charles P. (1990). "The Mass Naturalization and Further Integration of Rwandese Refugees in Tanzania: Process, Problems and Prospects”, Journal of Refugee Studies Vol.3, No. 2, pp.88-109.

Gasarasi, Charles P. (2008). “The Question of the Recent Expulsion of Rwandans from Tanzania”, Journal of African Conflicts and Peace Studies Vol. 1, No.1, pp.111-125.

Ghai, Dharam P. and Yash P. Ghai (1965). "Asians in East Africa: Problems and Prospects”, Journal of Modern African Studies, Vol.3, No.1, pp. 35-51.

Ghai,Y. P. (1963). "The Kenya Council of State and the African Affairs Board of the Central African Federation: An Experiment in the Protection of Minorities", International and Comparative Law Quarterly, Vol. 12, No. 4, pp.1089-1132.

Heilman, Bruce (1998). "Who Are the Indigenous Tanzanians? Competing Conceptions of Tanzanian Citizenship in the Business Community." Africa Today Vol. 45, Nos.3-4, pp.369-387.

Human Rights Watch (1999). In the Name of Security: Forced Round-ups of Refugees in Tanzania. 
Human Rights Watch (2003). The Horn of Africa War: Mass Expulsions and the Nationality Issue (June 1998-April 2002).

Imbert-Vier, Simon (2013). “Afars, Issas . . and Djiboutians: Toward a History of Denominations”, Northeast African Studies,Vol.13, No.2, pp. 123-149.

International Crisis Group (1999). "Burundian Refugees in Tanzania: The Key Factor to the Burundi Peace Process”, Central Africa Report $N^{\circ} 12$.

International Refugee Rights Initiative (2005). "Citizenship and Forced Migration in the Great Lakes Region", Kampala.

International Refugee Rights Initiative (2008). "Going Home or Staying Home? Ending Displacement for Burundian Refugees in Tanzania”, Citizenship and Forced Migration in the Great Lakes Region Working Paper Kampala.

International Refugee Rights Initiative (2011). "Resisting Repatriation: Burundian Refugees Struggling to Stay in Tanzania”, Kampala.

International Refugee Rights Initiative (2012). "An urgent briefing on the situation of Burundian refugees in Mtabila camp in Tanzania”, Kampala.

International Refugee Rights Initiative (2013). "I can't be a citizen if I am still a refugee': Former Burundian Refugees Struggle to Assert their new Tanzanian Citizenship", Citizenship and Displacement in the Great Lakes Region Working Paper, Kampala.

International Refugee Rights Initiative (2013). "From refugee to returnee to asylum seeker: Burundian refugees struggle to find protection in the Great Lakes region", Briefing Note, Kampala.

Jembere, Aberra (2000). An introduction to the legal history of Ethiopia, 1434-1974, Münster; London: Lit Verlag.

Johnson, Douglas H. (2009). "Tribe or nationality? The Sudanese diaspora and the Kenyan Nubis", Journal of Eastern African Studies, Vol. 3, No. 1, pp.112131.

Kenya Human Rights Commission (2009). Foreigners at Home: The Dilemma of Citizenship in Northern Kenya.

Kenya National Commission on Human Rights (2007). An Identity Crisis? Study on the Issuance of National Identity Cards in Kenya.

Kenya National Commission on Human Rights (2010). Out of the Shadows: Towards Ensuring the Rights of Stateless Persons and Persons at Risk of Statelessness in Kenya.

Klein, Natalie S. (1999). Report on the Deportation of Eritreans and Ethiopians of Eritrean origin from Ethiopia, June - August, 1998, Embassy of Eritrea, Washington DC.

Legal and Human Rights Centre (LHRC) and International Federation for Human Rights (FIDH), (2001). Zanzibar Wave of Violence: A fact finding Report on Police Brutality and Election Mismanagement in Zanzibar.

Lynch, Gabrielle (2012). "Becoming indigenous in the pursuit of justice: The African Commission on Human and Peoples' Rights and the Endorois", African Affairs, Vol.111, No.442, pp.24-45.

Lynch, Maureen, and Katherine Southwick (2008). Ethiopia-Eritrea: Stalemate 
Takes Toll on Eritreans and Ethiopians of Eritrean Origin, Refugees International. Makoloo, Maurice Odhiambo (2005). Kenya: Minorities, Indigenous Peoples and Ethnic Diversity, Minority Rights Group International / CEMIRIDE.

Mamdani, Mahmood (1993). "The Ugandan Asian Expulsion: Twenty Years After” Journal of Refugee Studies Vol.6, No.3, pp.265-273.

Mazrui, Alamin (1999). Banditry and the Politics of Citizenship: The Case of the Galje'el Somali of Tana River, MUHURI, Mombasa.

Michael, Fantahun Haile (1989). "The Roots of Nationality Problems and the Challenge to Nation-building in Ethiopia”, DERAP Working paper Issue 250, Chr. Michelsen Institute.

Murphy, Sean D., Won Kidane and Thomas R. Snider (2013). Litigating War: Mass Civil Injury and the Eritrea-Ethiopia Claims Commission, Oxford University Press. Nahum, Fasil (1972). "Ethiopian nationality law and practice"Journal of Ethiopian Law, Vol.8, No.1, pp.168-183.

Nanjira, Daniel D. C. Don (1976). The Status of Aliens in East Africa: Asians and Europeans in Tanzania, Uganda and Kenya, New York, Praeger Publishers.

Ndegwa, S.N. (1997). "Citizenship and Ethnicity: an Examination of Two Transition Moments in Kenyan Politics", American Political Science Review, Vol.91, No.3, pp.599- 616.

Noor Mohammed N.A. (1972). The Legal System of the Somali Democratic Republic, Charlottesville,VA: Michie, Chapter 2, "Citizenship".

Plender, Richard (1971). "The Exodus of Asians from East and Central Africa: Some Comparative and International Law Aspects", American Journal of Comparative Law,Vol. 19, No. 2, pp. 287-324.

Rawlence, Ben (2005). "Briefing:The Zanzibar Election" African Affairs, Vol.104, No.416, pp. 515-523.

Read, James S. (1975). "Some Legal Aspects of the Expulsion", in Michael Twaddle (ed.) Expulsion of a Minority: Essays on Ugandan Asians, Athlone Press, London.

Refugee Law Project (2006). Critique of the Refugees Act, Kampala.

Rothschild, Donald (1968). "Kenya's Minorities and the African Crisis over Citizenship", Race \& Class Vol.9, No.4, pp.421-437.

Rutinwa, Bonaventure (1996) "The Tanzanian Government's Response to the Rwandan Emergency”, Journal of Refugee Studies, Vol.9, No. 3, pp.291-302.

Sedler, Robert Allen (1965). "Nationality, Domicile and the personal law in Ethiopia”, Journal of Ethiopian Law, Vol.2, No.1, pp.161-179.

Sharma, Vishnu D. and F. Wooldridge (1974). "Some Legal Questions Arising from the Expulsion of the Ugandan Asians", International and Comparative Law Quarterly,Vol.23, No.2. pp 397-425.

Smith, Alan H. (1971). "Prevention of Discrimination under Kenya Law", International and Comparative Law Quarterly,Vol.20, No.1, pp.136-142.

Smith, Lahra (2007). "Voting for an ethnic identity: procedural and institutional responses to ethnic conflict in Ethiopia", Journal of Modern African Studies, Vol. 45, No.4, pp.565-594. 
Smith, Lahra (2013). Making Citizens in Africa: Ethnicity, Gender, and National Identity in Ethiopia, Cambridge University Press.

Southwick, Katherine (2009). "Ethiopia-Eritrea: Statelessness and state succession”, Forced Migration Review, Vol. 32: Statelessness.

Suksi, Markku (2011). Sub-State Governance through Territorial Autonomy: A Comparative Study in Constitutional Law of Powers, Procedures and Institutions, Chapter 4.4, "Zanzibar: Appeasing internal conflict by uniting for sub-state status", Springer.

Thomas, Louise (2006). Refugees and Asylum Seekers from Mixed Eritrean-Ethiopian Families in Cairo, Centre for Forced Migration and Refugee Studies, American University in Cairo.

Uganda Constitutional Commission (1993). Final Report (Odoki Commission). Uganda Constitutional Review Commission (2003). Final Report.

UNHCR (2010). Finding a Home on Ancestral Land: Somali Bantu refugees gaining citizenship in Tanzania.

van der Beken, Christophe (2007). "Ethiopia: Constitutional Protection of Ethnic Minorities at the Regional Level”, Afrika Focus Vol.20, No.1-2, pp.105-151.

van der Beken, Christophe (2012). Unity in Diversity - Federalism as a Mechanism to Accommodate Ethnic Diversity: The Case of Ethiopia, monograph, Lit Verlag.

Walker, Iain (2014). "Identity and citizenship among the Comorians of Zanzibar, 1886-1963” in Abdul Sheriff \& Engseng Ho (eds.), The Indian Ocean: Oceanic Connections \& Creation of New Societies London: Hurst \& Co.

Walker, Samuel G. (2011). From refugee to citizen? Obstacles to the Naturalisation of Refugees in Uganda, Kampala: Refugee Law Project.

\section{Central Africa / DR Congo}

Bazonzi, José Mvuezolo (2008). "Crise identitaire et lutte de leadership dans la région des grands lacs : Lecture des principaux conflits fonciers et armés du Kivu 1900-2005”, in Bahru Zewde (ed.) Society, State, and Identity in African history, Addis Ababa: Forum for Social Studies, pp.218-230.

Bekker, Pieter H.F. (2002). "World Court Orders Belgium to Cancel an Arrest Warrant Issued Against the Congolese Foreign Minister", ASIL Insights.

Bucyalimwe Mararo, Stanislas (1997). "Land, Power, and Ethnic Conflict in Masisi (Congo-Kinshasa), 1940s-1994”, International Journal of African Historical Studies, Vol. 30, No. 3, pp. 503-538.

Bucyalimwe Mararo, Stanislas (2000). "La guerre des chiffres: Une constante dans la politique au Nord-Kivu”, L'Afrique des Grands Lacs Annuaire 1999-2000.

Bucyalimwe Mararo, Stanislas (2002). "Le Nord-Kivu au cœur de la crise congolaise", L'Afrique des Grands Lacs Annuaire 2001-2002.

Carter Center (2012). Presidential and Legislative Elections in the Democratic Republic of the Congo November 28, 2011, Final Report.

Durieux, André (1959). Nationalité et citoyenneté, Bruxelles: Académie Royale des Sciences Coloniales. 
Gray, Christopher J. (1998). "Cultivating citizenship through xenophobia in Gabon", Africa Today Vol.45, Nos.3-4, pp.389-410.

Human Rights Watch:

Rearming with Impunity: International Support for the Perpetrators of the Rwandan Genocide, May 1995

Forced to Flee: Violence Against the Tutsis in Zaire, July 1996

Zaire: 'Attacked By All Sides', March 1997

Zaire: Transition, War and Human Rights, April 1997

What Kabila is Hiding: Civilian Killings and Impunity in Congo, October 1997

Transition and Human Rights Violations in Congo, December 1997

Leave None to Tell the Story: Genocide in Rwanda, March 1999

D.R. Congo: War Crimes in Bukavu, June 2004

Renewed Crisis in North Kivu, October 2007

"You Will Be Punished": Attacks on Civilians in Eastern Congo, December 2009

Always on the Run: The Vicious Cycle of Displacement in Eastern Congo, September 2010

Human Security Report Project (2010). Human Security Report 2009/2010: The

Causes of Peace and The Shrinking Costs of War, Simon Fraser University, Canada.

Internal Displacement Monitoring Centre and International Refugee Rights

Initiative (2008). The Great Lakes Pact and the rights of displaced people: A guide for civil society.

International Crisis Group:

North Kivu: Into the Quagmire? An Overview of the Current Crisis in North Kivu, Africa Report N¹, 13 Aug 1998

Congo at War: A Briefing of the Internal and External Players in the Central African Conflict, Africa Report N², 17 Nov 1998

Africa's Seven-Nation War, Africa Report N4, 21 May 1999

Scramble for the Congo: Anatomy of an Ugly War, Africa Report N²6, 20 Dec 2000

The Kivus: The Forgotten Crucible of the Congo Conflict, Africa Report N56, 24 Jan 2003

Pulling Back from the Brink in the Congo, Africa Briefing N¹8, 7 Jul 2004

Maintaining Momentum in the Congo: The Ituri Problem, Africa Report No84, 26 Aug 2004

Back to the Brink in the Congo, Africa Briefing N²1, 17 Dec 2004

The Congo's Transition Is Failing: Crisis in the Kivus, Africa Report N91, 30

Mar 2005

Staying Engaged after the Elections, Africa Briefing N44, 9 Jan 2007

Consolidating the Peace, Africa Report N¹28, 5 Jul 2007

Bringing Peace to North Kivu, Africa Report N¹33, 31 Oct 2007

Four Priorities for Sustainable Peace in Ituri, Africa Report N¹40, 13 May 2008

Five Priorities for a Peacebuilding Strategy, Africa Report N¹50, 11 May 2009

A Comprehensive Strategy to Disarm the FDLR, Africa Report N¹51, 9 Jul 2009 
No Stability in Kivu despite Rapprochement with Rwanda, Africa Report N¹65, 16 Nov 2010

The Electoral Process Seen from the East, Africa Briefing N80, 5 Sep 2011

Eastern Congo: Why Stabilisation Failed, Africa Briefing N91, 4 October 2012

Congo: A Stalled Democratic Agenda, Africa Briefing N73, 8 Apr 2010

Congo: No Stability in Kivu despite Rapprochement with Rwanda, Africa Report N¹65, 16 Nov 2010

Congo: The Electoral Dilemma, Africa Report N¹75, 5 May 2011

Congo: The Electoral Process Seen from the East, Africa Briefing No80, 5 Sep 2011

Black Gold in the Congo: Threat to Stability or Development Opportunity?, Africa Report N¹88, 11 Jul 2012

Eastern Congo: Why Stabilisation Failed, Africa Briefing N91, 4 Oct 2012

Eastern Congo: The ADF-NALU's Lost Rebellion, Africa Briefing N93, 19 Dec 2012

Understanding Conflict in Eastern Congo (I): The Ruzizi Plain, Africa Report N²06, 23 Jul 2013

International Rescue Committee (2007). Mortality in the Democratic Republic of Congo: An Ongoing Crisis.

Jackson, Stephen (2006). "Sons of Which Soil? The Language and Politics of Autochthony in Eastern D.R. Congo", African Studies Review Vol.49, No.2, pp. 95-123.

Jackson, Stephen (2007). "Of 'Doubtful Nationality': Political Manipulation of Citizenship in the D. R. Congo”, Citizenship Studies,Vol.11, No.5, pp.481-500. Longman, Timothy (2001). "Identity cards, ethnic self-perception and genocide in Rwanda", in Caplan and Torpey (eds.) Documenting Individual Identity.

Mabanga, Monga Mabanga (1999). Le contentieux constitutionnel congolais, Editions Universitaires Africaines, Kinshasa.

Makombo, Angele N. (1997). "Civil Conflict in the Great Lakes Region: The Issue of Nationality of the Banyarwanda in the Democratic Republic of the Congo", African Yearbook of International Law,Vol.5, pp.49-62.

Mugisho, Emmanuel Lubala (1998). "La situation politique au Kivu: Vers une dualisation de la societé", L'Afrique des Grands Lacs Annuaire 1997-98, pp.307-333.

Namegabe Rugarabura, Paul-Robain (2008). Traditional Chieftaincy and Decentralisation in the Democratic Republic of Congo: Opportunities and Challenges", doctoral thesis, Libera Università Internazionale degli Studi Sociali, Rome.

Ndaywel è Nziem, Isidore (2004). "La nationalité congolaise à l'épreuve du séisme des Grands Lacs » in Pamphile Mabiala Mantuba-Ngoma (ed.), La Nouvelle Histoire du Congo : Mélanges euroafricains offerts à Frans Bontinck, Cahiers africains, Nos.65-66-67, Paris : L'Harmattan, pp.407-427.

Nellemann, Christian, Ian Redmond, and Johannes Refisch (eds). 2010. The Last Stand of the Gorilla - Environmental Crime and Conflict in the Congo Basin. A Rapid Response Assessment, UN Environment Programme, 
Nguya-Ndila Malengana, Célestin (2001). Nationalité et citoyenneté au Congo/ Kinshasa: Le cas du Kivu, Paris, L'Harmattan.

Pabanel, Jean-Pierre (1991). "La question de la nationalité au Kivu » Politique africaine, No.41, p.33.

Sanders, Edith R. (1969). "The Hamitic Hypothesis: Its origin and functions in time perspective”, Journal of African History, Vol.10, No.4, pp.521-31.

Stearns, Jason (2012). From CNDP to M23: The evolution of an armed movement in eastern Congo, London: Rift Valley Institute.

Stearns, Jason (2012). North Kivu: The background to conflict in North Kivu province of eastern Congo, London: Rift Valley Institute.

United Nations (1997). Report on the Situation of Human Rights in Zaire by the Special Rapporteur, Mr. Robert Garretón, in accordance with Commission resolution 1996/77, UN Doc. E/CN.4/1997/6/Add.1.

United Nations (2003). Interim report of the Special Rapporteur on the situation of human rights in the Democratic Republic of the Congo, UN Doc. A/58/534.

van Acker, Frank (1999). "La « Pembenisation » du Haut-Kivu : Opportunisme et droits fonciers revisités ", in L'Afrique des grands lacs Annuaire 1998-1999.

Vansina, Jan (1990). Paths in the Rainforest : Towards a History of Political Tradition in Equatorial Africa, London: James Currey.

Verstraete, Maurice (1959). La nationalité congolaise. Bruxelles : Académie Royale des Sciences d'Outre-Mer.

Vlassenroot, Koen (2002). "Citizenship, Identity Formation \& Conflict in South Kivu:The Case of the Banyamulenge", Review of African Political Economy Vol. 29 No. 93/94, pp. 499-515.

Willame, Jean-Claude (1997). Banyarwanda et Banyamulenge: Violences ethniques et gestion de l'identitaire au Kivu, Cahiers africains No.25, Bruxelles : Institut africain / Paris : L'Harmattan.

Willame, Jean-Claude (1998). "Kivu : La poudrière » in Colette Braeckman et al. Kabila prend le pouvoir, Brussels : Groupe de recherche et d'information sur la paix et la sécurité (GRIP), pp.31-46.

\section{West Africa}

Abdelkader, Galy Kadir and Moussa Zangaou (2012). Wahaya: Domestic and sexual slavery in Niger, Timidria and Anti-Slavery International

Adjami, Mirna (forthcoming). Statelessness and Nationality in Liberia, UNHCR.

Akyeampong, Emmanuel K. (2006). "Race, Identity and Citizenship in Black Africa:The case of the Lebanese in Ghana" AfricaVol.76., No.3, pp.297-323. Anarfi John, and Stephen Kwankye (2003). "Migration from and to Ghana: A Background Paper," Working Paper C4, Development Research Centre on Migration, Globalisation and Poverty, University of Sussex.

Anti-Slavery International (2010). Ending Child Trafficking in West Africa: Lessons from the Ivorian cocoa sector. 
Anti-Slavery International (2011). Time for Change: A call for urgent action to end the forced child begging of talibés in Senegal.

Arsan, Andrew (2014). Interlopers of Empire: The Lebanese Diaspora in Colonial French West Africa London and New York: Hurst and Oxford University Press. Awasom, Nicodemus Fru (2003). "From Migrants to Nationals and from Nationals to 'Undesirable Elements': The case of the Fulani (Mbororo) in the North West Province of Cameroon", in Coquery-Vidrovitch et al, Etre Etranger et Migrant en Afrique, Vol.1, pp.403-414.

Beydoun, Lina (2013). "The Complexities of Citizenship among Lebanese Immigrants in Sierra Leone", African Conflict \& Peacebuilding Review Vol.3, No.1 pp.112-143.

Beydoun, Lina, (2005). "Lebanese migration to Sierra Leone: Issues of transnationalism, gender, citizenship, and the construction of a globalized identity", unpublished $\mathrm{PhD}$ thesis, Wayne State University.

Bierwirth, Chris (1999). "The Lebanese communities of Côte d'Ivoire", African Affairs Vol.98, pp.79-99.

Bob-Milliar, George and Gloria Bob-Milliar (2014). "Mobilizing the African Diaspora for development: The politics of dual citizenship in Ghana", in: Toyin Falola and Kwame Essien (eds.), Pan-Africanism, and the politics of African citizenship and identity, New York: Routledge, pp.137-151.

Brydon, Lynne (1985). "Ghanaian Responses to the Nigerian Expulsions of 1983”, African Affairs, Vol. 84, No. 337, pp. 561-585.

Byrne, Jennifer (2013). "Should I Stay or Should I go? National Identity and Attitudes Towards Local Integration Among Liberian Refugees in Ghana”, Refugee Survey Quarterly Vol.32, No.1, pp.50-73.

Challenor, Herschelle Sullivan (1979). "Strangers as colonial intermediaries: The Dahomeyans in Francophone Africa”, in Shack and Skinner (eds.) Strangers in African Societies, pp.67-83.

Chauveau, Jean-Pierre and Paul Richards (2008). "West African Insurgencies in Agrarian Perspective: Côte d'Ivoire and Sierra Leone Compared", Journal of Agrarian Change,Vol.8, No.(4) pp. 515-552.

Coopération Belgique - France - Suisse (2012). Rapport de mission en République de Guinée 29 octobre - 19 novembre 2011, Commissariat Général aux Réfugiés et aux Apatrides (CGRA/Belgique), de l'Office Français de Protection des Réfugiés et Apatrides (OFPRA/France) et de l'Office Fédéral des Migrations (ODM/Suisse).

Coquery-Vidrovitch, Catherine (2001). "Nationalité et citoyenneté en Afrique occidentale français: Originaires et citoyens dans le Sénégal colonial”, Journal of African History, Vol. 42, No. 2, pp.285-305.

Dick, Shelly (2002). Responding to protracted refugee situations: A case study of Liberian refugees in Ghana, UNHCR, EPAU/2002/06.

Duffy, Helen (2009). "Hadijatou Mani Koraou v Niger: Slavery Unveiled by the ECOWAS Court”, Human Rights Law Review,Vol.9, No.1, pp.151-170. 
Ferme, Mariane (2004). "Deterritorialized Citizenship and the Resonances of the Sierra Leonean State" in Veena Das and Deborah Poole (eds.), Anthropology in the Margins of the State, Santa Fe: School of American Research Press.

Forum des organisations de défense des droits de l'enfant au Togo (FODDET) (2011). Rapport Alternatif de la société civile sur la mise en cuvre de la Convention relative aux droits de l'enfant, 2005-2010.

Frantz, Charles (1990). "West African Pastoralism: Transformation and Resilience", in Carl Salzman and J. G. Galaty (eds). Nomads in a Changing World. Naples, Instituto Universitario Orientale.

Gale, Lacey Andrews (2008). “The Invisible Refugee Camp: Durable Solutions for Boreah 'Residuals' in Guinea”, Journal of Refugee Studies, Vol. 21, No. 4, pp.538-552.

Gasiokwu, Martin Uzochukwu (1998). ECOWAS : Problems of citizenship and free movement, Jos, Nigeria : Mono Expressions.

Gberie, Lansana (2002). "Sierra Leone: Diamonds, Corruption and the Lebanese Connection”, Occasional Paper \#6, Diamonds and Human Security Project, Partnership Africa Canada.

Groelsema, Robert J. (1998). "The Dialectics of Citizenship and Ethnicity in Guinea”, Africa Today Vol.45, Nos.3-4, pp.411-421.

Hall, Bruce S. (2011). A history of race in Muslim West Africa, 1600-1960, Cambridge University Press.

Healy, Claire (2013). Counter-Trafficking: Baseline Assessment, FMM West Africa Project.

Hickey, Sam (2007). "Caught at the crossroads: citizenship, marginality and the Mbororo Fulani in northwest Cameroon", in Dorman et al Making Nations, Creating Strangers.

Human Rights Watch (1994). Mauritania's Campaign of Terror: State-Sponsored Repression of Black Africans.

Human Rights Watch (2001). Refugees Still at Risk: Continuing Refugee Protection Concerns in Guinea.

Human Rights Watch (2007). Bottom of the Ladder: Exploitation and Abuse of Girl Domestic Workers in Guinea.

Human Rights Watch (2010). "Sur le dos des enfants " Mendicité forcée et autres mauvais traitements à l'encontre des talibés au Sénégal,;

Humphrey, Michael (2004). "Lebanese identities: between cities, nations and trans-nations”, Arab Studies Quarterly Vol.26 No.1, pp.31-50.

Imam, Ayesha and Evelien Kamminga (2012). Women in search of citizenship: Experiences from West Africa, Royal Tropical Institute (KIT), Netherlands.

International Crisis Group (2012). Mali: Avoiding Escalation, Africa Report $N^{\circ} 189$.

International Labour Organization, UNICEF and World Bank (2007). Enfants mendicants dans la region de Dakar, Understanding Children's Work Project Working Paper Series. 
Jalloh, Alusine, (1999). African Entrepreneurship: Muslim Fula Merchants in Sierra Leone, Ohio University Press.

King, Jamesina (2005). Africa Discrimination and Citizenship Audit: Report on Sierra Leone, Open Society Justice Initiative.

Kinni, Fongot Kini-Yen (2013). Bakassi: Or the Politics of Exclusion and Occupation? Langaa Research and Publishing Common Initiative Group, Cameroon / African Books Collective.

Kobo, Ousman (2010). "We are citizens too': The politics of citizenship in independent Ghana”, Journal of Modern African Studies, Vol.48, pp 67-94.

Konan, Silvère (2013). Migrants en détresse: Analyse de situation et cadre de protection: Le cas $d u$ Niger et $d u$ Togo, UNHCR and IOM.

Konneh, Augustine (1996). "Citizenship at the Margins: Status, Ambiguity, and the Mandingo of Liberia", African Studies Review,Vol. 39, No. 2, pp. 141-154.

Kuba, Richard and Carola Lentz (eds.) (2006). Land and the Politics of Belonging in West Africa, Leiden/Boston: Brill.

Leighton, Neil O. (1979). "The political economy of a stranger population: The Lebanese of Sierra Leone", in Shack and Skinner (eds.) Strangers in African Society.

Lubkemann, Stephen, Deborah H. Isser and Philip A.Z. Banks III (2011). "Constraint of Customary Justice in Post-Conflict Liberia", in Deborah Isser (ed.) Customary Justice and the Rule of Law in War-torn Societies, Washington DC: US Institute of Peace.

Lukong, Hilary V. (2011). The Cameroon-Nigeria Border Dispute: Management and Resolution, 1981-2011, Langaa Research and Publishing Common Initiative Group, Cameroon / African Books Collective.

Mabogunje, Akin L. (1972). Regional Mobility and Resource Development in West Africa, Centre for Developing-Area Studies, McGill University, Montreal, Canada.

Manby, Bronwen (forthcoming, 2015). Nationality, Migration and Statelessness in West Africa, UNHCR and IOM.

Mendy, Peter Karibe (2003). “Portugal's Civilizing Mission in Colonial GuineaBissau: Rhetoric and Reality", International Journal of African Historical Studies, Vol. 36, No. 1.

Ngang, Kevin (2007). "Understanding the Bakassi Conflict: A Showcase of Conflict Prevention in Practice", EPU Research Papers Issue 04/07, European University Centre for Peace Studies (EPU), Stadtschlaining/Austria.

Olinga, Alain-Didier (2009). L'Accord de Greentree du 12 juin 2006 relatif à la presqu'île de Bakassi, Paris: L'Harmattan.

Orock, Rogers Tabe Egbe (2005). "The Indigene-Settler Divide, Modernisation and the Land Question: Indications for Social (Dis) order in Cameroon", Nordic Journal of African Studies, Vol. 14, No. 1, p. 68.

Peil, Margaret (1971). "The expulsion of West African aliens", Journal of Modern African Studies Vol.9, No.2: 203-29. 
Peil, Margaret (1974). “Ghana’s aliens”, International Migration ReviewVol.8, No.3, pp.367-81.

Peil, Margaret (1979). "Host reactions: aliens in Ghana", in Shack \& Skinner, (eds). Strangers in African Societies, pp.123-40.

Pelican, Michaela (2008). "Mbororo Claims to Regional Citizenship and Minority Status in North-West Cameroon” Africa,Vol.78, pp 540-560.

Queffélec, Ambroise, and Bah Ould Zein (2001). "La 'Longue Marche' de l'arabisation en Mauritanie ", Le français en Afrique (Revue du Réseau des Observatoires du Français Contemporain en Afrique Noire), No.15.

Renner-Thomas, Ade (2010). Land Tenure in Sierra Leone: The Law, Dualism and the Making of a Land Policy, AuthorHouse.

Sawyer, Amos (1992). The Emergence of Autocracy in Liberia: Tragedy and Challenge, San Francisco: Institute for Contemporary Studies Press.

Stone, David (2005). Enhancing livelihood security among Mauritanian refugees in Northern Senegal: a case study, UNHCR, EPAU/2005/11.

Tannenbaum, Jessie (2009). Analysis of the Aliens and Nationality Law of the Republic of Liberia, American Bar Association Rule of Law Initiative.

Tonah, Steve (2002). "The Politics of Exclusion: The expulsion of Fulbe pastoralists from Ghana in 1999/2000”, Working Paper No. 44, Max Planck Institute.

van der Laan, H. L., (1975). The Lebanese Traders in Sierra Leone: Change and Continuity in Africa, Mouton, The Hague.

van der Straaten, Jaap (2013). Towards Universal Birth Registration in Guinea: Analysis and recommendations for civil registration reform in Guinea for Government and UNICEF, Civil Registration Centre for Development-CRC4D.

Wrubel, Thomas P. (1971). "Liberia: The Dynamics of Continuity", Journal of Modern African Studies,Vol. 9, No. 2, pp.189-204.

\section{Nigeria}

Adepoju, Aderanti (1984). "Illegals and Expulsion in Africa: The Nigerian Experience", International Migration Review, Vol. 18, No. 3, Special Issue: Irregular Migration: An International Perspective, pp. 426-436.

Adesoji, Abimbola O and Akin Alao (2009), "Indigeneship and Citizenship in Nigeria: Myth and Reality" Journal of Pan African Studies, Vol.2, No.9, pp.151165.

Adigun. O. (1989). "Nationality and Citizenship: The Legal Problematic of Transborder Ethnic Communities in Nigeria", in Asiwaju, A.I. and P.O. Adeniyi (eds.) Borderlands in Africa: A Multidisciplinary and Comparative Focus on Nigeria and West Africa, University of Lagos Press.

Akanmode, Samuel (1980). The Shugaba Affair, Nigerian Council for National Awareness.

Aluko, Olajide (1985). "The Expulsion of Illegal Aliens from Nigeria: A study in Nigeria's decision making”, African Affairs, Vol.84, No.337, pp.539-560. 
Bach, Daniel C. (1997). "Federalism, Indigeneity and Ethnicity in Nigeria" in: Larry Diamond, Tom Bierstecker, A.H.M. Kirk-Greene and Oye Oyediran (eds.), Transition without End; Nigerian Politics and Civil Society under Babangida, Lynne Rienner : Boulder, pp.333-350.

Emelonye, Uchenna (ed.) (2011). Nigeria: Peace Building through Integration and Citizenship, International Development Law Organization.

Gravil, Roger (1985). “The Nigerian Aliens Expulsion Order of 1983”, African Affairs, Vol. 84, No. 337, pp. 523-537.

Human Rights Watch (April 2006). "They Do Not Own This Place”: Government discrimination against "non-indigenes" in Nigeria.

Isumonha, V. Adefemi (2003). "Migration, Land Tenure, Citizenship and Communal Conflicts in Africa", Nationalism and Ethnic Politics Vol.9, No.1, pp.1-19.

Nigeria Research Network (2014). "Indigeneity, Belonging, \& Religious Freedom in Nigeria: Citizens' Views from the Street", Policy Brief No.5, University of Oxford / Development Research and Project Centre Kano.

Nigerian Universal Basic Education Commission (2010). National Framework for the Development and Integration of Almajiri Education into UBE Scheme.

Nwachukwu, Ijeoma (2005). "The Challenge of Local Citizenship for Human Rights in Nigeria”, African Journal of International and Comparative Law Vol.13, pp.235-261.

Nwogugu, E. I. (1976)."Recent Changes in Nigerian Nationality and Citizenship Law”, International and Comparative Law Quarterly, Vol.25, pp 423-439.

Nylander, Arthur V.J. (1973). The Nationality and Citizenship Laws of Nigeria, Lagos: University of Lagos.

Odinkalu, Chidi Anselm (forthcoming, 2015). "Natives, subjects, and wannabes: Internal citizenship problems in post-colonial Africa", in Rhoda E. HowardHassmann and Margaret Walton-Roberts (eds.) The Human Right to Citizenship: A Slippery Concept, University of Pennsylvania Press.

Okafor, Obiora Chinedu (1996). "The Fundamental Right to a Passport under Nigerian Law: An Integrated Viewpoint”, Journal of African Law, Vol. 40, No. 1, pp. 53-61

Okoli, K. C. (1990). “Nigerian Citizenship Law: A Current Perspective”, Journal of African Law, Vol.34, pp.27-41.

Pereira, Charmaine (2004). “Understanding Women's Experiences of Citizenship in Nigeria: From Advocacy to Research", in Elizabeth Annan-Yao et al, Gender, Economies and Entitlements in Africa, CODESRIA, Dakar.

Taiwo, Olufemi (2004). "Of Citizens and Citizenship", in Okon Akibá (ed.), Constitutionalism and Society in Africa, Aldershot, UK: Ashgate, pp. 55-78.

Willink Commission (1958). Report of the Commission Appointed to Enquire into the Fears of Minorities and the Means of Allaying Them, Colonial Office, Great Britain. 


\section{Côte d'Ivoire}

Adjami, Mirna (forthcoming). Statelessness and Nationality in Côte d'Ivoire, UNHCR.

Akindès, Francis (2004). The Roots of the Military-Political Crises in Côte d'Ivoire, Nordiska Afrikainstitutet, Uppsala, Research Report No. 128.

Amnesty International (2011). They looked at his Identity Card and Shot him Dead: Six Months of Post-Electoral Violence in Côte d'Ivoire, AFR 31/002/2011.

Babo, Alfred (2013). "The Crisis of Public Policies in Côte d'Ivoire: Land law and the nationality trap in Tabou's rural communities", Africa,Vol.83, Special Issue 01, pp 100-119.

Banégas, Richard (2006). "Côte d'Ivoire: patriotism, ethnonationalism and other African modes of self-writing”, African Affairs, Vol.105, No.421, pp.535-552.

Banégas, Richard, and Ruth Marshall-Fratani (2007). "Côte d'Ivoire: Negotiating Identity and Citizenship", in Morten Boas and Kevin C. Dunn (eds.), African Guerrillas: Raging Against the Machine, Lynne Rienner, pp. 81-111.

Bjarnesen, Jesper (2013). "Diaspora at Home? Wartime Mobilities in the Burkina Faso-Côte d'Ivoire Transnational Space”, Uppsala Studies in Cultural Anthropology no 53, University of Uppsala.

Blion, Reynald and Sylvie Bredeloup (1997). "La Côte d'Ivoire dans les stratégies migratoires des burkinabès et des sénégalais", in Bernard Contamin and Harris Memel-Fotê (eds.), Le modèle ivoirien en questions : Crise, réajustements, récompositions, Karthala.

Bonnecase, Vincent (2001). Les étrangers et la terre en Côte d'Ivoire à l'époque coloniale, Montpellier : Institut de Recherche pour le Développement (IRD), Document de l'Unité de Recherche 095, № 2.

Bonzon, Suzanne (1967). «Les Dahoméens en Afrique de l'Ouest » Revue française de science politique, Vol.17, No.4, pp. 718-726.

Bouquet, Christian (2007). "La crise ivoirienne par les cartes ", Géoconfluences, Université de Lyon.

Bredeloup, Sylvie (2003). "La Côte d'Ivoire ou l'étrange destin de l'étranger » Revue Européenne des Migrations Internationales Vol.19, No.2, pp. 85-113.

Chauveau, Jean-Pierre (2000). "Question foncière et construction nationale en Côte d'Ivoire", Politique africaine, No.78, pp.94-126.

Chauveau, Jean-Pierre (2002). «La Loi Ivoirienne de 1998 sur le Domaine Foncier Rural et l'Agriculture de Plantation Villageoise: Une Mise en Perspective Historique et Sociologique " Land Reform: Land Settlement and Cooperatives, (FAO), pp.62-78.

Chauveau, Jean-Pierre and Jean-Pierre Dozon (1987). "Au cœur des ethnies ivoriennes : L'Etat, l'économie de plantation et les ethnies en Côte d'Ivoire”, in Emmanuel Terray (ed.) L'Etat contemporain en Afrique, Paris : Harmattan.

Cissé, Chikouna (2013). Migration et mise en valeur de la basse Côte d'Ivoire (19201960), Paris : Harmattan.

Collett, Maya (2006). "Ivorian identity constructions: Ethnicity and nationalism in the prelude to civil war", Nations and Nationalism,Vol.12, No.4, p.613-629. 
Contamin, Bernard and Harris Memel-Fotê (eds.)(1997). Le modèle ivoirien en questions : Crise, réajustements, récompositions, Karthala.

Courtin, Fabrice, Florence Fournet and Philippe Solano (2010). "La crise ivoirienne et les migrants burkinabés : L'effet boomerang d'une migration internationale", Afrique contemporaine No.236, pp.11-27.

de Benoist, Joseph-Roger (2003). « Pogrom contre les Dahomeens et les Togolais en Cote d'Ivoire en octobre 1958 » in Coquery-Vidrovitch et al, Etre Etranger et Migrant en Afrique, Vol.1, pp.437-452.

Dembélé, Ousmane (2002). "La construction économique et politique de la catégorie 'étranger' en Côte d'Ivoire ", in Le Pape and Vidal (ed.) Côte d'Ivoire : L'année terrible 1999-2000, pp.123-171.

Dozon, Jean-Pierre (1997). "L'étranger et l'allochtone en Côte d'Ivoire", in Bernard Contamin et Harris Memel-Fotê (eds.), Le modèle ivoirien en questions : Crise, réajustements, récompositions, Karthala, pp.779-798.

Dozon, Jean-Pierre (2000). "La Côte d'Ivoire entre démocratie, nationalisme et ethnonationalisme", Politique africaine, No.78, pp.45-62.

Emma, Yéo O. (2008), Idéologie politique et conflit en Côte d'Ivoire : Une analyse $d u$ discours politique sur l'identité nationale, Centre de Recherche et d'Action pour la Paix (CERAP)/ Consortium for Development Partnerships (CDP) Research Report No.3.

European Union Observation Mission, C6te d'Ivoire : Rapport Final : Election Présidentielle 31 octobre - 28 novembre 2010, 25 January 2011.

Gary-Tounkara, Daouda (2008). Migrants soudanais/maliens et conscience ivoirienne: Les étrangers en Côte d'Ivoire 1903-1980, L'Harmattan.

Human Rights Watch (2001). The New Racism: The Political Manipulation of Ethnicity in Côte d'Ivoire.

Human Rights Watch (2013). “That Land Is My Family's Wealth” Addressing Land Dispossession after Côte d'Ivoire's Post-Election Conflict.

International Crisis Group:

“The War Is Not Yet Over”, Africa Report N72, 28 November 2003

No Peace in Sight, Africa Report N82, 12 July 2004

The Worst May Be Yet to Come, Africa Report N90, 24 March 2005

Peace as an Option, Africa Report N¹09, 17 May 2006

Can the Ouagadougou Agreement Bring Peace?, Africa Report N¹27, 27 June 2007

Ensuring Credible Elections, Africa Report N¹39, 22 April 2008

What's Needed to End the Crisis, Africa Briefing N62, 2 Jul 2009

Securing the Electoral Process, Africa Report N¹58, 5 May 2010

Finally Escaping the Crisis?, Africa Briefing N77, 25 Nov 2010

Is War the Only Option?, Africa Report N¹71, 3 Mar 2011

A Critical Period for Ensuring Stability in Côte d'Ivoire, Africa Report N¹76, 1 Aug 2011

Poursuivre la convalescence, Africa Briefing No83 16 Dec 2011 
Langer, Arnim (2005). "Horizontal Inequalities and Violent Conflict: Côte d'Ivoire Country Paper", UNDP Human Development Report Office, Occasional Paper 2005/32.

Le Pape, Marc and Claudine Vidal (eds.) (2002). Côte d'Ivoire : L'année terrible, 1999-2000, Paris : Karthala.

Losch, Bruno (ed.)(2000). "Dossier: Côte d'Ivoire, la tentation ethnonationaliste", Politique africaine No. 78.

Marshall-Fratani, Ruth (2007). “The war of 'Who is Who': Autochthony, Nationalism and Citizenship in the Ivorian Crisis", in Dorman et al, Making Nations, Creating Strangers.

McCallin, Barbara and Marzia Montemurro (2009). Whose land is this? Land disputes and forced displacement in the western forest area of Côte d'Ivoire, Norwegian Refugee Council / Internal Displacement Monitoring Centre.

McGovern, Mike (2011). Making War in Côte d'Ivoire, University of Chicago Press.

Morris, Karen (2012). "Avoiding vagabond nationality: The emergence of ivoirité in 1990s Côte d'Ivoire", in Brian D. Behnken and Simon Wendt (eds.), Crossing Boundaries: Ethnicity, race and national belonging in a transnational world, Lexington Books, pp.161-183.

Piccolino, Giulia (2014). "Ultranationalism, democracy and the law: insights from Côte d'Ivoire", Journal of Modern African Studies, Vol.52, No.1, pp.45-68. République de la Côte d'Ivoire (1992). Recensement Général de la Population et de l'Habitat, 1988 :Vol.2, Répartition Spatiale de la Population et Migrations, Analyse des résultats définitifs, andVol.3, Caractéristiques socio-culturelles et économiques de la population.

Tapinos, Georges Photios (2001). "La population étrangère”, in Georges Photios Tapinos, Philippe Hugon and PatriceVimard (eds.) La Côte d'Ivoire à l'aube du XXIe siècle. Défis démographiques et développement durable, Paris: Karthala.

Tirefort, Alain (2003). "L'affaire "Daho-Togo »: Une fièvre de xenophobie en Côte d'Ivoire", in Coquery-Vidrovitch et al, Etre Etranger et Migrant en Afrique, Vol.1, pp.415-452.

Toungara, Jeanne Maddox (2001). "Ethnicity and Political Crisis in Cote d'Ivoire", Journal of Democracy, Vol.12, No.3, pp. 63-72.

United Nations (various). Progress Reports of the Secretary-General on the United Nations Operation in Côte d'Ivoire, Security Council (periodic reports).

Weiss, Pierre (2004). "L'Opération Licorne en Côte d'Ivoire : Banc d'essai de la nouvelle politique française de sécurité en Afrique', Annuaire français de relations internationales, $\mathrm{Vol}$.V.

Zanou, Benjamin and Siaka Lougue (2009). Impact de la crise ivoirienne sur les migrations de retour au Burkina Faso, Paper presented at the XXVI IUSSP International Population Conference, Marrakech.

Zoro Bi, Epiphane (2004). Juge en Côte d'Ivoire, Karthala.

Zoro Bi, Epiphane (2008). "Je suis un Sidibé de Tiémélékro : L'acquisition de la nationalité ivoirienne à titre originaire : Critère juridique ou critère 
anthropologique?" in Jean-Bernard Ouédraogo and Ebrima Sall (eds.) Frontières de la citoyenneté et violence politique en Côte d'Ivoire. Dakar, CODESRIA.

\section{South and Southern Africa}

Amnesty International (2004). Swaziland: Human rights at risk $n$ a climate of political and legal uncertainty, AI Index: AFR 55/004/2004.

Anderson, Bently J. (1993-1994). "The Restoration of The South African Citizenship Act: An Exercise in Statutory Obfuscation", Connecticut Journal of International Law, Vol. 9, pp.295-323.

Bakewell, Oliver (2000). "Repatriation and Self-Settled Refugees in Zambia: Bringing Solutions to the Wrong Problems”, Journal of Refugee Studies, Vol 13, No. 4, pp.356-373.

Cheater, A. P. and R. B. Gaidzanwa (1996). "Citizenship in Neo-Patrilineal States: Gender and Mobility in Southern Africa", Journal of Southern African Studies, Vol. 22, No. 2, pp. 189-200.

Citizenship Rights in Africa Initiative (2010). Submission on the South African Citizenship Amendment Bill, B 17 - 2010.

Constitutional Review Commission (2005). Final Report, Lusaka, Zambia.

Crush, Jonathan, and Vincent Williams (eds.) (1999). The New South Africans? Immigration Amnesties and their Aftermath, Cape Town, Idasa.

Gaidzanwa, Rudo (1993). "Citizenship, Nationality, Gender, and Class in Southern Africa”, Alternatives: Global, Local, Political,Vol. 18, No. 1, Feminists Write International Relations, pp. 39-59.

George Jessica P. and Rosalind Elphick (2013). Statelessness and Nationality in South Africa, Pretoria: Lawyers for Human Rights.

Hammett, Daniel (2008). "The challenge of a perception of 'un-entitlement' to citizenship in post-apartheid South Africa”, Political Geography, Vol.27, No.6, pp.652-668.

Harris, Bronwyn (2001). "A Foreign Experience: Violence, Crime and Xenophobia during South Africa's Transition", Violence and Transition Series, Vol. 5, South Africa, Centre for the Study ofViolence and Reconciliation;

Hitchcock, Robert K. (2002). “'We are the First People': Land, Natural Resources and Identity in the Central Kalahari, Botswana", Journal of Southern African Studies, Vol. 28, No. 4, Special Issue: Minorities and Citizenship in Botswana, pp. 797-824.

Human Rights Watch (1996). Zambia: Elections and human rights in the Third Republic.

Human Rights Watch (1998). Prohibited Persons: Abuse of Undocumented Migrants, Asylum Seekers and Refugees in South Africa.

Human Rights Watch (2003). Struggling through Peace: Return and Resettlement in Angola.

Human Rights Watch (2012). "If You Come Back We Will Kill You”: Sexual Violence and other Abuses against Congolese Migrants during Expulsions from Angola. 
Human Sciences Research Council (2008). Citizenship, Violence and Xenophobia in South Africa: Perceptions from South African Communities, Pretoria.

International Bar Association Human Rights Institute (2003). Swaziland: Law, Custom and Politics: Constitutional Crisis and the Breakdown in the Rule of Law.

International Commission of Jurists Centre for the Independence of Judges and Lawyers (2003). Fact-Finding Mission to the Kingdom of Swaziland.;

Keightley, Raylene (1998). "A child's right to nationality and the acquisition of citizenship in South Africa", South African Journal on Human Rights, Vol.14, pp.411-429.

Klaaren, Jonathan (2000). "Post-Apartheid Citizenship in South Africa", in A. Aleinikoff (ed.), From Migrants to Citizens: Membership in a Changing World, Brookings Institution Press, pp.221-252.

Klaaren, Jonathan (2010). "Constitutional citizenship in South Africa", International Journal of Constitutional Law, Vol.8, No.1, pp. 94-110.

Klaaren, Jonathan, and Bonaventure Rutinwa, (2004). Towards the Harmonisation of Immigration and Refugee Law in SADC, Migration Dialogue for Southern Africa (MIDSA), Report No.1.

Landau, Loren B. (2004). The Laws of (In)Hospitality: Black Africans in South Africa, Forced Migration Working Paper Series No.7, University of the Witwatersrand.

Lawyers for Human Rights (2011). Towards Universal Birth Registration in South Africa: A Briefing Paper, Pretoria.

Lawyers for Human Rights (2013). Statelessness and Nationality in South Africa, Pretoria.

Lee, Christopher Joon-Hai (2005).“'The 'Native’Undefined:Colonial Categories, Anglo-African Status and the Politics of Kinship in British Central Africa, 1929-38", Journal of African History, Vol. 46, No. 3, pp. 455-478.

Leys, Colin and Cranford Pratt (1960). A New Deal in Central Africa, Praeger.

Mabeko-Tali, Jean-Michel (2003). “" Congolenses », « Congoleses », « Zairenses » : L'immigration centr-africaine et la problématique identitaire angolaise”, in Coquery-Vidrovitch et al, Etre Etranger et Migrant en Afrique, Vol.1, pp.189206.

Macmillan, Hugh (1989). "A Nation Divided? The Swazi in Swaziland and the Transvaal, 1865-1986”, in LeroyVail (ed.), The Creation of Tribalism in Southern Africa, James Currey.

Mamdani, Mahmood (2000). "Indirect Rule and the Struggle for Democracy: A Response to Bridget O'Laughlin", African Affairs, Vol. 99, No.394, pp. 43-46. Manby, Bronwen (2012). Statelessness in Southern Africa, Briefing paper for UNHCR Regional Conference on Statelessness in Southern Africa Mbombela (Nelspruit), South Africa 1-3 November 2011, UNHCR

Maseko, Thulani Rudolf (2005). The writing of a democratic constitution in Africa with reference to Swaziland and Uganda, LLM thesis, University of Pretoria.

Mbao, Melvin L.M (1998). "Human Rights and Discrimination: Zambia's Constitutional Amendment, 1996”, Journal of African Law Vol.42, pp.1-11. 
McInerney, Caroline (2014). "Accessing Malagasy Citizenship: The Nationality Code and its impact on the Karana", Tilburg Law Review Vol.19, pp.182-193.

Metlhaetsile Women's Information Centre (1995). The Citizenship Case: The Attorney General of the Republic of Botswana vs. Unity Dow, Court Documents, Judgements, Cases and Materials.

Minaar, Anthony and Mike Hough (1996). Who Goes There? Perspectives on clandestine migration and illegal aliens in southern Africa, Pretoria, HSRC Publishers.

Misago, Jean Pierre with Loren B. Landau and Tamlyn Monson (2009). Towards Tolerance, Law, and Dignity: Addressing Violence against Foreign Nationals in South Africa, 25 March 2014Johannesburg: International Organisation for Migration.

Mvududu, Sara C, and Patricia McFadden (2001). Reconceptualizing the Family in a Changing Southern African Environment, Women \& Law in Southern Africa.

Nyamnjoh, Francis B. (2002). "Local attitudes towards foreigners in Botswana: An appraisal of recent press stories", Journal of Southern African Studies, Vol.28, No.4, pp.755-775.

Nyamnjoh, Francis B. (2006). Insiders and Outsiders: Citizenship and Xenophobia in Contemporary Southern Africa, Codesria/Zed Books, London.

O'Laughlin, Bridget (2000). "Class and the customary: the ambiguous legacy of the Indigenato in Mozambique”, African Affairs, Vol.99, No.394, pp. 5-42.

Oucho, John O. and Jonathan Crush (2001). “Contra Free Movement: South Africa and the SADC Migration Protocols”, Africa Today Vol.8, No.3, pp.139-158.

Polzer, Tara (2007). Local Government and Migration Management in Border Areas Challenges and Opportunities for Public Service Provision, Johannesburg: Forced Migration Studies Programme, University of the Witwatersrand.

Public Protector of South Africa (2011). Report on an investigation into allegations of failure to register the birth of a child and the naturalisation of the mother by the Northern Cape Department of Home Affairs, Report No.38 of 2011.

Somerville, JJB (1963). "The Central African Federation”, International Affairs, Vol.39, No.3,. pp.386-402.

Statistics South Africa (2007). The coverage and quality of birth registration data in South Africa: 1998-2005, Report no. 06-03-01.

Steinberg, Jonny (2008). “South Africa's Xenophobic Eruption”, ISS Paper 169, Institute for Security Studies, Pretoria.

Vail, Leroy (ed.) (1989). The Creation of Tribalism in Southern Africa, James Currey, London.

\section{Zimbabwe}

Cheater, A.P. (1998). "Transcending the State? Gender and borderline constructions of citizenship in Zimbabwe", in Thomas M. Wilson and Hastings Donnan (eds.), Border Identities: Nation and State at International Frontiers, Cambridge University Press. 
Coldham, Simon (1994). "Case Note: Devagi Rattigan and others v. Chief Immigration Officer and others", Journal of African Law, Vol. 38, pp.189-190.

Dube, Rumbidzai (2008). A Right or a Privilege: Access to Identity and Citizenship in Zimbabwe, Harare, Research and Advocacy Unit.

Dube, Rumbidzai (2012). Identity, Citizenship, and the Registrar General: The Politicking of Identity in Zimbabwe, Harare, Research and Advocacy Unit.

Hammar, Amanda, Brian Raftopoulos and Stig Jensen (2003). Zimbabwe's Unfinished Business: Rethinking Land, State and Nation in the Context of Crisis, Harare: Weaver Press.

Moyo, Sam, Blair Rutherford and Dede Amanor-Wilks (2000). "Land Reform and Changing Social Relations for Farm Workers in Zimbabwe", Review of African Political Economy, Vol.27, No.84, pp.181-202.

Ncube, Welshman (1998). "Defending and Protecting Gender Equality and the Family Under a Decidedly Undecided Constitution in Zimbabwe”, in John Eekelaar and Thandabantu Nhlapo, (eds.) The Changing Family: International Perspectives on the Family and Family Law, Oxford, Hart Publishing, pp.509528.

Newitt, Malyn (1995). A History of Mozambique, London: Hurst \& Company.

Nkiwane, Tandeka C. (2000). "Gender, Citizenship, and Constitutionalism in Zimbabwe: The Fight Against Amendment 14", Citizenship Studies, Vol. 4, No.3, pp.325-338.

Polzer, Tara (2009). "Regularising Zimbabwean Migration to South Africa", Migration Policy Brief, Forced Migration Studies Program University of the Witwatersrand and Consortium for Refugees and Migrants in South Africa, Johannesburg.

Raftopoulos, Brian (2001). The State in Crisis: Authoritarian nationalism, selective citizenship and distortions of democracy in Zimbabwe. Centre for Development Research, Harare.

Raftopoulos, Brian (2007). "Nation, Race and History in Zimbabwe", in Dorman et al, Making Nations, Creating Strangers.

Rutherford, Blair (2007). "Shifting grounds in Zimbabwe: Citizenship and farm workers in the new politics of land", in Dorman et al, Making Nations, Creating Strangers.

Selby, Angus (2006). "Commercial farmers and the state: Interest group politics and land reform in Zimbabwe", unpublished DPhil Thesis, Oxford University.

Zimamoza Institute (2007). Ethnic Cleansing In Zimbabwe: The origins and objectives of the Zimamoza Institute, Harare.

Zimbabwe Human Rights NGO Forum (2005). Constitution of Zimbabwe Amendment (no. 17) Bill, 2005 ( $h b, 2005)$ - Representations made by the to the Portfolio Committee on Justice, Legal and Parliamentary Affairs.

Zimbabwean Lawyers for Human Rights (2007). Submissions on the interpretation of citizenship laws to the Parliamentary Committee on Defence and Home Affairs. 


\section{List of African nationality laws and amendments since independence}

\begin{tabular}{|c|c|}
\hline Algeria & $\begin{array}{l}\text { Constitution 1989, amended } 1996 \\
\text { Loi No.63-96 du } 27 \text { mars } 1963 \text { portant Code de la nationalité algérienne } \\
\text { Ordonnance n } 70-86 \text { du } 15 \text { décembre } 1970 \text { portant Code de la nationalité } \\
\text { algérienne } \\
\begin{array}{l}\text { Ordonnance No. 05-01 du } 27 \text { février } 2005 \text { modifiant et complétant Code de la } \\
\text { nationalité algérienne }\end{array}\end{array}$ \\
\hline Angola & $\begin{array}{l}\text { Lei da nacionalidade de } 11 \text { de novembro } 1975 \\
\text { Lei No.8/84 da nacionalidade de } 7 \text { de fevereiro } \\
\text { Lei No.13/91 da nacionalidade, de } 11 \text { de maio } \\
\text { Lei No.1/05 da nacionalidade, de } 1 \text { de julho } \\
\text { Decreto No.31/07 dos registos de nascimentos, de } 14 \text { de maio } \\
\text { Constitution, } 2010\end{array}$ \\
\hline Benin & Loi No. 65-17 du 23/06/65 portant Code de la nationalité dahoméenne \\
\hline Botswana & $\begin{array}{l}\text { Constitution } 1966 \\
\text { Citizenship of Botswana (Supplementary Provisions) Law No.39 of } 1966 \\
\text { Citizenship of Botswana (Supplementary Provisions) (Amendment) Act No.56 of } \\
1969 \\
\text { Citizenship Act No.25 of } 1982 \\
\text { Constitution (Amendment) Act No.32 of } 1982 \\
\text { Citizenship (Amendment) Act No.17 of } 1984 \\
\text { Citizenship (Amendment) Act No.14 of } 1995 \\
\text { Citizenship Act No.8 of } 1998 \\
\text { Citizenship Amendment Act No.9 of } 2002 \\
\text { Citizenship Amendment Act No.1 of } 2004\end{array}$ \\
\hline Burkina Faso & $\begin{array}{l}\text { Loi No.50-61-AN du } 1 \text { décembre } 1961 \text { portant adoption d'un Code de la nationalité } \\
\text { voltaïque } \\
\text { Zatu No.An VII 0013/FP/PRES du } 16 \text { novembre 1989, portant institution et } \\
\text { application du Code des personnes et de la famille }\end{array}$ \\
\hline Burundi & $\begin{array}{l}\text { Décret-loi no } 1 / 93 \text { du } 10 \text { août } 1971 \text { portant Code de la Nationalité } \\
\text { Loi No. } 1-013 \text { du } 18 \text { juillet } 2000 \text { portant reforme du Code de la nationalité } \\
\text { Constitution } 2005\end{array}$ \\
\hline Cameroon & $\begin{array}{l}\text { Ordonnance No.59-66 du } 26 \text { novembre } 1959 \text { portant Code de la nationalité } \\
\text { camerounaise } \\
\text { Loi No. } 1968 \text {-LF-3 du } 11 \text { juin } 1968 \text { portant Code de la nationalité camerounaise }\end{array}$ \\
\hline Cape Verde & 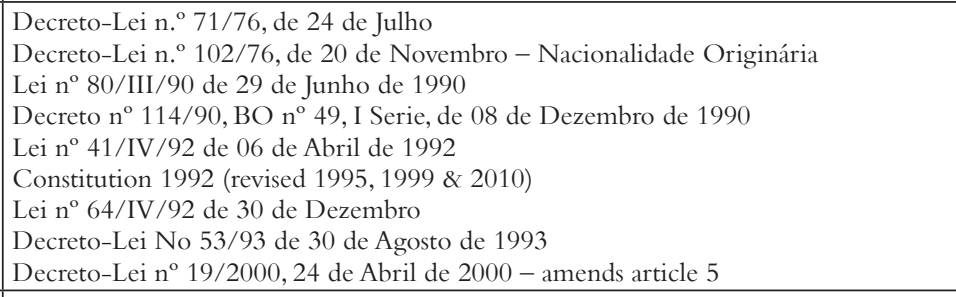 \\
\hline CAR & Loi No. 61-212 du 27 mai 1961 portant Code de la nationalité centrafricaine \\
\hline Chad & $\begin{array}{l}\text { Loi No.31-60 du } 27 \text { février } 1961 \text { portant Code de la nationalité tchadienne } \\
\text { Décret No.16/PG du } 28 \text { septembre } 1961 \text { relatif au Code de la nationalité tchadienne } \\
\text { Ordonnance No. 33/PG-INT du } 14 \text { août } 1962 \text { portant Code de la nationalité } \\
\text { tchadienne } \\
\text { Décret No. 211-PG.-INT. du } 6 \text { novembre } 1963 \text { portant application du Code de la } \\
\text { nationalité }\end{array}$ \\
\hline
\end{tabular}




\begin{tabular}{|c|c|}
\hline Comoros & $\begin{array}{l}\text { Constitution, } 2001 \\
\text { Loi No. } 79-12 \text { du } 12 \text { décembre } 1979 \text { portant Code de la nationalité comorienne }\end{array}$ \\
\hline $\begin{array}{l}\text { Congo } \\
\text { Republic }\end{array}$ & $\begin{array}{l}\text { Loi No. 35-61 du } 20 \text { juin } 1961 \text { portant Code de la nationalité congolaise } \\
\text { Décret No. 61-178 du } 29 \text { juillet } 1961 \text { fixant les modalités d'application du Code de } \\
\text { la nationalité } \\
\text { Loi No. 2-93 du } 30 \text { septembre } 1993 \text { modifiant l'article } 30 \text { de la loi No. 35-61 du } 20 \\
\text { juin } 1961\end{array}$ \\
\hline Côte d'Ivoire & $\begin{array}{l}\text { Loi n } 61-415 \text { du } 14 \text { Décembre } 1961 \text { portant Code de la nationalité ivoirienne } \\
\text { Loi No.64-381 du } 7 \text { octobre } 1964 \text { modifiant la Loi } 61-415 \text { du } 14 \text { décembre } 1961 \\
\text { portant Code de la nationalité } \\
\text { Loi No.72-852 du } 21 \text { Décembre } 1972 \text { modifiant la Loi } 61-415 \text { du } 14 \text { décembre } 1961 \\
\text { portant Code de la nationalité } \\
\text { Constitution de la République de Côte d'Ivoire Loi No.2000-513 du } 23 \text { juillet } 2000 \\
\text { Loi no } 2004-662 \text { du } 17 \text { décembre } 2004 \text { modifiant et complétant la Loi } 61-415 \text { du } 14 \\
\text { décembre } 1961 \text { portant Code de la nationalité } \\
\text { Loi No.2004-663 du } 17 \text { décembre } 2004 \text { portant dispositions spéciales en matière de } \\
\text { naturalisation } \\
\text { Décision No. } 2005-03 / P R \text { du } 15 \text { juillet } 2005 \text { relative au Code de la nationalité. } \\
\text { Décision No. } 2005-04 / P R \text { du } 15 \text { juillet } 2005 \text { portant dispositions spéciales en matière } \\
\text { de naturalisation } \\
\text { Décision No. } 2005-09 / P R \text { du } 29 \text { août } 2005 \text { relative au Code de la nationalité } \\
\text { Décision No. } 2005-10 / P R \text { du } 29 \text { août } 2005 \text { relative aux dispositions spéciales en } \\
\text { matière de naturalisation } \\
\text { Loi No.2013-653 du } 13 \text { septembre } 2013 \text { portant dispositions particulières en matière } \\
\text { d'acquisition de la nationalité par déclaration } \\
\text { Loi No.2013-654 du } 13 \text { septembre } 2013 \text { portant modification des articles } 12,13,14 \\
\text { et } 16 \text { de la Loi nº61-415 du } 14 \text { décembre } 1961 \text { portant Code de la nationalité }\end{array}$ \\
\hline DR Congo & $\begin{array}{l}\text { Constitution } 2005 \\
\text { Loi No. } 1972-002 \text { du } 5 \text { janvier } 1972 \text { relative à la nationalité zaïroise } \\
\text { Loi No. } 1981-002 \text { du } 29 \text { juin } 1981 \text { relative à la nationalité zaïroise } \\
\text { Loi No. 04-024 du } 12 \text { novembre } 2004 \text { relative à la nationalité congolaise }\end{array}$ \\
\hline Djibouti & $\begin{array}{l}\text { Loi n²00/AN/81 portant Code de la nationalité djiboutienne. } \\
\text { Loi n } 79 / \mathrm{AN} / 04 / 5 \text { eme } \mathrm{L} \text { du } 24 \text { octobre } 2004 \text { portant Code de la nationalité } \\
\text { djiboutienne }\end{array}$ \\
\hline Egypt & $\begin{array}{l}\text { Law No. } 26 \text { of } 1975 \text { concerning Egyptian nationality } \\
\text { Law No. } 154 \text { of } 14 \text { July } 2004 \text { amending Law No. } 26 \text { of } 1975 \\
\text { Decree No. } 12025 \text { of } 26 \text { July } 2004 \text { concerning certain provisions enforcing Law No. } \\
154\end{array}$ \\
\hline $\begin{array}{l}\text { Equatorial } \\
\text { Guinea }\end{array}$ & $\begin{array}{l}\text { Ley Fundamental } 1982 \\
\text { Ley Fundamental } 1991 \text {, as amended } 1995 \\
\text { Ley núm. 8/1990, de fecha } 24 \text { de octubre, reguladora de la nacionalidad ecuato- } \\
\text { guineana } \\
\text { Ley Fundamental } 2012\end{array}$ \\
\hline Eritrea & \begin{tabular}{|l|} 
Constitution 1997 \\
Eritrean Nationality Proclamation No. 21/1992 \\
\end{tabular} \\
\hline Ethiopia & $\begin{array}{l}\text { Constitution } 1995 \\
\text { Nationality Law } 1930 \\
\text { Proclamation No. } 270 / 2002 \text { concerning the rights of foreign nationals of Ethiopian } \\
\text { origin } \\
\text { Proclamation No. } 378 / 2003 \text { on Ethiopian Nationality } \\
\end{array}$ \\
\hline Gabon & $\begin{array}{l}\text { Loi No.89/61 du } 2 \text { mars } 1962 \text { portant de la nationalité gabonaise } \\
\text { Loi No. 37-1998 portant Code de la nationalité gabonaise }\end{array}$ \\
\hline Gambia & $\begin{array}{l}\text { Constitution } 1965 \\
\text { Gambia Nationality and Citizenship Act No. } 1 \text { of } 1965 \\
\text { Constitution } 1970 \text { Act No. } 1 \text { of } 1970 \\
\text { Constitution } 1996 \text { as amended } 2001\end{array}$ \\
\hline
\end{tabular}




\begin{tabular}{|c|c|}
\hline Ghana & $\begin{array}{l}\text { Ghana (Constitution) Order in Council 1957/277 } \\
\text { Ghana Nationality and Citizenship Act } 1 \text { of } 1957 \\
\text { Constitution (Consequential Provisions) Act (CA8) } \\
\text { Ghana Nationality Act } 62 \text { of } 1961 \\
\text { Ghana Nationality Decree, NLCD } 191 \text { of } 1967 \\
\text { Ghana Nationality (Amendment) Decree NLCD } 333 \text { of } 1969 \\
\text { Constitution of the Republic of Ghana } 1969 \\
\text { Ghana Nationality Act } 361 \text { of } 1971 \\
\text { Ghana Nationality (Amendment) Decree } 1972 \text { NRCD } \\
\text { Constitution of the Republic of Ghana } 1979 \\
\text { Constitution of the Republic of Ghana } 1992 \\
\text { Constitution of the Republic of Ghana (Amendment) Act } 527 \text { of } 1996 \\
\text { Citizenship Act } 591 \text { of } 2000 \\
\text { Dual Citizenship Regulation Act } 91 \text { of } 2002\end{array}$ \\
\hline Guinea & $\begin{array}{l}\text { Ordonnance No.011 du } 1 \text { mars } 1960 \text { portant code de la nationalité guinéenne } \\
\text { Loi 004/APN/83 du } 16 \text { février 1983, portant Code civil de Guinée }\end{array}$ \\
\hline Guinea Bissau & $\begin{array}{l}\text { Lei da nacionalidade No.1/76 de } 4 \text { de maio } \\
\text { Lei da nacionalidade No.1/84 de } 15 \text { de fevereiro } \\
\text { Constitution } 1984 \text { (modified } 1991,1993 \text { and 1996) } \\
\text { Lei da nacionalidade No.2/92 de } 6 \text { de abril } \\
\text { Lei da nacionalidade No.6/2010 de } 21 \text { de junho } \\
\end{array}$ \\
\hline Kenya & $\begin{array}{l}\text { Constitution } 1963 \\
\text { Citizenship Act Cap170, } 1963 \\
\text { Constitution } 1969 \\
\text { Constitution of Kenya (Amendment) Act No.6 of } 1985 \\
\text { Children's Act No.8 of } 2001 \\
\text { Refugee Act } 2006 \\
\text { Constitution of Kenya } 2010 \\
\text { Kenya Citizenship and Immigration Act No.12 of } 2011 \text { as amended by the Statute } \\
\text { Law (Miscellaneous Amendments) Act No. } 12 \text { of } 2012\end{array}$ \\
\hline Lesotho & $\begin{array}{l}\text { Constitution } 1993 \\
\text { Lesotho Citizenship Order No. } 16 \text { of } 1971 \text { (amended 1993) } \\
\text { Passports and Travel Documents Act No. } 15 \text { of } 1998 \\
\end{array}$ \\
\hline Liberia & $\begin{array}{l}\text { Aliens and Nationality Law, Title 3, Liberian Code of Laws } 1956 \\
\text { Aliens and Nationality Law } 1973 \\
\text { Constitution } 1986\end{array}$ \\
\hline Libya & $\begin{array}{l}\text { Law No. } 17 \text { of } 1954 \text { on Nationality } \\
\text { Law No.18 of } 1980 \text { pertaining to the resolutions of the Nationality Act } \\
\text { Regulatory Code for Law no. } 18 \text { of } 1980 \text { pertaining to the resolutions of the } \\
\text { Nationality Act } \\
\text { Law No. } 24 \text { of } 2010 \text { on the Provisions of Libyan Nationality }\end{array}$ \\
\hline Madagascar & $\begin{array}{l}\text { Ordonnance No. 60-064 du } 22 \text { juillet } 1960 \text { portant Code de la nationalité malgache } \\
\text { (modifiée par la loi no. 1961-052 ; la loi no.1962-005; l'ordonnance no.1973-049; et } \\
\text { la loi no.1995-021) } \\
\text { Loi no. 1961-052 portant modification de l'article } 93 \text { du Code de la nationalité } \\
\text { malgache, modifiant les articles } 24,58,82 \text { et } 93 \text { du Code de la nationalité }\end{array}$ \\
\hline Malawi & $\begin{array}{l}\text { Constitution } 1964 \\
\text { Malawi Citizenship Act No.2 of } 1964 \\
\text { Malawi Citizenship Act No.28 of } 1966 \\
\text { Statute Law (Miscellaneous Amendments) Act No.37 of } 1967 \\
\text { Amendment Act No.5 of } 1971 \\
\text { Amendment Act No.22 of } 1992 \\
\text { Constitution } 1994 \text { (Act No.20 of 1994, as amended by Acts No.31 of 1994, } 6 \text { of } 1995, \\
7 \text { of } 1995,1 \text { of } 1997 \text { and } 38 \text { of } 1998 \text { ) } \\
\end{array}$ \\
\hline Mali & $\begin{array}{l}\text { Ordonnance No.55 du } 24 \text { novembre } 1960 \text { relative à l'attribution de la nationalité } \\
\text { malienne à tous les ressortissants de la République du Mali } \\
\text { Loi No. 62-18 AN-RM du } 3 \text { février } 1962 \text { portant Code de la nationalité malienne } \\
\text { Loi No. 95-70 du } 25 \text { août } 1995 \text { portant modification du Code de la nationalité } \\
\text { malienne } \\
\text { Loi No.2011-087 du } 30 \text { décembre } 2011 \text { portant Code des personnes et de la famille }\end{array}$ \\
\hline
\end{tabular}




\begin{tabular}{|c|c|}
\hline Mauritania & $\begin{array}{l}\text { Constitution } 1991 \\
\text { Loi No.61-112 du } 12 \text { juin } 1961 \text { portant Code de la nationalité mauritanienne tel que } \\
\text { modifié par la Loi No.1962-157 et la Loi No.1976-207 } \\
\text { Loi. No.2010-023 du } 11 \text { février } 2010 \text { abrogeant et remplaçant certaines dispositions } \\
\text { de la loi } 61-112 \text { du } 12 \text { juin } 1961 \text { portant Code de la nationalité mauritanienne } \\
\end{array}$ \\
\hline Mauritius & $\begin{array}{l}\text { Constitution } 1968 \\
\text { Mauritius Citizenship Act } 1968 \\
\text { Mauritius Constitution Amendment Act No.23 of } 1995 \\
\text { Mauritius Citizenship Amendment Act No.24 of } 1995 \\
\end{array}$ \\
\hline Morocco & $\begin{array}{l}\text { Dahir No.1-58-250 du } 6 \text { septembre } 1958 \text { portant Code de la nationalité marocaine } \\
\text { tel que modifié et complété par la Loi No. } 62-06 \text { promulguée par le dahir No. 1-07- } \\
80 \text { du } 23 \text { mars } 2007\end{array}$ \\
\hline Mozambique & $\begin{array}{l}\text { Constitution } 2004 \\
\text { Lei da Nacionalidade de } 20 \text { de Junho de } 1975 \text { as amended by Lei No. 16/87 de } 21 \text { de } \\
\text { Dezembro }\end{array}$ \\
\hline Namibia & $\begin{array}{l}\text { Constitution } 1990 \\
\text { Namibian Citizenship Act No. } 14 \text { of } 1990 \\
\text { Namibian Citizenship (Special Conferment) Act No.14 of } 1991 \\
\text { Namibia Refugees (Recognition and Control) Act No. } 2 \text { of } 1999 \\
\text { Namibian Constitution Second Amendment Act No. } 7 \text { of } 2010\end{array}$ \\
\hline Niger & $\begin{array}{l}\text { Loi No.61-26 du } 12 \text { juillet } 1961 \text { déterminant la nationalité nigérienne } \\
\text { Ordonnance No.84-33 du } 23 \text { août } 1984 \text { portant Code de la nationalité nigérienne } \\
\text { Ordonnance No.88-13 du } 18 \text { février } 1988 \\
\text { Ordonnance No.99-17 du } 4 \text { juin } 1999 \text { portant modification de l'Ordonnance No.84- } \\
33 \text { du } 23 \text { août } 1984 \text { portant Code de la nationalité nigérienne } \\
\text { Constitution } 1999 \\
\text { Loi No.2014-60 du } 05 \text { novembre } 2014 \text { portant modification de l'Ordonnance } \\
\text { No.84-33 du } 23 \text { août } 1984 \text { portant Code de la nationalité de la nationalité nigérienne }\end{array}$ \\
\hline Nigeria & $\begin{array}{l}\text { Constitution } 1960 \\
\text { Nigerian Citizenship Act } 1960 \\
\text { Nigeria Constitution (Amendment) Decree No. } 33 \text { of } 1974 \\
\text { Constitution } 1979 \\
\text { Constitution } 1999\end{array}$ \\
\hline Rwanda & $\begin{array}{l}\text { Loi du } 28 \text { septembre } 1963 \text { portant Code de la nationalité rwandaise } \\
\text { Constitution } 2003 \\
\text { Loi organique No. } 29 / 2004 \text { du } 03 / 12 / 2004 \text { portant code de la nationalité rwandaise } \\
\text { Loi organique No. } 30 / 2008 \text { du } 25 / 07 / 2008 \text { portant code de la nationalité rwandaise } \\
\end{array}$ \\
\hline SADR & No info \\
\hline $\begin{array}{l}\text { São Tomé and } \\
\text { Príncipe }\end{array}$ & $\begin{array}{l}\text { Lei 39/75 da nacionalidade de } 15 \text { de dezembro } 1975 \\
\text { Lei n. }{ }^{\circ} \text { 6/90, de } 13 \text { de Setembro de 1990, Lei da Nacionalidade } \\
\text { Constitution } 2003\end{array}$ \\
\hline Senegal & $\begin{array}{l}\text { Loi No. 61-70 du } 7 \text { mars } 1961 \text { déterminant la nationalité sénégalaise (modifiée par la } \\
\text { Loi No.61-10 du } 7 \text { mars 1961, la Loi No.67-17 du } 28 \text { février 1967, la Loi No.70-27 } \\
\text { du } 27 \text { juin 1970, la Loi No.70-31 du } 13 \text { octobre 1970, la Loi No.79-01 du } 6 \text { janvier } \\
\text { 1979, la Loi No.84-10 du } 4 \text { janvier 1984, et la Loi No.89-42 du } 26 \text { décembre 1989) } \\
\text { Loi No.2013-05 du } 8 \text { juillet } 2013 \text { portant modification de la loi no 61-10 du } 7 \text { mars } \\
\text { 1961 déterminant la nationalité sénégalaise }\end{array}$ \\
\hline Seychelles & $\begin{array}{l}\text { Constitution } 1976 \\
\text { Citizenship Ordinance No. } 9 \text { of } 1976 \\
\text { Constitution Decree } 1979 \\
\text { Citizenship (Amendment) Regulations } 1983 \\
\text { Constitution } 1993 \text { (as amended by Act } 7 \text { of } 1994 \text {, Act } 5 \text { of } 1995 \text {, Act } 19 \text { of } 1995 \text {, Act } \\
14 \text { of } 1996 \text {, SI } 11 \text { of } 1998 \text {, Act } 7 \text { of } 2000 \text {, SI } 31 \text { of } 2000 \text {, SI } 22 \text { of 2001, SI } 32 \text { of } 2002 \\
\text { and Act } 7 \text { of } 2011 \text { ) } \\
\text { Citizenship Act No. } 18 \text { of } 1994 \text { (as amended by Act } 11 \text { of 2013) }\end{array}$ \\
\hline
\end{tabular}




\begin{tabular}{|c|c|}
\hline Sierra Leone & $\begin{array}{l}\text { Constitution } 1961 \\
\text { Sierra Leone Constitution (Amendment) (No.2) Act } 1962 \\
\text { Sierra Leone Citizenship Act, No } 4 \text { of 1973, as amended by Act No.13 of } 1976 \\
\text { Constitution } 1991 \\
\text { Sierra Leone Citizenship Amendment Act No. } 11 \text { of } 2006 \\
\text { Refugees Protection Act No. } 6 \text { of } 2007 \\
\text { Child Rights Act No. } 7 \text { of } 2007\end{array}$ \\
\hline Somalia & $\begin{array}{l}\text { Law No.28 of } 22 \text { December } 1962 \text { on Somali Citizenship } \\
\text { Somali Transitional Federal Charter } 2004 \\
\text { Provisional Constitution } 2012\end{array}$ \\
\hline South Africa & $\begin{array}{l}\text { Constitution } 1996 \\
\text { South African Citizenship Act No. } 88 \text { of } 1995 \\
\text { South African Citizenship Amendment Act No.19 of } 1997 \\
\text { South African Citizenship Amendment Act No.17 of } 2004 \\
\text { South African Citizenship Amendment Act No.17 of } 2010\end{array}$ \\
\hline South Sudan & $\begin{array}{l}\text { Transitional Constitution of the Republic of South Sudan } 2011 \\
\text { Nationality Act } 2011\end{array}$ \\
\hline Sudan & $\begin{array}{l}\text { Definition of Sudanese Ordinance } 1948 \\
\text { Sudanese Nationality Act } 1957 \\
\text { Sudan Nationality Decree No. } 18 \text { of } 1993 \\
\text { Sudanese Nationality Act } 1994 \text { (amended by Act No.1 of 2006) } \\
\text { Constitution } 1998 \\
\text { Sudanese Nationality (Amendment) Act } 2011 \\
\end{array}$ \\
\hline Swaziland & $\begin{array}{l}\text { Constitution } 1967 \\
\text { Constitution } 1968 \\
\text { Swaziland Citizenship Act No.17 of } 1967 \\
\text { Swaziland Citizenships Order, No.22 of } 1974 \\
\text { Swaziland Citizenship Act No.14 of } 1992 \\
\text { Constitution } 2005\end{array}$ \\
\hline Tanzania & $\begin{array}{l}\text { Constitution } 1961 \\
\text { Citizenship Act } 1961 \\
\text { Constitution } 1977 \text { (as amended to 2005) } \\
\text { Tanzania Citizenship Act No. } 6 \text { of } 1995 \\
\text { Law of the Child Act No } 21 \text { of } 2009 \\
\text { Zanzibar Nationality and Naturalisation Decree } 1911 \\
\text { Zanzibar Nationality Decree No.30 of 1952, amended by Act No.16 of } 1958 \\
\text { Zanzibar Act } 1963 \\
\text { Zanzibari Act No.5 of } 1985\end{array}$ \\
\hline Togo & $\begin{array}{l}\text { Loi No. 61-18 du } 25 \text { juillet } 1961 \text { relative à la nationalité togolaise } \\
\text { Ordonnance 78-34 du } 7 \text { septembre } 1978 \text { portant Code de la nationalité togolaise } \\
\text { Constitution } 1992\end{array}$ \\
\hline
\end{tabular}




\begin{tabular}{|c|c|}
\hline Tunisia & $\begin{array}{l}\text { Décret No.34 du } 26 \text { janvier } 1956 \text { portant promulgation du Code de la nationalité } \\
\text { tunisienne } \\
\text { Constitution } 1959 \text { (as amended to 2008) } \\
\text { Décret-loi No.63-6 du } 28 \text { février } 1962 \text { portant refonte du Code de la nationalité } \\
\text { tunisienne. } \\
\text { Loi No.63-7 du } 22 \text { avril } 1963 \text { ratifiant le décret loi No.63-6 du } 28 \text { février } 1963 \\
\text { portant refonte du Code de la nationalité tunisienne, } \\
\text { Loi No.21-12 du } 9 \text { mars } 1971 \text { modifiant les article } 63 \text { et } 65 \text { du Code de la nationalité } \\
\text { tunisienne } \\
\text { Loi No.84-81 du } 30 \text { novembre } 1984 \text { portant modification de l'article } 30 \text { du code de } \\
\text { la nationalité } \\
\text { Loi No.84-81 du } 30 \text { novembre } 1984 \text { modifiant l'article } 32 \text { du Code de la nationalité } \\
\text { tunisienne } \\
\text { Loi No.95-92 du } 9 \text { novembre } 1995 \text { relative à la publication du Code de la protection } \\
\text { de l'enfant } \\
\text { Loi No.2010-55 du 1er décembre } 2010 \text { modifiant certaines dispositions du Code de } \\
\text { la nationalité tunisienne } \\
\text { Constitution } 2014\end{array}$ \\
\hline Uganda & $\begin{array}{l}\text { Constitution } 1962 \\
\text { Citizenship Act } 1962 \text { (Chapter 65) } \\
\text { Constitution } 1967 \\
\text { Constitution } 1995 \\
\text { Uganda Citizenship and Immigration Control Act No.3 of } 1999 \text { (Chapter 66) } \\
\text { Constitution (Amendment) Act } 2005 \\
\text { Uganda Citizenship and Immigration Control (Amendment) Act } 5 \text { of } 2009\end{array}$ \\
\hline Zambia & $\begin{array}{l}\text { Constitution } 1964 \\
\text { Constitution } 1973 \\
\text { Citizenship Act } 1977 \text { (Chapter 124), as amended to } 1994 \\
\text { Constitution } 1991 \text { as amended } 1996 \text { and } 2009\end{array}$ \\
\hline Zimbabwe & $\begin{array}{l}\text { Constitution } 1979 \\
\text { Constitution of Zimbabwe Amendment (No.3) Act No.1 of } 1983 . \\
\text { Citizenship of Zimbabwe Act No.23 of } 1984 \text { (Cap.4.01) } \\
\text { Constitution of Zimbabwe Amendment (No.11) Act No.30 of } 1990 \\
\text { Citizenship of Zimbabwe Amendment Act No.7 of } 1990 \text { = Electoral Act??? } \\
\text { Constitution of Zimbabwe Amendment (No.14) Act No.14 of } 1996 \\
\text { Citizenship Amendment Act No.12 of } 2001 \\
\text { Citizenship of Zimbabwe Amendment Act No. } 22 \text { of } 2001 \\
\text { Citizenship of Zimbabwe Amendment Act No. } 23 \text { of } 2001 \\
\text { Citizenship of Zimbabwe Amendment Act No.1 of } 2002 \\
\text { Citizenship of Zimbabwe Amendment Act, No } 12 \text { of } 2003 \\
\text { Constitution of Zimbabwe Amendment (No.17) Act No.5 of } 2005 \\
\text { Constitution of Zimbabwe Amendment (No.18) Act No.11 of } 2007 \\
\text { Constitution of Zimbabwe Amendment (No.19) Act No } 1 \text { of } 2009 \\
\text { Constitution of Zimbabwe Amendment Act No.20 of } 2013 \text { (enacting new } \\
\text { constitution) }\end{array}$ \\
\hline
\end{tabular}

